ORNL/TM-2001/248

\title{
U.S. DEPARTMENT OF TRANSPORTATION
}

FEdERAL HighWAY AdMinistration

\section{NPTS DATABOOK}

BASED ON DATA FROM THE

1995 Nationwide Personal Transportation SurVey (NPTS)

\author{
Prepared by: \\ OAK RIDGE National LabORATORY \\ OAK RIDGE, TenNessee \\ Prepared For: \\ Office of Highway Policy Information, HPPI \\ (202) 366-0160, FAX (202) 366-7742
}


This report has been reproduced directly from the best available copy.

Available to DOE and DOE contractors from the Office of Scientific and Technical Information, P. O. Box 62, Oak Ridge, TN 37831; prices available from (615) 576-8401.

Available to the public from the National Technical Information

This report was prepared as an account of work sponsored by an agency of the United States Government. Neither the United States Government nor any agency thereof, nor any of their employees, makes any warranty, express or implied, or assumes any legal liability or responsibility for the accuracy, completeness, or usefulness of any information, apparatus, product, or process disclosed, or represents that its use would not infringe privately owned rights. Reference herein to any specific commercial product, process, or service by trade name, trademark, manufacturer, or otherwise, does not necessarily constitute or imply its endorsement, recommendation, or favoring by the United States Government or any agency thereof. The views and 


\section{TABLE OF CONTENTS}

\section{ChAPTER 1 INTRODUCTION}

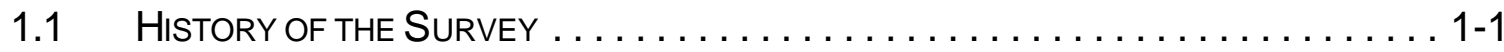

1.2 Brief Description of The SurVey Method . . . . . . . . . . . . . . . 1 1-1

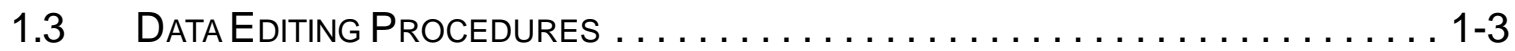

1.4 DifFERENCES AMONG NPTS SURVEYS AND DATA CompatiBILITY ......... 1-3

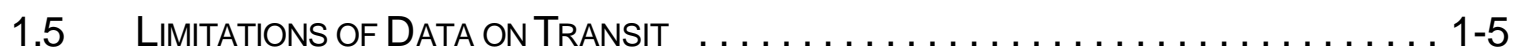

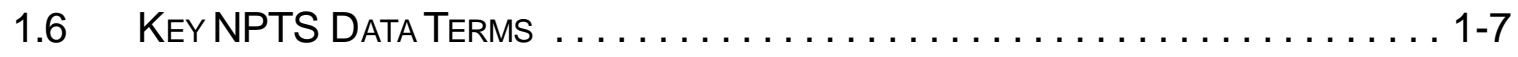

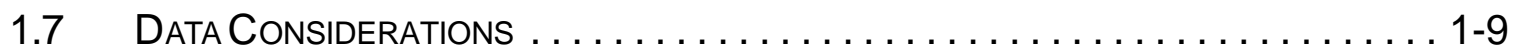

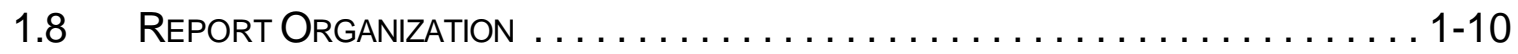

\section{Chapter 2 Estimates of Total Travel}

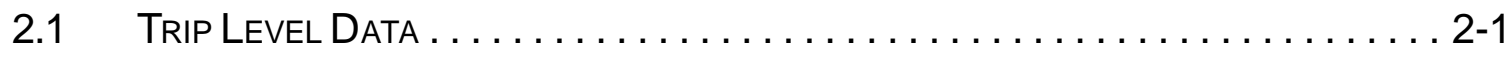

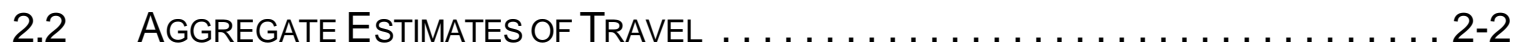

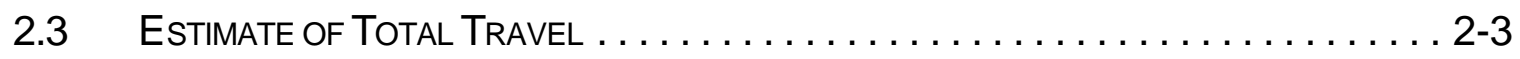

\section{Chapter 3 Determinants of Travel}

3.1 Person Characteristics . . . . . . . . . . . . . . . . . . . . . . . 3 .

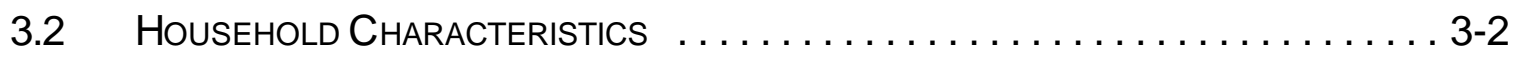

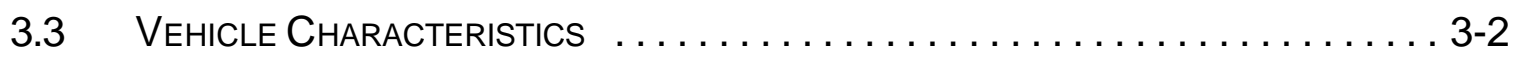

\section{Chapter 4 Person Trips and Person Miles of Travel}

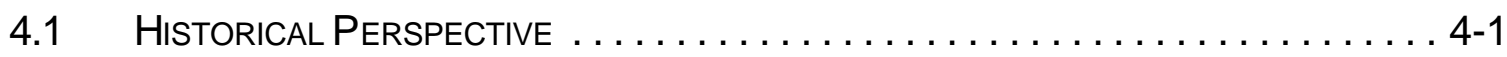

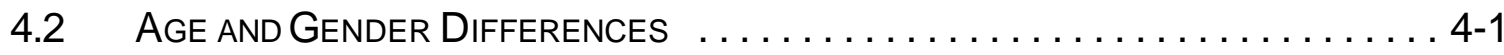

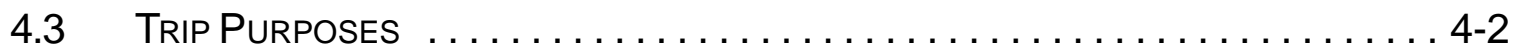

4.4 Household and Demographic Statistics $\ldots \ldots \ldots \ldots \ldots \ldots \ldots \ldots . \ldots .2$

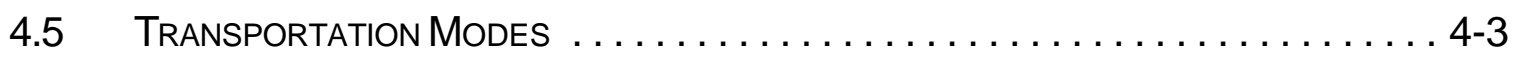

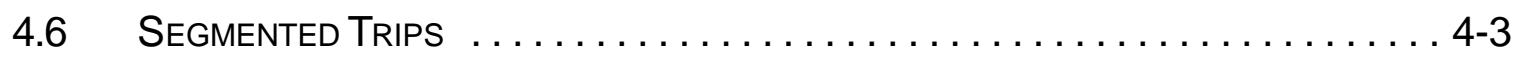

4.7 TriPS by Day of WeEk AND TIME OF DaY $\ldots \ldots \ldots \ldots \ldots \ldots \ldots \ldots \ldots .3$ 


\section{Chapter 5 Vehicle Trips and Vehicle Miles of Travel}

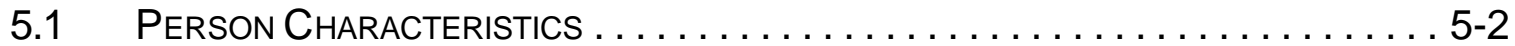

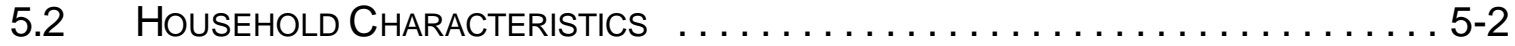

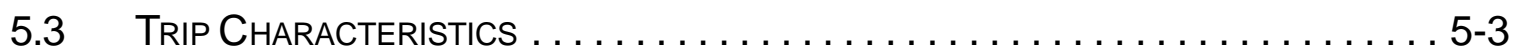

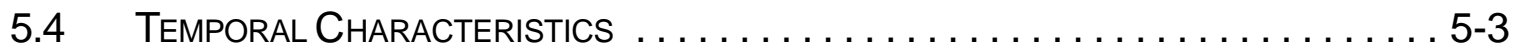

\section{Chapter 6 Journey to Work ANd Work-Related Trips}

6.1 Journey to Work And Work-Related Travel Characteristics . . . . . . . 6-1

6.2 Journey to Work and Work-Related Modes of Transportation $\ldots \ldots .6-2$

6.3 Segmented JourneY To Work TriPS $\ldots \ldots \ldots \ldots \ldots \ldots \ldots \ldots \ldots .6 \ldots \ldots$

6.4 Temporal Patterns of Commuting $\ldots \ldots \ldots \ldots \ldots \ldots \ldots \ldots \ldots \ldots .6 \ldots \ldots$

\section{Chapter 7 Vehicle Occupancy ANd Ride-Sharing}

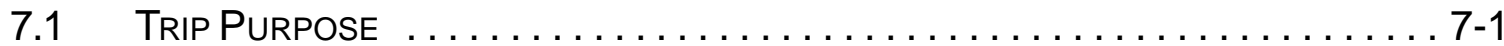

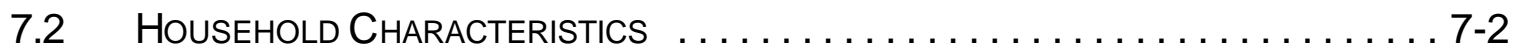

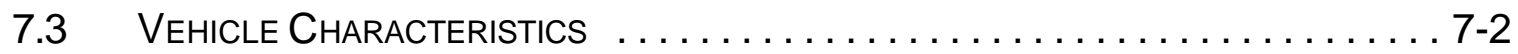

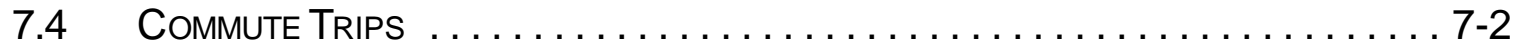

\section{Chapter 8 Travel Behavior of Population Subgroups}

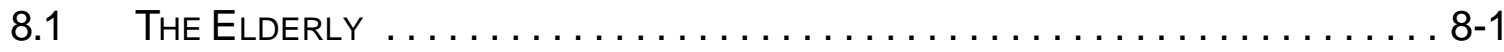

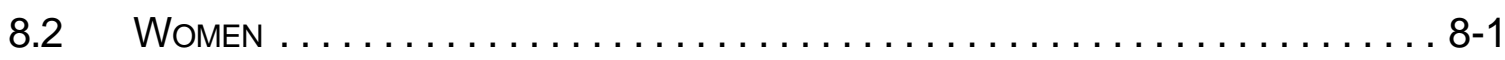

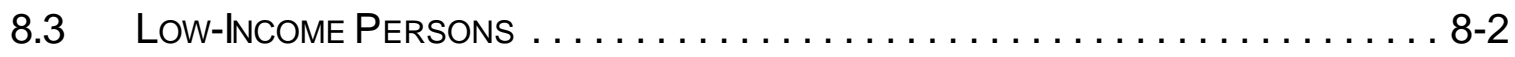

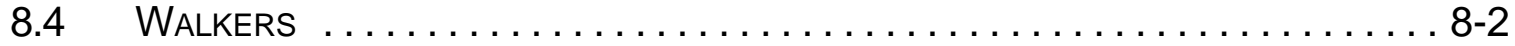

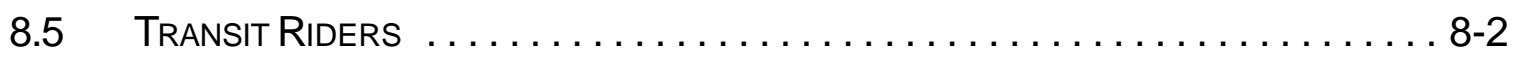




\section{APPENDICES}

Appendix A Travel Concepts and Glossary of Terms ................ A-1

Appendix B Changes in the 1995 NPTS Survey Methodology and Their

Probable Impacts $\ldots \ldots \ldots \ldots \ldots \ldots \ldots \ldots \ldots \ldots \ldots \ldots \ldots$ B-1

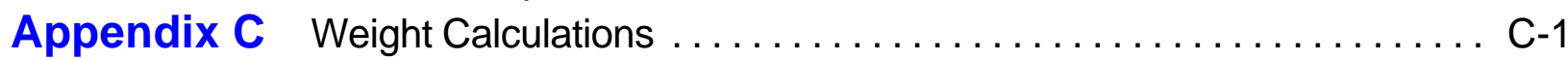

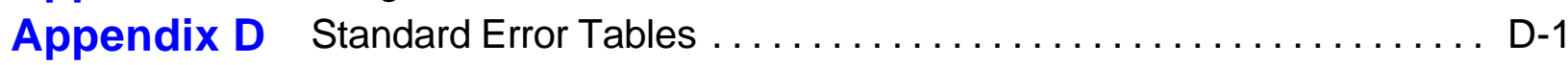

Appendix E Adjustment of 1990 Travel Data ...................... E-1

Appendix F Differences in Workers and Commute Trips Between 1990 and 1995 Data ...................................

Appendix G Differences in Metropolitan Area Definitions Between 1983

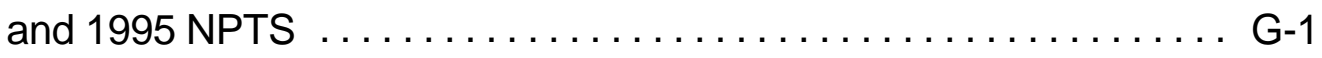

Appendix $\mathrm{H}$ Segmented Trips in NPTS $\ldots \ldots \ldots \ldots \ldots \ldots \ldots \ldots \ldots \ldots \ldots, \mathrm{H}-1$

Appendix I Revised Average Annual Miles Driven per Driver .............. I-1

Appendix J Procedure to Adjust 1983 and 1990 Income Categories into 1995 Dollars ..................................... J-1 

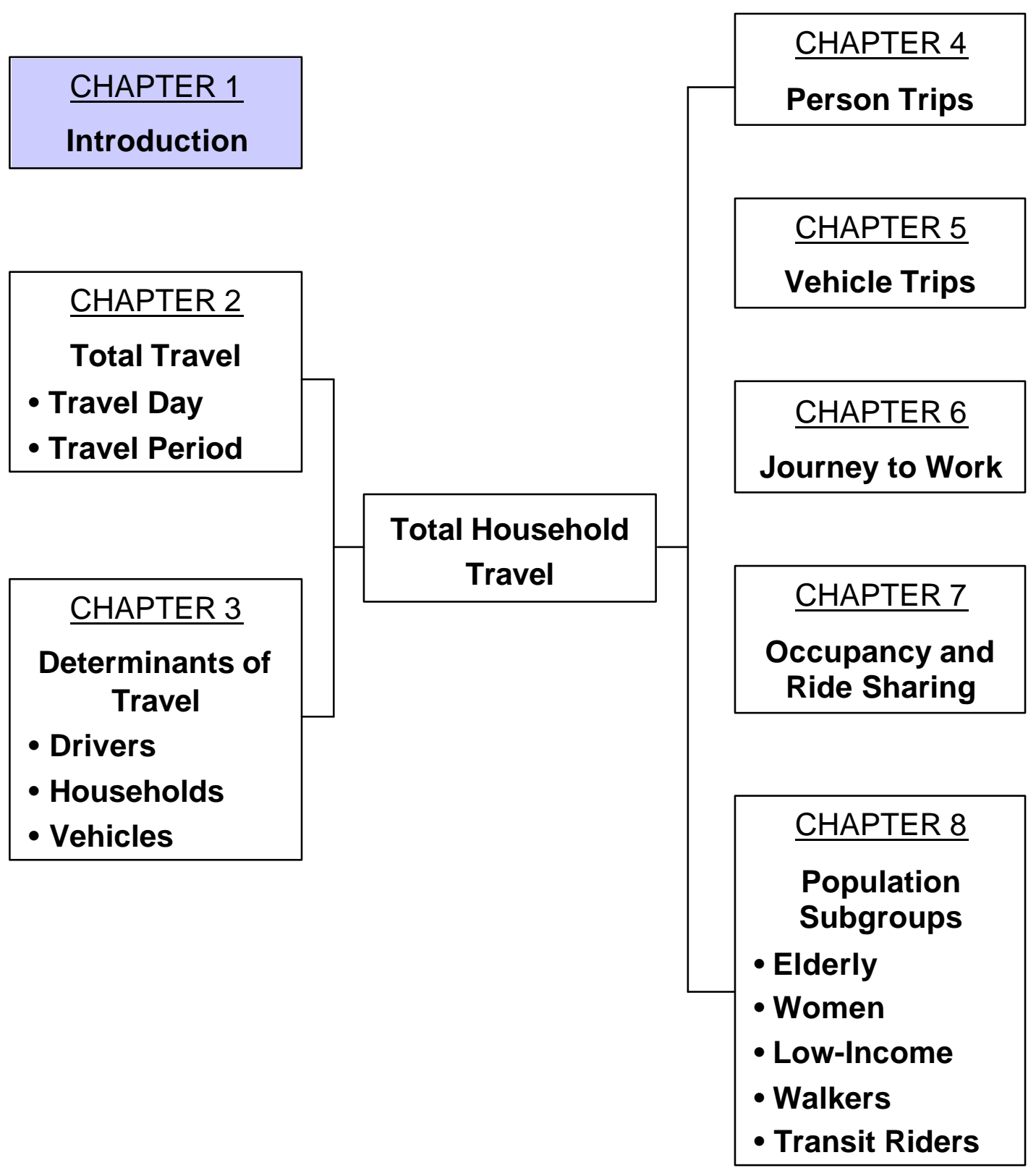


\section{Chapter 1}

INTRODUCTION 


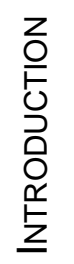




\section{LIST OF FIGURES}

Figure 1.1 Distinction Between Person Trip, Person Miles of Travel,

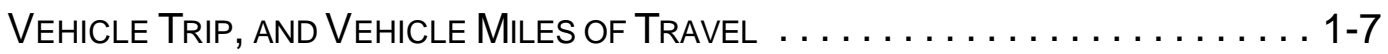

Figure 1.2 Distinction Between Travel Day and Travel Period $\ldots \ldots \ldots \ldots \ldots \ldots .1-8$ 


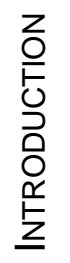




\section{ChAPTER 1 INTRODUCTION}

$\mathrm{P}$ OLICYMAKERS rely on transportation statistics, including data on personal travel behavior, to formulate strategic transportation policies and to improve the safety and efficiency of the U.S. transportation system. Data on personal travel trends are needed to examine the reliability, efficiency, capacity, and flexibility of the Nation's transportation system to meet current demands and accommodate future demands; to assess the feasibility and efficiency of alternative congestion-alleviating technologies (e.g., highspeed rail, magnetically levitated trains, intelligent vehicle and highway systems); to evaluate the merits of alternative transportation investment programs; and to assess the energyuse and air-quality impacts of various policies.

\subsection{History OF THE SURVEY}

To address these data needs, the Department of Transportation (DOT) initiated an effort in 1969 to collect detailed data on personal travel. The 1969 survey was the first Nationwide Personal Transportation Survey (NPTS). The survey was conducted again in 1977, 1983, 1990, and 1995. The 1995 survey was cosponsored by four DOT agencies: Federal Highway Administration (FHWA), Bureau of Transportation Statistics (BTS), Federal Transit Administration (FTA), and National Highway Traffic Safety Administration (NHTSA). The primary objective of the survey was to collect trip-based data on the nature and characteristics of personal travel. Commercial and institutional travel were not part of the survey.

\subsection{Brief Description Of the SURVEY METHOD}

The target population for the 1995 NPTS consisted of all persons 5 years of age or older who resided within the 50 States and the District of Columbia during the data collection period (May 1995 to June 1996). The survey design was based on a stratified two-stage cluster sampling plan. All counties in the United States were stratified into geographic areas based on (1) the nine U.S. Bureau of the Census divisions, (2) presence or absence of a subway or an elevated- rail public transportation system, (3) three metropolitan size categories, and (4) the density of listed phone numbers. To capture seasonal variation in travel, the interviews were conducted over a 14-month period, and weighted to capture annual travel characteristics. Travel days were assigned to all seven days of the week, including holidays, to capture the variation in personal travel during the course of an entire year.

The 1995 NPTS User's Guide for the Public Data Files $^{l}$ describes the ways in which the 1995 NPTS represents a significant change in survey methods and procedures from earlier NPTSs. These survey changes have had a significant impact on the results of the survey. The greatest impacts are most likely from:

\footnotetext{
${ }^{1}$ Research Triangle Institute and Federal Highway Administration, 1995 NPTS User's Guide for the Public Data Files, FHWA-PL-98-002, October 1997; also http://www-cta.ornl.gov/npts/1995/Doc/users guide. $\underline{\text { shtml. }}$
} 
1. Use of a written diary as a memory jogger for travel on a specific day. In the pretest conducted in 1994 for the 1995 NPTS, a written diary was compared to the retrospective, or recall, method. The diary method averaged 0.5 trips more per person per day than the retrospective method. ${ }^{2}$

2. The household roster of trips, which maintained a list of trips for household members who had already been interviewed for comparison with responses from other household respondents.

3. The $\$ 2.00$ incentive that was sent with each travel diary. This may have made the respondents feel obligated to record and report all of their travel.

4. Use of an advance letter to notify potential respondents that they would be recruited for the survey. We believe that the advance letter added legitimacy to the telephone recruitment, which contributed to higher quality data. The effect of the advance letter on the travel data cannot be measured quantitatively.

5. Confirmation of "no travel" to distinguish from "soft refusals." The proportion of persons who said they made no trips on the assigned travel day was approximately 12 percent in 1995, compared to about 25 percent in $1990 .^{3}$

The survey was conducted by telephone, using a computer-assisted telephone interviewing system (CATI). The advantages of CATI for the NPTS are that it

- allows the interviewers to enter data as the respondent is speaking;

\footnotetext{
2 "PlanTrans," Draft report on NPTS Pretest Methods, Spring 1997.

31995 NPTS User's Guide for the Public Data Files, pp. 3-25 to 3-26.
}

- allows for a certain amount of on-line checking for data consistency (e.g., the respondent says that she made a trip in the pickup truck she owns; however, there is no pickup truck recorded as a household vehicle for this household);

- allows a number of edits, such as range checks, to be performed while the interview is in progress, thereby giving the interviewer the opportunity to correct problems while still on the phone with the respondent.

Households included in the NPTS sample were identified by random-digit-dialing procedures. Of more than 112,000 randomly selected telephone numbers, a total of 82,663 households were eligible to be included in the sample. Of these eligible households, 58,276 accepted a travel diary. From these, a total of 42,033 household interviews were completed.

A set of basic information on demographics, household composition, household vehicles, availability of public transportation, household location, and household income was first obtained to provide a general profile of American households. Data were then collected from each person, including education, driver information, typical travel activities, and accident experience, as well as data on all travel during the sampled day. From 103,466 eligible household residents, 95,360 personal interviews were completed, for a within-household response rate of 92 percent.

Because longer trips are a rare event, the NPTS survey sponsors decided that trip data on a oneday sample would not be sufficient to adequately represent longer trips (defined in the NPTS as trips of 75 miles or more one way). Therefore, the recall period for longer trips was extended to two weeks and was referred to as the travel period.

Nationwide PERsonal TRANSPortation SuRVEy 
As in the previous surveys, in the 1995 survey everyone 14 years or older in the household was asked to report detailed information, such as mode and purpose, on every trip taken during the sampled day. This designated day was referred to as the travel day.

Questions about trips taken by household members between the ages of 5 and 13 were answered by an adult household member serving as a proxy, or substitute, for the respondent. However, unlike the NPTS surveys prior to 1990, proxy interviews were allowed in the 1990 and 1995 surveys for household members 14 years or older under certain circumstances: if the person was (1) unable to be interviewed due to an impairment or language barrier; (2) unavailable during the entire period allowed for interviewing the household; or (3) not contacted for interview after repeated attempts. Proxy interviews for persons 14 or older occurred in approximately 18 percent of the cases in the 1995 survey.

\subsection{Data Editing Procedures}

A number of quality control measures were used during data collection. As described in the user's guide, several variables were edited in real-time during the NPTS interviews. The on-line edit checks notified the interviewers of a possible discrepancy and allowed them an opportunity to correct an entry or other errors. For example, the combination of trip length and time reported in the travel day section were checked against pre-programmed miles per hour ranges for most modes of travel. Reported ages for sampled persons in the person interview were checked for consistency with the ages and relationships reported by the household's reference person. Reported zip codes were checked against pre-entered lists of valid codes. $^{4}$

Post-processing edits were also performed on all files (e.g., household, person, travel day). A more detailed description of the sample design and survey procedures is available in the 1995 NPTS User's Guide for the Public Data Files.

\subsection{Differences Among NPTS SURVEYS AND DATA COMPATIBILITY}

Changes in travel behavior and characteristics can be determined by comparing NPTS data for all five survey years: 1969, 1977, 1983, 1990, and 1995. However, to properly compare NPTS data over time, differences in survey methodology and terminology must be clearly identified and evaluated. Unfortunately, changes in travel that may actually be a result of differences in methodology and terminology cannot be quantified without further detailed analysis.

The main differences in methodology and terminology between the 1990 and 1995 NPTS and earlier surveys can be summarized as follows:

- The 1990 and 1995 surveys were telephone surveys, while the earlier surveys used in-person home interviews. Limiting the sample framework to households with

41995 NPTS User's Guide for the Public

Data Files, p. 3-10. 
telephones may result in an under-count of lower income households. Data from the 1990 Census indicate that 4.7 percent of U.S. households do not have telephones, and those households are largely found in the South and West.

- $\quad$ The 1990 and 1995 surveys allowed another household member (proxy) to report an individual's trips if the individual (14 and older) could not be contacted after several attempts, while the earlier surveys did not allow such proxy interviews. This type of proxy interviews, which occurred in approximately 18 percent of the cases in the 1995 survey, may contribute to a greater number of trips being reported than in earlier surveys.

- In the 1969 survey, "vehicles" were automobiles, station wagons, and passenger vans. In later surveys, vehicles also included pickup trucks, other light trucks, sport utility vehicles, motorcycles, and mopeds. Footnotes have been added throughout this publication to remind readers of this difference.

- The 1990 and 1995 survey data were edited by CATI during the data collection process, while data from the earlier surveys were edited manually after the interview. The advantage of CATI over conventional home interviews is that many data inconsistencies and data quality problems can be immediately identified and corrected.

- The sample size of the surveys varied considerably: 15,000 households for the 1969 survey, 18,000 for 1977, 6,500 for $1983,22,000$ for 1990 , and 42,000 for 1995. The small sample size in the 1983 survey (less than one-third that of 1990) contributed to a larger sampling error.

The following changes, taken from the User's Guide, apply only to the 1995 NPTS:

- Two odometer readings and the associated date of the readings, planned to be taken two to six months apart, were attempted for each household vehicle. A model to estimate annual miles driven from these two readings and other information was developed. The odometer readings were collected and annualized to produce a separate estimate of vehicle miles of travel (VMT), in addition to the owner's estimate and the summation of travel day trips made in that vehicle.

- The first three surveys were conducted by the U.S. Census Bureau using an area household sample in 1969, 1977, and 1983. However, because the Census Bureau had conducted the survey, there were very strict confidentiality requirements and neither the address nor the Census tract could be identified outside the Bureau. For the 1990 NPTS, FHWA chose not to collect address information. It was not necessary to do so because the survey was conducted totally by phone with no diary mailings. Home and work addresses were collected in the 1995 NPTS. The purpose of collecting the addresses in 1995 was to mail the travel diaries, and also to add additional geographic detail to the data files. However, addresses are not part of the dataset. A series of characteristics of the area of the residence and workplace locations was appended to the data files to allow analyses of the land use-transportation connection.

- For the first time in the NPTS series, the 1995 survey contained questions on the

Nationwide Personal Transportation SuRVey 
public's opinion of transportation services and systems. The data user can analyze these attitudes in the context of how much the respondent travels, which modes are used, vehicle ownership, income, and so forth. It is anticipated that customer satisfaction questions will be incorporated in the next NPTS.

- Questions were included on how often people use seat belts. For those using seat belts some or most of the time, additional questions were asked on the reasons for not using them all of the time. This will benefit safety analysis of seat belt use, and provide a thorough catalog of reasons people do not always use seat belts.

- In an effort to better understand travel, more detailed trip purpose data were collected. New trip purpose categories in the 1995 NPTS are return to work, take someone somewhere, pick up someone, out to eat, and return home. The collection of trip purposes changed from a descriptive format (e.g., what best describes your reason for making this trip) to a FROMTO format (e.g., a trip from "other family and personal business" to "home"). This is a more objective and more straightforward way to collect the data. This approach also allows for an improved analysis of trip chaining. See Appendix M of the 1995 NPTS User's Guide for the Public Data Files $^{5}$ for a more detailed explanation of trip purpose coding and the trip purpose variables on the 1995 NPTS dataset.

\footnotetext{
${ }^{5} 1995$ NPTS User's Guide for the Public Data Files, pp. 2-7 to 2-9.
}

\subsection{LIMITATIONS OF DATA ON TRANSIT}

The NPTS dataset permits analysis of user characteristics, such as demographic and socioeconomic characteristics, by various modes of transportation. These data are rarely available, especially on a national level, outside of NPTS. However, the reader is cautioned that the sample of transit trips in the 1995 NPTS may not be accurate enough to draw specific conclusions regarding transit use, particularly assumptions regarding policy and funding of transit programs. The remainder of this section provides further information on issues that may contribute to the differences in transit use between NPTS and the Section 15 reporting system of the Federal Transit Administration (FTA).

The NPTS data on transit use are based on information from 7,499 travel day transit trips that were collected in the survey. The breakout of these trips is:

- $\quad 4,681$ by bus,

- $\quad 1,986$ by subway or elevated rail,

- $\quad 778$ by commuter rail, and

- 54 by streetcar or trolleycar.

Using these 7,499 trips, the NPTS results differ considerably from data in the Section 15 reporting system. The reader is cautioned that differences in the way the data are generated between NPTS and Section 15 make direct comparisons difficult. The Section 15 data are based on reports submitted by each transit operator to the FTA as part of the requirements for receiving Federal funding. Transit operators generally obtain the Section 15 information using a combination of farebox receipts and onboard surveys. The Section 15 data do not include demographic or socioeconomic 
characteristics of transit users or trip purpose, distance, travel time, or other trip attributes available from the NPTS. The basic NPTS/Section 15 comparisons for unlinked trips in 1995 are:

\begin{tabular}{|c|c|c|c|}
\hline \multicolumn{4}{|c|}{ Unlinked Transit Trips (millions) } \\
\hline & NPTS & $\begin{array}{c}\text { Sect. } \\
15\end{array}$ & $\begin{array}{c}\text { NPTS } \\
\text { as } \% \\
\text { of Sect. } 15 \\
\end{array}$ \\
\hline Bus & 5,744 & 4,579 & $125.4 \%$ \\
\hline $\begin{array}{l}\text { Rail/ } \\
\text { Subway }\end{array}$ & 2,636 & 2,925 & $90.1 \%$ \\
\hline $\begin{array}{l}\text { Total } \\
\text { Transit }\end{array}$ & 8,380 & 7,504 & $111.7 \%$ \\
\hline
\end{tabular}

These comparisons show that NPTS data report 8.38 billion unlinked transit trips, while Section 15 data report 7.50 billion unlinked trips, for a difference of 900 million unlinked trips. A likely explanation for this difference is found in the oversampling of areas that contain public transit.

This table uses unlinked transit trips as a basis of comparison because the Section 15 data are reported as unlinked trips. An unlinked trip is basically defined as a boarding. For example, you take a bus and a subway to work; this is one linked trip and two unlinked trips (i.e., the bus boarding and the subway boarding). In NPTS, unlinked trips were collected only if one portion of the trip was on transit. Thus the NPTS data for modes other than transit are presented as linked trips. The data on person trips in Chapters 4 and 6 of this Databook uses the linked trips so that a comparable trip definition is used across modes.

The following comparison of linked and unlinked transit trips in NPTS is provided to show how the two relate:

\begin{tabular}{lccc}
\hline \multicolumn{4}{c}{ NPTS Transit Trips (millions) } \\
\hline & Unlinked & Linked & Ratio \\
\hline Bus & 5,744 & 4,541 & 1.26 \\
Rail/ Subway & 2,636 & 2,097 & 1.26 \\
Total Transit & 8,380 & 6,638 & 1.26 \\
\hline
\end{tabular}

Another issue regarding NPTS transit trips is that there clearly appears to be confusion on the part of the survey respondents between commuter rail and subway/elevated rail. Data from the 25 largest urbanized areas show that many trips were coded as commuter rail trips in an area where there was a subway/elevated rail system, but no commuter rail, such as Atlanta or Cleveland. Additionally, in areas that had both commuter rail and subway/elevated rail, the NPTS data show considerably more commuter rail trips than Section 15 and considerably fewer subway trips. This occurred most notably in New York, which has a sufficient proportion of the nation's transit trips to skew the national totals if subway/elevated rail trips are misclassified as commuter rail. Because of this confusion between commuter rail and subway, the transit trip data are categorized as:

- Bus —which includes bus and streetcar, and

- Rail/Subway_which includes commuter rail, subway, and elevated rail.

Trips made by Amtrak are not considered to be public transit trips and are included in the "Other Modes" category, rather than the "Rail/Subway" category.

There is another distinction between Section 15 and NPTS. In the 1995 NPTS, the only locational data known about the respondent is his area of residence. In analyzing NPTS data, 
there is no way of knowing which trips on the travel day were outside of the area of the respondent's residence. Therefore, all of the respondent's travel is attributed to the place of residence. By contrast, the Section 15 data are collected at the point of tripmaking and would reflect the actual location of the travel. There is no way to quantify the impact of this difference between the NPTS and Section 15 datasets.

\subsection{Key NPTS Data Terms}

Appendix A of this Databook contains a full glossary of terms used in this report; however, a few basic terms and concepts need to be introduced before data are presented.

Person Trip is used to describe and quantify travel for all modes of transportation. The definition of person trip - a trip by one person in any mode of transportation - is versatile enough to allow this measure to be applied to any mode. Unless otherwise specified, the tables on person trips contain all travel data collected in the NPTS by all modes (private vehicle, public transportation, walking, bicycle, airplane, etc.). A person trip is counted regardless of whether the person is a driver or a passenger. Two people traveling together in one car are counted as two person trips.

Person Miles are the number of miles traveled by each person on a trip. A 3-mile vehicle trip made by two people traveling together would count as six person miles.

Vehicle Trip is a trip by a single privately owned vehicle (POV), regardless of the number of persons in the vehicle. The trip defined above (two people traveling together in one vehicle) would be considered one vehicle trip. To be counted as a vehicle trip in the
NPTS reports, a trip must be made in a POV and the driver must be a member of a household in the NPTS sample. The 1969 survey was not constrained this way and included all vehicle trips reported by the surveyed household, even those in which the driver was not a household member. Although there are vehicle trips made by modes other than POV, such as bus and streetcar, these are excluded in the NPTS because the survey traces individuals' movements throughout a day, rather than vehicle movements. The distinction among person trip, person miles of travel, vehicle trip, and vehicle miles of travel is better illustrated in Figure 1.1.

FIGURE 1.1

\section{DISTINCTION BETWEEN PERSON TRIP, PERSON Miles OF TraVel, Vehicle TriP, AND VEHICLE MILES OF TRAVEL}

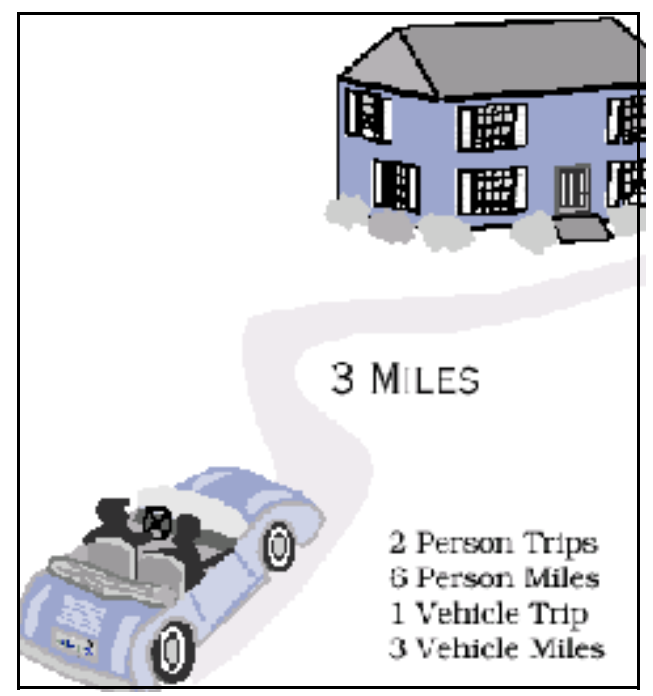

Travel Day and Travel Period refer to two sections of the NPTS questionnaire designed to complement each other. In the travel day section, the respondent is asked to report all trips of any length by any mode of travel during 
a 24-hour period. This reporting provides data on the types of trips made on a daily basis, such as trips to work, to stores, running errands, and visiting friends. Because most people make outof-town trips less frequently, respondents are asked to report any long trips (defined as 75 miles or more one way) for a 2-week period. This is known as the travel period and includes the travel day as well as the preceding 13 days (Figure 1.2).

FIGURE 1.2

\section{DISTINCTION BETWEEN TRAVEL DAY AND} Travel Period

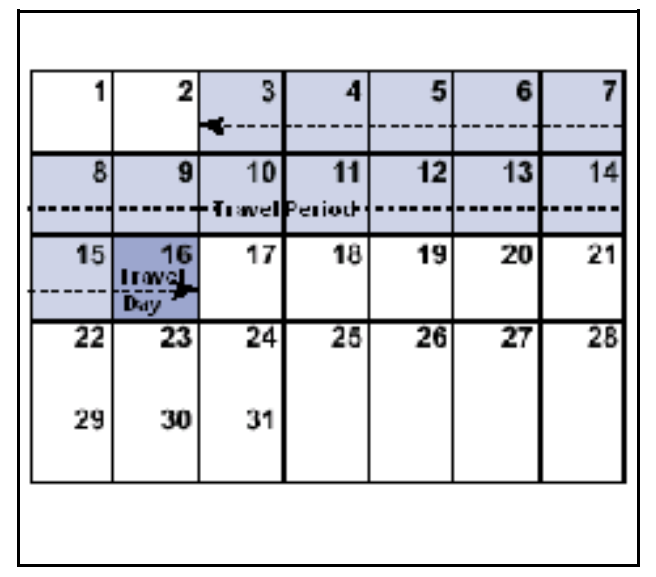

Chapter 2 contains a more complete description of travel day and travel period data and presents the estimates of travel generated from each. The purpose of this discussion is to alert the reader that the great majority of tables in this Databook are based on travel day data only. Thus, the longer trips are not fully represented in those tables. See Chapter 2, "Estimates of Total Travel," for more information on combined estimates from travel day and travel period data.

Commercial Driving is not the focus of the NPTS. The purpose of NPTS is to obtain a profile of personal travel as opposed to commercial travel. For NPTS purposes, personal travel is defined as travel made for all purposes except

- driving a commercial vehicle, such as a bus, airplane, or train;

- driving a car or truck when delivering goods or passengers for hire;

- working at a job that involves too much driving to report on a trip-by-trip basis (e.g., a police officer on patrol duty).

These types of driving are considered "commercial driving" in the NPTS and are not included in travel day or travel period estimates because a significant burden would have been placed on the respondent to report detailed information on each such trip. Instead, respondents were asked to provide separate estimates of the number of miles driven in a typical day and the number of days per week that commercial driving was done. Because commercial driving is not included in travel day or travel period sections, there are consistent differences between NPTS data from travel day and travel period sections and data from other sources, particularly traffic count data.

The reader should note that it is beyond the scope of the NPTS project to obtain a fully representative sample of commercial drivers and/or commercial driving. It is highly likely that the estimate of commercial driving in the NPTS is underestimated.

Estimates of Total Travel, as provided in Chapter 2, include an estimate of total travel from all three sections combined - travel day, travel period, and commercial driving sections. When data from all three sources are combined, travel day trips account for 80.6 
percent of total VMT; travel period trips for 15.7 percent; and commercial travel for 3.7 percent. As discussed in Chapter 2, combining data from travel day with data from travel period is not straightforward and one should not add the number of trips reported in the travel day section to those reported in the travel period section, as the definition of a "trip" was not the same in the two sections.

\subsection{Data Considerations}

Data considerations in comparing 1995 data and earlier survey data are carefully described in the 1995 report series. Nevertheless, to maintain the self-contained nature of this report, pertinent data considerations are repeated here. Also included are data considerations regarding the 1995 survey that users of this publication are advised to bear in mind when using or comparing data from different NPTS surveys.

\section{Workers}

"Workers" in this survey series include parttime workers. For consistency, 1977 data have been revised to include part-time workers, and therefore differ from those reported in the 1977 report series.

\section{Number of drivers per household}

A total of 42,033 households completed interviews in 1995. However, in 6,119 households, not all members were interviewed. The impact of not interviewing all household members is that not all licensed drivers were enumerated in the survey; thus, the number of licensed drivers on a per household basis is misleading and is not reported in this publication. However, weighting factors at the individual level were developed to take this nonresponse into account; thus, the statistics on the total number of licensed drivers are valid.

\section{Number of persons by household composition}

In this publication, the number of one-person households does not equal the total number of persons in one-person households because different weighting schemes were used to develop the weighting factors at the household level and at the person level.

\section{Income}

Historically, income information was collected by income categories, and these categories varied from one survey to the next. To group income categories into consistent categories between surveys and to accurately reflect inflation, a mathematical procedure was developed to aggregate income categories and compare 1990 and 1995 data by income category. This procedure is described in Appendix J.

\section{Work trips}

Questions on the journey to work were asked in two different sections of the 1995 questionnaire. In one section the respondent was asked about the typical or usual trip to work during the week preceding the interview. In that section, only information on the modes that were usually used for work trips and the mode used for the longest distance were identified. In the travel day section, more information was collected on work trips that actually occurred during the designated sampled day (travel day), such as trip duration, trip length, and travel modes used. The statistics on work trips in this report were primarily based on data in the travel day section. Any tabulations from the usual work trip section are so identified.

\section{Segmented trips}

Certain trips reported in the travel day section were given "segmented" treatment (broken into components) to get improved data on transit 
use. A trip was segmented when more than one mode was used on that trip and one of the modes was public transit (bus, subway, elevated rail, commuter train, or streetcar). A trip was also segmented when there was a transfer on the same public transit mode (e.g., bus to bus). When a trip was given segmented treatment, certain data, such as mode and travel time, were collected for each segment. For a complete discussion of segmented trips, see the material preceding Table 4.21 in Chapter 4 and Appendix $\mathrm{H}$.

\section{Trip purpose}

The 1995 survey collected much more detail than the other surveys on trip purpose - 17 purposes in 1995 compared with 11 in all prior surveys except 1977. Among the changes between 1990 and 1995:

- The 1990 purpose "To or from work" has been divided into two purposes: "To work" and "Return to work"

- "School or church" has been divided into two distinct 1995 purposes, "School" and "Church"

- $\quad$ Five new purposes were added in 1995: "Take someone somewhere," "Pick someone up," "Went out to eat," "Change means of transportation," and "Home." The 1990 purpose "Pleasure Driving" was deleted.

The 1995 data has been coded in a way such that the 1990 purpose can be determined in order to allow comparisons between 1990 and 1995 measures.

\section{Vehicle age}

Vehicle age in this publication is calculated as the difference between the model year and 1996. For example, if the model year of a vehicle is 1992, this vehicle was 4 years old for the 1995 survey. If the difference between the model year of a vehicle and the survey year was less than zero, the vehicle age was categorized as "1 year old or younger." All earlier data related to vehicle age were revised by this approach and therefore may not agree with data published earlier.

\subsection{Report Organization}

The primary purpose of this Databook is to serve as a statistical compendium of the 1995 NPTS.

In Chapter 2, estimates of annual travel data from the 1995 NPTS are reported. Estimates reported include total person miles of travel (PMT) and total vehicle miles of travel (VMT). These estimates are broken down by the different data sources, such as the travel day or travel period, within the 1995 NPTS.

Chapter 3 contains demographic characteristics and household vehicle ownership patterns that shape travel activities at the individual and the household level. The remainder of the Databook consists of the following:

- Chapter 4 discusses data on person trips and travel.

- Chapter 5 includes analysis of vehicle travel, in terms of the number of vehicle trips and VMT.

- Chapter 6 presents data on journey-towork and work-related trips.

- Chapter 7 reports on ride-sharing and vehicle occupancy distributions. 
- Chapter 8 presents data on the travel behavior of special population subgroups the elderly, women, low-income individuals, pedestrians, and transit riders.

The appendices contain material needed by the NPTS data users, as follows:

- Appendix A: Travel Concepts and Glossary of Terms

- Appendix B: Changes in the 1995 NPTS Survey Methodology and Their Probable Impacts

- Appendix C: Weight Calculations

- Appendix D: Standard Error Tables

- Appendix E: Adjustment of 1990 Travel Data

- Appendix F: Differences in Workers and Commute Trips Between 1990 and 1995 NPTS

- Appendix G: Differences in Metropolitan Area Definitions Between 1983 and 1995 NPTS

- Appendix H: Segmented Trips in NPTS

- Appendix I: Revised Average Annual Miles Driven per Driver
- Appendix J: Procedure to Adjust 1983 and 1990 Income Categories into 1995 Dollars

Each chapter has a similar format, which consists of the following elements:

- A diagram identifies the main subject of the chapter in the context of all NPTS data.

- Key statistics are displayed in a tree format. For example, the chapter on person trips and person miles has two trees - one by trip mode and the other by purpose.

- A chapter table of contents, list of tables, and list of figures are next. For the reader's convenience, they are listed at the chapter level.

- Tables, figures, and the accompanying analysis are presented, in subsections of each chapter, generally arranged by person characteristics (e.g., age, sex, driver license status), household characteristics (e.g., income, place of residence), trip characteristics (e.g., mode, purpose, length), and temporal patterns (e.g., time of day, day of week).

It should be noted that totals in some tables may not add due to rounding.

The title of the chapter and the subsections within each chapter are indicated on the edge of each page alongside the thumb tab. 

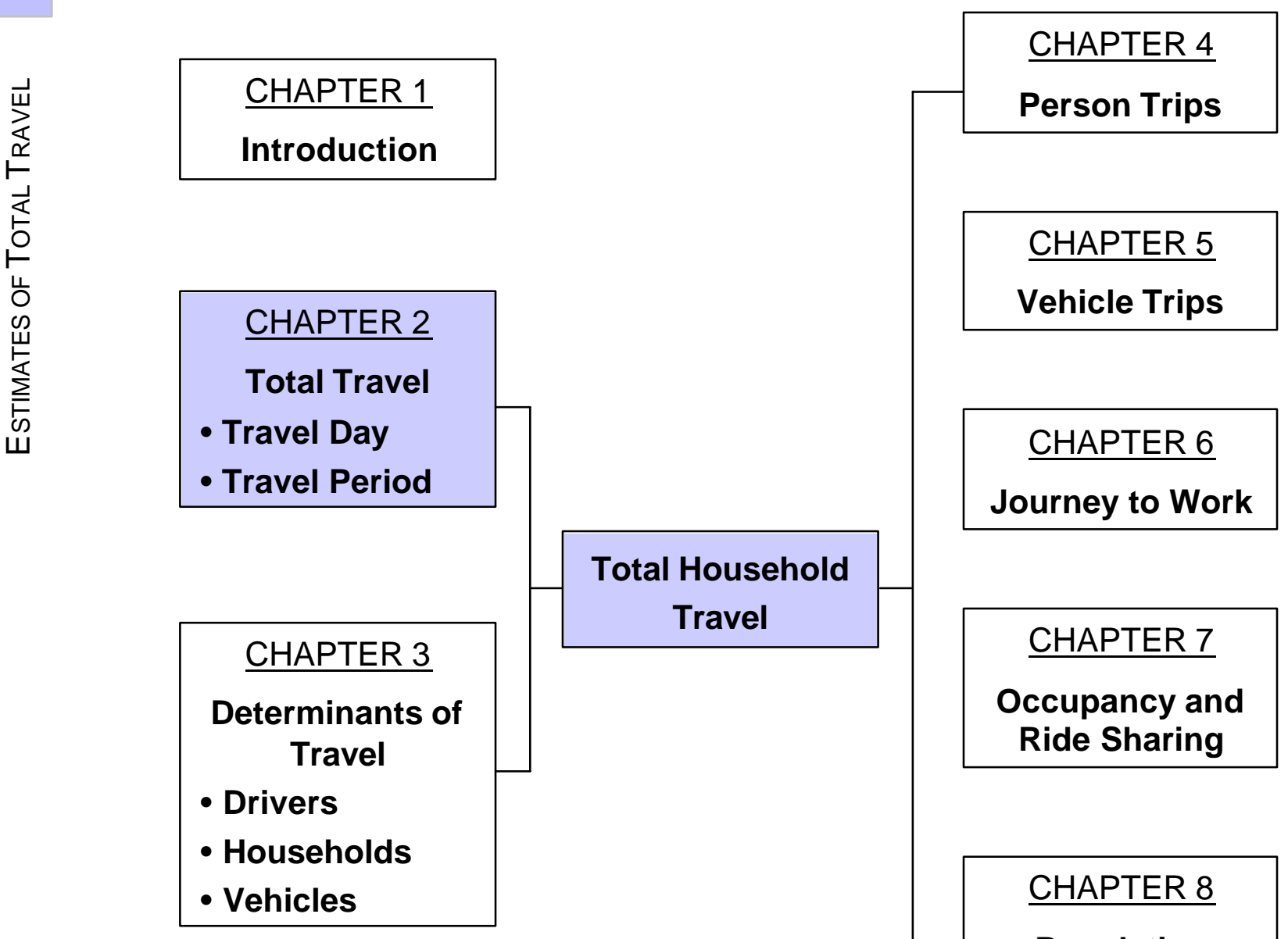
CHAPTER 7
Occupancy and
Ride Sharing

- Drivers

- Households

- Vehicles

CHAPTER 8

Population

Subgroups

- Elderly

- Women

- Low-Income

- Walkers

- Transit Riders 


\section{Chapter 2}

\section{ESTIMATES OF TOTAL TRAVEL}

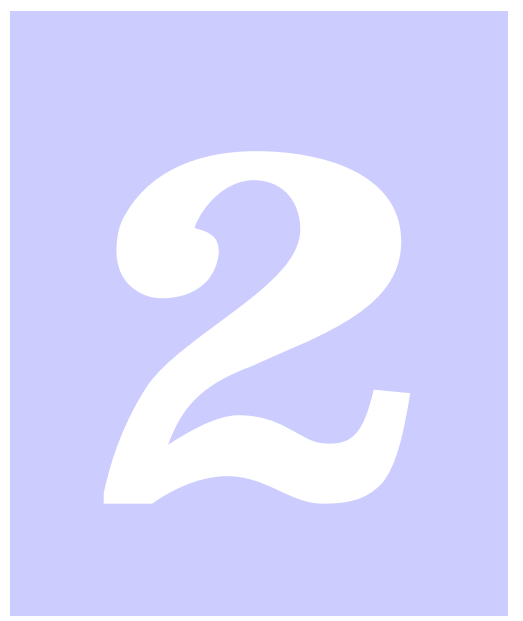

m 


峞




\section{LIST OF TABLES}

Table 2.1 Travel Summary Statistics by Data Source 1995 NPTS (millions) $\ldots . .2$ 2-5

Table 2.2 Total Person Miles of Travel by Data Source and Trip Purpose

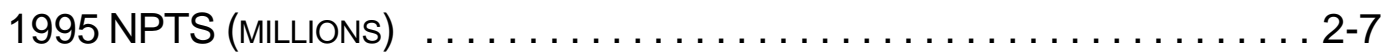

Table 2.3 Total Person Miles of Travel by Data Source and 1990 Trip

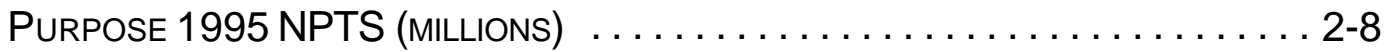

Table 2.4 Total Person Miles of Travel by Data Source and Mode of

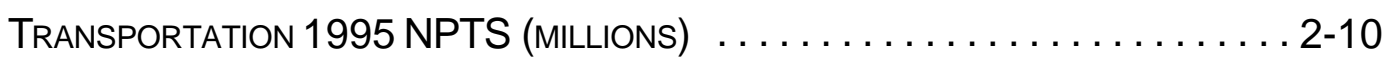

Table 2.5 Total Person Miles of Travel by Data Source, Mode of TRANSPORTATION, AND TRIP PURPOSE 1995 NPTS (MILLIONS) $\ldots \ldots \ldots \ldots 2-12$

Table 2.6 Total Person Miles of Travel by Data Source, Mode of TRANSPORTATION, AND TRIP LENGTH 1995 NPTS (MILLIONS) ........... 2-13

Table 2.7 Total Vehicle Miles of Travel by Data Source and Trip Purpose

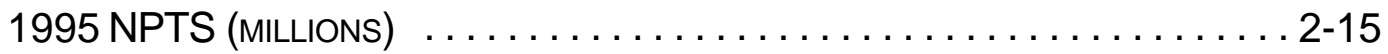

Table 2.8 Total Vehicle Miles of Travel by Data Source AND 1990TriP PURPOSE 1995 NPTS (MILLIONS) ........................ 2-16

Table 2.9 Total Vehicle Miles of Travel by Data Source and Vehicle Type 1995 NPTS (MILLIONS) . . . . . . . . . . . . . . . . . .

Table 2.10 Total Vehicle Miles of Travel by Data Source and Trip Length 1995 NPTS (MILLIONS) $\ldots \ldots \ldots \ldots \ldots \ldots \ldots \ldots \ldots \ldots \ldots \ldots \ldots \ldots \ldots \ldots \ldots . .18$

\section{LIST OF FIGURES}

Figure 2.1 Distribution of Person Miles of Travel by Data Source and TriP

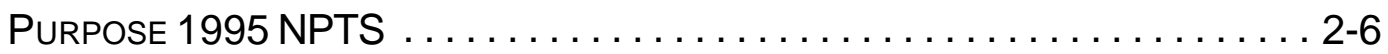

Figure 2.2 Distribution of Person Miles of Travel by Data Source and Mode of Transportation 1995 NPTS $\ldots \ldots \ldots \ldots \ldots \ldots \ldots \ldots \ldots .2-9$

Figure 2.3 Distribution of Vehicle Miles by Data Source and Trip Purpose

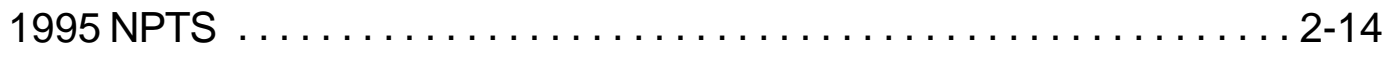




峞




\section{Chapter 2 Estimates of Total Travel}

$\mathrm{E}$ STIMATES of total personal travel are critical for planning for future transportation needs. Total person and vehicle miles are used for analyzing traffic by mode, trips by purpose, and lengths of trips. Personal transportation by vehicle type can be useful for evaluation of the environmental effects of transportation. In addition, decisions on infrastructure enhancements and community facilities are based on transportation patterns and trends.

Using interviews and travel diaries, NPTS collected travel data from the perspectives of both individual trips and aggregate mileage estimates. This survey design was selected because having more than one source for travel data reduces imputation of missing data.

Trip level data were collected for:

- a single travel day (information on trips of household members and vehicles), and

- a travel period of two weeks (information on trips of 75 miles or more).

Aggregate estimates were collected for:

- annual estimates of travel for each household driver,

- annual estimates of mileage for each household vehicle, and

- commercial driving for respondents who drive as part of their work.

Using multiple approaches to questions concerning travel distances permits a clearer analysis of the impact of long, infrequent trips and commercial travel relative to usual daily travel. The combined estimates from travel day data plus travel period data plus commercial driving are used most often when comparing NPTS data to sources that are designed to reflect the full universe of travel, such as the Federal Highway Administration (FHWA) document Highway Statistics. The combined estimates are also used when the longer-trip component of travel is a critical element of the travel inventory. The next two sections discuss the trip level data and aggregate estimates in greater detail.

\subsection{Trip LeVel Data}

Trip level data in the 1995 NPTS were collected using the travel day data source and the travel period data source (two different sections of the NPTS questionnaire).

The travel day for each household encompassed a 24-hour period from 4 a.m. of the designated day until 3:59 a.m. of the following day. Although the travel on this single day may not be typical of the household's usual travel, the aggregation of travel reported by all households provides a representative look at overall travel behavior. Data on all trips taken on the designated travel day were collected, including trips of all lengths, all modes, all purposes, and for all family members of age 5 and over. For each trip on the designated travel day, a wide variety of characteristics were collected, including time of day, trip length (miles), trip duration (minutes), vehicle used, number of people on the trip, and identity of the driver. Travel day data estimate the following totals for 1995:

- 3,411 billion annual national person miles of travel (PMT), and 
- 2,068 billion annual national vehicle miles of travel (VMT).

These figures represent an annual increase of about 581 billion person miles and almost 373 billion vehicle miles over the 1990 adjusted NPTS national travel estimates. ${ }^{1}$ On a per driver basis, the average American drove 11,730 miles in household-based vehicles in 1995 and traveled 14,115 miles by all modes of transportation (including private vehicles).

In addition to the trips reported on a respondent's travel day, NPTS included separate questions on long trips (defined as trips of 75 miles or more one-way) taken during the two-week period prior to and including the travel day. The purpose of reporting longer trips over this extended period was to identify intercity trips that occur infrequently.

If a long trip occurred on the travel day, it was reported in both the travel day and the travel period sections. Trips reported in both sections are referred to as the travel day - travel period overlap. When data from the travel day are used in combination with data from the travel period, those overlap trips are removed from the travel day estimates to avoid doublecounting. The tables in this Databook that represent travel day data with the overlap trips removed are labeled "Travel Day Adjusted."

Data from travel day and travel period sections are combined to generate estimates of total person miles of travel and total vehicle miles of

\footnotetext{
${ }^{1}$ Because the 1995 NPTS used improved survey methodologies, the 1990 data were adjusted to make them more comparable to the 1995 data. See Section 1.4 and Appendix $\mathrm{B}$ for a more comprehensive explanation of these adjustments.
}

travel. To find a total number of trips, one should not, however, add the number of trips reported for the travel day to those reported for the travel period because the definition of a "trip" was not the same in those two sections. In the travel day section, a trip was defined as any one-way travel from one place (address) to another by any means of transportation. When travel was to more than one destination, a separate trip was generated each time the purpose for one destination was different from that of another or when the travel time between two destinations exceeded five minutes. In the travel period section, a trip was defined as travel to a destination at least 75 miles from home, with the return trip within the two-week travel period.

\subsection{Aggregate Estimates of TrAVEL}

Respondents were requested to provide three different estimates of miles driven: annual miles by driver, annual miles by household vehicle, and weekly miles for persons who drive as an essential part of their work.

In addition to the trip-level data, an annual estimate of miles driven was obtained for each household driver. For the driver, the estimate included driving done in all vehicles, whether the vehicles belonged to the household or not.

The annual estimate of miles driven in each vehicle owned by or available to the household was obtained by asking for an estimate of all miles driven in that vehicle, whether driven by household members or not. If a vehicle had been owned less than a year, the respondent was asked to estimate the miles driven from the time the vehicle was acquired by this household and to provide the number of months since it 
was acquired. Thus, an annual estimate was generated for those vehicles acquired within the past year. In addition to the owner's estimate, two odometer readings and the associated date of the readings, taken two to six months apart, were attempted for each household vehicle. A model to estimate annual miles driven from these two readings and other information was developed. The odometer readings were collected and annualized to produce a separate estimate of VMT.

People who drive commercially were not asked to list the individual trips they made on the job. Rather they were asked to estimate total miles driven as part of their work during an average week. The other data collected on commercial driving included the type of vehicle used and the number of days in a typical week that this type of driving was done. All of the mileage estimates reported for commercial driving are for work-related travel. For their other travel, such as trips to the store, picking up children from school, going to a movie, or commuting between home and work, they were asked to report information for each individual trip.

\subsection{Estimate of Total Travel}

Total PMT may be estimated from the individual trip data - travel day data, or travel day data adjusted (i.e., without the overlap trips) combined with travel period data. However, PMT for commercial driving can not be estimated since information on the average number of persons on a typical trip is unavailable.

Total VMT may be calculated using various sections (i.e., data sources) of the NPTS questionnaire - travel day, travel period, and aggregate estimates by driver miles, vehicle miles, and commercial driving miles.

The following chart identifies the sections of the NPTS questionnaire from which data can be used to estimate PMT and VMT.

\begin{tabular}{|c|c|c|}
\hline Section of the 1995 NPTS Questionnaire & Person Miles & Vehicle Miles \\
\hline Travel Day & $\boldsymbol{x}$ & $\boldsymbol{x}$ \\
\hline Travel Period & $\mathbf{x}$ & $\boldsymbol{x}$ \\
\hline Travel Day Adjusted Plus Travel Period & $\boldsymbol{*}$ & $\boldsymbol{*}$ \\
\hline Commercial Driving Milage Estimate & & $\boldsymbol{*}$ \\
\hline Travel Day Adjusted Plus Travel Period Plus Commercial Driving & & $\mathbf{x}$ \\
\hline Estimated Annual Miles Driven per Driver & & $\boldsymbol{x}$ \\
\hline Estimated Annual Miles Driven per Vehicle & & $\boldsymbol{*}$ \\
\hline Odometer Readings & & $\boldsymbol{x}$ \\
\hline
\end{tabular}


Data reported in the travel day section of the NPTS questionnaire serve as the core data source of the Databook simply because of the high degree of interest in average daily travel patterns and the level of detail on individual trips. However, in some instances, a given data source is used for the convenience of comparing 1995 data with those from earlier NPTS surveys. The chart below lists the main data sources of material in each chapter. In the remainder of this chapter, estimated total travel using data from different sections is presented.

\begin{tabular}{|c|c|c|c|c|c|}
\hline & Travel Day & Travel Period & $\begin{array}{l}\text { Estimated } \\
\text { Mileage per } \\
\text { Driver }\end{array}$ & $\begin{array}{c}\text { Estimated } \\
\text { Mileage per } \\
\text { Vehicle }\end{array}$ & $\begin{array}{c}\text { Commercial } \\
\text { Driving Section }\end{array}$ \\
\hline Chapter 2 & * & $x$ & $x$ & $x$ & $x$ \\
\hline Chapter 3 & & & $\boldsymbol{*}$ & $x$ & \\
\hline Chapter 4 & x & & & & \\
\hline Chapter 5 & * & & & & \\
\hline Chapter 6 & $\boldsymbol{x}$ & & & & \\
\hline Chapter 7 & $x$ & & & & \\
\hline Chapter 8 & $x$ & & & & \\
\hline
\end{tabular}


Table 2.1 provides summary statistics of total annual travel based on different sections of the NPTS questionnaire. Because information was not collected on the average number of persons on a typical commercial trip, total person miles for commercial trips can not be estimated. Aggregate estimates for annual driver VMT and vehicle VMT from the driver and vehicle sections of the questionnaire are provided, as are annualized results of the odometer readings.

The sum of all annual estimates of driving should be comparable to total VMT estimates from other sources. Based on annual estimates made by individual drivers, the 1995 NPTS estimated the annual national VMT at 2,077,568 million miles, while the estimate based on traffic counts submitted by the State highway agencies to the Federal Highway Administration (FHWA) as reported in its publication Highway Statistics, Table VM-1, for 1995, was 2,228,435 million miles, which is $7.3 \%$ higher than the NPTS estimate. Total VMT based on the sum of the vehicle miles recorded in the travel day (adjusted) section, travel period section, and commercial driving section equals 2,452,847 million miles, which is within $1 \%$ of the FHWA estimates for total VMT.

\section{TABLE 2.1}

\section{Travel Summary Statistics by Data Source 1995 NPTS}

(MILLIONS)

\begin{tabular}{|c|c|c|c|c|c|c|c|}
\hline & \multirow{2}{*}{$\begin{array}{c}\text { Travel Day } \\
\text { Section } \\
\text { Adjusted }\end{array}$} & \multirow{2}{*}{$\begin{array}{l}\text { Travel } \\
\text { Period } \\
\text { Section }\end{array}$} & \multirow{2}{*}{$\begin{array}{c}\text { Commer- } \\
\text { cial } \\
\text { Driving } \\
\text { Section }\end{array}$} & \multirow[b]{2}{*}{ TOTAL } & \multirow{2}{*}{$\begin{array}{c}\text { Driver } \\
\text { Section }\end{array}$} & \multicolumn{2}{|c|}{ Vehicle Section } \\
\hline & & & & & & $\begin{array}{c}\text { Self- } \\
\text { Estimate }\end{array}$ & $\begin{array}{l}\text { Odometer } \\
\text { Estimate }\end{array}$ \\
\hline $\begin{array}{l}\text { PMT } \\
(000,000)\end{array}$ & $\begin{array}{l}3,188,127 \\
(222,994)\end{array}$ & 869,571 & $* *$ & $4,057,698$ & $* *$ & $* *$ & $* *$ \\
\hline PMT/Person & $\begin{array}{r}13,192 \\
(923)\end{array}$ & 3,598 & $* *$ & 16,790 & $* *$ & $* *$ & $* *$ \\
\hline $\begin{array}{l}\text { VMT } \\
\qquad(000,000)\end{array}$ & $\begin{array}{r}1,976,879 \\
(91,489)\end{array}$ & 385,997 & 89,971 & $2,452,847$ & $2,077,568$ & $1,846,716$ & 850,488 \\
\hline $\begin{array}{l}\text { VMT/Driver } \\
\text { (or Household) }\end{array}$ & $\begin{array}{r}11,211 \\
(519)\end{array}$ & 2,189 & 6,402 & 19,802 & 13,476 & 12,226 & 11,801 \\
\hline
\end{tabular}

Note:

- All tables reporting totals could include some unreported characteristics.

- The numbers in parentheses are the travel estimated for overlap trips, which are excluded from the travel day estimates to avoid double-counting. Travel day estimates without overlap trips are referred to as the "Travel Day Section Adjusted."

- The denominator for annual Commercial VMT per Driver includes the total number of commercial drivers, including those who did not take trips on their travel day.

- $\quad * *$ Indicates no data available. 
Figure 2.1 and Table 2.2 show the distributions of person miles of travel by trip purpose as reported through the travel day and travel period sections of the questionnaire. Almost $80 \%$ of personal travel was reported in the travel day (adjusted) section, which implies that most travel was comprised of trips less than 75 miles long. Trips of 75 miles or more (one way) - that is, the travel period section - were primarily social/recreational trips. Although less than 13\% of all person miles for going to work were listed in the travel period section, over half of the person miles for work-related business were reported in the travel period section.

The returning home category, added in the 1995 NPTS to assist in coding to-from trips, designates the purpose of returning to the respondent's residence. Returning home represents about one-third of all travel day trip purposes. Table 2.3, which is comparable to Table 2.2, uses 1990 trip purposes.

\section{FIGURE 2.1}

Distribution of Person Miles of Travel by Data Source and Trip Purpose 1995 NPTS

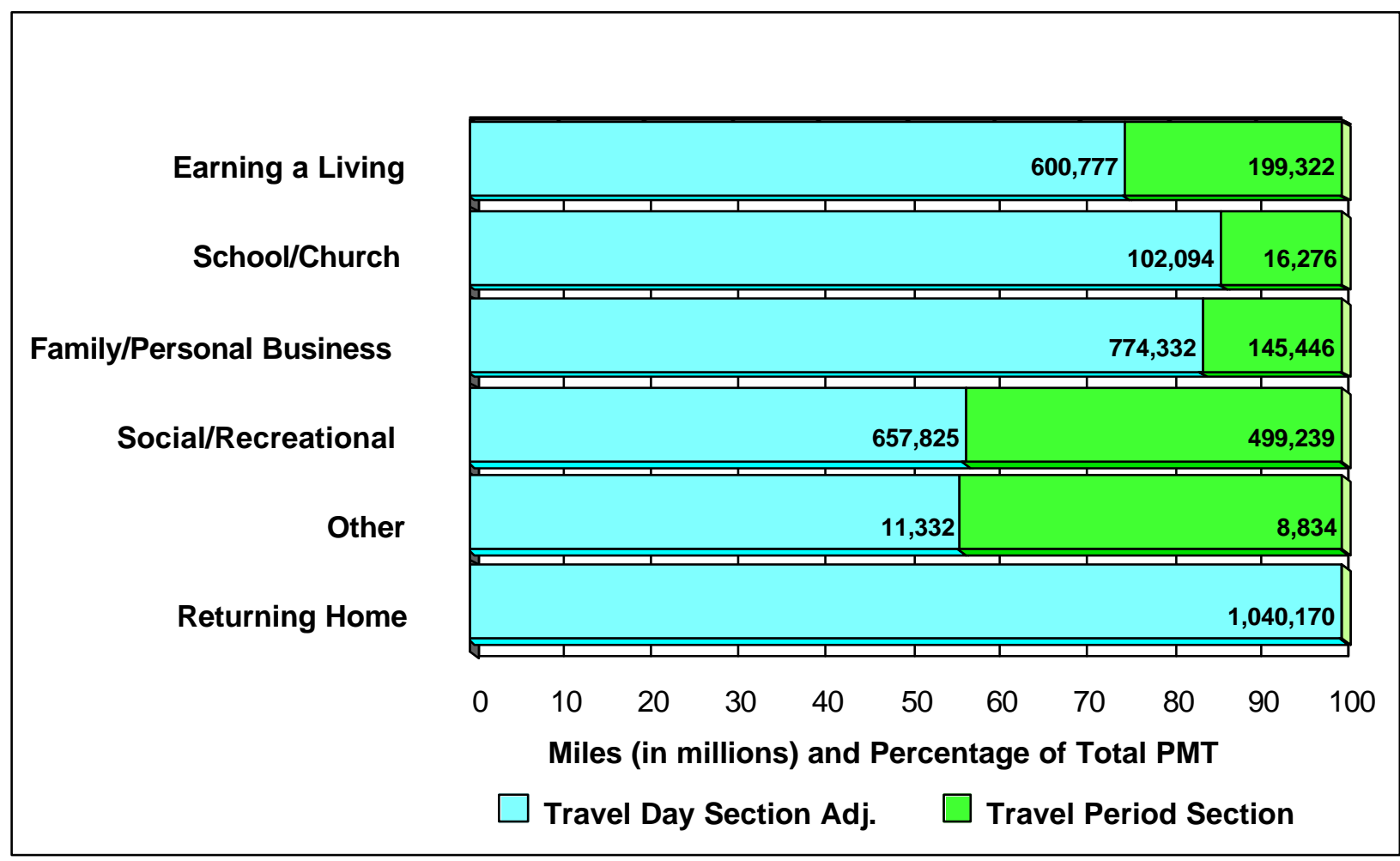


TABLE 2.2

\section{Total Person Miles of Travel by Data Source and Trip Purpose} 1995 NPTS

(MILLIONS)

\begin{tabular}{|c|c|c|c|}
\hline & Travel Day Section Adj. & Travel Period Section & TOTAL \\
\hline ALL & $\begin{array}{c}3,188,127 \\
(222,994)\end{array}$ & 869,571 & $4,057,699$ \\
\hline \multicolumn{4}{|l|}{ Earning a Living } \\
\hline To work & $\begin{array}{r}364,153 \\
(6,025)\end{array}$ & 52,755 & 416,908 \\
\hline Work-related business & $\begin{array}{l}198,723 \\
(11,270)\end{array}$ & 146,567 & 345,291 \\
\hline Return to work & $\begin{array}{l}37,901 \\
(1,784)\end{array}$ & $* *$ & 37,901 \\
\hline \multicolumn{4}{|l|}{ School/Church } \\
\hline School & $\begin{array}{l}64,489 \\
(2,171)\end{array}$ & 10,278 & 74,767 \\
\hline Religious activity & $\begin{array}{r}37,605 \\
(312)\end{array}$ & 5,998 & 43,604 \\
\hline \multicolumn{4}{|l|}{ Family/Personal Business } \\
\hline Shopping & $\begin{array}{l}292,871 \\
(16,398)\end{array}$ & 29,516 & 322,387 \\
\hline Medical/dental & $\begin{array}{r}32,820 \\
(891)\end{array}$ & 10,838 & 43,659 \\
\hline Other family or personal business & $\begin{array}{l}271,635 \\
(23,435)\end{array}$ & 77,295 & 348,930 \\
\hline Take someone somewhere & $\begin{array}{r}100,254 \\
(8,259)\end{array}$ & 14,725 & 114,979 \\
\hline Pick up someone & $\begin{array}{c}76,752 \\
(4,453)\end{array}$ & 13,072 & 89,823 \\
\hline \multicolumn{4}{|l|}{ Social/Recreational } \\
\hline Vacation & $\begin{array}{c}49,263 \\
(2,884)\end{array}$ & 122,240 & 171,504 \\
\hline Visit friends or relatives & $\begin{array}{c}242,120 \\
(14,463)\end{array}$ & 198,232 & 440,353 \\
\hline Out to eat & $\begin{array}{r}115,682 \\
(7,285)\end{array}$ & 750 & 116,432 \\
\hline Other social/recreational & $\begin{array}{l}250,760 \\
(20,879)\end{array}$ & 178,017 & 428,777 \\
\hline \multicolumn{4}{|l|}{ Other and Returning Home } \\
\hline Other & $\begin{array}{l}11,332 \\
(1,303)\end{array}$ & 8,834 & 20,166 \\
\hline Returning Home & $\begin{array}{c}1,040,170 \\
(101,181)\end{array}$ & $* *$ & $1,040,170$ \\
\hline
\end{tabular}

Note:

- All tables reporting totals could include some unreported characteristics.

- Totals may not equal sums of columns due to rounding errors.

- The numbers in parentheses are the travel estimated for overlap trips, which are excluded from the travel day estimates to avoid double-counting. Travel day estimates without overlap trips are referred to as the "Travel Day Section Adjusted."

- $\quad * *$ Indicates no data available.

- For information on comparing 1990 and 1995 trip purpose codes see Table 4.7 of Chapter 4 . All tables in Chapter 2 utilize the 1995 trip purpose codes unless otherwise noted. 
TABLE 2.3

Total Person Miles of Travel by Data Source And 1990 Trip Purpose
1995 NPTS
(Millions)

\begin{tabular}{|c|c|c|c|}
\hline & Travel Day Section Adj. & Travel Period Section & TOTAL \\
\hline ALL & $\begin{array}{c}3,188,127 \\
(222,994)\end{array}$ & 869,571 & $4,057,699$ \\
\hline \multicolumn{4}{|l|}{ Earning a Living } \\
\hline To work & $\begin{array}{l}743,123 \\
(23,051)\end{array}$ & 52,755 & 795,878 \\
\hline Work-related business & $\begin{array}{l}186,591 \\
(10,108)\end{array}$ & 146,567 & 333,158 \\
\hline \multicolumn{4}{|l|}{ School/Church } \\
\hline School/church & $\begin{array}{r}188,143 \\
(7,143)\end{array}$ & 16,276 & 204,419 \\
\hline \multicolumn{4}{|l|}{ Family/Personal Business } \\
\hline Shopping & $\begin{array}{l}433,683 \\
(27,490)\end{array}$ & 29,516 & 463,199 \\
\hline Medical/dental & $\begin{array}{l}50,392 \\
(2,326)\end{array}$ & 10,838 & 61,230 \\
\hline Other family or personal business & $\begin{array}{l}620,357 \\
(57,541)\end{array}$ & 105,092 & 725,449 \\
\hline \multicolumn{4}{|l|}{ Social/Recreational } \\
\hline Vacation & $\begin{array}{l}52,889 \\
(4,304)\end{array}$ & 122,240 & 175,130 \\
\hline Visit friends or relatives & $\begin{array}{l}344,937 \\
(37,781)\end{array}$ & 198,232 & 543,169 \\
\hline Other social/recreational & $\begin{array}{l}554,841 \\
(51,679)\end{array}$ & 178,767 & 733,608 \\
\hline \multicolumn{4}{|l|}{ Other } \\
\hline Other & $\begin{array}{c}11,436 \\
(1,572)\end{array}$ & 8,834 & 20,270 \\
\hline
\end{tabular}

Note:

- All tables reporting totals could include some unreported characteristics.

- Totals may not equal sums of columns due to rounding errors.

- The numbers in parentheses are the travel estimated for overlap trips. These estimates are excluded from the travel day estimates to avoid double-counting. Travel day estimates without overlap trips are referred to as the "Travel Day Section Adjusted".

- For information on comparing 1990 and 1995 trip purpose codes see Table 4.7 of Chapter 4 . All tables in Chapter 2 utilize the 1995 trip purpose codes unless otherwise noted. 
The distribution of travel by data source and mode of transportation is shown in Figure 2.2. In this figure, the person miles reported via the travel section of the report are shown in "exploded" format, which demonstrates the importance of the travel day reporting.

Table 2.4 provides person miles in detail for the different modes. Private vehicles are the most frequent mode used (about $88 \%$ ) for all travel, in both the travel day and the travel period sections. Of all travel in privately owned vehicles (POVs), $82 \%$ is from the travel day section. When travel is by public transit, about $60 \%$ is from the travel day section. For travel by all other modes (about $8.7 \%$ of all travel), over half $(56 \%)$ of the person miles traveled is reported in the travel period section rather than in the travel day section.

FIGURE 2.2

Distribution of Person Miles of Travel by Data Source and Mode of Transportation 1995 NPTS

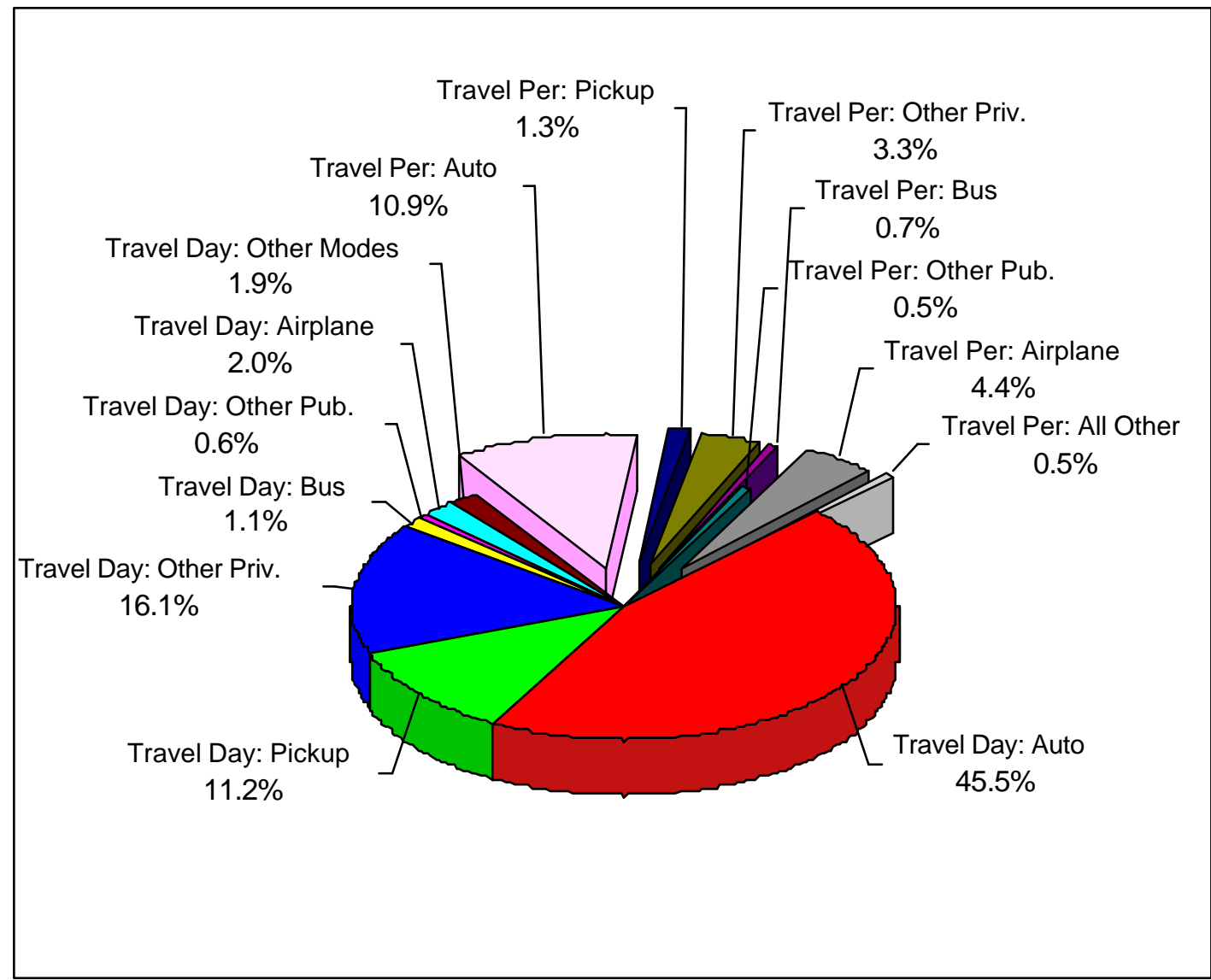


TABLE 2.4

\section{Total Person Miles of Travel by Data Source and Mode of Transportation 1995 NPTS}

(MILLIONS)

\begin{tabular}{|c|c|c|c|}
\hline & $\begin{array}{c}\text { Travel Day } \\
\text { Section Adjusted } \\
\end{array}$ & $\begin{array}{l}\text { Travel Period } \\
\text { Section } \\
\end{array}$ & TOTAL \\
\hline ALL & $\begin{array}{l}3,188,127 \\
(222,994)\end{array}$ & 869,571 & $4,057,698$ \\
\hline Private Vehicles, SUBTOTAL & $2,930,432$ & 625,182 & $3,555,614$ \\
\hline Auto & $\begin{array}{l}1,832,602 \\
(111,401)\end{array}$ & 440,373 & $2,272,975$ \\
\hline Van & $\begin{array}{l}332,073 \\
(26,511)\end{array}$ & 83,311 & 415,384 \\
\hline Sports Utility Vehicle & $\begin{array}{l}225,443 \\
(12,799)\end{array}$ & 24,979 & 250,422 \\
\hline Pickup & $\begin{array}{l}449,397 \\
(22,019)\end{array}$ & 50,800 & 500,197 \\
\hline Other Truck & $\begin{array}{l}79,649 \\
(5,974)\end{array}$ & 21,923 & 101,572 \\
\hline RV & $\begin{array}{c}5,542 \\
(1,115)\end{array}$ & 1,799 & 7,341 \\
\hline Motorcycle & $\begin{array}{r}3,994 \\
(* *)\end{array}$ & 541 & 4,535 \\
\hline Other POV & $\begin{array}{r}1,732 \\
(0)\end{array}$ & 1,456 & 3,188 \\
\hline Public transportation, SUBTOTAL & 70,453 & 47,202 & 95,553 \\
\hline Bus & $\begin{array}{l}45,946 \\
(2,082)\end{array}$ & 28,329 & 74,275 \\
\hline Commuter Train & $\begin{array}{r}12,472 \\
(26)\end{array}$ & 8,507 & 20,979 \\
\hline Streetcar/Trolley & $\begin{array}{l}127 \\
(* *)\end{array}$ & 150 & 277 \\
\hline Subway/Elevated Rail & $\begin{array}{r}11,908 \\
(17)\end{array}$ & 10,216 & 22,124 \\
\hline All Other Modes, SUBTOTAL & 156,227 & 196,658 & 326,938 \\
\hline Amtrak & $\begin{array}{r}1,642 \\
(22)\end{array}$ & 4,742 & 6,384 \\
\hline Airplane & $\begin{array}{c}81,240 \\
(35,455)\end{array}$ & 178,304 & 259,544 \\
\hline Taxi & $\begin{array}{r}2,919 \\
(286)\end{array}$ & 0 & 2,919 \\
\hline Bike & $\begin{array}{l}4,561 \\
(25)\end{array}$ & 1 & 4,562 \\
\hline Walk & $\begin{array}{r}10,780 \\
(41)\end{array}$ & 1,328 & 12,108 \\
\hline School Bus & $\begin{array}{r}42,875 \\
\quad(517)\end{array}$ & 1,257 & 44,132 \\
\hline Other & $\begin{array}{l}12,210 \\
(1,650)\end{array}$ & 11,026 & 23,236 \\
\hline
\end{tabular}

Note:

- All tables reporting totals could include some unreported characteristics.

- The numbers in parentheses are the travel estimated for overlap trips, which are excluded from the travel day estimates to avoid double-counting. Travel day estimates without overlap trips are referred to as the "Travel Day Section Adjusted."

- ** Indicates no data available. 
Nearly $80 \%$ of all travel was reported on the travel day (adjusted data). Tables 2.5 and 2.6 compare trip purposes and trip lengths by mode for travel day and travel period sections. As might be expected, most airplane travel was reported in the travel period section. Over half of the PMT reported in the travel period section was for a social/recreational trip purpose. Of the 499,239 million miles traveled for social/recreational purposes, about $75 \%$ was via POV and $18 \%$ was via airplane. While about $92 \%$ of all travel day travel was by POV, only about $72 \%$ of travel period travel used private vehicles. 


\section{TABLE 2.5}

Total Person Miles of Travel by Data Source, Mode of Transportation, AND TRIP PURPOSE

1995 NPTS

(MILLIONS)

\begin{tabular}{|c|c|c|c|c|c|c|c|}
\hline & ALL & Private & $\begin{array}{c}\text { Commuter } \\
\text { Train } \\
\end{array}$ & $\begin{array}{l}\text { Other } \\
\text { Public }\end{array}$ & Amtrak & Airplane & Other \\
\hline \multicolumn{8}{|l|}{ ALL } \\
\hline Travel Day Adjusted & $3,188,127$ & $2,930,431$ & 12,472 & 57,980 & 1,642 & 81,240 & 73,343 \\
\hline Travel Period & 869,571 & 625,180 & 8,507 & 38,695 & 4,742 & 178,304 & 13,613 \\
\hline \multicolumn{8}{|l|}{ Earning a Living } \\
\hline Travel Day Adjusted & 600,778 & 542,003 & 5,019 & 10,947 & 109 & 27,162 & 10,205 \\
\hline Travel Period & 199,322 & 116,306 & 3,273 & 7,505 & 248 & 64,401 & 7,550 \\
\hline \multicolumn{8}{|c|}{ Family/Personal Business } \\
\hline Travel Day Adjusted & 774,332 & 735,954 & 1,242 & 8,648 & 358 & 12,952 & 7,310 \\
\hline Travel Period & 145,446 & 117,262 & 3,411 & 4,702 & 257 & 19,445 & 248 \\
\hline \multicolumn{8}{|l|}{ School/Church } \\
\hline Travel Day Adjusted & 102,095 & 78,086 & 101 & 3,889 & $* *$ & 0 & 19,150 \\
\hline Travel Period & 16,276 & 14,387 & $* *$ & 1,064 & 88 & 408 & 307 \\
\hline \multicolumn{8}{|l|}{ Social/Recreational } \\
\hline Travel Day Adjusted & 657,826 & 600,347 & 1,362 & 12,217 & 856 & 26,164 & 11,513 \\
\hline Travel Period & 499,239 & 371,352 & 1,823 & 24,388 & 4,104 & 92,231 & 5,199 \\
\hline \multicolumn{8}{|l|}{ Other } \\
\hline Travel Day Adjusted & 11,332 & 6,843 & 25 & 89 & $* *$ & 4,090 & 200 \\
\hline Travel Period & 8,834 & 5,616 & 1 & 1,036 & 44 & 1,820 & 308 \\
\hline \multicolumn{8}{|l|}{ Returning Home } \\
\hline Travel Day Adjusted & $1,040,170$ & 965,621 & 4,722 & 22,192 & 320 & 10,871 & 24,964 \\
\hline Travel Period & $* *$ & $* *$ & $* *$ & $* *$ & $* *$ & $* *$ & $* *$ \\
\hline
\end{tabular}

Note:

- All tables reporting totals could include some unreported characteristics.

- Travel day estimates without overlap trips are referred to as the "Travel Day Section Adjusted."

- ** Indicates no data available.

- For information on comparing 1990 and 1995 trip purpose codes see Table 4.7 of Chapter 4. All tables in Chapter 2 utilize the 1995 trip purpose codes unless otherwise noted. 
TABLE 2.6

Total Person Miles of Travel by Data Source, Mode of Transportation,

AND TRIP LENGTH

1995 NPTS

(MILLIONS)

\begin{tabular}{|c|c|c|c|c|c|c|c|}
\hline & ALL & Private & $\begin{array}{c}\text { Commuter } \\
\text { Train }\end{array}$ & $\begin{array}{l}\text { Other } \\
\text { Public }\end{array}$ & Amtrak & Airplane & Other \\
\hline \multicolumn{8}{|l|}{ ALL } \\
\hline Travel Day Adjusted & $3,188,127$ & $2,930,431$ & 12,472 & 57,980 & 1,642 & 81,240 & 73,343 \\
\hline Travel Period & 869,571 & 625,180 & 8,507 & 38,695 & 4,742 & 178,304 & 13,613 \\
\hline \multicolumn{8}{|l|}{0 to 5 miles } \\
\hline Travel Day Adjusted & 489,549 & 448,329 & 311 & 8,097 & 2 & 1 & 26,820 \\
\hline Travel Period & 83 & 68 & 2 & 8 & 0 & 4 & 1 \\
\hline \multicolumn{8}{|l|}{6 to 10 miles } \\
\hline Travel Day Adjusted & 472,547 & 445,198 & 741 & 7,820 & 1 & $* *$ & 14,110 \\
\hline Travel Period & 166 & 146 & 0 & 10 & $* *$ & 5 & 4 \\
\hline \multicolumn{8}{|l|}{11 to 20 miles } \\
\hline Travel Day Adjusted & 641,308 & 607,520 & 1,775 & 10,922 & 62 & $* *$ & 13,576 \\
\hline Travel Period & 1,334 & 1,251 & 4 & 48 & 3 & 7 & 18 \\
\hline \multicolumn{8}{|l|}{21 to 30 miles } \\
\hline Travel Day Adjusted & 367,021 & 349,937 & 2,261 & 6,303 & $* *$ & $* *$ & 4,290 \\
\hline Travel Period & 5,351 & 5,165 & 39 & 37 & 32 & 14 & 60 \\
\hline \multicolumn{8}{|l|}{31 to 50 miles } \\
\hline Travel Day Adjusted & 394,872 & 375,312 & 3,548 & 5,628 & 17 & 240 & 6,960 \\
\hline Travel Period & 20,596 & 19,887 & 80 & 290 & 12 & 94 & 212 \\
\hline \multicolumn{8}{|l|}{51 to 100 miles } \\
\hline Travel Day Adjusted & 301,969 & 286,258 & 2,697 & 6,243 & 255 & 634 & 3,895 \\
\hline Travel Period & 99,431 & 96,258 & 114 & 1,484 & 319 & 295 & 877 \\
\hline \multicolumn{8}{|l|}{ Over 100 miles } \\
\hline Travel Day Adjusted & 520,861 & 417,877 & 1,139 & 12,967 & 1,305 & 80,364 & 3,692 \\
\hline Travel Period & 742,610 & 502,405 & 8,267 & 36,819 & 4,376 & 177,886 & 12,441 \\
\hline
\end{tabular}

Note:

- All tables reporting totals could include some unreported characteristics.

- Travel day estimates without overlap trips are referred to as the "Travel Day Section Adjusted."

- ** Indicates no data available. 
Figure 2.3 shows the distribution of vehicle miles of travel by trip purpose as reported through the travel day, travel period, and commercial driving sections of the questionnaire. As shown in the figure, commercial driving vehicles were only driven in the category of earning a living.
Tables 2.7-2.8 describe total VMT for household vehicles from the perspective of trip purpose.. Table 2.7 uses 1995 trip purpose codes and Table 2.8 uses 1990 codes. While over $21.4 \%$ of the total PMT was listed in the travel period section (see Table 2.2), the travel period section contained only about $16 \%$ of the household VMT. Most household VMT was for a social/recreational trip purpose.

\section{FIGURE 2.3}

Distribution of Vehicle Miles by Data Source And Trip Purpose 1995 NPTS

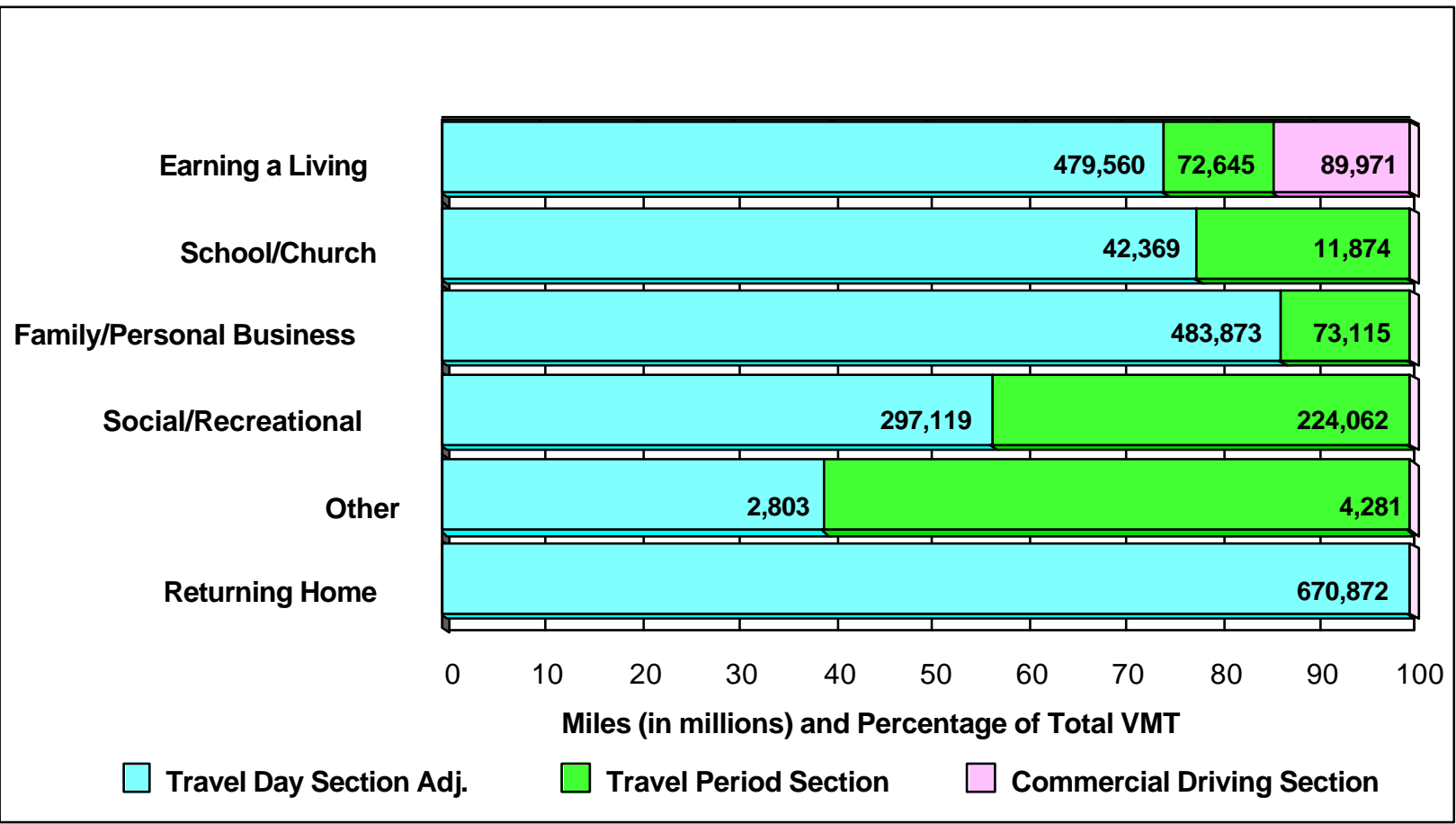


TABLE 2.7

Total Vehicle Miles of Travel by Data Source and Trip Purpose 1995 NPTS

(MILLIONS)

\begin{tabular}{|c|c|c|c|c|}
\hline & $\begin{array}{c}\text { Travel Day Section } \\
\text { Adjusted }\end{array}$ & Travel Period Section & $\begin{array}{c}\text { Commercial Driving } \\
\text { Section }\end{array}$ & TOTAL \\
\hline ALL & $\begin{array}{r}1,976,879 \\
(91,489)\end{array}$ & 385,997 & 89,971 & $2,452,847$ \\
\hline \multicolumn{5}{|l|}{ Earning a Living } \\
\hline To work & $\begin{array}{r}308,379 \\
\quad(5,117)\end{array}$ & 16,032 & $* *$ & 324,411 \\
\hline Work-related business & $\begin{array}{r}141,578 \\
(6,811)\end{array}$ & 56,613 & 89,971 & 288,162 \\
\hline Return to work & $\begin{array}{l}29,603 \\
(1,306)\end{array}$ & $* *$ & $* *$ & 29,603 \\
\hline \multicolumn{5}{|l|}{ School/Church } \\
\hline School & $\begin{array}{l}23,355 \\
(1,541)\end{array}$ & 8,535 & $* *$ & 31,890 \\
\hline Religious activity & $\begin{array}{r}19,014 \\
(255)\end{array}$ & 3,339 & $* *$ & 22,353 \\
\hline \multicolumn{5}{|l|}{ Family/Personal Business } \\
\hline Shopping & $\begin{array}{r}178,194 \\
(6,160)\end{array}$ & 13,377 & $* *$ & 191,571 \\
\hline Medical/dental & $\begin{array}{r}19,677 \\
(197)\end{array}$ & 5,016 & $* *$ & 24,693 \\
\hline $\begin{array}{l}\text { Other family/personal } \\
\text { business }\end{array}$ & $\begin{array}{r}153,983 \\
(4,732)\end{array}$ & 32,012 & $* *$ & 185,996 \\
\hline Take someone somewhere & $\begin{array}{l}70,342 \\
(5,707)\end{array}$ & 12,136 & $* *$ & 82,477 \\
\hline Pick up someone & $\begin{array}{l}61,677 \\
(2,856)\end{array}$ & 10,574 & $* *$ & 72,252 \\
\hline \multicolumn{5}{|l|}{ Social/Recreational } \\
\hline Vacation & $\begin{array}{l}17,505 \\
(1,184)\end{array}$ & 38,765 & $* *$ & 56,270 \\
\hline Visit friends or relatives & $\begin{array}{l}123,800 \\
(5,806)\end{array}$ & 99,308 & $* *$ & 223,108 \\
\hline Out to eat & $\begin{array}{l}57,003 \\
(2,279)\end{array}$ & 305 & $* *$ & 57,308 \\
\hline Other social/recreational & $\begin{array}{l}98,811 \\
(7,239)\end{array}$ & 85,684 & $* *$ & 184,495 \\
\hline \multicolumn{5}{|l|}{ Other and Returning Home } \\
\hline Other & $\begin{array}{r}2,803 \\
(681)\end{array}$ & 4,281 & $* *$ & 7,084 \\
\hline Returning Home & $\begin{array}{l}670,872 \\
(39,616) \\
\end{array}$ & $* *$ & $* *$ & 670,872 \\
\hline
\end{tabular}

Note:

- All tables reporting totals could include some unreported characteristics.

- Totals may not equal sums of columns due to rounding errors.

- The numbers in parentheses are the travel estimated for overlap trips, which are excluded from the travel day estimates to avoid double-counting. Travel day estimates without overlap trips are referred to as the "Travel Day Section Adjusted."

- ** Indicates no data available.

- For information on comparing 1990 and 1995 trip purpose codes see Table 4.7 of Chapter 4 . All tables in Chapter 2 utilize the 1995 trip purpose codes unless otherwise noted. 


\section{TABLE 2.8}

\section{Total Vehicle Miles of Travel by Data Source And 1990 Trip Purpose 1995 NPTS \\ (MILLIONS)}

\begin{tabular}{|c|c|c|c|c|}
\hline & $\begin{array}{c}\text { Travel Day Section } \\
\text { Adjusted } \\
\end{array}$ & Travel Period Section & $\begin{array}{c}\text { Commercial Driving } \\
\text { Section } \\
\end{array}$ & TOTAL \\
\hline ALL & $\begin{array}{r}1,976,879 \\
(91,489)\end{array}$ & 385,997 & 89,971 & $2,452,847$ \\
\hline \multicolumn{5}{|l|}{ Earning a Living } \\
\hline To work & $\begin{array}{l}627,635 \\
(14,975)\end{array}$ & 16,032 & $* *$ & 643,667 \\
\hline Work-related business & $\begin{array}{r}132,211 \\
(5,656)\end{array}$ & 56,613 & 89,971 & 278,796 \\
\hline \multicolumn{5}{|l|}{ School/Church } \\
\hline School/church & $\begin{array}{l}74,972 \\
(3,342)\end{array}$ & 11,873 & $* *$ & 86,845 \\
\hline \multicolumn{5}{|l|}{ Family/Personal Business } \\
\hline Shopping & $\begin{array}{l}267,223 \\
(10,638)\end{array}$ & 13,377 & $* *$ & 280,600 \\
\hline Medical/dental & $\begin{array}{r}30,251 \\
(363)\end{array}$ & 5,016 & $* *$ & 35,266 \\
\hline $\begin{array}{l}\text { Other family/personal } \\
\text { business }\end{array}$ & $\begin{array}{l}402,766 \\
(23,564)\end{array}$ & 54,722 & $* *$ & 457,488 \\
\hline \multicolumn{5}{|l|}{ Social/Recreational } \\
\hline Vacation & $\begin{array}{l}18,234 \\
(2,084)\end{array}$ & 38,765 & $* *$ & 56,999 \\
\hline Visit friends or relatives & $\begin{array}{l}183,272 \\
(11,796)\end{array}$ & 99,308 & $* *$ & 282,580 \\
\hline Other social/recreational & $\begin{array}{l}237,174 \\
(18,995)\end{array}$ & 85,989 & $* *$ & 323,163 \\
\hline \multicolumn{5}{|l|}{ Other } \\
\hline Other & $\begin{array}{r}2,719 \\
(77) \\
\end{array}$ & 4,281 & $* *$ & 7,000 \\
\hline
\end{tabular}

Note:

- All tables reporting totals could include some unreported characteristics.

- Totals may not equal sums of columns due to rounding errors.

- The numbers in parentheses are the travel estimated for overlap trips. These estimates are excluded from the travel day estimates to avoid double-counting. Travel day estimates without overlap trips are referred to as the "Travel Day Section Adjusted".

- ** Indicates no data available.

- For information on comparing 1990 and 1995 trip purpose codes see Table 4.7 of Chapter 4. All tables in Chapter 2 utilize the 1995 trip purpose codes unless otherwise noted. 
In 1995, most household transportation needs were met using POVs. As shown in Table 2.9, $80 \%$ of the VMT was reported in the travel day (adjusted) section, about $16 \%$ in the travel period section, and about $4 \%$ in the commercial driving section.
About $63 \%$ of the VMT was in automobiles (cars and station wagons). Vans and minivans made up $9 \%$ of the VMT. A new vehicle code for sports utility vehicles (SUVs) was added in the 1995 NPTS for the first time. SUVs accounted for slightly over $7 \%$ of all VMT.

\section{TABLE 2.9}

Total Vehicle Miles of Travel by Data Source and Vehicle Type 1995 NPTS

(MILLIONS)

\begin{tabular}{||l|c|c|c|c||}
\hline \hline \multirow{3}{*}{ ALL } & $\begin{array}{c}\text { Travel Day } \\
\text { Section Adjusted }\end{array}$ & $\begin{array}{c}\text { Travel Period } \\
\text { Section }\end{array}$ & $\begin{array}{c}\text { Commercial Driving } \\
\text { Section }\end{array}$ & TOTAL \\
\hline Auto & $\begin{array}{r}1,976,879 \\
(91,489)\end{array}$ & 385,997 & 89,971 & $2,452,847$ \\
Van & $\begin{array}{c}1,231,246 \\
(57,829)\end{array}$ & 296,031 & 21,056 & $1,548,333$ \\
SUV & $\begin{array}{c}182,858 \\
(10,684)\end{array}$ & 30,443 & 15,064 & 228,365 \\
Truck & $\begin{array}{c}152,611 \\
(6,506)\end{array}$ & 16,909 & 5,949 & 175,469 \\
Other POV & $\begin{array}{c}(16,458) \\
6,231\end{array}$ & 41,895 & 41,585 & 487,414 \\
Other & $* 11)$ & 718 & 1,265 & 8,214 \\
\hline \hline
\end{tabular}

Note:

- All tables reporting totals could include some unreported characteristics.

- The numbers in parentheses are the travel estimated for overlap trips, which are excluded from the travel day estimates to avoid double-counting. Travel day estimates without overlap trips are referred to as the "Travel Day Section Adjusted."

- The "other" mode category for the commercial driving section includes buses, school buses, and taxis.

- ** Indicates no data available. 
Most travel (78\%) recorded in the travel period section was for trips over 100 miles in length.

Trips of 11 to 20 miles in length resulted in more VMT than trips of any other distance. These trips made up 22\% of the total VMT in the travel day (adjusted) section.

TABLE 2.10

Total Vehicle Miles of Travel by Data Source and Trip Length 1995 NPTS

(MILLIONS)

\begin{tabular}{|c|c|c|}
\hline & $\begin{array}{c}\text { Travel Day Adjusted } \\
\text { Section }\end{array}$ & $\begin{array}{l}\text { Travel Period } \\
\text { Section }\end{array}$ \\
\hline TOTAL & $\begin{array}{l}1,976,879 \\
(91,489)\end{array}$ & 385,997 \\
\hline 0 to 5 miles & $\begin{array}{r}314,779 \\
(739)\end{array}$ & 47 \\
\hline 6 to 10 miles & $\begin{array}{r}315,352 \\
(852)\end{array}$ & 97 \\
\hline 11 to 20 miles & $\begin{array}{r}437,805 \\
(1,378)\end{array}$ & 881 \\
\hline 21 to 30 miles & $\begin{array}{r}254,363 \\
(1,977)\end{array}$ & 3,814 \\
\hline 31 to 50 miles & $\begin{array}{r}255,536 \\
(3,366)\end{array}$ & 14,222 \\
\hline 51 to 100 miles & $\begin{array}{l}167,687 \\
(22,264)\end{array}$ & 63,955 \\
\hline Over 100 miles & $\begin{array}{l}231,357 \\
(60,914)\end{array}$ & 302,980 \\
\hline
\end{tabular}

Note:

- All tables reporting totals could include some unreported characteristics.

- The numbers in parentheses are the travel estimated for overlap trips, which are excluded from the travel day estimates to avoid double-counting. Travel day estimates without overlap trips are referred to as the "Travel Day Section Adjusted." Vehicle miles in commercial driving cannot be shown on this table because individual trip lengths were not collected for commercial driving data.

- The travel day section includes linking trips that are part of a travel period trip. For example, an airplane trip from Washington, DC, to Oak Ridge, TN, taken on the travel day, plus ground transportation to and from the airports are considered one trip in the travel period section. However, due to definitional differences, these trips are three separate trips recorded in the travel day section. All of the three trips are referred to as "overlap trips." Consequently, there are overlap trips recorded in the travel day section which, individually, are less than 75 miles long, but collectively are over 75 miles long and, therefore, included in the travel period section as well as in the travel day section. These miles are then adjusted out of the travel day estimates to avoid double counting. 


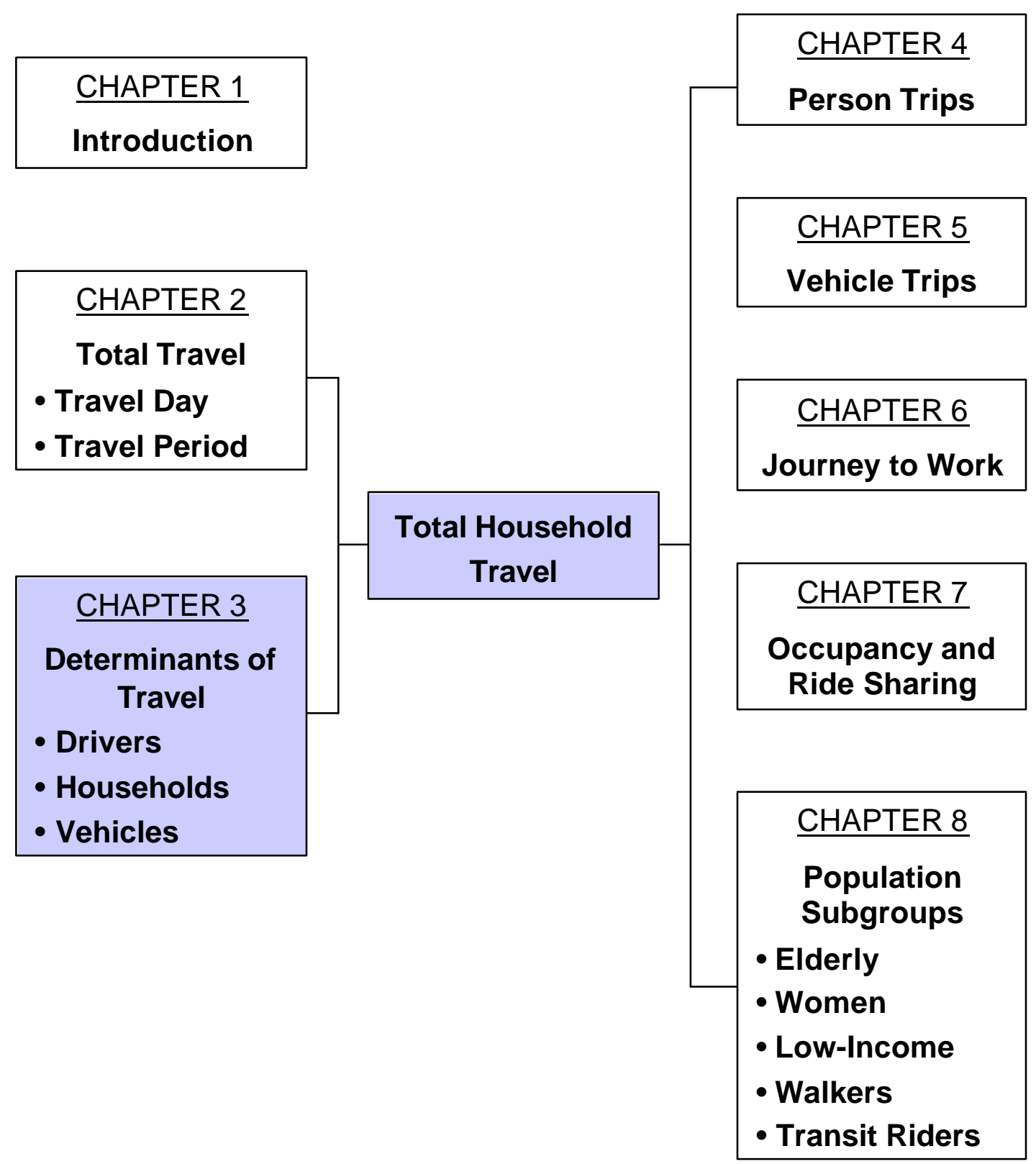




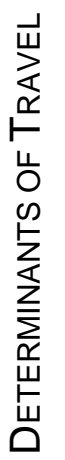

Nationwide PERSONAL TRAVEL SuRVEy 


\section{Chapter 3}

\section{DeterminantS OF TRAVEL}

\section{BETWEEN 1969 AND 1995:}

- The age group 65 or over has increased its ranks by $60 \%$ since the first NPTS in 1969.

- The number of male workers saw a 47\% increase between 1969 and 1995; however, the number of women in the workforce increased $122 \%$.

- The average annual mileage per vehicle was 12,226 miles in 1995 .

- The sport utility vehicle (SUV) made up $6.9 \%$ of the entire household vehicle fleet in 1995. 
(THOUSANDS)

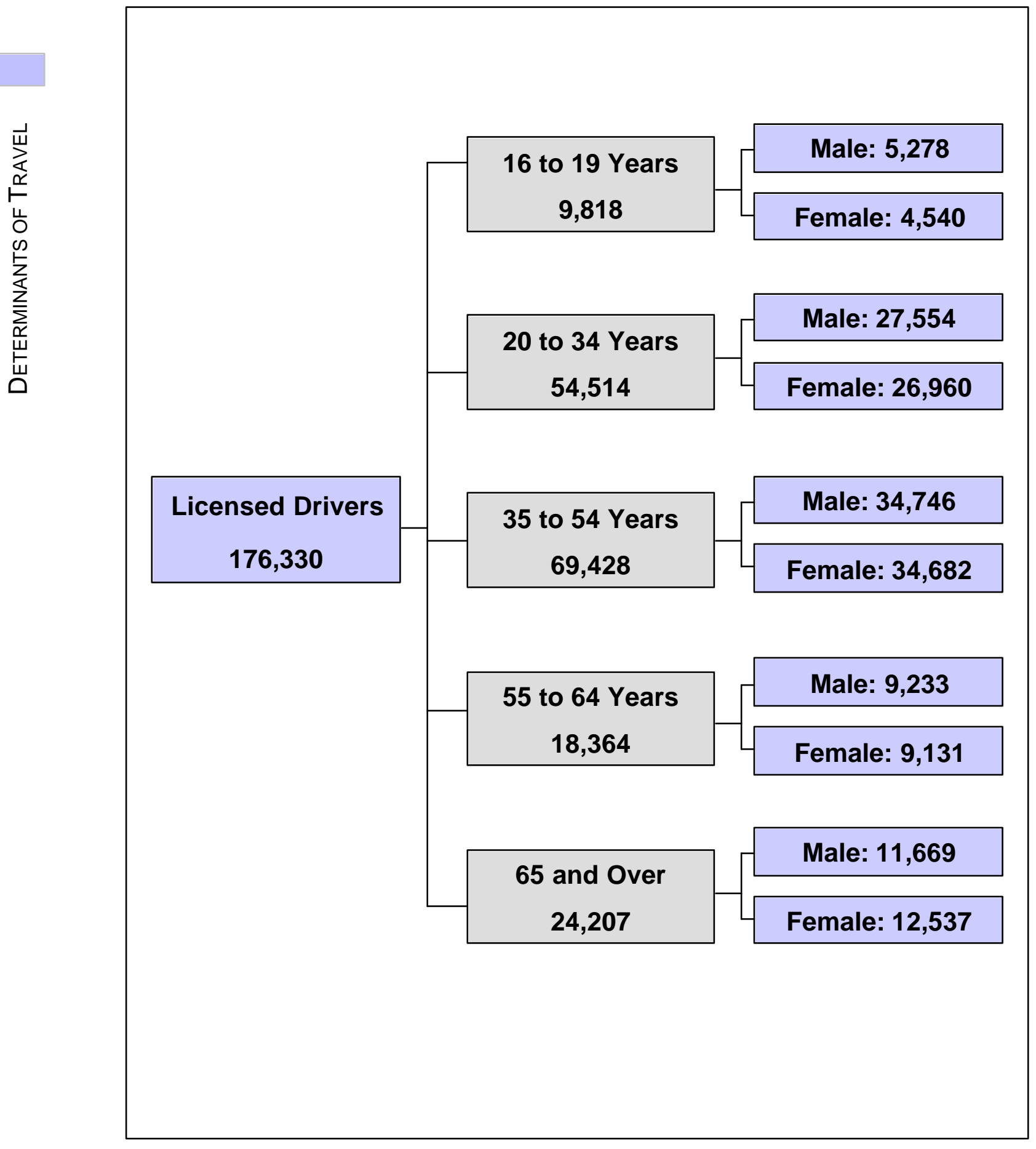


(THOUSANDS)

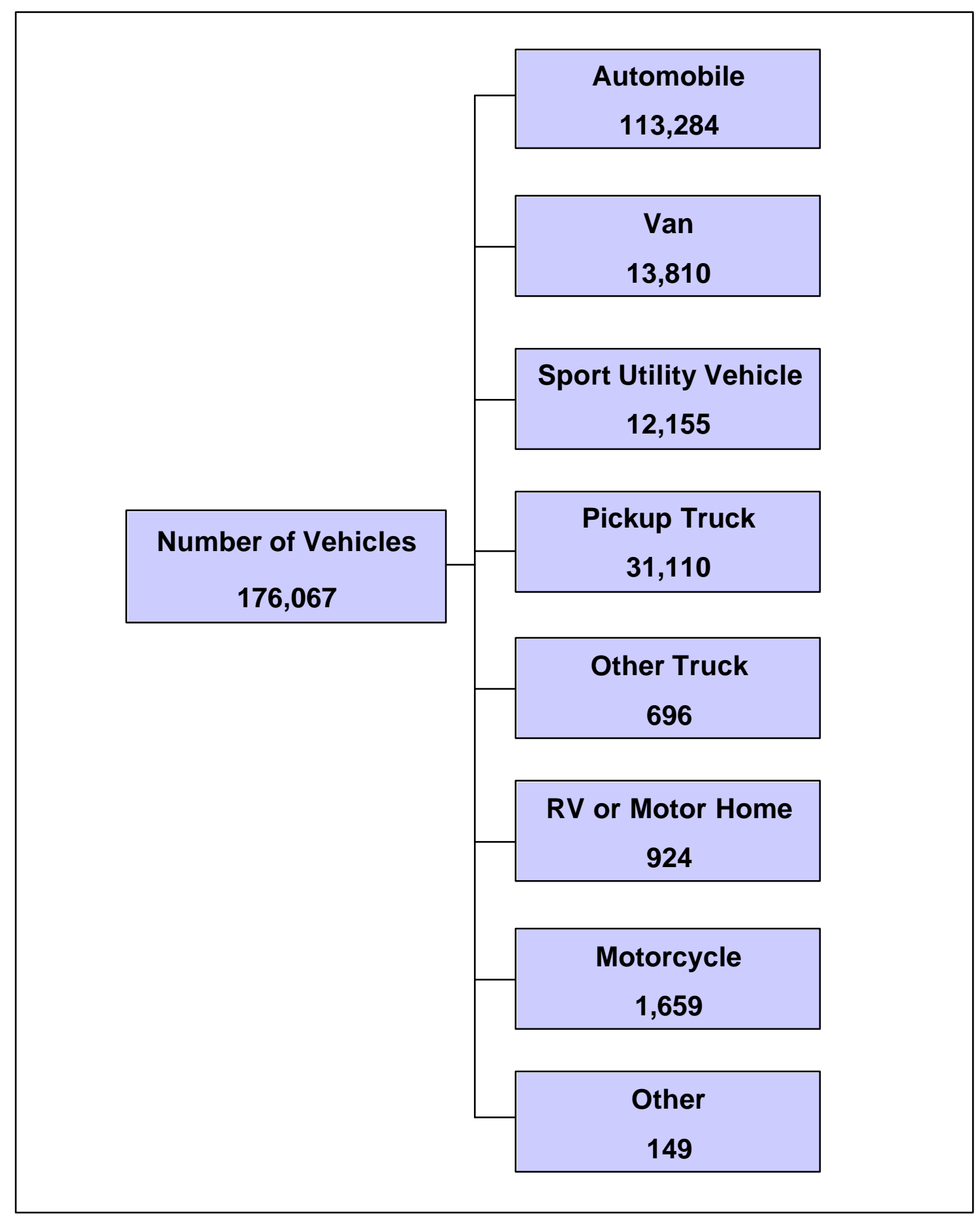


(THOUSANDS)

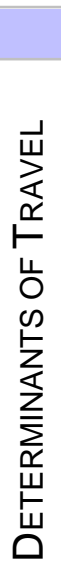

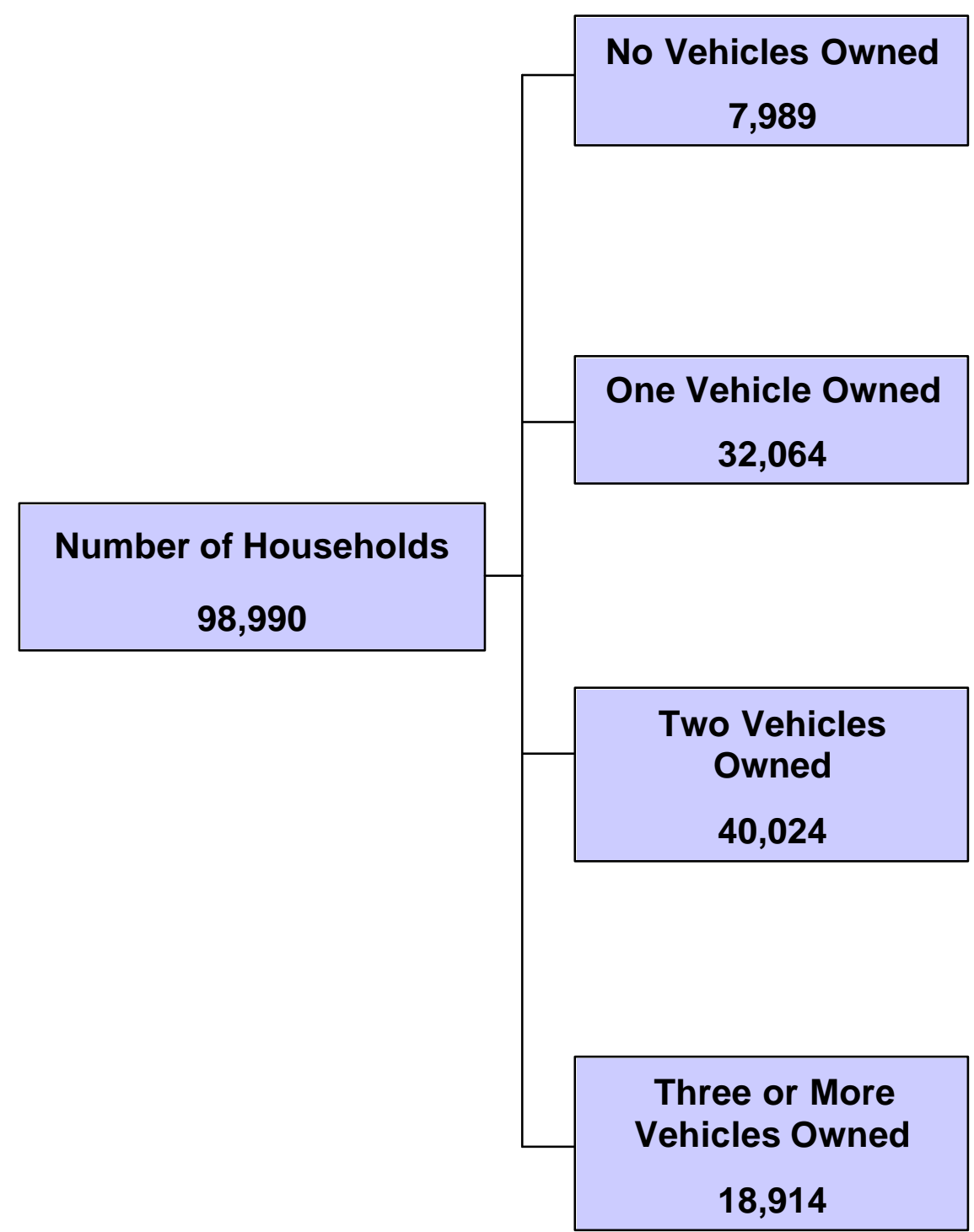




\section{LIST OF TABLES}

TABle 3.1 Summary Statistics On Demographic Characteristics and Total Travel 1969, 1977, 1983, 1990, AND 1995 NPTS . ................ 3-4

TABle 3.2 Number of Persons by MSA Size 1983, 1990, AND 1995 NPTS

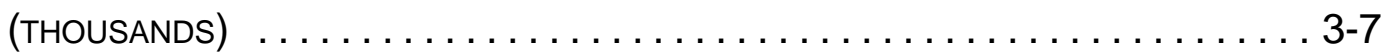

Table 3.3 Number of Adults and Licensed Drivers by Employment Status AND GeNDER 1990 AND 1995 NPTS (THOUSANDS) .................. 3-8

TABle 3.4 Number of AdULtS AND LicENSEd DRIVERS By HOUSEHOLd INCOME 1990 AND 1995 NPTS (THOUSANDS) . . . . . . . . . . . . . . 3-10

Table 3.5 Number of Adults and Licensed Drivers by Driver's AGE AND GENDER 1990 AND 1995 NPTS (thousands) ….............. 3-11

TABle 3.6 AVerage AnNual Miles PeR Licensed Driver by Driver's Age AND GENDER 1969, 1977, 1983, 1990, AND 1995 NPTS (SELF-ESTIMATED

Table 3.7 Average Annual Miles per Licensed Driver by Driver's Gender AND EMPLOYMENT STATUS 1990 AND 1995 NPTS (SELF-ESTIMATED

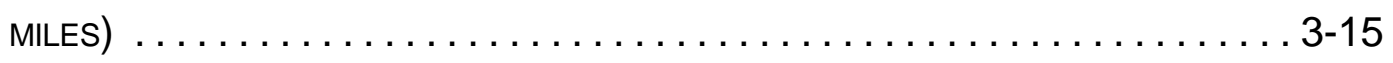

Table 3.8 Number of Households by Household Vehicle OWNership 1969, 1977, 1983, 1990, AND 1995 NPTS (THOUSANDS) $\ldots \ldots \ldots \ldots \ldots \ldots . .17$

TABle 3.9 Distribution of Households by Number of HouseHold Adults AND Number of Household-Based Vehicles 1969, 1977, 1983, 1990, AND

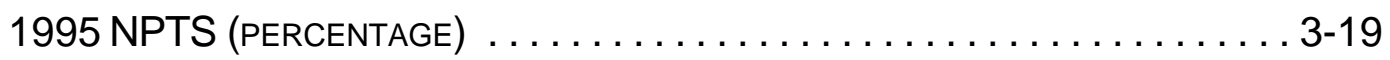

TABLE 3.10 Distribution of HOUSEHOLdS by Number OF HOUSEHOLd DRIVERS and Number of Household-Based Vehicles 1995 NPTS (PERCENTAGE) .

Table 3.11 Number of Households and Number of Vehicles per Household BY HOUSEHOLD INCOME 1983, 1990, AND 1995 NPTS (INCOME IN 1995

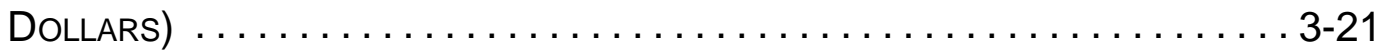

TAble 3.12 Number of Households and Number of Persons by Household COMPOSITION 1983, 1990, AND 1995 NPTS (THOUSANDS) . . . . . . . . . 3-22

Table 3.13 Number of Vehicles by Vehicle Type 1977, 1983, 1990, and 1995

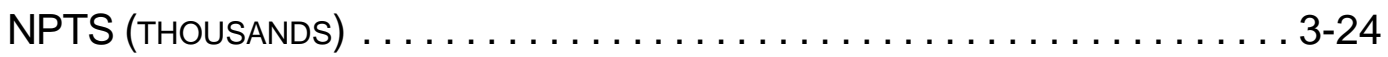

Table 3.14 Distribution of Household Vehicles by Vehicle Age and Vehicle TYPE 1990 AND 1995 NPTS (PERCENTAGE) $\ldots \ldots \ldots \ldots \ldots \ldots \ldots \ldots . . \ldots \ldots$ 
Table 3.15 Average Annual Miles per Vehicle by Vehicle Age 1969, 1977, 1983,1990, AND 1995 NPTS (HOUSEHOLD EStIMATED MILES) . . . . . . . 3-27

Table 3.16 Average Annual Miles per Vehicle by Vehicle to Driver Ratio 1995 NPTS (HOUSEHOLD ESTIMATED MILES AND ODOMETER ESTIMATED MILES) $\ldots . .3-28$

\section{LIST OF FIGURES}

Figure 3.1 Changes in Summary Demographic AND TRAVEl PATterns 1969, 1977, 1983, 1990, 1990 AdJUSTEd, AND 1995 NPTS .............. 3-5

Figure 3.2 NUMBER OF PERSONS WITH AND WITHOUT DRIVER'S LICENSES BY Gender All Persons Age 16 ANd Older 1969, 1977, 1983, 1990,

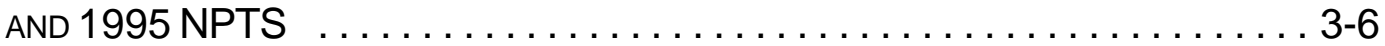

Figure 3.3 Percentage of All Persons 16 and OVer in the Workforce 1969, 1977, 1983, 1990, AND 1995 NPTS . . . . . . . . . . . . . 3-6

FiguRE 3.4 DistRIBUTION OF DRIVER'S LICENSES BY EMPLOYMENT STATUS AND GENDER 1990 AND 1995 NPTS ......................... 3-9

Figure 3.5 Number ANd Percentage of Licensed Drivers by Driver's Age

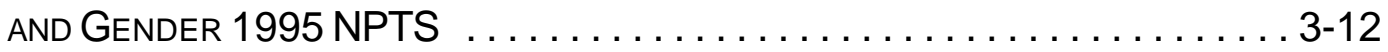

Figure 3.6 Changes in Annual Miles of Travel per Male Driver, Number of Male Licensed Drivers, ANd Number of Male Workers, 1969, 1977, 1983, 1990, AND 1995 NPTS $\ldots \ldots \ldots \ldots \ldots \ldots \ldots \ldots \ldots . .14$

Figure 3.7 Changes in Annual Miles of Travel Per Female Driver, Number of Female Licensed Drivers, and Number of Female Workers, 1969, 1977, 1983, 1990, AND 1995 NPTS . .................. 3-14

Figure 3.8 Household Vehicle OWNership By Number of Vehicles OWNed 1969, 1977, 1983, 1990, AND 1995 NPTS . . . . . . . . . . . . . 3-18

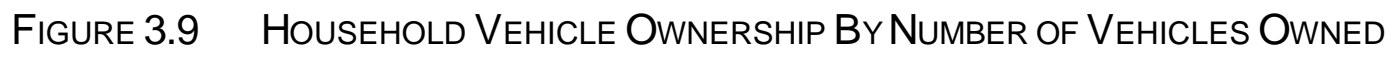
1969, 1977, 1983, 1990, AND 1995 NPTS .................. 3-18

FIGURE 3.10 DistRIBUTION OF HOUSEHOLDS BY HOUSEHOLD COMPOSITION 1983, 1990, AND 1995 NPTS $\ldots \ldots \ldots \ldots \ldots \ldots \ldots \ldots \ldots \ldots \ldots \ldots \ldots \ldots \ldots .23$

Figure 3.11 Distribution of Vehicles by VehicLe Type 1977, 1983, 1990, AND

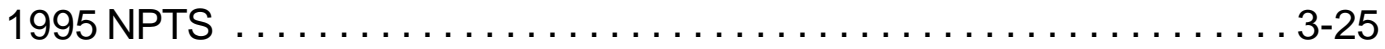

Figure 3.12 Average Annual Miles per Vehicle by Vehicle Age $\ldots \ldots \ldots \ldots \ldots .3-28$ 


\section{Chapter 3. Determinants of Travel}

$\mathrm{T}$ RAVEL behavior is the result of a complex synthesis of cultural, technological, demographic, economic, and geographic factors. Demographic characteristics of the population bear particularly strong relationships to travel behavior because of the strong associations between demographics and lifecycle stages, roles and functions in society, and resulting activity patterns.

In this section we explore the relationships among demographics, income, location, vehicle ownership, and travel behavior. We examine the determinants of travel by looking at driver, household, and vehicle characteristics, especially noting changes over time.

\subsection{Person Characteristics}

The major change in the American population since 1969 is the increase in the number of persons who are 65 and over. This age group has increased its ranks by $60 \%$ since the first NPTS. Both men and women are living longer than in earlier generations, traveling more, and remaining mobile to later ages. Women outnumber men among the elderly population, and women in the "baby boom" generation have experienced more independence than women of earlier generations. It is, therefore, expected that women of the baby boom generation will place greater demands on the transportation system as they enter the 65 and over age group. Spain analyzed this phenomenon with reference to licensing status, head-of-household status, and other factors. ${ }^{1}$

A second important demographic change is the movement of the American population out of smaller Metropolitan Statistical Areas (MSAs) and non-metropolitan areas into the largest MSAs. Between 1983 and 1995, only the largest MSAs (i.e., those with 3,000,000 or more persons) saw a positive growth.

A third major change involves gender. "One of the most significant trends in the past three decades is the changing social and economic role of women. Increasing labor force participation, licensing, and changes in the type and amount of trips made by women have had a permanent effect on travel behavior analysis and implications for the future of transportation planning." Although a larger percentage of men than women hold driver's licenses, women are obtaining licenses in greater numbers. In 1995, $85.3 \%$ of all women ages 16 and older held driver's licenses. In addition, while the number of male workers saw a $47 \%$ increase between 1969 and 1995, the number of women in the workforce increased 122\%. Between 1969 and 1995, men increased their average annual miles driven by $45.8 \%$ (from 11,352 miles annually to 16,559); women increased their average annual miles driven by $87.4 \%$ (from

\footnotetext{
${ }^{1}$ Spain, Daphne, "Societal Trends: The Aging Baby Boom and Women's Increased Independence," 1995 NPTS website publication, http://wwwcta.ornl.gov/npts/1995/Doc/SocTrends.pdf .

${ }^{2}$ McGuckin, Nancy, and Elaine Murakami, "Examining Trip-Chaining Behavior, A Comparison of Travel by Men and Women," 1995 NPTS website publication, http://wwwcta.ornl.gov/npts/1995/Doc/Chain2.pdf , p. 2.
} 
5,411 miles to 10,142 miles). Women who are employed drive an average of 11,925 miles annually, $17.6 \%$ more than the average mileage for women and 5,239 miles further than unemployed females.

In $1995,95 \%$ of all individuals who were employed full time or part time held driver's licenses; however, only $76.7 \%$ of the unemployed held driver's licenses. Generally, the higher the household income, the more likely it is that adult members of the household will have driver's licenses.

\subsection{HOUSEHOLD Characteristics}

Since the first NPTS in 1969, the number of vehicles in a household has grown from one vehicle less than the total number of adults in the household to about the same number of vehicles as adults. However, between 1990 and 1995, the average number of household vehicles per household remained almost constant.

The number of vehicles per household for households in the same income range has remained fairly constant since 1983 . Between 1983 and 1995, the number of households comprised of retired adults increased more than any other category of household composition.

\subsection{Vehicle Characteristics}

In 1995, the automobile remained the predominant household vehicle in the United States although trucks and vans (including sport utility vehicles) had become more popular through the years - rising from a $16.7 \%$ share to a $32.8 \%$ share of all household vehicles. According to the 1995 NPTS, the typical household vehicle was 7.9 years old, and almost a third of all household vehicles were over ten years old. The average annual mileage per vehicle was 12,226 miles in 1995. Vehicles less than two years old were driven considerably more than the average household vehicle - 16,092 miles annually. Older vehicles were driven fewer miles.

Persons living in very densely populated areas generally took fewer and shorter vehicle trips and traveled fewer vehicle miles. Although the private automobile was the preferred mode of transportation for all racial groups, African Americans, Asians, and Hispanics were a little more likely to use alternative modes of transportation. $^{3}$

\footnotetext{
${ }^{3}$ Ross, Catherine L., and Anne E. Dunning,

"Land Use Transportation Interaction: An Examination of the 1995 NPTS Data," 1995 NPTS website publication, http://wwwcta.ornl.gov/npts/1995/Doc/landuse3.pdf , p. 5.
} 
Dramatic changes in demographics and travel characteristics have occurred since the first NPTS was conducted in 1969. Some of these changes are shown in Table 3.1. The total population increased by almost a third between 1969 and 1995; however, not all age categories saw the same level of increases. The number of persons in the 16-19 age group actually decreased by $4 \%$, and the age category of 65 and older increased $60 \%$. The number of female licensed drivers almost doubled between 1969 and 1995, and the number of women workers increased $122 \%$.

(In Table 3.1, these percent changes are shown for 1969-1990 and 1990-1995 because of changes in survey methodology.)

Household and person travel increased substantially between 1969 and 1995 . Even in the five-year span between 1990 and 1995 (based on 1990 adjusted figures), the total number of household vehicle trips and household VMT saw increases of $18.5 \%$ and $22 \%$, respectively. Total person trips and PMT also saw increases of $24.5 \%$ and $20.5 \%$, respectively.

Figure 3.1 graphically demonstrates the increases in total travel characteristics. While successive surveys have all reported steady increases in persons, households, and even drivers, the greatest increases have been in vehicle and person travel.

Figure 3.2 compares the number of persons with and without driver's licenses, by gender, over the span of the five NPTSs. Figure 3.3 compares the percentage of persons, by gender, who were in the workforce from 1969 through 1995. 
TABLE 3.1

Summary Statistics ON DeMOGRAPHIC CHARACTERISTICS AND TOTAL TRAVEL
$1969,1977,1983,1990$, AND 1995 NPTS

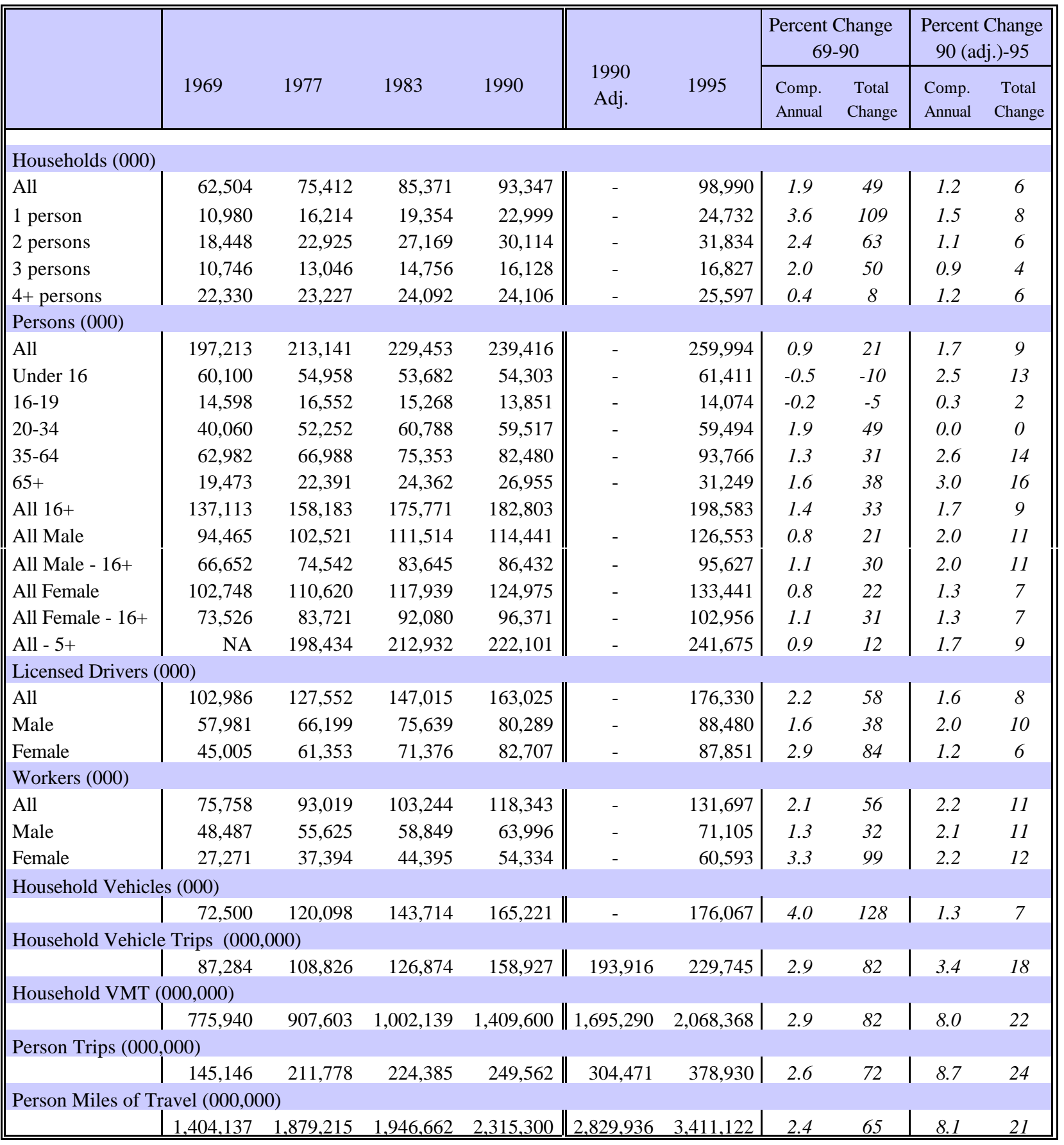

Note:

- All tables reporting totals could include some unreported characteristics.

- In expanding (weighting) the sample to the total population, slightly different approaches were used in 1990 and 1995 . Thus, the growth in the under 16 age group is probably overstated. Other age groups track closer to Census data.

- Note that only the 1990 data have been adjusted to make them more comparable with the 1995 data. Thus, there are limits on the conclusions that can be drawn in comparing travel with earlier survey years. The adjustments to 1990 data affect only person trips, vehicle trips, person miles of travel (PMT) and vehicle miles of travel (VMT).

- The 1969 survey included only automobiles, station wagons, vans, and minibuses as household vehicles. 
FIGURE 3.1

Changes in Summary Demographic and Travel Patterns

1969, 1977, 1983, 1990, 1990 ADJUSTED, AND 1995 NPTS

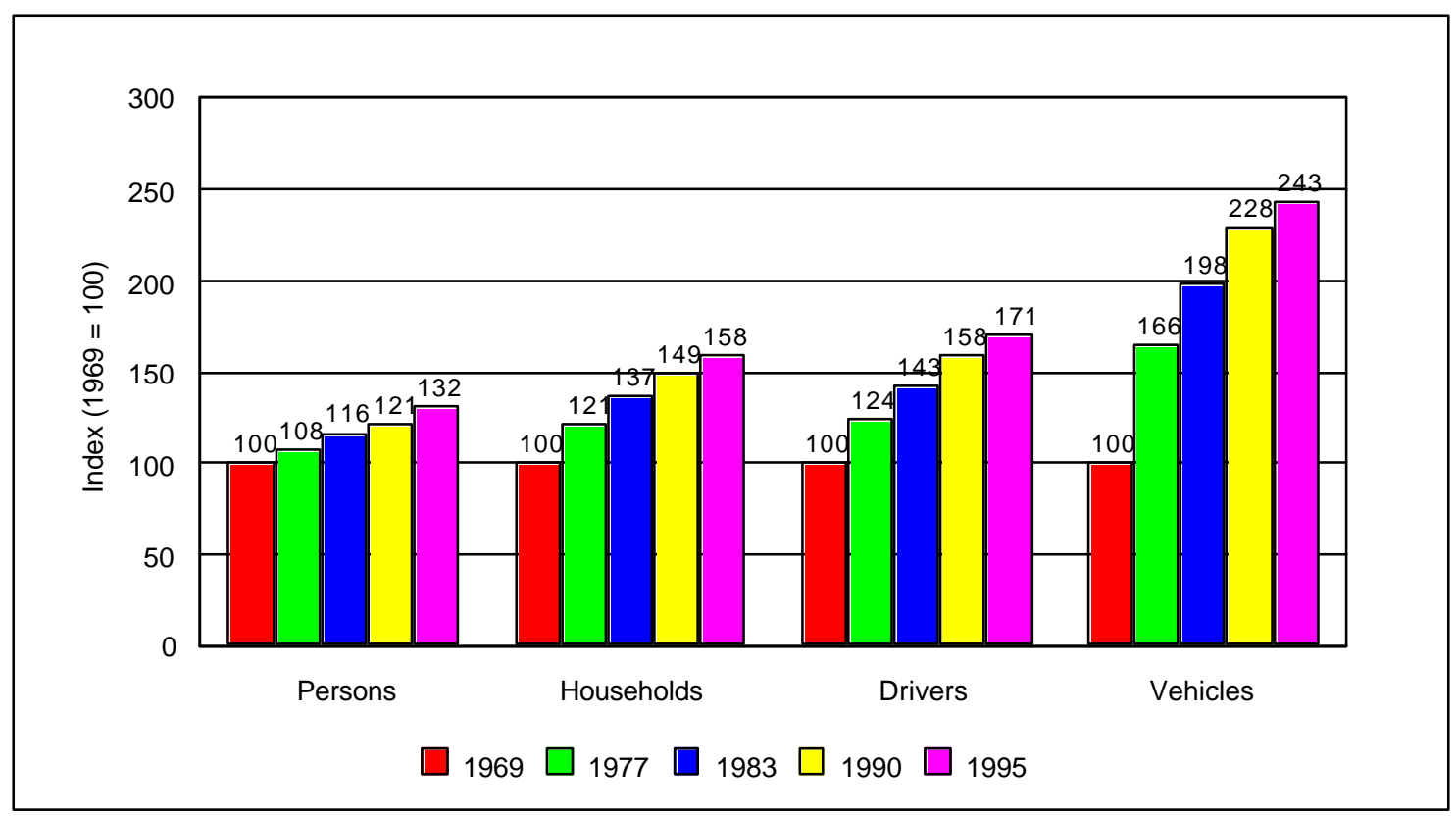

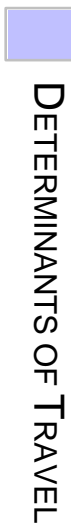

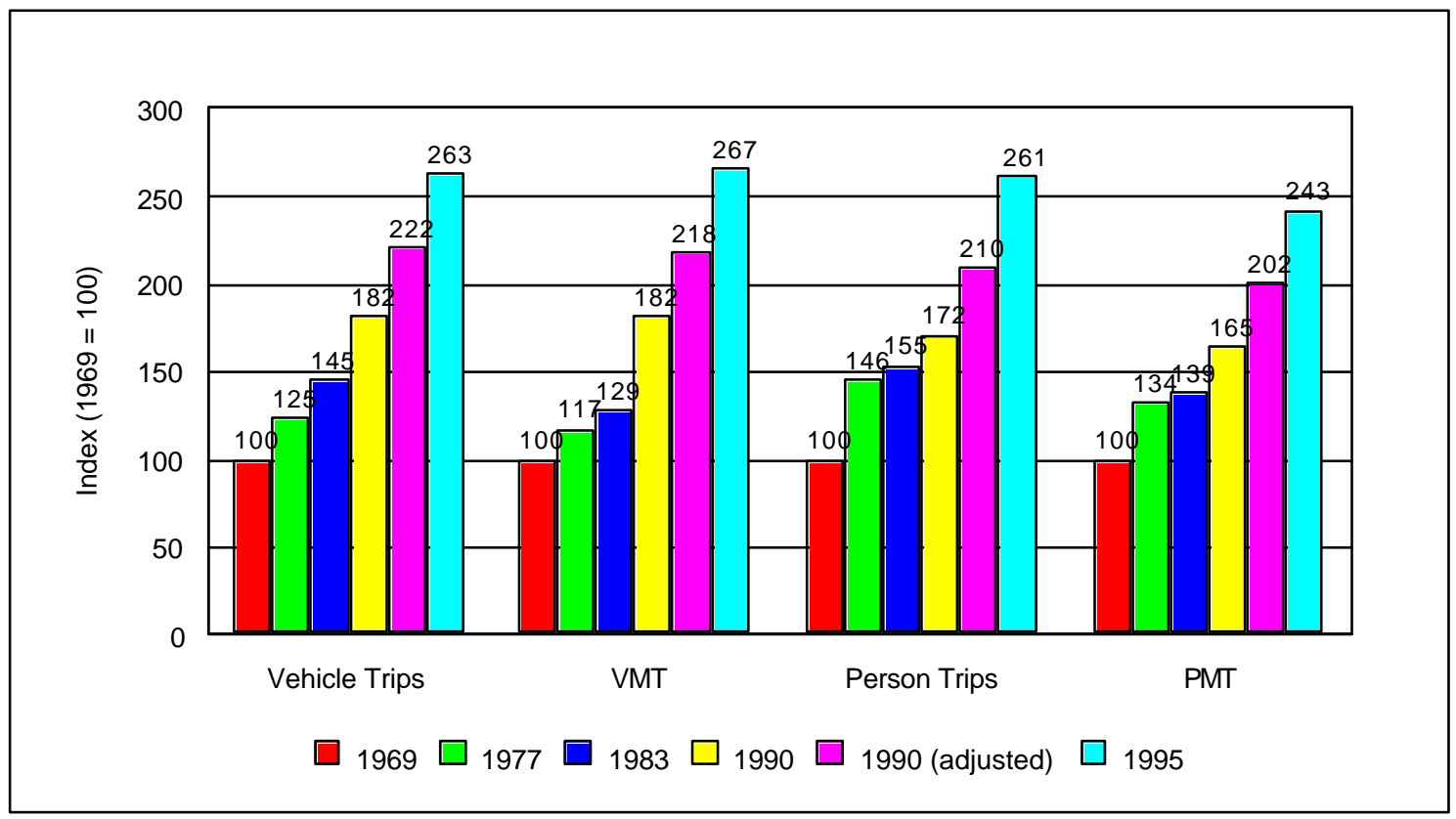


FIGURE 3.2

Number of Persons With AND Without Driver's LiCENSES By GENDER

All Persons Age 16 And Older

1969, 1977, 1983, 1990, AND 1995 NPTS

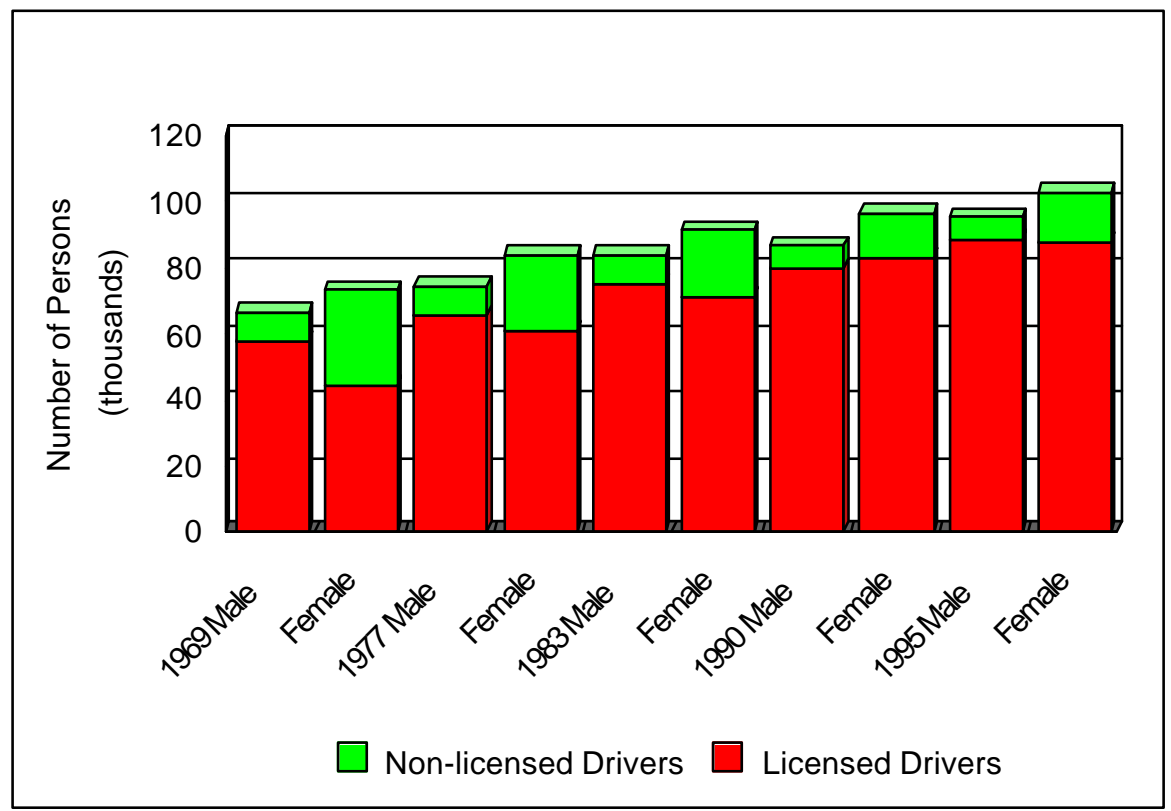

FIGURE 3.3

Percentage of All Persons 16 and Over in the Workforce 1969, 1977, 1983, 1990, AND 1995 NPTS

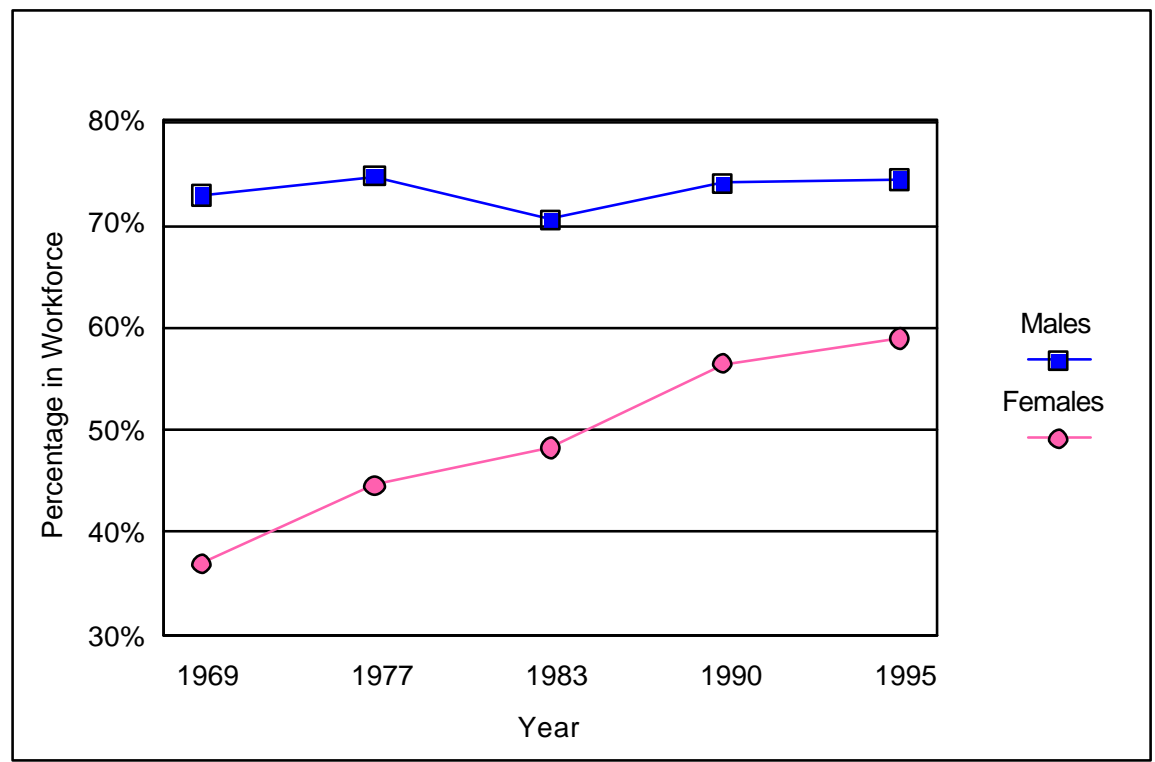


Table 3.2 shows that the population is generally becoming more concentrated in larger, more densely populated MSAs. The population decreased by $7 \%$ between 1983 and 1995 for persons not in an (S)MSA and by over $20 \%$ for MSAs of less than 500,000; during the same time period, the population increased by $151 \%$ for MSAs of 3 million or more.

\section{TABLE 3.2}

\section{Number of Persons by MSA Size 1983, 1990, AND 1995 NPTS}

(THOUSANDS)

\begin{tabular}{|c|c|c|c|c|c|c|c|}
\hline & TOTAL & $\begin{array}{c}\text { Less than } \\
250,000\end{array}$ & $\begin{array}{c}250,000 \text { - } \\
499,999 \\
\end{array}$ & $\begin{array}{c}500,000- \\
999,999 \\
\end{array}$ & $\begin{array}{l}1,000,000- \\
2,999,999 \\
\end{array}$ & $\begin{array}{l}3,000,000 \\
\text { and Over }\end{array}$ & $\begin{array}{c}\text { Not in } \\
\text { (S)MSA }\end{array}$ \\
\hline 1983 & $\begin{array}{l}212,932 \\
(100 \%)\end{array}$ & $\begin{array}{c}23,624 \\
(11.1 \%)\end{array}$ & $\begin{array}{c}21,655 \\
(10.2 \%)\end{array}$ & $\begin{array}{l}20,456 \\
(9.6 \%)\end{array}$ & $\begin{array}{c}45,633 \\
(21.4 \%)\end{array}$ & $\begin{array}{c}37,815 \\
(17.8 \%)\end{array}$ & $\begin{array}{c}52,828 \\
(24.8 \%)\end{array}$ \\
\hline 1990 & $\begin{array}{l}222,101 \\
(100 \%)\end{array}$ & $\begin{array}{l}21,048 \\
(9.5 \%)\end{array}$ & $\begin{array}{l}18,851 \\
(8.5 \%)\end{array}$ & $\begin{array}{l}20,429 \\
(9.2 \%)\end{array}$ & $\begin{array}{c}43,693 \\
(19.7 \%)\end{array}$ & $\begin{array}{c}68,260 \\
(30.7 \%)\end{array}$ & $\begin{array}{c}49,820 \\
(22.4 \%)\end{array}$ \\
\hline 1995 & $\begin{array}{l}241,675 \\
(100 \%)\end{array}$ & $\begin{array}{l}18,769 \\
(7.8 \%)\end{array}$ & $\begin{array}{l}17,245 \\
(7.1 \%)\end{array}$ & $\begin{array}{l}19,999 \\
(8.3 \%)\end{array}$ & $\begin{array}{c}41,553 \\
(17.2 \%)\end{array}$ & $\begin{array}{c}94,972 \\
(39.3 \%)\end{array}$ & $\begin{array}{c}49,137 \\
(20.3 \%)\end{array}$ \\
\hline $\begin{array}{l}\text { \% Change } \\
1983-1995\end{array}$ & 13.5 & -20.6 & -20.4 & -2.2 & -8.9 & 151.1 & -7.0 \\
\hline
\end{tabular}

Note:

- The 1983 total includes 5.1\% of persons living in MSAs for which MSA size is unknown.

- The population size groups for the 1983 NPTS are SMSA Size Groups and 1990 - 1995 are MSA Size Groups.

- All tables reporting totals could include some unreported characteristics. 
Although the total number of adults with driver's licenses increased by $8 \%$ between 1990 and 1995, the percentage of all adults with driver's licenses actually decreased slightly (Table 3.3). This decrease was seen for both employed and unemployed adults although it was greatest among those not employed.

As shown in Figure 3.4, the overall distribution of driver's licenses by employment status and gender did not change significantly between 1990 and 1995. In this figure, the pie slices which are slightly separated from the pie represent unemployed persons. An individual, whether employed or not, generally possesses a driver's license. Unemployed females make up the greatest percentage of those without licenses.

\section{TABLE 3.3}

\section{Number of Adults AND Licensed Drivers by EMPloyment Status ANd Gender 1990 AND 1995 NPTS}

(THOUSANDS)

\begin{tabular}{|c|c|c|c|c|c|c|}
\hline \multirow[b]{2}{*}{$\begin{array}{l}\text { Employment } \\
\text { Status }\end{array}$} & \multicolumn{3}{|c|}{1990} & \multicolumn{3}{|c|}{1995} \\
\hline & Adults & $\begin{array}{c}\text { Licensed } \\
\text { Drivers }\end{array}$ & $\begin{array}{c}\% \\
\text { Licensed } \\
\text { Drivers } \\
\end{array}$ & Adults & $\begin{array}{c}\text { Licensed } \\
\text { Drivers }\end{array}$ & $\begin{array}{c}\% \\
\text { Licensed } \\
\text { Drivers } \\
\end{array}$ \\
\hline \multicolumn{7}{|c|}{ Employed Full Time or Part Time } \\
\hline TOTAL & $\begin{array}{c}117,255 \\
(100.0 \%)\end{array}$ & $\begin{array}{l}111,960 \\
(100.0 \%)\end{array}$ & 95.5 & $\begin{array}{l}131,670 \\
(100.0 \%)\end{array}$ & $\begin{array}{l}125,041 \\
(100.0 \%)\end{array}$ & 95.0 \\
\hline Male & $\begin{array}{c}63,590 \\
(54.2 \%)\end{array}$ & $\begin{array}{c}61,240 \\
(54.7 \%)\end{array}$ & 96.3 & $\begin{array}{c}71,088 \\
(54.0 \%)\end{array}$ & $\begin{array}{c}68,446 \\
(54.7 \%)\end{array}$ & 96.3 \\
\hline Female & $\begin{array}{c}53,660 \\
(45.8 \%)\end{array}$ & $\begin{array}{c}50,710 \\
(45.3 \%)\end{array}$ & 93.5 & $\begin{array}{c}60,582 \\
(46.0 \%)\end{array}$ & $\begin{array}{c}56,595 \\
(45.3 \%)\end{array}$ & 93.4 \\
\hline \multicolumn{7}{|l|}{ Not Employed } \\
\hline TOTAL & $\begin{array}{c}65,548 \\
(100.0 \%)\end{array}$ & $\begin{array}{c}51,064 \\
(100.0 \%)\end{array}$ & 77.9 & $\begin{array}{c}66,913 \\
(100.0 \%)\end{array}$ & $\begin{array}{c}51,289 \\
(100.0 \%)\end{array}$ & 76.7 \\
\hline Male & $\begin{array}{c}22,839 \\
(34.8 \%)\end{array}$ & $\begin{array}{l}19,050 \\
(37.3 \%)\end{array}$ & 83.4 & $\begin{array}{c}24,539 \\
(36.7 \%)\end{array}$ & $\begin{array}{c}20,033 \\
(39.1 \%)\end{array}$ & 81.6 \\
\hline Female & $\begin{array}{c}42,709 \\
(65.2 \%)\end{array}$ & $\begin{array}{c}32,000 \\
(62.7 \%)\end{array}$ & 74.9 & $\begin{array}{c}42,374 \\
(63.3 \%)\end{array}$ & $\begin{array}{c}31,256 \\
(60.9 \%)\end{array}$ & 73.8 \\
\hline $\begin{array}{l}\text { TOTAL } \\
\text { ADULTS }\end{array}$ & 182,803 & 163,025 & 89.2 & 198,583 & 176,330 & 88.8 \\
\hline
\end{tabular}

Note:

- Adults are considered to be persons 16 or older (i.e., anyone eligible to have a driver's license).

- All tables reporting totals could include some unreported characteristics. 


\section{FIGURE 3.4}

Distribution OF DRIVER's LiCENSES By EMPLOYMENT STATUS AND GENDER 1990 AND 1995 NPTS

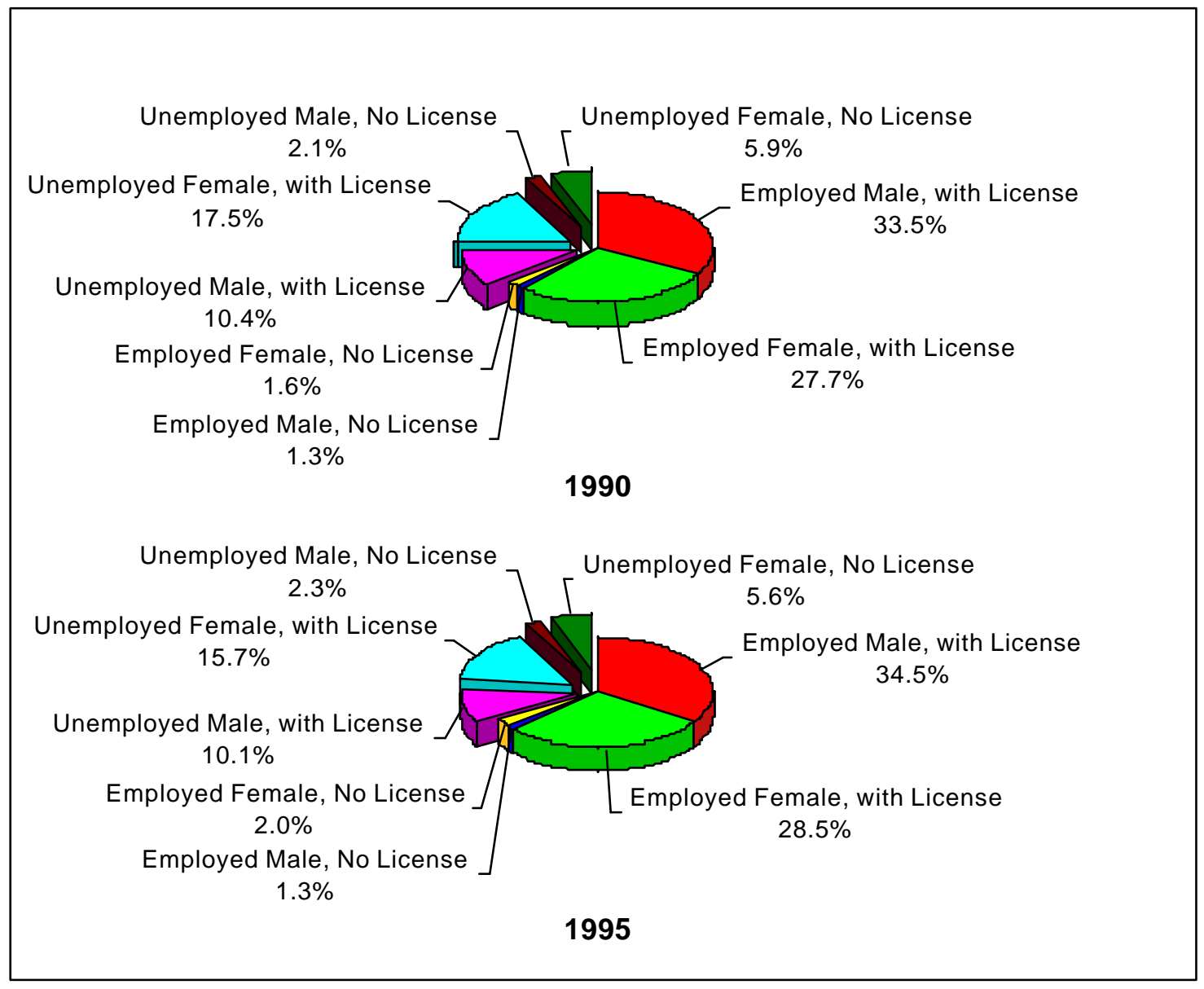


The percentage of all adults that hold a driver's license remained at about $89 \%$ between 1990 and 1995 (Table 3.4). For households with annual incomes under $\$ 20,000$ or over
$\$ 80,000$, the percentage holding driver's licenses fell slightly, while the percentage rose for all other income levels.

TABLE 3.4

Number of Adults AND LicENSEd DRIVERS by HouseHold INCOME 1990 AND 1995 NPTS

(THOUSANDS)

\begin{tabular}{||l|rrr|rrr||}
\hline \multirow{2}{*}{$\begin{array}{l}\text { Annual Household } \\
\text { Income } \\
\text { (1995 Dollars) }\end{array}$} & \multicolumn{3}{|c|}{1990} & \multicolumn{3}{|c||}{1995} \\
\cline { 2 - 8 } & Adults & \multicolumn{2}{c|}{$\begin{array}{c}\text { Licensed } \\
\text { Drivers }\end{array}$} & $\begin{array}{c}\text { L } \begin{array}{c}\text { Licensed } \\
\text { Drivers }\end{array} \\
\text { Adults }\end{array}$ & \multicolumn{3}{c||}{$\begin{array}{c}\text { Licensed } \\
\text { Drivers }\end{array}$} & $\begin{array}{c}\text { Licensed } \\
\text { Drivers }\end{array}$ \\
\hline TOTAL & 182,803 & 163,025 & 89.18 & 198,583 & 176,330 & 88.79 \\
Less than $\$ 10,000$ & 10,854 & 7,907 & 72.84 & 12,855 & 8,506 & 66.17 \\
$\$ 10,000-\$ 20,000$ & 18,537 & 15,371 & 82.92 & 24,212 & 19,980 & 82.52 \\
$\$ 20,000-\$ 30,000$ & 20,775 & 18,340 & 88.28 & 29,556 & 26,458 & 89.52 \\
$\$ 30,000-\$ 40,000$ & 20,522 & 18,744 & 91.33 & 26,109 & 24,315 & 93.13 \\
$\$ 40,000-\$ 50,000$ & 18,163 & 16,838 & 92.71 & 21,349 & 19,994 & 93.65 \\
$\$ 50,000-\$ 60,000$ & 14,457 & 13,417 & 92.81 & 15,077 & 14,403 & 95.53 \\
$\$ 60,000-\$ 70,000$ & 10,376 & 9,592 & 92.44 & 10,776 & 10,257 & 95.18 \\
$\$ 70,000-\$ 80,000$ & 6,871 & 6,431 & 93.60 & 7,327 & 7,034 & 96.00 \\
$\$ 80,000$ and above & 15,150 & 14,887 & 98.27 & 16,615 & 16,015 & 96.39 \\
Unreported Income & 47,098 & 41,499 & 88.11 & 34,706 & 29,368 & 84.62 \\
\hline \hline
\end{tabular}

Note:

- Adults are considered to be persons 16 or older (e.g. anyone eligible to have a driver's license).

- All tables reporting totals could include some unreported characteristics. 
The percentage of both males and females holding driver's licenses changed very little between 1990 and 1995. The greatest changes for females were in age groups of 55 and above, but these growths were very modest. In 1990 , there were more female licensed drivers than male in every age group except 55-64; in 1995 , however, this characteristic was no longer true. There were more male licensed drivers in every category except age 65 and over. The number and percentage of licensed drivers by age group and gender are shown in Figure 3.5.

\section{TABLE 3.5}

\section{Number of Adults AND LicENSEd Drivers by Driver's Age AND GeNDER 1990 AND 1995 NPTS \\ (THOUSANDS)}

\begin{tabular}{|c|c|c|c|c|c|c|c|c|c|}
\hline \multirow[b]{2}{*}{ Age Group } & \multicolumn{3}{|c|}{ Male } & \multicolumn{3}{|c|}{ Female } & \multicolumn{3}{|c|}{ All } \\
\hline & \multicolumn{3}{|c|}{ Licensed } & \multicolumn{3}{|c|}{ Licensed } & \multicolumn{3}{|c|}{ Licensed } \\
\hline \multicolumn{10}{|l|}{1990} \\
\hline TOTAL & 86,432 & 80,289 & 92.9 & 96,371 & 82,707 & 85.8 & 182,803 & 163,025 & 89.2 \\
\hline $16-19$ & 6,727 & 4,633 & 68.9 & 7,124 & 4,913 & 69.0 & 13,851 & 9,546 & 68.9 \\
\hline $20-34$ & 28,563 & 26,727 & 93.6 & 30,954 & 28,021 & 90.5 & 59,517 & 54,748 & 92.0 \\
\hline $35-54$ & 30,168 & 29,029 & 96.2 & 31,782 & 29,328 & 92.3 & 61,950 & 58,357 & 94.2 \\
\hline $55-64$ & 9,645 & 9,229 & 95.7 & 10,885 & 9,057 & 83.2 & 20,530 & 18,285 & 89.1 \\
\hline $65+$ & 11,329 & 10,025 & 88.5 & 15,626 & 10,255 & 65.6 & 26,955 & 20,281 & 75.2 \\
\hline \multicolumn{10}{|l|}{1995} \\
\hline TOTAL & 95,627 & 88,480 & 92.5 & 102,956 & 87,851 & 85.3 & 198,583 & 176,330 & 88.8 \\
\hline $16-19$ & 7,294 & 5,278 & 72.4 & 6,780 & 4,540 & 67.0 & 14,074 & 9,818 & 69.8 \\
\hline $20-34$ & 29,470 & 27,554 & 93.5 & 30,024 & 26,960 & 89.8 & 59,494 & 54,514 & 91.6 \\
\hline $35-54$ & 36,135 & 34,746 & 96.2 & 37,254 & 34,682 & 93.1 & 73,389 & 69,428 & 94.6 \\
\hline $55-64$ & 9,726 & 9,233 & 94.9 & 10,651 & 9,131 & 85.7 & 20,377 & 18,364 & 90.1 \\
\hline $65+$ & 13,002 & 11,669 & 89.7 & 18,247 & 12,537 & 68.7 & 31,249 & 24,207 & 77.5 \\
\hline
\end{tabular}

Note:

- Adults are considered to be persons 16 or older (e.g. anyone eligible to have a driver's license).

- All tables reporting totals could include some unreported characteristics. 


\section{FIGURE 3.5}

Number And Percentage of Licensed Drivers by Driver’s Age ANd Gender 1995 NPTS

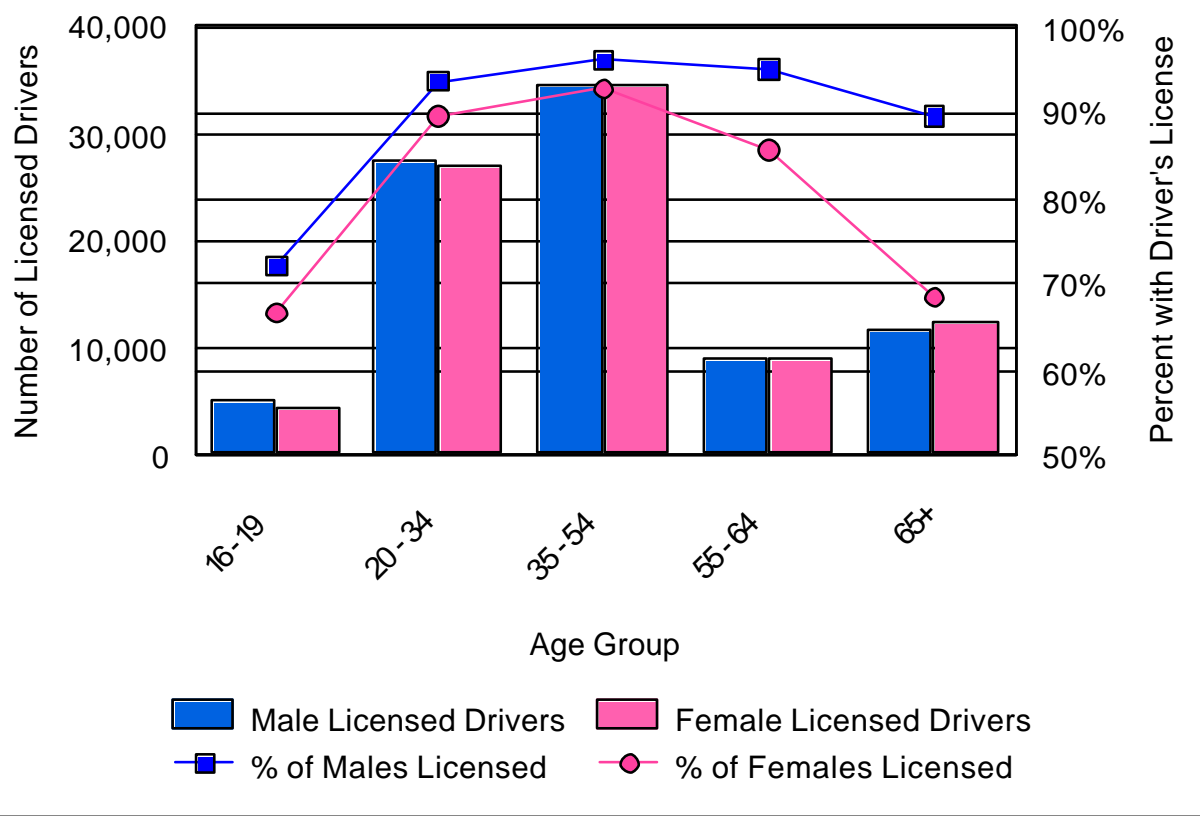


Between 1969 and 1995, the average annual miles driven increased for every age-gender grouping; however, the percentage of increase was greatest for women ( $87 \%$ overall), especially those of working ages. For males, the greatest increase was for men age 65 and over ( $74 \%$ increase).
Figures 3.6 and 3.7 show the changes for men and for women between 1969 and 1995 in average annual miles traveled, number of driver's licenses, and number employed. Women's travel patterns and employment status experienced dramatic increases during these years.

TABLE 3.6

Average Annual Miles Per Licensed Driver by Driver's Age and Gender 1969, 1977, 1983, 1990, AND 1995 NPTS

(SELF-ESTIMATED MILES)

\begin{tabular}{|c|c|c|c|c|c|c|c|}
\hline \multirow[b]{2}{*}{ Age } & \multirow[b]{2}{*}{1969} & \multirow[b]{2}{*}{1977} & \multirow[b]{2}{*}{1983} & \multirow[b]{2}{*}{1990} & \multirow[b]{2}{*}{1995} & \multicolumn{2}{|c|}{ Percent Change, 69-95 } \\
\hline & & & & & & $\begin{array}{l}\text { Compound } \\
\text { Annual Rate }\end{array}$ & $\begin{array}{c}\text { Total } \\
\text { Change } \\
\text { for Period }\end{array}$ \\
\hline \multicolumn{8}{|l|}{ Male } \\
\hline $16-19$ & 5,461 & 7,045 & 5,908 & 9,543 & 8,206 & $1.6 \%$ & $50.3 \%$ \\
\hline $20-34$ & 13,133 & 15,222 & 15,844 & 18,310 & 17,976 & $1.2 \%$ & $36.9 \%$ \\
\hline $35-54$ & 12,841 & 16,097 & 17,808 & 18,871 & 18,858 & $1.5 \%$ & $46.9 \%$ \\
\hline $55-64$ & 10,696 & 12,455 & 13,431 & 15,224 & 15,859 & $1.5 \%$ & $48.3 \%$ \\
\hline $65+$ & 5,919 & 6,795 & 7,198 & 9,162 & 10,304 & $2.2 \%$ & $74.1 \%$ \\
\hline Average & 11,352 & 13,397 & 13,962 & 16,536 & 16,550 & $1.5 \%$ & $45.8 \%$ \\
\hline \multicolumn{8}{|l|}{ Female } \\
\hline $16-19$ & 3,586 & 4,036 & 3,874 & 7,387 & 6,873 & $2.5 \%$ & $91.7 \%$ \\
\hline $20-34$ & 5,512 & 6,571 & 7,121 & 11,174 & 12,004 & $3.0 \%$ & $117.8 \%$ \\
\hline $35-54$ & 6,003 & 6,534 & 7,347 & 10,539 & 11,464 & $2.5 \%$ & $91.0 \%$ \\
\hline $55-64$ & 5,375 & 5,097 & 5,432 & 7,211 & 7,780 & $1.4 \%$ & $44.7 \%$ \\
\hline $65+$ & 3,664 & 3,572 & 3,308 & 4,750 & 4,785 & $1.0 \%$ & $30.6 \%$ \\
\hline Average & 5,411 & 5,940 & 6,382 & 9,528 & 10,142 & $2.4 \%$ & $87.4 \%$ \\
\hline
\end{tabular}




\section{FIGURE 3.6}

Changes in Annual Miles of Travel Per Male Driver, Number of Male Licensed Drivers, AND NuMBER OF MALE WORKERS, 1969, 1977, 1983, 1990, AND 1995 NPTS

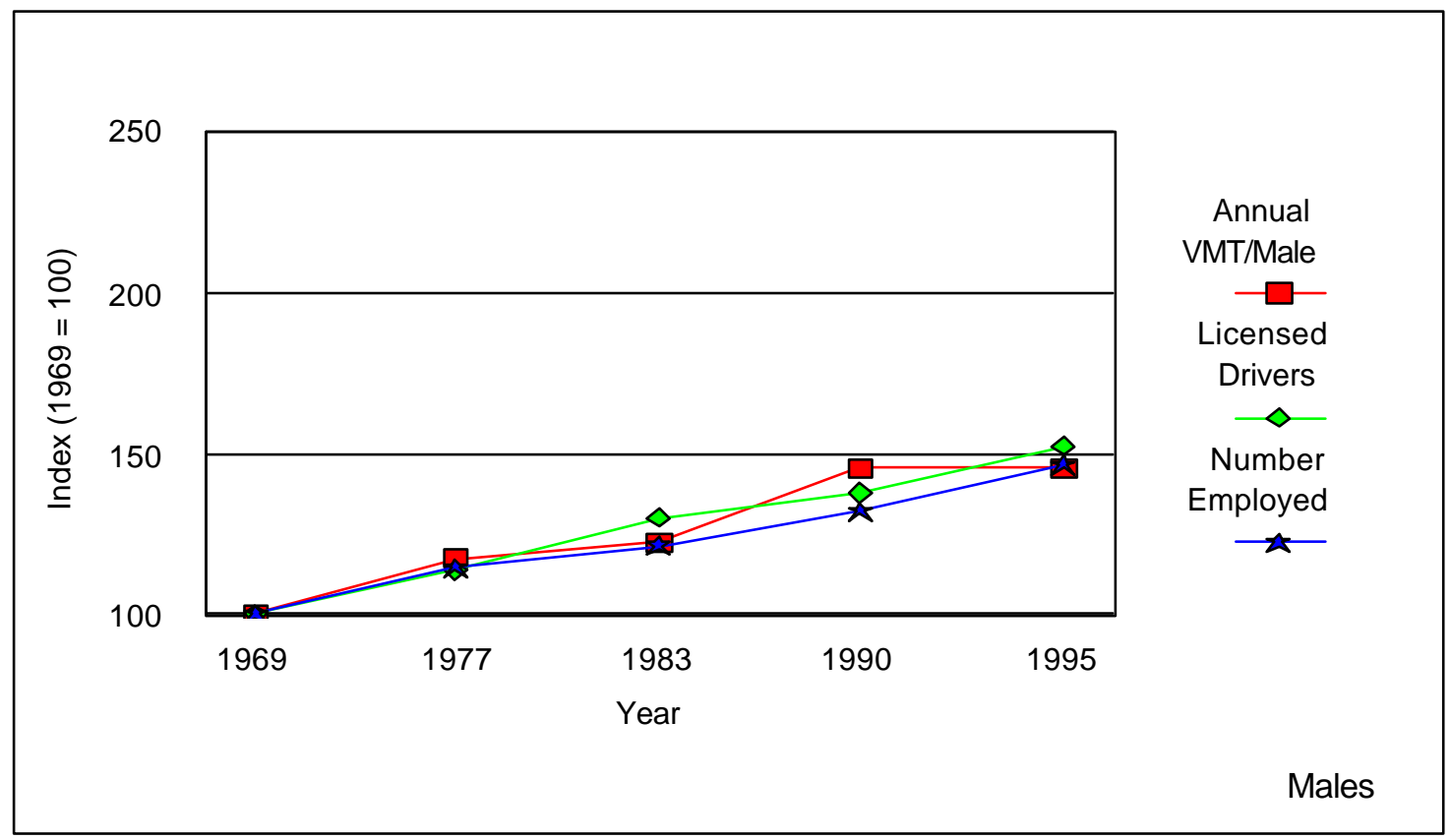

FIGURE 3.7

Changes in Annual Miles of Travel per Female Driver, Number of Female Licensed DrIVERS, AND NuMBER OF FEMALE WORKERS, 1969, 1977, 1983, 1990, AND 1995 NPTS

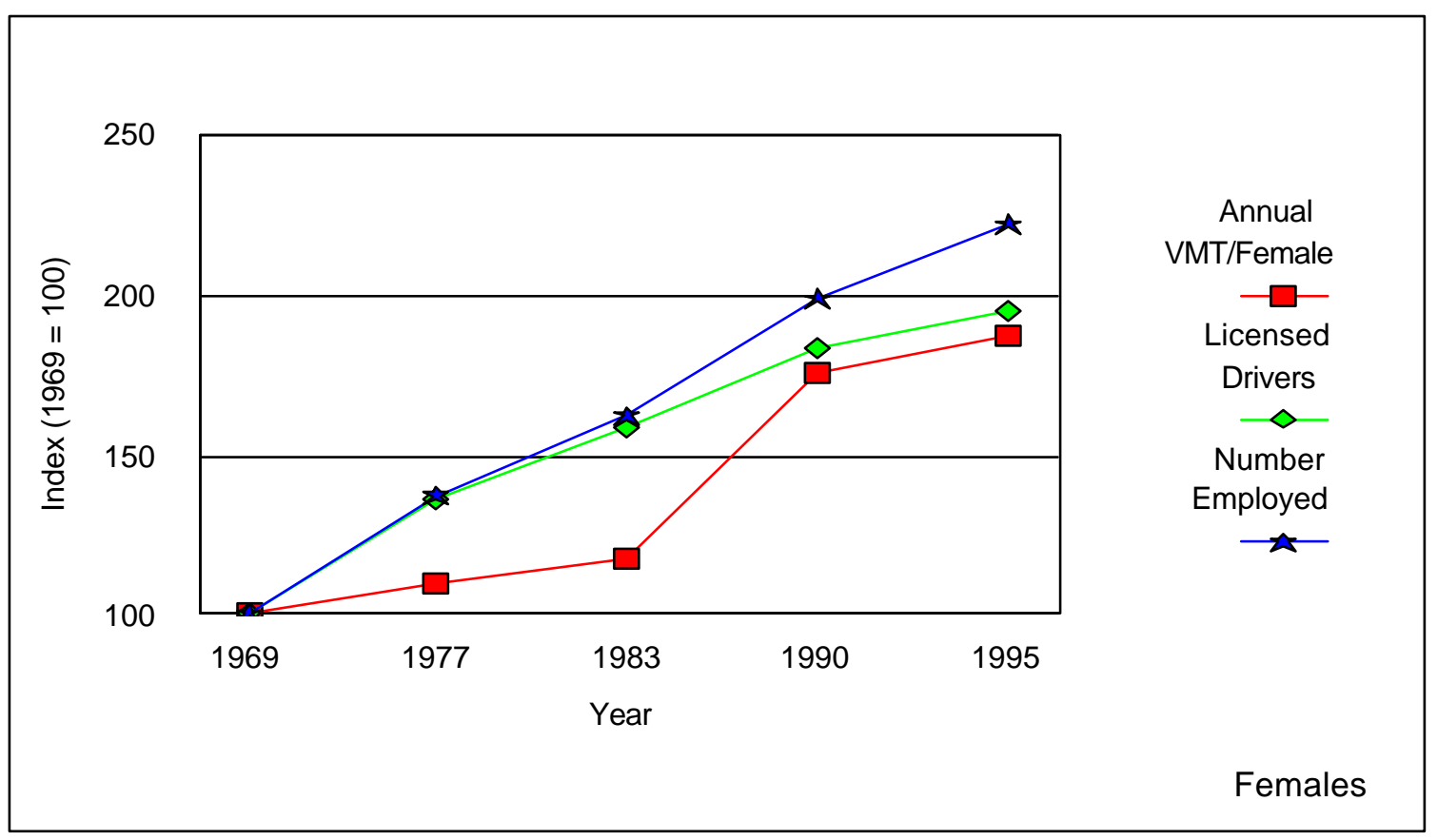


Employment status influences the average annual miles driven. As shown in Table 3.7, drivers who were employed full time or part time in 1995 drove almost twice as many miles as those persons who were not employed.

Increases in average annual miles driven were much smaller between 1990 and $1995(2.7 \%$ increase) than between 1983 and 1990 (27.6\% increase, according to the 1990 NPTS Databook, Table 3.13). As shown in Table 3.7, the greatest increase between 1990 and 1995 was for females who were employed (6.7\%). Employed males and unemployed females actually decreased their annual mileage.

\section{TABLE 3.7}

Average Annual Miles Per Licensed Driver by DRIVER's Gender AND

EMPLOYMENT STATUS

1990 AND 1995 NPTS

(SELF-ESTIMATED MILES)

\begin{tabular}{|c|c|c|c|}
\hline Employment Status & 1990 & 1995 & $\begin{array}{l}\text { Percent } \\
\text { Change } \\
\end{array}$ \\
\hline \multicolumn{4}{|c|}{ Employed Full Time or Part Time } \\
\hline TOTAL & 15,280 & 15,551 & $1.8 \%$ \\
\hline Male & 18,461 & 18,391 & $-0.4 \%$ \\
\hline Female & 11,180 & 11,925 & $6.7 \%$ \\
\hline \multicolumn{4}{|l|}{ Not Employed } \\
\hline TOTAL & 8,048 & 8,128 & $1.0 \%$ \\
\hline Male & 10,090 & 10,151 & $0.6 \%$ \\
\hline Female & 6,712 & 6,686 & $-0.4 \%$ \\
\hline TOTAL, ALL DRIVERS & 13,125 & 13,476 & $2.7 \%$ \\
\hline
\end{tabular}


Tables 3.8-3.12 and Figures 3.8-3.10 provide information on households and household vehicles from several perspectives.

In 1969, almost $70 \%$ of all households had either no vehicle $(20.6 \%)$ or only one vehicle (48.4\%) available to the household (Table 3.8). In 1995 , only $8.1 \%$ of all households had no vehicle, and almost $73 \%$ of all households had either one or two vehicles. In 1995, when almost $92 \%$ of all households owned at least one vehicle, there was an average of 1.78 vehicles per household. While the total number of households grew by $58.4 \%$, the total number of household vehicles grew by $142.9 \%$. Figures 3.8 and 3.9 demonstrate these changes in household-vehicle demographics. In Figure 3.8, the slice of the pie representing "no household vehicles" gets smaller in each successive NPTS, while the slice representing "three or more vehicles" grows larger. Figure 3.9 shows the growth in households and household vehicles (indexed to the value of 1969). The growth in household vehicles per household was greatest between 1969 and 1977 (1.16 to 1.59 vehicles per household) and became less after 1977. Between 1990 and 1995, the ratio changed very little (from 1.77 to 1.78 vehicles per household).

Generally, the average number of vehicles per household has increased by one car per household since 1969. For example, as seen in Table 3.9, a majority of one-adult households (56.2\%) owned no vehicle in 1969; however, in 1995 , most one-adult households $(68.7 \%)$ owned one vehicle. Households with two adults went from ownership of one vehicle in 1969 (57.3\%) to two vehicles in 1995 (59.4\%). Finally, households with three or more adults progressed from owning two vehicles in 1969 $(42.6 \%)$ to owning three or more vehicles in 1995 (58.6\%). 


\section{TABLE 3.8}

Number OF HouseHoldS By HouseHOLd VeHICLE OWNERSHIP

1969, 1977, 1983, 1990, AND 1995 NPTS

(THOUSANDS)

\begin{tabular}{|c|c|c|c|c|c|c|c|}
\hline \multirow[b]{2}{*}{$\begin{array}{l}\text { Number of } \\
\text { Household-based } \\
\text { Vehicles }\end{array}$} & \multirow[b]{2}{*}{1969} & \multirow[b]{2}{*}{1977} & \multirow[b]{2}{*}{1983} & \multirow[b]{2}{*}{1990} & \multirow[b]{2}{*}{1995} & \multicolumn{2}{|c|}{ Percent Change 69-95 } \\
\hline & & & & & & $\begin{array}{l}\text { Compound } \\
\text { Annual Rate }\end{array}$ & $\begin{array}{c}\text { Total } \\
\text { Change } \\
\text { for Period }\end{array}$ \\
\hline No vehicle & $\begin{array}{r}12,876 \\
(20.6 \%)\end{array}$ & $\begin{array}{r}11,538 \\
(15.3 \%)\end{array}$ & $\begin{array}{r}11,548 \\
(13.5 \%)\end{array}$ & $\begin{array}{r}8,573 \\
(9.2 \%)\end{array}$ & $\begin{array}{r}7,989 \\
(8.1 \%)\end{array}$ & $-1.8 \%$ & $-38.0 \%$ \\
\hline One vehicle & $\begin{array}{r}30,252 \\
(48.4 \%)\end{array}$ & $\begin{array}{r}26,092 \\
(34.6 \%)\end{array}$ & $\begin{array}{r}28,780 \\
(33.7 \%)\end{array}$ & $\begin{array}{r}30,654 \\
(32.8 \%)\end{array}$ & $\begin{array}{r}32,064 \\
(32.4 \%)\end{array}$ & $0.2 \%$ & $6.0 \%$ \\
\hline Two vehicles & $\begin{array}{r}16,501 \\
(26.4 \%)\end{array}$ & $\begin{array}{r}25,942 \\
(34.4 \%)\end{array}$ & $\begin{array}{r}28,632 \\
(33.5 \%)\end{array}$ & $\begin{array}{c}35,872 \\
(38.4 \%)\end{array}$ & $\begin{array}{r}40,024 \\
(40.4 \%)\end{array}$ & $3.5 \%$ & $142.6 \%$ \\
\hline Three+ vehicles & $\begin{array}{r}2,875 \\
(4.6 \%)\end{array}$ & $\begin{array}{r}11,840 \\
(15.7 \%)\end{array}$ & $\begin{array}{r}16,411 \\
(19.2 \%)\end{array}$ & $\begin{array}{r}18,248 \\
(19.5 \%)\end{array}$ & $\begin{array}{r}18,914 \\
(19.1 \%)\end{array}$ & $7.5 \%$ & $557.9 \%$ \\
\hline Total Households & 62,504 & 75,412 & 85,371 & 93,347 & 98,990 & $1.8 \%$ & $58.4 \%$ \\
\hline Total HH Vehicles & 72,500 & 120,098 & 143,714 & 165,221 & 176,067 & $3.5 \%$ & $142.9 \%$ \\
\hline Vehicles Per HH & 1.16 & 1.59 & 1.68 & 1.77 & 1.78 & $1.7 \%$ & $53.4 \%$ \\
\hline
\end{tabular}

Note:

- Household-based vehicles include all vehicles owned by or available on a regular basis to the household.

- The 1969 survey does not include pickups or other light trucks as household vehicles.

- All tables reporting totals could include some unreported characteristics. 


\section{FigURE 3.8}

Household Vehicle OWNership By NuMBer of Vehicles OWNed 1969, 1977, 1983, 1990, AND 1995 NPTS

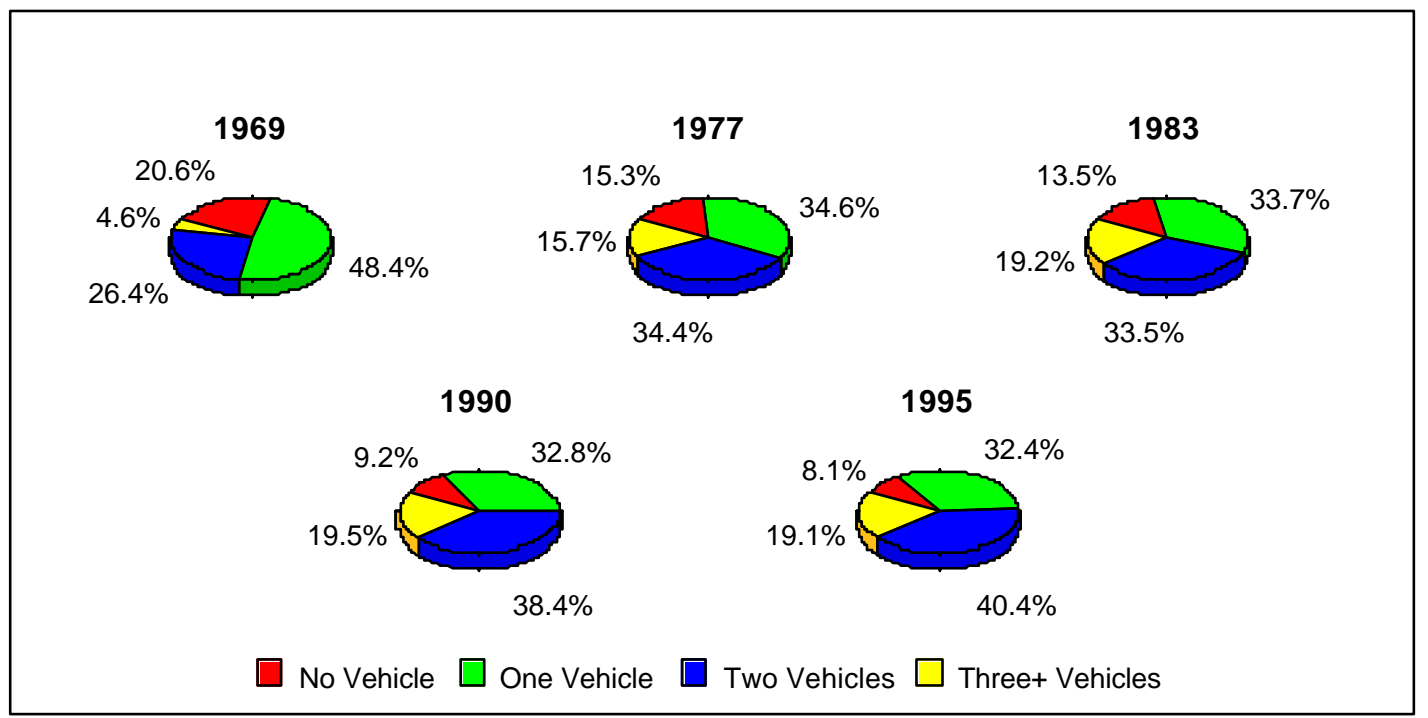

FIGURE 3.9

Household Vehicle OWNership By Number of Vehicles OWNED 1969, 1977, 1983, 1990, AND 1995 NPTS

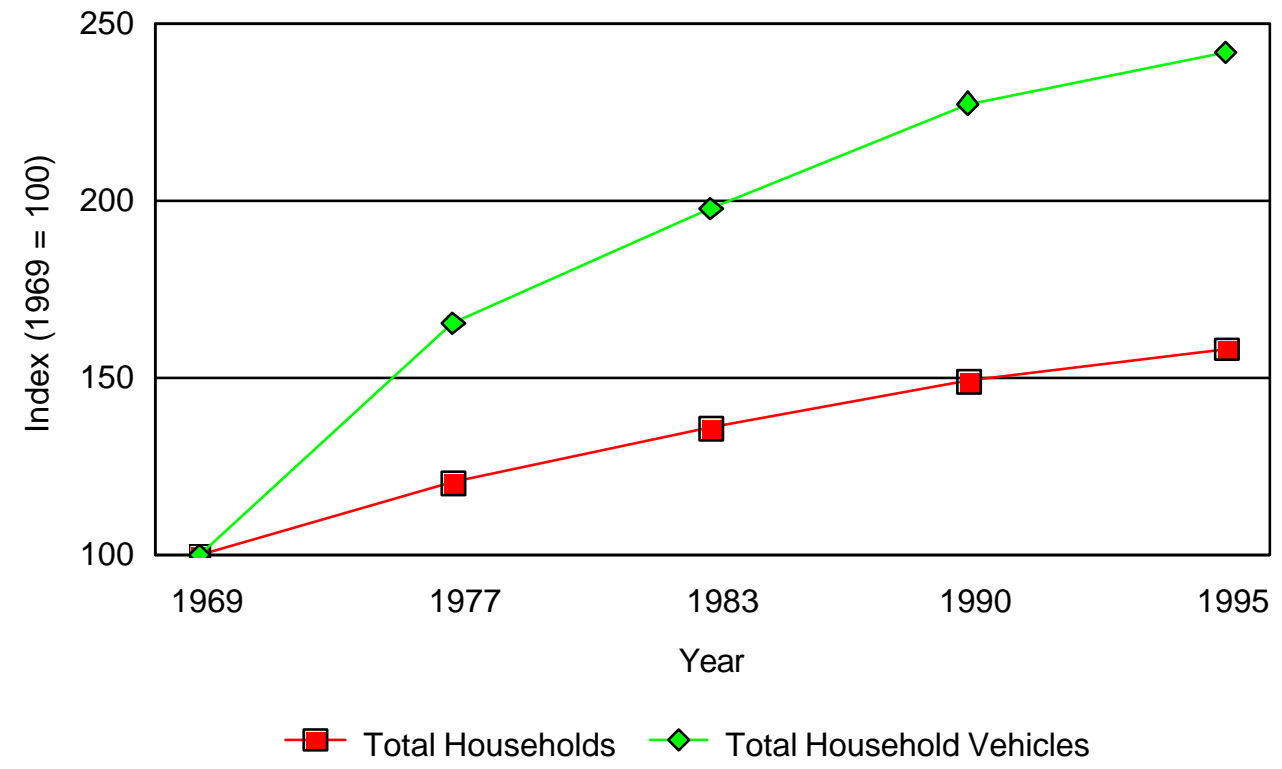




\section{TABLE 3.9}

Distribution of Households by Number of Household Adults

AND Number of HouseHold-BASED VeHIClES

1969, 1977, 1983, 1990, AND 1995 NPTS

(PERCENTAGE)

\begin{tabular}{||lrrrrr||}
\hline & 1969 & 1977 & 1983 & 1990 & 1995 \\
\hline Households with One Adult & & & & & \\
No Vehicle & 56.2 & 39.2 & 34.0 & 21.4 & 18.6 \\
One Vehicle & 42.3 & 53.2 & 57.1 & 63.7 & 68.7 \\
Two Vehicles & 1.5 & 5.7 & 7.1 & 11.4 & 10.2 \\
Three or More Vehicles & 0.0 & 1.9 & 1.8 & 3.5 & 2.5 \\
TOTAL & 100.0 & 100.0 & 100.0 & 100.0 & 100.0 \\
No. of Households (000) & na & 19,381 & 23,360 & 28,045 & 28,898 \\
Households with Two Adults & & & & & \\
No Vehicle & 12.4 & 7.5 & 5.8 & 3.6 & 3.7 \\
One Vehicle & 57.3 & 33.1 & 29.2 & 20.4 & 18.9 \\
Two Vehicles & 29.1 & 48.2 & 49.7 & 54.8 & 59.4 \\
Three or More Vehicles & 1.2 & 11.2 & 15.3 & 21.2 & 17.9 \\
TOTAL & 100.0 & 100.0 & 100.0 & 100.0 & 100.0 \\
No. of Households (000) & na & 40,270 & 45,065 & 53,407 & 56,235 \\
Households with Three or More Adults & & & & & 10.0 \\
No Vehicle & 8.2 & 5.9 & 5.6 & 4.7 & 3.6 \\
One Vehicle & 32.2 & 15.9 & 13.4 & 14.3 & 11.2 \\
Two Vehicles & 42.6 & 34.4 & 27.1 & 28.5 & 26.6 \\
Three or More Vehicles & 17.0 & 43.8 & 53.9 & 52.5 & 58.6 \\
TOTAL & 100.0 & 100.0 & 100.0 & 100.0 & 100.0 \\
No. of Households (000) & 15,761 & 16,914 & 11,119 & 13,856 \\
ALL HOUSEHOLDS (000) & & & & & \\
\hline \hline
\end{tabular}

Note:

- Household-based vehicles include all vehicles owned by or available on a regular basis to the household.

- The 1969 survey does not include pickups or other light trucks as household vehicles.

- Household adults are considered to be all persons in the household who are 18 or older.

- All tables reporting totals could include some unreported characteristics. 
In general, the number of household vehicles equals the number of household drivers (Table 3.10). Almost half of all households have two drivers, and about $31 \%$ have only one driver; there is an average of 1.78 vehicles per household.

TABLE 3.10

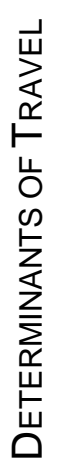

Distribution OF HOUSEHOLDS By NUMBER OF HOUSEHOLD DRIVERS

AND Number of Household-BASEd Vehicles

1995 NPTS

(PERCENTAGE)

\begin{tabular}{||l|rrrrrr||}
\hline \multirow{2}{*}{$\begin{array}{l}\text { Number of } \\
\text { Vehichold }\end{array}$} & \multicolumn{6}{c||}{ Number of Household Drivers } \\
\cline { 2 - 7 } & TOTAL & Zero & \multicolumn{1}{c||}{ One } & \multicolumn{1}{c||}{ Two } & Three & Four+ \\
\hline None & 8.1 & 92.0 & 7.5 & 1.2 & 0.7 & 0.1 \\
One & 32.4 & 6.7 & 76.7 & 15.0 & 5.6 & 3.5 \\
Two & 40.4 & 1.2 & 12.9 & 66.2 & 26.4 & 13.6 \\
Three & 14.0 & 0.2 & 2.1 & 14.1 & 53.0 & 28.0 \\
Four or More & 5.1 & 0.0 & 0.7 & 3.4 & 14.3 & 54.8 \\
TOTAL & 100.0 & 100.0 & 100.0 & 100.0 & 100.0 & 100.0 \\
No. of Households (000) & 98,990 & 5,453 & 30,713 & 49,738 & 10,026 & 3,059 \\
Vehicles per Household & 1.78 & 0.10 & 1.12 & 2.05 & 2.79 & 3.62 \\
& & & & & & \\
\hline
\end{tabular}

Note:

- Household-based vehicles include all vehicles owned by or available on a regular basis to the household.

- All tables reporting totals could include some unreported characteristics. 
The number of vehicles per household by household income level remained fairly constant between 1983 and 1995. For households with annual incomes above $\$ 40,000$, the overall percentage of households in each income level also remained fairly close.

\section{TABLE 3.11}

Number OF Households AND Number of VeHIClES PER HOUSEHOLd by HOUSEHOLd INCOME 1983, 1990, AND 1995 NPTS

(INCOME IN 1995 DollaRS)

\begin{tabular}{|c|c|c|c|c|c|c|}
\hline \multirow[b]{2}{*}{$\begin{array}{l}\text { Household } \\
\text { Income }\end{array}$} & \multicolumn{2}{|c|}{1983} & \multicolumn{2}{|c|}{1990} & \multicolumn{2}{|c|}{1995} \\
\hline & $\begin{array}{c}\text { Number of } \\
\text { Households } \\
(000)\end{array}$ & $\begin{array}{l}\text { Number of } \\
\text { Vehicles per } \\
\text { Household } \\
\end{array}$ & $\begin{array}{c}\text { Number of } \\
\text { Households } \\
(000)\end{array}$ & $\begin{array}{c}\text { Number of } \\
\text { Vehicles per } \\
\text { Household } \\
\end{array}$ & $\begin{array}{c}\text { Number of } \\
\text { Households } \\
(000)\end{array}$ & $\begin{array}{l}\text { Number of } \\
\text { Vehicles per } \\
\text { Household }\end{array}$ \\
\hline TOTAL & $\begin{array}{r}85,371 \\
(100.0 \%)\end{array}$ & 1.7 & $\begin{array}{r}93,347 \\
(100.0 \%)\end{array}$ & 1.8 & $\begin{array}{r}98,990 \\
(100.0 \%)\end{array}$ & 1.8 \\
\hline $\begin{array}{l}\text { Less than } \\
\$ 10,000\end{array}$ & $\begin{array}{r}13,492 \\
(15.8 \%)\end{array}$ & 0.7 & $\begin{array}{r}7,247 \\
(7.8 \%)\end{array}$ & 0.9 & $\begin{array}{r}8,410 \\
(8.5 \%)\end{array}$ & 0.9 \\
\hline $\begin{array}{l}\$ 10,000- \\
\$ 20,000\end{array}$ & $\begin{array}{c}16,691 \\
(19.6 \%)\end{array}$ & 1.2 & $\begin{array}{r}11,121 \\
(11.9 \%)\end{array}$ & 1.3 & $\begin{array}{r}13,983 \\
(14.1 \%)\end{array}$ & 1.3 \\
\hline $\begin{array}{l}\$ 20,000- \\
\$ 30,000\end{array}$ & $\begin{array}{c}14,559 \\
(17.1 \%)\end{array}$ & 1.6 & $\begin{array}{r}11,050 \\
(11.8 \%)\end{array}$ & 1.6 & $\begin{array}{c}15,152 \\
(15.3 \%)\end{array}$ & 1.7 \\
\hline $\begin{array}{l}\$ 30,000- \\
\$ 40,000\end{array}$ & $\begin{array}{c}11,995 \\
(14.1 \%)\end{array}$ & 2.0 & $\begin{array}{c}10,017 \\
(10.7 \%)\end{array}$ & 1.8 & $\begin{array}{r}12,775 \\
(12.9 \%)\end{array}$ & 1.9 \\
\hline $\begin{array}{l}\$ 40,000- \\
\$ 50,000\end{array}$ & $\begin{array}{r}9,291 \\
(10.9 \%)\end{array}$ & 2.2 & $\begin{array}{r}8,318 \\
(8.9 \%)\end{array}$ & 2.0 & $\begin{array}{r}9,830 \\
(9.9 \%)\end{array}$ & 2.1 \\
\hline $\begin{array}{l}\$ 50,000- \\
\$ 60,000\end{array}$ & $\begin{array}{r}6,702 \\
(7.9 \%)\end{array}$ & 2.3 & $\begin{array}{r}6,312 \\
(6.8 \%)\end{array}$ & 2.2 & $\begin{array}{r}6,985 \\
(7.1 \%)\end{array}$ & 2.2 \\
\hline $\begin{array}{l}\$ 60,000- \\
\$ 70,000\end{array}$ & $\begin{array}{r}4,448 \\
(5.2 \%)\end{array}$ & 2.3 & $\begin{array}{r}4,373 \\
(4.7 \%)\end{array}$ & 2.3 & $\begin{array}{c}4,708 \\
(4.8 \%)\end{array}$ & 2.3 \\
\hline $\begin{array}{l}\$ 70,000- \\
\$ 80,000\end{array}$ & $\begin{array}{r}2,696 \\
(3.2 \%)\end{array}$ & 2.4 & $\begin{array}{c}2,821 \\
(3.0 \%)\end{array}$ & 2.4 & $\begin{array}{r}3,246 \\
(3.3 \%)\end{array}$ & 2.3 \\
\hline $\begin{array}{l}\$ 80,000 \text { and } \\
\text { above }\end{array}$ & $\begin{array}{r}5,496 \\
(6.4 \%)\end{array}$ & 2.7 & $\begin{array}{r}6,327 \\
(6.8 \%)\end{array}$ & 2.6 & $\begin{array}{r}7,352 \\
(7.4 \%)\end{array}$ & 2.4 \\
\hline $\begin{array}{l}\text { Unreported } \\
\text { Income }\end{array}$ & NA & NA & $\begin{array}{r}25,762 \\
(27.6 \%) \\
\end{array}$ & 1.7 & $\begin{array}{r}16,550 \\
(16.7 \%)\end{array}$ & 1.8 \\
\hline
\end{tabular}

Note:

- The 1983 NPTS does not detail any unreported income information. 
Numbers of households and persons per household composition are shown in Table 3.12 and Figure 3.10. Most households (60.6\%) contained no children. The greatest change in household composition was in the category of retired adults, which grew from about 10\% (1983) to almost 20\% (1995) of all households.

\section{TABLE 3.12}

\section{Number of Households AND Number of Persons by Household COMPosition 1983, 1990, AND 1995 NPTS}

(THOUSANDS)

\begin{tabular}{|c|c|c|c|c|c|c|}
\hline \multirow[b]{2}{*}{ Household Composition } & \multicolumn{2}{|c|}{1983} & \multicolumn{2}{|c|}{1990} & \multicolumn{2}{|c|}{1995} \\
\hline & $\begin{array}{c}\text { No. of } \\
\text { Households }\end{array}$ & $\begin{array}{l}\text { No. of } \\
\text { Persons }\end{array}$ & $\begin{array}{c}\text { No. of } \\
\text { Households }\end{array}$ & $\begin{array}{l}\text { No. of } \\
\text { Persons } \\
\end{array}$ & $\begin{array}{c}\text { No. of } \\
\text { Households }\end{array}$ & $\begin{array}{l}\text { No. of } \\
\text { Persons }\end{array}$ \\
\hline TOTAL & $\begin{array}{r}85,375 \\
(100 \%)\end{array}$ & $\begin{array}{l}212,932 \\
(100 \%)\end{array}$ & $\begin{array}{l}93,347 \\
(100 \%)\end{array}$ & $\begin{array}{l}222,101 \\
(100 \%)\end{array}$ & $\begin{array}{l}98,990 \\
(100 \%)\end{array}$ & $\begin{array}{l}241,675 \\
(100 \%)\end{array}$ \\
\hline $\begin{array}{l}\text { Single Adult, } \\
\text { No Children }\end{array}$ & $\begin{array}{r}16,955 \\
(19.9 \%)\end{array}$ & $\begin{array}{l}16,149 \\
(7.6 \%)\end{array}$ & $\begin{array}{r}15,505 \\
(16.6 \%)\end{array}$ & $\begin{array}{l}17,264 \\
(7.8 \%)\end{array}$ & $\begin{array}{c}16,958 \\
(17.1 \%)\end{array}$ & $\begin{array}{l}18,614 \\
(7.7 \%)\end{array}$ \\
\hline $\begin{array}{l}\text { Two or More Adults, } \\
\text { No Children }\end{array}$ & $\begin{array}{c}22,629 \\
(26.5 \%)\end{array}$ & $\begin{array}{l}47,756 \\
(22.4 \%)\end{array}$ & $\begin{array}{c}24,182 \\
(25.9 \%)\end{array}$ & $\begin{array}{c}51,917 \\
(23.4 \%)\end{array}$ & $\begin{array}{l}23,335 \\
(23.6 \%)\end{array}$ & $\begin{array}{r}51,227 \\
(21.2 \%)\end{array}$ \\
\hline $\begin{array}{l}\text { Single Adult, } \\
\text { Youngest Child Under } 6\end{array}$ & $\begin{array}{c}1,942 \\
(2.2 \%)\end{array}$ & $\begin{array}{c}5,947 \\
(2.8 \%)\end{array}$ & $\begin{array}{l}1,698 \\
(1.8 \%)\end{array}$ & $\begin{array}{c}3,753 \\
(1.7 \%)\end{array}$ & $\begin{array}{l}1,610 \\
(1.6 \%)\end{array}$ & $\begin{array}{r}3,580 \\
(1.5 \%)\end{array}$ \\
\hline $\begin{array}{l}\text { Two or More Adults, } \\
\text { Youngest Child Under } 6\end{array}$ & $\begin{array}{l}13,776 \\
(16.1 \%)\end{array}$ & $\begin{array}{l}54,369 \\
(25.5 \%)\end{array}$ & $\begin{array}{l}13,791 \\
(14.8 \%)\end{array}$ & $\begin{array}{l}43,436 \\
(19.6 \%)\end{array}$ & $\begin{array}{c}14,739 \\
(14.9 \%)\end{array}$ & $\begin{array}{r}48,348 \\
(20.0 \%)\end{array}$ \\
\hline $\begin{array}{l}\text { Single Adult, } \\
\text { Youngest Child 6-15 }\end{array}$ & $\begin{array}{c}3,394 \\
(4.0 \%)\end{array}$ & $\begin{array}{l}8,966 \\
(4.2 \%)\end{array}$ & $\begin{array}{c}2,382 \\
(2.6 \%)\end{array}$ & $\begin{array}{c}6,952 \\
(5.1 \%)\end{array}$ & $\begin{array}{l}2,573 \\
(2.6 \%)\end{array}$ & $\begin{array}{r}7,620 \\
(3.2 \%)\end{array}$ \\
\hline $\begin{array}{l}\text { Two or More Adults, } \\
\text { Youngest Child 6-15 }\end{array}$ & $\begin{array}{c}12,277 \\
(14.4 \%)\end{array}$ & $\begin{array}{l}46,378 \\
(21.8 \%)\end{array}$ & $\begin{array}{r}12,332 \\
(13.2 \%)\end{array}$ & $\begin{array}{l}50,276 \\
(22.6 \%)\end{array}$ & $\begin{array}{l}14,644 \\
(14.8 \%)\end{array}$ & $\begin{array}{r}59,712 \\
(24.7 \%)\end{array}$ \\
\hline $\begin{array}{l}\text { Single Adult, } \\
\text { Youngest Child } 16 \text { or Older }\end{array}$ & $\begin{array}{c}838 \\
(1.0 \%)\end{array}$ & $\begin{array}{c}1,866 \\
(0.9 \%)\end{array}$ & $\begin{array}{c}819 \\
(0.9 \%)\end{array}$ & $\begin{array}{c}1,892 \\
(0.9 \%)\end{array}$ & $\begin{array}{c}1,043 \\
(1.1 \%)\end{array}$ & $\begin{array}{r}2,292 \\
(0.9 \%)\end{array}$ \\
\hline $\begin{array}{l}\text { Two or More Adults, } \\
\text { Youngest Child } 16 \text { or Older }\end{array}$ & $\begin{array}{c}4,618 \\
(5.4 \%)\end{array}$ & $\begin{array}{l}15,734 \\
(7.4 \%)\end{array}$ & $\begin{array}{l}4,444 \\
(4.8 \%)\end{array}$ & $\begin{array}{l}14,599 \\
(6.6 \%)\end{array}$ & $\begin{array}{l}4,346 \\
(4.4 \%)\end{array}$ & $\begin{array}{l}15,410 \\
(6.4 \%)\end{array}$ \\
\hline $\begin{array}{l}\text { Single Adult, } \\
\text { Retired - No Children }\end{array}$ & $\begin{array}{l}2,400 \\
(2.8 \%)\end{array}$ & $\begin{array}{c}2,069 \\
(1.0 \%)\end{array}$ & $\begin{array}{l}7,642 \\
(8.2 \%)\end{array}$ & $\begin{array}{l}8,340 \\
(3.8 \%)\end{array}$ & $\begin{array}{c}7,821 \\
(7.9 \%)\end{array}$ & $\begin{array}{r}8,293 \\
(3.4 \%)\end{array}$ \\
\hline $\begin{array}{l}\text { Two or More Adults, } \\
\text { Retired - No Children }\end{array}$ & $\begin{array}{c}6,546 \\
(7.7 \%)\end{array}$ & $\begin{array}{l}13,698 \\
(6.4 \%)\end{array}$ & $\begin{array}{c}9,777 \\
(10.5 \%)\end{array}$ & $\begin{array}{c}22,502 \\
(10.1 \%)\end{array}$ & $\begin{array}{l}11,921 \\
(12.0 \%)\end{array}$ & $\begin{array}{r}26,578 \\
(11.0 \%)\end{array}$ \\
\hline
\end{tabular}

Note:

- Different expansion factors contribute to the difference between the number of households and the number of persons for oneperson households (e.g. Single Adult, No Children; Single Adult, Retired - No Children).

- All tables reporting totals could include some unreported characteristics. 
FIGURE 3.10

Distribution OF Households By Household COMPOSITION 1983, 1990, AND 1995 NPTS

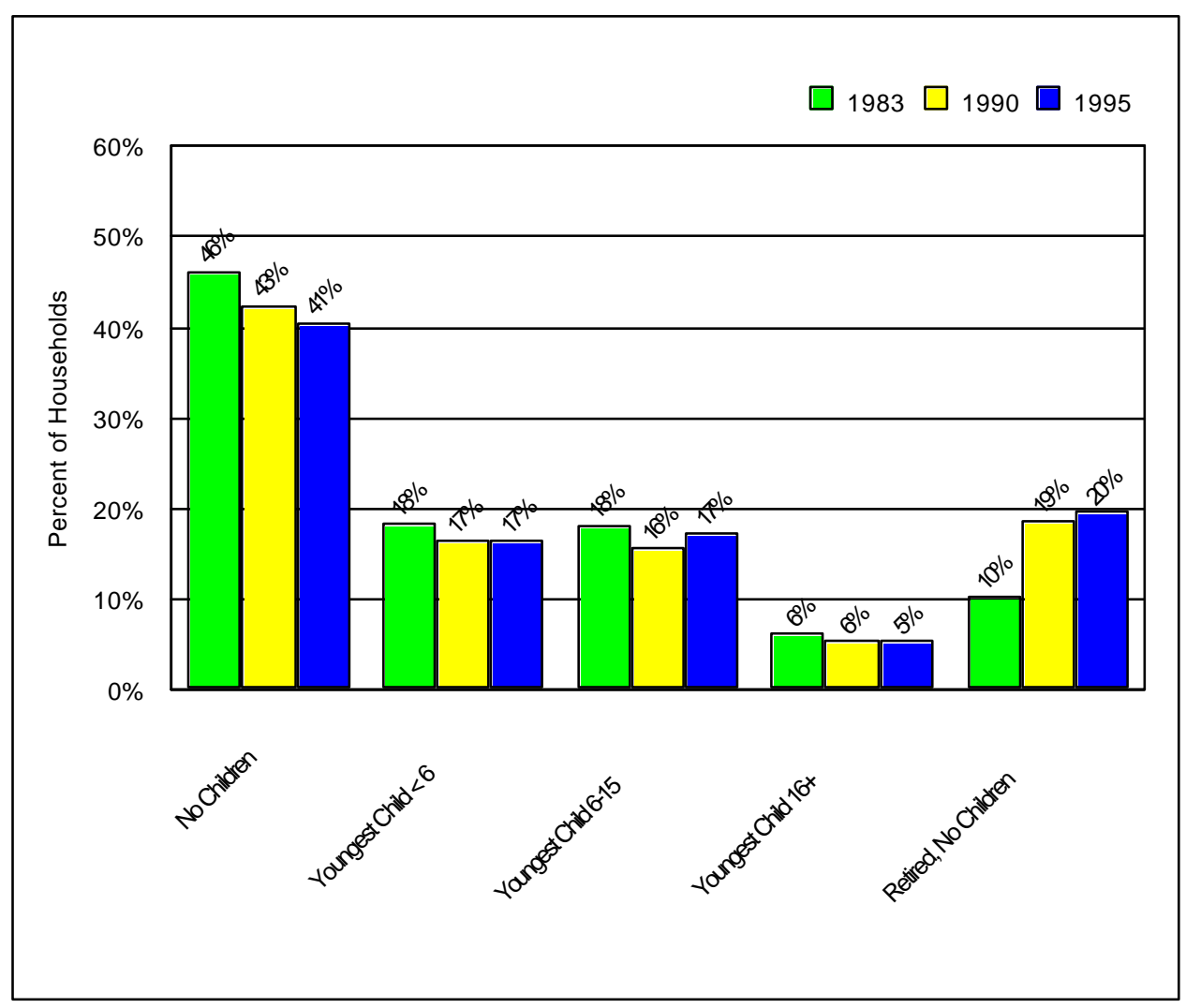


In 1995, automobiles remained the most common type of household vehicle. The truck and van category almost doubled between 1977 and 1995, however, and grew by 50\% between 1990 and 1995. Most of this growth was in the areas of minivans and sport utility vehicles (SUVs). SUVs, which were not a separate vehicle category until the 1995 NPTS, made up $6.9 \%$ of the entire household vehicle fleet in 1995.

TABLE 3.13

\section{Number of Vehicles by Vehicle Type 1977, 1983, 1990, AND 1995 NPTS \\ (THOUSANDS)}

\begin{tabular}{|c|c|c|c|c|}
\hline Vehicle Type & 1977 & 1983 & 1990 & 1995 \\
\hline TOTAL & $\begin{array}{c}120,098 \\
(100.0 \%)\end{array}$ & $\begin{array}{c}143,714 \\
(100.0 \%)\end{array}$ & $\begin{array}{c}165,221 \\
(100.0 \%)\end{array}$ & $\begin{array}{c}176,067 \\
(100.0 \%)\end{array}$ \\
\hline Autos & $\begin{array}{c}95,598 \\
(79.6 \%)\end{array}$ & $\begin{array}{l}109,079 \\
(75.9 \%)\end{array}$ & $\begin{array}{l}123,420 \\
(74.7 \%)\end{array}$ & $\begin{array}{l}113,284 \\
(64.3 \%)\end{array}$ \\
\hline Total Trucks and Vans & $\begin{array}{c}20,297 \\
(16.9 \%)\end{array}$ & $\begin{array}{c}29,174 \\
(20.3 \%)\end{array}$ & $\begin{array}{c}38,496 \\
(23.3 \%)\end{array}$ & $\begin{array}{c}57,771 \\
(32.8 \%)\end{array}$ \\
\hline Van & $\begin{array}{c}3,363 \\
(2.8 \%)\end{array}$ & $\begin{array}{c}5,173 \\
(3.6 \%)\end{array}$ & $\begin{array}{c}9,087 \\
(5.5 \%)\end{array}$ & $\begin{array}{l}13,810 \\
(7.8 \%)\end{array}$ \\
\hline Sport Utility Vehicle & NA & NA & NA & $\begin{array}{l}12,155 \\
(6.9 \%)\end{array}$ \\
\hline Pickup & $\begin{array}{l}15,373 \\
(12.8 \%)\end{array}$ & $\begin{array}{c}21,845 \\
(15.2 \%)\end{array}$ & $\begin{array}{c}28,418 \\
(17.2 \%)\end{array}$ & $\begin{array}{c}31,110 \\
(17.7 \%)\end{array}$ \\
\hline Other Truck & $\begin{array}{c}1,561 \\
(1.3 \%)\end{array}$ & $\begin{array}{c}2,156 \\
(1.5 \%)\end{array}$ & $\begin{array}{c}991 \\
(0.6 \%)\end{array}$ & $\begin{array}{c}696 \\
(0.4 \%)\end{array}$ \\
\hline Total Recreational Vehicles & $\begin{array}{c}3,963 \\
(3.3 \%)\end{array}$ & $\begin{array}{c}5,174 \\
(3.6 \%)\end{array}$ & $\begin{array}{c}3,139 \\
(1.9 \%)\end{array}$ & $\begin{array}{c}2,583 \\
(1.5 \%)\end{array}$ \\
\hline RV/Motor Home & $\begin{array}{c}480 \\
(0.4 \%)\end{array}$ & $\begin{array}{c}719 \\
(0.5 \%)\end{array}$ & $\begin{array}{c}826 \\
(0.5 \%)\end{array}$ & $\begin{array}{c}924 \\
(0.5 \%)\end{array}$ \\
\hline Motorcycle & $\begin{array}{c}3,243 \\
(2.7 \%)\end{array}$ & $\begin{array}{c}3,593 \\
(2.5 \%)\end{array}$ & $\begin{array}{c}2,148 \\
(1.3 \%)\end{array}$ & $\begin{array}{c}1,659 \\
(0.9 \%)\end{array}$ \\
\hline Moped & $\begin{array}{c}240 \\
(0.2 \%)\end{array}$ & $\begin{array}{c}862 \\
(0.6 \%)\end{array}$ & $\begin{array}{c}165 \\
(0.1 \%)\end{array}$ & NA \\
\hline Other Vehicles & $\begin{array}{c}240 \\
(0.2 \%)\end{array}$ & $\begin{array}{c}287 \\
(0.2 \%)\end{array}$ & $\begin{array}{c}166 \\
(0.1 \%)\end{array}$ & $\begin{array}{c}149 \\
(0.1 \%)\end{array}$ \\
\hline
\end{tabular}

Note:

- The 1977, 1983, and 1990 surveys do not include a separate category for sports utility vehicles (SUVs), while the 1995 survey does. In the 1990 survey, most SUVs were classified as automobiles. The 1995 survey does not include a separate category for mopeds.

- All tables reporting totals could include some unreported characteristics.

- The category "Other Vehicles" includes any privately owned vehicle that cannot be classified into one of the other categories. 
Figure 3.11 shows the share of household vehicles by vehicle type. Automobiles continue to be the predominant household vehicle of choice; however, their share is decreasing as the share of trucks and vans increases.

FIGURE 3.11

Distribution of Vehicles by Vehicle Type

1977, 1983, 1990, AND 1995 NPTS

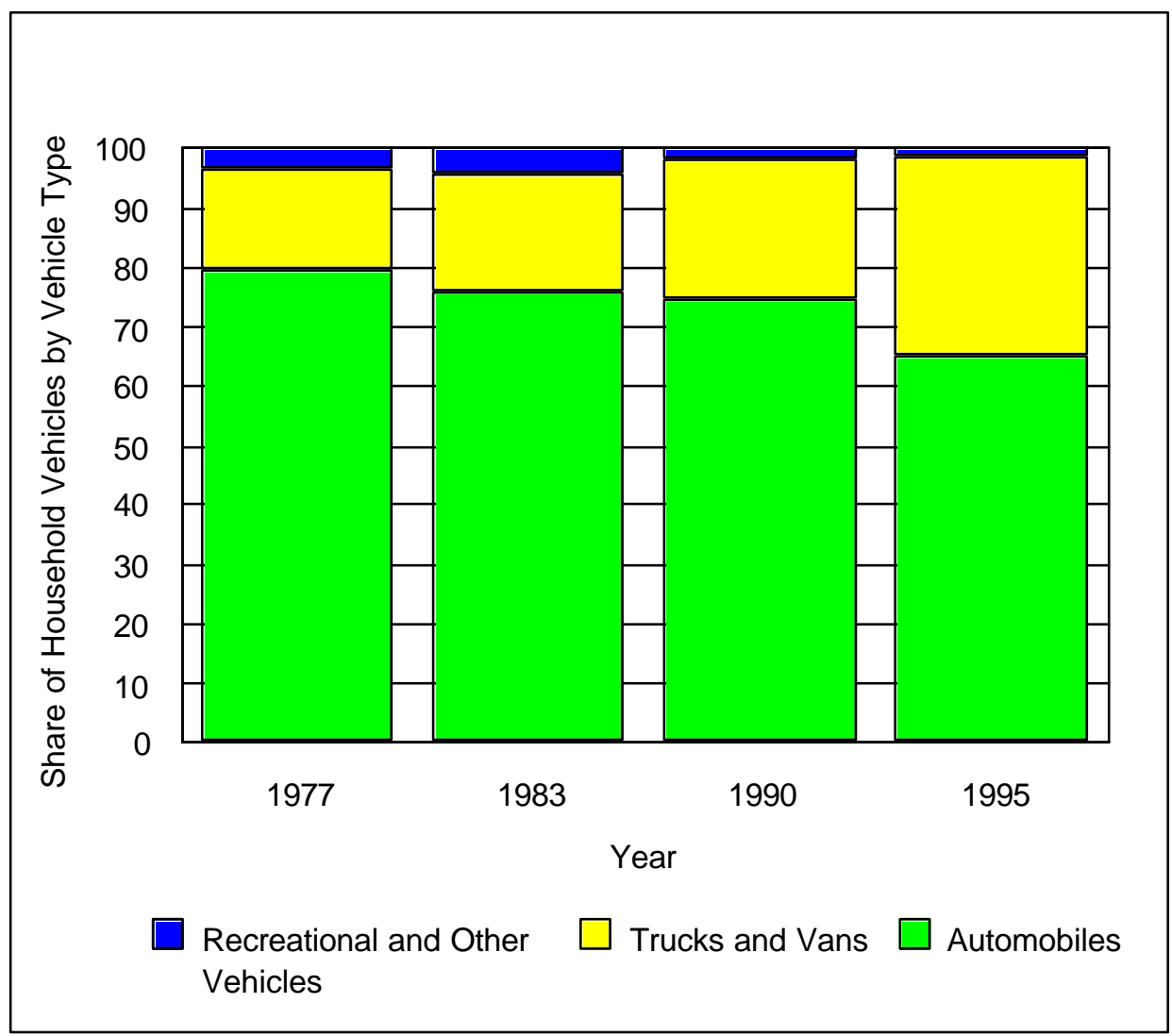


Americans are keeping their vehicles longer than they did in earlier years. According to Table 3.24 of the 1990 NPTS Databook, $31.4 \%$ of all vehicles in 1969 were less than two years old. By 1983, only $19 \%$ were less than two years old, and, in 1995, only $15.6 \%$ were less than two years old. The average age of a household vehicle was 5.1 years in 1969 and 7.9 years in 1995 . The average age of RVs (12.6 years) is higher than the average age of automobiles and trucks/vans. In 1969, 10.8\% of household vehicles were 10 or more years old; by 1995, almost a third of all household vehicles were 10 or more years old.

\section{TABLE 3.14}

Distribution of Household Vehicles by Vehicle Age and Vehicle Type 1990 AND 1995 NPTS

(PERCENTAGE)

\begin{tabular}{|c|c|c|c|c|c|c|c|c|}
\hline \multirow{2}{*}{$\begin{array}{l}\text { Vehicle } \\
\text { Age } \\
\text { (years) }\end{array}$} & \multicolumn{4}{|c|}{1990} & \multicolumn{4}{|c|}{1995} \\
\hline & TOTAL & Autos & Truck/Van & RVs & TOTAL & Autos & Truck/Van & $\mathrm{RVs}$ \\
\hline TOTAL & 100.0 & 100.0 & 100.0 & 100.0 & 100.0 & 100.0 & 100.0 & 100.0 \\
\hline$\leq 1$ & 7.0 & 6.4 & 8.8 & 11.6 & 7.7 & 7.1 & 9.3 & 1.3 \\
\hline 2 & 9.6 & 9.2 & 10.9 & 4.8 & 7.9 & 7.4 & 9.4 & 1.0 \\
\hline 3 & 9.1 & 8.9 & 9.7 & 5.8 & 7.2 & 7.2 & 7.5 & 3.8 \\
\hline 4 & 9.0 & 9.1 & 9.1 & 2.3 & 6.7 & 6.8 & 7.0 & 1.4 \\
\hline 5 & 9.4 & 9.7 & 8.4 & 3.1 & 6.7 & 7.1 & 6.4 & 2.4 \\
\hline 6 & 8.6 & 9.0 & 7.5 & 6.1 & 6.4 & 6.7 & 6.0 & 5.1 \\
\hline 7 & 7.5 & 7.9 & 6.3 & 5.7 & 7.7 & 8.4 & 6.8 & 8.2 \\
\hline 8 & 4.9 & 5.2 & 3.8 & 4.5 & 7.0 & 7.4 & 6.4 & 5.5 \\
\hline 9 & 4.3 & 4.6 & 3.3 & 1.2 & 6.4 & 7.0 & 5.6 & 5.1 \\
\hline$\geq 10$ & 30.6 & 30.0 & 32.2 & 54.9 & 32.6 & 32.3 & 32.7 & 60.7 \\
\hline \multicolumn{9}{|c|}{ Number of Vehicles (000) } \\
\hline & 158,643 & 120,712 & 37,110 & 821 & 176,067 & 113,284 & 57,771 & 924 \\
\hline \multicolumn{9}{|c|}{ Average Vehicle Age (years) } \\
\hline & 7.7 & 7.6 & 8.0 & 10.4 & 7.9 & 7.9 & 7.9 & 12.6 \\
\hline
\end{tabular}

Note:

- All tables reporting totals could include some unreported characteristics. Total vehicle type includes ALL vehicle types. 
In 1995, the average mileage driven per vehicle decreased slightly from the 1990 value (Table 3.15). Vehicles that were less than two years old were driven $32 \%$ more miles than the average annual mileage of all vehicles. As shown in Figure 3.12, the older the vehicle, the less it was driven annually.

\section{TABLE 3.15}

Average Annual Miles Per Vehicle by Vehicle Age

1969, 1977, 1983,1990, AND 1995 NPTS

(HOUSEHOLD ESTIMATED MILES)

\begin{tabular}{|c|c|c|c|c|c|c|c|}
\hline \multirow[b]{2}{*}{$\begin{array}{l}\text { Vehicle Age } \\
\text { (years) }\end{array}$} & \multirow[b]{2}{*}{1969} & \multirow[b]{2}{*}{1977} & \multirow[b]{2}{*}{1983} & \multirow[b]{2}{*}{1990} & \multirow[b]{2}{*}{1995} & \multicolumn{2}{|c|}{ Percent Change 69-95 } \\
\hline & & & & & & $\begin{array}{l}\text { Compound } \\
\text { Annual Rate }\end{array}$ & $\begin{array}{c}\text { Total } \\
\text { Change } \\
\text { for Period }\end{array}$ \\
\hline $0-2$ & 15,700 & 14,460 & 15,292 & 16,811 & 16,092 & $0.1 \%$ & $2.5 \%$ \\
\hline $3-5$ & 11,200 & 11,074 & 11,902 & 13,706 & 14,004 & $0.9 \%$ & $25.0 \%$ \\
\hline $6-9$ & 9,700 & 9,199 & 9,253 & 12,554 & 12,608 & $1.0 \%$ & $30.0 \%$ \\
\hline 10 or more & 6,500 & 6,755 & 7,023 & 9,176 & 8,758 & $1.2 \%$ & $34.7 \%$ \\
\hline Average & 11,600 & 10,679 & 10,315 & 12,458 & 12,226 & $0.2 \%$ & $5.4 \%$ \\
\hline
\end{tabular}




\section{FIGURE 3.12}

Average Annual Miles Per Vehicle by Vehicle Age

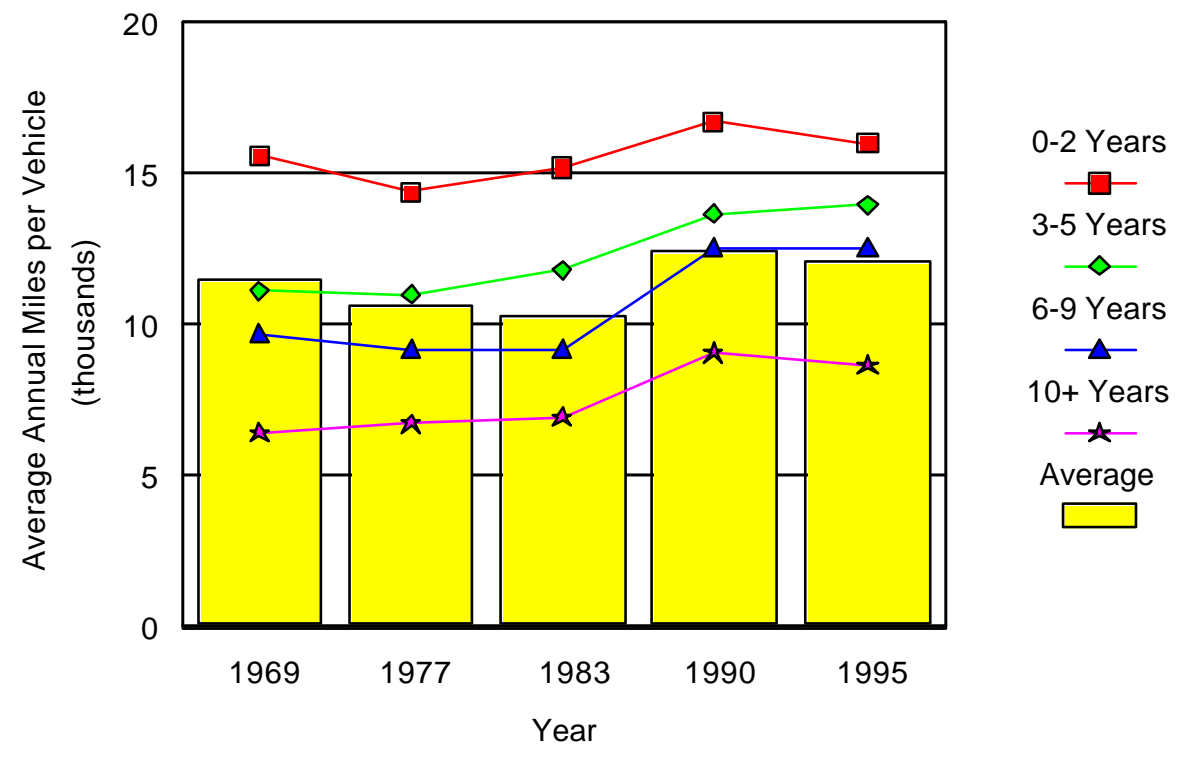

As shown in Table 3.16, when a household had more drivers than vehicles, each household vehicle was driven more miles annually then when there were more vehicles than there were drivers.

TABLE 3.16

Average Annual Miles Per Vehicle by Vehicle to Driver Ratio 1995 NPTS

(HOUSEHOLD ESTIMATED MILES AND ODOMETER ESTIMATED MILES)

\begin{tabular}{||l|c|c||}
\hline \hline Vehicle to Driver Ratio & Household Estimated Mileage & Odometer Estimated Mileage \\
\hline ALL & 12,226 & 11,801 \\
Vehicles < Drivers & 13,978 & 14,675 \\
Vehicles = Drivers & 12,823 & 11,795 \\
Vehicles > Drivers & 10,314 & 10,731 \\
\hline
\end{tabular}




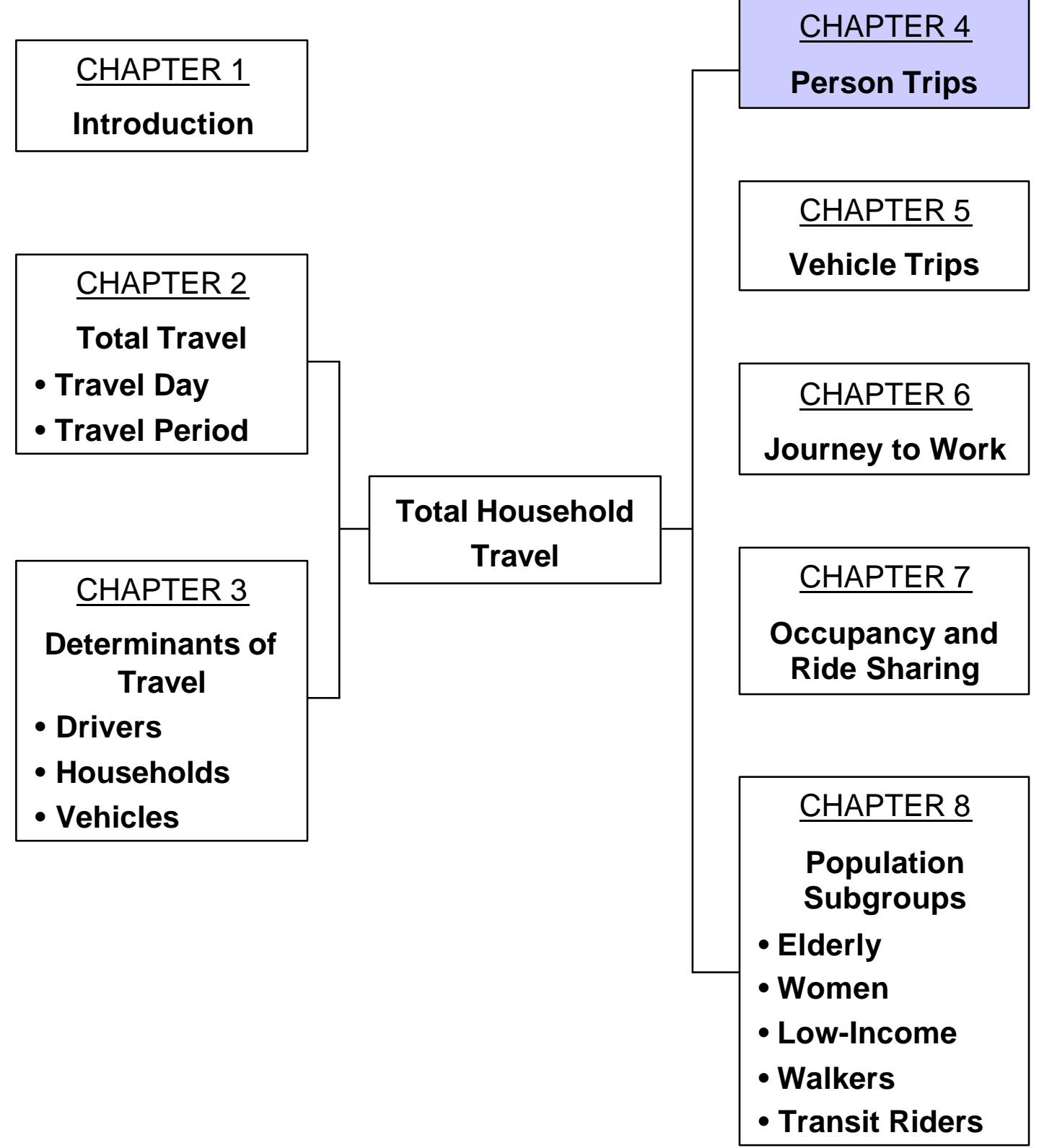




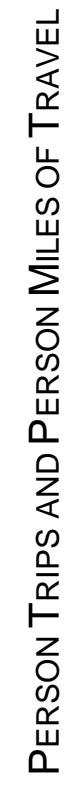

NATIONWIDE PERSONAL TRANSPORTATION SURVEY 


\section{Chapter 4}

\section{Person Trips and Person miles of Travel}

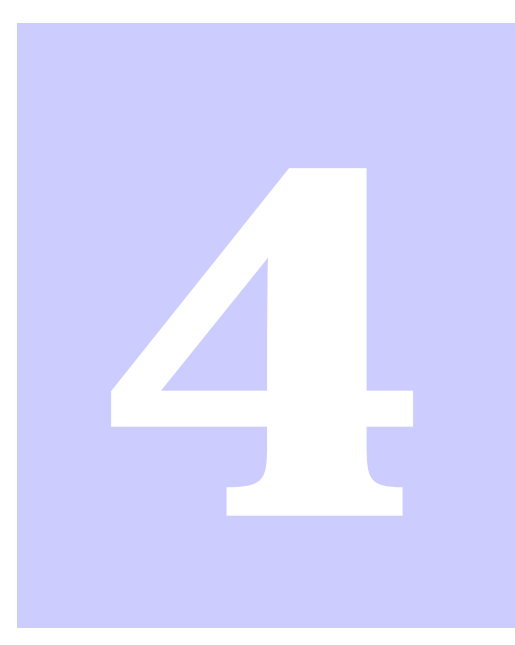

\section{BETWEEN 1969 AND 1995:}

- Every NPTS since 1969 shows a growth in annual person trips and annual person miles; between 1990 and 1995, this growth was about $25 \%$ and $21 \%$ respectively.

- The greatest number of person trips for both men and women across all age groups was for family/personal business.

- Persons in large metropolitan areas took fewer person trips per person and traveled fewer person miles per person than any other demographic group.

- Only about $1 \%$ of all trips in NPTS were considered segmented trips. 
1995 Person Trips and Person Miles by Mode

(MILLIONS)

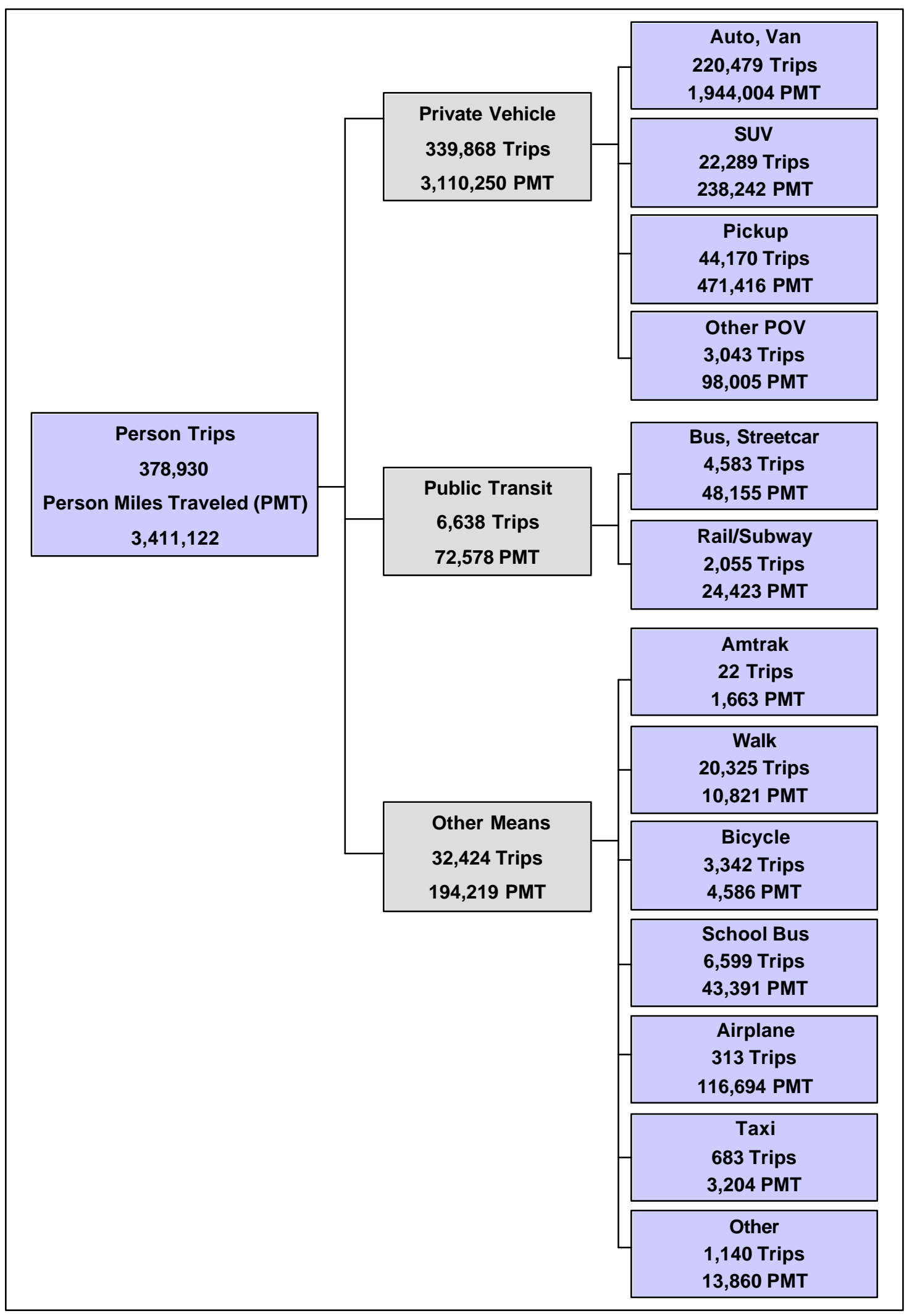


(MILLIONS)

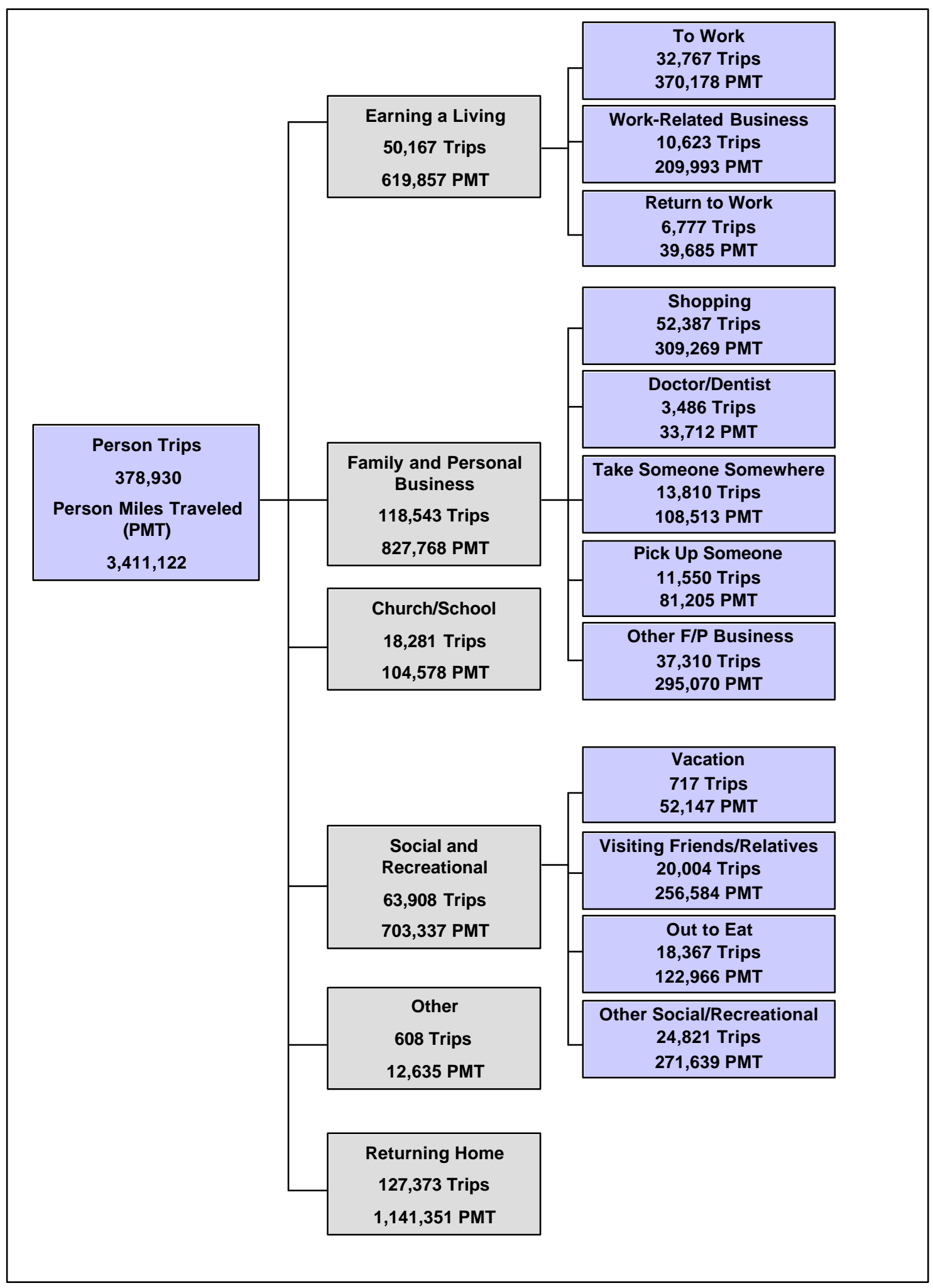




\section{LIST OF TABLES}

Table 4.1 Summary of National Estimates 1969, 1977, 1983, 1990, 1990

AdJUSTED, AND 1995 NPTS . . . . . . . . . . . . . . . . . . . . 4-4

TAble 4.2 Number OF Person Trips by Age AND Gender 1990 AdJusted AND

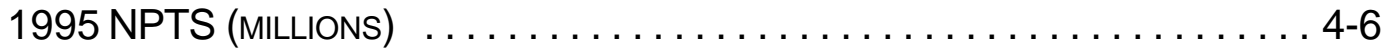

Table 4.3 Number of Person Miles of Travel by Age and Gender 1990 AdJUSTED AND 1995 NPTS (MILLIONS) . .................. 4-7

Table 4.4 Average Daily Person Trips per Person by Age and Gender 1990 ADJUSTED AND 1995 NPTS . . . . . . . . . . . . . . . . . . . . 4-9

Table 4.5 Average PMT per Person by Age and Gender 1990 Adjusted AND 1995 NPTS .............................. 4-10

Table 4.6 Average Person Trip Length by Age and Gender 1990 Adjusted AND 1995 NPTS (MILES) $\ldots \ldots \ldots \ldots \ldots \ldots \ldots \ldots \ldots \ldots \ldots \ldots \ldots \ldots \ldots \ldots \ldots \ldots .12$

Table 4.7 Number of Person Trips by 1995 Trip Purpose Codes vs. 1990 TRIP PuRPose Codes 1995 NPTS (MILLIONS) . . .............. 4-15

Table 4.8 Average Daily Person Travel by Gender, Driver's License (DL) StATUS, AND TRIP PURPOSE 1995 NPTS $\ldots \ldots \ldots \ldots \ldots \ldots \ldots \ldots .4 .17$

Table 4.9 Number of Person Trips Taken by Menby Age and Trip Purpose

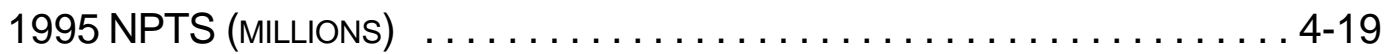

Table 4.10 Number of Person Trips Taken by Menby Age And 1990TriP PURPOSE 1995 NPTS (MILLIONS) …..................... 4-20

Table 4.11 Number of Person Trips Taken by Womenby Age and Trip PuRPOSE 1995 NPTS (MILLIONS) $\ldots \ldots \ldots \ldots \ldots \ldots \ldots \ldots \ldots \ldots . . \ldots \ldots .21$

Table 4.12 Number of Person Trips Taken by Womenby Age and 1990 TriP PuRPOSE 1995 NPTS (MILLIONS) . . . . . . . . . . . . . . . . . 4-22

Table 4.13 Average Dally Person Trips Per Person by Mode of TRANSPORTATION AND TRIP PURPOSE BY INDIVIDUALS 65 YEARS OR OLDER VS. INDIVIDUALS UNDER 65 YEARS 1995 NPTS

Table 4.14 Average Daily Person Trips per Person by Mode of

TRANSPORTATION AND 1990 TRIP PURPOSE BY INDIVIDUALS 65 YEARS OR OLDER VS. INDIVIDUALS UNDER 65 YEARS 1995 NPTS

Table 4.15 Statistics on Person Trips and Travel by Household COMPOSITION 1995 NPTS . . . . . . . . . . . . . . . . . . . . . . 4-28

Table 4.16 Demographic and Personal Travel Statistics by MSA Size 1995

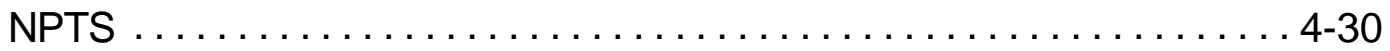

Table 4.17 Number of Person Trips by Public Transit vs. Other Modes, TRIP PuRPoSE, AND MSA SIZE 1995 NPTS (MILLIONS) . . . . . . . . . . . 4 4-31

Table 4.18 Average Trip Length by 1990 Trip PuRPoses 1990 AdJusted AND

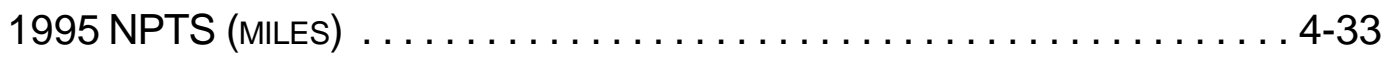

TABle 4.19 Average TriP Length by Mode OF TRANSPORTATION 1990 AdJuSted

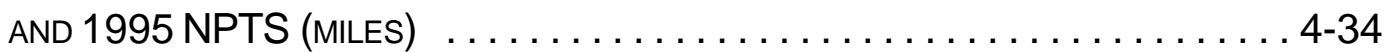

Table 4.20 Average Person Trip Length by MSA Size and 1990 TriP PuRPoses 1990 AdJUSTEd AND 1995 NPTS (MILES) . . . . . . . . . . . . . . 4-35 
Table 4.21 Statistics on Segmented Person Travel by Census Tract

URBAN/RURAL Code 1995 NPTS .......................... 4-37

Table 4.22 Statistics on Non-Segmented Person Travel by Census Tract

URBAN/RURAL Code 1995 NPTS ....................... 4-38

TABle 4.23 Statistics on Dally Person Travel by Household INCOME AND

Trip PuRPose 1995 NPTS . . . . . . . . . . . . . . . . . . . . 4-41

TABle 4.24 Statistics on Dally PeRson TRAVEL by Household INCOME AND

1990 Trip PuRPose 1995 NPTS . . . . . . . . . . . . . . . . . . 4-42

TABLE 4.25 Number OF PeRSON TRIPS BY HOUSEHOLd INCOME AND MOdE OF

TRANSPORTATION 1995 NPTS (MILLIONS) ................... 4-44

TABle 4.26 Number of Person Trips by Mode of Transportation AND TRIP

PURPOSE 1995 NPTS (MILLIONS) $\ldots \ldots \ldots \ldots \ldots \ldots \ldots \ldots \ldots . . . . .47$

TABle 4.27 Number OF Person Trips by Mode OF Transportation and 1990

TRIP PURPOSE 1995 NPTS (MILLIONS) ….................. 4-48

Table 4.28 Number of Person Miles of Travel by Mode of Transportation AND TRIP PuRPose 1995 NPTS (MILLIONS) $\ldots \ldots \ldots \ldots \ldots \ldots \ldots \ldots .4 .49$

Table 4.29 Number of Person Miles of Travel by Mode of Transportation AND 1990 TRIP PURPOSE 1995 NPTS (MILLIONS) .............. 4-50

TABle 4.30 Number of Person Trips by Mode of Transportation, TriP Purpose, AND AVAILABILITY of Public Transit 1995 NPTS (MILLIONS) . . . . 4-51

Table 4.31 Statistics on Person Travel by Day of Week 1990 Adjusted and 1995 NPTS . . . . .............................. 4-54

TAble 4.32 Number of Person Trips by Time OF Day and Trip Purpose 1995

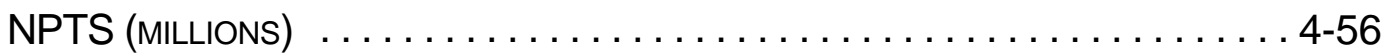

Table 4.33 Number OF Person Trips by Time of Day and 1990 Trip Purpose 1995 NPTS (MILLIONS) . . . . . . . . . . . . . . . . . . . . 4-57

TAble 4.34 Number of WeEKDAY Person Trips by Time OF DaY AND TRIP PURPOSE 1995 NPTS (MILLIONS) ….................. 4-58

Table 4.35 Number of WeEKEND Person Trips by Time of Day and TriP

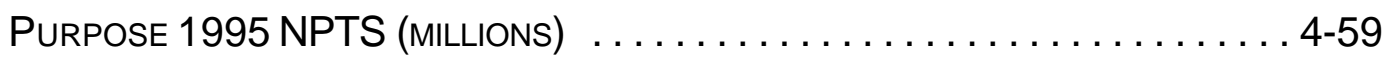

\section{LIST OF FIGURES}

Figure 4.1 Summary of National Travel Estimates 1969, 1977, 1983, 1990, 1990 ADJUSTED, AND 1995 NPTS . . . . . . . . . . . . . . . . . . 4-5

Figure 4.2 Distribution of Total Person Trips and Person Miles of Travel bY AgE GRoup 1995 NPTS . . . . . . . . . . . . . . . . . . . . . . . . . 4-8

Figure 4.3 Average Daily Person Trips Per Person and Average Daily Person Miles Traveled by Age and Gender 1995 NPTS ........... 4-11

Figure 4.4 Average Person Trip Length by Age and Gender 1995 NPTS . . . . . . . 4-13

Figure 4.5 Average Daily Person Travel by Gender, Driver's License Status, AND TRIP PuRPose 1995 NPTS $\ldots \ldots \ldots \ldots \ldots \ldots \ldots \ldots .4 .18$

Figure 4.6 Percentage of Person Trips by Gender and Trip Purpose 1995 NPTS 
Figure 4.7 Average Daily Person Trips per Person by Mode of TRANSPORTATION AND TRIP PURPOSE BY INDIVIDUALS UNDER 65 AND INDIVIDUALS 65 YEARS OR OLDER 1995 NPTS . . . . . . . . . . . . . . . 4-26

Figure 4.8 Statistics on Households, Household Person TRIPS, and Household Person Miles of Travel 1995 NPTS . . . . . . . . . . . . . . . . . 4-27

Figure 4.9 Demographic Travel Statistics by MSA Size 1995 NPTS . . . . . . . . . 4 4-29

Figure 4.10 Statistics on Segmented and Non-Segmented Person Travel By Census Tract Urban/Rural Code 1995 NPTS $\ldots \ldots \ldots \ldots \ldots \ldots .4$. 39

Figure 4.11 Statistics on Dally Person Travel by Household InCOME AND Trip PuRPose 1995 NPTS . . . . . . . . . . . . . . . . . . . 43

Figure 4.12 Distribution of Person TriPS by Household InCOME AND MOde of TRANSPORTATION 1995 NPTS $\ldots \ldots \ldots \ldots \ldots \ldots \ldots \ldots \ldots \ldots \ldots .4 .45$

Figure 4.13 Distribution of Person Trips by Mode of Transportation AND Trip Purpose Based on Avallability of Public Transportation $\ldots \ldots \ldots 4-52$

Figure 4.14 Distribution of Person Travel by Day of WeEk 1995 NPTS $\ldots \ldots \ldots .4$. . . 55 


\section{Chapter 4 Person Trips and Person Miles of Travel}

$\mathrm{T}$ HIS chapter reports statistics on person trips and person miles of travel (PMT) based on 1995 NPTS data. Note that a person trip is a trip by one or more persons in any mode of transportation. Each traveler is counted as one person trip. When a person travels one mile, one PMT results. Three persons traveling together for 5 miles equals 15 PMT.

Historical data comparing 1995 data with earlier surveys are presented when appropriate. It must be remembered that improvements in the 1995 survey make the 1995 data on person trips and PMT not directly comparable to earlier surveys. Thus, the 1990 NPTS data have been adjusted to allow comparison with 1995 results. In tables of historical data, there will be columns of both 1990 NPTS data (for comparison with pre-1990 data) and 1990 adjusted data (for comparison with 1995 data).

\subsection{Historical Perspective}

The United States population is growing, but not as rapidly as the increase in personal travel. Every NPTS since 1969 shows a growth in annual person trips (a total of about 161\% growth between 1969 and 1995) and annual PMT (a total change of almost 143\% between 1969 and 1995). The only statistic showing an overall decrease is the average person trip length, which changed from 9.67 miles in 1969 to 9.13 miles in 1995 .

\subsection{AGe ANd Gender DiFFERENCES}

As a group, in 1995, women took more person trips than men; men and women between the ages of 20 and 49 took over half of the trips taken by individuals of all ages. Over all, men took more average daily person trips/person than women in 1995; however, this statistic is not true over all age groups. For example, females up to age 50 took as many average daily person trips per person as, or more than, men. Beginning at age 50, elderly men took more person trips per person than women in the same age group - almost $10 \%$ more for ages 50-59; about $21 \%$ more for ages $60-64$, and $28 \%$ more for those 65 and over.

In the 1995 NPTS, males of all ages, except 515 , had greater PMT per person than females. The average trip length decreased for both genders between 1990 and 1995 .

Both males and females without driver's licenses took fewer average person trips per person than those with licenses. The primary trip purpose for a male without a driver's license was social/recreational while for a female it was family/personal business. The number of average daily person trips per person for school/church was higher for both males and females without licenses than with licenses.

Persons 65 years old and older took about three-fourths as many average daily person trips per person as persons under 65. Most of these trips were as a driver of a privately owned vehicle for family/personal business.

\subsection{TRIP PURPOSES}

In 1995, new trip purpose codes were added to provide objectivity in assigning the trip 
purpose and to improve trip chaining analysis. The most significant new code was "home," the designation of a trip purpose of returning home.

The greatest number of person trips (excluding the trip purpose of going home) for both men and women, across all age groups, was for family/personal business. For men, ages 20-64, the second most common trip purpose was earning a living, which was also the second most common trip purpose for women ages 30-49. The second most common trip purpose for all other age groups of females was social/recreational.

The privately owned vehicle (POV) remains the most common mode of transportation for all trip purposes. Persons without driver's licenses and households with low income levels generally took fewer trips for all trip purposes.

\subsection{HouseHOLD AND Demographic Statistics}

In $1995,60.6 \%$ of all households had no children. These households took $41.4 \%$ of all person trips and drove $53.5 \%$ of all PMT. Households with a single adult, with or without children, made up $30.3 \%$ of all households; however, they took only $16.2 \%$ of all person trips. Households with two or more adults, with or without children, made up less than $70 \%$ of all households but accounted for $83.8 \%$ of all person trips and $86.2 \%$ of all person miles.

Persons in large metropolitan areas took fewer person trips per person and traveled fewer person miles per person than any other demographic group. In addition, a greater percentage of this group's travel was by transit and by walking than was that of any other group.
Household income influences travel behavior. Households with incomes less than $\$ 10,000$ took fewer average daily person trips per person, traveled less daily person miles per person, took shorter trips, and used public transit more often. They had a trip purpose of earning a living only about half as often as households with incomes of $\$ 20,000$ or more.

As more women enter the labor force and as the composition of the household changes, marriage and family responsibilities change, and these changes precipitate changes in travel patterns. According to McGuckin and Murakami, ${ }^{1}$

- Adult women are more likely than men to practice trip chaining on the way to/from work.

- Single adult men and women in households with no children have more travel similarities than differences.

- Women in households with children create more complex trip chains than women in households without children or than men.

- Single mothers, especially those with small children, create more trip chains than do single fathers or mothers in two-adult households.

\subsection{Transportation MOdes}

Most travel continued to be by privately owned vehicle, even when public transit was available. When public transit was available, it was used most frequently for trips involving earning a living and family/personal business purposes.

\footnotetext{
${ }^{1}$ McGuckin, Nancy, and Elaine Murakami, "Examining Trip-Chaining Behavior, A Comparison of Travel by Men and Women," 1995 NPTS website publication, http://www-cta.ornl.gov/npts/1995/Doc/Chain2.pdf, p. 1.
}

Nationwide Personal Transportation SuRVey 
According to Public Transit in America, ${ }^{2}$ which based its research on the 1995 NPTS, most persons who used public transit did so because it was the most convenient way for them to get around. Other reasons included cost, lack of access to an automobile, stress avoidance, and environmental benefits. In contrast, the top three reasons given by individuals as to why they chose not to use public transit were that they didn't like it, it was unavailable at work, and it had inconvenient schedules.

\subsection{Segmented Trips}

In the 1995 NPTS, as in the 1990, certain trips were "segmented"; that is, they were broken into their component parts. A trip was segmented if both of the following conditions were met.

- There was a change of vehicle or a change of mode on the trips.
- One of the modes used was a public transit mode or Amtrak. Public transit modes include bus, subway, elevated rail, commuter train, streetcar, or trolley car.

Only about $1 \%$ of all trips in NPTS were considered segmented trips. Most segmented trips were taken by individuals living in urban areas. Persons in suburban areas took the most non-segmented trips and traveled the most nonsegmented person miles.

\subsection{Trips by Day of WeEk AND TIME OF DAY}

The distribution of trips and person miles across the days of the week generally stayed very similar between 1990 and 1995, except for Friday, which increased, and Sunday, which decreased. The temporal distribution of personal trips remained the same during the past decade, with most trips occurring between 9 am and $7 \mathrm{pm}$.

\footnotetext{
${ }^{2}$ Polzin, Joel R. Rey, and Xuehao Chu, Public Transit in America: Findings from the 1995 Nationwide Personal Transportation Survey, University of South Florida, Tampa, September 1998, pp. 4-2 and 4-3.
} 
Table 4.1 shows the dramatic increases between 1969 and 1995 in total annual person trips and person miles of travel. Although the total population increased by $31.8 \%$ during this time, the number of person trips and person miles traveled increased at a greater rate.
Interestingly, the length of the average person trip decreased slightly.

Figure 4.1 shows the relative growths in the national statistics on person travel. In this chart, an index was created with data for 1969 set equal to 100 .

\section{TABLE 4.1}

\section{SUMmARY OF NATIONAL Estimates}

1969, 1977, 1983, 1990, 1990 ADJUSTED, AND 1995 NPTS

\begin{tabular}{|c|c|c|c|c|c|c|c|c|}
\hline & 1969 & 1977 & 1983 & 1990 & $1990 \mathrm{adj}$ & 1995 & $\begin{array}{c}\text { Percent } \\
\text { Change } \\
1969- \\
1990 \\
\end{array}$ & $\begin{array}{c}\text { Percent } \\
\text { Change } \\
1990- \\
1995 \\
\end{array}$ \\
\hline $\begin{array}{l}\text { Persons (000), Including } \\
\text { Persons Age } 5 \text { and } \\
\text { Under }\end{array}$ & 197,213 & 213,141 & 229,453 & 239,416 & 239,416 & 259,994 & 21.4 & 8.6 \\
\hline $\begin{array}{l}\text { Annual Person Trips } \\
(000,000)\end{array}$ & 145,146 & 211,778 & 224,385 & 249,562 & 304,471 & 378,930 & 71.9 & 24.5 \\
\hline $\begin{array}{l}\text { Annual Person Miles of } \\
\text { Travel }(000,000)\end{array}$ & $1,404,137$ & $1,879,215$ & $1,946,662$ & $2,315,273$ & $2,829,936$ & $3,411,122$ & 64.9 & 20.5 \\
\hline $\begin{array}{l}\text { Number of Person Trips } \\
\text { per Person }\end{array}$ & 736 & 994 & 978 & 1,042 & 1,272 & 1,457 & 41.6 & 14.5 \\
\hline $\begin{array}{l}\text { Annual Person Miles of } \\
\text { Travel per Person } \\
\text { (miles) }\end{array}$ & 7,120 & 8,817 & 8,484 & 9,671 & 11,820 & 13,120 & 35.8 & 11.0 \\
\hline $\begin{array}{l}\text { Average Person Trip } \\
\text { Length (miles) }\end{array}$ & 9.67 & 8.87 & 8.68 & 9.45 & 9.29 & 9.13 & -2.3 & -1.7 \\
\hline
\end{tabular}

Note:

- All tables reporting totals could include some unreported characteristics.

- Average Trip Length is calculated using only those records with trip mileage information present.

- Note that only the 1990 data have been adjusted to make them more comparable with the 1995 data. Thus, there are limits on the conclusions that can be drawn in comparing travel with earlier survey years. The adjustments to 1990 data affect only person trips, vehicle trips, person miles of travel (PMT), and vehicle miles of travel (VMT). 
FIGURE 4.1

Summary of National Travel Estimates

1969, 1977, 1983, 1990, 1990 ADJUSTED, AND 1995 NPTS

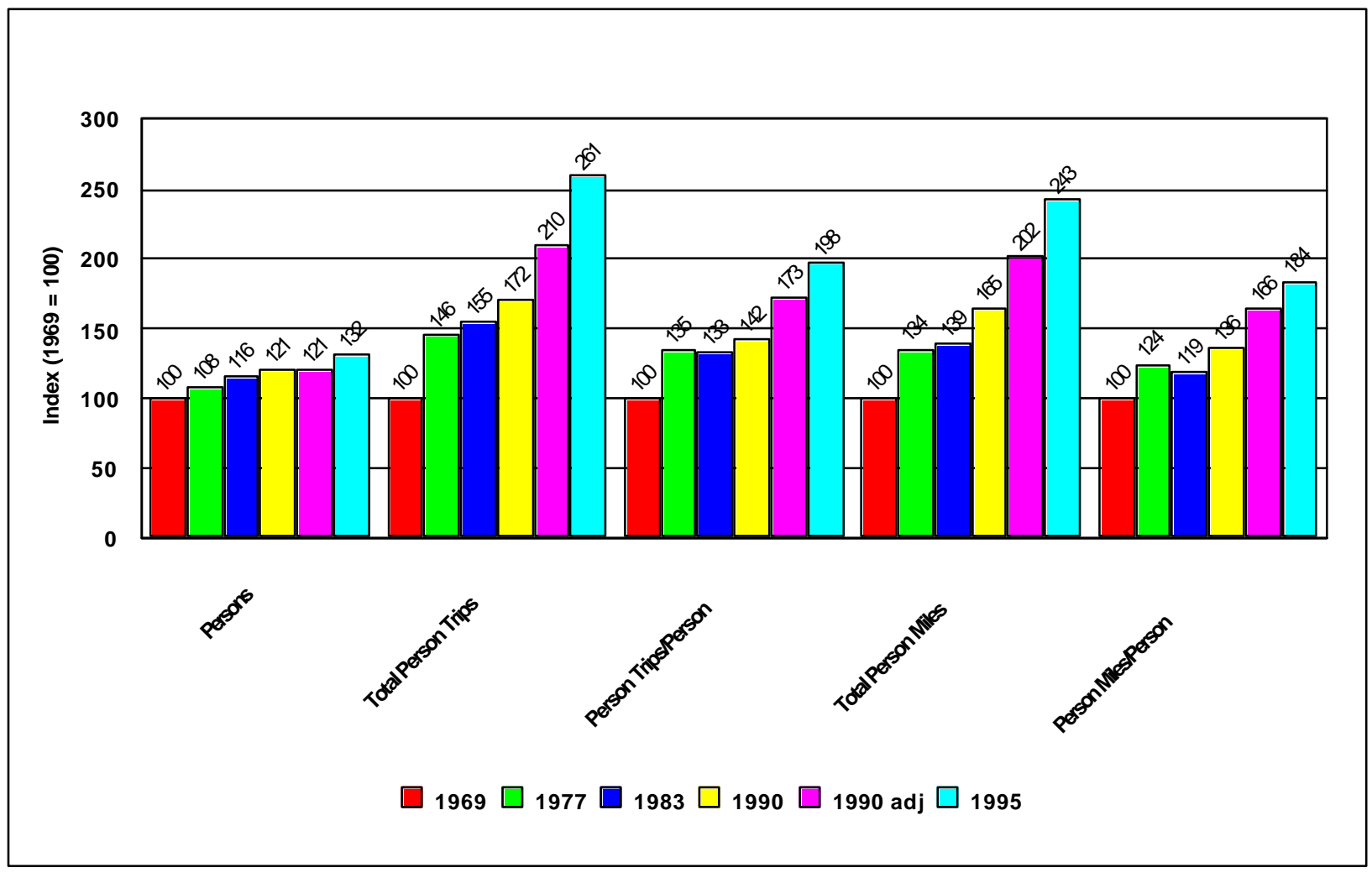


Overall, females - especially those in the 30 50 age groups - continued to take slightly more trips than males. In the age range of $65+$, both males and females increased their number of person trips between 1990 and 1995 , women by over $60 \%$.

\section{TABLE 4.2}

\section{Number of Person Trips by Age ANd Gender 1990 ADJUSTED AND 1995 NPTS}

(MILLIONS)

\begin{tabular}{|c|c|c|c|c|c|c|}
\hline \multirow[b]{2}{*}{ Age } & \multicolumn{3}{|c|}{$1990 \mathrm{adj}$} & \multicolumn{3}{|c|}{1995} \\
\hline & TOTAL & Male & Female & TOTAL & Male & Female \\
\hline TOTAL & $\begin{array}{r}304,471 \\
(100.0 \%)\end{array}$ & $\begin{array}{r}142,102 \\
(100.0 \%)\end{array}$ & $\begin{array}{r}162,325 \\
(100.0 \%)\end{array}$ & $\begin{array}{r}378,930 \\
(100.0 \%)\end{array}$ & $\begin{array}{r}185,735 \\
(100.0 \%)\end{array}$ & $\begin{array}{r}193,196 \\
(100.0 \%)\end{array}$ \\
\hline $5-15$ & $\begin{array}{r}41,612 \\
(13.7 \%)\end{array}$ & $\begin{array}{r}21,089 \\
(14.8 \%)\end{array}$ & $\begin{array}{r}20,517 \\
(12.6 \%)\end{array}$ & $\begin{array}{r}58,255 \\
(15.4 \%)\end{array}$ & $\begin{array}{r}29,422 \\
(15.8 \%)\end{array}$ & $\begin{array}{r}28,833 \\
(14.9 \%)\end{array}$ \\
\hline $16-19$ & $\begin{array}{l}21,145 \\
(6.9 \%)\end{array}$ & $\begin{array}{l}10,257 \\
(7.2 \%)\end{array}$ & $\begin{array}{l}10,888 \\
(6.7 \%)\end{array}$ & $\begin{array}{l}23,789 \\
(6.3 \%)\end{array}$ & $\begin{array}{l}12,336 \\
(6.6 \%)\end{array}$ & $\begin{array}{l}11,453 \\
(5.9 \%)\end{array}$ \\
\hline $20-29$ & $\begin{array}{r}61,107 \\
(20.1 \%)\end{array}$ & $\begin{array}{r}28,917 \\
(20.3 \%)\end{array}$ & $\begin{array}{r}32,190 \\
(19.8 \%)\end{array}$ & $\begin{array}{r}58,683 \\
(15.5 \%)\end{array}$ & $\begin{array}{r}28,817 \\
(15.5 \%)\end{array}$ & $\begin{array}{r}29,866 \\
(15.5 \%)\end{array}$ \\
\hline $30-39$ & $\begin{array}{r}67,241 \\
(22.1 \%)\end{array}$ & $\begin{array}{r}29,239 \\
(20.6 \%)\end{array}$ & $\begin{array}{r}38,002 \\
(23.4 \%)\end{array}$ & $\begin{array}{r}81,126 \\
(21.4 \%)\end{array}$ & $\begin{array}{r}38,179 \\
(20.6 \%)\end{array}$ & $\begin{array}{r}42,946 \\
(22.2 \%)\end{array}$ \\
\hline $40-49$ & $\begin{array}{r}46,386 \\
(15.2 \%)\end{array}$ & $\begin{array}{r}20,686 \\
(14.6 \%)\end{array}$ & $\begin{array}{r}25,700 \\
(15.8 \%)\end{array}$ & $\begin{array}{r}66,219 \\
(17.5 \%)\end{array}$ & $\begin{array}{r}31,772 \\
(17.1 \%)\end{array}$ & $\begin{array}{r}34,446 \\
(17.8 \%)\end{array}$ \\
\hline $50-59$ & $\begin{array}{l}27,808 \\
(9.1 \%)\end{array}$ & $\begin{array}{l}13,275 \\
(9.3 \%)\end{array}$ & $\begin{array}{l}14,533 \\
(9.0 \%)\end{array}$ & $\begin{array}{l}36,722 \\
(9.7 \%)\end{array}$ & $\begin{array}{r}18,512 \\
(10.0 \%)\end{array}$ & $\begin{array}{l}18,211 \\
(9.4 \%)\end{array}$ \\
\hline $60-64$ & $\begin{array}{l}12,370 \\
(4.1 \%)\end{array}$ & $\begin{array}{r}6,055 \\
(4.3 \%)\end{array}$ & $\begin{array}{r}6,315 \\
(3.9 \%)\end{array}$ & $\begin{array}{l}15,037 \\
(4.0 \%)\end{array}$ & $\begin{array}{r}8,036 \\
(4.3 \%)\end{array}$ & $\begin{array}{r}7,002 \\
(3.6 \%)\end{array}$ \\
\hline $65+$ & $\begin{array}{l}24,506 \\
(8.0 \%)\end{array}$ & $\begin{array}{l}11,816 \\
(8.3 \%)\end{array}$ & $\begin{array}{l}12,690 \\
(7.8 \%)\end{array}$ & $\begin{array}{r}39,100 \\
(10.3 \%)\end{array}$ & $\begin{array}{r}18,660 \\
(10.0 \%)\end{array}$ & $\begin{array}{r}20,440 \\
(10.6 \%)\end{array}$ \\
\hline
\end{tabular}

Note:

- All tables reporting totals could include some unreported characteristics.

- Note that the 1990 data have been adjusted to make them more comparable with the 1995 data. Thus, there are limits on the conclusions that can be drawn in comparing travel with earlier survey years. The adjustments to 1990 data affect only person trips, vehicle trips, person miles of travel (PMT), and vehicle miles of travel (VMT). 
Both males and females increased their total PMT between 1990 and 1995. Although women generally took more total trips, they traveled fewer total miles than males. In 1990, females 65 and over drove more miles than males in that age group; in 1995, however, males over 65 drove 20.2 million miles more than females.

\section{TABLE 4.3}

\section{Number of Person Miles of Travel by Age and Gender 1990 ADJUSTED AND 1995 NPTS}

(MILLIONS)

\begin{tabular}{|c|c|c|c|c|c|c|}
\hline \multirow[b]{2}{*}{ Age } & \multicolumn{3}{|c|}{$1990 \mathrm{adj}$} & \multicolumn{3}{|c|}{1995} \\
\hline & TOTAL & Male & Female & TOTAL & Male & Female \\
\hline TOTAL & $\begin{array}{r}2,829,936 \\
(100.0 \%)\end{array}$ & $\begin{array}{r}1,473,015 \\
(100.0 \%)\end{array}$ & $\begin{array}{r}1,356,595 \\
(100.0 \%)\end{array}$ & $\begin{array}{r}3,411,122 \\
(100.0 \%)\end{array}$ & $\begin{array}{r}1,883,237 \\
(100.0 \%)\end{array}$ & $\begin{array}{r}1,527,884 \\
(100.0 \%)\end{array}$ \\
\hline $5-15$ & $\begin{array}{r}271,039 \\
(9.6 \%)\end{array}$ & $\begin{array}{r}140,625 \\
(9.5 \%)\end{array}$ & $\begin{array}{r}130,384 \\
(9.6 \%)\end{array}$ & $\begin{array}{l}392,399 \\
(11.5 \%)\end{array}$ & $\begin{array}{l}190,695 \\
(10.1 \%)\end{array}$ & $\begin{array}{l}201,704 \\
(13.2 \%)\end{array}$ \\
\hline $16-19$ & $\begin{array}{r}168,633 \\
(6.0 \%)\end{array}$ & $\begin{array}{l}89,398 \\
(6.1 \%)\end{array}$ & $\begin{array}{l}79,234 \\
(5.8 \%)\end{array}$ & $\begin{array}{r}185,151 \\
(5.4 \%)\end{array}$ & $\begin{array}{r}100,412 \\
(5.3 \%)\end{array}$ & $\begin{array}{l}84,739 \\
(5.5 \%)\end{array}$ \\
\hline $20-29$ & $\begin{array}{l}606,257 \\
(21.4 \%)\end{array}$ & $\begin{array}{l}322,208 \\
(21.9 \%)\end{array}$ & $\begin{array}{l}284,049 \\
(20.9 \%)\end{array}$ & $\begin{array}{l}573,830 \\
(16.8 \%)\end{array}$ & $\begin{array}{l}325,910 \\
(17.3 \%)\end{array}$ & $\begin{array}{l}247,920 \\
(16.2 \%)\end{array}$ \\
\hline $30-39$ & $\begin{array}{l}659,629 \\
(23.3 \%)\end{array}$ & $\begin{array}{l}336,703 \\
(22.9 \%)\end{array}$ & $\begin{array}{l}322,925 \\
(23.8 \%)\end{array}$ & $\begin{array}{l}794,493 \\
(23.3 \%)\end{array}$ & $\begin{array}{l}433,404 \\
(23.0 \%)\end{array}$ & $\begin{array}{l}361,090 \\
(23.6 \%)\end{array}$ \\
\hline $40-49$ & $\begin{array}{l}508,407 \\
(18.0 \%)\end{array}$ & $\begin{array}{l}261,652 \\
(17.8 \%)\end{array}$ & $\begin{array}{l}246,755 \\
(18.2 \%)\end{array}$ & $\begin{array}{l}648,168 \\
(19.0 \%)\end{array}$ & $\begin{array}{l}367,472 \\
(19.5 \%)\end{array}$ & $\begin{array}{l}280,696 \\
(18.4 \%)\end{array}$ \\
\hline $50-59$ & $\begin{array}{l}296,906 \\
(10.5 \%)\end{array}$ & $\begin{array}{l}158,959 \\
(10.8 \%)\end{array}$ & $\begin{array}{l}137,947 \\
(10.2 \%)\end{array}$ & $\begin{array}{l}384,146 \\
(11.3 \%)\end{array}$ & $\begin{array}{l}223,497 \\
(11.9 \%)\end{array}$ & $\begin{array}{l}160,649 \\
(10.5 \%)\end{array}$ \\
\hline $60-64$ & $\begin{array}{r}103,836 \\
(3.7 \%)\end{array}$ & $\begin{array}{l}56,847 \\
(3.9 \%)\end{array}$ & $\begin{array}{l}46,988 \\
(3.5 \%)\end{array}$ & $\begin{array}{r}145,058 \\
(4.3 \%)\end{array}$ & $\begin{array}{l}87,789 \\
(4.7 \%)\end{array}$ & $\begin{array}{l}57,269 \\
(3.7 \%)\end{array}$ \\
\hline $65+$ & $\begin{array}{r}195,251 \\
(6.9 \%)\end{array}$ & $\begin{array}{l}96,949 \\
(6.6 \%)\end{array}$ & $\begin{array}{l}98,302 \\
(7.2 \%)\end{array}$ & $\begin{array}{r}287,876 \\
(8.4 \%)\end{array}$ & $\begin{array}{r}154,058 \\
(8.2 \%)\end{array}$ & $\begin{array}{r}133,818 \\
(8.8 \%)\end{array}$ \\
\hline
\end{tabular}

Note:

- All tables reporting totals could include some unreported characteristics.

- Note that the 1990 data have been adjusted to make them more comparable with the 1995 data. Thus, there are limits on the conclusions that can be drawn in comparing travel with earlier survey years. The adjustments to 1990 data affect only person trips, vehicle trips, person miles of travel (PMT), and vehicle miles of travel (VMT). 
Figure 4.2 compares the number of total person trips taken by each age group and the number of person miles of travel. This chart shows that the age group 30-39 had the greatest share of both person trips and person miles.

FIGURE 4.2

Distribution of Total Person Trips and Person Miles of Travel by Age Group 1995 NPTS

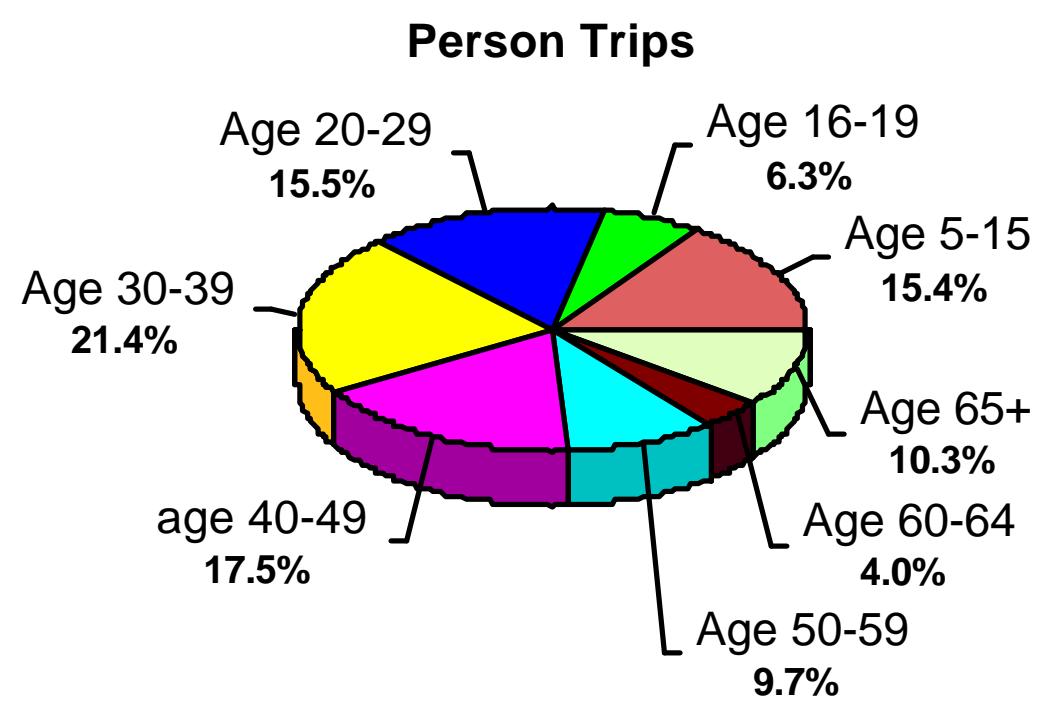

Person Miles of Travel

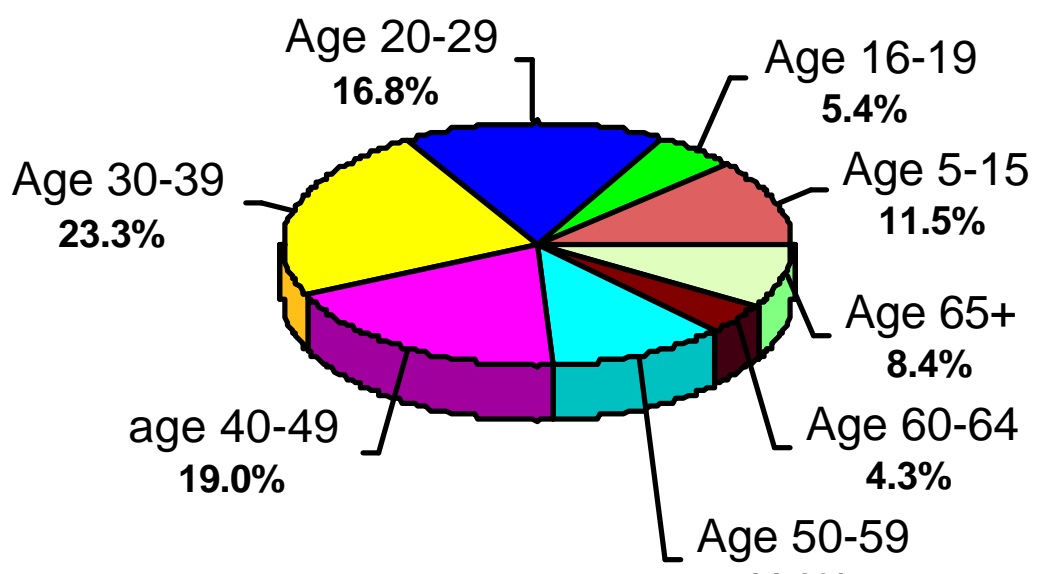

$11.3 \%$ 
The number of average daily person trips per person for females increased by $11 \%$ between 1990 and 1995; during the same time, the number of average daily person trips per person for males increased by about $18 \%$. Women ages $16-50$ continued to average more daily person trips per person than men in 1995. For ages 50 and above, males averaged more daily person trips per person than females, perhaps because older women stop or curtail their driving sooner than older men. In addition, women of the baby boom generation (roughly age groups 30-39 and 40-49 in 1995) are more likely to drive than women of older generations.

The top part of Figure 4.3 graphically displays this distribution of person trips by age and gender.

\section{TABLE 4.4}

\section{Average Daily Person Trips Per Person by Age and Gender 1990 ADJUSTED AND 1995 NPTS}

\begin{tabular}{||c|ccc|ccc||}
\hline \multirow{2}{*}{ Age } & \multicolumn{3}{|c|}{$1990 \mathrm{adj}$} & & \multicolumn{2}{c||}{1995} \\
\cline { 2 - 6 } TOTAL & TOTAL & Male & Female & TOTAL & Male & Female \\
$5-15$ & 3.76 & 3.67 & 3.84 & 4.30 & 4.33 & 4.27 \\
$16-19$ & 3.08 & 3.04 & 3.13 & 3.70 & 3.66 & 3.75 \\
$20-29$ & 4.18 & 4.18 & 4.19 & 4.63 & 4.63 & 4.63 \\
$30-39$ & 4.37 & 4.29 & 4.44 & 4.55 & 4.49 & 4.61 \\
$40-49$ & 4.48 & 4.04 & 4.88 & 4.81 & 4.60 & 5.00 \\
$50-59$ & 4.13 & 3.77 & 4.48 & 4.80 & 4.67 & 4.93 \\
$60-64$ & 3.52 & 3.50 & 3.55 & 4.20 & 4.40 & 4.01 \\
$65+$ & 3.35 & 3.57 & 3.16 & 4.13 & 4.54 & 3.75 \\
\hline
\end{tabular}

Note:

- All tables reporting totals could include some unreported characteristics.

- Note that the 1990 data have been adjusted to make them more comparable with the 1995 data. Thus, there are limits on the conclusions that can be drawn in comparing travel with earlier survey years. The adjustments to 1990 data affect only person trips, vehicle trips, person miles of travel (PMT), and vehicle miles of travel (VMT). 
Between 1990 and 1995, males increased their average daily PMT per person by $15.4 \%$, women by only $5.2 \%$ overall. In addition, two age groups of females (20-29 and 40-49) saw decreases in average daily PMT.
The bottom section of Figure 4.3 graphically shows this distribution of person miles per person for each gender and age group.

\section{TABLE 4.5}

\section{Average PMT Per Person by Age and Gender 1990 ADJUSTED AND 1995 NPTS}

\begin{tabular}{||c|ccc|ccc||}
\hline \multirow{2}{*}{ Age } & \multicolumn{3}{|c|}{$1990 \mathrm{adj}$} & & \multicolumn{2}{c||}{1995} \\
\cline { 2 - 6 } TOTAL & TOTAL & Male & Female & TOTAL & Male & Female \\
$5-15$ & 34.91 & 38.01 & 32.08 & 38.67 & 43.86 & 33.75 \\
$16-19$ & 20.08 & 20.28 & 19.88 & 24.95 & 23.74 & 26.21 \\
$20-29$ & 33.36 & 36.41 & 30.47 & 36.04 & 37.72 & 34.24 \\
$30-39$ & 43.34 & 47.79 & 39.20 & 44.53 & 50.81 & 38.31 \\
$40-49$ & 43.91 & 46.54 & 41.47 & 47.07 & 52.24 & 42.08 \\
$50-59$ & 37.62 & 41.88 & 33.68 & 43.93 & 53.12 & 35.40 \\
$60-64$ & 28.09 & 33.50 & 23.50 & 39.85 & 49.55 & 30.65 \\
$65+$ & 19.85 & 23.44 & 17.24 & 25.24 & 32.46 & 20.09 \\
\hline \hline
\end{tabular}

Note:

- All tables reporting totals could include some unreported characteristics.

- Note that the 1990 data have been adjusted to make them more comparable with the 1995 data. Thus, there are limits on the conclusions that can be drawn in comparing travel with earlier survey years. The adjustments to 1990 data affect only person trips, vehicle trips, person miles of travel (PMT), and vehicle miles of travel (VMT). 


\section{FIGURE 4.3}

Average Daily Person Trips per Person and Average Daily Person Miles Traveled BY AGE AND GENDER

1995 NPTS
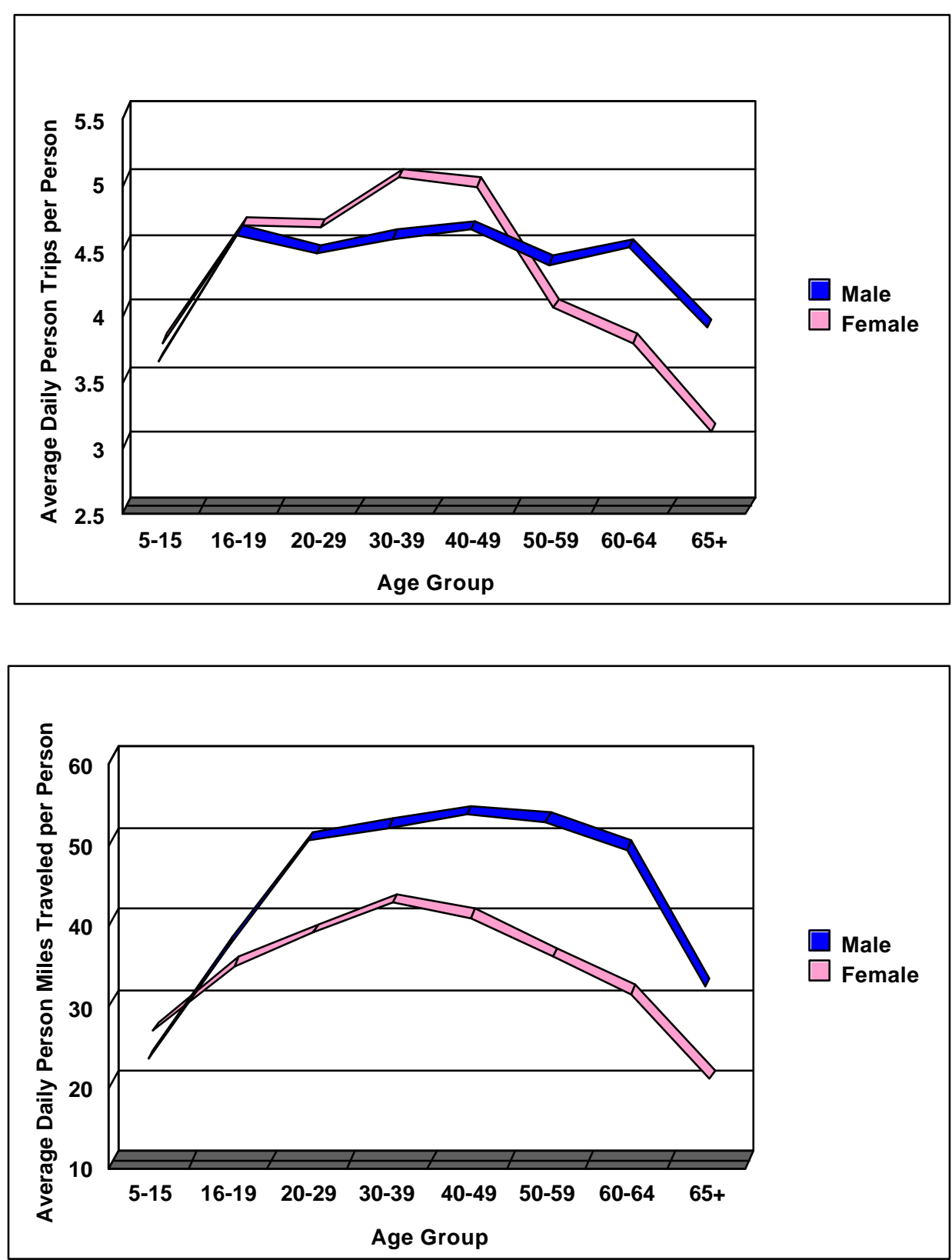
The average trip length for both males and females declined between 1990 and 1995. The only age groups that saw an increase in average trip length were ages 5-15 and 60-64.

Figure 4.4 compares the average person trip length for males and females by age group and the total average trip length. As shown in this figure, males begin to take longer trips than females at about the age that they obtain a license to drive.

\section{TABLE 4.6}

\section{Average Person Trip Length by Age and Gender 1990 ADJUSTED AND 1995 NPTS \\ (MILES)}

\begin{tabular}{|c|c|c|c|c|c|c|}
\hline \multirow[b]{2}{*}{ Age } & \multicolumn{3}{|c|}{1990 adj } & \multicolumn{3}{|c|}{1995} \\
\hline & TOTAL & Male & Female & TOTAL & Male & Female \\
\hline TOTAL & 9.47 & 10.50 & 8.56 & 9.13 & 10.26 & 8.05 \\
\hline $5-15$ & 6.67 & 6.82 & 6.52 & 6.84 & 6.57 & 7.11 \\
\hline $16-19$ & 8.22 & 8.87 & 7.58 & 8.00 & 8.30 & 7.67 \\
\hline $20-29$ & 10.10 & 11.25 & 9.05 & 9.94 & 11.47 & 8.46 \\
\hline $30-39$ & 9.95 & 11.64 & 8.65 & 9.93 & 11.48 & 8.54 \\
\hline $40-49$ & 11.15 & 12.83 & 9.79 & 9.89 & 11.68 & 8.24 \\
\hline $50-59$ & 10.83 & 12.10 & 9.66 & 10.60 & 12.21 & 8.97 \\
\hline $60-64$ & 8.51 & 9.45 & 7.60 & 9.79 & 11.01 & 8.37 \\
\hline $65+$ & 8.12 & 8.29 & 7.96 & 7.46 & 8.31 & 6.68 \\
\hline
\end{tabular}

Note:

- All tables reporting totals could include some unreported characteristics.

- Average Trip Length is calculated using only those records with trip mileage information present.

- Note that the 1990 data have been adjusted to make them more comparable with the 1995 data. Thus, there are limits on the conclusions that can be drawn in comparing travel with earlier survey years. The adjustments to 1990 data affect only person trips, vehicle trips, person miles of travel (PMT), and vehicle miles of travel (VMT). 
FIGURE 4.4

Average Person Trip Length by Age and Gender 1995 NPTS

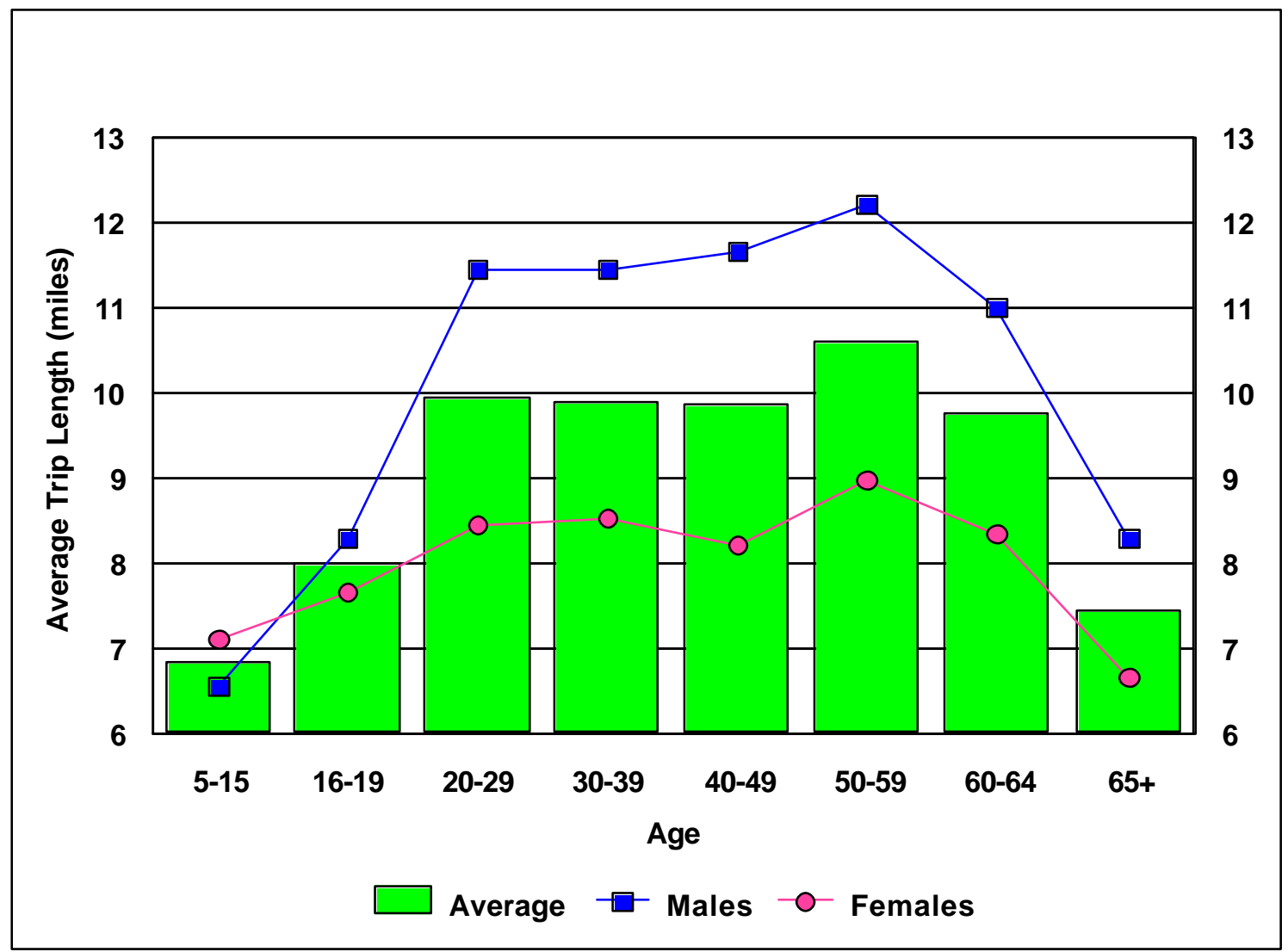


Five new trip purpose codes - return to work, take someone somewhere, pick up someone, out to eat, and home (the code "home" meant that returning home was the trip purpose) were added in 1995. The collection of trip purposes changed from a descriptive format (e.g., what best describes your reason for making this trip) to a FROM-TO format (e.g., a trip from "other family and personal business" to "home"). This question format was more objective and provided a more straightforward way to collect the data. This approach also allowed for an improved analysis of trip chaining.
Table 4.7 compares the number of person trips by 1995 trip purpose codes with the responses based on the 1990 trip purpose codes. The 1995 trip purposes represent a fairly significant departure from the purposes used in earlier NPTSs. For the typical user, the trip purpose changes were probably the most significant questionnaire content change in 1995. The 1995 NPTS Databook utilizes the 1995 trip purpose codes unless otherwise specified.

For more information on changes in trip purposes, see Appendix $M$ of the User's Guide. 


\section{TABLE 4.7}

\section{Number of Person Trips by 1995 Trip Purpose Codes vs. 1990 Trip Purpose Codes 1995 NPTS \\ (MILLIONS)}

\begin{tabular}{|c|c|c|c|c|c|c|c|c|c|c|}
\hline \multirow[b]{2}{*}{$\begin{array}{l}1995 \text { Trip } \\
\text { Purposes }\end{array}$} & \multicolumn{10}{|c|}{1990 Trip Purposes } \\
\hline & TOTAL & $\begin{array}{l}\text { To or } \\
\text { From } \\
\text { Work }\end{array}$ & $\begin{array}{c}\text { Work- } \\
\text { Related } \\
\text { Business }\end{array}$ & Shopping & $\begin{array}{l}\text { Other } \\
\text { Family/ } \\
\text { Personal }\end{array}$ & $\begin{array}{l}\text { School/ } \\
\text { Church }\end{array}$ & $\begin{array}{l}\text { Doctor/ } \\
\text { Dentist }\end{array}$ & Soc/Rec & Other & $\begin{array}{l}\text { Unre- } \\
\text { ported }\end{array}$ \\
\hline TOTAL & 378,930 & 66,901 & 9,860 & 76,688 & 91,493 & 33,355 & 5,583 & 94,362 & 623 & 67 \\
\hline To Work & 32,767 & 31,364 & 3 & 358 & 936 & 24 & 23 & 57 & 2 & \\
\hline $\begin{array}{l}\text { Work-Related } \\
\text { Business }\end{array}$ & 10,623 & 1 & 9,854 & 162 & 518 & 7 & 15 & 62 & 3 & \\
\hline Return to Work & 6,777 & 2,938 & & 849 & 2,724 & 22 & 79 & 165 & 1 & \\
\hline Shopping & 52,387 & 1 & & 52,364 & 7 & 0 & 3 & 12 & 0 & \\
\hline School & 12,162 & . & & . & 0 & 12,160 & . & 2 & . & \\
\hline $\begin{array}{l}\text { Religious } \\
\text { Activity }\end{array}$ & 6,120 & . & 1 & 3 & . & 6,113 & . & 2 & . & \\
\hline Medical/Dental & 3,486 & . & & 0 & . & & 3,486 & . & . & \\
\hline $\begin{array}{l}\text { Other Family or } \\
\text { Personal }\end{array}$ & 37,310 & 2 & . & 16 & 37,095 & 12 & . & 178 & 6 & \\
\hline $\begin{array}{l}\text { Take Someone } \\
\text { Somewhere }\end{array}$ & 13,810 & 0 & . & 8 & 13,796 & . & . & 5 & . & \\
\hline $\begin{array}{l}\text { Pick Up } \\
\text { Someone }\end{array}$ & 11,550 & . & & 0 & 11,550 & & . & & . & \\
\hline Vacation & 717 & . & . & 10 & 4 & . & . & 703 & . & \\
\hline $\begin{array}{l}\text { Visit Friends/ } \\
\text { Relatives }\end{array}$ & 20,004 & 2 & . & 45 & 18 & 16 & 3 & 19,914 & 5 & \\
\hline Out to Eat & 18,367 & . & & 3 & 3,068 & & . & 15,295 & . & \\
\hline $\begin{array}{l}\text { Other Social/ } \\
\text { Recreational }\end{array}$ & 24,821 & 0 & . & 17 & 9 & 5 & . & 24,788 & 1 & \\
\hline Other & 608 & . & . & 17 & 1 & . & 5 & 62 & 522 & \\
\hline $\begin{array}{l}\text { Returning } \\
\text { Home }\end{array}$ & 127,374 & 32,592 & 1 & 22,834 & 21,767 & 14,993 & 1,969 & 33,116 & 80 & 20 \\
\hline Unreported & 49 & . & & & & & . & 1 & 1 & 47 \\
\hline
\end{tabular}

Note:

- For example, in 1995 there were 11,550 trips to "pick up someone.” In 1990, these trips would have been coded as "other family/personal trips. 
As shown in Table 4.8, overall, persons without a driver's license took $38 \%$ fewer average daily person trips than individuals with driver's licenses. In addition, persons without a driver's license traveled only about half as many person miles per person and their average trip length was $45 \%$ shorter (65\% shorter for males; $24 \%$ shorter for females). Two trip purposes for which persons without driver's licenses took more average daily trips than those with licenses were school/church (223\% more trips) and social/recreational (12\% more trips). Persons without driver's licenses traveled almost double the person miles as those with licenses for school/church purposes.

Figure 4.5 shows the relationships by gender and trip purpose of having/not having a driver's license.

Tables 4.9 and 4.11 show the number of and share of person trips by trip purpose for men and women, respectively, by 1995 trip purpose. The new trip purpose code for returning home represents the majority of trips $-33 \%$. Trips for family/personal business represent $35 \%$ of all trips for women and $27 \%$ for men. Tables 4.10 and 4.12 show comparable data based on 1990 trip purpose codes.

The reasons for taking trips varied by age group as well as gender. Between the ages of 5 and 15 , social/recreational pursuits were second only to returning home. Excluding the purpose of going home, both men and women over 20 took more trips for family/personal business than any other trip purpose. For men between the ages of 20 and 65 , the next greatest number of trips was earning a living, while for women in this age group, slightly more trips were taken for social/recreational purposes than for earning a living.

Figure 4.6 compares percentages of person trips taken by trip purpose for men and women. 


\section{TABLE 4.8}

Average Daily Person Travel

By GENDER, DRIVER's LicEnse (DL) StATUS, AND TRIP PuRPose

1995 NPTS

\begin{tabular}{|c|c|c|c|c|c|c|}
\hline \multirow[b]{2}{*}{ Purpose } & \multicolumn{2}{|c|}{ ALL Persons } & \multicolumn{2}{|c|}{ Male } & \multicolumn{2}{|c|}{ Female } \\
\hline & $\begin{array}{l}\text { With } \\
\text { DL }\end{array}$ & $\begin{array}{c}\text { Without } \\
\text { DL }\end{array}$ & $\begin{array}{c}\text { With } \\
\text { DL }\end{array}$ & $\begin{array}{c}\text { Without } \\
\text { DL }\end{array}$ & $\begin{array}{l}\text { With } \\
\text { DL }\end{array}$ & $\begin{array}{c}\text { Without } \\
\text { DL }\end{array}$ \\
\hline \multicolumn{7}{|c|}{ Average Daily Person Trips per Person } \\
\hline TOTAL & 4.64 & 3.36 & 4.60 & 3.49 & 4.68 & 3.25 \\
\hline Earning a Living & 0.74 & 0.09 & 0.91 & 0.10 & 0.57 & 0.09 \\
\hline Family/Personal Business & 1.54 & 0.80 & 1.32 & 0.75 & 1.77 & 0.84 \\
\hline School/Church & 0.13 & 0.42 & 0.11 & 0.47 & 0.14 & 0.39 \\
\hline Social/Recreational & 0.70 & 0.79 & 0.72 & 0.87 & 0.68 & 0.73 \\
\hline Other & 0.01 & 0.01 & 0.01 & 0.01 & 0.01 & 0.01 \\
\hline Returning Home & 1.52 & 1.24 & 1.52 & 1.31 & 1.51 & 1.19 \\
\hline \multicolumn{7}{|c|}{ Average Daily Person Miles of Travel per Person } \\
\hline TOTAL & 44.76 & 22.06 & 50.65 & 23.00 & 38.83 & 21.30 \\
\hline Earning a Living & 9.40 & 0.56 & 13.35 & 0.66 & 5.42 & 0.48 \\
\hline Family/Personal Business & 11.00 & 4.97 & 10.37 & 4.99 & 11.64 & 4.96 \\
\hline School/Church & 0.94 & 1.84 & 0.83 & 1.98 & 1.06 & 1.74 \\
\hline Social/Recreational & 8.37 & 6.89 & 9.16 & 7.20 & 7.58 & 6.64 \\
\hline Other & 0.17 & 0.06 & 0.18 & 0.05 & 0.17 & 0.07 \\
\hline Returning Home & 14.85 & 7.73 & 16.72 & 8.13 & 12.96 & 7.42 \\
\hline \multicolumn{7}{|c|}{ Average Person Trip Length (Miles) } \\
\hline ALL PURPOSES & 9.76 & 6.74 & 11.13 & 6.71 & 8.40 & 6.76 \\
\hline Earning a Living & 12.78 & 6.68 & 14.79 & 7.31 & 9.54 & 6.10 \\
\hline Family/Personal Business & 7.20 & 6.36 & 7.93 & 6.74 & 6.66 & 6.08 \\
\hline School/Church & 7.52 & 4.45 & 7.29 & 4.35 & 7.70 & 4.54 \\
\hline Social/Recreational & 12.14 & 8.87 & 12.86 & 8.42 & 11.37 & 9.31 \\
\hline Other & 27.41 & 8.93 & 28.23 & 9.48 & 26.58 & 8.66 \\
\hline Returning Home & 9.89 & 6.40 & 11.08 & 6.35 & 8.68 & 6.45 \\
\hline
\end{tabular}

Note:

- All tables reporting totals could include some unreported characteristics.

- Average Trip Length is calculated using only those records with trip mileage information present.

- $\mathrm{DL}=$ driver's license. 
FIGURE 4.5

Average Daily Person Travel

By GENDER, DRIVER's License Status, AND TRIP PURPOSE 1995 NPTS
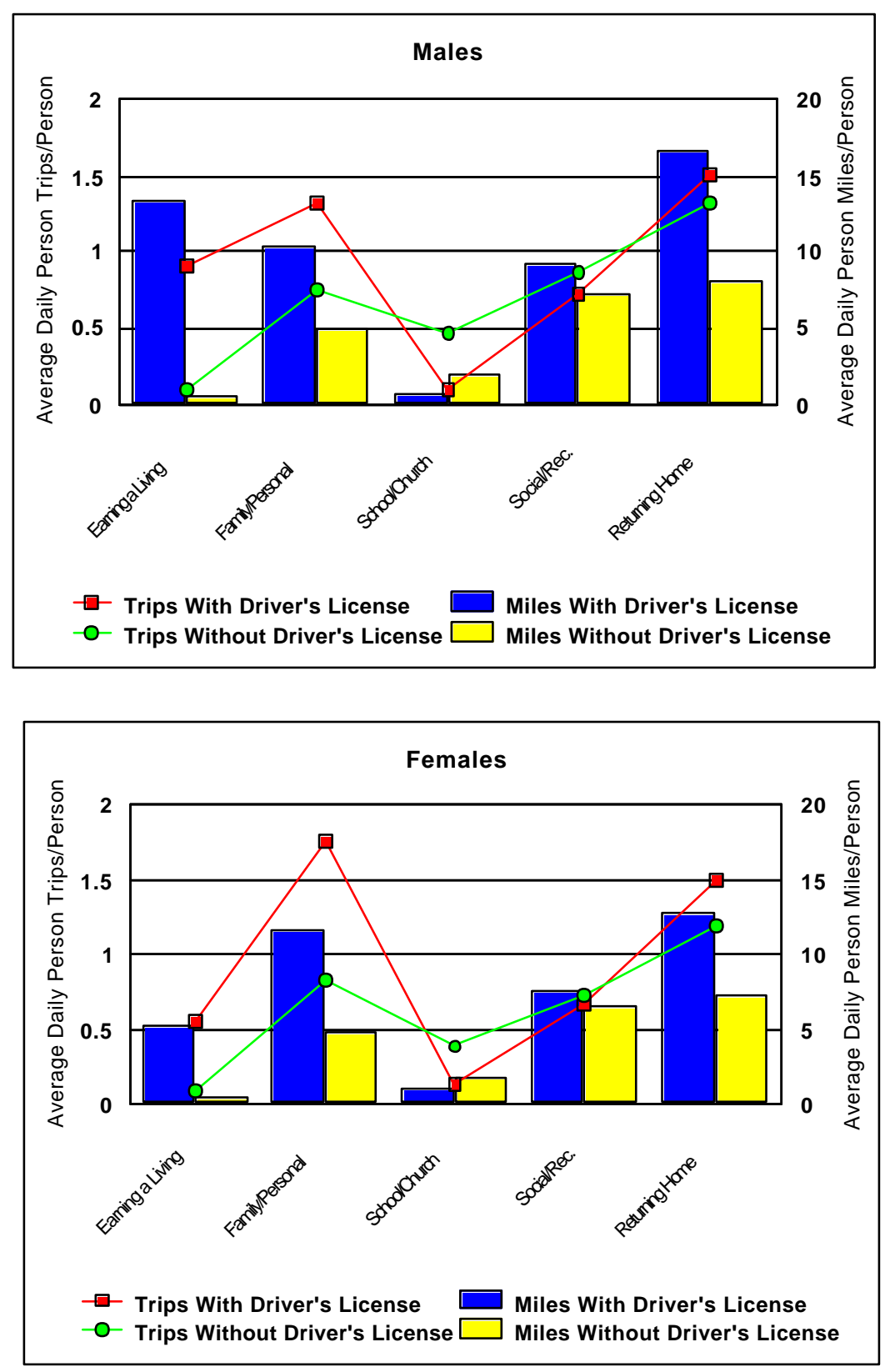


\section{TABLE 4.9}

\section{Number of Person Trips TaKen by Men by Age And Trip Purpose 1995 NPTS \\ (MILLIONS)}

\begin{tabular}{|c|c|c|c|c|c|c|c|}
\hline $\begin{array}{l}\text { Age } \\
\text { Category }\end{array}$ & TOTAL & $\begin{array}{l}\text { Earning a } \\
\text { Living }\end{array}$ & $\begin{array}{l}\text { Family/ } \\
\text { Personal } \\
\text { Business }\end{array}$ & $\begin{array}{l}\text { School/ } \\
\text { Church }\end{array}$ & $\begin{array}{c}\text { Social/ } \\
\text { Recreational }\end{array}$ & Other & $\begin{array}{l}\text { Returning } \\
\text { Home }\end{array}$ \\
\hline TOT AL & $\begin{array}{r}185,735 \\
(100.0 \%)\end{array}$ & $\begin{array}{r}30,566 \\
(100.0 \%)\end{array}$ & $\begin{array}{r}50,611 \\
(100.0 \%)\end{array}$ & $\begin{array}{r}8,628 \\
(100.0 \%)\end{array}$ & $\begin{array}{r}32,491 \\
(100.0 \%)\end{array}$ & $\begin{array}{r}277 \\
(100.0 \%)\end{array}$ & $\begin{array}{r}63,132 \\
(100.0 \%)\end{array}$ \\
\hline 5 to 15 & $\begin{array}{r}29,422 \\
(15.8 \%)\end{array}$ & $\begin{array}{r}167 \\
(0.5 \%)\end{array}$ & $\begin{array}{r}6,017 \\
(11.9 \%)\end{array}$ & $\begin{array}{r}4,446 \\
(51.5 \%)\end{array}$ & $\begin{array}{r}7,659 \\
(23.6 \%)\end{array}$ & $\begin{array}{r}44 \\
(15.9 \%)\end{array}$ & $\begin{array}{r}11,089 \\
(17.6 \%)\end{array}$ \\
\hline 16 to 19 & $\begin{array}{l}12,336 \\
(6.6 \%)\end{array}$ & $\begin{array}{r}1,132 \\
(3.7 \%)\end{array}$ & $\begin{array}{r}2,804 \\
(5.5 \%)\end{array}$ & $\begin{array}{r}1,202 \\
(13.9 \%)\end{array}$ & $\begin{array}{r}2,839 \\
(8.7 \%)\end{array}$ & $\begin{array}{r}14 \\
(5.1 \%)\end{array}$ & $\begin{array}{r}4,345 \\
(6.9 \%)\end{array}$ \\
\hline 20 to 29 & $\begin{array}{r}28,817 \\
(15.5 \%)\end{array}$ & $\begin{array}{r}5,956 \\
(19.5 \%)\end{array}$ & $\begin{array}{r}6,972 \\
(13.8 \%)\end{array}$ & $\begin{array}{r}1,029 \\
(11.9 \%)\end{array}$ & $\begin{array}{r}5,196 \\
(16.0 \%)\end{array}$ & $\begin{array}{r}32 \\
(11.6 \%)\end{array}$ & $\begin{array}{r}9,630 \\
(15.3 \%)\end{array}$ \\
\hline 30 to 39 & $\begin{array}{r}38,179 \\
(20.6 \%)\end{array}$ & $\begin{array}{r}9,241 \\
(30.2 \%)\end{array}$ & $\begin{array}{r}10,384 \\
(20.5 \%)\end{array}$ & $\begin{array}{r}514 \\
(6.0 \%)\end{array}$ & $\begin{array}{r}5,560 \\
(17.1 \%)\end{array}$ & $\begin{array}{r}60 \\
(21.7 \%)\end{array}$ & $\begin{array}{r}12,419 \\
(19.7 \%)\end{array}$ \\
\hline 40 to 49 & $\begin{array}{r}31,772 \\
(17.1 \%)\end{array}$ & $\begin{array}{r}7,643 \\
(25.0 \%)\end{array}$ & $\begin{array}{r}9,072 \\
(17.9 \%)\end{array}$ & $\begin{array}{r}513 \\
(5.9 \%)\end{array}$ & $\begin{array}{r}4,243 \\
(13.1 \%)\end{array}$ & $\begin{array}{r}31 \\
(11.2 \%)\end{array}$ & $\begin{array}{r}10,260 \\
(16.3 \%)\end{array}$ \\
\hline 50 to 59 & $\begin{array}{r}18,512 \\
(10.0 \%)\end{array}$ & $\begin{array}{r}4,067 \\
(13.3 \%)\end{array}$ & $\begin{array}{r}5,377 \\
(10.6 \%)\end{array}$ & $\begin{array}{r}289 \\
(3.3 \%)\end{array}$ & $\begin{array}{r}2,603 \\
(8.0 \%)\end{array}$ & $\begin{array}{r}50 \\
(18.1 \%)\end{array}$ & $\begin{array}{r}6,123 \\
(9.7 \%)\end{array}$ \\
\hline 60 to 64 & $\begin{array}{r}8,036 \\
(4.3 \%)\end{array}$ & $\begin{array}{r}1,208 \\
(4.0 \%)\end{array}$ & $\begin{array}{r}2,769 \\
(5.5 \%)\end{array}$ & $\begin{array}{r}150 \\
(1.7 \%)\end{array}$ & $\begin{array}{r}1,187 \\
(3.7 \%)\end{array}$ & $\begin{array}{r}16 \\
(5.8 \%)\end{array}$ & $\begin{array}{r}2,698 \\
(4.3 \%)\end{array}$ \\
\hline $65+$ & $\begin{array}{r}18,660 \\
(10.0 \%)\end{array}$ & $\begin{array}{r}1,152 \\
(3.8 \%)\end{array}$ & $\begin{array}{r}7,215 \\
(14.3 \%)\end{array}$ & $\begin{array}{r}485 \\
(5.6 \%)\end{array}$ & $\begin{array}{r}3,205 \\
(9.9 \%)\end{array}$ & $\begin{array}{r}31 \\
(11.2 \%)\end{array}$ & $\begin{array}{r}6,567 \\
(10.4 \%)\end{array}$ \\
\hline
\end{tabular}

Note:

- All tables reporting totals could include some unreported characteristics. 


\section{TABLE 4.10}

\section{Number of Person Trips Taken by Men by Age and 1990 Trip Purpose 1995 NPTS \\ (MILLIONS)}

\begin{tabular}{|c|c|c|c|c|c|c|}
\hline $\begin{array}{l}\text { Age } \\
\text { Category }\end{array}$ & TOTAL & $\begin{array}{l}\text { Earning a } \\
\text { Living }\end{array}$ & $\begin{array}{l}\text { Family/ } \\
\text { Personal } \\
\text { Business }\end{array}$ & $\begin{array}{l}\text { School/ } \\
\text { Church }\end{array}$ & $\begin{array}{c}\text { Social/ } \\
\text { Recreational }\end{array}$ & Other \\
\hline \multirow[t]{2}{*}{ TOTAL } & 185,735 & 45,542 & 76,283 & 15,803 & 47,798 & 266 \\
\hline & $(100.0 \%)$ & $(100.0 \%)$ & $(100.0 \%)$ & $(100.0 \%)$ & $(100.0 \%)$ & $(100.0 \%)$ \\
\hline \multirow[t]{2}{*}{5 to 15} & 29,422 & 330 & 8,465 & 8,436 & 12,153 & 38 \\
\hline & $(15.8 \%)$ & $(0.7 \%)$ & (11.1\%) & $(53.4 \%)$ & $(25.4 \%)$ & $(14.3 \%)$ \\
\hline \multirow[t]{2}{*}{16 to 19} & 12,336 & 1,895 & 4,070 & 2,170 & 4,185 & 15 \\
\hline & $(6.6 \%)$ & $(4.2 \%)$ & $(5.3 \%)$ & (13.7\%) & $(8.8 \%)$ & $(5.6 \%)$ \\
\hline \multirow[t]{2}{*}{20 to 29} & 28,817 & 9,171 & 10,513 & 1,727 & 7,369 & 31 \\
\hline & $(15.5 \%)$ & $(20.1 \%)$ & $(13.8 \%)$ & $(10.9 \%)$ & $(15.4 \%)$ & $(11.7 \%)$ \\
\hline \multirow[t]{2}{*}{30 to 39} & 38,179 & 13,649 & 15,932 & 888 & 7,651 & 58 \\
\hline & $(20.6 \%)$ & $(30.0 \%)$ & $(20.9 \%)$ & $(5.6 \%)$ & $(16.0 \%)$ & $(21.8 \%)$ \\
\hline \multirow[t]{2}{*}{40 to 49} & 31,772 & 11,070 & 13,869 & 912 & 5,868 & 36 \\
\hline & $(17.1 \%)$ & $(24.3 \%)$ & $(18.2 \%)$ & $(5.8 \%)$ & $(12.3 \%)$ & $(13.5 \%)$ \\
\hline \multirow[t]{2}{*}{50 to 59} & 18,512 & 5,969 & 8,335 & 508 & 3,652 & 44 \\
\hline & $(10.0 \%)$ & $(13.1 \%)$ & $(10.9 \%)$ & $(3.2 \%)$ & $(7.6 \%)$ & $(16.5 \%)$ \\
\hline \multirow[t]{2}{*}{60 to 64} & 8,036 & 1,735 & 4,224 & 266 & 1,786 & 17 \\
\hline & $(4.3 \%)$ & $(3.8 \%)$ & $(5.5 \%)$ & $(1.7 \%)$ & $(3.7 \%)$ & $(6.4 \%)$ \\
\hline \multirow[t]{2}{*}{$65+$} & 18,660 & 1,722 & 10,874 & 897 & 5,133 & 27 \\
\hline & $(10.0 \%)$ & $(3.8 \%)$ & $(14.3 \%)$ & $(5.7 \%)$ & $(10.7 \%)$ & $(10.2 \%)$ \\
\hline
\end{tabular}

Note:

- All tables reporting totals could include some unreported characteristics. 


\section{TABLE 4.11}

\section{Number of Person Trips Taken by Women by Age and Trip Purpose 1995 NPTS \\ (MILLIONS)}

\begin{tabular}{|c|c|c|c|c|c|c|c|}
\hline $\begin{array}{l}\text { Age } \\
\text { Category }\end{array}$ & TOTAL & $\begin{array}{l}\text { Earning a } \\
\text { Living }\end{array}$ & $\begin{array}{l}\text { Family/ } \\
\text { Personal } \\
\text { Business }\end{array}$ & $\begin{array}{l}\text { School/ } \\
\text { Church }\end{array}$ & $\begin{array}{c}\text { Social/ } \\
\text { Recreational }\end{array}$ & Other & $\begin{array}{l}\text { Returning } \\
\text { Home }\end{array}$ \\
\hline TOT AL & $\begin{array}{r}193,196 \\
(100.0 \%)\end{array}$ & $\begin{array}{r}19,601 \\
(100.0 \%)\end{array}$ & $\begin{array}{r}67,932 \\
(100.0 \%)\end{array}$ & $\begin{array}{r}9,654 \\
(100.0 \%)\end{array}$ & $\begin{array}{r}31,417 \\
(100.0 \%)\end{array}$ & $\begin{array}{r}331 \\
(100.0 \%)\end{array}$ & $\begin{array}{r}64,242 \\
(100.0 \%)\end{array}$ \\
\hline 5 to 15 & $\begin{array}{r}28,833 \\
(14.9 \%)\end{array}$ & $\begin{array}{r}146 \\
(0.7 \%)\end{array}$ & $\begin{array}{r}6,317 \\
(9.3 \%)\end{array}$ & $\begin{array}{r}4,440 \\
(46.0 \%)\end{array}$ & $\begin{array}{r}7,293 \\
(23.2 \%)\end{array}$ & $\begin{array}{r}81 \\
(24.5 \%)\end{array}$ & $\begin{array}{r}10,550 \\
(16.4 \%)\end{array}$ \\
\hline 16 to 19 & $\begin{array}{l}11,453 \\
(5.9 \%)\end{array}$ & $\begin{array}{r}863 \\
(4.4 \%)\end{array}$ & $\begin{array}{r}3,172 \\
(4.7 \%)\end{array}$ & $\begin{array}{r}1,177 \\
(12.2 \%)\end{array}$ & $\begin{array}{r}2,325 \\
(7.4 \%)\end{array}$ & $\begin{array}{r}23 \\
(6.9 \%)\end{array}$ & $\begin{array}{r}3,888 \\
(6.1 \%)\end{array}$ \\
\hline 20 to 29 & $\begin{array}{r}29,866 \\
(15.5 \%)\end{array}$ & $\begin{array}{r}4,210 \\
(21.5 \%)\end{array}$ & $\begin{array}{r}10,253 \\
(15.1 \%)\end{array}$ & $\begin{array}{r}1,037 \\
(10.7 \%)\end{array}$ & $\begin{array}{r}4,612 \\
(14.7 \%)\end{array}$ & $\begin{array}{r}48 \\
(14.5 \%)\end{array}$ & $\begin{array}{r}9,701 \\
(15.1 \%)\end{array}$ \\
\hline 30 to 39 & $\begin{array}{r}42,946 \\
(22.2 \%)\end{array}$ & $\begin{array}{r}5,732 \\
(29.2 \%)\end{array}$ & $\begin{array}{r}16,907 \\
(24.9 \%)\end{array}$ & $\begin{array}{r}880 \\
(9.1 \%)\end{array}$ & $\begin{array}{r}5,773 \\
(18.4 \%)\end{array}$ & $\begin{array}{r}69 \\
(20.8 \%)\end{array}$ & $\begin{array}{r}13,584 \\
(21.1 \%)\end{array}$ \\
\hline 40 to 49 & $\begin{array}{r}34,446 \\
(17.8 \%)\end{array}$ & $\begin{array}{r}4,985 \\
(25.4 \%)\end{array}$ & $\begin{array}{r}13,196 \\
(19.4 \%)\end{array}$ & $\begin{array}{r}711 \\
(7.4 \%)\end{array}$ & $\begin{array}{r}4,336 \\
(13.8 \%)\end{array}$ & $\begin{array}{r}32 \\
(9.7 \%)\end{array}$ & $\begin{array}{r}11,186 \\
(17.4 \%)\end{array}$ \\
\hline 50 to 59 & $\begin{array}{l}18,211 \\
(9.4 \%)\end{array}$ & $\begin{array}{r}2,499 \\
(12.7 \%)\end{array}$ & $\begin{array}{r}6,577 \\
(9.7 \%)\end{array}$ & $\begin{array}{r}489 \\
(5.1 \%)\end{array}$ & $\begin{array}{r}2,575 \\
(8.2 \%)\end{array}$ & $\begin{array}{r}41 \\
(12.4 \%)\end{array}$ & $\begin{array}{r}6,029 \\
(9.4 \%)\end{array}$ \\
\hline 60 to 64 & $\begin{array}{r}7,002 \\
(3.6 \%)\end{array}$ & $\begin{array}{r}601 \\
(3.1 \%)\end{array}$ & $\begin{array}{r}2,758 \\
(4.1 \%)\end{array}$ & $\begin{array}{r}200 \\
(2.1 \%)\end{array}$ & $\begin{array}{r}1,072 \\
(3.4 \%)\end{array}$ & $\begin{array}{r}14 \\
(4.2 \%)\end{array}$ & $\begin{array}{r}2,353 \\
(3.7 \%)\end{array}$ \\
\hline $65+$ & $\begin{array}{r}20,440 \\
(10.6 \%)\end{array}$ & $\begin{array}{r}566 \\
(2.9 \%)\end{array}$ & $\begin{array}{r}8,751 \\
(12.9 \%)\end{array}$ & $\begin{array}{r}719 \\
(7.4 \%)\end{array}$ & $\begin{array}{r}3,430 \\
(10.9 \%)\end{array}$ & $\begin{array}{r}23 \\
(6.9 \%)\end{array}$ & $\begin{array}{r}6,951 \\
(10.8 \%)\end{array}$ \\
\hline
\end{tabular}

Note:

- All tables reporting totals could include some unreported characteristics. 


\section{TABLE 4.12}

\section{Number of Person Trips Taken by Women by Age And 1990 Trip Purpose 1995 NPTS \\ (MILLIONS)}

\begin{tabular}{|c|c|c|c|c|c|c|}
\hline $\begin{array}{c}\text { Age } \\
\text { Category }\end{array}$ & TOTAL & $\begin{array}{l}\text { Earning a } \\
\text { Living }\end{array}$ & $\begin{array}{c}\text { Family/ } \\
\text { Personal } \\
\text { Business }\end{array}$ & $\begin{array}{l}\text { School/ } \\
\text { Church }\end{array}$ & $\begin{array}{c}\text { Social/ } \\
\text { Recreational }\end{array}$ & Other \\
\hline \multirow[t]{2}{*}{ TOTAL } & 193,196 & 31,219 & 97,481 & 17,551 & 46,564 & 356 \\
\hline & $(100.0 \%)$ & $(100.0 \%)$ & $(100.0 \%)$ & $(100.0 \%)$ & $(100.0 \%)$ & $(100.0 \%)$ \\
\hline \multirow[t]{2}{*}{5 to 15} & 28,833 & 291 & 8,852 & 8,337 & 11,255 & 94 \\
\hline & $(14.9 \%)$ & $(0.9 \%)$ & $(9.1 \%)$ & $(47.5 \%)$ & $(24.2 \%)$ & $(26.4 \%)$ \\
\hline \multirow[t]{2}{*}{16 to 19} & 11,453 & 1,549 & 4,403 & 2,081 & 3,382 & 32 \\
\hline & $(5.9 \%)$ & $(5.0 \%)$ & $(4.5 \%)$ & $(11.9 \%)$ & $(7.3 \%)$ & $(9.0 \%)$ \\
\hline \multirow[t]{2}{*}{20 to 29} & 29,866 & 6,757 & 14,734 & 1,782 & 6,527 & 59 \\
\hline & $(15.5 \%)$ & $(21.6 \%)$ & $(15.1 \%)$ & $(10.2 \%)$ & $(14.0 \%)$ & $(16.6 \%)$ \\
\hline \multirow[t]{2}{*}{30 to 39} & 42,946 & 8,877 & 24,181 & 1,544 & 8,273 & 69 \\
\hline & $(22.2 \%)$ & $(28.4 \%)$ & $(24.8 \%)$ & $(8.8 \%)$ & $(17.8 \%)$ & $(19.4 \%)$ \\
\hline \multirow[t]{2}{*}{40 to 49} & 34,446 & 7,791 & 19,103 & 1,262 & 6,261 & 28 \\
\hline & $(17.8 \%)$ & $(25.0 \%)$ & $(19.6 \%)$ & $(7.2 \%)$ & $(13.4 \%)$ & $(7.9 \%)$ \\
\hline \multirow[t]{2}{*}{50 to 59} & 18,211 & 4,058 & 9,404 & 863 & 3,846 & 39 \\
\hline & $(9.4 \%)$ & $(13.0 \%)$ & $(9.6 \%)$ & $(4.9 \%)$ & $(8.3 \%)$ & $(11.0 \%)$ \\
\hline \multirow[t]{2}{*}{60 to 64} & 7,002 & 946 & 4,041 & 369 & 1,628 & 15 \\
\hline & $(3.6 \%)$ & $(3.0 \%)$ & $(4.1 \%)$ & $(2.1 \%)$ & $(3.5 \%)$ & $(4.2 \%)$ \\
\hline \multirow[t]{2}{*}{$65+$} & 20,440 & 951 & 12,763 & 1,313 & 5,393 & 19 \\
\hline & $(10.6 \%)$ & $(3.0 \%)$ & $(13.1 \%)$ & $(7.5 \%)$ & $(11.6 \%)$ & $(5.3 \%)$ \\
\hline
\end{tabular}

Note:

- All tables reporting totals could include some unreported characteristics. 
FIGURE 4.6

Percentage of Person Trips by Gender and Trip Purpose 1995 NPTS

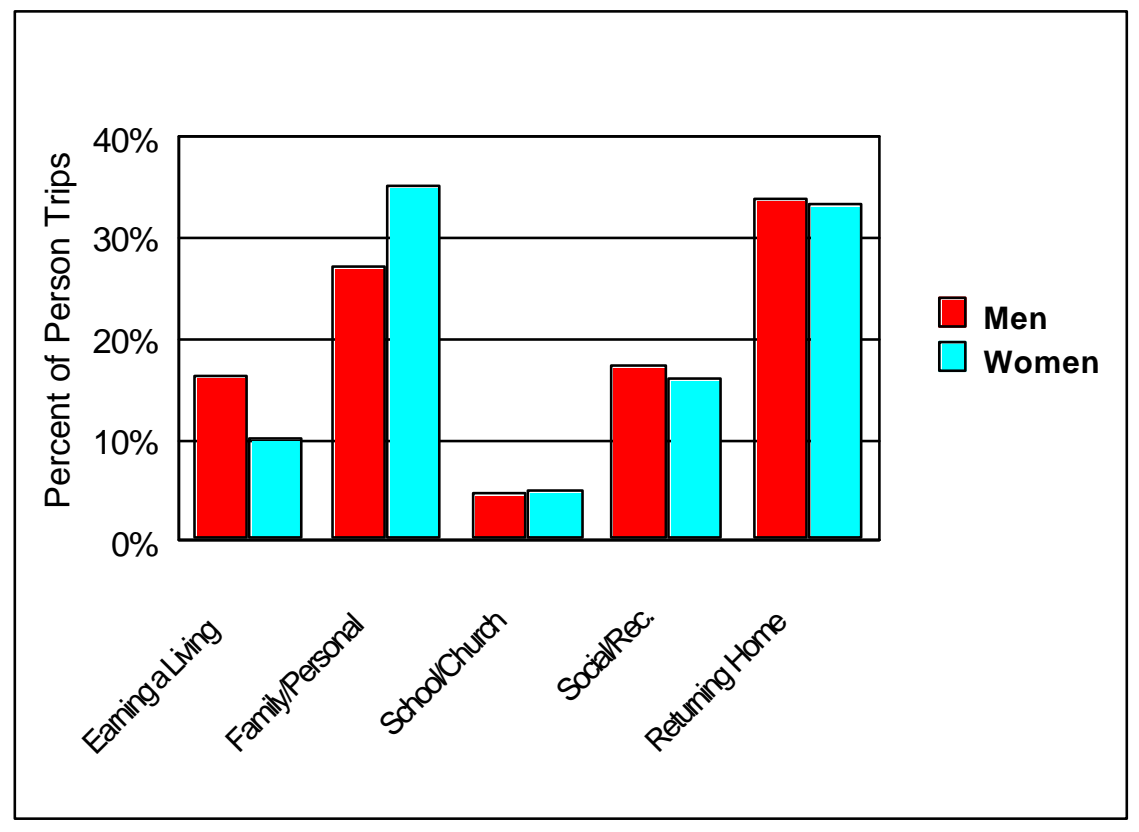


As the baby boom generation prepares to enter retirement age, an understanding of travel characteristics of persons age 65 or over becomes more important. Table 4.13 shows average daily person trips by 1995 trip purpose codes. In 1995, persons 65 years old or older took fewer trips (77\% as many) than persons under 65 . For both age groups, transit was used for less than $2 \%$ of all trips. Of the total trips taken, persons under 65 took about $14 \%$ for earning a living; persons $65+$ took only $4 \%$ for earning a living. For the trip purpose of earning a living, about $79 \%$ within both age groups drove personal vehicles. Overall, about $60 \%$ of all trips for persons under 65 were taken by a POV driver and $26 \%$ as a POV passenger; for persons over 65 , the percentages are $63 \%$ and $22 \%$. Table 4.14 shows average daily person trips based on 1990 trip purpose codes.

As can be seen in Figure 4.7, there are no great differences in the number of average daily person trips between those under age 65 and those who are 65 or over. The greatest difference is in the category of earning a living.

\section{TABLE 4.13}

Average Daily Person Trips Per Person by Mode of Transportation and Trip Purpose BY INDIVIDUALS 65 YEARS OR OLDER VS. INDIVIDUALS UNDER 65 YEARS

1995 NPTS

\begin{tabular}{||lccccc||}
\hline \multicolumn{1}{||}{ TOTAL } & POV Driver & $\begin{array}{c}\text { POV } \\
\text { Passenger }\end{array}$ & Public Transit & Other \\
\hline Trips by Persons Under 65 Years of Age & & & & \\
TOTAL & 4.42 & 2.65 & 1.16 & 0.08 & 0.39 \\
Earning a Living & 0.63 & 0.50 & 0.06 & 0.02 & 0.03 \\
Family/Personal & 1.34 & 0.87 & 0.34 & 0.01 & 0.07 \\
$\quad$ Business & & & & & \\
School/Church & 0.22 & 0.06 & 0.08 & 0.01 & 0.06 \\
Social/Recreational & 0.75 & 0.33 & 0.29 & 0.01 & 0.08 \\
Other & 0.01 & 0.00 & 0.00 & 0.00 & 0.00 \\
Returning Home & 1.48 & 0.88 & 0.38 & 0.03 & 0.14 \\
Trips by Persons 65 Years & or Older & & & & 0.21 \\
TOTAL & 3.43 & 2.28 & 0.78 & 0.06 & 0.01 \\
Earning a Living & 0.15 & 0.12 & 0.01 & 0.00 & 0.07 \\
Family/Personal & 1.40 & 0.97 & 0.29 & 0.02 & 0.01 \\
Business & & & & & 0.05 \\
School/Church & 0.11 & 0.06 & 0.03 & 0.00 & 0.00 \\
Social/Recreational & 0.58 & 0.32 & 0.18 & 0.01 & 0.07 \\
\hline Other & 0.00 & 0.00 & 0.00 & 0.00 & 0.02 \\
Returning Home & 1.19 & 0.80 & 0.26 & &
\end{tabular}

Note:

- All tables reporting totals could include some unreported characteristics. 


\section{TABLE 4.14}

Average Daily Person Trips per Person by Mode of Transportation and 1990 Trip

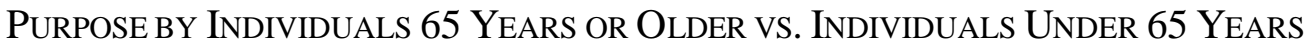
1995 NPTS

\begin{tabular}{||lccccc||}
\hline \multicolumn{1}{||}{} & TOTAL & POV Driver & POV Passenger & Public Transit & Other \\
\hline Trips by Persons Under & 65 Years of Age & & & & \\
TOTAL & 4.42 & 2.65 & 1.16 & 0.08 & 0.39 \\
Earning a Living & 0.96 & 0.79 & 0.09 & 0.03 & 0.04 \\
Family/Personal & 1.95 & 1.28 & 0.47 & 0.02 & 0.12 \\
Business & & & & & \\
School/Church & 0.41 & 0.11 & 0.16 & 0.01 & 0.11 \\
Social/Recreational & 1.09 & 0.47 & 0.44 & 0.01 & 0.12 \\
Other & 0.01 & 0.00 & 0.00 & 0.00 & 0.00 \\
Trips by Persons 65 or Older & 3.43 & 2.28 & 0.78 & 0.06 & 0.21 \\
TOTAL & 0.23 & 0.19 & 0.02 & 0.01 & 0.01 \\
Earning a Living & 2.07 & 1.45 & 0.42 & 0.03 & 0.11 \\
Family/Personal & & & & & \\
Business & 0.19 & 0.11 & 0.06 & 0.00 & 0.01 \\
School/Church & 0.92 & 0.52 & 0.28 & 0.02 & 0.07 \\
Social/Recreational & 0.00 & 0.00 & 0.00 & 0.00 & 0.00 \\
\hline Other & & & & \\
\hline
\end{tabular}

Note:

- All tables reporting totals could include some unreported characteristics. 


\section{FIGURE 4.7}

AVERAGE DAILY PERSON TRIPS PER PERSON BY MODE OF TRANSPORTATION AND

TRIP PURPOSE BY INDIVIDUALS UNDER 65 AND INDIVIDUALS 65 YEARS OR OLDER 1995 NPTS

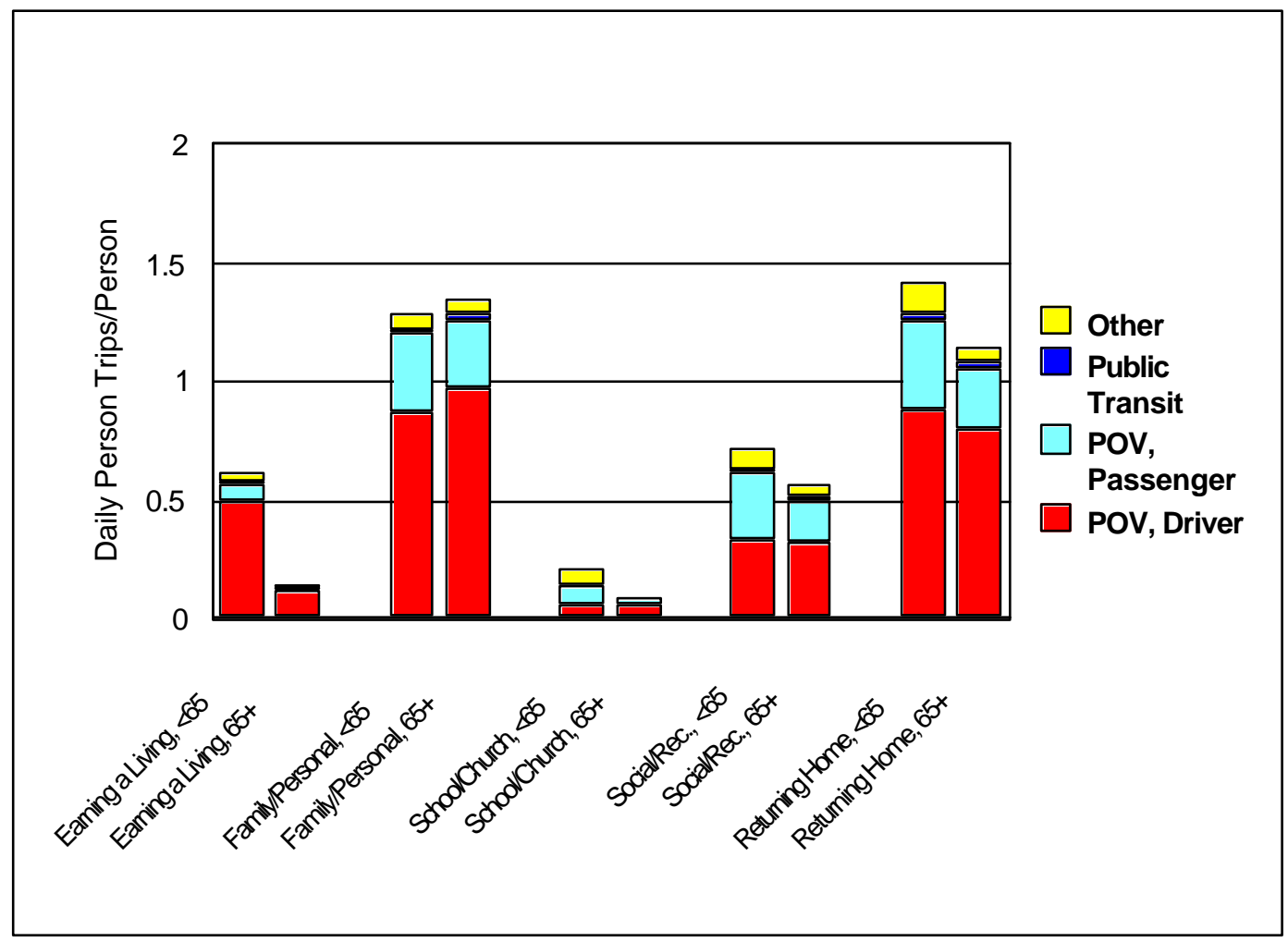


In 1995, most households were comprised of two adults and no children (Figure 4.8).

Households with two or more adults with a youngest child between ages 6 and 15 took the most person trips and traveled the most person miles.

As shown in Table 4.15 , about $68 \%$ of all trips were taken by two-adult households with either no children or two-adult households in which the youngest child was under 16 . These groups also drove the most - almost $70 \%$ of all person miles. The shortest average trip length was taken by single-adult households with a youngest child between 6 and 15, followed closely by single-adult households with a youngest child under 6 . These statistics are very similar to those recorded in the 1990 NPTS.

FIGURE 4.8

Statistics On Households, Household Person TRIPS, AND

Household Person Miles of Travel

1995 NPTS

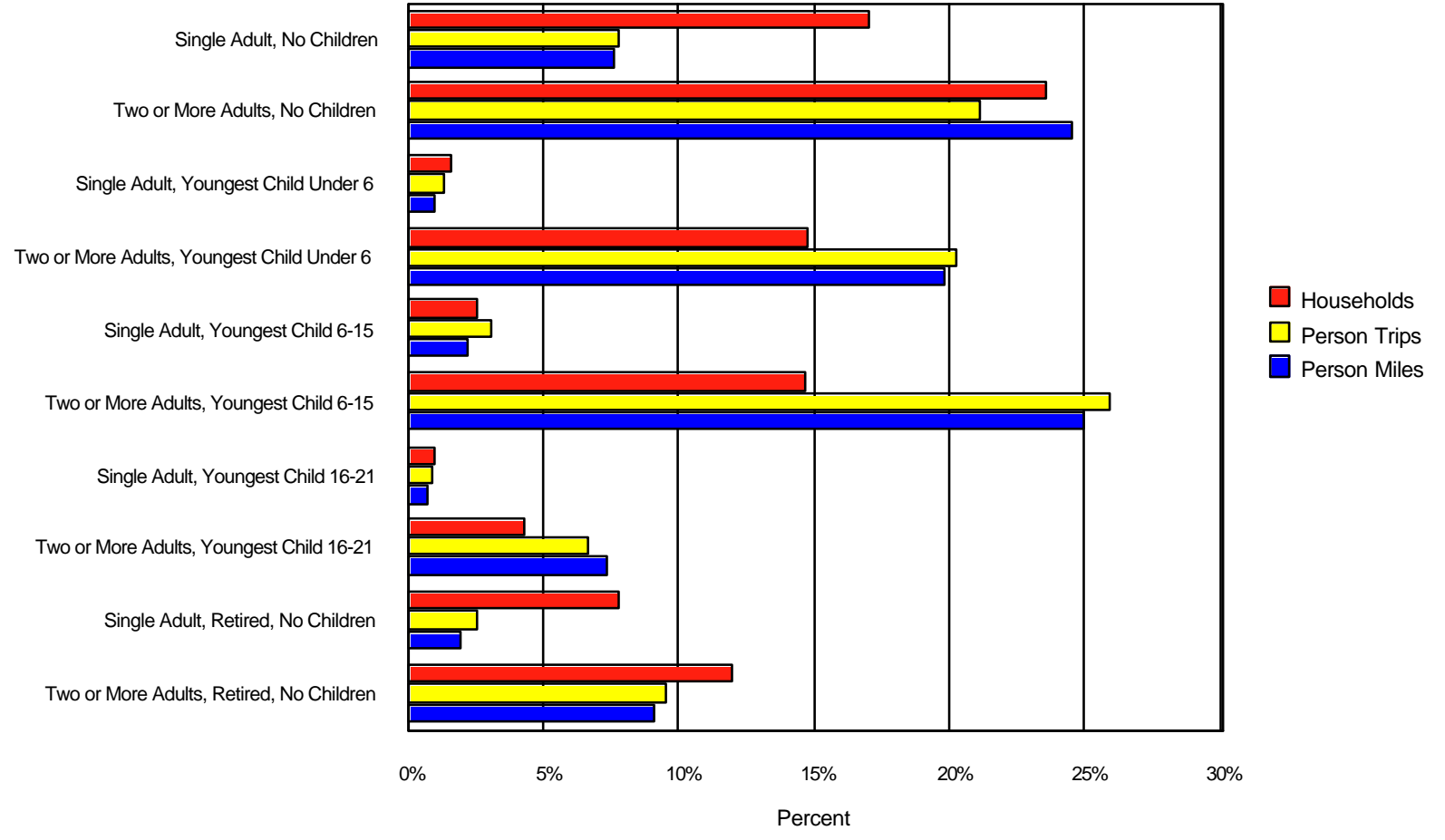




\section{TABLE 4.15}

\section{Statistics on Person Trips and Travel by Household Composition 1995 NPTS}

\begin{tabular}{|c|c|c|c|}
\hline Household Composition & $\begin{array}{c}\text { Number of Person } \\
\text { Trips }(000,000) \\
\end{array}$ & $\begin{array}{l}\text { Number of Person } \\
\text { Miles }(000,000)\end{array}$ & $\begin{array}{c}\text { Average Trip } \\
\text { Length (Miles) }\end{array}$ \\
\hline TOTAL & $\begin{array}{l}378,930 \\
(100.0 \%)\end{array}$ & $\begin{array}{l}3,411,122 \\
(100.0 \%)\end{array}$ & 9.13 \\
\hline Single Adult, No Children & $\begin{array}{l}29,987 \\
(7.9 \%)\end{array}$ & $\begin{array}{l}262,204 \\
(7.7 \%)\end{array}$ & 8.88 \\
\hline $\begin{array}{l}\text { Two or More Adults, } \\
\text { No Children }\end{array}$ & $\begin{array}{l}80,421 \\
(21.2 \%)\end{array}$ & $\begin{array}{l}838,671 \\
(24.6 \%)\end{array}$ & 10.57 \\
\hline $\begin{array}{l}\text { Single Adult, Youngest } \\
\text { Child Under } 6\end{array}$ & $\begin{array}{l}5,342 \\
(1.4 \%)\end{array}$ & $\begin{array}{l}33,904 \\
(1.0 \%)\end{array}$ & 6.54 \\
\hline $\begin{array}{l}\text { Two or More Adults, } \\
\text { Youngest Child Under } 6\end{array}$ & $\begin{array}{l}76,890 \\
(20.3 \%)\end{array}$ & $\begin{array}{l}678,158 \\
(19.9 \%)\end{array}$ & 8.94 \\
\hline $\begin{array}{l}\text { Single Adult, Youngest } \\
\text { Child 6-15 }\end{array}$ & $\begin{array}{l}12,114 \\
(3.2 \%)\end{array}$ & $\begin{array}{l}76,460 \\
(2.2 \%)\end{array}$ & 6.44 \\
\hline $\begin{array}{l}\text { Two or More Adults, } \\
\text { Youngest Child 6-15 }\end{array}$ & $\begin{array}{l}98,579 \\
(26.0 \%)\end{array}$ & $\begin{array}{l}855,097 \\
(25.1 \%)\end{array}$ & 8.8 \\
\hline $\begin{array}{l}\text { Single Adult, Youngest } \\
\text { Child } 16-21\end{array}$ & $\begin{array}{c}3,636 \\
(1.0 \%)\end{array}$ & $\begin{array}{l}30,005 \\
(0.9 \%)\end{array}$ & 8.45 \\
\hline $\begin{array}{l}\text { Two or More Adults, } \\
\text { Youngest Child 16-21 }\end{array}$ & $\begin{array}{l}25,530 \\
(6.7 \%)\end{array}$ & $\begin{array}{l}253,796 \\
(7.4 \%)\end{array}$ & 10.09 \\
\hline $\begin{array}{l}\text { Single Adult, Retired, } \\
\text { No Children }\end{array}$ & $\begin{array}{l}10,073 \\
(2.7 \%)\end{array}$ & $\begin{array}{l}69,612 \\
(2.0 \%)\end{array}$ & 7.05 \\
\hline $\begin{array}{l}\text { Two or More Adults, } \\
\text { Retired, No Children }\end{array}$ & $\begin{array}{l}36,359 \\
(9.6 \%)\end{array}$ & $\begin{array}{l}313,216 \\
(9.2 \%)\end{array}$ & 8.72 \\
\hline
\end{tabular}

Note:

- All tables reporting totals could include some unreported characteristics.

- Average Trip Length is calculated using only those records with trip mileage information present. 
Figure 4.9 and Table 4.16 illustrate travel patterns by metropolitan statistical area (MSA) size based on place of residence. Households are gradually moving into metropolitan areas. In $1995,80 \%$ of all households lived in metropolitan areas and, of these, about $40 \%$ were in cities with a population of at least 3 million persons (see Figure 4.9). Persons living in large metropolitan areas ( $\geq 3$ million) took fewer person trips per person and traveled fewer person miles per person than any other demographic group (Table 4.16). However, because of the large number of persons concentrated in large metropolitan areas, the percentage of total person trips and PMT was high (Figure 4.9). A greater percentage of the travel (both person trips and person miles traveled) of persons living in large metropolitan areas was by transit and by walking than was that of any other group.

As shown in Table 4.17, most person trips on transit $(79 \%)$ were taken by persons living in MSAs of 3 million or more. Most transit trips, other than returning home, are for earning a living (21.2\%) and family/personal business (20\%). For persons not in an MSA, only 5.2\% of the transit trips are for earning a living.

\section{FIGURE 4.9}

Demographic Travel Statistics by MSA Size

1995 NPTS

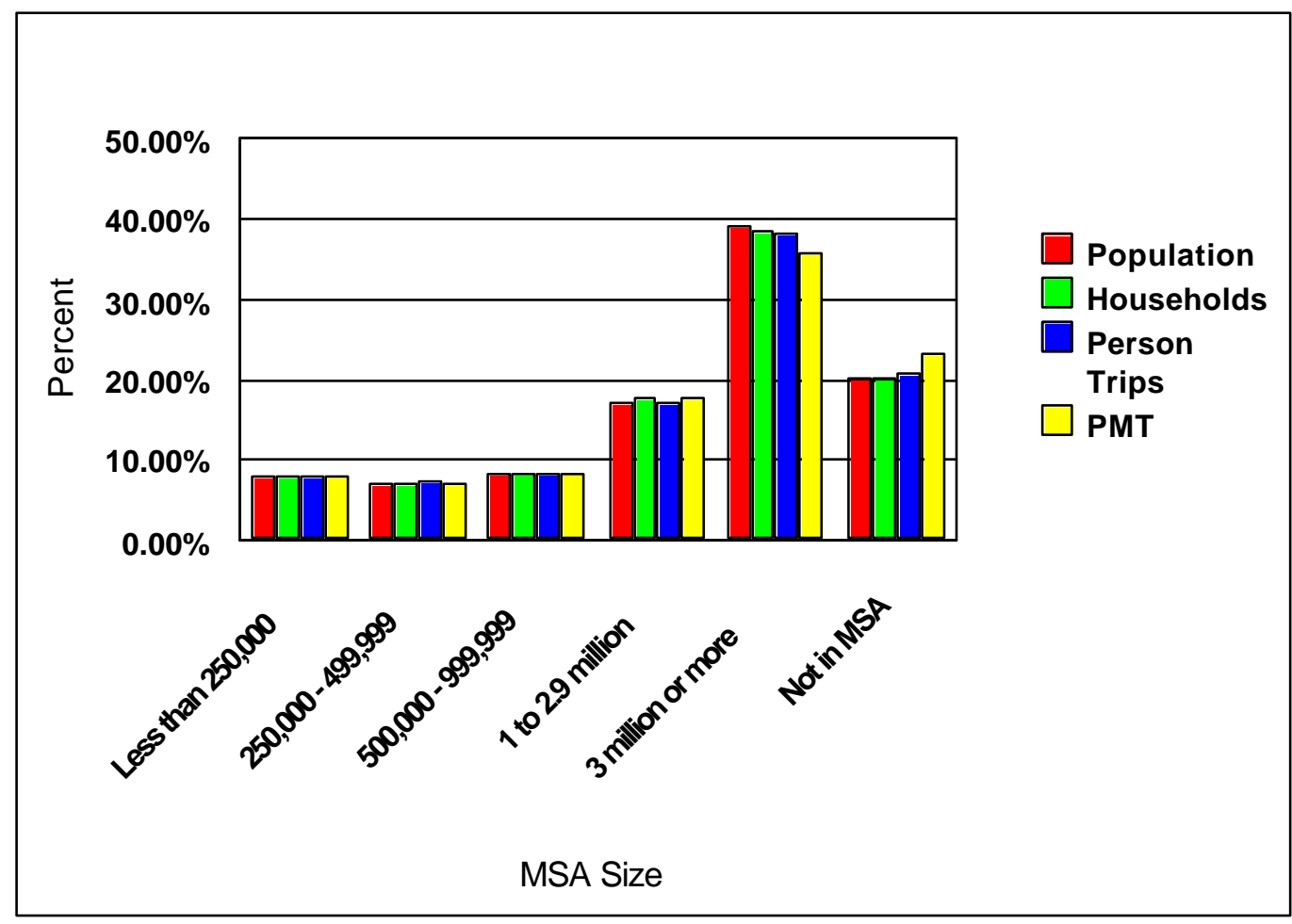


TABLE 4.16

Demographic and Personal Travel Statistics by MSA Size 1995 NPTS

\begin{tabular}{|c|c|c|c|c|c|c|c|}
\hline & \multicolumn{7}{|c|}{ MSA Size } \\
\hline & TOTAL & $\begin{array}{l}\text { Less than } \\
250,000\end{array}$ & $\begin{array}{c}250,000- \\
499,999 \\
\end{array}$ & $\begin{array}{l}500,000- \\
999,999 \\
\end{array}$ & $\begin{array}{l}1 \text { to } 2.9 \\
\text { million }\end{array}$ & $\begin{array}{c}3 \text { million } \\
\text { or more }\end{array}$ & $\begin{array}{l}\text { Not in } \\
\text { MSA }\end{array}$ \\
\hline $\begin{array}{l}\text { Population } \\
\text { (in thousands) }\end{array}$ & $\begin{array}{l}241,675 \\
(100 \%)\end{array}$ & $\begin{array}{l}18,769 \\
(7.8 \%)\end{array}$ & $\begin{array}{l}17,245 \\
(7.1 \%)\end{array}$ & $\begin{array}{l}19,999 \\
(8.3 \%)\end{array}$ & $\begin{array}{r}41,553 \\
(17.2 \%)\end{array}$ & $\begin{array}{r}94,972 \\
(39.3 \%)\end{array}$ & $\begin{array}{r}49,137 \\
(20.3 \%)\end{array}$ \\
\hline $\begin{array}{l}\text { Total No. of } \\
\text { Households } \\
\text { (in thousands) }\end{array}$ & $\begin{array}{r}98,990 \\
(100 \%)\end{array}$ & $\begin{array}{r}7,809 \\
(7.9 \%)\end{array}$ & $\begin{array}{r}7,117 \\
(7.2 \%)\end{array}$ & $\begin{array}{r}8,152 \\
(8.2 \%)\end{array}$ & $\begin{array}{r}17,360 \\
(17.5 \%)\end{array}$ & $\begin{array}{r}38,303 \\
(38.7 \%)\end{array}$ & $\begin{array}{r}20,249 \\
(20.5 \%)\end{array}$ \\
\hline $\begin{array}{l}\text { Average Household } \\
\text { Size }\end{array}$ & 2.58 & 2.52 & 2.61 & 2.60 & 2.55 & 2.62 & 2.54 \\
\hline $\begin{array}{l}\text { Person Trips } \\
\text { (in millions) }\end{array}$ & $\begin{array}{l}378,930 \\
(100 \%)\end{array}$ & $\begin{array}{l}30,660 \\
(8.1 \%)\end{array}$ & $\begin{array}{l}27,717 \\
(7.3 \%)\end{array}$ & $\begin{array}{l}31,921 \\
(8.4 \%)\end{array}$ & $\begin{array}{r}65,879 \\
(17.4 \%)\end{array}$ & $\begin{array}{l}144,224 \\
(38.1 \%)\end{array}$ & $\begin{array}{r}78,529 \\
(20.7 \%)\end{array}$ \\
\hline $\begin{array}{l}\text { Person Trips per } \\
\text { Person }\end{array}$ & 1,568 & 1,634 & 1,607 & 1,596 & 1,585 & 1,519 & 1,598 \\
\hline $\begin{array}{l}\text { Person Miles of } \\
\text { Travel (PMT) } \\
\text { (in millions) }\end{array}$ & $\begin{array}{r}3,411,122 \\
(100 \%)\end{array}$ & $\begin{array}{r}267,096 \\
(7.8 \%)\end{array}$ & $\begin{array}{r}245,941 \\
(7.2 \%)\end{array}$ & $\begin{array}{r}288,557 \\
(8.5 \%)\end{array}$ & $\begin{array}{l}602,212 \\
(17.7 \%)\end{array}$ & $\begin{array}{r}1,216,291 \\
(35.7 \%)\end{array}$ & $\begin{array}{l}791,025 \\
(23.2 \%)\end{array}$ \\
\hline PMT per Person & 14,115 & 14,231 & 14,262 & 14,429 & 14,492 & 12,807 & 16,098 \\
\hline $\begin{array}{l}\text { Average Trip } \\
\text { Length (miles) }\end{array}$ & 9.13 & 8.8 & 8.96 & 9.18 & 9.24 & 8.62 & 10.15 \\
\hline \multicolumn{8}{|l|}{ \% Person Trips by } \\
\hline$-\mathrm{POV}$ & $86.4 \%$ & $89.2 \%$ & $89.1 \%$ & $89.6 \%$ & $88.4 \%$ & $81.7 \%$ & $90.1 \%$ \\
\hline - Public Transit & $1.8 \%$ & $0.6 \%$ & $0.5 \%$ & $0.8 \%$ & $1.0 \%$ & $3.6 \%$ & $0.2 \%$ \\
\hline - Walk & $5.4 \%$ & $3.5 \%$ & $3.9 \%$ & $3.5 \%$ & $4.3 \%$ & $8.0 \%$ & $3.4 \%$ \\
\hline \multicolumn{8}{|l|}{ \% PMT by } \\
\hline$-\mathrm{POV}$ & $91.2 \%$ & $92.6 \%$ & $89.5 \%$ & $94.8 \%$ & $90.3 \%$ & $89.2 \%$ & $93.6 \%$ \\
\hline - Public Transit & $2.1 \%$ & $0.8 \%$ & $1.5 \%$ & $1.0 \%$ & $1.0 \%$ & $4.3 \%$ & $0.6 \%$ \\
\hline - Walk & $0.3 \%$ & $0.2 \%$ & $0.2 \%$ & $0.2 \%$ & $0.2 \%$ & $0.5 \%$ & $0.2 \%$ \\
\hline
\end{tabular}

Note:

- All tables reporting totals could include some unreported characteristics.

- Average Trip Length is calculated using only those records with trip mileage information present. 
TABLE 4.17
Number of Person Trips by Public Transit vs. Other Modes, TRIP PuRPose, AND MSA SizE
1995 NPTS
(MILLIONS)

\begin{tabular}{|c|c|c|c|c|c|c|c|}
\hline & \multicolumn{7}{|c|}{ MSA Size } \\
\hline & TOTAL & $\begin{array}{c}\text { Less } \\
\text { than } \\
250,000 \\
\end{array}$ & $\begin{array}{l}250,000- \\
499,999 \\
\end{array}$ & $\begin{array}{l}500,000- \\
999,999 \\
\end{array}$ & $\begin{array}{l}1 \text { to } 2.9 \\
\text { million }\end{array}$ & $\begin{array}{l}3 \text { million } \\
\text { or more }\end{array}$ & $\begin{array}{l}\text { Not in } \\
\text { MSA }\end{array}$ \\
\hline \multicolumn{8}{|c|}{ Public Transportation Trips } \\
\hline TOTAL & $\begin{array}{c}6,638 \\
(100 \%)\end{array}$ & $\begin{array}{r}183 \\
(100 \%)\end{array}$ & $\begin{array}{r}129 \\
(100 \%)\end{array}$ & $\begin{array}{r}271 \\
(100 \%)\end{array}$ & $\begin{array}{r}644 \\
(100 \%)\end{array}$ & $\begin{array}{r}5,239 \\
(100 \%)\end{array}$ & $\begin{array}{r}172 \\
(100 \%)\end{array}$ \\
\hline Earning a Living & $\begin{array}{r}1,404 \\
(21.2 \%)\end{array}$ & $\begin{array}{r}50 \\
(27.3 \%)\end{array}$ & $\begin{array}{r}20 \\
(15.5 \%)\end{array}$ & $\begin{array}{r}61 \\
(22.5 \%)\end{array}$ & $\begin{array}{r}133 \\
(20.7 \%)\end{array}$ & $\begin{array}{r}1,132 \\
(21.6 \%)\end{array}$ & $\begin{array}{r}9 \\
(5.2 \%)\end{array}$ \\
\hline $\begin{array}{l}\text { Family/Personal } \\
\text { Business }\end{array}$ & $\begin{array}{r}1,327 \\
(20.0 \%)\end{array}$ & $\begin{array}{r}25 \\
(13.7 \%)\end{array}$ & $\begin{array}{r}28 \\
(21.7 \%)\end{array}$ & $\begin{array}{r}53 \\
(19.6 \%)\end{array}$ & $\begin{array}{r}160 \\
(24.8 \%)\end{array}$ & $\begin{array}{r}1,034 \\
(19.7 \%)\end{array}$ & $\begin{array}{r}26 \\
(15.1 \%)\end{array}$ \\
\hline School/Church & $\begin{array}{r}487 \\
(7.3 \%)\end{array}$ & $\begin{array}{r}34 \\
(18.6 \%)\end{array}$ & $\begin{array}{r}6 \\
(4.7 \%)\end{array}$ & $\begin{array}{r}29 \\
(10.7 \%)\end{array}$ & $\begin{array}{r}36 \\
(5.6 \%)\end{array}$ & $\begin{array}{r}348 \\
(6.6 \%)\end{array}$ & $\begin{array}{r}34 \\
(19.8 \%)\end{array}$ \\
\hline Social/Recreational & $\begin{array}{r}921 \\
(13.9 \%)\end{array}$ & $\begin{array}{r}19 \\
(10.4 \%)\end{array}$ & $\begin{array}{r}25 \\
(19.4 \%)\end{array}$ & $\begin{array}{r}36 \\
(13.3 \%)\end{array}$ & $\begin{array}{r}74 \\
(11.5 \%)\end{array}$ & $\begin{array}{r}723 \\
(13.8 \%)\end{array}$ & $\begin{array}{r}45 \\
(26.2 \%)\end{array}$ \\
\hline Other & $\begin{array}{r}18 \\
(0.3 \%)\end{array}$ & $(1.6 \%)^{3}$ & $* *$ & $\begin{array}{r}0 \\
(0.0 \%)\end{array}$ & $(0.3 \%)$ & $(0.1 \%)$ & $(4.1 \%)$ \\
\hline Returning Home & $\begin{array}{r}2,481 \\
(37.4 \%)\end{array}$ & $\begin{array}{r}53 \\
(29.0 \%)\end{array}$ & $\begin{array}{r}50 \\
(38.8 \%)\end{array}$ & $\begin{array}{r}91 \\
(33.6 \%)\end{array}$ & $\begin{array}{r}239 \\
(37.1 \%)\end{array}$ & $\begin{array}{r}1,995 \\
(38.1 \%)\end{array}$ & $\begin{array}{r}52 \\
(30.2 \%)\end{array}$ \\
\hline \multicolumn{8}{|l|}{ All Other Modes } \\
\hline TOTAL & $\begin{array}{l}372,292 \\
(100 \%)\end{array}$ & $\begin{array}{l}30,477 \\
(100 \%)\end{array}$ & $\begin{array}{c}27,588 \\
(100 \%)\end{array}$ & $\begin{array}{l}31,650 \\
(100 \%)\end{array}$ & $\begin{array}{l}65,235 \\
(100 \%)\end{array}$ & $\begin{array}{l}138,985 \\
(100 \%)\end{array}$ & $\begin{array}{l}78,357 \\
(100 \%)\end{array}$ \\
\hline Earning a Living & $\begin{array}{r}48,763 \\
(13.1 \%)\end{array}$ & $\begin{array}{r}4,147 \\
(13.6 \%)\end{array}$ & $\begin{array}{r}3,568 \\
(12.9 \%)\end{array}$ & $\begin{array}{r}4,089 \\
(12.9 \%)\end{array}$ & $\begin{array}{r}8.471 \\
(13.0 \%)\end{array}$ & $\begin{array}{r}18,015 \\
(13.0 \%)\end{array}$ & $\begin{array}{c}10,474 \\
(13.4 \%)\end{array}$ \\
\hline $\begin{array}{l}\text { Family/Personal } \\
\text { Business }\end{array}$ & $\begin{array}{l}117,216 \\
(31.5 \%)\end{array}$ & $\begin{array}{r}9,535 \\
(31.3 \%)\end{array}$ & $\begin{array}{r}8,629 \\
(31.3 \%)\end{array}$ & $\begin{array}{r}9,997 \\
(31.6 \%)\end{array}$ & $\begin{array}{c}20,861 \\
(32.0 \%)\end{array}$ & $\begin{array}{r}43,865 \\
(31.6 \%)\end{array}$ & $\begin{array}{r}24,331 \\
(31.1 \%)\end{array}$ \\
\hline School/Church & $\begin{array}{l}17,795 \\
(4.8 \%)\end{array}$ & $\begin{array}{l}1,498 \\
(4.9 \%)\end{array}$ & $\begin{array}{l}1,345 \\
(4.9 \%)\end{array}$ & $\begin{array}{l}1,480 \\
(4.7 \%)\end{array}$ & $\begin{array}{r}2,829 \\
(4.3 \%)\end{array}$ & $\begin{array}{r}6,638 \\
(4.8 \%)\end{array}$ & $\begin{array}{l}4,004 \\
(5.1 \%)\end{array}$ \\
\hline Social/Recreational & $\begin{array}{l}62,987 \\
(16.9 \%)\end{array}$ & $\begin{array}{r}5,142 \\
(16.9 \%)\end{array}$ & $\begin{array}{r}4,731 \\
(17.1 \%)\end{array}$ & $\begin{array}{r}5,582 \\
(17.6 \%)\end{array}$ & $\begin{array}{l}11,139 \\
(17.1 \%)\end{array}$ & $\begin{array}{l}23,315 \\
(16.8 \%)\end{array}$ & $\begin{array}{l}13,078 \\
(16.7 \%)\end{array}$ \\
\hline Other & $\begin{array}{r}590 \\
(0.2 \%)\end{array}$ & $\begin{array}{r}44 \\
(0.1 \%)\end{array}$ & $\begin{array}{r}32 \\
(0.1 \%)\end{array}$ & $\begin{array}{r}46 \\
(0.1 \%)\end{array}$ & $\begin{array}{r}98 \\
(0.2 \%)\end{array}$ & $\begin{array}{r}202 \\
(0.1 \%)\end{array}$ & $\begin{array}{r}168 \\
(0.2 \%)\end{array}$ \\
\hline Returning Home & $\begin{array}{l}124,892 \\
(33.5 \%)\end{array}$ & $\begin{array}{r}10,106 \\
(33.2 \%)\end{array}$ & $\begin{array}{r}9,282 \\
(33.6 \%)\end{array}$ & $\begin{array}{r}10,446 \\
(33.0 \%)\end{array}$ & $\begin{array}{r}21,832 \\
(33.5 \%)\end{array}$ & $\begin{array}{r}46,933 \\
(33.8 \%) \\
\end{array}$ & $\begin{array}{r}26,294 \\
(33.6 \%) \\
\end{array}$ \\
\hline
\end{tabular}

Note:

- All tables reporting totals could include some unreported characteristics.

- ** Indicates no data available. 
Tables 4.18-4.20 compare average trip lengths between the 1990 (adjusted) NPTS values and the 1995 NPTS. Although the average trip length decreased slightly (3.7\%) between 1990 and 1995, it actually increased slightly for the earning a living category (Table 4.18). As seen in Table 4.19, the average trip length for trips via private vehicle and public transportation remained about the same between 1990 and decreased by almost $30 \%$, and air travel decreased by almost half. Table 4.20 examines trip length by MSA size. In 1990, trips with a social/recreational purpose generally were longer than for any other purpose for every MSA size. In 1995, however, this fact was no longer true, and the Other category included longer trip lengths for all except the two largest MSA categories. 
TABLE 4.18

Average Trip Length By 1990 Trip PuRPoses 1990 ADJUSTED AND 1995 NPTS

(MILES)

\begin{tabular}{||lcc||}
\hline & $1990 \mathrm{adj}$ & 1995 \\
\hline TOTAL & 9.47 & 9.13 \\
Earning a Living & & \\
To or From Work & 10.65 & 11.63 \\
Work-Related Business & 28.20 & 20.28 \\
$\quad$ Subtotal & 11.80 & 12.74 \\
Family and Personal Business & & \\
Shopping & 5.38 & 6.08 \\
Doctor/Dentist & 10.59 & 9.67 \\
Other Family or Personal Business & 8.44 & 7.50 \\
$\quad$ Subtotal & 7.20 & 6.94 \\
Civic, Educational, and Religious & & \\
$\quad$ Subtotal & 5.39 & 5.98 \\
Social and Recreational & 11.23 & 9.85 \\
Vacation & 13.19 & 11.27 \\
Visiting Friends/Relatives & & \\
Pleasure Driving & 218.22 & 76.25 \\
Other Social/Recreational & 11.73 & 12.53 \\
$\quad$ Subtotal & 22.21 & $* .30$ \\
\hline Other & & \\
\hline & & \\
\hline
\end{tabular}

Note:

- All tables reporting totals could include some unreported characteristics.

- The purpose codes used for 1995 NPTS reflect the 1990 purpose code scheme.

- Average Trip Length is calculated using only those records with trip mileage information present.

- ** Indicates no data available.

- Note that only the 1990 data have been adjusted to make them more comparable with the 1995 data. Thus, there are limits on the conclusions that can be drawn in comparing travel with earlier survey years. The adjustments to 1990 data affect only person trips, vehicle trips, person miles of travel (PMT) and vehicle miles of travel (VMT). 
TABLE 4.19

\section{Average Trip Length B y Mode of Transportation 1990 ADJUSTED AND 1995 NPTS \\ (MILES)}

\begin{tabular}{|c|c|c|}
\hline & $1990 \mathrm{adj}$ & 1995 \\
\hline TOTAL & 9.47 & 9.13 \\
\hline \multicolumn{3}{|l|}{ Private Vehicle } \\
\hline Auto & 9.19 & 8.91 \\
\hline Van & 10.87 & 9.68 \\
\hline Sport Utility Vehicle & NA & 10.74 \\
\hline Pickup & 10.44 & 10.73 \\
\hline Other Truck & 15.17 & 39.40 \\
\hline $\mathrm{RV}$ & 49.79 & 37.42 \\
\hline Motorcycle & 11.70 & 10.32 \\
\hline Moped & 6.50 & NA \\
\hline Other Private Vehicle & 11.55 & 7.78 \\
\hline Subtotal - Private & 9.51 & 9.59 \\
\hline \multicolumn{3}{|l|}{ Public Transportation } \\
\hline Bus & 11.35 & 11.72 \\
\hline Commuter Train & 24.82 & 24.30 \\
\hline Streetcar/Trolley & 6.86 & 3.62 \\
\hline Subway, Elevated Rail & 12.10 & 9.99 \\
\hline Subtotal - Public & 12.49 & 12.43 \\
\hline \multicolumn{3}{|l|}{ Other Means } \\
\hline Amtrak & 106.60 & 108.75 \\
\hline Walk & 0.64 & 0.53 \\
\hline Bike & 2.03 & 1.38 \\
\hline School Bus & 5.77 & 6.80 \\
\hline Airplane & $1,089.48$ & 565.67 \\
\hline Taxi & 4.61 & 4.92 \\
\hline Other & 45.50 & 12.78 \\
\hline Subtotal - Other & 8.62 & 6.07 \\
\hline
\end{tabular}

Note:

- All tables reporting totals could include some unreported characteristics.

- Average Trip Length is calculated using only those records with trip mileage information present.

- The 1990 survey does not include a separate category for sport utility vehicles, while the 1995 survey does. In the 1990 survey, most SUVs were classified as automobiles. The 1995 survey does not include a separate category for mopeds.

- Note that only the 1990 data have been adjusted to make them more comparable with the 1995 data. Thus, there are limits on the conclusions that can be drawn in comparing travel with earlier survey years. The adjustments to 1990 data affect only person trips, vehicle trips, person miles of travel (PMT) and vehicle miles of travel (VMT). 
TABLE 4.20

Average Person Trip Length by MSA Size And 1990 Trip PurPoses

1990 ADJUSTED AND 1995 NPTS

(MILES)

\begin{tabular}{|c|c|c|c|c|c|c|c|}
\hline Trip Purpose & $\begin{array}{c}\text { ALL } \\
\text { AREAS } \\
\end{array}$ & $\begin{array}{c}<50,000 \\
\end{array}$ & $\begin{array}{l}250,000- \\
499,999 \\
\end{array}$ & $\begin{array}{l}500,000- \\
999,999 \\
\end{array}$ & $\begin{array}{c}1 \text { to } 2.9 \\
\text { million }\end{array}$ & $\begin{array}{c}3 \text { million } \\
\quad+ \\
\end{array}$ & $\begin{array}{l}\text { Not in } \\
\text { MSA } \\
\end{array}$ \\
\hline \multicolumn{8}{|l|}{1990 adj } \\
\hline ALL PURPOSES & 9.47 & 9.32 & 8.46 & 8.72 & 9.68 & 9.60 & 9.89 \\
\hline Earning a Living & 11.80 & 9.82 & 9.77 & 10.54 & 12.08 & 13.47 & 11.39 \\
\hline $\begin{array}{l}\text { Family/Personal } \\
\text { Business }\end{array}$ & 7.20 & 7.24 & 6.54 & 7.19 & 6.89 & 6.65 & 8.41 \\
\hline School/Church & 5.39 & 4.85 & 5.44 & 5.54 & 5.05 & 5.09 & 6.12 \\
\hline Social/Recreational & 13.19 & 13.76 & 11.80 & 11.37 & 14.30 & 13.24 & 13.15 \\
\hline Other & 10.30 & 7.93 & 4.12 & 9.47 & 11.08 & 15.35 & 8.42 \\
\hline \multicolumn{8}{|l|}{1995} \\
\hline ALL PURPOSES & 9.13 & 8.80 & 8.96 & 9.18 & 9.24 & 8.62 & 10.15 \\
\hline Earning a Living & 12.74 & 10.95 & 12.42 & 11.99 & 12.71 & 13.27 & 12.89 \\
\hline $\begin{array}{l}\text { Family/Personal } \\
\text { Business }\end{array}$ & 6.94 & 6.71 & 6.58 & 6.91 & 6.80 & 6.30 & 8.48 \\
\hline School/Church & 5.98 & 5.84 & 6.75 & 6.96 & 5.48 & 5.30 & 6.92 \\
\hline Social/Recreational & 11.27 & 11.71 & 11.33 & 11.55 & 12.15 & 10.30 & 11.92 \\
\hline Other & 22.83 & 57.91 & 20.17 & 29.53 & 9.50 & 9.76 & 36.31 \\
\hline
\end{tabular}

Note:

- All tables reporting totals could include some unreported characteristics.

- The purpose codes used for 1995 NPTS reflect the 1990 purpose code scheme.

- Average Trip Length is calculated using only those records with trip mileage information present.

- Note that only the 1990 data have been adjusted to make them more comparable with the 1995 data. Thus, there are limits on the conclusions that can be drawn in comparing travel with earlier survey years. The adjustments to 1990 data affect only person trips, vehicle trips, person miles of travel (PMT) and vehicle miles of travel (VMT). 
Generally, for travel day trips, each new destination constitutes a separate trip, except for a trip which is segmented. Segmented trips collected more complete data on multi-modal trips, with particular emphasis on the use of public transit. There was a limit of four segments per trip, and the typical travel day trip information was collected, along with the mode, start time, and duration of each of the segments.

Trips in which the respondent went from one $\mathrm{POV}$ to another were not classified as segmented trips. For example, the respondent drives his sport utility vehicle to the pickup point for his carpool, then rides to work in the car of another carpool member. These POVto-POV transfers were not considered as segmented trips because they would have added to the respondent burden in reporting travel day trips, without an offsetting value in improving our understanding of travel behavior. When more than one POV was used for a trip, the travel mode was assigned to the vehicle type used for the longest distance. In the example above, the car was probably the mode used for the longest distance.

Segmented trips are a small subset of the universe of NPTS travel day trips. Of the
409,025 travel day trips collected in the 1995 NPTS, 3,779 (less than 1\%) were segmented. When a travel day trip was segmented, most of the trip information was on the travel day trip record. In addition, a segmented trip record was established on the segmented trip file. This segmented record, which had the same identifiers as the travel day trip record, contained information on each of the segments of the trip (e.g., the mode, start time, and duration in minutes).

As can be seen by comparing Tables 4.214.22 and Figure 4.10, segmented and nonsegmented travel differs considerably based on residence location within urban/rural census tracts. As shown in Table 4.21 and Figure 4.10 , most segmented trips ( $68 \%$ of all segmented person trips) were taken by individuals living in urban areas; the fewest segmented trips were taken by persons in rural areas. As shown in Table 4.22, persons in urban areas took the smallest number of nonsegmented trips (14.2\%). The average trip length of non-segmented trips (9.09 miles) was shorter than the average length of segmented trips (14.28 miles). While urban travelers took the most segmented trips, they had the shortest average trip length. 


\section{TABLE 4.21}

\section{Statistics on Segmented Person Travel by Census Tract Urban/Rural Code 1995 NPTS}

\begin{tabular}{||lccc||}
\hline Urbanized Area Size & $\begin{array}{c}\text { Number of Person } \\
\text { Trips } \\
(000,000)\end{array}$ & $\begin{array}{c}\text { Number of Person } \\
\text { Miles } \\
(000,000)\end{array}$ & $\begin{array}{c}\text { Average Trip } \\
\text { Length } \\
\text { (miles) }\end{array}$ \\
\hline ALL & 3,441 & 42,352 & 14.28 \\
Second City & $(100.0 \%)$ & $(100.0 \%)$ & \\
& 372 & 5,177 & 15.87 \\
Rural & $(10.8 \%)$ & $(12.2 \%)$ & 29.06 \\
Suburban & 38 & 1,022 & 20.60 \\
& $(1.1 \%)$ & $(2.4 \%)$ & \\
Town & 575 & 10,803 & 96.48 \\
& $(16.7 \%)$ & $(25.5 \%)$ & \\
Urban & 77 & 6,779 & 9.17 \\
\hline
\end{tabular}

Note:

- All tables reporting totals could include some unreported characteristics.

- Average Trip Length is calculated using only those records with trip mileage information present.

- See Appendix $\mathrm{H}$ for the definition of a segmented trip. 


\section{TABLE 4.22}

\section{Statistics on Non-Segmented Person Travel by Census Tract Urban/Rural Code 1995 NPTS}

\begin{tabular}{|c|c|c|c|}
\hline Urbanized Area Size & $\begin{array}{c}\text { Number of Person } \\
\text { Trips } \\
(000,000) \\
\end{array}$ & $\begin{array}{c}\text { Number of Person } \\
\text { Miles } \\
(000,000) \\
\end{array}$ & $\begin{array}{c}\text { Average Trip } \\
\text { Length } \\
\text { (miles) }\end{array}$ \\
\hline ALL & $\begin{array}{l}375,490 \\
(100.0 \%)\end{array}$ & $\begin{array}{r}3,368,770 \\
(100.0 \%)\end{array}$ & 9.09 \\
\hline Second City & $\begin{array}{l}66,189 \\
(17.6 \%)\end{array}$ & $\begin{array}{l}535,501 \\
(15.9 \%)\end{array}$ & 8.20 \\
\hline Rural & $\begin{array}{l}75,201 \\
(20.0 \%)\end{array}$ & $\begin{array}{l}814,732 \\
(24.2 \%)\end{array}$ & 10.94 \\
\hline Suburban & $\begin{array}{l}94,881 \\
(25.3 \%)\end{array}$ & $\begin{array}{l}826,712 \\
(24.5 \%)\end{array}$ & 8.82 \\
\hline Town & $\begin{array}{l}82,917 \\
(22.1 \%)\end{array}$ & $\begin{array}{l}808,526 \\
(24.0 \%)\end{array}$ & 9.84 \\
\hline Urban & $\begin{array}{l}53,411 \\
(14.2 \%) \\
\end{array}$ & $\begin{array}{l}354,121 \\
(10.5 \%) \\
\end{array}$ & 6.83 \\
\hline
\end{tabular}

Note:

- All tables reporting totals could include some unreported characteristics.

- Average Trip Length is calculated using only those records with trip mileage information present.

- See Appendix $\mathrm{H}$ for the definition of a segmented trip. 
FIGURE 4.10

\section{Statistics on Segmented and Non-Segmented Person Travel By Census Tract Urban/Rural Code}

1995 NPTS

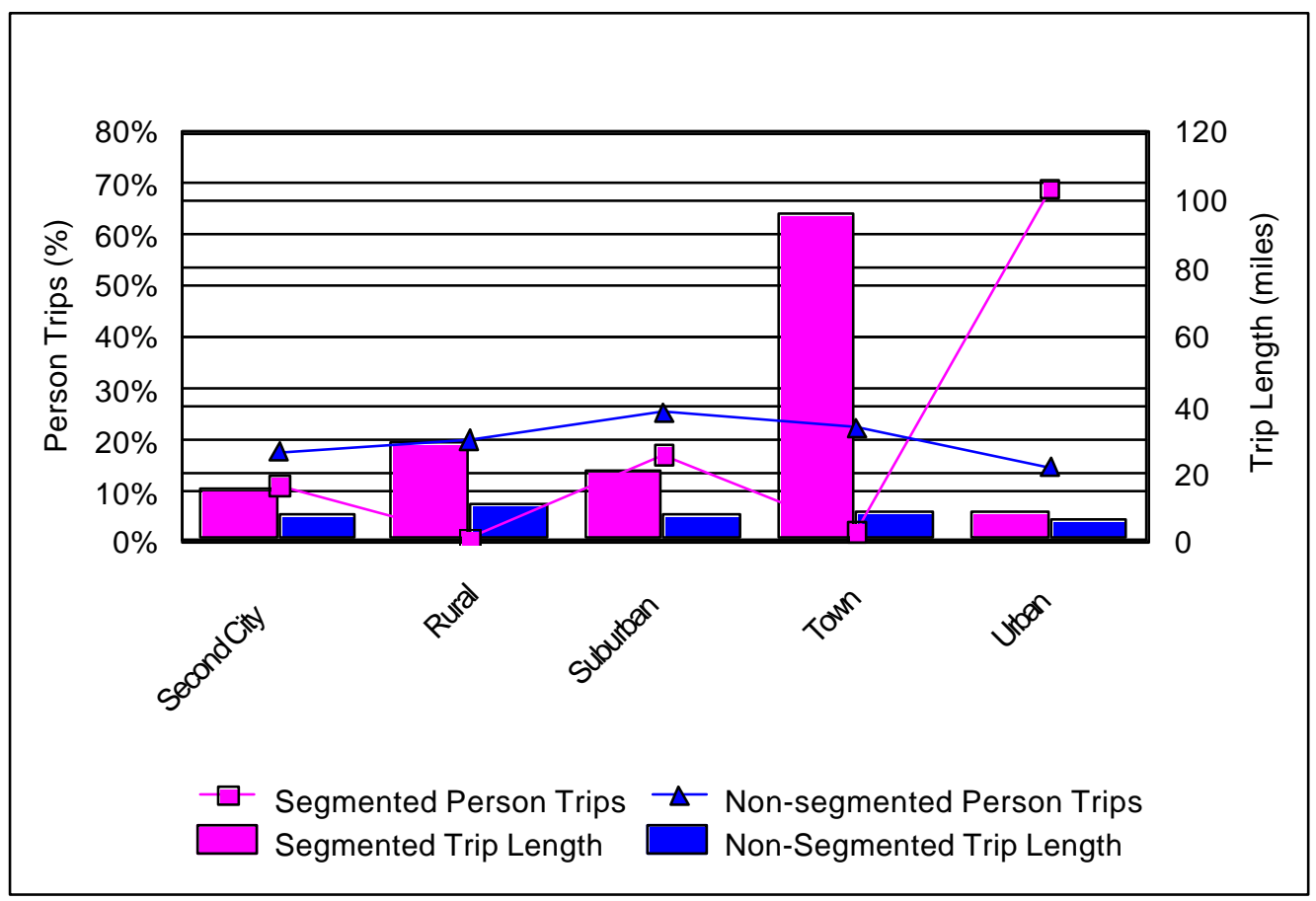

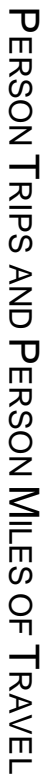


Household income is closely related to travel behavior. In 1995, persons with incomes less than $\$ 10,000$ took fewer average daily person trips per person, traveled less daily person miles per person, and averaged shorter trip lengths (Tables 4.23-24 and Figure 4.11). Most trips (except for going home) were on personal business; as incomes increased, generally, so did the average daily person miles traveled and average trip lengths. Only $7 \%$ of the average daily person trips for persons earning less than $\$ 10,000$ were for earning a living, which was about half that of groups earning $\$ 20,000$ or more.

Table 4.25 shows that, although persons of incomes less than $\$ 20,000$ took less than $16 \%$ of the total trips taken, they took over $36 \%$ of the total trips taken on public transit. Figure 4.12 illustrates the distribution of person trips by household income for mode of transportation. Persons with incomes less than $\$ 10,000$ used public transportation more than any other income group and were the drivers of personally owned vehicles for fewer trips than any other income group. 
TABLE 4.23

Statistics on Daily Person Travel by Household Income and Trip Purpose 1995 NPTS

\begin{tabular}{|c|c|c|c|c|c|c|c|}
\hline $\begin{array}{l}\text { Household } \\
\text { Income }\end{array}$ & TOTAL & $\begin{array}{c}\text { Earning a } \\
\text { Living }\end{array}$ & $\begin{array}{l}\text { Family/ } \\
\text { Personal }\end{array}$ & $\begin{array}{l}\text { School/ } \\
\text { Church }\end{array}$ & $\begin{array}{c}\text { Social/ } \\
\text { Rec }\end{array}$ & Other & $\begin{array}{c}\text { Returning } \\
\text { Home }\end{array}$ \\
\hline \multicolumn{8}{|c|}{ Average Daily Person Trips per Person } \\
\hline TOTAL & 4.30 & 0.57 & 1.34 & 0.21 & 0.72 & 0.01 & 1.44 \\
\hline$<\$ 10,000$ & 3.35 & 0.23 & 1.16 & 0.21 & 0.55 & 0.00 & 1.19 \\
\hline$\$ 10$ to $\$ 20,000$ & 3.94 & 0.43 & 1.29 & 0.19 & 0.65 & 0.00 & 1.37 \\
\hline$\$ 20$ to $\$ 30,000$ & 4.36 & 0.59 & 1.37 & 0.20 & 0.72 & 0.01 & 1.47 \\
\hline$\$ 30$ to $\$ 40,000$ & 4.54 & 0.64 & 1.42 & 0.21 & 0.76 & 0.00 & 1.50 \\
\hline$\$ 40$ to $\$ 50,000$ & 4.64 & 0.65 & 1.39 & 0.24 & 0.78 & 0.01 & 1.57 \\
\hline$\$ 50$ to $\$ 60,000$ & 4.63 & 0.71 & 1.38 & 0.22 & 0.80 & 0.01 & 1.52 \\
\hline$\$ 60$ to $\$ 70,000$ & 4.64 & 0.70 & 1.41 & 0.21 & 0.78 & 0.01 & 1.54 \\
\hline$\$ 70$ to $\$ 80,000$ & 4.65 & 0.69 & 1.36 & 0.22 & 0.86 & 0.01 & 1.51 \\
\hline$\$ 80,000+$ & 4.73 & 0.68 & 1.47 & 0.19 & 0.84 & 0.01 & 1.54 \\
\hline \multicolumn{8}{|c|}{ Average Daily Person Miles of Travel per Person } \\
\hline TOTAL & 38.67 & 7.03 & 9.38 & 1.19 & 7.97 & 0.14 & 12.94 \\
\hline$<\$ 10,000$ & 21.55 & 1.90 & 6.64 & 1.47 & 4.55 & 0.04 & 6.94 \\
\hline$\$ 10$ to $\$ 20,000$ & 28.88 & 4.15 & 7.54 & 0.96 & 5.48 & 0.07 & 10.56 \\
\hline$\$ 20$ to $\$ 30,000$ & 38.80 & 7.19 & 8.91 & 1.31 & 8.62 & 0.26 & 12.53 \\
\hline$\$ 30$ to $\$ 40,000$ & 41.29 & 7.79 & 9.44 & 1.12 & 8.63 & 0.04 & 14.26 \\
\hline$\$ 40$ to $\$ 50,000$ & 40.94 & 7.81 & 9.74 & 1.36 & 7.44 & 0.05 & 14.54 \\
\hline$\$ 50$ to $\$ 60,000$ & 45.46 & 9.32 & 11.09 & 1.17 & 9.23 & 0.14 & 14.51 \\
\hline$\$ 60$ to $\$ 70,000$ & 45.22 & 9.52 & 10.01 & 1.05 & 9.74 & 0.08 & 14.80 \\
\hline$\$ 70$ to $\$ 80,000$ & 51.22 & 11.16 & 9.81 & 1.46 & 11.49 & 0.05 & 17.24 \\
\hline$\$ 80,000+$ & 51.26 & 10.15 & 12.05 & 1.22 & 10.69 & 0.62 & 16.53 \\
\hline \multicolumn{8}{|c|}{ Average Person Trip Length (miles) } \\
\hline TOTAL & 9.13 & 12.53 & 7.07 & 5.84 & 11.18 & 22.41 & 9.10 \\
\hline$<\$ 10,000$ & 6.70 & 8.80 & 5.92 & 7.13 & 8.51 & 11.79 & 6.11 \\
\hline$\$ 10$ to $\$ 20,000$ & 7.48 & 9.84 & 5.94 & 5.10 & 8.65 & 25.02 & 7.85 \\
\hline$\$ 20$ to $\$ 30,000$ & 9.01 & 12.39 & 6.56 & 6.56 & 12.17 & 30.34 & 8.63 \\
\hline$\$ 30$ to $\$ 40,000$ & 9.20 & 12.28 & 6.70 & 5.35 & 11.56 & 8.16 & 9.61 \\
\hline$\$ 40$ to $\$ 50,000$ & 8.91 & 12.08 & 7.05 & 5.78 & 9.64 & 10.40 & 9.35 \\
\hline$\$ 50$ to $\$ 60,000$ & 9.89 & 13.25 & 8.07 & 5.48 & 11.64 & 17.67 & 9.64 \\
\hline$\$ 60$ to $\$ 70,000$ & 9.86 & 13.78 & 7.18 & 5.24 & 12.58 & 10.19 & 9.76 \\
\hline$\$ 70$ to $\$ 80,000$ & 11.14 & 16.39 & 7.28 & 6.87 & 13.49 & 5.82 & 11.55 \\
\hline$\$ 80,000+$ & 10.91 & 14.97 & 8.25 & 6.34 & 12.84 & 60.05 & 10.85 \\
\hline
\end{tabular}

Note:

- All tables reporting totals could include some unreported characteristics.

- Average Trip Length is calculated using only those records with trip mileage information present. 
TABLE 4.24

Statistics on Daily Person Travel by Household Income And 1990 Trip Purpose 1995 NPTS

\begin{tabular}{|c|c|c|c|c|c|c|}
\hline $\begin{array}{l}\text { Household } \\
\text { Income }\end{array}$ & TOTAL & $\begin{array}{c}\text { Earning a } \\
\text { Living }\end{array}$ & $\begin{array}{l}\text { Family/ } \\
\text { Personal } \\
\end{array}$ & $\begin{array}{l}\text { School/ } \\
\text { Church }\end{array}$ & $\begin{array}{c}\text { Social/ } \\
\text { Recreational }\end{array}$ & Other \\
\hline \multicolumn{7}{|c|}{ Average Daily Person Trips per Person } \\
\hline TOTAL & 4.30 & 0.87 & 1.97 & 0.38 & 1.07 & 0.01 \\
\hline$<\$ 10,000$ & 3.35 & 0.38 & 1.71 & 0.39 & 0.86 & 0.00 \\
\hline$\$ 10$ to $\$ 20,000$ & 3.94 & 0.70 & 1.90 & 0.35 & 0.98 & 0.00 \\
\hline$\$ 20$ to $\$ 30,000$ & 4.36 & 0.90 & 2.01 & 0.37 & 1.07 & 0.01 \\
\hline$\$ 30$ to $\$ 40,000$ & 4.54 & 0.97 & 2.07 & 0.39 & 1.11 & 0.00 \\
\hline$\$ 40$ to $\$ 50,000$ & 4.64 & 1.00 & 2.05 & 0.44 & 1.14 & 0.01 \\
\hline$\$ 50$ to $\$ 60,000$ & 4.63 & 1.06 & 2.02 & 0.39 & 1.15 & 0.01 \\
\hline$\$ 60$ to $\$ 70,000$ & 4.64 & 1.03 & 2.10 & 0.37 & 1.13 & 0.01 \\
\hline$\$ 70$ to $\$ 80,000$ & 4.65 & 1.03 & 1.99 & 0.40 & 1.22 & 0.01 \\
\hline$\$ 80,000+$ & 4.73 & 1.00 & 2.15 & 0.37 & 1.21 & 0.01 \\
\hline \multicolumn{7}{|c|}{ Average Daily Person Miles of Travel per Person } \\
\hline TOTAL & 38.67 & 10.92 & 13.51 & 2.21 & 11.86 & 0.15 \\
\hline$<\$ 10,000$ & 21.55 & 3.01 & 9.52 & 2.35 & 6.65 & 0.02 \\
\hline$\$ 10$ to $\$ 20,000$ & 28.88 & 6.84 & 11.53 & 1.81 & 8.56 & 0.02 \\
\hline$\$ 20$ to $\$ 30,000$ & 38.80 & 10.78 & 12.83 & 2.35 & 12.60 & 0.25 \\
\hline$\$ 30$ to $\$ 40,000$ & 41.29 & 12.16 & 13.93 & 2.03 & 13.12 & 0.04 \\
\hline$\$ 40$ to $\$ 50,000$ & 40.94 & 12.04 & 14.50 & 2.64 & 11.69 & 0.06 \\
\hline$\$ 50$ to $\$ 60,000$ & 45.46 & 14.51 & 15.21 & 2.18 & 13.42 & 0.14 \\
\hline$\$ 60$ to $\$ 70,000$ & 45.22 & 14.72 & 14.64 & 1.94 & 13.83 & 0.09 \\
\hline$\$ 70$ to $\$ 80,000$ & 51.22 & 16.53 & 13.90 & 2.86 & 17.86 & 0.07 \\
\hline$\$ 80,000+$ & 51.26 & 15.60 & 17.33 & 2.23 & 15.32 & 0.78 \\
\hline \multicolumn{7}{|c|}{ Average Person Trip Length (miles) } \\
\hline TOTAL & 9.13 & 12.74 & 6.94 & 5.98 & 11.27 & 22.83 \\
\hline$<\$ 10,000$ & 6.70 & 8.23 & 5.76 & 6.30 & 8.08 & 4.54 \\
\hline$\$ 10$ to $\$ 20,000$ & 7.48 & 10.04 & 6.16 & 5.30 & 8.89 & 6.44 \\
\hline$\$ 20$ to $\$ 30,000$ & 9.01 & 12.11 & 6.46 & 6.52 & 11.90 & 27.52 \\
\hline$\$ 30$ to $\$ 40,000$ & 9.20 & 12.74 & 6.80 & 5.32 & 11.93 & 9.10 \\
\hline$\$ 40$ to $\$ 50,000$ & 8.91 & 12.16 & 7.13 & 6.12 & 10.30 & 12.97 \\
\hline$\$ 50$ to $\$ 60,000$ & 9.89 & 13.81 & 7.57 & 5.62 & 11.74 & 18.13 \\
\hline$\$ 60$ to $\$ 70,000$ & 9.86 & 14.45 & 7.05 & 5.34 & 12.37 & 10.44 \\
\hline$\$ 70$ to $\$ 80,000$ & 11.14 & 16.36 & 7.02 & 7.36 & 14.81 & 6.70 \\
\hline$\$ 80,000+$ & 10.91 & 15.70 & 8.12 & 6.17 & 12.80 & 73.71 \\
\hline
\end{tabular}

Note:

- All tables reporting totals could include some unreported characteristics.

- Average Trip Length is calculated using only those records with trip mileage information present. 
FIGURE 4.11

\section{Statistics on Daily Person Travel by Household Income and Trip Purpose} 1995 NPTS
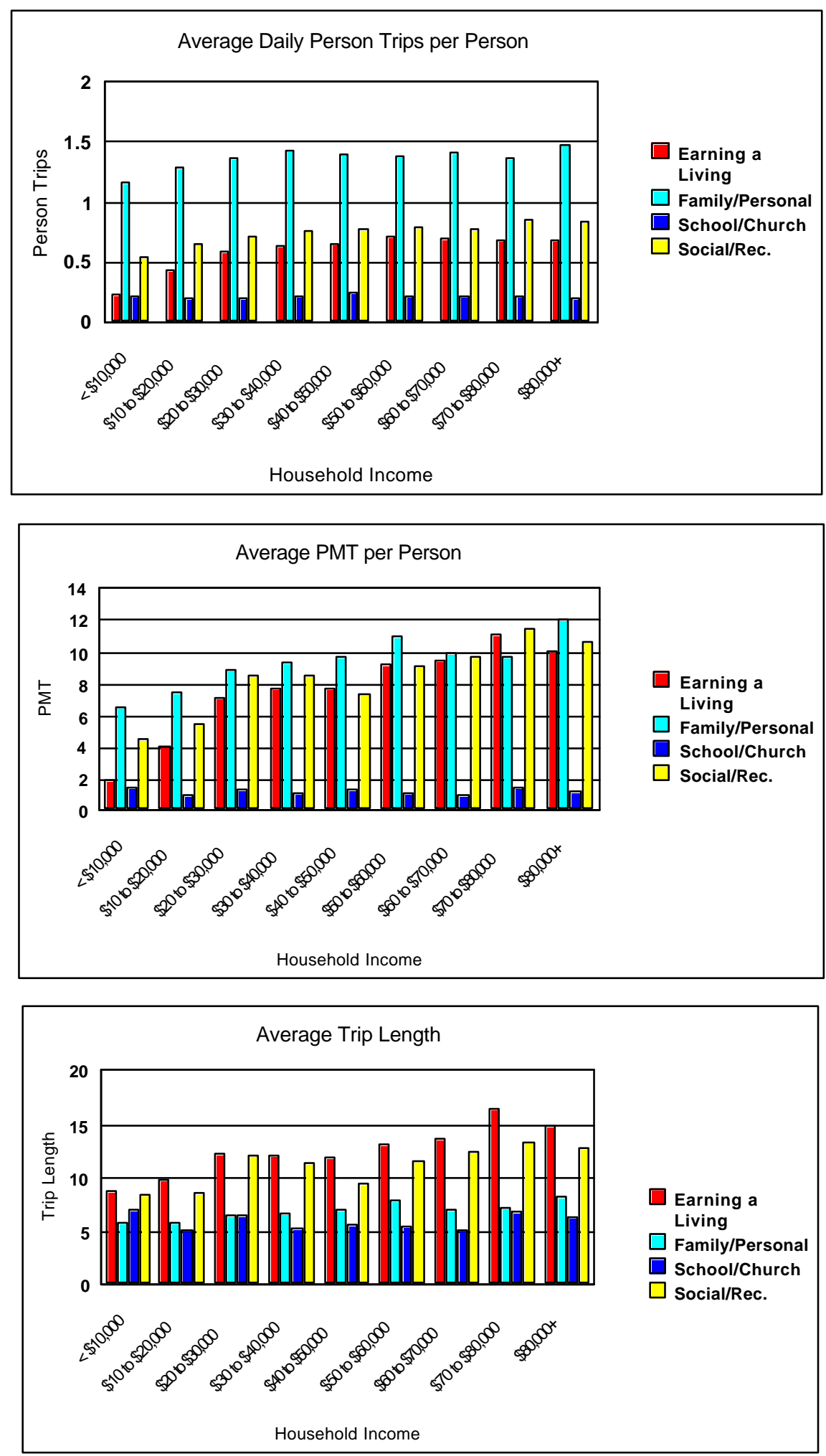


\section{Table 4.25}

\section{Number of Person Trips by Household Income and Mode of Transportation 1995 NPTS \\ (MILLIONS)}

\begin{tabular}{|c|c|c|c|c|c|}
\hline $\begin{array}{l}\text { Household } \\
\text { Income }\end{array}$ & TOTAL & POV - Driver & $\begin{array}{c}\text { POV - } \\
\text { Passenger }\end{array}$ & Public Transit & Other \\
\hline TOTAL & $\begin{array}{c}378,930 \\
(100.0 \%)\end{array}$ & $\begin{array}{l}229,745 \\
(100.0 \%)\end{array}$ & $\begin{array}{c}97,655 \\
(100.0 \%)\end{array}$ & $\begin{array}{c}6,638 \\
(100.0 \%)\end{array}$ & $\begin{array}{c}32,424 \\
(100.0 \%)\end{array}$ \\
\hline \multirow[t]{2}{*}{$<\$ 10,000$} & 18,765 & 8,508 & 5,228 & 1,128 & 2,944 \\
\hline & $(5.0 \%)$ & $(3.7 \%)$ & $(5.4 \%)$ & $(17.0 \%)$ & $(9.1 \%)$ \\
\hline \multirow[t]{2}{*}{$\$ 10$ to $\$ 20,000$} & 41,610 & 23,370 & 10,409 & 1,273 & 4,840 \\
\hline & $(11.0 \%)$ & $(10.2 \%)$ & $(10.7 \%)$ & $(19.2 \%)$ & $(14.9 \%)$ \\
\hline \multirow[t]{2}{*}{$\$ 20$ to $\$ 30,000$} & 56,476 & 35,406 & 13,618 & 853 & 4,904 \\
\hline & $(14.9 \%)$ & $(15.4 \%)$ & $(13.9 \%)$ & $(12.9 \%)$ & $(15.1 \%)$ \\
\hline \multirow[t]{2}{*}{$\$ 30$ to $\$ 40,000$} & 53,351 & 33,346 & 13,690 & 629 & 4,052 \\
\hline & $(14.1 \%)$ & $(14.5 \%)$ & $(14.0 \%)$ & $(9.5 \%)$ & $(12.5 \%)$ \\
\hline \multirow[t]{2}{*}{$\$ 40$ to $\$ 50,000$} & 45,904 & 28,119 & 12,237 & 481 & 3,577 \\
\hline & $(12.1 \%)$ & $(12.2 \%)$ & $(12.5 \%)$ & $(7.2 \%)$ & $(11.0 \%)$ \\
\hline \multirow[t]{2}{*}{$\$ 50$ to $\$ 60,000$} & 32,011 & 20,098 & 8,601 & 309 & 2,252 \\
\hline & $(8.4 \%)$ & $(8.7 \%)$ & $(8.8 \%)$ & $(4.7 \%)$ & $(6.9 \%)$ \\
\hline \multirow[t]{2}{*}{$\$ 60$ to $\$ 70,000$} & 23,079 & 14,254 & 6,230 & 208 & 1,713 \\
\hline & $(6.1 \%)$ & $(6.2 \%)$ & $(6.4 \%)$ & $(3.1 \%)$ & $(5.3 \%)$ \\
\hline \multirow[t]{2}{*}{$\$ 70$ to $\$ 80,000$} & 15,465 & 9,682 & 4,076 & 192 & 1,024 \\
\hline & $(4.1 \%)$ & $(4.2 \%)$ & $(4.2 \%)$ & $(2.9 \%)$ & $(3.2 \%)$ \\
\hline \multirow[t]{2}{*}{$\$ 80,000+$} & 35,594 & 22,349 & 9,459 & 382 & 2,607 \\
\hline & $(9.4 \%)$ & $(9.7 \%)$ & $(9.7 \%)$ & $(5.8 \%)$ & $(8.0 \%)$ \\
\hline \multirow[t]{2}{*}{ Unreported } & 56,674 & 34,612 & 14,109 & 1,183 & 4,511 \\
\hline & $(15.0 \%)$ & $(15.1 \%)$ & $(14.4 \%)$ & $(17.8 \%)$ & $(13.9 \%)$ \\
\hline
\end{tabular}

Note:

- All tables reporting totals could include some unreported characteristics. 
FIGURE 4.12

Distribution of Person Trips By Household Income and Mode of Transportation 1995 NPTS

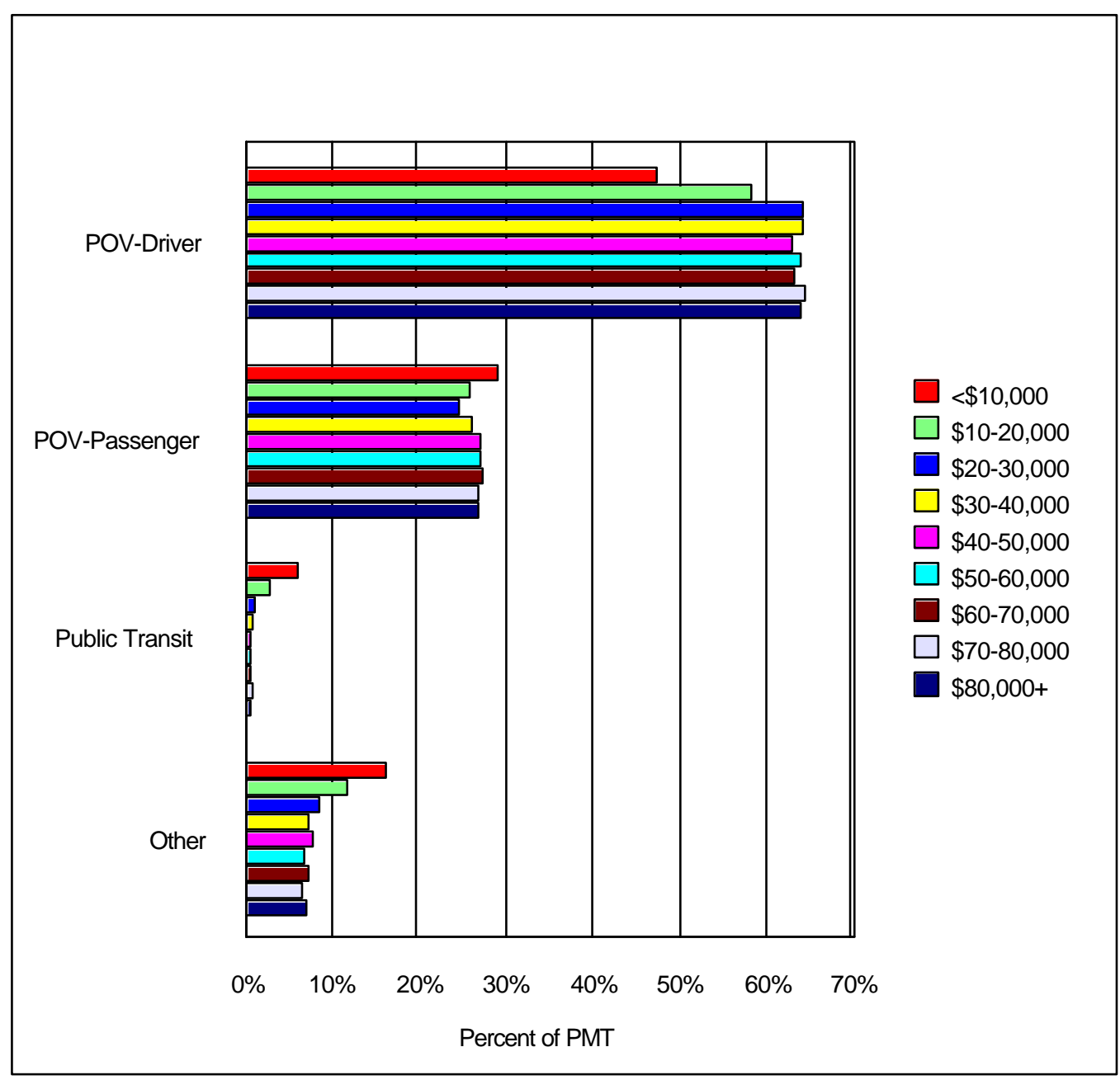


Tables 4.26, 4.28, and 4.30 show different travel perspectives based on mode of transportation for 1995 trip purposes. Tables 4.27 and 4.29, which are based on 1990 trip purpose codes, are provided for comparison. As expected, most trips (86.5\%) and most person miles $(91.2 \%)$ were by private vehicle, of which automobiles were the predominant vehicle used. For school/church, 26.1\% were by other means (which included school buses). Sport utility vehicles (SUVs), added to the list of private vehicle choices for the first time in the 1995 NPTS, were used for $5.9 \%$ of all trips and $7 \%$ of all person miles traveled.

Table 4.30 compares the number of person trips when public transportation is, or is not, available. Public transportation includes bus, subway, commuter train, and streetcar services that are available for local or commuter travel and for which a stop or station is within onehalf mile of the residence. Public transportation includes "Dial-a-Bus" and Senior Citizen bus service but excludes long distance or chartered buses.

When public transportation was available, trip lengths were shorter (18\% shorter overall). When available, public transportation was used most frequently for trips involving earning a living and personal business purposes.

Figure 4.13 illustrates the mode of transportation used according to whether public transportation was available (as defined above) or unavailable. 
TABLE 4.26

Number of Person Trips by Mode of Transportation and Trip Purpose 1995 NPTS

(MILLIONS)

\begin{tabular}{|c|c|c|c|c|c|c|c|}
\hline & TOTAL & $\begin{array}{c}\text { Earning a } \\
\text { Living }\end{array}$ & $\begin{array}{l}\text { Family/ } \\
\text { Personal } \\
\end{array}$ & $\begin{array}{l}\text { School/ } \\
\text { Church }\end{array}$ & Social/Rec & Other & $\begin{array}{c}\text { Returning } \\
\text { Home }\end{array}$ \\
\hline TOTAL & $\begin{array}{c}378,930 \\
(100.0 \%)\end{array}$ & $\begin{array}{c}50,167 \\
(100.0 \%)\end{array}$ & $\begin{array}{c}118,543 \\
(100.0 \%)\end{array}$ & $\begin{array}{c}18,281 \\
(100.0 \%)\end{array}$ & $\begin{array}{c}63,908 \\
(100.0 \%)\end{array}$ & $\begin{array}{c}608 \\
(100.0 \%)\end{array}$ & $\begin{array}{c}127,374 \\
(100.0 \%)\end{array}$ \\
\hline \multicolumn{8}{|l|}{ Private Vehicle } \\
\hline Auto & $\begin{array}{l}220,479 \\
(58.2 \%)\end{array}$ & $\begin{array}{c}26,929 \\
(53.7 \%)\end{array}$ & $\begin{array}{c}74,496 \\
(62.8 \%)\end{array}$ & $\begin{array}{c}8,789 \\
(48.1 \%)\end{array}$ & $\begin{array}{c}36,114 \\
(56.5 \%)\end{array}$ & $\begin{array}{c}298 \\
(49.0 \%)\end{array}$ & $\begin{array}{c}73,835 \\
(58.0 \%)\end{array}$ \\
\hline Van & $\begin{array}{l}37,418 \\
(9.9 \%)\end{array}$ & $\begin{array}{c}4,135 \\
(8.2 \%)\end{array}$ & $\begin{array}{c}12,816 \\
(10.8 \%)\end{array}$ & $\begin{array}{c}1,782 \\
(9.7 \%)\end{array}$ & $\begin{array}{c}6,470 \\
(10.1 \%)\end{array}$ & $\begin{array}{c}54 \\
(8.9 \%)\end{array}$ & $\begin{array}{l}12,161 \\
(9.5 \%)\end{array}$ \\
\hline SUV & $\begin{array}{l}22,289 \\
(5.9 \%)\end{array}$ & $\begin{array}{c}3,177 \\
(6.3 \%)\end{array}$ & $\begin{array}{c}6,931 \\
(5.8 \%)\end{array}$ & $\begin{array}{c}800 \\
(4.4 \%)\end{array}$ & $\begin{array}{c}3,780 \\
(5.9 \%)\end{array}$ & $\begin{array}{c}38 \\
(6.3 \%)\end{array}$ & $\begin{array}{c}7,562 \\
(5.9 \%)\end{array}$ \\
\hline Pickup & $\begin{array}{c}44,170 \\
(11.7 \%)\end{array}$ & $\begin{array}{c}8,938 \\
(17.8 \%)\end{array}$ & $\begin{array}{c}12,647 \\
(10.7 \%)\end{array}$ & $\begin{array}{c}954 \\
(5.2 \%)\end{array}$ & $\begin{array}{c}6,535 \\
(10.2 \%)\end{array}$ & $\begin{array}{c}59 \\
(9.7 \%)\end{array}$ & $\begin{array}{c}15,026 \\
(11.8 \%)\end{array}$ \\
\hline Other Truck & $\begin{array}{c}2,242 \\
(0.6 \%)\end{array}$ & $\begin{array}{c}1,505 \\
(3.0 \%)\end{array}$ & $\begin{array}{c}280 \\
(0.2 \%)\end{array}$ & $\begin{array}{c}7 \\
(0.0 \%)\end{array}$ & $\begin{array}{c}129 \\
(0.2 \%)\end{array}$ & $\begin{array}{c}0 \\
(0.0 \%)\end{array}$ & $\begin{array}{c}320 \\
(0.3 \%)\end{array}$ \\
\hline RV & $\begin{array}{c}183 \\
(0.0 \%)\end{array}$ & $\begin{array}{c}17 \\
(0.0 \%)\end{array}$ & $\begin{array}{c}51 \\
(0.0 \%)\end{array}$ & $\begin{array}{c}7 \\
(0.0 \%)\end{array}$ & $\begin{array}{c}63 \\
(0.1 \%)\end{array}$ & $\begin{array}{c}1 \\
(0.2 \%)\end{array}$ & $\begin{array}{c}44 \\
(0.0 \%)\end{array}$ \\
\hline Motorcycle & $\begin{array}{c}387 \\
(0.1 \%)\end{array}$ & $\begin{array}{c}65 \\
(0.1 \%)\end{array}$ & $\begin{array}{c}69 \\
(0.1 \%)\end{array}$ & $\begin{array}{c}7 \\
(0.0 \%)\end{array}$ & $\begin{array}{c}89 \\
(0.1 \%)\end{array}$ & $\begin{array}{c}3 \\
(0.5 \%)\end{array}$ & $\begin{array}{c}154 \\
(0.1 \%)\end{array}$ \\
\hline Other POV & $\begin{array}{c}231 \\
(0.1 \%)\end{array}$ & $\begin{array}{c}14 \\
(0.0 \%)\end{array}$ & $\begin{array}{c}72 \\
(0.1 \%)\end{array}$ & $\begin{array}{c}6 \\
(0.0 \%)\end{array}$ & $\begin{array}{c}59 \\
(0.1 \%)\end{array}$ & $\begin{array}{c}2 \\
(0.3 \%)\end{array}$ & $\begin{array}{c}77 \\
(0.1 \%)\end{array}$ \\
\hline \multicolumn{8}{|l|}{ Public Transit } \\
\hline Bus & $\begin{array}{c}4,541 \\
(1.2 \%)\end{array}$ & $\begin{array}{c}769 \\
(1.5 \%)\end{array}$ & $\begin{array}{c}1,014 \\
(0.9 \%)\end{array}$ & $\begin{array}{c}387 \\
(2.1 \%)\end{array}$ & $\begin{array}{c}659 \\
(1.0 \%)\end{array}$ & $\begin{array}{c}15 \\
(2.5 \%)\end{array}$ & $\begin{array}{c}1,697 \\
(1.3 \%)\end{array}$ \\
\hline Commuter Train & $\begin{array}{c}625 \\
(0.2 \%)\end{array}$ & $\begin{array}{c}201 \\
(0.4 \%)\end{array}$ & $\begin{array}{c}83 \\
(0.1 \%)\end{array}$ & $\begin{array}{c}21 \\
(0.1 \%)\end{array}$ & $\begin{array}{c}66 \\
(0.1 \%)\end{array}$ & $\begin{array}{c}0 \\
(0.0 \%)\end{array}$ & $\begin{array}{c}253 \\
(0.2 \%)\end{array}$ \\
\hline Streetcar/Trolley & $\begin{array}{c}42 \\
(0.0 \%)\end{array}$ & $\begin{array}{c}9 \\
(0.0 \%)\end{array}$ & $\begin{array}{c}10 \\
(0.0 \%)\end{array}$ & $\begin{array}{c}0 \\
(0.0 \%)\end{array}$ & $\begin{array}{c}9 \\
(0.0 \%)\end{array}$ & $\begin{array}{c}3 \\
(0.5 \%)\end{array}$ & $\begin{array}{c}10 \\
(0.0 \%)\end{array}$ \\
\hline Subway/El Rail & $\begin{array}{c}1,430 \\
(0.4 \%)\end{array}$ & $\begin{array}{c}425 \\
(0.8 \%)\end{array}$ & $\begin{array}{c}219 \\
(0.2 \%)\end{array}$ & $\begin{array}{c}78 \\
(0.4 \%)\end{array}$ & $\begin{array}{c}187 \\
(0.3 \%)\end{array}$ & $* *$ & $\begin{array}{c}522 \\
(0.4 \%)\end{array}$ \\
\hline \multicolumn{8}{|l|}{ Other Means } \\
\hline Amtrak & $\begin{array}{c}22 \\
(0.0 \%)\end{array}$ & $\begin{array}{c}3 \\
(0.0 \%)\end{array}$ & $\begin{array}{c}1 \\
(0.0 \%)\end{array}$ & $\begin{array}{c}0 \\
(0.0 \%)\end{array}$ & $\begin{array}{c}9 \\
(0.0 \%)\end{array}$ & $* *$ & $\begin{array}{c}8 \\
(0.0 \%)\end{array}$ \\
\hline Airplane & $\begin{array}{c}313 \\
(0.1 \%)\end{array}$ & $\begin{array}{c}87 \\
(0.2 \%)\end{array}$ & $\begin{array}{c}70 \\
(0.1 \%)\end{array}$ & $\begin{array}{c}0 \\
(0.0 \%)\end{array}$ & $\begin{array}{c}72 \\
(0.1 \%)\end{array}$ & $\begin{array}{c}4 \\
(0.7 \%)\end{array}$ & $\begin{array}{c}79 \\
(0.1 \%)\end{array}$ \\
\hline Taxi & $\begin{array}{c}683 \\
(0.2 \%)\end{array}$ & $\begin{array}{c}120 \\
(0.2 \%)\end{array}$ & $\begin{array}{c}141 \\
(0.1 \%)\end{array}$ & $\begin{array}{c}9 \\
(0.0 \%)\end{array}$ & $\begin{array}{c}161 \\
(0.3 \%)\end{array}$ & $\begin{array}{c}5 \\
(0.8 \%)\end{array}$ & $\begin{array}{c}247 \\
(0.2 \%)\end{array}$ \\
\hline Bicycle & $\begin{array}{c}3,342 \\
(0.9 \%)\end{array}$ & $\begin{array}{c}164 \\
(0.3 \%)\end{array}$ & $\begin{array}{c}466 \\
(0.4 \%)\end{array}$ & $\begin{array}{c}152 \\
(0.8 \%)\end{array}$ & $\begin{array}{c}1,162 \\
(1.8 \%)\end{array}$ & $\begin{array}{c}2 \\
(0.3 \%)\end{array}$ & $\begin{array}{c}1,395 \\
(1.1 \%)\end{array}$ \\
\hline Walk & $\begin{array}{l}20,325 \\
(5.4 \%)\end{array}$ & $\begin{array}{c}1,772 \\
(3.5 \%)\end{array}$ & $\begin{array}{c}5,191 \\
(4.4 \%)\end{array}$ & $\begin{array}{c}1,542 \\
(8.4 \%)\end{array}$ & $\begin{array}{c}4,863 \\
(7.6 \%)\end{array}$ & $\begin{array}{c}47 \\
(7.7 \%)\end{array}$ & $\begin{array}{c}6,911 \\
(5.4 \%)\end{array}$ \\
\hline School Bus & $\begin{array}{c}6,599 \\
(1.7 \%)\end{array}$ & $\begin{array}{c}207 \\
(0.4 \%)\end{array}$ & $\begin{array}{c}330 \\
(0.3 \%)\end{array}$ & $\begin{array}{c}3,078 \\
(16.8 \%)\end{array}$ & $\begin{array}{c}233 \\
(0.4 \%)\end{array}$ & $\begin{array}{c}14 \\
(2.3 \%)\end{array}$ & $\begin{array}{c}2,737 \\
(2.1 \%)\end{array}$ \\
\hline Other & $\begin{array}{c}1,140 \\
(0.3 \%)\end{array}$ & $\begin{array}{c}426 \\
(0.8 \%)\end{array}$ & $\begin{array}{c}185 \\
(0.2 \%)\end{array}$ & $\begin{array}{c}25 \\
(0.1 \%)\end{array}$ & $\begin{array}{c}253 \\
(0.4 \%)\end{array}$ & $\begin{array}{c}7 \\
(1.2 \%)\end{array}$ & $\begin{array}{c}245 \\
(0.2 \%)\end{array}$ \\
\hline
\end{tabular}

Note:

- All tables reporting totals could include some unreported characteristics.

- ** Indicates no data available.

- $\mathrm{SUV}=$ sport utility vehicle. 
TABLE 4.27

Number of Person Trips by Mode of Transportation and 1990 Trip Purpose 1995 NPTS

(MILLIONS)

\begin{tabular}{|c|c|c|c|c|c|c|}
\hline & TOTAL & $\begin{array}{l}\text { Earning a } \\
\text { Living }\end{array}$ & $\begin{array}{l}\text { Family/ } \\
\text { Personal }\end{array}$ & $\begin{array}{l}\text { School/ } \\
\text { Church }\end{array}$ & $\begin{array}{c}\text { Social/ } \\
\text { Recreational }\end{array}$ & Other \\
\hline TOTAL & $\begin{array}{c}378,930 \\
(100.0 \%)\end{array}$ & $\begin{array}{c}76,761 \\
(100.0 \%)\end{array}$ & $\begin{array}{c}173,764 \\
(100.0 \%)\end{array}$ & $\begin{array}{c}33,355 \\
(100.0 \%)\end{array}$ & $\begin{array}{c}94,362 \\
(100.0 \%)\end{array}$ & $\begin{array}{c}623 \\
(100.0 \%)\end{array}$ \\
\hline \multicolumn{7}{|l|}{ Private Vehicle } \\
\hline Auto & $\begin{array}{l}220,479 \\
(58.2 \%)\end{array}$ & $\begin{array}{c}43,163 \\
(56.2 \%)\end{array}$ & $\begin{array}{l}107,474 \\
(61.9 \%)\end{array}$ & $\begin{array}{c}15,797 \\
(47.4 \%)\end{array}$ & $\begin{array}{c}53,698 \\
(56.9 \%)\end{array}$ & $\begin{array}{c}314 \\
(50.4 \%)\end{array}$ \\
\hline Van & $\begin{array}{l}37,418 \\
(9.9 \%)\end{array}$ & $\begin{array}{l}6,039 \\
(7.9 \%)\end{array}$ & $\begin{array}{c}18,389 \\
(10.6 \%)\end{array}$ & $\begin{array}{c}3,341 \\
(10.0 \%)\end{array}$ & $\begin{array}{c}9,585 \\
(10.2 \%)\end{array}$ & $\begin{array}{c}63 \\
(10.1 \%)\end{array}$ \\
\hline SUV & $\begin{array}{l}22,289 \\
(5.9 \%)\end{array}$ & $\begin{array}{c}5,047 \\
(6.6 \%)\end{array}$ & $\begin{array}{l}10,127 \\
(5.8 \%)\end{array}$ & $\begin{array}{c}1,467 \\
(4.4 \%)\end{array}$ & $\begin{array}{c}5,624 \\
(6.0 \%)\end{array}$ & $\begin{array}{c}24 \\
(3.9 \%)\end{array}$ \\
\hline Pickup & 44,170 & 13,567 & 19,271 & 1,778 & 9,478 & 64 \\
\hline & $(11.7 \%)$ & $(17.7 \%)$ & $(11.1 \%)$ & $(5.3 \%)$ & $(10.0 \%)$ & $(10.3 \%)$ \\
\hline Other Truck & $\begin{array}{c}2,242 \\
(0.6 \%)\end{array}$ & $\begin{array}{c}1,590 \\
(2.1 \%)\end{array}$ & $\begin{array}{c}524 \\
(0.3 \%)\end{array}$ & $\begin{array}{c}11 \\
(0.0 \%)\end{array}$ & $\begin{array}{c}116 \\
(0.1 \%)\end{array}$ & $\begin{array}{c}1 \\
(0.2 \%)\end{array}$ \\
\hline RV & $\begin{array}{c}183 \\
(0.0 \%)\end{array}$ & $\begin{array}{c}25 \\
(0.0 \%)\end{array}$ & $\begin{array}{c}73 \\
(0.0 \%)\end{array}$ & $\begin{array}{c}10 \\
(0.0 \%)\end{array}$ & $\begin{array}{c}76 \\
(0.1 \%)\end{array}$ & $* *$ \\
\hline Motorcycle & $\begin{array}{c}387 \\
(0.1 \%)\end{array}$ & $\begin{array}{c}116 \\
(0.2 \%)\end{array}$ & $\begin{array}{c}108 \\
(0.1 \%)\end{array}$ & $\begin{array}{c}21 \\
(0.1 \%)\end{array}$ & $\begin{array}{c}139 \\
(0.1 \%)\end{array}$ & $\begin{array}{c}3 \\
(0.5 \%)\end{array}$ \\
\hline Other POV & $\begin{array}{c}231 \\
(0.1 \%)\end{array}$ & $\begin{array}{c}27 \\
(0.0 \%)\end{array}$ & $\begin{array}{c}99 \\
(0.1 \%)\end{array}$ & $\begin{array}{c}11 \\
(0.0 \%)\end{array}$ & $\begin{array}{c}92 \\
(0.1 \%)\end{array}$ & $\begin{array}{c}2 \\
(0.3 \%)\end{array}$ \\
\hline \multicolumn{7}{|l|}{ Public Transit } \\
\hline Bus & $\begin{array}{c}4,541 \\
(1.2 \%)\end{array}$ & $\begin{array}{c}1,331 \\
(1.7 \%)\end{array}$ & $\begin{array}{c}1,558 \\
(0.9 \%)\end{array}$ & $\begin{array}{c}666 \\
(2.0 \%)\end{array}$ & $\begin{array}{c}976 \\
(1.0 \%)\end{array}$ & $\begin{array}{c}11 \\
(1.8 \%)\end{array}$ \\
\hline Commuter Train & $\begin{array}{c}625 \\
(0.2 \%)\end{array}$ & $\begin{array}{c}391 \\
(0.5 \%)\end{array}$ & $\begin{array}{l}110 \\
(0.1 \%)\end{array}$ & $\begin{array}{c}33 \\
(0.1 \%)\end{array}$ & $\begin{array}{c}91 \\
(0.1 \%)\end{array}$ & $\begin{array}{c}0 \\
(0.0 \%)\end{array}$ \\
\hline Streetcar/Trolley & $\begin{array}{c}42 \\
(0.0 \%)\end{array}$ & $\begin{array}{c}10 \\
(0.0 \%)\end{array}$ & $\begin{array}{c}12 \\
(0.0 \%)\end{array}$ & $\begin{array}{c}1 \\
(0.0 \%)\end{array}$ & $\begin{array}{c}19 \\
(0.0 \%)\end{array}$ & $\begin{array}{c}0 \\
(0.0 \%)\end{array}$ \\
\hline Subway/El Rail & $\begin{array}{l}1,430 \\
(0.4 \%)\end{array}$ & $\begin{array}{c}718 \\
(0.9 \%)\end{array}$ & $\begin{array}{c}321 \\
(0.2 \%)\end{array}$ & $\begin{array}{c}127 \\
(0.4 \%)\end{array}$ & $\begin{array}{c}264 \\
(0.3 \%)\end{array}$ & $* *$ \\
\hline \multicolumn{7}{|l|}{ Other Means } \\
\hline Amtrak & $\begin{array}{c}22 \\
(0.0 \%)\end{array}$ & $\begin{array}{c}8 \\
(0.0 \%)\end{array}$ & $\begin{array}{c}1 \\
(0.0 \%)\end{array}$ & $\begin{array}{c}1 \\
(0.0 \%)\end{array}$ & $\begin{array}{c}13 \\
(0.0 \%)\end{array}$ & $* *$ \\
\hline Airplane & $\begin{array}{c}313 \\
(0.1 \%)\end{array}$ & $\begin{array}{c}113 \\
(0.1 \%)\end{array}$ & $\begin{array}{c}84 \\
(0.0 \%)\end{array}$ & $\begin{array}{c}5 \\
(0.0 \%)\end{array}$ & $\begin{array}{c}104 \\
(0.1 \%)\end{array}$ & $\begin{array}{c}7 \\
(1.1 \%)\end{array}$ \\
\hline Taxi & $\begin{array}{c}683 \\
(0.2 \%)\end{array}$ & $\begin{array}{c}178 \\
(0.2 \%)\end{array}$ & $\begin{array}{c}249 \\
(0.1 \%)\end{array}$ & $\begin{array}{c}15 \\
(0.0 \%)\end{array}$ & $\begin{array}{c}239 \\
(0.3 \%)\end{array}$ & $\begin{array}{c}3 \\
(0.5 \%)\end{array}$ \\
\hline Bicycle & $\begin{array}{c}3,342 \\
(0.9 \%)\end{array}$ & $\begin{array}{c}297 \\
(0.4 \%)\end{array}$ & $\begin{array}{c}749 \\
(0.4 \%)\end{array}$ & $\begin{array}{c}296 \\
(0.9 \%)\end{array}$ & $\begin{array}{c}1,996 \\
(2.1 \%)\end{array}$ & $\begin{array}{c}4 \\
(0.6 \%)\end{array}$ \\
\hline Walk & $\begin{array}{l}20,325 \\
(5.4 \%)\end{array}$ & $\begin{array}{c}1,751 \\
(2.3 \%)\end{array}$ & $\begin{array}{c}8,756 \\
(5.0 \%)\end{array}$ & $\begin{array}{l}2,925 \\
(8.8 \%)\end{array}$ & $\begin{array}{c}6,845 \\
(7.3 \%)\end{array}$ & $\begin{array}{c}47 \\
(7.5 \%)\end{array}$ \\
\hline School Bus & $\begin{array}{c}6,599 \\
(1.7 \%)\end{array}$ & $\begin{array}{c}245 \\
(0.3 \%)\end{array}$ & $\begin{array}{c}386 \\
(0.2 \%)\end{array}$ & $\begin{array}{c}5,678 \\
(17.0 \%)\end{array}$ & $\begin{array}{c}273 \\
(0.3 \%)\end{array}$ & $\begin{array}{c}16 \\
(2.6 \%)\end{array}$ \\
\hline Other & $\begin{array}{c}1,140 \\
(0.3 \%)\end{array}$ & $\begin{array}{c}463 \\
(0.6 \%)\end{array}$ & $\begin{array}{c}299 \\
(0.2 \%)\end{array}$ & $\begin{array}{c}41 \\
(0.1 \%)\end{array}$ & $\begin{array}{c}330 \\
(0.3 \%)\end{array}$ & $\begin{array}{c}7 \\
(1.1 \%)\end{array}$ \\
\hline
\end{tabular}

Note:

- All tables reporting totals could include some unreported characteristics.

- ** Indicates no data available.

- $\mathrm{SUV}=$ sport utility vehicle. 
TABLE 4.28

Number of Person Miles of Travel by Mode of Transportation and Trip Purpose
1995 NPTS

(MILLIONS)

\begin{tabular}{|c|c|c|c|c|c|c|c|}
\hline & TOTAL & $\begin{array}{c}\text { Earning a } \\
\text { Living }\end{array}$ & $\begin{array}{c}\text { Family/ } \\
\text { Personal } \\
\end{array}$ & $\begin{array}{l}\text { School// } \\
\text { Church }\end{array}$ & Social/Rec & Other & $\begin{array}{c}\text { Returning } \\
\text { Home }\end{array}$ \\
\hline TOTAL & $\begin{array}{l}3,411,122 \\
(100.0 \%)\end{array}$ & $\begin{array}{c}619,857 \\
(100.0 \%)\end{array}$ & $\begin{array}{c}827,768 \\
(100.0 \%)\end{array}$ & $\begin{array}{c}104,578 \\
(100.0 \%)\end{array}$ & $\begin{array}{c}703,337 \\
(100.0 \%)\end{array}$ & $\begin{array}{c}12,635 \\
(100.0 \%)\end{array}$ & $\begin{array}{l}1,141,351 \\
(100.0 \%)\end{array}$ \\
\hline \multicolumn{8}{|l|}{ Private Vehicle } \\
\hline Auto & $\begin{array}{c}1,944,004 \\
(57.0 \%)\end{array}$ & $\begin{array}{l}291,487 \\
(47.0 \%)\end{array}$ & $\begin{array}{l}510,936 \\
(61.7 \%)\end{array}$ & $\begin{array}{c}57,807 \\
(55.3 \%)\end{array}$ & $\begin{array}{l}408,386 \\
(58.1 \%)\end{array}$ & $\begin{array}{c}6,338 \\
(50.2 \%)\end{array}$ & $\begin{array}{l}668,904 \\
(58.6 \%)\end{array}$ \\
\hline Van & $\begin{array}{l}358,583 \\
(10.5 \%)\end{array}$ & $\begin{array}{l}50,489 \\
(8.1 \%)\end{array}$ & $\begin{array}{c}96,114 \\
(11.6 \%)\end{array}$ & $\begin{array}{c}10,429 \\
(10.0 \%)\end{array}$ & $\begin{array}{c}81,306 \\
(11.6 \%)\end{array}$ & $\begin{array}{c}703 \\
(5.6 \%)\end{array}$ & $\begin{array}{l}119,538 \\
(10.5 \%)\end{array}$ \\
\hline SUV & $\begin{array}{c}238,242 \\
(7.0 \%)\end{array}$ & $\begin{array}{l}33,083 \\
(5.3 \%)\end{array}$ & $\begin{array}{l}58,477 \\
(7.1 \%)\end{array}$ & $\begin{array}{c}5,201 \\
(5.0 \%)\end{array}$ & $\begin{array}{l}58,152 \\
(8.3 \%)\end{array}$ & $\begin{array}{c}484 \\
(3.8 \%)\end{array}$ & $\begin{array}{l}82,843 \\
(7.3 \%)\end{array}$ \\
\hline Pickup & $\begin{array}{l}471,416 \\
(13.8 \%)\end{array}$ & $\begin{array}{l}115,272 \\
(18.6 \%)\end{array}$ & $\begin{array}{l}100,083 \\
(12.1 \%)\end{array}$ & $\begin{array}{c}6,493 \\
(6.2 \%)\end{array}$ & $\begin{array}{c}80,825 \\
(11.5 \%)\end{array}$ & $\begin{array}{c}449 \\
(3.6 \%)\end{array}$ & $\begin{array}{l}166,869 \\
(14.6 \%)\end{array}$ \\
\hline Other Truck & $\begin{array}{l}85,623 \\
(2.5 \%)\end{array}$ & $\begin{array}{c}67,051 \\
(10.8 \%)\end{array}$ & $\begin{array}{c}5,579 \\
(0.7 \%)\end{array}$ & $\begin{array}{c}29 \\
(0.0 \%)\end{array}$ & $\begin{array}{c}4,403 \\
(0.6 \%)\end{array}$ & $\begin{array}{c}26 \\
(0.2 \%)\end{array}$ & $\begin{array}{c}8,535 \\
(0.7 \%)\end{array}$ \\
\hline RV & $\begin{array}{c}6,656 \\
(0.2 \%)\end{array}$ & $\begin{array}{c}131 \\
(0.0 \%)\end{array}$ & $\begin{array}{c}1,063 \\
(0.1 \%)\end{array}$ & $\begin{array}{c}13 \\
(0.0 \%)\end{array}$ & $\begin{array}{c}3,958 \\
(0.6 \%)\end{array}$ & $\begin{array}{c}41 \\
(0.3 \%)\end{array}$ & $\begin{array}{c}1,449 \\
(0.1 \%)\end{array}$ \\
\hline Motorcycle & $\begin{array}{c}3,994 \\
(0.1 \%)\end{array}$ & $\begin{array}{c}667 \\
(0.1 \%)\end{array}$ & $\begin{array}{c}635 \\
(0.1 \%)\end{array}$ & $\begin{array}{c}17 \\
(0.0 \%)\end{array}$ & $\begin{array}{c}1,050 \\
(0.1 \%)\end{array}$ & $\begin{array}{c}86 \\
(0.7 \%)\end{array}$ & $\begin{array}{c}1,539 \\
(0.1 \%)\end{array}$ \\
\hline Other POV & $\begin{array}{c}1,732 \\
(0.1 \%)\end{array}$ & $\begin{array}{c}194 \\
(0.0 \%)\end{array}$ & $\begin{array}{c}439 \\
(0.1 \%)\end{array}$ & $\begin{array}{c}33 \\
(0.0 \%)\end{array}$ & $\begin{array}{c}473 \\
(0.1 \%)\end{array}$ & $\begin{array}{c}8 \\
(0.1 \%)\end{array}$ & $\begin{array}{c}586 \\
(0.1 \%)\end{array}$ \\
\hline \multicolumn{8}{|l|}{ Public Transit } \\
\hline Bus & $\begin{array}{l}48,028 \\
(1.4 \%)\end{array}$ & $\begin{array}{c}7,258 \\
(1.2 \%)\end{array}$ & $\begin{array}{c}7,588 \\
(0.9 \%)\end{array}$ & $\begin{array}{c}3,275 \\
(3.1 \%)\end{array}$ & $\begin{array}{l}11,606 \\
(1.7 \%)\end{array}$ & $\begin{array}{c}86 \\
(0.7 \%)\end{array}$ & $\begin{array}{l}18,214 \\
(1.6 \%)\end{array}$ \\
\hline Commuter Train & $\begin{array}{l}12,498 \\
(0.4 \%)\end{array}$ & $\begin{array}{c}5,025 \\
(0.8 \%)\end{array}$ & $\begin{array}{c}1,242 \\
(0.2 \%)\end{array}$ & $\begin{array}{c}111 \\
(0.1 \%)\end{array}$ & $\begin{array}{c}1,362 \\
(0.2 \%)\end{array}$ & $\begin{array}{c}25 \\
(0.2 \%)\end{array}$ & $\begin{array}{c}4,733 \\
(0.4 \%)\end{array}$ \\
\hline Streetcar/Trolley & $\begin{array}{c}127 \\
(0.0 \%)\end{array}$ & $\begin{array}{c}26 \\
(0.0 \%)\end{array}$ & $\begin{array}{c}13 \\
(0.0 \%)\end{array}$ & $\begin{array}{c}0 \\
(0.0 \%)\end{array}$ & $\begin{array}{c}50 \\
(0.0 \%)\end{array}$ & $\begin{array}{c}9 \\
(0.1 \%)\end{array}$ & $\begin{array}{c}29 \\
(0.0 \%)\end{array}$ \\
\hline Subway/El Rail & $\begin{array}{l}11,925 \\
(0.3 \%)\end{array}$ & $\begin{array}{c}3,679 \\
(0.6 \%)\end{array}$ & $\begin{array}{c}1,431 \\
(0.2 \%)\end{array}$ & $\begin{array}{c}701 \\
(0.7 \%)\end{array}$ & $\begin{array}{c}1,417 \\
(0.2 \%)\end{array}$ & $* *$ & $\begin{array}{c}4,697 \\
(0.4 \%)\end{array}$ \\
\hline \multicolumn{8}{|l|}{ Other Means } \\
\hline Amtrak & $\begin{array}{c}1,663 \\
(0.0 \%)\end{array}$ & $\begin{array}{c}109 \\
(0.0 \%)\end{array}$ & $\begin{array}{c}358 \\
(0.0 \%)\end{array}$ & $* *$ & $\begin{array}{c}877 \\
(0.1 \%)\end{array}$ & $* *$ & $\begin{array}{c}320 \\
(0.0 \%)\end{array}$ \\
\hline Airplane & $\begin{array}{l}116,694 \\
(3.4 \%)\end{array}$ & $\begin{array}{l}29,272 \\
(4.7 \%)\end{array}$ & $\begin{array}{l}28,446 \\
(3.4 \%)\end{array}$ & $\begin{array}{c}0 \\
(0.0 \%)\end{array}$ & $\begin{array}{l}31,118 \\
(4.4 \%)\end{array}$ & $\begin{array}{c}4,090 \\
(32.4 \%)\end{array}$ & $\begin{array}{l}23,769 \\
(2.1 \%)\end{array}$ \\
\hline Taxi & $\begin{array}{c}3,204 \\
(0.1 \%)\end{array}$ & $\begin{array}{c}687 \\
(0.1 \%)\end{array}$ & $\begin{array}{c}634 \\
(0.1 \%)\end{array}$ & $\begin{array}{c}28 \\
(0.0 \%)\end{array}$ & $\begin{array}{c}689 \\
(0.1 \%)\end{array}$ & $\begin{array}{c}48 \\
(0.4 \%)\end{array}$ & $\begin{array}{c}1,118 \\
(0.1 \%)\end{array}$ \\
\hline Bicycle & $\begin{array}{c}4,586 \\
(0.1 \%)\end{array}$ & $\begin{array}{c}474 \\
(0.1 \%)\end{array}$ & $\begin{array}{c}599 \\
(0.1 \%)\end{array}$ & $\begin{array}{c}173 \\
(0.2 \%)\end{array}$ & $\begin{array}{c}1,461 \\
(0.2 \%)\end{array}$ & $\begin{array}{c}4 \\
(0.0 \%)\end{array}$ & $\begin{array}{c}1,875 \\
(0.2 \%)\end{array}$ \\
\hline Walk & $\begin{array}{l}10,821 \\
(0.3 \%)\end{array}$ & $\begin{array}{c}919 \\
(0.1 \%)\end{array}$ & $\begin{array}{c}2,405 \\
(0.3 \%)\end{array}$ & $\begin{array}{c}774 \\
(0.7 \%)\end{array}$ & $\begin{array}{c}2,708 \\
(0.4 \%)\end{array}$ & $\begin{array}{c}34 \\
(0.3 \%)\end{array}$ & $\begin{array}{c}3,980 \\
(0.3 \%)\end{array}$ \\
\hline School Bus & $\begin{array}{l}43,391 \\
(1.3 \%)\end{array}$ & $\begin{array}{c}2,780 \\
(0.4 \%)\end{array}$ & $\begin{array}{c}1,997 \\
(0.2 \%)\end{array}$ & $\begin{array}{c}18,324 \\
(17.5 \%)\end{array}$ & $\begin{array}{c}3,669 \\
(0.5 \%)\end{array}$ & $\begin{array}{c}96 \\
(0.8 \%)\end{array}$ & $\begin{array}{l}16,525 \\
(1.4 \%)\end{array}$ \\
\hline Other & $\begin{array}{r}13,860 \\
(0.4 \%) \\
\end{array}$ & $\begin{array}{c}5,895 \\
(1.0 \%) \\
\end{array}$ & $\begin{array}{r}1,849 \\
(0.2 \%) \\
\end{array}$ & $\begin{array}{c}301 \\
(0.3 \%) \\
\end{array}$ & $\begin{array}{c}3,071 \\
(0.4 \%) \\
\end{array}$ & $\begin{array}{c}22 \\
(0.2 \%) \\
\end{array}$ & $\begin{array}{c}2,722 \\
(0.2 \%) \\
\end{array}$ \\
\hline
\end{tabular}

Note:

- All tables reporting totals could include some unreported characteristics.

- ** Indicates no data available.

- $\quad \mathrm{SUV}=$ sport utility vehicle. 
TABLE 4.29

Number of Person Miles of Travel By Mode of Transportation ANd 1990 Trip Purpose
1995 NPTS
(MILlions)

\begin{tabular}{|c|c|c|c|c|c|c|}
\hline & TOTAL & $\begin{array}{c}\text { Earning a } \\
\text { Living }\end{array}$ & $\begin{array}{l}\text { Family/ } \\
\text { Personal }\end{array}$ & $\begin{array}{l}\text { School/ } \\
\text { Church }\end{array}$ & $\begin{array}{c}\text { Social/ } \\
\text { Recreational }\end{array}$ & Other \\
\hline TOTAL & $\begin{array}{l}3,411,122 \\
(100.0 \%)\end{array}$ & $\begin{array}{c}962,872 \\
(100.0 \%)\end{array}$ & $\begin{array}{l}1,191,788 \\
(100.0 \%)\end{array}$ & $\begin{array}{c}195,286 \\
(100.0 \%)\end{array}$ & $\begin{array}{l}1,046,431 \\
(100.0 \%)\end{array}$ & $\begin{array}{c}13,009 \\
(100.0 \%)\end{array}$ \\
\hline \multicolumn{7}{|l|}{ Private Vehicle } \\
\hline Auto & $\begin{array}{c}1,944,004 \\
(57.0 \%)\end{array}$ & $\begin{array}{l}488,652 \\
(50.7 \%)\end{array}$ & $\begin{array}{l}728,830 \\
(61.2 \%)\end{array}$ & $\begin{array}{l}103,926 \\
(53.2 \%)\end{array}$ & $\begin{array}{l}616,452 \\
(58.9 \%)\end{array}$ & $\begin{array}{c}5,865 \\
(45.1 \%)\end{array}$ \\
\hline Van & $\begin{array}{l}358,583 \\
(10.5 \%)\end{array}$ & $\begin{array}{l}73,904 \\
(7.7 \%)\end{array}$ & $\begin{array}{l}140,545 \\
(11.8 \%)\end{array}$ & $\begin{array}{c}21,334 \\
(10.9 \%)\end{array}$ & $\begin{array}{l}121,143 \\
(11.6 \%)\end{array}$ & $\begin{array}{c}1,653 \\
(12.7 \%)\end{array}$ \\
\hline SUV & $\begin{array}{l}238,242 \\
(7.0 \%)\end{array}$ & $\begin{array}{l}60,677 \\
(6.3 \%)\end{array}$ & $\begin{array}{l}83,252 \\
(7.0 \%)\end{array}$ & $\begin{array}{c}9,555 \\
(4.9 \%)\end{array}$ & $\begin{array}{l}84,522 \\
(8.1 \%)\end{array}$ & $\begin{array}{c}233 \\
(1.8 \%)\end{array}$ \\
\hline Pickup & $\begin{array}{l}471,416 \\
(13.8 \%)\end{array}$ & $\begin{array}{l}181,619 \\
(18.9 \%)\end{array}$ & $\begin{array}{l}153,228 \\
(12.9 \%)\end{array}$ & $\begin{array}{l}13,089 \\
(6.7 \%)\end{array}$ & $\begin{array}{l}121,511 \\
(11.6 \%)\end{array}$ & $\begin{array}{c}538 \\
(4.1 \%)\end{array}$ \\
\hline Other Truck & $\begin{array}{l}85,623 \\
(2.5 \%)\end{array}$ & $\begin{array}{l}69,879 \\
(7.3 \%)\end{array}$ & $\begin{array}{l}11,431 \\
(1.0 \%)\end{array}$ & $\begin{array}{c}55 \\
(0.0 \%)\end{array}$ & $\begin{array}{c}4,176 \\
(0.4 \%)\end{array}$ & $\begin{array}{c}81 \\
(0.6 \%)\end{array}$ \\
\hline RV & $\begin{array}{c}6,656 \\
(0.2 \%)\end{array}$ & $\begin{array}{c}234 \\
(0.0 \%)\end{array}$ & $\begin{array}{c}1,358 \\
(0.1 \%)\end{array}$ & $\begin{array}{c}16 \\
(0.0 \%)\end{array}$ & $\begin{array}{c}5,048 \\
(0.5 \%)\end{array}$ & $* *$ \\
\hline Motorcycle & $\begin{array}{c}3,994 \\
(0.1 \%)\end{array}$ & $\begin{array}{l}1,171 \\
(0.1 \%)\end{array}$ & $\begin{array}{l}1,007 \\
(0.1 \%)\end{array}$ & $\begin{array}{c}48 \\
(0.0 \%)\end{array}$ & $\begin{array}{c}1,681 \\
(0.2 \%)\end{array}$ & $\begin{array}{c}86 \\
(0.7 \%)\end{array}$ \\
\hline Other POV & $\begin{array}{c}1,732 \\
(0.1 \%)\end{array}$ & $\begin{array}{c}344 \\
(0.0 \%)\end{array}$ & $\begin{array}{c}604 \\
(0.1 \%)\end{array}$ & $\begin{array}{c}66 \\
(0.0 \%)\end{array}$ & $\begin{array}{c}710 \\
(0.1 \%)\end{array}$ & $\begin{array}{c}8 \\
(0.1 \%)\end{array}$ \\
\hline \multicolumn{7}{|l|}{ Public Transit } \\
\hline Bus & $\begin{array}{l}48,028 \\
(1.4 \%)\end{array}$ & $\begin{array}{l}13,278 \\
(1.4 \%)\end{array}$ & $\begin{array}{l}12,597 \\
(1.1 \%)\end{array}$ & $\begin{array}{l}5,092 \\
(2.6 \%)\end{array}$ & $\begin{array}{l}16,981 \\
(1.6 \%)\end{array}$ & $\begin{array}{c}81 \\
(0.6 \%)\end{array}$ \\
\hline Commuter Train & $\begin{array}{l}12,498 \\
(0.4 \%)\end{array}$ & $\begin{array}{c}8,778 \\
(0.9 \%)\end{array}$ & $\begin{array}{l}1,727 \\
(0.1 \%)\end{array}$ & $\begin{array}{c}183 \\
(0.1 \%)\end{array}$ & $\begin{array}{c}1,785 \\
(0.2 \%)\end{array}$ & $\begin{array}{c}25 \\
(0.2 \%)\end{array}$ \\
\hline Streetcar/Trolley & $\begin{array}{c}127 \\
(0.0 \%)\end{array}$ & $\begin{array}{c}40 \\
(0.0 \%)\end{array}$ & $\begin{array}{c}22 \\
(0.0 \%)\end{array}$ & $\begin{array}{c}1 \\
(0.0 \%)\end{array}$ & $\begin{array}{c}63 \\
(0.0 \%)\end{array}$ & $\begin{array}{c}0 \\
(0.0 \%)\end{array}$ \\
\hline Subway/El Rail & $\begin{array}{l}11,925 \\
(0.3 \%)\end{array}$ & $\begin{array}{c}6,666 \\
(0.7 \%)\end{array}$ & $\begin{array}{c}2,166 \\
(0.2 \%)\end{array}$ & $\begin{array}{c}1,079 \\
(0.6 \%)\end{array}$ & $\begin{array}{c}2,014 \\
(0.2 \%)\end{array}$ & $* *$ \\
\hline \multicolumn{7}{|l|}{ Other Means } \\
\hline Amtrak & $\begin{array}{c}1,663 \\
(0.0 \%)\end{array}$ & $\begin{array}{c}401 \\
(0.0 \%)\end{array}$ & $\begin{array}{c}361 \\
(0.0 \%)\end{array}$ & $* *$ & $\begin{array}{c}901 \\
(0.1 \%)\end{array}$ & $* *$ \\
\hline Airplane & $\begin{array}{l}116,694 \\
(3.4 \%)\end{array}$ & $\begin{array}{l}35,568 \\
(3.7 \%)\end{array}$ & $\begin{array}{l}31,910 \\
(2.7 \%)\end{array}$ & $\begin{array}{c}3,824 \\
(2.0 \%)\end{array}$ & $\begin{array}{l}41,302 \\
(3.9 \%)\end{array}$ & $\begin{array}{c}4,090 \\
(31.4 \%)\end{array}$ \\
\hline Taxi & $\begin{array}{c}3,204 \\
(0.1 \%)\end{array}$ & $\begin{array}{c}986 \\
(0.1 \%)\end{array}$ & $\begin{array}{c}1,094 \\
(0.1 \%)\end{array}$ & $\begin{array}{c}74 \\
(0.0 \%)\end{array}$ & $\begin{array}{c}1,007 \\
(0.1 \%)\end{array}$ & $\begin{array}{c}43 \\
(0.3 \%)\end{array}$ \\
\hline Bicycle & $\begin{array}{c}4,586 \\
(0.1 \%)\end{array}$ & $\begin{array}{c}881 \\
(0.1 \%)\end{array}$ & $\begin{array}{c}945 \\
(0.1 \%)\end{array}$ & $\begin{array}{c}344 \\
(0.2 \%)\end{array}$ & $\begin{array}{c}2,411 \\
(0.2 \%)\end{array}$ & $\begin{array}{c}4 \\
(0.0 \%)\end{array}$ \\
\hline Walk & $\begin{array}{l}10,821 \\
(0.3 \%)\end{array}$ & $\begin{array}{c}1,233 \\
(0.1 \%)\end{array}$ & $\begin{array}{c}3,957 \\
(0.3 \%)\end{array}$ & $\begin{array}{l}1,610 \\
(0.8 \%)\end{array}$ & $\begin{array}{c}3,983 \\
(0.4 \%)\end{array}$ & $\begin{array}{c}38 \\
(0.3 \%)\end{array}$ \\
\hline School Bus & $\begin{array}{l}43,391 \\
(1.3 \%)\end{array}$ & $\begin{array}{c}3,117 \\
(0.3 \%)\end{array}$ & $\begin{array}{c}2,471 \\
(0.2 \%)\end{array}$ & $\begin{array}{c}32,858 \\
(16.8 \%)\end{array}$ & $\begin{array}{c}4,837 \\
(0.5 \%)\end{array}$ & $\begin{array}{c}107 \\
(0.8 \%)\end{array}$ \\
\hline Other & $\begin{array}{l}13,860 \\
(0.4 \%) \\
\end{array}$ & $\begin{array}{c}6,463 \\
(0.7 \%) \\
\end{array}$ & $\begin{array}{c}2,759 \\
(0.2 \%) \\
\end{array}$ & $\begin{array}{c}423 \\
(0.2 \%) \\
\end{array}$ & $\begin{array}{c}4,193 \\
(0.4 \%) \\
\end{array}$ & $\begin{array}{c}22 \\
(0.2 \%) \\
\end{array}$ \\
\hline
\end{tabular}

Note:

- All tables reporting totals could include some unreported characteristics.

- ** Indicates no data available.

- $\mathrm{SUV}=$ sport utility vehicle. 
TABLE 4.30

Number of Person Trips by Mode of Transportation, Trip Purpose, and Availability of Public Transit

1995 NPTS

(MILLIONS)

\begin{tabular}{|c|c|c|c|c|c|c|c|}
\hline Mode & TOTAL & $\begin{array}{c}\text { Earning a } \\
\text { Living }\end{array}$ & $\begin{array}{r}\text { Family/ } \\
\text { Personal } \\
\end{array}$ & $\begin{array}{l}\text { Church/ } \\
\text { School } \\
\end{array}$ & $\begin{array}{c}\text { Social/ } \\
\text { Rec }\end{array}$ & Other & $\begin{array}{c}\text { Returning } \\
\text { Home }\end{array}$ \\
\hline \multicolumn{8}{|c|}{ Where Public Transportation Is Available } \\
\hline TOTAL & $\begin{array}{l}233,928 \\
(100 \%)\end{array}$ & $\begin{array}{c}30,466 \\
(100 \%)\end{array}$ & $\begin{array}{c}73,511 \\
(100 \%)\end{array}$ & $\begin{array}{l}11,171 \\
(100 \%)\end{array}$ & $\begin{array}{r}39,630 \\
(100 \%)\end{array}$ & $\begin{array}{r}375 \\
(100 \%)\end{array}$ & $\begin{array}{c}78,737 \\
(100 \%)\end{array}$ \\
\hline $\begin{array}{c}\text { Private - } \\
\text { Driver }\end{array}$ & $\begin{array}{l}137,937 \\
(59.0 \%)\end{array}$ & $\begin{array}{r}23,538 \\
(77.3 \%)\end{array}$ & $\begin{array}{r}47,443 \\
(64.5 \%)\end{array}$ & $\begin{array}{r}3,250 \\
(29.1 \%)\end{array}$ & $\begin{array}{r}17,178 \\
(43.3 \%)\end{array}$ & $\begin{array}{r}115 \\
(30.7 \%)\end{array}$ & $\begin{array}{r}46,402 \\
(58.9 \%)\end{array}$ \\
\hline $\begin{array}{l}\text { Private - } \\
\quad \text { Passenger }\end{array}$ & $\begin{array}{r}58,829 \\
(25.1 \%)\end{array}$ & $\begin{array}{r}2,847 \\
(9.3 \%)\end{array}$ & $\begin{array}{c}17,472 \\
(23.8 \%)\end{array}$ & $\begin{array}{r}4,133 \\
(37.0 \%)\end{array}$ & $\begin{array}{r}14,890 \\
(37.6 \%)\end{array}$ & $\begin{array}{r}158 \\
(42.1 \%)\end{array}$ & $\begin{array}{r}19,315 \\
(24.5 \%)\end{array}$ \\
\hline Public & $\begin{array}{r}6,224 \\
(2.7 \%)\end{array}$ & $\begin{array}{r}1,303 \\
(4.3 \%)\end{array}$ & $\begin{array}{r}1,265 \\
(1.7 \%)\end{array}$ & $\begin{array}{r}444 \\
(4.0 \%)\end{array}$ & $\begin{array}{r}846 \\
(2.1 \%)\end{array}$ & $\begin{array}{r}10 \\
(2.7 \%)\end{array}$ & $\begin{array}{r}2,355 \\
(3.0 \%)\end{array}$ \\
\hline Other & $\begin{array}{l}22,975 \\
(9.8 \%)\end{array}$ & $\begin{array}{r}2,048 \\
(6.7 \%)\end{array}$ & $\begin{array}{r}5,045 \\
(6.9 \%)\end{array}$ & $\begin{array}{r}2,923 \\
(26.2 \%)\end{array}$ & $\begin{array}{r}4,783 \\
(12.1 \%)\end{array}$ & $\begin{array}{r}55 \\
(14.7 \%)\end{array}$ & $\begin{array}{r}8,120 \\
(10.3 \%)\end{array}$ \\
\hline $\begin{array}{l}\text { Average Trip } \\
\text { Length (miles) }\end{array}$ & 8.40 & 11.42 & 6.52 & 5.15 & 10.95 & 16.94 & 8.13 \\
\hline \multicolumn{8}{|c|}{ Where Public Transportation Is NOT Available } \\
\hline TOTAL & $\begin{array}{l}145,003 \\
(100 \%)\end{array}$ & $\begin{array}{l}19,701 \\
(100 \%)\end{array}$ & $\begin{array}{l}45,032 \\
(100 \%)\end{array}$ & $\begin{array}{r}7,110 \\
(100 \%)\end{array}$ & $\begin{array}{c}24,278 \\
(100 \%)\end{array}$ & $\begin{array}{r}233 \\
(100 \%)\end{array}$ & $\begin{array}{r}48,636 \\
(100 \%)\end{array}$ \\
\hline $\begin{array}{c}\text { Private - } \\
\text { Driver }\end{array}$ & $\begin{array}{r}91,808 \\
(63.3 \%)\end{array}$ & $\begin{array}{r}16,546 \\
(84.0 \%)\end{array}$ & $\begin{array}{r}30,675 \\
(68.1 \%)\end{array}$ & $\begin{array}{r}2,258 \\
(31.8 \%)\end{array}$ & $\begin{array}{r}11,617 \\
(47.8 \%)\end{array}$ & $\begin{array}{r}81 \\
(34.8 \%)\end{array}$ & $\begin{array}{r}30,624 \\
(63.0 \%)\end{array}$ \\
\hline $\begin{array}{l}\text { Private - } \\
\quad \text { Passenger }\end{array}$ & $\begin{array}{r}38,825 \\
(26.8 \%)\end{array}$ & $\begin{array}{r}1,849 \\
(9.4 \%)\end{array}$ & $\begin{array}{c}11,771 \\
(26.1 \%)\end{array}$ & $\begin{array}{r}2,710 \\
(38.1 \%)\end{array}$ & $\begin{array}{r}9,555 \\
(39.4 \%)\end{array}$ & $\begin{array}{r}101 \\
(43.3 \%)\end{array}$ & $\begin{array}{r}12,837 \\
(26.4 \%)\end{array}$ \\
\hline Public & $\begin{array}{r}415 \\
(0.3 \%)\end{array}$ & $\begin{array}{r}101 \\
(0.5 \%)\end{array}$ & $\begin{array}{r}61 \\
(0.1 \%)\end{array}$ & $\begin{array}{r}43 \\
(0.6 \%)\end{array}$ & $\begin{array}{r}75 \\
(0.3 \%)\end{array}$ & $\begin{array}{r}8 \\
(3.4 \%)\end{array}$ & $\begin{array}{r}126 \\
(0.3 \%)\end{array}$ \\
\hline Other & $\begin{array}{r}9,449 \\
(6.5 \%)\end{array}$ & $\begin{array}{r}730 \\
(3.7 \%)\end{array}$ & $\begin{array}{r}1,339 \\
(3.0 \%)\end{array}$ & $\begin{array}{r}1,883 \\
(26.5 \%)\end{array}$ & $\begin{array}{r}1,972 \\
(8.1 \%)\end{array}$ & $\begin{array}{r}25 \\
(10.7 \%)\end{array}$ & $\begin{array}{r}3,501 \\
(7.2 \%)\end{array}$ \\
\hline $\begin{array}{l}\text { Average Trip } \\
\text { Length (miles) }\end{array}$ & 10.30 & 14.24 & 7.97 & 6.91 & 11.56 & 31.17 & 10.65 \\
\hline
\end{tabular}

Note:

- All tables reporting totals could include some unreported characteristics.

- Average Trip Length is calculated using only those records with trip mileage information present. 
FIGURE 4.13

\section{Distribution of Person Trips by Mode of Transportation and Trip Purpose \\ Based on Availability of Public Transportation}
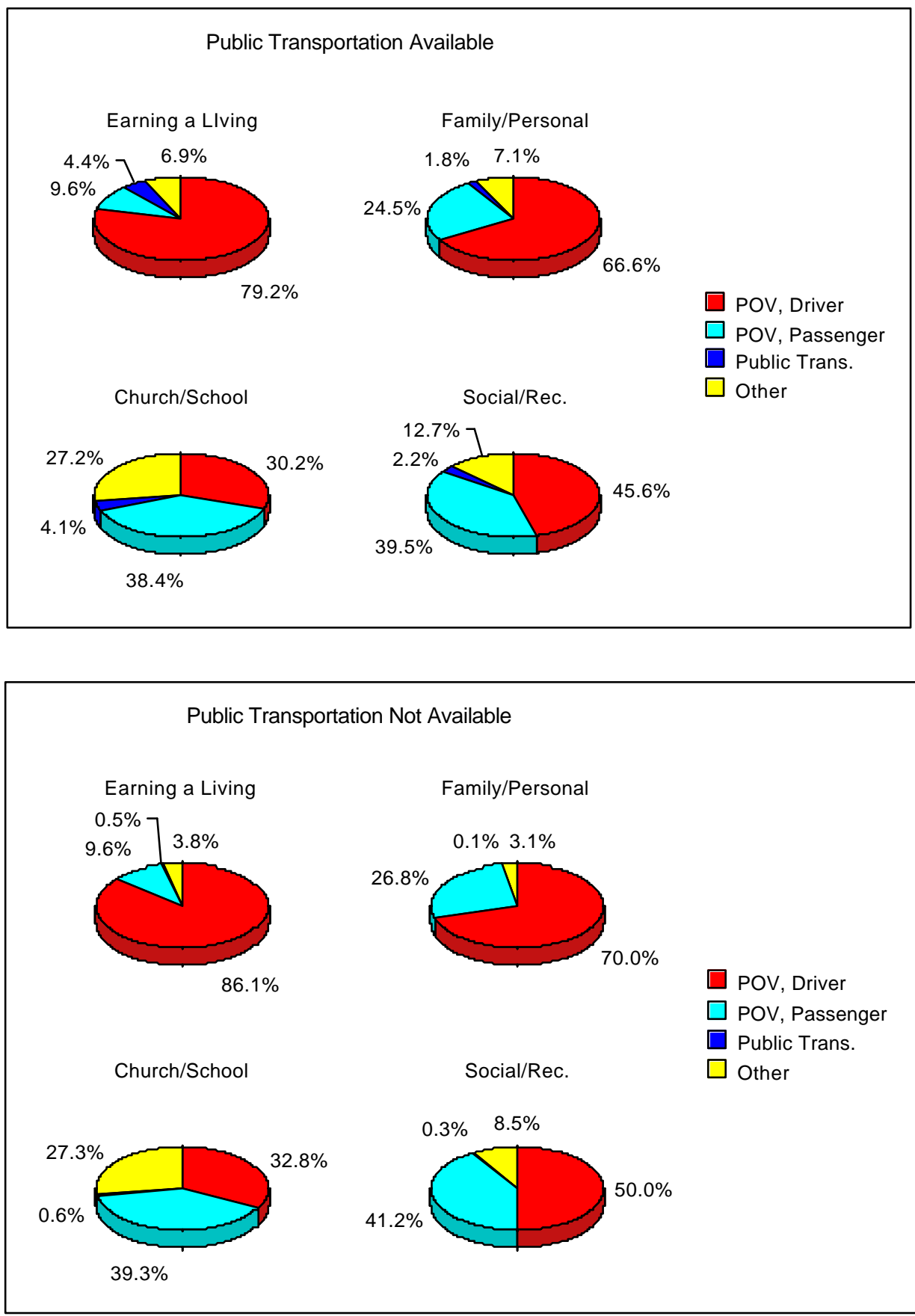
Tables 4.31-4.34 provide day-of-week and time-of-day travel statistics. As shown in Table 4.31, people took more trips and traveled more miles in 1995 than they did in 1990. The distribution of trips and person miles across the days of the week generally stayed very similar between 1990 and 1995, except for Friday, which increased its share of person miles of travel, and Sunday, which saw a decrease. This distribution of person travel by day of week is shown in Figure 4.14.

The temporal distribution of personal trips remained the same during the past decade - almost $70 \%$ of the trips were between 9 a.m. and 7 p.m. However, this distribution varied somewhat by trip purpose. As expected, commuting to work began predominately between 6 and 9 a.m., and more than $82.8 \%$ of all trips for earning a living occurred between 6 a.m. and 4 p.m.

The most common weekday trip purpose was family/personal business, and earning a living was second. On the weekend, the most common trip purpose was for family or personal business, and a social or recreational purpose was second. 
TABLE 4.31

\section{Statistics on Person Travel by Day of Week 1990 ADJUSTED AND 1995 NPTS}

\begin{tabular}{|c|c|c|c|c|c|c|}
\hline \multirow[b]{2}{*}{ Day } & \multicolumn{2}{|c|}{$\begin{array}{c}\text { Person Trips } \\
(000,000)\end{array}$} & \multicolumn{2}{|c|}{$\begin{array}{c}\text { Person Miles of Travel } \\
(000,000)\end{array}$} & \multicolumn{2}{|c|}{$\begin{array}{l}\text { Average Trip Length } \\
\text { (miles) }\end{array}$} \\
\hline & 1990 adj & 1995 & $1990 \mathrm{adj}$ & 1995 & $1990 \mathrm{adj}$ & 1995 \\
\hline TOTAL & $\begin{array}{r}304,471 \\
(100.0 \%)\end{array}$ & $\begin{array}{r}378,930 \\
(100.0 \%)\end{array}$ & $\begin{array}{r}2,829,936 \\
(100.0 \%)\end{array}$ & $\begin{array}{r}3,411,122 \\
(100.0 \%)\end{array}$ & 9.47 & 9.13 \\
\hline Sunday & $\begin{array}{r}41,424 \\
(13.6 \%)\end{array}$ & $\begin{array}{r}46,298 \\
(12.2 \%)\end{array}$ & $\begin{array}{l}508,269 \\
(18.0 \%)\end{array}$ & $\begin{array}{l}497,615 \\
(14.6 \%)\end{array}$ & 12.48 & 10.88 \\
\hline Monday & $\begin{array}{r}44,704 \\
(14.7 \%)\end{array}$ & $\begin{array}{r}52,319 \\
(13.8 \%)\end{array}$ & $\begin{array}{l}410,314 \\
(14.5 \%)\end{array}$ & $\begin{array}{l}444,136 \\
(13.0 \%)\end{array}$ & 9.34 & 8.62 \\
\hline Tuesday & $\begin{array}{r}46,548 \\
(15.3 \%)\end{array}$ & $\begin{array}{r}54,663 \\
(14.4 \%)\end{array}$ & $\begin{array}{l}389,700 \\
(13.8 \%)\end{array}$ & $\begin{array}{l}447,335 \\
(13.1 \%)\end{array}$ & 8.51 & 8.31 \\
\hline Wednesday & $\begin{array}{r}42,765 \\
(14.0 \%)\end{array}$ & $\begin{array}{r}56,315 \\
(14.9 \%)\end{array}$ & $\begin{array}{l}376,203 \\
(13.3 \%)\end{array}$ & $\begin{array}{l}488,810 \\
(14.3 \%)\end{array}$ & 8.99 & 8.79 \\
\hline Thursday & $\begin{array}{r}45,914 \\
(15.1 \%)\end{array}$ & $\begin{array}{r}54,772 \\
(14.5 \%)\end{array}$ & $\begin{array}{l}356,018 \\
(12.6 \%)\end{array}$ & $\begin{array}{l}441,755 \\
(13.0 \%)\end{array}$ & 7.91 & 8.19 \\
\hline Friday & $\begin{array}{r}40,732 \\
(13.4 \%)\end{array}$ & $\begin{array}{r}60,526 \\
(16.0 \%)\end{array}$ & $\begin{array}{l}351,281 \\
(12.4 \%)\end{array}$ & $\begin{array}{l}547,632 \\
(16.1 \%)\end{array}$ & 8.79 & 9.20 \\
\hline Saturday & $\begin{array}{r}42,384 \\
(13.9 \%)\end{array}$ & $\begin{array}{r}54,038 \\
(14.3 \%)\end{array}$ & $\begin{array}{l}438,152 \\
(15.5 \%)\end{array}$ & $\begin{array}{l}543,838 \\
(15.9 \%)\end{array}$ & 10.55 & 10.22 \\
\hline
\end{tabular}

Note:

- All tables reporting totals could include some unreported characteristics.

- Average Trip Length is calculated using only those records with trip mileage information present.

- Note that only the 1990 data have been adjusted to make them more comparable with the 1995 data. Thus, there are limits on the conclusions that can be drawn in comparing travel with earlier survey years. The adjustments to 1990 data affect only person trips, vehicle trips, person miles of travel (PMT) and vehicle miles of travel (VMT). 


\section{FIGURE 4.14}

\section{Distribution of Person Travel by Day of Week}

1995 NPTS

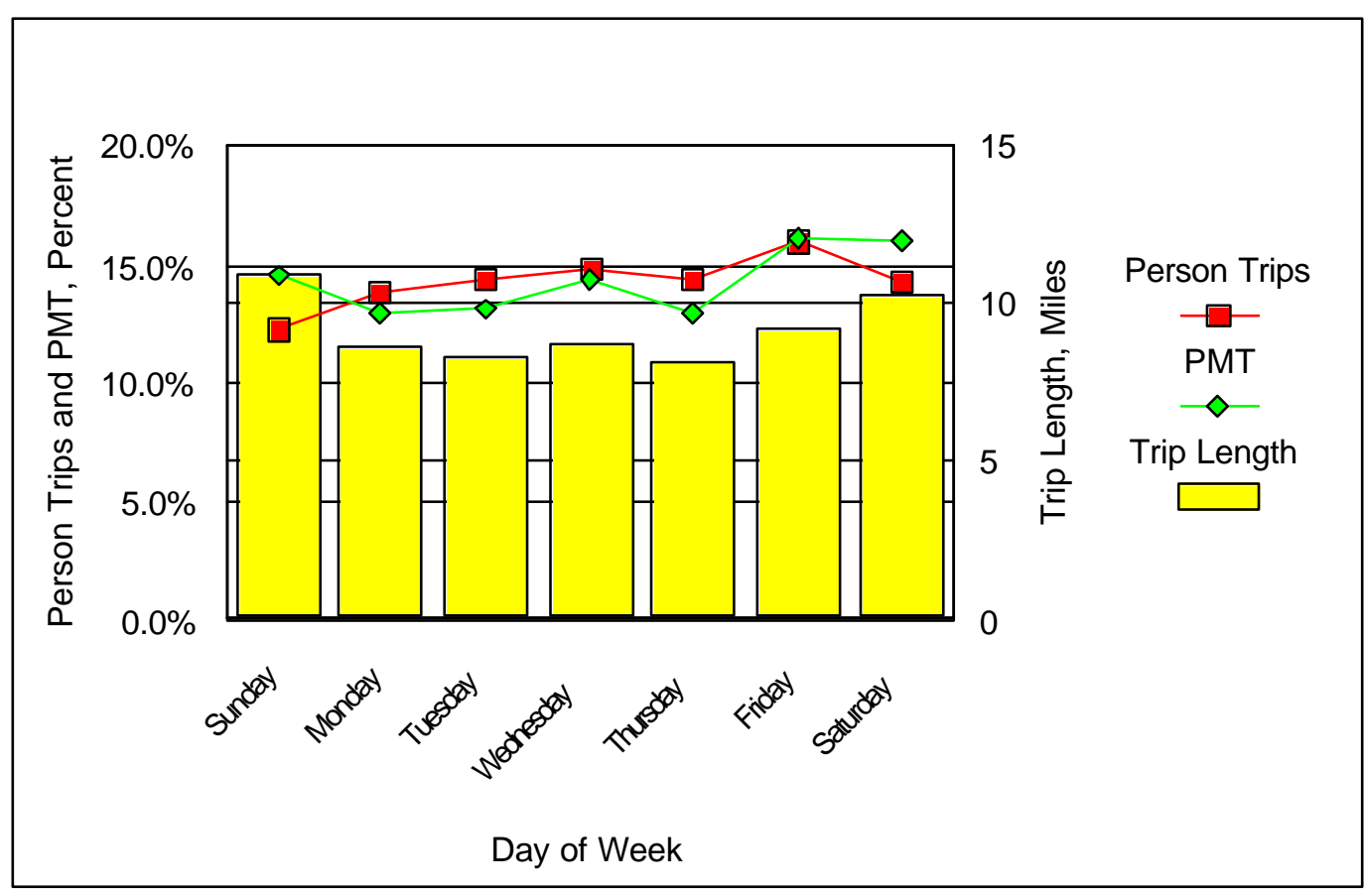

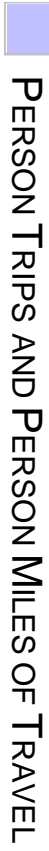




\section{TABLE 4.32}

\section{Number of Person Trips by Time of Day And Trip Purpose 1995 NPTS \\ (MILLIONS)}

\begin{tabular}{|c|c|c|c|c|c|c|c|c|}
\hline & TOTAL & $\begin{array}{c}\text { 1:00 a.m. } \\
\text { to } \\
\text { 6:00 a.m. }\end{array}$ & $\begin{array}{c}\text { 6:00 a.m. } \\
\text { to } \\
\text { 9:00 a.m. }\end{array}$ & $\begin{array}{c}\text { 9:00 a.m. } \\
\text { to } \\
\text { 1:00 p.m. }\end{array}$ & $\begin{array}{c}\text { 1:00 p.m. } \\
\text { to } \\
\text { 4:00 p.m. }\end{array}$ & $\begin{array}{c}\text { 4:00 p.m. } \\
\text { to } \\
\text { 7:00 p.m. }\end{array}$ & $\begin{array}{l}\text { 7:00 p.m. } \\
\text { to } \\
\text { 10:00 p.m. }\end{array}$ & $\begin{array}{c}\text { 10:00 p.m. } \\
\text { to } \\
\text { 1:00 a.m. }\end{array}$ \\
\hline TOTAL & $\begin{array}{r}378,930 \\
(100.0 \%)\end{array}$ & $\begin{array}{r}6,481 \\
(100.0 \%)\end{array}$ & $\begin{array}{r}52,262 \\
(100.0 \%)\end{array}$ & $\begin{array}{r}91,551 \\
(100.0 \%)\end{array}$ & $\begin{array}{r}83,615 \\
(100.0 \%)\end{array}$ & $\begin{array}{r}86,992 \\
(100.0 \%)\end{array}$ & $\begin{array}{r}44,667 \\
(100.0 \%)\end{array}$ & $\begin{array}{r}13,267 \\
(100.0 \%)\end{array}$ \\
\hline $\begin{array}{c}\text { Earning a } \\
\text { Living }\end{array}$ & $\begin{array}{r}50,167 \\
(13.2 \%)\end{array}$ & $\begin{array}{r}3,103 \\
(47.9 \%)\end{array}$ & $\begin{array}{r}20,263 \\
(38.8 \%)\end{array}$ & $\begin{array}{r}12,185 \\
(13.3 \%)\end{array}$ & $\begin{array}{r}9,092 \\
(10.9 \%)\end{array}$ & $\begin{array}{c}3,738 \\
(4.3 \%)\end{array}$ & $\begin{array}{r}1,103 \\
(2.5 \%)\end{array}$ & $\begin{array}{r}667 \\
(5.0 \%)\end{array}$ \\
\hline $\begin{array}{l}\text { Family/ } \\
\text { Personal } \\
\text { Business }\end{array}$ & $\begin{array}{l}118,543 \\
(31.3 \%)\end{array}$ & $\begin{array}{r}961 \\
(14.8 \%)\end{array}$ & $\begin{array}{c}13,094 \\
(25.1 \%)\end{array}$ & $\begin{array}{c}36,342 \\
(39.7 \%)\end{array}$ & $\begin{array}{r}30,086 \\
(36.0 \%)\end{array}$ & $\begin{array}{c}25,831 \\
(29.7 \%)\end{array}$ & $\begin{array}{r}10,124 \\
(22.7 \%)\end{array}$ & $\begin{array}{r}2,062 \\
(15.5 \%)\end{array}$ \\
\hline $\begin{array}{l}\text { School/ } \\
\text { Church }\end{array}$ & $\begin{array}{l}18,281 \\
(4.8 \%)\end{array}$ & $\begin{array}{r}75 \\
(1.2 \%)\end{array}$ & $\begin{array}{c}10,302 \\
(19.7 \%)\end{array}$ & $\begin{array}{r}4,169 \\
(4.6 \%)\end{array}$ & $\begin{array}{r}1,118 \\
(1.3 \%)\end{array}$ & $\begin{array}{r}1,951 \\
(2.2 \%)\end{array}$ & $\begin{array}{r}640 \\
(1.4 \%)\end{array}$ & $\begin{array}{r}26 \\
(0.2 \%)\end{array}$ \\
\hline $\begin{array}{l}\text { Social/ } \\
\text { Rec. }\end{array}$ & $\begin{array}{r}63,908 \\
(16.9 \%)\end{array}$ & $\begin{array}{r}580 \\
(8.9 \%)\end{array}$ & $\begin{array}{r}4,022 \\
(7.7 \%)\end{array}$ & $\begin{array}{r}17,525 \\
(19.1 \%)\end{array}$ & $\begin{array}{r}13,129 \\
(15.7 \%)\end{array}$ & $\begin{array}{c}17,451 \\
(20.1 \%)\end{array}$ & $\begin{array}{r}9,506 \\
(21.3 \%)\end{array}$ & $\begin{array}{r}1,674 \\
(12.6 \%)\end{array}$ \\
\hline Other & $\begin{array}{r}608 \\
(0.2 \%)\end{array}$ & $\begin{array}{r}13 \\
(0.2 \%)\end{array}$ & $\begin{array}{r}33 \\
(0.1 \%)\end{array}$ & $\begin{array}{r}136 \\
(0.1 \%)\end{array}$ & $\begin{array}{r}98 \\
(0.1 \%)\end{array}$ & $\begin{array}{r}131 \\
(0.2 \%)\end{array}$ & $\begin{array}{r}124 \\
(0.3 \%)\end{array}$ & $\begin{array}{r}65 \\
(0.5 \%)\end{array}$ \\
\hline $\begin{array}{l}\text { Returning } \\
\text { Home }\end{array}$ & $\begin{array}{l}127,374 \\
(33.6 \%)\end{array}$ & $\begin{array}{r}1,747 \\
(27.0 \%)\end{array}$ & $\begin{array}{r}4,543 \\
(8.7 \%)\end{array}$ & $\begin{array}{c}21,181 \\
(23.1 \%)\end{array}$ & $\begin{array}{r}30,078 \\
(36.0 \%)\end{array}$ & $\begin{array}{r}37,885 \\
(43.5 \%)\end{array}$ & $\begin{array}{c}23,161 \\
(51.9 \%)\end{array}$ & $\begin{array}{r}8,771 \\
(66.1 \%)\end{array}$ \\
\hline
\end{tabular}

Note:

- All tables reporting totals could include some unreported characteristics. 


\section{TABLE 4.33}

\section{Number of Person Trips by Time of Day and 1990 Trip Purpose 1995 NPTS \\ (MILLIONS)}

\begin{tabular}{|c|c|c|c|c|c|c|c|c|}
\hline & TOTAL & $\begin{array}{c}\text { 1:00 a.m. } \\
\text { to } \\
\text { 6:00 a.m. }\end{array}$ & $\begin{array}{c}\text { 6:00 a.m. to } \\
\text { 9:00 a.m. }\end{array}$ & $\begin{array}{c}\text { 9:00 a.m. to } \\
\text { 1:00 p.m. }\end{array}$ & $\begin{array}{c}\text { 1:00 p.m. } \\
\text { to } \\
\text { 4:00 p.m. }\end{array}$ & $\begin{array}{c}\text { 4:00 p.m. } \\
\text { to } \\
\text { 7:00 p.m. }\end{array}$ & $\begin{array}{l}\text { 7:00 p.m. } \\
\text { to } \\
\text { 10:00 p.m. }\end{array}$ & $\begin{array}{c}\text { 10:00 p.m. } \\
\text { to } \\
\text { 1:00 a.m. }\end{array}$ \\
\hline TOTAL & $\begin{array}{r}378,930 \\
(100.0 \%)\end{array}$ & $\begin{array}{r}6,481 \\
(100.0 \%)\end{array}$ & $\begin{array}{r}52,262 \\
(100.0 \%)\end{array}$ & $\begin{array}{r}91,551 \\
(100.0 \%)\end{array}$ & $\begin{array}{r}83,615 \\
(100.0 \%)\end{array}$ & $\begin{array}{r}86,992 \\
(100.0 \%)\end{array}$ & $\begin{array}{r}44,667 \\
(100.0 \%)\end{array}$ & $\begin{array}{r}13,267 \\
(100.0 \%)\end{array}$ \\
\hline $\begin{array}{l}\text { Earning a } \\
\text { Living }\end{array}$ & $\begin{array}{c}76,761 \\
(20.3 \%)\end{array}$ & $\begin{array}{r}3,752 \\
(57.9 \%)\end{array}$ & $\begin{array}{c}20,945 \\
(40.1 \%)\end{array}$ & $\begin{array}{r}12,552 \\
(13.7 \%)\end{array}$ & $\begin{array}{r}12,584 \\
(15.0 \%)\end{array}$ & $\begin{array}{r}18,789 \\
(21.6 \%)\end{array}$ & $\begin{array}{r}5,110 \\
(11.4 \%)\end{array}$ & $\begin{array}{r}3,010 \\
(22.7 \%)\end{array}$ \\
\hline $\begin{array}{l}\text { Family/ } \\
\text { Personal } \\
\text { Business }\end{array}$ & $\begin{array}{l}173,764 \\
(45.9 \%)\end{array}$ & $\begin{array}{r}1,265 \\
(19.5 \%)\end{array}$ & $\begin{array}{c}16,088 \\
(30.8 \%)\end{array}$ & $\begin{array}{c}52,622 \\
(57.5 \%)\end{array}$ & $\begin{array}{c}44,533 \\
(53.3 \%)\end{array}$ & $\begin{array}{r}38,009 \\
(43.7 \%)\end{array}$ & $\begin{array}{c}17,613 \\
(39.4 \%)\end{array}$ & $\begin{array}{r}3,591 \\
(27.1 \%)\end{array}$ \\
\hline $\begin{array}{l}\text { School/ } \\
\text { Church }\end{array}$ & $\begin{array}{l}33,355 \\
(8.8 \%)\end{array}$ & $\begin{array}{r}97 \\
(1.5 \%)\end{array}$ & $\begin{array}{c}10,584 \\
(20.3 \%)\end{array}$ & $\begin{array}{r}7,132 \\
(7.8 \%)\end{array}$ & $\begin{array}{r}8,073 \\
(9.7 \%)\end{array}$ & $\begin{array}{r}4,607 \\
(5.3 \%)\end{array}$ & $\begin{array}{r}2,450 \\
(5.5 \%)\end{array}$ & $\begin{array}{r}408 \\
(3.1 \%)\end{array}$ \\
\hline $\begin{array}{l}\text { Social/ } \\
\text { Rec. }\end{array}$ & $\begin{array}{r}94,362 \\
(24.9 \%)\end{array}$ & $\begin{array}{r}1,347 \\
(20.8 \%)\end{array}$ & $\begin{array}{r}4,604 \\
(8.8 \%)\end{array}$ & $\begin{array}{c}19,093 \\
(20.9 \%)\end{array}$ & $\begin{array}{c}18,291 \\
(21.9 \%)\end{array}$ & $\begin{array}{c}25,445 \\
(29.2 \%)\end{array}$ & $\begin{array}{c}19,357 \\
(43.3 \%)\end{array}$ & $\begin{array}{r}6,206 \\
(46.8 \%)\end{array}$ \\
\hline Other & $\begin{array}{r}623 \\
(0.2 \%)\end{array}$ & $\begin{array}{r}17 \\
(0.3 \%)\end{array}$ & $\begin{array}{r}35 \\
(0.1 \%)\end{array}$ & $\begin{array}{r}138 \\
(0.2 \%)\end{array}$ & $\begin{array}{r}119 \\
(0.1 \%)\end{array}$ & $\begin{array}{r}127 \\
(0.1 \%)\end{array}$ & $\begin{array}{r}121 \\
(0.3 \%)\end{array}$ & $\begin{array}{r}51 \\
(0.4 \%)\end{array}$ \\
\hline
\end{tabular}

Note:

- All tables reporting totals could include some unreported characteristics. 


\section{TABLE 4.34}

\section{Number of Weekday Person Trips by Time of Day and TRIP Purpose 1995 NPTS \\ (MILLIONS)}

\begin{tabular}{|c|c|c|c|c|c|c|c|c|}
\hline & TOTAL & $\begin{array}{c}\text { 1:00 a.m. } \\
\text { to } \\
\text { 6:00 a.m. }\end{array}$ & $\begin{array}{c}\text { 6:00 a.m. } \\
\text { to } \\
\text { 9:00 a.m. }\end{array}$ & $\begin{array}{c}\text { 9:00 a.m. } \\
\text { to } \\
\text { 1:00 p.m. }\end{array}$ & $\begin{array}{l}\text { 1:00 p.m. } \\
\text { to } \\
\text { 4:00 p.m. }\end{array}$ & $\begin{array}{c}\text { 4:00 p.m. } \\
\text { to } \\
\text { 7:00 p.m. }\end{array}$ & $\begin{array}{c}\text { 7:00 p.m. } \\
\text { to } \\
\text { 10:00 p.m. }\end{array}$ & $\begin{array}{c}\text { 10:00 p.m. } \\
\text { to } \\
\text { 1:00 a.m. }\end{array}$ \\
\hline TOTAL & $\begin{array}{r}265,156 \\
(100.0 \%)\end{array}$ & $\begin{array}{r}4,982 \\
(100.0 \%)\end{array}$ & $\begin{array}{r}45,292 \\
(100.0 \%)\end{array}$ & $\begin{array}{r}61,730 \\
(100.0 \%)\end{array}$ & $\begin{array}{r}59,995 \\
(100.0 \%)\end{array}$ & $\begin{array}{r}61,280 \\
(100.0 \%)\end{array}$ & $\begin{array}{r}25,140 \\
(100.0 \%)\end{array}$ & $\begin{array}{r}6,687 \\
(100.0 \%)\end{array}$ \\
\hline $\begin{array}{c}\text { Earning a } \\
\text { Living }\end{array}$ & $\begin{array}{c}44,698 \\
(16.9 \%)\end{array}$ & $\begin{array}{r}2,764 \\
(55.5 \%)\end{array}$ & $\begin{array}{r}18,785 \\
(41.5 \%)\end{array}$ & $\begin{array}{r}10,745 \\
(17.4 \%)\end{array}$ & $\begin{array}{r}8,171 \\
(13.6 \%)\end{array}$ & $\begin{array}{c}3,021 \\
(4.9 \%)\end{array}$ & $\begin{array}{r}745 \\
(3.0 \%)\end{array}$ & $\begin{array}{r}454 \\
(6.8 \%)\end{array}$ \\
\hline $\begin{array}{l}\text { Family/ } \\
\text { Personal } \\
\text { Business }\end{array}$ & $\begin{array}{r}83,523 \\
(31.5 \%)\end{array}$ & $\begin{array}{r}704 \\
(14.1 \%)\end{array}$ & $\begin{array}{r}11,066 \\
(24.4 \%)\end{array}$ & $\begin{array}{r}25,000 \\
(40.5 \%)\end{array}$ & $\begin{array}{c}21,508 \\
(35.8 \%)\end{array}$ & $\begin{array}{c}18,508 \\
(30.2 \%)\end{array}$ & $\begin{array}{r}5,681 \\
(22.6 \%)\end{array}$ & $\begin{array}{r}1,034 \\
(15.5 \%)\end{array}$ \\
\hline $\begin{array}{l}\text { School/ } \\
\text { Church }\end{array}$ & $\begin{array}{l}13,439 \\
(5.1 \%)\end{array}$ & $\begin{array}{r}44 \\
(0.9 \%)\end{array}$ & $\begin{array}{r}9,325 \\
(20.6 \%)\end{array}$ & $\begin{array}{c}1,732 \\
(2.8 \%)\end{array}$ & $\begin{array}{r}693 \\
(1.2 \%)\end{array}$ & $\begin{array}{r}1,159 \\
(1.9 \%)\end{array}$ & $\begin{array}{r}474 \\
(1.9 \%)\end{array}$ & $\begin{array}{r}10 \\
(0.1 \%)\end{array}$ \\
\hline $\begin{array}{l}\text { Social/ } \\
\text { Rec. }\end{array}$ & $\begin{array}{c}36,639 \\
(13.8 \%)\end{array}$ & $\begin{array}{r}327 \\
(6.6 \%)\end{array}$ & $\begin{array}{r}2,573 \\
(5.7 \%)\end{array}$ & $\begin{array}{r}10,680 \\
(17.3 \%)\end{array}$ & $\begin{array}{r}7,488 \\
(12.5 \%)\end{array}$ & $\begin{array}{c}10,405 \\
(17.0 \%)\end{array}$ & $\begin{array}{r}4,460 \\
(17.7 \%)\end{array}$ & $\begin{array}{r}693 \\
(10.4 \%)\end{array}$ \\
\hline Other & $\begin{array}{r}377 \\
(0.1 \%)\end{array}$ & $\begin{array}{r}6 \\
(0.1 \%)\end{array}$ & $\begin{array}{r}30 \\
(0.1 \%)\end{array}$ & $\begin{array}{r}91 \\
(0.1 \%)\end{array}$ & $\begin{array}{r}71 \\
(0.1 \%)\end{array}$ & $\begin{array}{r}73 \\
(0.1 \%)\end{array}$ & $\begin{array}{r}68 \\
(0.3 \%)\end{array}$ & $\begin{array}{r}38 \\
(0.6 \%)\end{array}$ \\
\hline $\begin{array}{l}\text { Returning } \\
\text { Home }\end{array}$ & $\begin{array}{c}86,442 \\
(32.6 \%)\end{array}$ & $\begin{array}{r}1,134 \\
(22.8 \%)\end{array}$ & $\begin{array}{r}3,509 \\
(7.7 \%)\end{array}$ & $\begin{array}{r}13,469 \\
(21.8 \%)\end{array}$ & $\begin{array}{c}22,056 \\
(36.8 \%)\end{array}$ & $\begin{array}{c}28,111 \\
(45.9 \%)\end{array}$ & $\begin{array}{c}13,704 \\
(54.5 \%)\end{array}$ & $\begin{array}{r}4,457 \\
(66.7 \%)\end{array}$ \\
\hline
\end{tabular}

Note:

- All tables reporting totals could include some unreported characteristics

- Weekday is defined as the time between 12:01 a.m. Monday and 6:00 p.m. Friday. 


\section{TABLE 4.35}

\section{Number of Weekend Person Trips by Time of Day and Trip Purpose 1995 NPTS \\ (MILLIONS)}

\begin{tabular}{|c|c|c|c|c|c|c|c|c|}
\hline & TOTAL & $\begin{array}{l}\text { 1:00 a.m } \\
\text { to } \\
\text { 6:00 a.m. }\end{array}$ & $\begin{array}{l}\text { 6:00 a.m. } \\
\text { to } \\
\text { 9:00 a.m. }\end{array}$ & $\begin{array}{l}\text { 9:00 a.m. } \\
\text { to } \\
\text { 1:00 p.m. }\end{array}$ & $\begin{array}{l}\text { 1:00 p.m. } \\
\text { to } \\
\text { 4:00 p.m. }\end{array}$ & $\begin{array}{c}\text { 4:00 p.m. } \\
\text { to } \\
\text { 7:00 p.m. }\end{array}$ & $\begin{array}{c}\text { 7:00 p.m. } \\
\text { to } \\
\text { 10:00 p.m. }\end{array}$ & $\begin{array}{l}\text { 10:00 p.m. } \\
\text { to } \\
\text { 1:00 a.m. }\end{array}$ \\
\hline TOTAL & $\begin{array}{c}113,742 \\
(100.0 \%)\end{array}$ & $\begin{array}{r}1,499 \\
(100.0 \%)\end{array}$ & $\begin{array}{r}6,970 \\
(100.0 \%)\end{array}$ & $\begin{array}{r}29,820 \\
(100.0 \%)\end{array}$ & $\begin{array}{r}23,620 \\
(100.0 \%)\end{array}$ & $\begin{array}{r}25,711 \\
(100.0 \%)\end{array}$ & $\begin{array}{r}19,527 \\
(100.0 \%)\end{array}$ & $\begin{array}{r}6,580 \\
(100.0 \%)\end{array}$ \\
\hline $\begin{array}{c}\text { Earning a } \\
\text { Living }\end{array}$ & $\begin{array}{r}5,469 \\
(4.8 \%)\end{array}$ & $\begin{array}{r}339 \\
(22.6 \%)\end{array}$ & $\begin{array}{r}1,478 \\
(21.2 \%)\end{array}$ & $\begin{array}{r}1,440 \\
(4.8 \%)\end{array}$ & $\begin{array}{r}921 \\
(3.9 \%)\end{array}$ & $\begin{array}{r}717 \\
(2.8 \%)\end{array}$ & $\begin{array}{r}357 \\
(1.8 \%)\end{array}$ & $\begin{array}{r}213 \\
(3.2 \%)\end{array}$ \\
\hline $\begin{array}{l}\text { Family/ } \\
\text { Personal } \\
\text { Business }\end{array}$ & $\begin{array}{r}35,000 \\
(30.8 \%)\end{array}$ & $\begin{array}{r}257 \\
(17.1 \%)\end{array}$ & $\begin{array}{r}2,028 \\
(29.1 \%)\end{array}$ & $\begin{array}{r}11,342 \\
(38.0 \%)\end{array}$ & $\begin{array}{r}8,578 \\
(36.3 \%)\end{array}$ & $\begin{array}{r}7,323 \\
(28.5 \%)\end{array}$ & $\begin{array}{r}4,443 \\
(22.8 \%)\end{array}$ & $\begin{array}{r}1,028 \\
(15.6 \%)\end{array}$ \\
\hline $\begin{array}{l}\text { School/ } \\
\text { Church }\end{array}$ & $\begin{array}{r}4,842 \\
(4.3 \%)\end{array}$ & $\begin{array}{r}31 \\
(2.1 \%)\end{array}$ & $\begin{array}{r}977 \\
(14.0 \%)\end{array}$ & $\begin{array}{r}2,437 \\
(8.2 \%)\end{array}$ & $\begin{array}{r}424 \\
(1.8 \%)\end{array}$ & $\begin{array}{r}792 \\
(3.1 \%)\end{array}$ & $\begin{array}{r}166 \\
(0.9 \%)\end{array}$ & $\begin{array}{r}16 \\
(0.2 \%)\end{array}$ \\
\hline $\begin{array}{l}\text { Social/ } \\
\text { Rec. }\end{array}$ & $\begin{array}{c}27,265 \\
(24.0 \%)\end{array}$ & $\begin{array}{r}253 \\
(16.9 \%)\end{array}$ & $\begin{array}{r}1,449 \\
(20.8 \%)\end{array}$ & $\begin{array}{r}6,845 \\
(23.0 \%)\end{array}$ & $\begin{array}{r}5,641 \\
(23.9 \%)\end{array}$ & $\begin{array}{r}7,047 \\
(27.4 \%)\end{array}$ & $\begin{array}{r}5,046 \\
(25.8 \%)\end{array}$ & $\begin{array}{r}981 \\
(14.9 \%)\end{array}$ \\
\hline Other & $\begin{array}{r}225 \\
(0.2 \%)\end{array}$ & $\begin{array}{r}7 \\
(0.5 \%)\end{array}$ & $\begin{array}{r}3 \\
(0.0 \%)\end{array}$ & $\begin{array}{r}45 \\
(0.2 \%)\end{array}$ & $\begin{array}{r}27 \\
(0.1 \%)\end{array}$ & $\begin{array}{r}58 \\
(0.2 \%)\end{array}$ & $\begin{array}{r}56 \\
(0.3 \%)\end{array}$ & $\begin{array}{r}26 \\
(0.4 \%)\end{array}$ \\
\hline $\begin{array}{l}\text { Returning } \\
\text { Home }\end{array}$ & $\begin{array}{r}40,928 \\
(36.0 \%)\end{array}$ & $\begin{array}{r}613 \\
(40.9 \%)\end{array}$ & $\begin{array}{r}1,034 \\
(14.8 \%)\end{array}$ & $\begin{array}{r}7,712 \\
(25.9 \%)\end{array}$ & $\begin{array}{r}8,022 \\
(34.0 \%)\end{array}$ & $\begin{array}{r}9,774 \\
(38.0 \%)\end{array}$ & $\begin{array}{r}9,456 \\
(48.4 \%)\end{array}$ & $\begin{array}{r}4,315 \\
(65.6 \%)\end{array}$ \\
\hline
\end{tabular}

Note:

- All tables reporting totals could include some unreported characteristics

- Weekend is defined as the time between 6:01 p.m. Friday and midnight Sunday. 


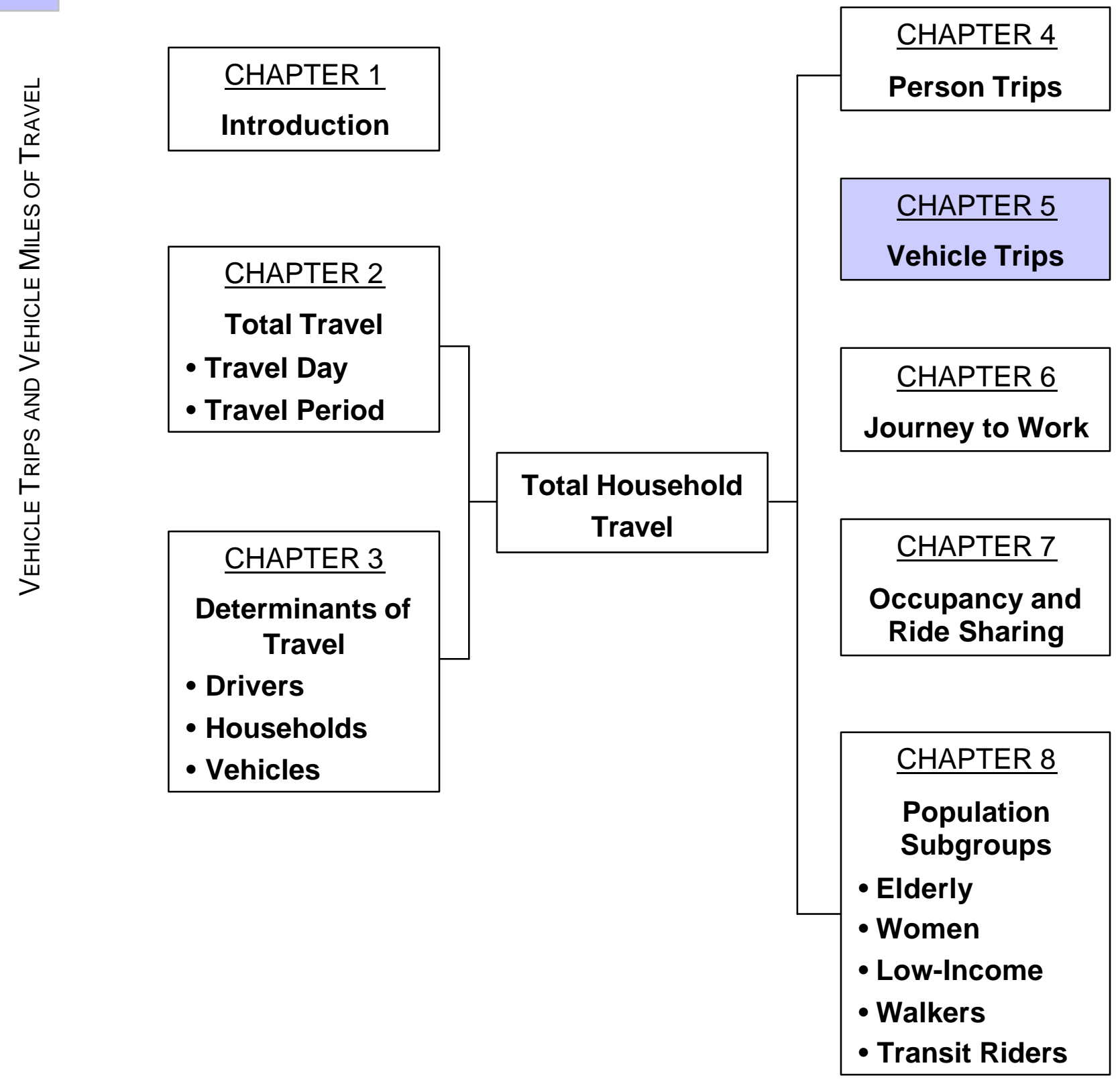




\section{Chapter 5}

\section{Vehicle Trips and Vehicle Miles of Travel}

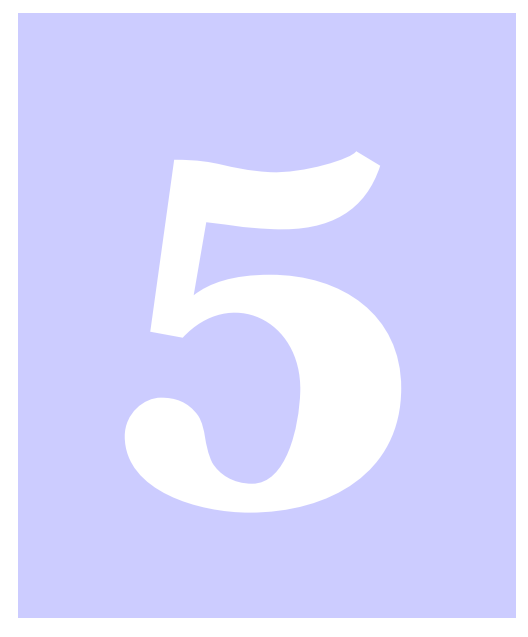

\section{IN 1995:}

- Within every age group, men took slightly more vehicle trips than women; in addition their trip lengths were also longer.

- Trip lengths were shorter for persons 65 or over than for any other age group.

- Persons who were employed spent an average of over an hour each day driving.

- Households with the least annual vehicle miles of travel were those of single, retired adults with no children; households with the greatest number of vehicle miles were those with two or more adults and a young child between the ages of 16 and 21 . 
(millions)
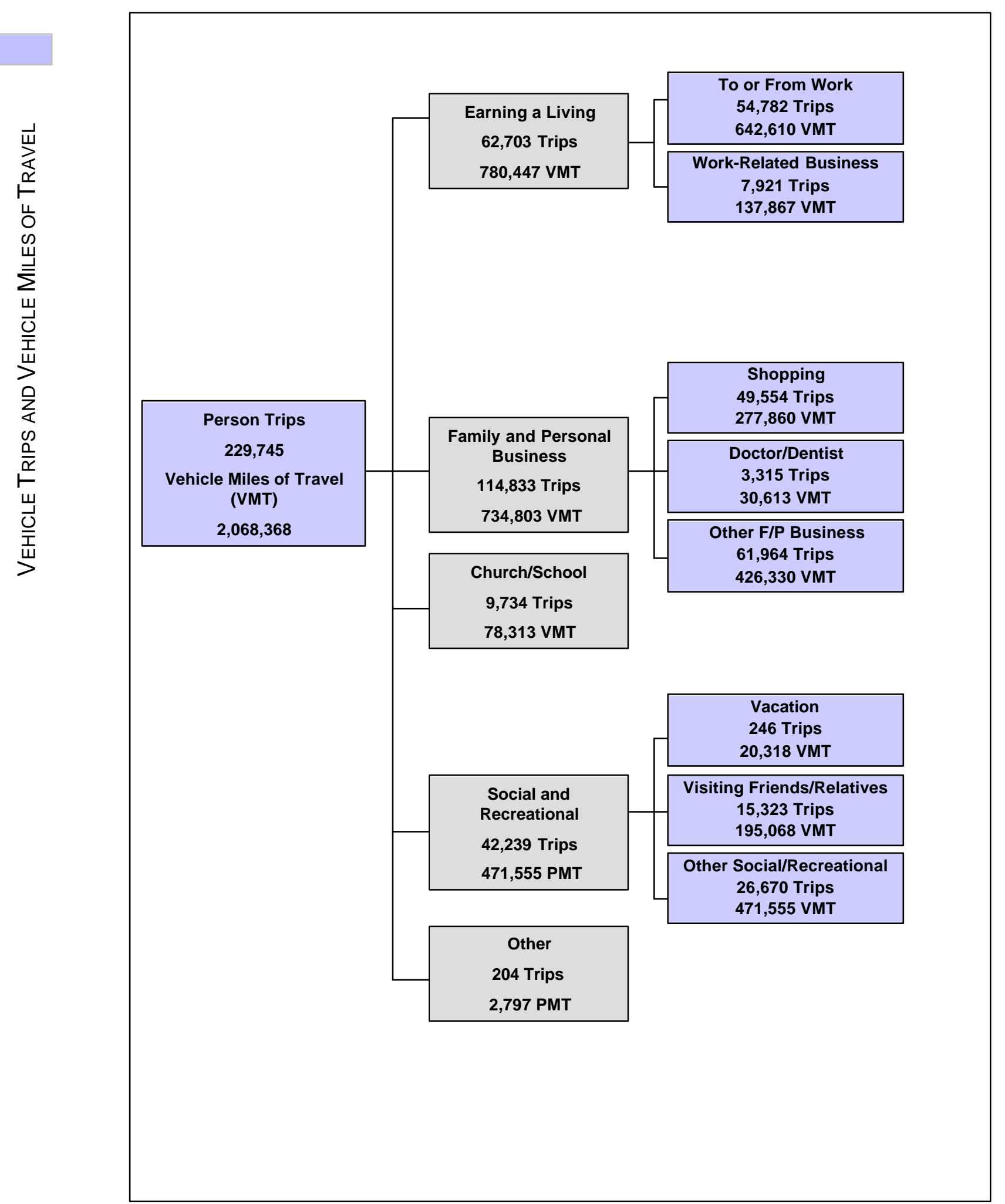


\section{List of Tables}

Table 5.1 Statistics on Vehicle Travel by Driver's Age and Gender 1995 NPTS . . 5-5

TABLE 5.2

Number of Vehicle Trips by Driver's Age, Gender, ANd TriP

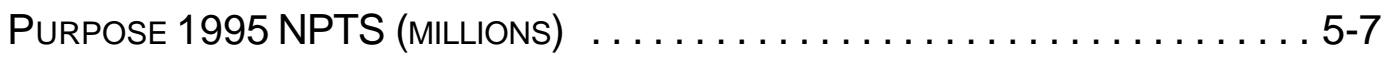

Table 5.3 Number of Vehicle TriPS by Driver's Age, Gender, And 1990 TriP PuRPOSE1995 NPTS (MILLIONS) ...................... 5

Table 5.4 Number of Vehicle Miles of Travel by Driver's Age, Gender, AND TRIP PuRPose 1995 NPTS (MILLIONS) .................... 5-11

Table 5.5 Number of Vehicle Miles of Travel by Driver's Age, Gender, AND 1990 TriP PuRPose 1995 NPTS (MILLIONS) $\ldots \ldots \ldots \ldots \ldots \ldots \ldots \ldots .12$

Table 5.6 Average Time Spent Driving a Privately Operated Vehicle in a Typical Dayby Age And Gender 1990 AdJusted AND 1995 NPTS $\ldots . .5$ 5-14

Table 5.7 Average Time (MinUtes) Spent Driving a Privately OWNed Vehicle In A TYPICAL Dayby EMPLOYMENT Status AND GENDER

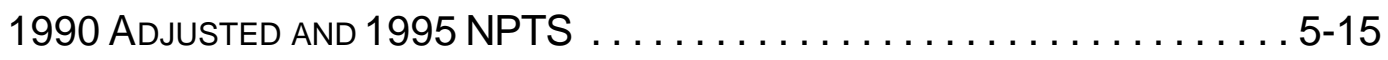

TABLE 5.8 Number OF VeHICle MILES OF TRAVEL by INDIVIDUALS 65 OR OLDER VS. INDIVIDUALS UNDER 65 AND TRIP PURPOSE 1995 NPTS (MILLIONS) . . . . 5-16

TABLE 5.9 AVERAGE LENGTH OF VEHICLE TRIPS (MILES) BY INDIVIDUALS 65 AND OLdER VS. INDIVIDUALS UNDER 65 BY TRIP PURPOSE 1995 NPTS ...... . 5-17

Table 5.10 Annual Vehicle Miles of Travel Per Household by Trip Purpose

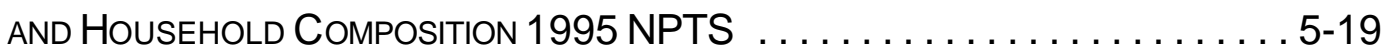

Table 5.11 Annual Vehicle Miles of Travel Per Household by 1990 Trip PuRPose ANd Household Composition 1995 NPTS ............. 5-20

Table 5.12 Statistics on Vehicle Travel Per Household by 1990 TriP PuRPoses 1969, 1977, 1983, 1990, 1990 AdJusted, AND 1995 NPTS . . 5-22

Table 5.13 Annual Vehicle Trips Per Household by 1990 Trip PuRPoses AND HOUSEHOLd INCOME 1990 AdJUSTED AND 1995 NPTS ........... 5-23

Table 5.14 Annual Vehicle Miles of Travel Per Household by 1990 TriP PuRPoses ANd Household INCOME 1990 AdJusted AND 1995 NPTS . . . . 5-24

Table 5.15 Statistics on Vehicle Travel by 1990 Trip Purposes 1969, 1977, 1983, 1990, 1990 ADJUSTED, AND 1995 NPTS . . . . . . . . . . . . 5-27

Table 5.16 Average VehICLE TriP Length by MSA Size AND 1990 TriP PuRPoses 1990 AdJusted AND 1995 NPTS $\ldots \ldots \ldots \ldots \ldots \ldots \ldots \ldots . \ldots \ldots$

Table 5.17 Average Vehicle Trip Length by Vehicle Type and Trip Purpose 1995 NPTS (MILES) ............................... 5-29

Table 5.18 Average Vehicle Trip Length by Vehicle Type and 1990 TriP PuRPose 1995 NPTS (MILES) ......................... 5-30

Table 5.19 Number of Vehicle Trips and VehicLe Miles of TRAVel by WeEkDAY Vs. WeEKEND 1990 AdJUSTED AND 1995 NPTS (MILLIONS) .... . 5-33

TABle 5.20 Number of WEEKDAY Vehicle TriPS BY Time OF DAY AND TRIP PURPOSE 1995 NPTS (MILLIONS) …................... 5-34

TABle 5.21 Number OF WEEKEND Vehicle Trips by Time of DaY AND TRIP

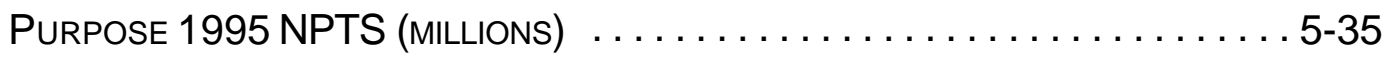


Table 5.22 Average Daily Vehicle Trips Per Driver Taken by Individuals 65 OR OLDER VS. INDIVIDUALS UNDER 65 BY DAY OF WEEK 1995 NPTS . . . . . . 5-37

Table 5.23 Number of Vehicle Trips by MSA Size And Time of Day 1995

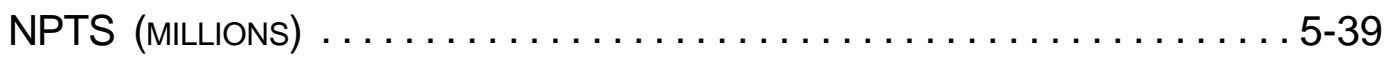

\section{LIST OF FIGURES}

Figure 5.1 Vehicle Trips (Lines) and AVERAGe Trip Lengths (BarS) By Driver's

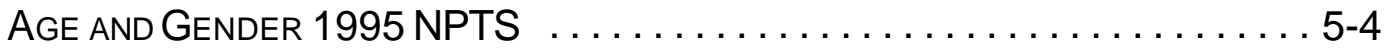

Figure 5.2 Distribution of Vehicle Trips by Trip Purpose ANd Gender 1995 NPTS ................................ 5 5

Figure 5.3 Distribution of Vehicle Trips by Trip PurPose AND Driver's Age

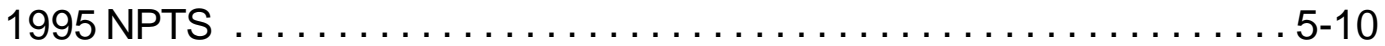

Figure 5.4 AVERAGE TIME (MINUTES) SPENT DRIVING, PER DAY, BY EMPLOYMENT

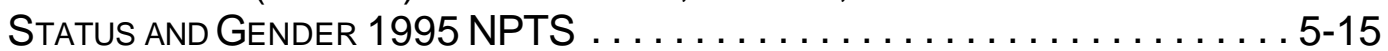

Figure 5.5 Annual Vehicle Miles of Travel Per Household by Trip Purpose AND HOUSEHOLD COMPOSITION 1995 NPTS ................... 5-21

Figure 5.6 AnNual Vehicle Trips Per Household by 1990 Trip Purposes and HOUSEHOLD INCOME 1990 AdJUSTED AND 1995 NPTS ............ 5-25

Figure 5.7 Annual Vehicle Miles of Travel Per Household by 1990 Trip PuRPoses 1990 AdJusted ANd 1995 NPTS . . . . . . . . . . . . . . 5-25

Figure 5.8 Average VehicLe Trip Length by VehicLe Type and Trip Purpose and Total Annual Vehicle Miles by Vehicle Type and Trip PURPOSE 1995 NPTS .............................. 5-31

Figure 5.9 Distribution OF TRIPS OVER WEEKDAYS AND WEEKENDS BY TRIP PURPOSE 1995 NPTS . .............................. 5-36

Figure 5.10 AVERAGE DaILY VeHICLE TRIPS PER DRIVER TAKEN By INDIVIDUALS 65 OR OLDER VS. INDIVIDUALS UNDER 65 BY DAY OF WEEK 1995 NPTS . . . . . . 5-38

Figure 5.11 AVERAGE VEHICLE TRIPS PER DRIVER TAKEN BY INDIVIDUALS 65 OR OLDER VS. INDIVIDUALS UNDER 65 BY TIME OF DAY 1995 NPTS . . $5-38$ 


\section{Chapter 5 Vehicle Trips and Vehicle Miles of Travel}

$\mathrm{S}$ TATISTICS on vehicle trips and vehicle miles of travel (VMT) are presented in this chapter. A vehicle trip is a trip by a single vehicle regardless of the number of people in the vehicle. Since the first NPTS was conducted in 1969, the number of vehicle trips taken each year has increased $163 \%$ - from 87,284 million in 1969 to 229,745 million in 1995. Other vehicle characteristics have also seen major increases; for example, the number of household vehicles has increased almost $143 \%$. Some vehicle and vehicle trip characteristics have not seen major changes, however. The average length of a vehicle trip in 1995, for example, was about 9 miles, which was about the same length as it was in 1969. Many of the changes in vehicle travel are shown in the chart below, which also presents an overview of changes in driver licensing demographics during the NPTS timeframes.

\begin{tabular}{|c|c|c|c|c|c|c|}
\hline & 1969 & 1977 & 1983 & 1990 & 1995 & $\begin{array}{c}\text { Percent } \\
\text { change, } \\
69-95\end{array}$ \\
\hline $\begin{array}{l}\text { Licensed Drivers } \\
\text { (000), TOTAL }\end{array}$ & 102,986 & 127,552 & 147,015 & 163,025 & 176,330 & $71.2 \%$ \\
\hline $\begin{array}{c}\text { - Licensed Drivers } \\
\text { (000), Male }\end{array}$ & 57,981 & 66,199 & 75,639 & 80,289 & 88,480 & $52.6 \%$ \\
\hline $\begin{array}{l}\text { - Licensed Drivers } \\
(000), \text { Female }\end{array}$ & 45,005 & 61,353 & 71,376 & 82,707 & 87,851 & $95.2 \%$ \\
\hline $\begin{array}{l}\text { Household vehicles } \\
\quad(000)\end{array}$ & 72,500 & 120,098 & 143,714 & 165,221 & 176,067 & $142.9 \%$ \\
\hline $\begin{array}{l}\text { Household Vehicle } \\
\text { Trips }(000,000)\end{array}$ & 87,284 & 108,826 & 126,874 & 158,927 & 229,745 & $163.2 \%$ \\
\hline $\begin{array}{l}\text { Household VMT } \\
(000,000)\end{array}$ & 775,940 & 907,603 & $1,002,139$ & $1,409,600$ & $2,068,368$ & $166.6 \%$ \\
\hline
\end{tabular}

As noted by Pickrell and Schimek, household vehicle use (as measured by annual VMT per driver or by annual VMT per vehicle) decreased slightly between the 1990 and 1995 surveys. The growth in overall VMT is due primarily to the aging of America, which results in more people of driving age, as well as slight increases in licensing and in population. ${ }^{1}$

\footnotetext{
${ }^{1}$ Pickrell, Don, and Paul Schimek, "Trends in Personal Motor Vehicle Ownership and Use; Evidence from the Nationwide Personal Transportation Survey," 1995 NPTS website publication, http://wwwcta.ornl.gov/npts/1995/Doc/Envecon.pdf , pp. 9-10.
} 
According to the 1995 NPTS, female drivers took $11.6 \%$ fewer vehicle trips than men and drove $40 \%$ fewer vehicle miles. The average trip length for females was 7.25 miles, 3.4 miles shorter than the average trip for males. Drivers who were ages 30-39 took more vehicle trips and drove more vehicle miles than any other age group. The average trip length for age groups 20-59 was over 9 miles long, while it was less than 9 miles for all other age groups.

Women took fewer vehicle trips than men for trip purposes of earning a living, social/recreational, other, and returning home, but more for family/personal business and school/church. Men of all ages spent more average time than women driving a vehicle in a typical day. Employed persons spent more time driving than unemployed persons spent.

Although individuals 65 and over took slightly more than $10 \%$ of all person trips (see Tables 4.9 and 4.10 ) and $11.3 \%$ of all vehicle trips, they drove only $8.4 \%$ of all vehicle miles. Trip lengths were shorter for persons 65 and over than for any other age group.

\subsection{HOUSEHOLD Characteristics}

Overall household vehicle travel has increased since 1969 , total household trips by $66.3 \%$ and household VMT by $68.2 \%$. Trips for family/personal business have seen the greatest increase while trips for school/church have actually decreased. The greatest increase in household VMT was for family/personal business, and the least increase was for social/recreational purposes, which may imply that more household trips for social/recreational purposes are being taken via modes other than household vehicles.

Households with children have much higher VMT levels than households without children. For households with two or more adults, the trip purpose (other than returning home) with the greatest VMT was earning a living; for households with one adult, the trip purpose with the greatest VMT was family/personal business.

Overall household vehicle trips and household VMT levels increased slightly between 1990 (adjusted) and 1995. Annual vehicle trips decreased for all income levels except $\$ 10,000-20,000, \$ 20,000-30,000$, and $\$ 30,000-40,000$, which saw slight increases. Between 1990 (adjusted) and 1995, household VMT decreased for the lowest and highest income levels (i.e., less than $\$ 10,000$ and over $\$ 60,000)$.

In a study of the impact of low income on travel, Murakami and Young defined lowincome households as 1-2 persons with a household income less than $\$ 10,000,3-4$ persons with a household income less than $\$ 20,000$, or 5+ persons with a household income less than $\$ 30,000$. They determined that $26 \%$ of low-income households do not have a car and that low-income households average only 0.7 vehicles per adult while households above the poverty level average over one vehicle per adult. Therefore, lowincome household trips are more likely to be taken in a vehicle owned by someone else. ${ }^{2}$

\footnotetext{
${ }^{2}$ Murakami, Elaine, and Jennifer Young, "Daily Travel by Persons with Low Income," 1995 NPTS website publication, http://wwwcta.ornl.gov/npts/1995/Doc/LowInc.pdf, p. 1.
} 
Household vehicle trips increased by $182 \%$ between 1969 and 1995. The trip purpose family/personal business saw the greatest increase.

Between the 1990 (adjusted) NPTS and the 1995 NPTS, the average vehicle trip length increased very little - from 8.85 miles to 9.06 miles. In 1995, the longest average trip length was for work-related business, and the longest average trip length was taken by persons living outside of a Metropolitan Statistical Area.

When looking at trips by vehicle type, the category of other truck had the greatest average trip length for trip purposes of earning a living, family/personal business, other, and returning home. The category recreational vehicle $(\mathrm{RV})$ had the greatest average trip length - over 71 miles.

\subsection{TEMPORAL Characteristics}

Between 1990 (adjusted) and 1995, greater increases occurred in the number of weekday trips and weekday VMT than weekends. Most weekday vehicle trips (86.5\%) were taken between 6 a.m. and 7 p.m. Most weekend vehicle trips $(85.3 \%)$ were taken between 9 a.m. and 10 p.m. (i.e., 3 hours later in the day).

Individuals 65 and over took more trips through the week than on Saturday or Sunday. They also took fewer trips overall than did individuals under 65. 
A new trip purpose category was added to the 1995 survey to assist in coding to-from trips.

The new category, which designates returning to the respondent's residence as the trip purpose, represented about a third of all vehicle trips.

Figure 5.1 and Table 5.1 compare the vehicle trips and average trip lengths by gender for different age groups. Males of all age groups took more vehicle trips and drove more vehicle miles than females of the same age groups. Overall, the average trip length for males was $46.9 \%$ longer than for females. Between the ages of 20 and 60, the differences between males and females with respect to trip length were even greater than at other ages. As shown in Table 5.1, the percentage of female licensed drivers in 1995 was almost equal to that of males.

\section{FIGURE 5.1}

Vehicle Trips (LINES) ANd Average TRIP LENGThs (BARs) BY

DRIVER's AGE AND GENDER

1995 NPTS

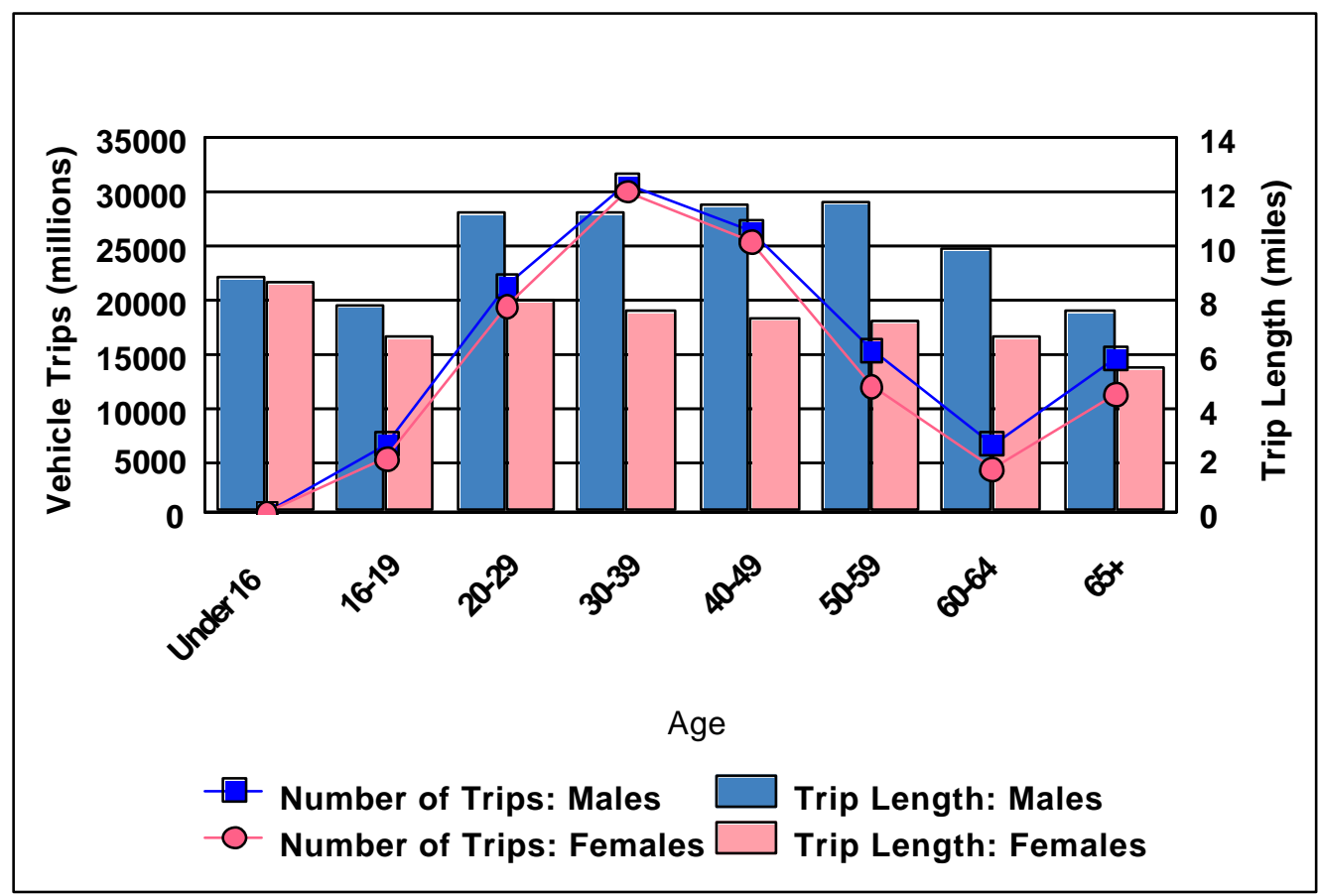




\section{TABLE 5.1}

\section{Statistics on Vehicle Travel by Driver's Age and Gender 1995 NPTS}

\begin{tabular}{|c|c|c|c|c|c|c|}
\hline Age & $\begin{array}{c}\text { Licensed Drivers } \\
(\%)\end{array}$ & \multicolumn{2}{|c|}{$\begin{array}{c}\text { Vehicle Trips } \\
(000,000)\end{array}$} & \multicolumn{2}{|c|}{$\begin{array}{l}\text { Vehicle Miles of Travel } \\
(000,000)\end{array}$} & $\begin{array}{l}\text { Average Trip } \\
\text { Length (miles) }\end{array}$ \\
\hline \multicolumn{7}{|l|}{ TOTAL } \\
\hline & 100.00 & 229,745 & $100.0 \%$ & $2,068,368$ & $100.0 \%$ & 9.06 \\
\hline \multicolumn{7}{|c|}{ TOTAL MALE } \\
\hline & 50.18 & 121,969 & $53.1 \%$ & $1,292,688$ & $62.5 \%$ & 10.65 \\
\hline \multicolumn{7}{|c|}{ TOTAL FEMALE } \\
\hline & 49.82 & 107,776 & $46.9 \%$ & 775,680 & $37.5 \%$ & 7.25 \\
\hline \multicolumn{7}{|l|}{ Under 16} \\
\hline TOTAL & 0.00 & 201 & $0.1 \%$ & 1,751 & $0.1 \%$ & 8.73 \\
\hline Male & 0.00 & 124 & $0.1 \%$ & 1,094 & $0.1 \%$ & 8.80 \\
\hline Female & 0.00 & 76 & $0.0 \%$ & 656 & $0.0 \%$ & 8.63 \\
\hline \multicolumn{7}{|l|}{$16-19$} \\
\hline TOTAL & 5.57 & 11,866 & $5.2 \%$ & 85,137 & $4.1 \%$ & 7.23 \\
\hline Male & 2.99 & 6,595 & $2.9 \%$ & 50,419 & $2.4 \%$ & 7.69 \\
\hline Female & 2.57 & 5,271 & $2.3 \%$ & 34,718 & $1.7 \%$ & 6.64 \\
\hline \multicolumn{7}{|l|}{$20-29$} \\
\hline TOTAL & 18.09 & 40,722 & $17.7 \%$ & 391,658 & $18.9 \%$ & 9.70 \\
\hline Male & 9.20 & 21,522 & $9.4 \%$ & 239,479 & $11.6 \%$ & 11.20 \\
\hline Female & 8.89 & 19,200 & $8.4 \%$ & 152,179 & $7.4 \%$ & 8.01 \\
\hline \multicolumn{7}{|l|}{$30-39$} \\
\hline TOTAL & 24.67 & 60,906 & $26.5 \%$ & 572,386 & $27.7 \%$ & 9.46 \\
\hline Male & 12.34 & 30,627 & $13.3 \%$ & 343,502 & $16.6 \%$ & 11.28 \\
\hline Female & 12.33 & 30,279 & $13.2 \%$ & 228,884 & $11.1 \%$ & 7.62 \\
\hline \multicolumn{7}{|l|}{$40-49$} \\
\hline TOTAL & 20.31 & 51,776 & $22.5 \%$ & 486,976 & $23.5 \%$ & 9.45 \\
\hline Male & 10.15 & 26,457 & $11.5 \%$ & 302,927 & $14.6 \%$ & 11.49 \\
\hline Female & 10.16 & 25,319 & $11.0 \%$ & 184,049 & $8.9 \%$ & 7.31 \\
\hline \multicolumn{7}{|l|}{$50-59$} \\
\hline TOTAL & 12.63 & 27,422 & $11.9 \%$ & 264,867 & $12.8 \%$ & 9.72 \\
\hline Male & 6.29 & 15,354 & $6.7 \%$ & 178,130 & $8.6 \%$ & 11.65 \\
\hline Female & 6.34 & 12,067 & $5.3 \%$ & 86,737 & $4.2 \%$ & 7.25 \\
\hline \multicolumn{7}{|l|}{$60-64$} \\
\hline TOTAL & 5.01 & 10,877 & $4.7 \%$ & 92,813 & $4.5 \%$ & 8.60 \\
\hline Male & 2.58 & 6,632 & $2.9 \%$ & 65,049 & $3.1 \%$ & 9.86 \\
\hline Female & 2.42 & 4,245 & $1.8 \%$ & 27,764 & $1.3 \%$ & 6.61 \\
\hline \multicolumn{7}{|l|}{$65+$} \\
\hline TOTAL & 13.73 & 25,976 & $11.3 \%$ & 172,781 & $8.4 \%$ & 6.69 \\
\hline Male & 6.62 & 14,657 & $6.4 \%$ & 112,089 & $5.4 \%$ & 7.67 \\
\hline Female & 7.11 & 11,319 & $4.9 \%$ & 60,692 & $2.9 \%$ & 5.41 \\
\hline
\end{tabular}

Note:

- All tables reporting totals could include some unreported characteristics.

- Average Trip Length is calculated using only those records with trip mileage information present.

- Some states issue learner permits to individuals at age 14 or 15 . The "under 16 " category reflects these drivers. 
Tables 5.2 and 5.3 provide data on vehicle trips by driver's age, gender, and trip purpose. (Table 5.2 data is based on 1995 trip purposes, and Table 5.3 is based on 1990 trip purpose codes.) For males ages 20-59, about half of all trips were for earning a living or family/personal business, with family/personal business trips being a few percentage points higher. For females of all age groups, most vehicle trips (almost $40 \%$ overall) were for family/personal business. After age 65, over $46 \%$ of all vehicle trips taken by females were for family/personal business. For males under age 16 , more trips (29\%) were taken for a social/recreational purpose than any other purpose (except returning home).
The distribution of trips by trip purpose between men drivers and women drivers is shown in Figure 5.2.

Figure 5.3 breaks this distribution down into vehicle trips by trip purpose and driver's age.

Tables 5.4 and 5.5 show number of vehicle miles traveled by age and gender based on 1995 and 1990 trip purposes, respectively. About a third of all miles in 1995 used the new trip purpose code for returning home. 
TABLE 5.2

Number of Vehicle Trips by Driver's Age, Gender, ANd Trip Purpose 1995 NPTS

(MILLIONS)

\begin{tabular}{|c|c|c|c|c|c|c|c|}
\hline & TOTAL & $\begin{array}{l}\text { Earning a } \\
\text { Living }\end{array}$ & $\begin{array}{l}\text { Family/ } \\
\text { Personal } \\
\text { Business }\end{array}$ & School/ Church & $\begin{array}{c}\text { Social/ } \\
\text { Recreational } \\
\end{array}$ & Other & $\begin{array}{c}\text { Returning } \\
\text { Home }\end{array}$ \\
\hline \multicolumn{8}{|l|}{ Male } \\
\hline ALL & $\begin{array}{c}121,969 \\
(100.0 \%)\end{array}$ & $\begin{array}{c}24,901 \\
(20.4 \%)\end{array}$ & $\begin{array}{c}35,787 \\
(29.3 \%)\end{array}$ & $\begin{array}{c}2,668 \\
(2.2 \%)\end{array}$ & $\begin{array}{c}17,089 \\
(14.0 \%)\end{array}$ & $\begin{array}{c}116 \\
(0.1 \%)\end{array}$ & $\begin{array}{c}41,392 \\
(33.9 \%)\end{array}$ \\
\hline Under 16 & $\begin{array}{c}124 \\
(100.0 \%)\end{array}$ & $\begin{array}{c}8 \\
(6.5 \%)\end{array}$ & $\begin{array}{c}22 \\
(17.7 \%)\end{array}$ & $\begin{array}{c}9 \\
(7.3 \%)\end{array}$ & $\begin{array}{c}36 \\
(29.0 \%)\end{array}$ & $* *$ & $\begin{array}{c}50 \\
(40.3 \%)\end{array}$ \\
\hline $16-19$ & $\begin{array}{c}6,595 \\
(100.0 \%)\end{array}$ & $\begin{array}{c}761 \\
(11.5 \%)\end{array}$ & $\begin{array}{c}1,583 \\
(24.0 \%)\end{array}$ & $\begin{array}{c}501 \\
(7.6 \%)\end{array}$ & $\begin{array}{c}1,381 \\
(20.9 \%)\end{array}$ & $\begin{array}{c}3 \\
(0.0 \%)\end{array}$ & $\begin{array}{c}2,365 \\
(35.9 \%)\end{array}$ \\
\hline $20-29$ & $\begin{array}{c}21,522 \\
(100.0 \%)\end{array}$ & $\begin{array}{c}4,731 \\
(22.0 \%)\end{array}$ & $\begin{array}{c}5,374 \\
(25.0 \%)\end{array}$ & $\begin{array}{c}648 \\
(3.0 \%)\end{array}$ & $\begin{array}{c}3,428 \\
(15.9 \%)\end{array}$ & $\begin{array}{c}17 \\
(0.1 \%)\end{array}$ & $\begin{array}{c}7,324 \\
(34.0 \%)\end{array}$ \\
\hline $30-39$ & $\begin{array}{c}30,627 \\
(100.0 \%)\end{array}$ & $\begin{array}{c}7,495 \\
(24.5 \%)\end{array}$ & $\begin{array}{c}8,390 \\
(27.4 \%)\end{array}$ & $\begin{array}{c}393 \\
(1.3 \%)\end{array}$ & $\begin{array}{c}4,038 \\
(13.2 \%)\end{array}$ & $\begin{array}{c}26 \\
(0.1 \%)\end{array}$ & $\begin{array}{c}10,285 \\
(33.6 \%)\end{array}$ \\
\hline $40-49$ & $\begin{array}{c}26,457 \\
(100.0 \%)\end{array}$ & $\begin{array}{c}6,478 \\
(24.5 \%)\end{array}$ & $\begin{array}{c}7,691 \\
(29.1 \%)\end{array}$ & $\begin{array}{c}411 \\
(1.6 \%)\end{array}$ & $\begin{array}{c}3,191 \\
(12.1 \%)\end{array}$ & $\begin{array}{c}19 \\
(0.1 \%)\end{array}$ & $\begin{array}{c}8,660 \\
(32.7 \%)\end{array}$ \\
\hline $50-59$ & $\begin{array}{c}15,354 \\
(100.0 \%)\end{array}$ & $\begin{array}{c}3,416 \\
(22.2 \%)\end{array}$ & $\begin{array}{c}4,534 \\
(29.5 \%)\end{array}$ & $\begin{array}{c}227 \\
(1.5 \%)\end{array}$ & $\begin{array}{c}1,934 \\
(12.6 \%)\end{array}$ & $\begin{array}{c}32 \\
(0.2 \%)\end{array}$ & $\begin{array}{c}5,211 \\
(33.9 \%)\end{array}$ \\
\hline $60-64$ & $\begin{array}{c}6,632 \\
(100.0 \%)\end{array}$ & $\begin{array}{c}1,055 \\
(15.9 \%)\end{array}$ & $\begin{array}{c}2,317 \\
(34.9 \%)\end{array}$ & $\begin{array}{c}131 \\
(2.0 \%)\end{array}$ & $\begin{array}{c}849 \\
(12.8 \%)\end{array}$ & $\begin{array}{c}4 \\
(0.1 \%)\end{array}$ & $\begin{array}{c}2,275 \\
(34.3 \%)\end{array}$ \\
\hline $65+$ & $\begin{array}{c}14,657 \\
(100.0 \%)\end{array}$ & $\begin{array}{c}956 \\
(6.5 \%)\end{array}$ & $\begin{array}{c}5,876 \\
(40.1 \%)\end{array}$ & $\begin{array}{c}348 \\
(2.4 \%)\end{array}$ & $\begin{array}{c}2,232 \\
(15.2 \%)\end{array}$ & $\begin{array}{c}15 \\
(0.1 \%)\end{array}$ & $\begin{array}{c}5,223 \\
(35.6 \%)\end{array}$ \\
\hline \multicolumn{8}{|l|}{ Female } \\
\hline ALL & $\begin{array}{c}107,776 \\
(100.0 \%)\end{array}$ & $\begin{array}{c}15,184 \\
(14.1 \%)\end{array}$ & $\begin{array}{c}42,331 \\
(39.3 \%)\end{array}$ & $\begin{array}{c}2,840 \\
(2.6 \%)\end{array}$ & $\begin{array}{c}11,706 \\
(10.9 \%)\end{array}$ & $\begin{array}{c}79 \\
(0.1 \%)\end{array}$ & $\begin{array}{c}35,634 \\
(33.1 \%)\end{array}$ \\
\hline Under 16 & $\begin{array}{c}76 \\
(100.0 \%)\end{array}$ & $\begin{array}{c}8 \\
(10.5 \%)\end{array}$ & $\begin{array}{c}18 \\
(23.7 \%)\end{array}$ & $\begin{array}{c}10 \\
(13.2 \%)\end{array}$ & $\begin{array}{c}11 \\
(14.5 \%)\end{array}$ & $* *$ & $\begin{array}{c}29 \\
(38.2 \%)\end{array}$ \\
\hline $16-19$ & $\begin{array}{c}5,271 \\
(100.0 \%)\end{array}$ & $\begin{array}{c}529 \\
(10.0 \%)\end{array}$ & $\begin{array}{c}1,525 \\
(28.9 \%)\end{array}$ & $\begin{array}{c}479 \\
(9.1 \%)\end{array}$ & $\begin{array}{c}913 \\
(17.3 \%)\end{array}$ & $\begin{array}{c}8 \\
(0.2 \%)\end{array}$ & $\begin{array}{c}1,816 \\
(34.5 \%)\end{array}$ \\
\hline $20-29$ & $\begin{array}{c}19,200 \\
(100.0 \%)\end{array}$ & $\begin{array}{c}3,171 \\
(16.5 \%)\end{array}$ & $\begin{array}{c}6,773 \\
(35.3 \%)\end{array}$ & $\begin{array}{c}614 \\
(3.2 \%)\end{array}$ & $\begin{array}{c}2,218 \\
(11.6 \%)\end{array}$ & $\begin{array}{c}21 \\
(0.1 \%)\end{array}$ & $\begin{array}{c}6,403 \\
(33.3 \%)\end{array}$ \\
\hline $30-39$ & $\begin{array}{c}30,279 \\
(100.0 \%)\end{array}$ & $\begin{array}{c}4,605 \\
(15.2 \%)\end{array}$ & $\begin{array}{c}12,416 \\
(41.0 \%)\end{array}$ & $\begin{array}{c}580 \\
(1.9 \%)\end{array}$ & $\begin{array}{c}2,970 \\
(9.8 \%)\end{array}$ & $\begin{array}{c}28 \\
(0.1 \%)\end{array}$ & $\begin{array}{c}9,680 \\
(32.0 \%)\end{array}$ \\
\hline $40-49$ & $\begin{array}{c}25,319 \\
(100.0 \%)\end{array}$ & $\begin{array}{c}4,076 \\
(16.1 \%)\end{array}$ & $\begin{array}{c}10,049 \\
(39.7 \%)\end{array}$ & $\begin{array}{c}446 \\
(1.8 \%)\end{array}$ & $\begin{array}{c}2,384 \\
(9.4 \%)\end{array}$ & $\begin{array}{c}9 \\
(0.0 \%)\end{array}$ & $\begin{array}{c}8,354 \\
(33.0 \%)\end{array}$ \\
\hline $50-59$ & $\begin{array}{c}12,067 \\
(100.0 \%)\end{array}$ & $\begin{array}{c}1,923 \\
(15.9 \%)\end{array}$ & $\begin{array}{c}4,538 \\
(37.6 \%)\end{array}$ & $\begin{array}{c}265 \\
(2.2 \%)\end{array}$ & $\begin{array}{c}1,292 \\
(10.7 \%)\end{array}$ & $\begin{array}{c}4 \\
(0.0 \%)\end{array}$ & $\begin{array}{c}4,045 \\
(33.5 \%)\end{array}$ \\
\hline $60-64$ & $\begin{array}{c}4,245 \\
(100.0 \%)\end{array}$ & $\begin{array}{c}441 \\
(10.4 \%)\end{array}$ & $\begin{array}{c}1,782 \\
(42.0 \%)\end{array}$ & $\begin{array}{c}90 \\
(2.1 \%)\end{array}$ & $\begin{array}{c}494 \\
(11.6 \%)\end{array}$ & $\begin{array}{c}5 \\
(0.1 \%)\end{array}$ & $\begin{array}{c}1,434 \\
(33.8 \%)\end{array}$ \\
\hline $65+$ & $\begin{array}{c}11,319 \\
(100.0 \%)\end{array}$ & $\begin{array}{c}431 \\
(3.8 \%)\end{array}$ & $\begin{array}{c}5,231 \\
(46.2 \%)\end{array}$ & $\begin{array}{c}357 \\
(3.2 \%)\end{array}$ & $\begin{array}{c}1,422 \\
(12.6 \%)\end{array}$ & $\begin{array}{c}4 \\
(0.0 \%)\end{array}$ & $\begin{array}{c}3,874 \\
(34.2 \%)\end{array}$ \\
\hline
\end{tabular}

Note:

- All tables reporting totals could include some unreported characteristics.

- Some states issue learner permits to individuals at age 14 or 15 . The "under 16" category reflects these drivers.

- ** Indicates no data available. 


\section{TABLE 5.3}

\section{Number of Vehicle Trips by Driver's Age, Gender, ANd 1990 Trip PuRpose 1995 NPTS}

(MILLIONS)

\begin{tabular}{|c|c|c|c|c|c|c|}
\hline & TOTAL & $\begin{array}{l}\text { Earning a } \\
\text { Living }\end{array}$ & $\begin{array}{l}\text { Family/ } \\
\text { Personal } \\
\text { Business }\end{array}$ & $\begin{array}{l}\text { School/ } \\
\text { Church }\end{array}$ & $\begin{array}{c}\text { Social/ } \\
\text { Recreational }\end{array}$ & Other \\
\hline \multicolumn{7}{|l|}{ Male } \\
\hline ALL & $\begin{array}{c}121,969 \\
(100.0 \%)\end{array}$ & $\begin{array}{c}37,922 \\
(31.1 \%)\end{array}$ & $\begin{array}{c}54,157 \\
(44.4 \%)\end{array}$ & $\begin{array}{c}4,725 \\
(3.9 \%)\end{array}$ & $\begin{array}{l}25,025 \\
(20.5 \%)\end{array}$ & $\begin{array}{c}112 \\
(0.1 \%)\end{array}$ \\
\hline \multirow[t]{2}{*}{ Under 16} & 124 & 15 & 38 & 17 & 55 & $* *$ \\
\hline & $(100.0 \%)$ & $(12.1 \%)$ & $(30.6 \%)$ & $(13.7 \%)$ & $(44.4 \%)$ & \\
\hline \multirow[t]{2}{*}{$16-19$} & 6,595 & 1,297 & 2,331 & 918 & 2,046 & 3 \\
\hline & $(100.0 \%)$ & $(19.7 \%)$ & $(35.3 \%)$ & $(13.9 \%)$ & $(31.0 \%)$ & $(0.0 \%)$ \\
\hline $20-29$ & 21,522 & $\begin{array}{l}7,446 \\
(34,6 \%)\end{array}$ & 8,051 & 1,098 & 4,909 & 16 \\
\hline \multirow[t]{2}{*}{$30-39$} & 30,627 & 11,419 & 12,745 & 670 & 5,768 & 25 \\
\hline & $(100.0 \%)$ & $(37.3 \%)$ & $(41.6 \%)$ & $(2.2 \%)$ & $(18.8 \%)$ & $(0.1 \%)$ \\
\hline \multirow[t]{2}{*}{$40-49$} & 26,457 & 9,571 & 11,583 & 734 & 4,536 & 20 \\
\hline & $(100.0 \%)$ & $(36.2 \%)$ & $(43.8 \%)$ & $(2.8 \%)$ & $(17.1 \%)$ & $(0.1 \%)$ \\
\hline \multirow[t]{2}{*}{$50-59$} & 15,354 & 5,158 & 6,976 & 408 & 2,784 & 27 \\
\hline & $(100.0 \%)$ & $(33.6 \%)$ & $(45.4 \%)$ & $(2.7 \%)$ & $(18.1 \%)$ & $(0.2 \%)$ \\
\hline \multirow[t]{2}{*}{$60-64$} & 6,632 & 1,543 & 3,558 & 231 & 1,293 & 5 \\
\hline & $(100.0 \%)$ & $(23.3 \%)$ & $(53.6 \%)$ & $(3.5 \%)$ & $(19.5 \%)$ & $(0.1 \%)$ \\
\hline \multirow[t]{2}{*}{$65+$} & 14,657 & 1,472 & 8,876 & 650 & 3,635 & 15 \\
\hline & $(100.0 \%)$ & $(10.0 \%)$ & $(60.6 \%)$ & $(4.4 \%)$ & $(24.8 \%)$ & $(0.1 \%)$ \\
\hline \multicolumn{7}{|l|}{ Female } \\
\hline \multirow[t]{2}{*}{ ALL } & 107,776 & 24,781 & 60,677 & 5,009 & 17,213 & 92 \\
\hline & $(100.0 \%)$ & $(23.0 \%)$ & $(56.3 \%)$ & $(4.6 \%)$ & $(16.0 \%)$ & $(0.1 \%)$ \\
\hline \multirow[t]{2}{*}{ Under 16} & 76 & 13 & 31 & 19 & 14 & $* *$ \\
\hline & $(100.0 \%)$ & $(17.1 \%)$ & $(40.8 \%)$ & $(25.0 \%)$ & $(18.4 \%)$ & \\
\hline \multirow[t]{2}{*}{$16-19$} & 5,271 & 958 & 2,114 & 845 & 1,339 & 12 \\
\hline & $(100.0 \%)$ & $(18.2 \%)$ & $(40.1 \%)$ & $(16.0 \%)$ & $(25.4 \%)$ & $(0.2 \%)$ \\
\hline \multirow[t]{2}{*}{$20-29$} & 19,200 & 5,235 & 9,694 & 1,069 & 3,180 & 22 \\
\hline & $(100.0 \%)$ & $(27.3 \%)$ & $(50.5 \%)$ & $(5.6 \%)$ & $(16.6 \%)$ & $(0.1 \%)$ \\
\hline \multirow[t]{2}{*}{$30-39$} & 30,279 & 7,383 & 17,633 & 1,016 & 4,214 & 34 \\
\hline & $(100.0 \%)$ & $(24.4 \%)$ & $(58.2 \%)$ & $(3.4 \%)$ & $(13.9 \%)$ & $(0.1 \%)$ \\
\hline \multirow[t]{2}{*}{$40-49$} & 25,319 & 6,567 & 14,491 & 786 & 3,464 & 11 \\
\hline & $(100.0 \%)$ & $(25.9 \%)$ & $(57.2 \%)$ & $(3.1 \%)$ & $(13.7 \%)$ & $(0.0 \%)$ \\
\hline \multirow[t]{2}{*}{$50-59$} & 12,067 & 3,209 & 6,446 & 466 & 1,942 & 3 \\
\hline & $(100.0 \%)$ & $(26.6 \%)$ & $(53.4 \%)$ & $(3.9 \%)$ & $(16.1 \%)$ & $(0.0 \%)$ \\
\hline \multirow[t]{2}{*}{$60-64$} & 4,245 & 701 & 2,623 & 167 & 748 & 5 \\
\hline & $(100.0 \%)$ & $(16.5 \%)$ & $(61.8 \%)$ & $(3.9 \%)$ & $(17.6 \%)$ & $(0.1 \%)$ \\
\hline \multirow[t]{2}{*}{$65+$} & 11,319 & 714 & 7,645 & 642 & 2,312 & 5 \\
\hline & $(100.0 \%)$ & $(6.3 \%)$ & $(67.5 \%)$ & $(5.7 \%)$ & $(20.4 \%)$ & $(0.0 \%)$ \\
\hline
\end{tabular}

Note:

- $\quad$ All tables reporting totals could include some unreported characteristics.

- $\quad$ Some states issue learner permits to individuals 14 or 15 . The "under 16" category reflects these drivers.

- $\quad * *$ Indicates no data available. 


\section{FIGURE 5.2}

\section{Distribution of Vehicle TriPs by TRIP Purpose AND Gender}

1995 NPTS

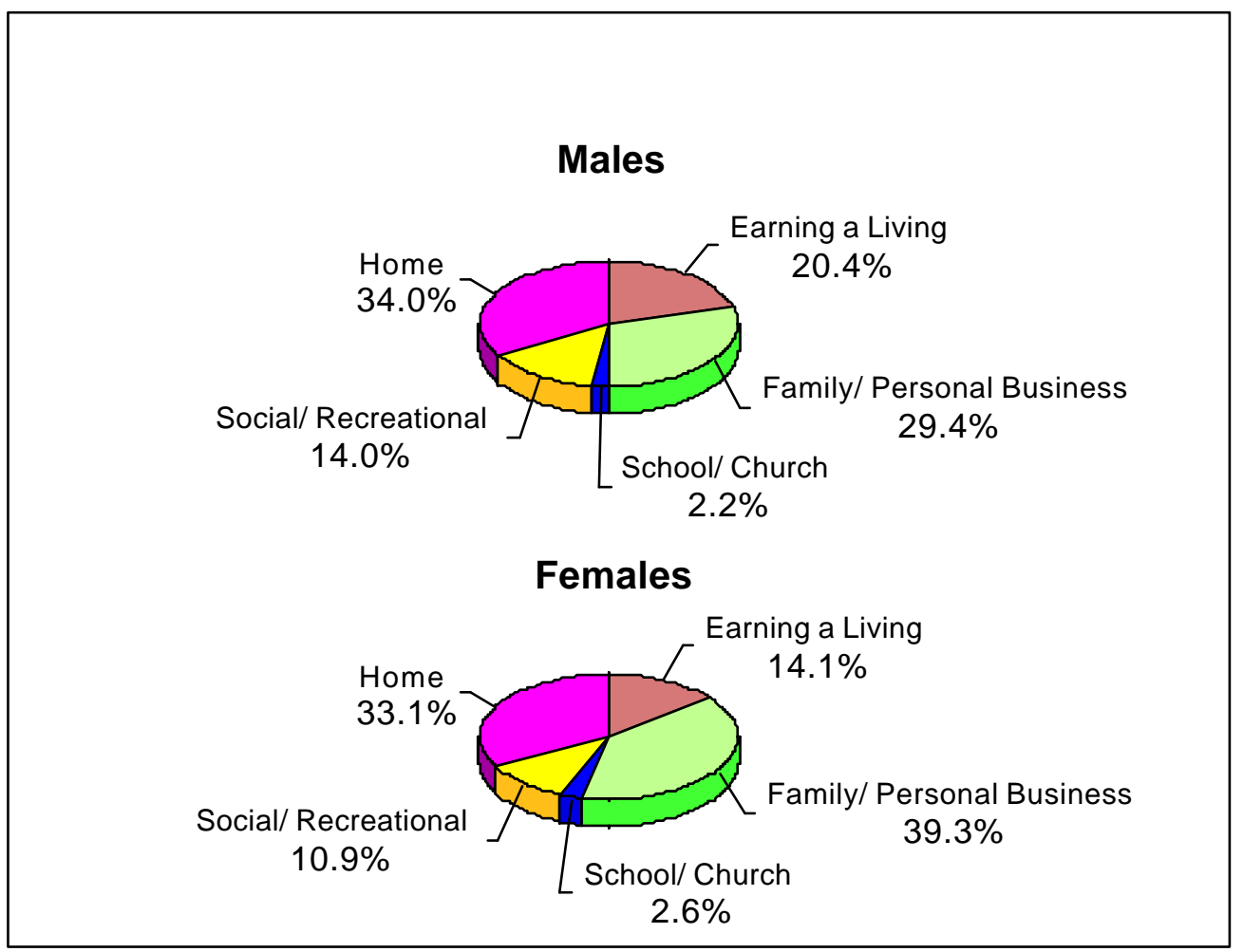

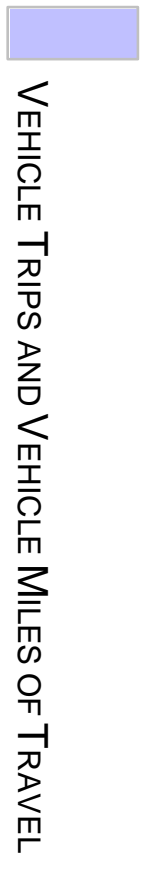


FIGURE 5.3

Distribution of Vehicle Trips by Trip Purpose And Driver's Age 1995 NPTS

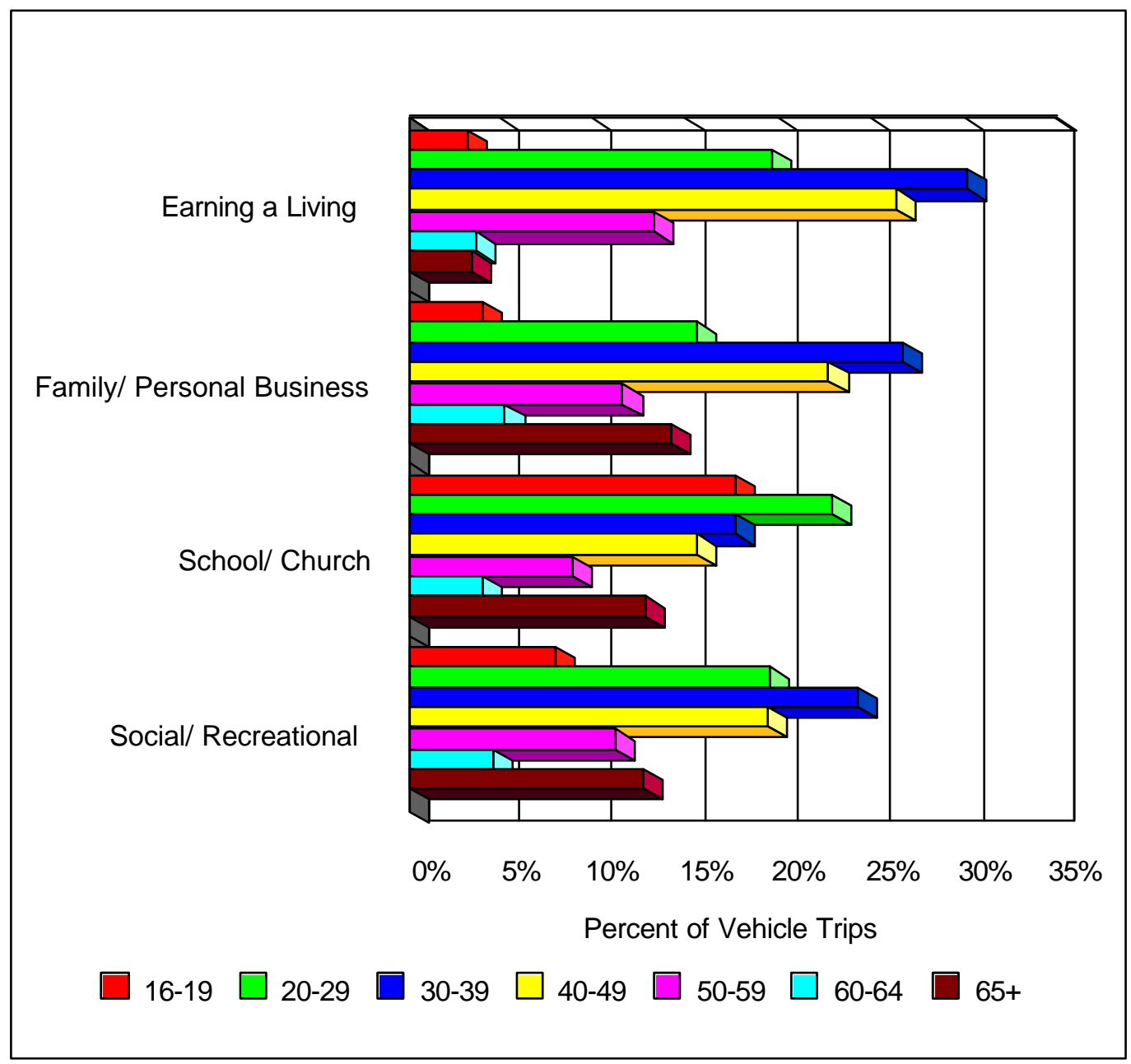


TABLE 5.4

Number of Vehicle Miles of Travel by Driver’s Age, Gender, and Trip Purpose
1995 NPTS

(MILLIONS)

\begin{tabular}{|c|c|c|c|c|c|c|c|}
\hline & TOTAL & $\begin{array}{c}\text { Earning a } \\
\text { Living } \\
\end{array}$ & $\begin{array}{l}\text { Family/ } \\
\text { Personal } \\
\text { Business }\end{array}$ & School/Church & $\begin{array}{c}\text { Social/ } \\
\text { Recreational } \\
\end{array}$ & Other & $\begin{array}{c}\text { Returning } \\
\text { Home }\end{array}$ \\
\hline \multicolumn{8}{|l|}{ Male } \\
\hline ALL & $\begin{array}{l}1,292,688 \\
(100.0 \%)\end{array}$ & $\begin{array}{l}354,079 \\
(27.4 \%)\end{array}$ & $\begin{array}{l}266,669 \\
(20.6 \%)\end{array}$ & $\begin{array}{l}21,570 \\
(1.7 \%)\end{array}$ & $\begin{array}{l}207,770 \\
(16.1 \%)\end{array}$ & $\begin{array}{c}2,806 \\
(0.2 \%)\end{array}$ & $\begin{array}{l}439,531 \\
(34.0 \%)\end{array}$ \\
\hline Under 16 & $\begin{array}{c}1,094 \\
(100.0 \%)\end{array}$ & $\begin{array}{c}184 \\
(16.8 \%)\end{array}$ & $\begin{array}{c}89 \\
(8.1 \%)\end{array}$ & $\begin{array}{c}12 \\
(1.1 \%)\end{array}$ & $\begin{array}{c}470 \\
(43.0 \%)\end{array}$ & $* *$ & $\begin{array}{c}340 \\
(31.1 \%)\end{array}$ \\
\hline $16-19$ & $\begin{array}{c}50,419 \\
(100.0 \%)\end{array}$ & $\begin{array}{c}5,776 \\
(11.5 \%)\end{array}$ & $\begin{array}{c}9,373 \\
(18.6 \%)\end{array}$ & $\begin{array}{c}3,138 \\
(6.2 \%)\end{array}$ & $\begin{array}{c}14,302 \\
(28.4 \%)\end{array}$ & $\begin{array}{c}18 \\
(0.0 \%)\end{array}$ & $\begin{array}{c}17,813 \\
(35.3 \%)\end{array}$ \\
\hline $20-29$ & $\begin{array}{c}239,479 \\
(100.0 \%)\end{array}$ & $\begin{array}{c}62,485 \\
(26.1 \%)\end{array}$ & $\begin{array}{c}44,415 \\
(18.5 \%)\end{array}$ & $\begin{array}{c}6,948 \\
(2.9 \%)\end{array}$ & $\begin{array}{c}40,384 \\
(16.9 \%)\end{array}$ & $\begin{array}{c}265 \\
(0.1 \%)\end{array}$ & $\begin{array}{c}84,962 \\
(35.5 \%)\end{array}$ \\
\hline $30-39$ & $\begin{array}{c}343,502 \\
(100.0 \%)\end{array}$ & $\begin{array}{l}108,688 \\
(31.6 \%)\end{array}$ & $\begin{array}{c}68,772 \\
(20.0 \%)\end{array}$ & $\begin{array}{c}3,004 \\
(0.9 \%)\end{array}$ & $\begin{array}{c}46,616 \\
(13.6 \%)\end{array}$ & $\begin{array}{c}231 \\
(0.1 \%)\end{array}$ & $\begin{array}{l}116,191 \\
(33.8 \%)\end{array}$ \\
\hline $40-49$ & $\begin{array}{c}302,927 \\
(100.0 \%)\end{array}$ & $\begin{array}{l}101,023 \\
(33.3 \%)\end{array}$ & $\begin{array}{c}58,669 \\
(19.4 \%)\end{array}$ & $\begin{array}{c}2,528 \\
(0.8 \%)\end{array}$ & $\begin{array}{c}40,179 \\
(13.3 \%)\end{array}$ & $\begin{array}{c}109 \\
(0.0 \%)\end{array}$ & $\begin{array}{l}100,398 \\
(33.1 \%)\end{array}$ \\
\hline $50-59$ & $\begin{array}{c}178,130 \\
(100.0 \%)\end{array}$ & $\begin{array}{c}52,805 \\
(29.6 \%)\end{array}$ & $\begin{array}{c}35,190 \\
(19.8 \%)\end{array}$ & $\begin{array}{c}2,044 \\
(1.1 \%)\end{array}$ & $\begin{array}{c}28,952 \\
(16.3 \%)\end{array}$ & $\begin{array}{c}531 \\
(0.3 \%)\end{array}$ & $\begin{array}{c}58,600 \\
(32.9 \%)\end{array}$ \\
\hline $60-64$ & $\begin{array}{c}65,049 \\
(100.0 \%)\end{array}$ & $\begin{array}{c}12,895 \\
(19.8 \%)\end{array}$ & $\begin{array}{c}13,622 \\
(20.9 \%)\end{array}$ & $\begin{array}{c}1,635 \\
(2.5 \%)\end{array}$ & $\begin{array}{c}14,006 \\
(21.5 \%)\end{array}$ & $\begin{array}{c}45 \\
(0.1 \%)\end{array}$ & $\begin{array}{c}22,741 \\
(35.0 \%)\end{array}$ \\
\hline $65+$ & $\begin{array}{c}112,089 \\
(100.0 \%)\end{array}$ & $\begin{array}{c}10,222 \\
(9.1 \%)\end{array}$ & $\begin{array}{c}36,539 \\
(32.6 \%)\end{array}$ & $\begin{array}{c}2,262 \\
(2.0 \%)\end{array}$ & $\begin{array}{c}22,861 \\
(20.4 \%)\end{array}$ & $\begin{array}{c}1,606 \\
(1.4 \%)\end{array}$ & $\begin{array}{c}38,487 \\
(34.3 \%)\end{array}$ \\
\hline Female & & & & & & & \\
\hline ALL & $\begin{array}{c}775,680 \\
(100.0 \%)\end{array}$ & $\begin{array}{l}138,715 \\
(17.9 \%)\end{array}$ & $\begin{array}{l}236,857 \\
(30.5 \%)\end{array}$ & $\begin{array}{l}22,595 \\
(2.9 \%)\end{array}$ & $\begin{array}{l}105,858 \\
(13.6 \%)\end{array}$ & $\begin{array}{c}679 \\
(0.1 \%)\end{array}$ & $\begin{array}{l}270,957 \\
(34.9 \%)\end{array}$ \\
\hline Under 16 & $\begin{array}{c}656 \\
(100.0 \%)\end{array}$ & $\begin{array}{c}42 \\
(6.4 \%)\end{array}$ & $\begin{array}{c}62 \\
(9.5 \%)\end{array}$ & $\begin{array}{c}28 \\
(4.3 \%)\end{array}$ & $\begin{array}{c}336 \\
(51.2 \%)\end{array}$ & $* *$ & $\begin{array}{c}188 \\
(28.7 \%)\end{array}$ \\
\hline $16-19$ & $\begin{array}{c}34,718 \\
(100.0 \%)\end{array}$ & $\begin{array}{c}3,456 \\
(10.0 \%)\end{array}$ & $\begin{array}{c}8,323 \\
(24.0 \%)\end{array}$ & $\begin{array}{c}3,782 \\
(10.9 \%)\end{array}$ & $\begin{array}{c}6,463 \\
(18.6 \%)\end{array}$ & $\begin{array}{c}30 \\
(0.1 \%)\end{array}$ & $\begin{array}{c}12,664 \\
(36.5 \%)\end{array}$ \\
\hline $20-29$ & $\begin{array}{c}152,179 \\
(100.0 \%)\end{array}$ & $\begin{array}{c}30,756 \\
(20.2 \%)\end{array}$ & $\begin{array}{c}39,989 \\
(26.3 \%)\end{array}$ & $\begin{array}{c}7,598 \\
(5.0 \%)\end{array}$ & $\begin{array}{c}19,571 \\
(12.9 \%)\end{array}$ & $\begin{array}{c}286 \\
(0.2 \%)\end{array}$ & $\begin{array}{c}53,964 \\
(35.5 \%)\end{array}$ \\
\hline $30-39$ & $\begin{array}{c}228,884 \\
(100.0 \%)\end{array}$ & $\begin{array}{c}44,560 \\
(19.5 \%)\end{array}$ & $\begin{array}{c}73,647 \\
(32.2 \%)\end{array}$ & $\begin{array}{c}4,543 \\
(2.0 \%)\end{array}$ & $\begin{array}{c}29,405 \\
(12.8 \%)\end{array}$ & $\begin{array}{c}145 \\
(0.1 \%)\end{array}$ & $\begin{array}{c}76,583 \\
(33.5 \%)\end{array}$ \\
\hline $40-49$ & $\begin{array}{c}184,049 \\
(100.0 \%)\end{array}$ & $\begin{array}{c}37,911 \\
(20.6 \%)\end{array}$ & $\begin{array}{c}57,763 \\
(31.4 \%)\end{array}$ & $\begin{array}{c}2,941 \\
(1.6 \%)\end{array}$ & $\begin{array}{c}21,569 \\
(11.7 \%)\end{array}$ & $\begin{array}{c}92 \\
(0.0 \%)\end{array}$ & $\begin{array}{c}63,768 \\
(34.6 \%)\end{array}$ \\
\hline $50-59$ & $\begin{array}{c}86,737 \\
(100.0 \%)\end{array}$ & $\begin{array}{c}16,822 \\
(19.4 \%)\end{array}$ & $\begin{array}{c}24,152 \\
(27.8 \%)\end{array}$ & $\begin{array}{c}1,641 \\
(1.9 \%)\end{array}$ & $\begin{array}{c}13,593 \\
(15.7 \%)\end{array}$ & $\begin{array}{c}37 \\
(0.0 \%)\end{array}$ & $\begin{array}{c}30,492 \\
(35.2 \%)\end{array}$ \\
\hline $60-64$ & $\begin{array}{c}27,764 \\
(100.0 \%)\end{array}$ & $\begin{array}{c}2,592 \\
(9.3 \%)\end{array}$ & $\begin{array}{c}10,248 \\
(36.9 \%)\end{array}$ & $\begin{array}{c}437 \\
(1.6 \%)\end{array}$ & $\begin{array}{c}4,368 \\
(15.7 \%)\end{array}$ & $\begin{array}{c}15 \\
(0.1 \%)\end{array}$ & $\begin{array}{c}10,104 \\
(36.4 \%)\end{array}$ \\
\hline $65+$ & $\begin{array}{c}60,692 \\
(100.0 \%) \\
\end{array}$ & $\begin{array}{c}2,575 \\
(4.2 \%) \\
\end{array}$ & $\begin{array}{c}22,673 \\
(37.4 \%) \\
\end{array}$ & $\begin{array}{c}1,625 \\
(2.7 \%) \\
\end{array}$ & $\begin{array}{c}10,554 \\
(17.4 \%) \\
\end{array}$ & $\begin{array}{c}74 \\
(0.1 \%) \\
\end{array}$ & $\begin{array}{c}23,193 \\
(38.2 \%) \\
\end{array}$ \\
\hline
\end{tabular}

Note:

- $\quad$ All tables reporting totals could include some unreported characteristics.

- Some states issue learner permits to individuals 14 or 15 . The "under 16 " category reflects these drivers.

- $\quad * *$ Indicates no data available. 


\section{TABLE 5.5}

\section{Number of Vehicle Miles of Travel by Driver's Age, Gender, and 1990 Trip Purpose 1995 NPTS}

(MILLIONS)

\begin{tabular}{|c|c|c|c|c|c|c|}
\hline & TOTAL & $\begin{array}{c}\text { Earning a } \\
\text { Living } \\
\end{array}$ & $\begin{array}{l}\text { Family/ } \\
\text { Personal } \\
\text { Business }\end{array}$ & School/Church & $\begin{array}{c}\text { Social/ } \\
\text { Recreational } \\
\end{array}$ & Other \\
\hline \multicolumn{7}{|l|}{ Male } \\
\hline ALL & $\begin{array}{l}1,292,688 \\
(100.0 \%)\end{array}$ & $\begin{array}{l}542,395 \\
(42.0 \%)\end{array}$ & $\begin{array}{l}398,659 \\
(30.8 \%)\end{array}$ & $\begin{array}{l}38,435 \\
(3.0 \%)\end{array}$ & $\begin{array}{l}310,783 \\
(24.0 \%)\end{array}$ & $\begin{array}{c}2,020 \\
(0.2 \%)\end{array}$ \\
\hline Under 16 & $\begin{array}{c}1,094 \\
(100.0 \%)\end{array}$ & $\begin{array}{c}367 \\
(33.5 \%)\end{array}$ & $\begin{array}{c}151 \\
(13.8 \%)\end{array}$ & $\begin{array}{c}28 \\
(2.6 \%)\end{array}$ & $\begin{array}{c}548 \\
(50.1 \%)\end{array}$ & $* *$ \\
\hline $16-19$ & $\begin{array}{c}50,419 \\
(100.0 \%)\end{array}$ & $\begin{array}{c}9,897 \\
(19.6 \%)\end{array}$ & $\begin{array}{c}13,897 \\
(27.6 \%)\end{array}$ & $\begin{array}{c}6,078 \\
(12.1 \%)\end{array}$ & $\begin{array}{c}20,529 \\
(40.7 \%)\end{array}$ & $\begin{array}{c}18 \\
(0.0 \%)\end{array}$ \\
\hline $20-29$ & $\begin{array}{c}239,479 \\
(100.0 \%)\end{array}$ & $\begin{array}{l}102,199 \\
(42.7 \%)\end{array}$ & $\begin{array}{c}65,301 \\
(27.3 \%)\end{array}$ & $\begin{array}{l}11,235 \\
(4.7 \%)\end{array}$ & $\begin{array}{c}60,366 \\
(25.2 \%)\end{array}$ & $\begin{array}{c}260 \\
(0.1 \%)\end{array}$ \\
\hline $30-39$ & $\begin{array}{c}343,502 \\
(100.0 \%)\end{array}$ & $\begin{array}{l}166,479 \\
(48.5 \%)\end{array}$ & $\begin{array}{c}99,636 \\
(29.0 \%)\end{array}$ & $\begin{array}{c}5,009 \\
(1.5 \%)\end{array}$ & $\begin{array}{c}72,146 \\
(21.0 \%)\end{array}$ & $\begin{array}{c}231 \\
(0.1 \%)\end{array}$ \\
\hline $40-49$ & $\begin{array}{c}302,927 \\
(100.0 \%)\end{array}$ & $\begin{array}{l}150,651 \\
(49.7 \%)\end{array}$ & $\begin{array}{c}87,347 \\
(28.8 \%)\end{array}$ & $\begin{array}{c}4,803 \\
(1.6 \%)\end{array}$ & $\begin{array}{c}59,990 \\
(19.8 \%)\end{array}$ & $\begin{array}{c}96 \\
(0.0 \%)\end{array}$ \\
\hline $50-59$ & $\begin{array}{c}178,130 \\
(100.0 \%)\end{array}$ & $\begin{array}{c}79,208 \\
(44.5 \%)\end{array}$ & $\begin{array}{c}53,721 \\
(30.2 \%)\end{array}$ & $\begin{array}{c}3,356 \\
(1.9 \%)\end{array}$ & $\begin{array}{c}41,520 \\
(23.3 \%)\end{array}$ & $\begin{array}{c}311 \\
(0.2 \%)\end{array}$ \\
\hline $60-64$ & $\begin{array}{c}65,049 \\
(100.0 \%)\end{array}$ & $\begin{array}{c}19,300 \\
(29.7 \%)\end{array}$ & $\begin{array}{c}22,969 \\
(35.3 \%)\end{array}$ & $\begin{array}{c}3,528 \\
(5.4 \%)\end{array}$ & $\begin{array}{c}19,092 \\
(29.4 \%)\end{array}$ & $\begin{array}{c}55 \\
(0.1 \%)\end{array}$ \\
\hline $65+$ & $\begin{array}{c}112,089 \\
(100.0 \%)\end{array}$ & $\begin{array}{c}14,294 \\
(12.8 \%)\end{array}$ & $\begin{array}{c}55,637 \\
(49.6 \%)\end{array}$ & $\begin{array}{c}4,398 \\
(3.9 \%)\end{array}$ & $\begin{array}{c}36,591 \\
(32.6 \%)\end{array}$ & $\begin{array}{c}1,047 \\
(0.9 \%)\end{array}$ \\
\hline Female & & & & & & \\
\hline ALL & $\begin{array}{c}775,680 \\
(100.0 \%)\end{array}$ & $\begin{array}{l}238,082 \\
(30.7 \%)\end{array}$ & $\begin{array}{l}336,144 \\
(43.3 \%)\end{array}$ & $\begin{array}{l}39,879 \\
(5.1 \%)\end{array}$ & $\begin{array}{l}160,772 \\
(20.7 \%)\end{array}$ & $\begin{array}{c}777 \\
(0.1 \%)\end{array}$ \\
\hline Under 16 & $\begin{array}{c}656 \\
(100.0 \%)\end{array}$ & $\begin{array}{c}87 \\
(13.3 \%)\end{array}$ & $\begin{array}{c}117 \\
(17.8 \%)\end{array}$ & $\begin{array}{c}95 \\
(14.5 \%)\end{array}$ & $\begin{array}{c}357 \\
(54.4 \%)\end{array}$ & $* *$ \\
\hline $16-19$ & $\begin{array}{c}34,718 \\
(100.0 \%)\end{array}$ & $\begin{array}{c}6,714 \\
(19.3 \%)\end{array}$ & $\begin{array}{c}12,195 \\
(35.1 \%)\end{array}$ & $\begin{array}{c}6,439 \\
(18.5 \%)\end{array}$ & $\begin{array}{c}9,321 \\
(26.8 \%)\end{array}$ & $\begin{array}{c}43 \\
(0.1 \%)\end{array}$ \\
\hline $20-29$ & $\begin{array}{c}152,179 \\
(100.0 \%)\end{array}$ & $\begin{array}{c}54,636 \\
(35.9 \%)\end{array}$ & $\begin{array}{c}55,103 \\
(36.2 \%)\end{array}$ & $\begin{array}{l}13,189 \\
(8.7 \%)\end{array}$ & $\begin{array}{c}28,944 \\
(19.0 \%)\end{array}$ & $\begin{array}{c}293 \\
(0.2 \%)\end{array}$ \\
\hline $30-39$ & $\begin{array}{c}228,884 \\
(100.0 \%)\end{array}$ & $\begin{array}{c}74,585 \\
(32.6 \%)\end{array}$ & $\begin{array}{l}101,781 \\
(44.5 \%)\end{array}$ & $\begin{array}{c}7,702 \\
(3.4 \%)\end{array}$ & $\begin{array}{c}44,632 \\
(19.5 \%)\end{array}$ & $\begin{array}{c}185 \\
(0.1 \%)\end{array}$ \\
\hline $40-49$ & $\begin{array}{c}184,049 \\
(100.0 \%)\end{array}$ & $\begin{array}{c}63,939 \\
(34.7 \%)\end{array}$ & $\begin{array}{c}82,373 \\
(44.8 \%)\end{array}$ & $\begin{array}{c}5,414 \\
(2.9 \%)\end{array}$ & $\begin{array}{c}32,223 \\
(17.5 \%)\end{array}$ & $\begin{array}{c}94 \\
(0.1 \%)\end{array}$ \\
\hline $50-59$ & $\begin{array}{c}86,737 \\
(100.0 \%)\end{array}$ & $\begin{array}{c}28,941 \\
(33.4 \%)\end{array}$ & $\begin{array}{c}34,239 \\
(39.5 \%)\end{array}$ & $\begin{array}{c}3,111 \\
(3.6 \%)\end{array}$ & $\begin{array}{c}20,351 \\
(23.5 \%)\end{array}$ & $\begin{array}{c}95 \\
(0.1 \%)\end{array}$ \\
\hline $60-64$ & $\begin{array}{c}27,764 \\
(100.0 \%)\end{array}$ & $\begin{array}{c}4,859 \\
(17.5 \%)\end{array}$ & $\begin{array}{c}15,217 \\
(54.8 \%)\end{array}$ & $\begin{array}{c}849 \\
(3.1 \%)\end{array}$ & $\begin{array}{c}6,824 \\
(24.6 \%)\end{array}$ & $\begin{array}{c}16 \\
(0.1 \%)\end{array}$ \\
\hline $65+$ & $\begin{array}{c}60,692 \\
(100.0 \%)\end{array}$ & $\begin{array}{c}4,321 \\
(7.1 \%)\end{array}$ & $\begin{array}{c}35,119 \\
(57.9 \%)\end{array}$ & $\begin{array}{c}3,080 \\
(5.1 \%)\end{array}$ & $\begin{array}{c}18,121 \\
(29.9 \%)\end{array}$ & $\begin{array}{c}52 \\
(0.1 \%)\end{array}$ \\
\hline
\end{tabular}

Note:

- $\quad$ All tables reporting totals could include some unreported characteristics.

- $\quad$ Some states issue learner permits to individuals 14 or 15 . The "under 16" category reflects these drivers.

- $\quad * *$ Indicates no data available. 
Tables 5.6 and 5.7 show the length of time spent in privately operated vehicles in a typical day by age/gender and employment status/gender, respectively. In 1995, males of all ages spent more time driving than did females. Between 1990 (adjusted) and 1995, overall, males increased their driving time in a typical day by $16.2 \%$ and females by $9.7 \%$. For the age group 65 and over, however, the increases were even greater - for males $37.4 \%$ and for females $44 \%$.

In 1995, both males and females, whether employed or not, spent more time driving each day than they did in 1990 (Table 5.7). As shown in Figure 5.4, employed males spent $38.2 \%$ more time in their vehicles each day than unemployed males; employed females spent $48.3 \%$ more time in their vehicles than unemployed females. 


\section{TABLE 5.6}

\section{Average Time Spent Driving a Privately Operated Vehicle in a Typical Day BY AGE AND GENDER 1990 ADJUSTED AND 1995 NPTS}

\begin{tabular}{|c|c|c|c|}
\hline Age & ALL & Male & Female \\
\hline \multicolumn{4}{|c|}{1990 Adjusted } \\
\hline ALL & 49.35 & 57.25 & 41.70 \\
\hline Under 16 & 40.20 & 34.67 & 44.90 \\
\hline $16-19$ & 39.89 & 44.90 & 35.12 \\
\hline $20-29$ & 53.77 & 61.41 & 46.45 \\
\hline $30-39$ & 56.55 & 62.64 & 50.73 \\
\hline $40-49$ & 54.61 & 62.85 & 46.42 \\
\hline $50-59$ & 47.12 & 57.08 & 36.94 \\
\hline $60-64$ & 43.19 & 55.23 & 31.16 \\
\hline $65+$ & 30.83 & 39.46 & 22.45 \\
\hline Unreported & 40.19 & 51.48 & 34.39 \\
\hline \multicolumn{4}{|l|}{1995} \\
\hline ALL & 56.20 & 66.55 & 45.76 \\
\hline Under 16 & 14.81 & 15.20 & 14.27 \\
\hline $16-19$ & 40.34 & 42.65 & 37.67 \\
\hline $20-29$ & 56.20 & 65.39 & 46.66 \\
\hline $30-39$ & 60.92 & 69.87 & 51.95 \\
\hline $40-49$ & 63.83 & 74.32 & 53.34 \\
\hline $50-59$ & 57.97 & 73.49 & 42.60 \\
\hline $60-64$ & 54.19 & 70.22 & 37.03 \\
\hline $65+$ & 42.89 & 54.21 & 32.37 \\
\hline
\end{tabular}

Note:

- All tables reporting totals could include some unreported characteristics.

- Note that only the 1990 data have been adjusted to make them more comparable with the 1995 data. Thus, there are limits on the conclusions that can be drawn in comparing travel with earlier survey years. The adjustments to 1990 data affect only person trips, vehicle trips, person miles of travel (PMT) and vehicle miles of travel (VMT). 
TABLE 5.7

\section{Average Time (minutes) Spent Driving a Privately Owned Vehicle in a TyPical Day by EMPLOYMENT Status AND GENDER 1990 ADJUSTED AND 1995 NPTS}

\begin{tabular}{||lccc||}
\hline & ALL & Male & Female \\
\hline 1990 Adjusted & & & \\
ALL & 49.35 & 57.25 & 41.70 \\
Employed & 56.31 & 62.55 & 48.79 \\
Not Employed & 34.26 & 40.48 & 30.57 \\
1995 & & & 45.76 \\
ALL & 56.20 & 66.55 & 51.79 \\
Employed & 62.34 & 71.06 & 34.92 \\
Not Employed & 41.41 & 51.42 & \\
\hline
\end{tabular}

Note:

- All tables reporting totals could include some unreported characteristics.

- Note that only the 1990 data have been adjusted to make them more comparable with the 1995 data. Thus, there are limits on the conclusions that can be drawn in comparing travel with earlier survey years. The adjustments to 1990 data affect only person trips, vehicle trips, person miles of travel (PMT) and vehicle miles of travel (VMT).

FIGURE 5.4

Average Time (minutes) Spent Driving, Per Day, BY EMPLOYMENT STATUS AND GENDER

1995 NPTS

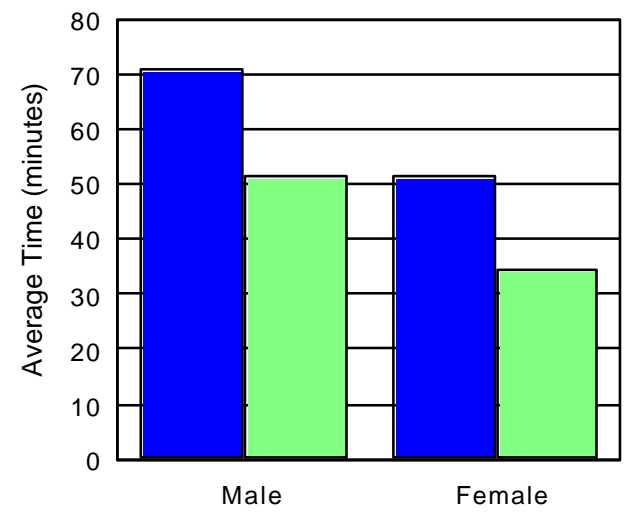

Employed

$\square$ Unemployed 
While $86.3 \%$ of all drivers were under the age of 65 , they drove $91.6 \%$ of all vehicle miles (Table 5.8). As expected, for drivers under 65, their trip purpose was most often earning a living (25.3\%); however, family/personal business $(23.4 \%)$ ran a close second. For those 65 or older, family/personal business (34.3\%) was the primary trip purpose by far, although earning a living was still given as the trip purpose for $7.4 \%$ of all trips.

\section{TABLE 5.8}

Number of Vehicle MiLes of TraVel by Individuals 65 OR OLdER vS. INDIVIDUALS UNDER 65 AND TRIP PURPOSE

1995 NPTS

(MILLIONS)

\begin{tabular}{|c|c|c|c|}
\hline & ALL & $\begin{array}{c}\text { Individuals } \\
\text { Under } 65 \text { Years }\end{array}$ & $\begin{array}{c}\text { Individuals } \\
\text { 65Years or Older }\end{array}$ \\
\hline \multirow[t]{2}{*}{ TOTAL } & $2,068,368$ & $1,895,587$ & 172,781 \\
\hline & $(100.0 \%)$ & $(100.0 \%)$ & $(100.0 \%)$ \\
\hline \multirow[t]{2}{*}{ Earning a Living } & 492,794 & 479,998 & 12,796 \\
\hline & $(23.8 \%)$ & $(25.3 \%)$ & $(7.4 \%)$ \\
\hline \multirow[t]{2}{*}{ Family/Personal Business } & 503,526 & 444,314 & 59,211 \\
\hline & $(24.3 \%)$ & $(23.4 \%)$ & $(34.3 \%)$ \\
\hline \multirow[t]{2}{*}{ School/Church } & 44,166 & 40,279 & 3,886 \\
\hline & $(2.1 \%)$ & $(2.1 \%)$ & $(2.2 \%)$ \\
\hline \multirow[t]{2}{*}{ Social/Recreational } & 313,628 & 280,213 & 33,415 \\
\hline & $(15.2 \%)$ & $(14.8 \%)$ & $(19.3 \%)$ \\
\hline \multirow[t]{2}{*}{ Other } & 3,484 & 1,804 & 1,680 \\
\hline & $(0.2 \%)$ & $(0.1 \%)$ & $(1.0 \%)$ \\
\hline \multirow[t]{2}{*}{ Returning Home } & 710,488 & 648,808 & 61,680 \\
\hline & $(34.4 \%)$ & $(34.2 \%)$ & $(35.7 \%)$ \\
\hline \multirow[t]{2}{*}{ Number of Drivers $(000)$} & 176,330 & 152,124 & 24,207 \\
\hline & $(100.0 \%)$ & $(86.3 \%)$ & $(13.7 \%)$ \\
\hline
\end{tabular}

Note:

- All tables reporting totals could include some unreported characteristics. 
Individuals 65 years of age and over generally took shorter trips than persons under 65 (Table 5.9 and Figure 5.5). Their trips were longer, however, when the trip purpose was take someone somewhere, school, or other.

TABLE 5.9

Average Length of Vehicle TRIPS (MILES) By INDIVIDUals 65 AND OldeR

VS. INDIVIDUALS UNDER 65 BY TRIP PURPOSE

1995 NPTS

\begin{tabular}{|c|c|c|c|}
\hline Trip Purpose & ALL & $\begin{array}{c}\text { Individuals } \\
\text { Under } 65 \\
\end{array}$ & $\begin{array}{l}\text { Individuals } \\
65 \text { or Older } \\
\end{array}$ \\
\hline ALL & 9.06 & 9.36 & 6.69 \\
\hline \multicolumn{4}{|l|}{ Earning a Living } \\
\hline To Work & 11.86 & 11.97 & 8.24 \\
\hline Work-Related Business & 17.54 & 17.80 & 12.87 \\
\hline Return to Work & 6.24 & 6.30 & 4.30 \\
\hline \multicolumn{4}{|l|}{ Family/Personal Business } \\
\hline Shopping & 5.50 & 5.70 & 4.44 \\
\hline Medical/Dental & 9.63 & 9.67 & 9.50 \\
\hline $\begin{array}{l}\text { Other Family and Personal } \\
\text { Business }\end{array}$ & 6.87 & 7.30 & 4.88 \\
\hline Take Someone Somewhere & 7.57 & 7.31 & 10.83 \\
\hline Pick up Someone & 7.24 & 7.26 & 6.95 \\
\hline \multicolumn{4}{|l|}{ School/Church } \\
\hline School & 9.96 & 9.95 & 10.47 \\
\hline Religious Activity & 6.49 & 6.81 & 5.41 \\
\hline \multicolumn{4}{|l|}{ Social/Recreational } \\
\hline Vacation & 88.86 & 91.96 & 67.35 \\
\hline Visit Friends or Relatives & 13.23 & 13.60 & 10.53 \\
\hline Out to Eat & 6.39 & 6.40 & 6.29 \\
\hline Other Social \& Recreational & 11.39 & 11.61 & 9.83 \\
\hline \multicolumn{4}{|l|}{ Other } \\
\hline Other & 18.21 & 10.50 & 86.05 \\
\hline \multicolumn{4}{|l|}{ Returning Home } \\
\hline Home & 9.28 & 9.61 & 6.81 \\
\hline
\end{tabular}

Note:

- All tables reporting totals could include some unreported characteristics.

- Average Trip Length is calculated using only those records with trip mileage information present. 
Tables 5.10-5.14 display vehicle travel information for certain household characteristics. (Table 5.11 is similar to Table 5.10 except it uses 1990 trip purpose codes.) Households with two or more adults, not retired, with or without children, traveled more miles annually than households with a single adult. Two or more adults with a youngest child aged 16-21 (that is, of driving age) drove 37,646 miles annually, almost twice as many vehicle miles as the average $(20,895)$ household. For households with two or more adults, the trip purpose (excluding returning home) that had the highest vehicle miles was earning a living; for households with a single adult, the primary trip purpose was family/personal business.

The differences in annual vehicle miles of travel between households with children and households without children is graphically displayed in Figure 5.5. Figure 5.5 also shows the distribution of trips by trip purpose for each household classification.

Table 5.12 provides information on annual household vehicle trips and VMT per household by trip purpose since the first NPTS in 1969. Total household trips increased by $66.3 \%$ between 1969 and 1995 and household VMT by $68.2 \%$ (from 12,423 miles to 20,895). The greatest increases in household vehicle trips was for family/personal business, an increase of $168.5 \%$. Household trips for school/church actually decreased by $32.7 \%$. Household VMT saw increases of $52.6 \%$ and $208.9 \%$ for earning a living and family/personal business; however, social/recreational VMT only increased $16.4 \%$, which may imply that more social/recreational travel is being accomplished via modes other than household vehicles.

Tables 5.13 and 5.14 display annual household travel information by trip purpose and household income. The total number of household trips increased slightly between 1990 and 1995. The annual VMT for categories involving work increased for every income level. The annual VMT for social/recreational and other purposes actually decreased across all income levels. The data provided in Tables 5.13 and 5.14 are presented graphically in Figures 5.6 and 5.7. 
TABLE 5.10

Annual Vehicle Miles of Travel per Household by TRip Purpose and Household COMPOSITION

1995 NPTS

\begin{tabular}{|c|c|c|c|c|c|c|c|}
\hline $\begin{array}{l}\text { Household } \\
\text { Composition }\end{array}$ & TOTAL & $\begin{array}{c}\text { Earning a } \\
\text { Living } \\
\end{array}$ & $\begin{array}{c}\text { Family/ } \\
\text { Personal } \\
\text { Business }\end{array}$ & $\begin{array}{l}\text { School/ } \\
\text { Church }\end{array}$ & $\begin{array}{l}\text { Social/ } \\
\text { Rec. }\end{array}$ & Other & $\begin{array}{c}\text { Returning } \\
\text { Home }\end{array}$ \\
\hline TOTAL & 20,895 & 4,978 & 5,087 & 446 & 3,168 & 35 & 7,177 \\
\hline $\begin{array}{l}\text { Single Adult, No } \\
\text { Children }\end{array}$ & 12,142 & 2,897 & 2,959 & 207 & 1,967 & 8 & 4,102 \\
\hline $\begin{array}{l}\text { Two or More Adults, } \\
\text { No Children }\end{array}$ & 24,126 & 6,834 & 5,183 & 545 & 3,446 & 16 & 8,093 \\
\hline $\begin{array}{l}\text { Single Adult, Youngest } \\
\text { Child Under } 6\end{array}$ & 10,391 & 1,845 & 3,192 & 344 & 1,583 & $* *$ & 3,427 \\
\hline $\begin{array}{l}\text { Two or More Adults, } \\
\text { Youngest Child Under } 6\end{array}$ & 27,660 & 7,507 & 6,960 & 433 & 3,416 & 20 & 9,325 \\
\hline $\begin{array}{l}\text { Single Adult, Youngest } \\
\text { Child 6-15 }\end{array}$ & 13,528 & 2,796 & 4,015 & 339 & 1,860 & 0 & 4,518 \\
\hline $\begin{array}{l}\text { Two or More Adults, } \\
\text { Youngest Child 6-15 }\end{array}$ & 29,176 & 7,081 & 7,008 & 526 & 4,393 & 38 & 10,129 \\
\hline $\begin{array}{l}\text { Single Adult, Youngest } \\
\text { Child 16-21 }\end{array}$ & 18,267 & 2,965 & 4,131 & 619 & 4,147 & 133 & 6,272 \\
\hline $\begin{array}{l}\text { Two or More Adults, } \\
\text { Youngest Child 16-21 }\end{array}$ & 37,646 & 9,188 & 7,809 & 1,447 & 5,666 & 24 & 13,511 \\
\hline $\begin{array}{l}\text { Single Adult, Retired, } \\
\text { No Children }\end{array}$ & 6,018 & 23 & 2,325 & 147 & 1,445 & 77 & 2,001 \\
\hline $\begin{array}{l}\text { Two or More Adults, } \\
\text { Retired, No Children }\end{array}$ & 15,375 & 1,384 & 4,638 & 364 & 3,154 & 107 & 5,726 \\
\hline
\end{tabular}

Note:

- All tables reporting totals could include some unreported characteristics.

- ** Indicates no data available. 


\section{TABLE 5.11}

\section{Annual Vehicle Miles of Travel Per Household by 1990 Trip PuRPose And Household COMPOSITION 1995 NPTS}

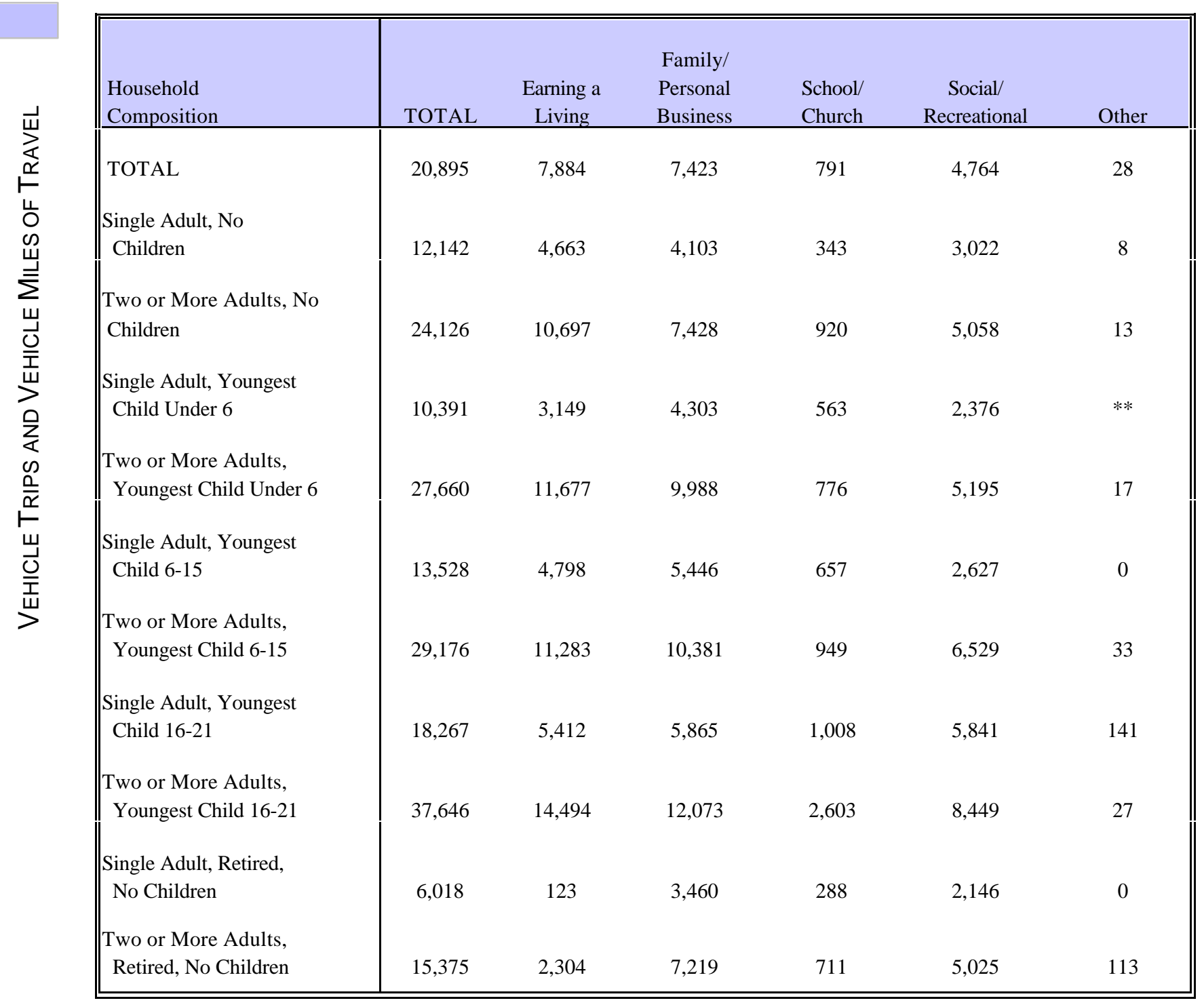

Note:

- $\quad$ All tables reporting totals could include some unreported characteristics.

- $\quad$ ** Indicates no data available. 
FIGURE 5.5

Annual Vehicle Miles of Travel Per Household by Trip Purpose AND HOUSEHOLD COMPOSITION

1995 NPTS

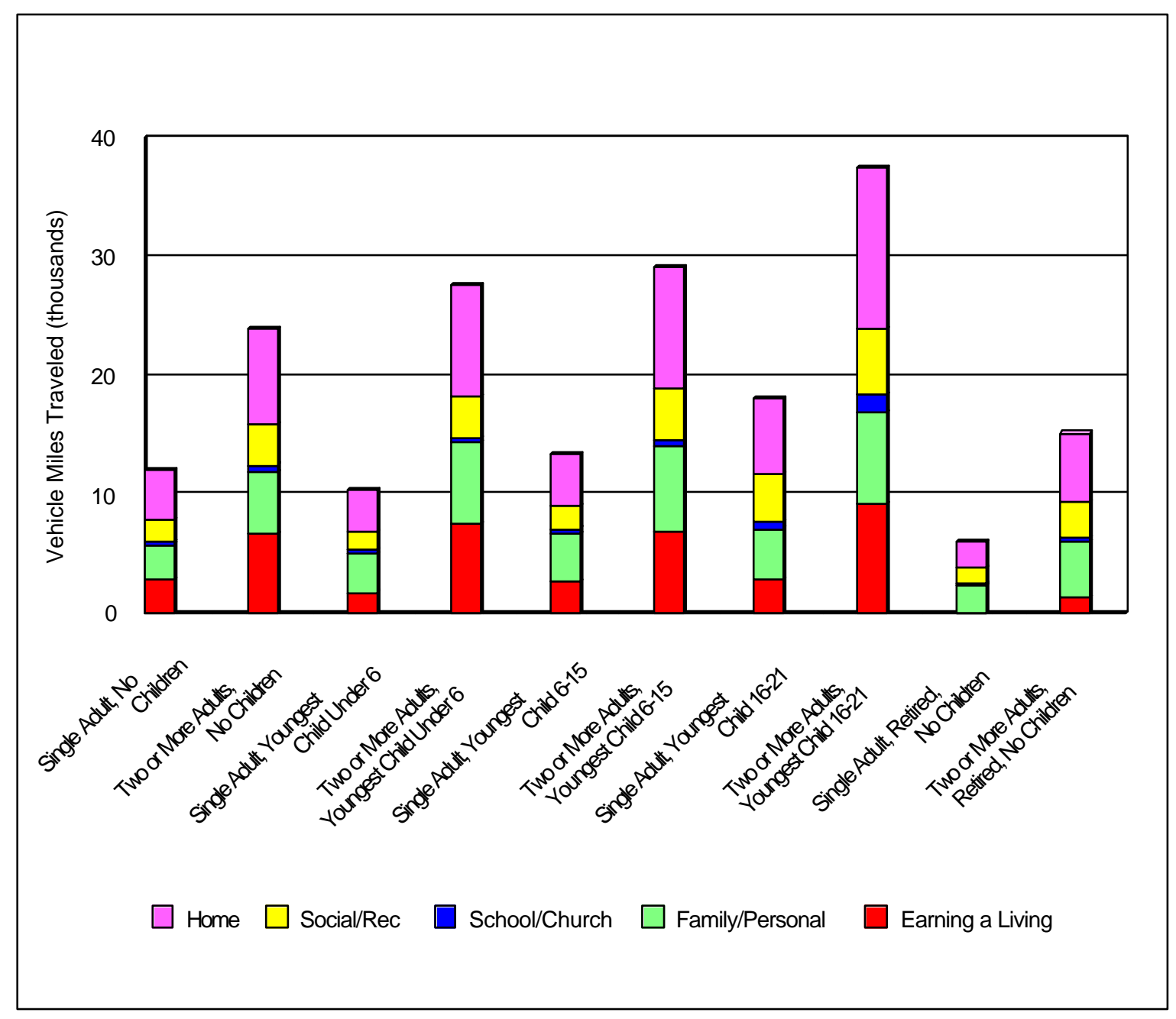

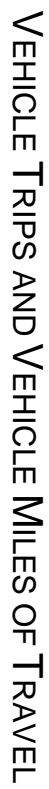




\section{VehicLe Trips and VehicLe Miles of Travel}

\section{TABLE 5.12}

Statistics on Vehicle Travel Per Household by 1990 Trip PuRPoses

1969, 1977, 1983, 1990, 1990 ADJUSTED, AND 1995 NPTS

\begin{tabular}{|c|c|c|c|c|c|c|c|c|c|c|c|c|}
\hline \multirow[b]{2}{*}{ Trip Purpose } & \multicolumn{6}{|c|}{ Vehicle Trips per Household } & \multicolumn{6}{|c|}{ Vehicle Miles of Travel per Household } \\
\hline & 1969 & 1977 & 1983 & 1990 & $\begin{array}{c}1990 \\
\text { adj }\end{array}$ & 1995 & 1969 & 1977 & 1983 & 1990 & $\begin{array}{c}1990 \\
\text { adj }\end{array}$ & 1995 \\
\hline TOTAL & 1,396 & 1,442 & 1,486 & 1,702 & 2,077 & 2,321 & 12,423 & 12,036 & 11,739 & 15,101 & 18,161 & 20,895 \\
\hline \multicolumn{13}{|l|}{ Earning a Living } \\
\hline To or From Work & 445 & 423 & 414 & 447 & 448 & 553 & 4,183 & 3,815 & 3,538 & 4,853 & 4,853 & 6,492 \\
\hline Work-Related Business & 62 & 76 & 43 & 30 & 30 & 80 & 986 & 915 & 495 & 454 & 454 & 1,393 \\
\hline Subtotal & 507 & 499 & 457 & 477 & 478 & 633 & 5,169 & 4,730 & 4,033 & 5,307 & 5,307 & 7,885 \\
\hline \multicolumn{13}{|l|}{ Family/Personal Business } \\
\hline Shopping & 213 & 268 & 297 & 345 & 431 & 501 & 929 & 1,336 & 1,567 & 1,743 & 2,178 & 2,807 \\
\hline Doctor/Dentist & 24 & 22 & 18 & 19 & 26 & 33 & 204 & 217 & 172 & 191 & 269 & 309 \\
\hline Other Family/Personal & 195 & 215 & 272 & 411 & 579 & 626 & 1,270 & 1,444 & 1,816 & 3,014 & 4,250 & 4,307 \\
\hline Subtotal & 432 & 505 & 587 & 775 & 1036 & 1160 & 2,403 & 2,997 & 3,555 & 4,948 & 6,697 & 7,423 \\
\hline \multicolumn{13}{|l|}{ School/Church } \\
\hline Subtotal & 130 & 105 & 88 & 90 & 90 & 98 & 608 & 626 & 481 & 666 & 666 & 791 \\
\hline \multicolumn{13}{|l|}{ Social/Recreational } \\
\hline Vacation & 0 & 1 & 3 & 2 & 3 & 2 & 321 & 72 & 250 & 220 & 290 & 205 \\
\hline Visit Friends/Relatives & 126 & 134 & 147 & 151 & 199 & 155 & 1,499 & 1,456 & 1,590 & 1,757 & 2,319 & 1,971 \\
\hline Pleasure Driving & 20 & 7 & 6 & 5 & 6 & $* *$ & 382 & 108 & 132 & 98 & 130 & $* *$ \\
\hline Other Social/Recreational & 166 & 178 & 179 & 191 & 253 & 269 & 1,892 & 1,650 & 1,562 & 1,985 & 2,620 & 2,588 \\
\hline Subtotal & 312 & 320 & 335 & 349 & 461 & 426 & 4,094 & 3,286 & 3,534 & 4,062 & 5,359 & 4,764 \\
\hline \multicolumn{13}{|l|}{ Other } \\
\hline Subtotal & 15 & 13 & 19 & 11 & 12 & 2 & 149 & 397 & 136 & 118 & 130 & 28 \\
\hline \multicolumn{13}{|c|}{$\begin{array}{l}\text { Note: } \\
\text { - } \quad \text { All tables reporting totals could include some unreported characteristics. } \\
\text { - } \quad \text { ** Indicates no data available. } \\
\text { - Note that only the } 1990 \text { data have been adjusted to make them more comparable with the } 1995 \text { data. Thus, there are limits on the conclusions that can be drawn in } \\
\text { comparing travel with earlier survey years. The adjustments to } 1990 \text { data affect only person trips, vehicle trips, person miles of travel (PMT) and vehicle miles of trave } \\
\text { (VMT). }\end{array}$} \\
\hline
\end{tabular}




\begin{tabular}{|c|c|c|c|c|c|c|c|c|c|c|}
\hline \multicolumn{11}{|c|}{ TABLE 5.13} \\
\hline \multirow{2}{*}{\multicolumn{11}{|c|}{$\begin{array}{l}\text { ANNUAL VEHICLE TRIPS PER HOUSEHOLD BY } 1990 \text { TRIP PURPOSES } \\
1990 \text { ADJUSTED AND } 1995 \text { NPTS }\end{array}$}} \\
\hline & & & & & & & & & & \\
\hline Trip Purpose & TOTAL & $\begin{array}{l}\text { Less than } \\
\$ 10,000\end{array}$ & $\begin{array}{l}\$ 10 \text { to } \\
\$ 20,000\end{array}$ & $\begin{array}{l}\$ 20 \text { to } \\
\$ 30,000\end{array}$ & $\begin{array}{l}\$ 30 \text { to } \\
\$ 40,000\end{array}$ & $\begin{array}{l}\$ 40 \text { to } \\
\$ 50,000\end{array}$ & $\begin{array}{l}\$ 50 \text { to } \\
\$ 60,000\end{array}$ & $\begin{array}{l}\$ 60 \text { to } \\
\$ 70,000\end{array}$ & $\begin{array}{l}\$ 70 \text { to } \\
\$ 80,000\end{array}$ & $\begin{array}{l}\$ 80,000 \text { or } \\
\text { more }\end{array}$ \\
\hline \multicolumn{11}{|l|}{1990 Adjusted } \\
\hline TOTAL & 2,077 & 1,045 & 1,655 & 2,192 & 2,526 & 2,907 & 2,986 & 3,100 & 3,309 & 3,092 \\
\hline To/From Work & 448 & 138 & 321 & 455 & 563 & 658 & 711 & 722 & 740 & 680 \\
\hline Work Related Business & 30 & 4 & 16 & 31 & 36 & 43 & 61 & 64 & 60 & 73 \\
\hline Family/Personal Business & 1,036 & 573 & 851 & 1,098 & 1,279 & 1,420 & 1,416 & 1,530 & 1,595 & 1,531 \\
\hline School/Church & 90 & 70 & 79 & 87 & 95 & 125 & 126 & 109 & 119 & 131 \\
\hline Social/Recreational & 460 & 253 & 380 & 505 & 541 & 643 & 655 & 655 & 765 & 660 \\
\hline Other & 12 & 6 & 8 & 14 & 12 & 17 & 17 & 19 & 29 & 16 \\
\hline $\begin{array}{l}\text { Nbr. of Households }(000) \\
\text { (Income in } 1995 \text { dollars) }\end{array}$ & 93,347 & 7,247 & 11,121 & 11,050 & 10,017 & 8,318 & 6,312 & 4,373 & 2,821 & 6,327 \\
\hline Percentage of Households & 100.00 & 7.76 & 11.91 & 11.84 & 10.73 & 8.91 & 6.76 & 4.68 & 3.02 & 6.78 \\
\hline \multicolumn{11}{|l|}{1995} \\
\hline TOTAL & 2,321 & 1,012 & 1,671 & 2,337 & 2,610 & 2,861 & 2,877 & 3,027 & 2,983 & 3,040 \\
\hline To/From Work & 553 & 155 & 351 & 551 & 646 & 738 & 762 & 787 & 791 & 739 \\
\hline Work Related Business & 80 & 10 & 36 & 82 & 90 & 113 & 125 & 139 & 119 & 130 \\
\hline Family/Personal Business & 1,160 & 572 & 890 & 1,178 & 1,297 & 1,412 & 1,358 & 1,488 & 1,410 & 1,501 \\
\hline School/Church & 98 & 78 & 73 & 99 & 101 & 101 & 114 & 105 & 120 & 109 \\
\hline Social/Recreational & 427 & 197 & 321 & 423 & 474 & 497 & 516 & 504 & 541 & 555 \\
\hline Other & 2 & 0 & 1 & 3 & 2 & 1 & 2 & 4 & 1 & 5 \\
\hline $\begin{array}{l}\text { Nbr. of Households (000) } \\
\text { (Income in } 1995 \text { dollars) }\end{array}$ & 98,990 & 8,410 & 13,983 & 15,152 & 12,775 & 9,830 & 6,985 & 4,708 & 3,246 & 7,352 \\
\hline Percentage of Households & 100.00 & 8.50 & 14.13 & 15.31 & 12.91 & 9.93 & 7.06 & 4.76 & 3.28 & 7.43 \\
\hline
\end{tabular}

- All tables reporting totals could include some unreported characteristics.

- The purpose codes used for 1995 NPTS reflect the 1990 purpose code scheme.

- Note that only the 1990 data have been adjusted to make them more comparable with the 1995 data. Thus, there are limits on the conclusions that can be drawn in comparing travel with earlier survey years. The adjustments to 1990 data affect only person trips, vehicle trips, person miles of travel (PMT) and 
Vehicle Trips and Vehicle Miles of Travel

\section{TABLE 5.14}

Annual Vehicle Miles of Travel Per Household by 1990 Trip Purposes and Household Income 1990 ADJUSTED AND 1995 NPTS

\begin{tabular}{|c|c|c|c|c|c|c|c|c|c|c|}
\hline Trip Purpose & TOTAL & $\begin{array}{l}\text { Less than } \\
\$ 10,000\end{array}$ & $\begin{array}{l}\$ 10 \text { to } \\
\$ 20,000\end{array}$ & $\begin{array}{l}\$ 20 \text { to } \\
\$ 30,000\end{array}$ & $\begin{array}{l}\$ 30 \text { to } \\
\$ 40,000\end{array}$ & $\begin{array}{l}\$ 40 \text { to } \\
\$ 50,000\end{array}$ & $\begin{array}{l}\$ 50 \text { to } \\
\$ 60,000 \\
\end{array}$ & $\begin{array}{l}\$ 60 \text { to } \\
\$ 70,000\end{array}$ & $\begin{array}{l}\$ 70 \text { to } \\
\$ 80,000 \\
\end{array}$ & $\begin{array}{c}\$ 80,000 \text { or } \\
\text { more }\end{array}$ \\
\hline \multicolumn{11}{|l|}{1990 Adjusted } \\
\hline TOTAL & 18,161 & 7,408 & 12,042 & 18,726 & 22,902 & 26,604 & 27,608 & 29,739 & 33,353 & 31,761 \\
\hline To/From Work & 4,853 & 1,244 & 2,944 & 4,443 & 6,118 & 7,379 & 8,681 & 9,195 & 9,650 & 8,698 \\
\hline Work Related Business & 454 & 88 & 137 & 366 & 558 & 434 & 1,139 & 1,113 & 1,012 & 1,368 \\
\hline Family/Personal Business & 6,698 & 3,167 & 4,689 & 7,244 & 8,389 & 9,807 & 8,662 & 10,159 & 11,075 & 11,073 \\
\hline School/Church & 666 & 439 & 485 & 674 & 806 & 759 & 1,106 & 811 & 1,036 & 942 \\
\hline Social/Recreational & 5,359 & 2,419 & 3,723 & 5,678 & 6,927 & 8,091 & 7,888 & 8,326 & 10,413 & 9,552 \\
\hline Other & 130 & 51 & 61 & 319 & 104 & 131 & 128 & 133 & 156 & 122 \\
\hline $\begin{array}{l}\text { Nbr. of Households (000) } \\
\text { (Income in } 1995 \text { dollars) }\end{array}$ & 93,347 & 7,247 & 11,121 & 11,050 & 10,017 & 8,318 & 6,312 & 4,373 & 2,821 & 6,327 \\
\hline Percentage of Households & 100.00 & 7.76 & 11.91 & 11.84 & 10.73 & 8.91 & 6.76 & 4.68 & 3.02 & 6.78 \\
\hline \multicolumn{11}{|l|}{1995} \\
\hline TOTAL & 20,895 & 7,112 & 12,588 & 20,883 & 24,205 & 26,268 & 28,116 & 28,859 & 32,448 & 30,127 \\
\hline To/From Work & 6,492 & 1,317 & 3,459 & 5,829 & 7,721 & 8,609 & 9,247 & 9,737 & 10,685 & 10,420 \\
\hline Work Related Business & 1,393 & 137 & 528 & 1,622 & 1,546 & 1,737 & 2,651 & 2,223 & 2,893 & 2,014 \\
\hline Family/Personal Business & 7,423 & 3,195 & 5,145 & 7,641 & 8,475 & 9,520 & 9,134 & 9,887 & 8,859 & 10,214 \\
\hline School/Church & 791 & 781 & 555 & 891 & 756 & 894 & 810 & 814 & 1,418 & 894 \\
\hline Social/Recreational & 4,764 & 1,682 & 2,886 & 4,808 & 5,689 & 5,488 & 6,264 & 6,168 & 8,569 & 6,552 \\
\hline Other & 28 & 0 & 8 & 92 & 13 & 10 & 11 & 31 & 23 & 33 \\
\hline $\begin{array}{l}\text { Nbr. of Households }(000) \\
\text { (Income in } 1995 \text { dollars) }\end{array}$ & 98,990 & 8,410 & 13,983 & 15,152 & 12,775 & 9,830 & 6,985 & 4,708 & 3,246 & 7,352 \\
\hline Percentage of Households & 100.00 & 8.50 & 14.13 & 15.31 & 12.91 & 9.93 & 7.06 & 4.76 & 3.28 & 7.43 \\
\hline
\end{tabular}

Note:

- All tables reporting totals could include some unreported characteristics.

- $\quad$ The purpose codes used for 1995 NPTS reflect the 1990 purpose code scheme.

- Note that only the 1990 data have been adjusted to make them more comparable with the 1995 data. Thus, there are limits on the conclusions that can be drawn in comparing travel with earlier survey years. The adjustments to 1990 data affect only person trips, vehicle trips, person miles of travel (PMT) and vehicle miles of travel (VMT). 


\section{FIGURE 5.6}

AnNual Vehicle Trips Per Household by 1990 Trip Purposes AND Household Income 1990 ADJUSTED AND 1995 NPTS

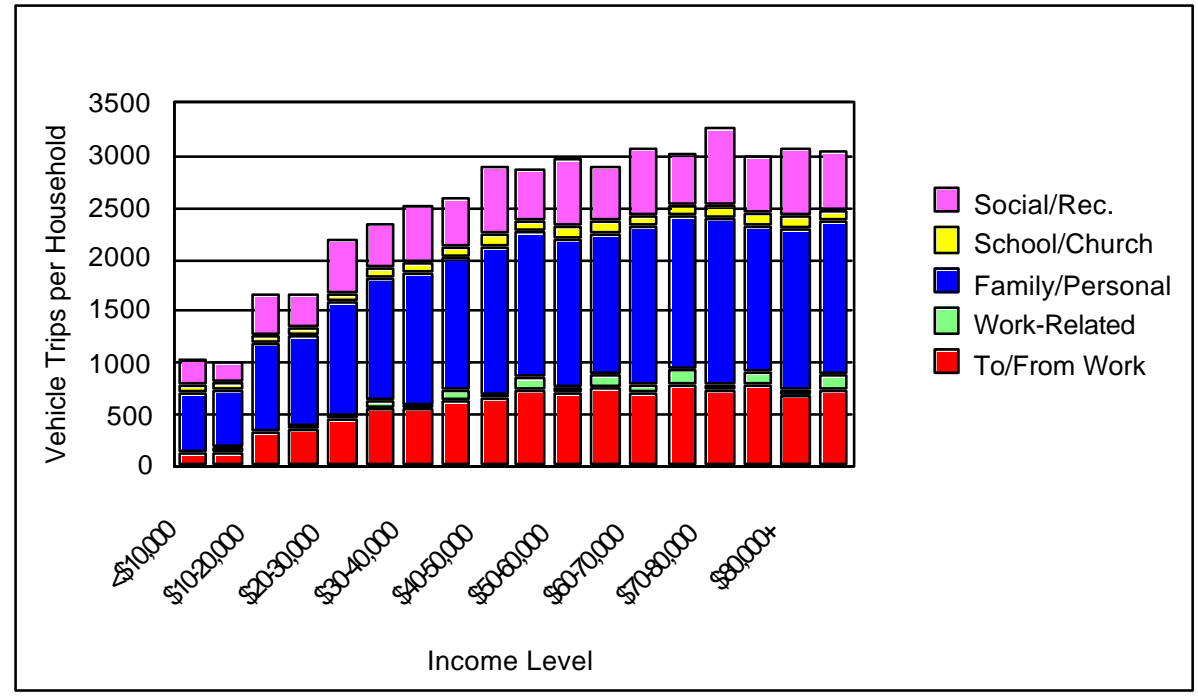

\section{FIGURE 5.7}

Annual Vehicle Miles of Travel Per Household by 1990 Trip Purposes 1990 ADJUSTED AND 1995 NPTS

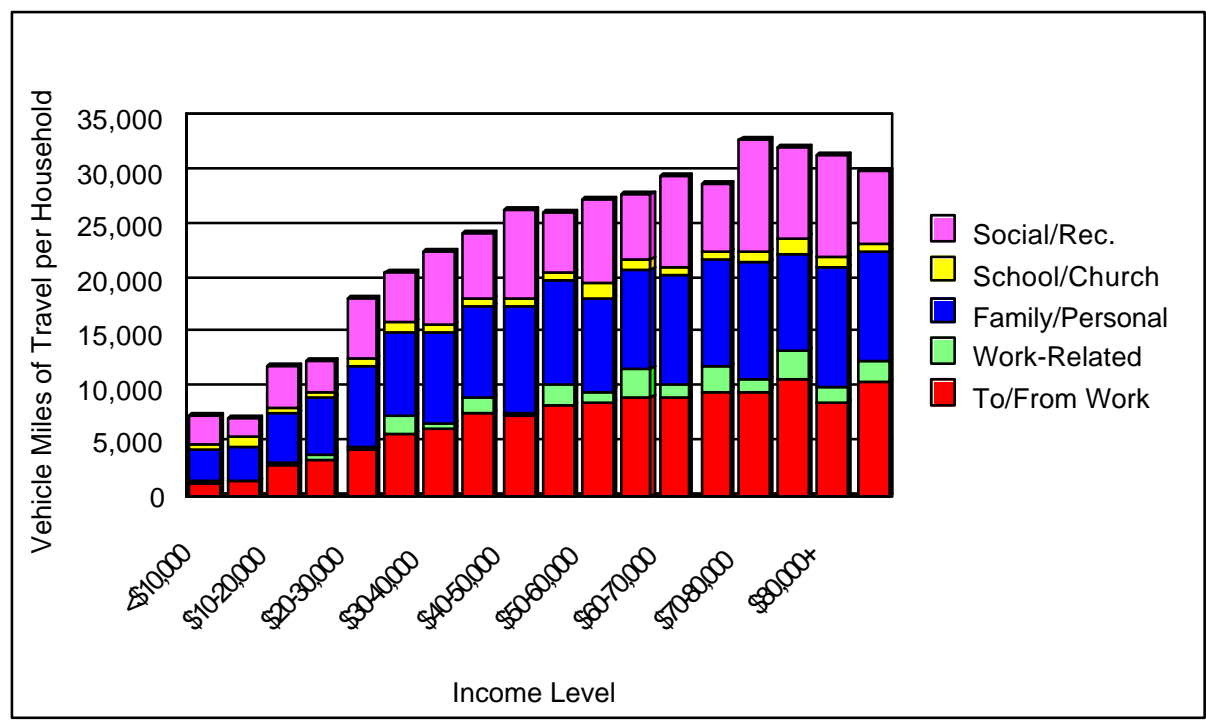


Tables 5.15-5.17 provide statistics on vehicle trip characteristics. In Table 5.15, changes in total numbers of trips and VMT by trip purpose are shown from the 1969 through the 1995 NPTS. The total number of vehicle trips for all trip purposes increased by $182 \%$ between 1969 and 1995. The greatest increase was in the category family/personal business, which increased by almost $267 \%$.

Table 5.16 shows average trip length by trip purposes for different MSA size categories. As might be expected, the average trip length was greatest for non-MSA groups (9.7 miles). The longest trip lengths were for work-related business purposes. 


\begin{tabular}{|c|c|c|c|c|c|c|c|c|c|c|c|c|}
\hline \multicolumn{13}{|c|}{ TABLE 5.15} \\
\hline \multicolumn{13}{|c|}{$\begin{array}{l}\text { Statistics ON VeHIClE TRAVEl By } 1990 \text { TRIP PURPOSES } \\
\text { 1969, 1977, 1983, 1990, } 1990 \text { AdJUSTED, AND } 1995 \text { NPTS }\end{array}$} \\
\hline \multirow{2}{*}{ Trip Purpose } & \multicolumn{6}{|c|}{ Vehicle Trips (millions) } & \multicolumn{6}{|c|}{ Vehicle Miles of Travel (millions) } \\
\hline & 1969 & 1977 & 1983 & 1990 & $1990 \mathrm{adj}$ & 1995 & 1969 & 1977 & 1983 & 1990 & 1990 adj & 1995 \\
\hline TOTAL & 87,284 & 108,826 & 126,874 & 158,927 & 193,916 & 229,745 & 775,940 & 907,603 & $1,002,139$ & $1,409,600$ & $1,695,290$ & $2,068,368$ \\
\hline \multicolumn{13}{|l|}{ Earning a Living } \\
\hline To or From Work & 27,844 & 31,886 & 35,271 & 41,792 & 41,792 & 54,782 & 260,716 & 287,710 & 301,644 & 453,052 & 453,042 & 642,610 \\
\hline Work-Related Bus. & 3,840 & 5,768 & 3,679 & 2,845 & 2,845 & 7,921 & 61,299 & 68,978 & 42,090 & 42,336 & 42,336 & 137,867 \\
\hline Subtotal & 31,684 & 37,654 & 38,950 & 44,637 & 44,637 & 62,703 & 322,015 & 356,688 & 343,734 & 495,378 & 495,378 & 780,477 \\
\hline \multicolumn{13}{|c|}{ Family/Personal Business } \\
\hline Shopping & 13,354 & 20,242 & 25,375 & 32,165 & 40,206 & 49,554 & 58,196 & 100,744 & 134,287 & 162,668 & 203,335 & 277,860 \\
\hline Doctor/Dentist & 1,484 & 1,632 & 1,522 & 1,749 & 2,466 & 3,315 & 12,415 & 16,337 & 15,032 & 17,809 & 25,110 & 30,613 \\
\hline $\begin{array}{l}\text { Other } \\
\text { Family/Personal }\end{array}$ & 12,220 & 16,215 & 23,218 & 38,323 & 54,035 & 61,964 & 79,146 & 108,912 & 155,332 & 281,390 & 396,760 & 426,330 \\
\hline Subtotal & 27,058 & 38,089 & 50,115 & 72,237 & 96,707 & 114,833 & 149,757 & 225,993 & 304,650 & 461,867 & 625,205 & 734,803 \\
\hline \multicolumn{13}{|l|}{ School/Church } \\
\hline Subtotal & 8,117 & 7,944 & 7,485 & 8,435 & 8,435 & 9,734 & 38,021 & 47,195 & 41,088 & 62,201 & 62,201 & 78,313 \\
\hline \multicolumn{13}{|l|}{ Social/Recreational } \\
\hline Vacation & 0 & 109 & 254 & 190 & 250 & 246 & 20,174 & 5,446 & 21,045 & 20,531 & 27,102 & 20,318 \\
\hline $\begin{array}{l}\text { Visit } \\
\text { Friends/Relatives }\end{array}$ & 7,855 & 10,121 & 12,561 & 14,053 & 18,550 & 15,323 & 93,889 & 109,820 & 135,289 & 163,980 & 216,453 & 195,068 \\
\hline Pleasure Driving & 1,222 & 544 & 507 & 435 & 575 & $* *$ & 24,054 & 8,168 & 11,024 & 9,166 & 12,100 & $* *$ \\
\hline Other Social/Rec. & 10,387 & 13,386 & 15,352 & 17,870 & 23,588 & 26,670 & 118,719 & 124,342 & 133,284 & 185,311 & 244,610 & 256,169 \\
\hline Subtotal & 19,464 & 24,159 & 28,674 & 32,548 & 42,963 & 42,239 & 256,836 & 247,776 & 300,642 & 378,988 & 500,265 & 471,555 \\
\hline \multicolumn{13}{|l|}{ Other } \\
\hline Subtotal & 960 & 979 & 1,649 & 1,070 & 1,124 & 204 & 9,311 & 29,951 & 12,026 & 11,166 & 12,096 & 2,797 \\
\hline
\end{tabular}

Note:

- All tables reporting totals could include some unreported characteristics.

- The purpose codes used for 1995 NPTS reflect the 1990 purpose code scheme.

- ** Indicates no data available

- Note that only the 1990 data have been adjusted to make them more comparable with the 1995 data. Thus, there are limits on the conclusions that can be drawn in comparing travel with earlier survey years. The adjustments to 1990 data affect only person trips, vehicle trips, person miles of travel (PMT) and vehicle miles of travel (VMT). 
TABLE 5.16

\section{Average Vehicle Trip Length by MSA Size and 1990 Trip Purposes 1990 ADJUSTED AND 1995 NPTS}

\begin{tabular}{|c|c|c|c|c|c|c|c|}
\hline & ALL & $\begin{array}{c}\text { To/From } \\
\text { Work }\end{array}$ & $\begin{array}{c}\text { Work- } \\
\text { Related } \\
\text { Business }\end{array}$ & $\begin{array}{l}\text { Family/ } \\
\text { Personal } \\
\text { Business }\end{array}$ & $\begin{array}{l}\text { School/ } \\
\text { Church }\end{array}$ & $\begin{array}{c}\text { Social/ } \\
\text { Recreational }\end{array}$ & Other \\
\hline \multicolumn{8}{|l|}{1990 Adjusted } \\
\hline ALL & 8.85 & 10.97 & 15.13 & 6.54 & 7.47 & 11.80 & 10.78 \\
\hline Less than 250,000 & 8.22 & 9.03 & 20.91 & 5.90 & 5.90 & 12.04 & 7.68 \\
\hline 250,000 to 499,999 & 8.05 & 9.84 & 11.28 & 6.06 & 7.10 & 10.78 & 4.20 \\
\hline 500,000 to 999,999 & 8.68 & 10.81 & 11.61 & 6.74 & 7.28 & 11.14 & 10.59 \\
\hline 1 to 2.9 million & 8.76 & 10.67 & 14.21 & 6.43 & 7.10 & 12.00 & 8.92 \\
\hline 3 million or more & 8.93 & 12.01 & 16.26 & 6.32 & 7.83 & 11.21 & 20.76 \\
\hline Not in MSA & 9.51 & 11.33 & 15.57 & 7.28 & 8.28 & 12.92 & 7.16 \\
\hline \multicolumn{8}{|l|}{1995} \\
\hline ALL & 9.06 & 11.80 & 17.50 & 6.44 & 8.11 & 11.24 & 14.16 \\
\hline Less than 250,000 & 8.41 & 10.32 & 14.28 & 6.31 & 8.06 & 10.34 & 73.60 \\
\hline 250,000 to 499,999 & 8.81 & 10.50 & 22.72 & 6.45 & 9.58 & 10.22 & 30.73 \\
\hline 500,000 to 999,999 & 8.87 & 11.02 & 14.58 & 6.47 & 8.11 & 11.72 & 11.63 \\
\hline 1 to 2.9 million & 8.90 & 11.07 & 18.46 & 6.20 & 7.34 & 12.02 & 8.47 \\
\hline 3 million or more & 9.01 & 13.20 & 14.44 & 6.10 & 7.80 & 10.86 & 6.35 \\
\hline Not in MSA & 9.70 & 11.41 & 21.81 & 7.26 & 8.61 & 11.68 & 10.13 \\
\hline
\end{tabular}

Note:

- All tables reporting totals could include some unreported characteristics.

- Average Trip Length is calculated using only those records with trip mileage information present.

- The purpose codes used for 1995 NPTS reflect the 1990 purpose code scheme.

- Note that only the 1990 data have been adjusted to make them more comparable with the 1995 data. Thus, there are limits on the conclusions that can be drawn in comparing travel with earlier survey years. The adjustments to 1990 data affect only person trips, vehicle trips, person miles of travel (PMT) and vehicle miles of travel (VMT). 
As shown in Table 5.17, the greatest average vehicle trip length (39 miles) was by the category of other truck, primarily for trips to earn a living (average trip length $=44.5$ miles) and other (average trip length $=78.2$ miles). The other truck category also had higher average trip lengths than other types of vehicles for family/personal business and trip purposes. Recreational vehicles (RVs), with an average trip length of 22.4 miles were used primarily for social/recreational purposes ( 71.3 miles average trip length). The sport utility vehicle (SUV), a separate vehicle type for the first time in the 1995 NPTS, had an average trip length of just under 10 miles. Table 5.18, which is comparable to Table 5.17, uses 1990 trip purpose codes.

Figure 5.8 shows average trip length by vehicle type and trip purpose in the top portion of the figure and total annual vehicle miles traveled by vehicle type and trip purpose in the bottom portion. Although the automobile had the shortest overall average trip length (Table 5.17), it was used for more trips than any other type of vehicle. The total annual vehicle miles for the automobile, therefore, was greater than for any other vehicle type.

TABLE 5.17

Average Vehicle Trip Length by Vehicle Type and TRip Purpose 1995 NPTS

(MILES)

\begin{tabular}{|c|c|c|c|c|c|c|c|}
\hline & ALL & $\begin{array}{l}\text { Earning a } \\
\text { Living }\end{array}$ & $\begin{array}{l}\text { Family/ } \\
\text { Personal } \\
\text { Business }\end{array}$ & $\begin{array}{l}\text { School/ } \\
\text { Church }\end{array}$ & $\begin{array}{c}\text { Social/ } \\
\text { Recreational }\end{array}$ & Other & $\begin{array}{c}\text { Returning } \\
\text { Home }\end{array}$ \\
\hline ALL & 9.06 & 12.37 & 6.49 & 8.08 & 10.97 & 18.21 & 9.28 \\
\hline Automobile & 8.38 & 10.86 & 6.16 & 8.15 & 10.39 & 21.86 & 8.76 \\
\hline Van & 8.84 & 11.83 & 6.52 & 7.08 & 12.41 & 9.72 & 8.97 \\
\hline SUV & 9.89 & 10.58 & 7.54 & 8.18 & 13.03 & 16.26 & 10.64 \\
\hline Pickup & 10.36 & 13.01 & 7.39 & 8.39 & 11.25 & 8.68 & 10.77 \\
\hline Other Truck & 39.02 & 44.47 & 23.14 & 4.69 & 24.97 & 78.17 & 28.49 \\
\hline RV & 22.43 & 8.38 & 7.15 & 1.00 & 71.31 & 30.00 & 9.00 \\
\hline Motorcycle & 10.79 & 11.63 & 10.10 & 2.50 & 12.26 & 60.00 & 10.47 \\
\hline Other POV & 9.34 & 11.99 & 8.15 & 7.31 & 10.82 & $* *$ & 9.11 \\
\hline
\end{tabular}

Note:

- All tables reporting totals could include some unreported characteristics.

- ** Indicates no data available.

- Average Trip Length is calculated using only those records with trip mileage information present.

- $\mathrm{SUV}=$ sport utility vehicle. 


\section{TABLE 5.18}

\section{Average Vehicle Trip Length by Vehicle Type and 1990 Trip Purpose 1995 NPTS}

(MILES)

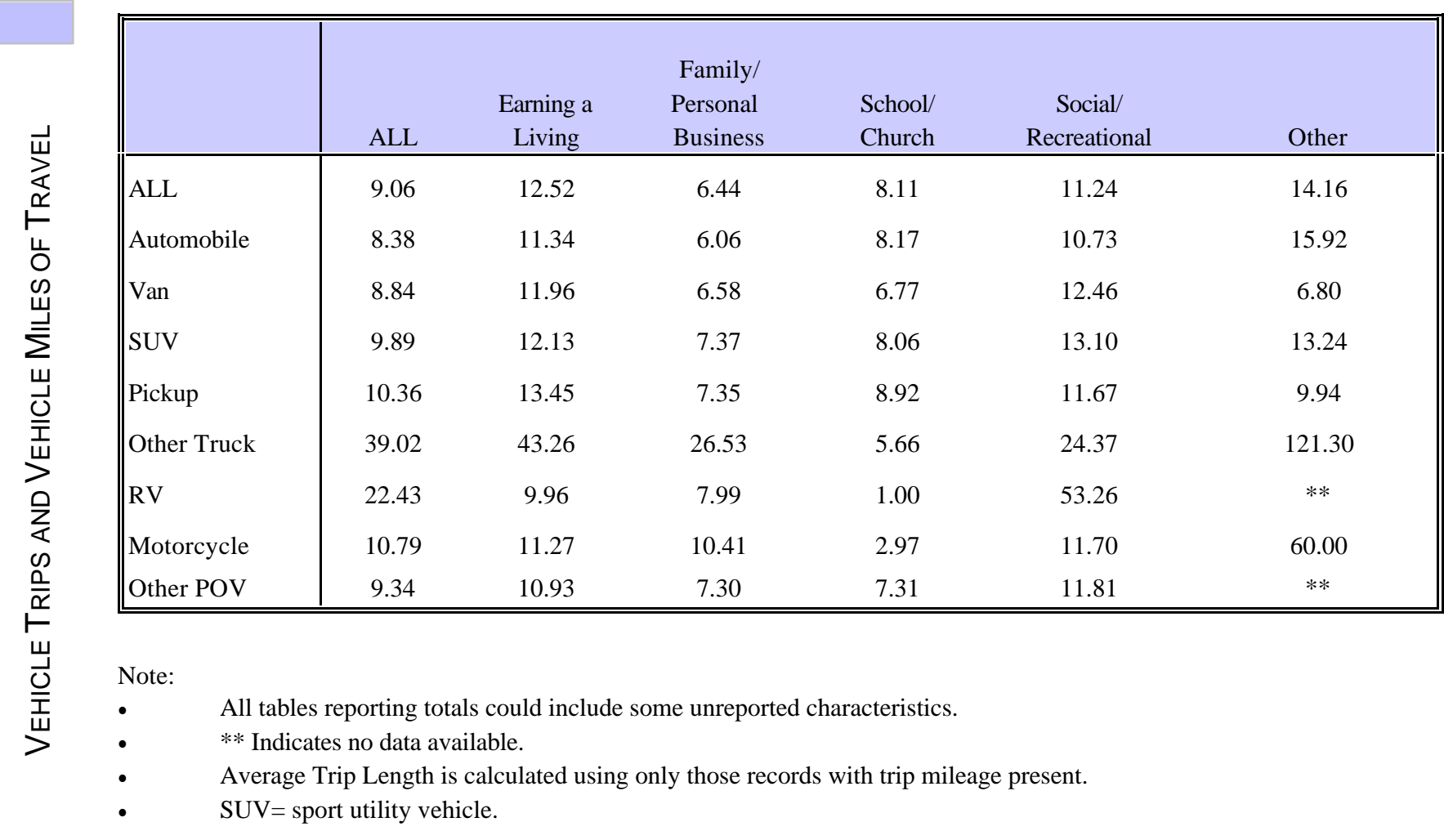


FIGURE 5.8

Average Vehicle Trip Length by Vehicle Type and Trip Purpose and

Total Annual Vehicle Miles by Vehicle Type and Trip Purpose

1995 NPTS
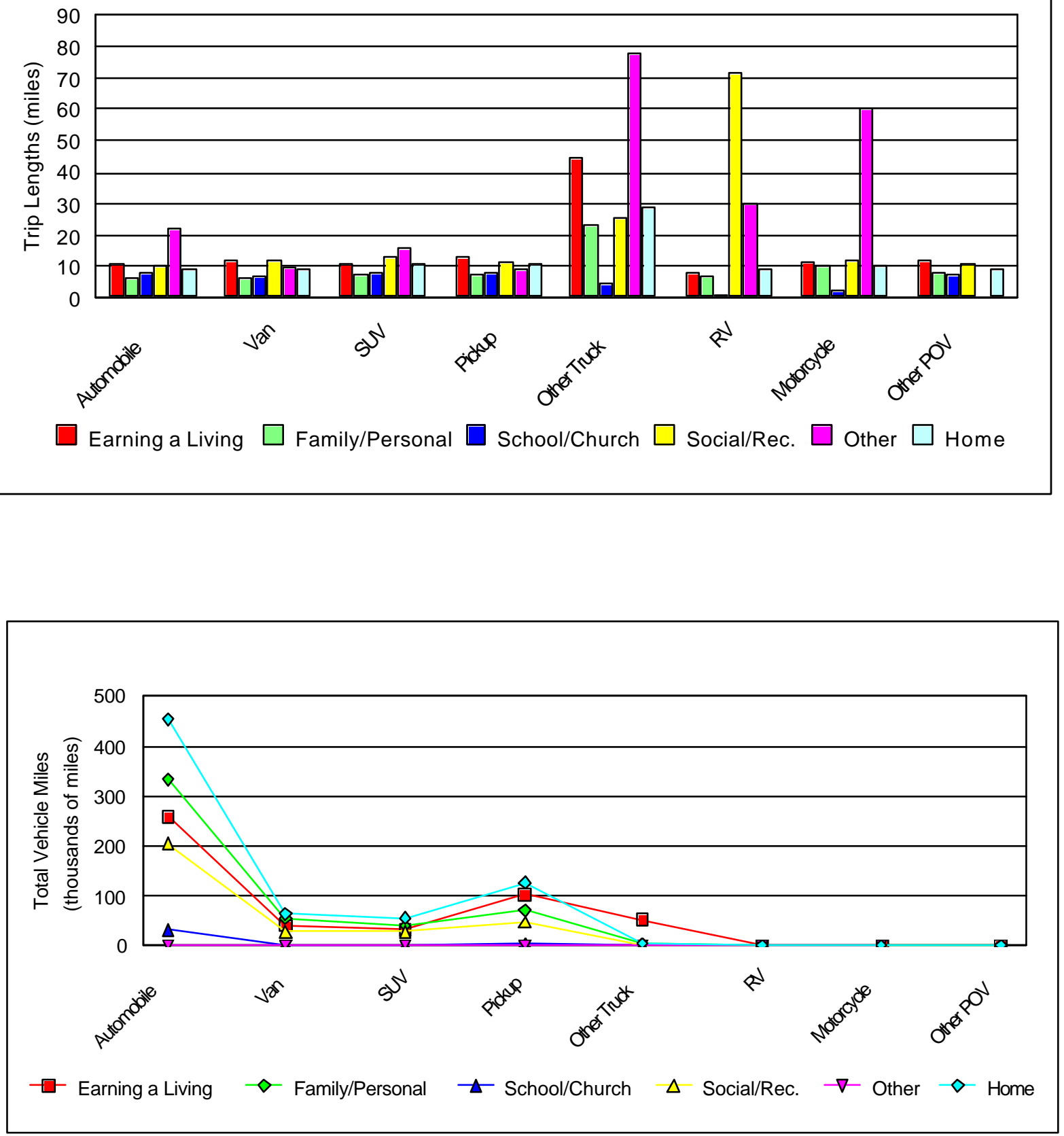
Tables 5.19-5.23 show variations in trips over days of the week and hours of the day.

As shown in Table 5.19, both the number of vehicle trips and VMT increased between 1990 (adjusted) and 1995. Weekday trips increased by $22.3 \%$ and weekend trips by $11.7 \%$. Weekday VMT increased by $28.5 \%$ and weekend VMT by $10 \%$.

Table 5.20 shows that most weekday vehicle trips $(86.4 \%)$ were taken between 6 a.m. and 7 p.m., with the primary traffic between 9 a.m. and 1 p.m. The primary trip purpose was family/personal business. Most social/recreational vehicle trips were taken between 9 a.m. to 1 p.m. or from 4 to 7 p.m. The highest traffic period for earning a living and school/church vehicle trips was 6 to 9 a.m.

On the weekend (Table 5.21), most vehicle trips were taken for family/personal business (34\%) and social/recreational (18.6\%) purposes. Almost $50 \%$ of the school/church vehicle trips were taken between 9 a.m. and 1 p.m.

Figure 5.9 shows the distribution of trips over weekdays and weekends by trip purpose. 


\section{TABLE 5.19}

Number of Vehicle Trips and Vehicle Miles of Travel by Weekday Vs. WeEKend 1990 ADJUSTED AND 1995 NPTS

(MILLIONS)

\begin{tabular}{|c|c|c|}
\hline & Vehicle Trips & VMT \\
\hline \multicolumn{3}{|c|}{1990 Adjusted } \\
\hline TOTAL & $\begin{array}{c}193,916 \\
(100.0 \%)\end{array}$ & $\begin{array}{r}1,695,290 \\
(100.0 \%)\end{array}$ \\
\hline Weekday & $\begin{array}{l}136,692 \\
(70.5 \%)\end{array}$ & $\begin{array}{c}1,143,481 \\
(67.5 \%)\end{array}$ \\
\hline Weekend & $\begin{array}{c}55,987 \\
(28.9 \%)\end{array}$ & $\begin{array}{l}544,218 \\
(32.1 \%)\end{array}$ \\
\hline \multicolumn{3}{|l|}{1995} \\
\hline TOTAL & $\begin{array}{c}229,745 \\
(100.0 \%)\end{array}$ & $\begin{array}{r}2,068,368 \\
(100.0 \%)\end{array}$ \\
\hline Weekday & $\begin{array}{l}167,209 \\
(72.8 \%)\end{array}$ & $\begin{array}{c}1,469,782 \\
(71.1 \%)\end{array}$ \\
\hline Weekend & $\begin{array}{c}62,520 \\
(27.2 \%)\end{array}$ & $\begin{array}{l}598,557 \\
(28.9 \%)\end{array}$ \\
\hline
\end{tabular}

Note:

- $\quad$ All tables reporting totals could include some unreported characteristics.

- Weekday is defined as the time between 12.01 a.m. Monday and 6:00 p.m. Friday.

- Weekend is defined as the time between 6:00 p.m. Friday and midnight Sunday. 


\section{TABLE 5.20}

\section{Number of WeEkdaY Vehicle Trips by Time of DAy AND Trip Purpose 1995 NPTS \\ (MILLIONS)}

\begin{tabular}{|c|c|c|c|c|c|c|c|}
\hline & ALL & $\begin{array}{l}\text { Earning a } \\
\text { Living }\end{array}$ & $\begin{array}{l}\text { Family/ } \\
\text { Personal } \\
\text { Business }\end{array}$ & $\begin{array}{l}\text { School/ } \\
\text { Church }\end{array}$ & $\begin{array}{c}\text { Social/ } \\
\text { Recreational }\end{array}$ & Other & $\begin{array}{c}\text { Returning } \\
\text { Home }\end{array}$ \\
\hline ALL & $\begin{array}{c}167,209 \\
(100.0 \%)\end{array}$ & $\begin{array}{c}35,814 \\
(100.0 \%)\end{array}$ & $\begin{array}{c}56,940 \\
(100.0 \%)\end{array}$ & $\begin{array}{c}3,265 \\
(100.0 \%)\end{array}$ & $\begin{array}{c}17,163 \\
(100.0 \%)\end{array}$ & $\begin{array}{c}141 \\
(100.0 \%)\end{array}$ & $\begin{array}{c}53,873 \\
(100.0 \%)\end{array}$ \\
\hline 1 to 6 a.m. & $\begin{array}{l}3,777 \\
(2.3 \%)\end{array}$ & $\begin{array}{l}2,271 \\
(6.3 \%)\end{array}$ & $\begin{array}{c}483 \\
(0.8 \%)\end{array}$ & $\begin{array}{c}12 \\
(0.4 \%)\end{array}$ & $\begin{array}{c}209 \\
(1.2 \%)\end{array}$ & $\begin{array}{c}3 \\
(2.1 \%)\end{array}$ & $\begin{array}{c}800 \\
(1.5 \%)\end{array}$ \\
\hline 6 to 9 a.m. & $\begin{array}{c}28,861 \\
(17.3 \%)\end{array}$ & $\begin{array}{c}15,528 \\
(43.4 \%)\end{array}$ & $\begin{array}{c}7,922 \\
(13.9 \%)\end{array}$ & $\begin{array}{c}1,290 \\
(39.5 \%)\end{array}$ & $\begin{array}{l}1,413 \\
(8.2 \%)\end{array}$ & $\begin{array}{c}16 \\
(11.3 \%)\end{array}$ & $\begin{array}{l}2,692 \\
(5.0 \%)\end{array}$ \\
\hline $\begin{array}{l}9 \text { a.m. to } \\
1 \text { p.m. }\end{array}$ & $\begin{array}{c}41,558 \\
(24.9 \%)\end{array}$ & $\begin{array}{c}8,517 \\
(23.8 \%)\end{array}$ & $\begin{array}{c}17,431 \\
(30.6 \%)\end{array}$ & $\begin{array}{c}755 \\
(23.1 \%)\end{array}$ & $\begin{array}{c}5,457 \\
(31.8 \%)\end{array}$ & $\begin{array}{c}41 \\
(29.1 \%)\end{array}$ & $\begin{array}{c}9,352 \\
(17.4 \%)\end{array}$ \\
\hline 1 to 4 p.m. & $\begin{array}{c}35,660 \\
(21.3 \%)\end{array}$ & $\begin{array}{c}6,325 \\
(17.7 \%)\end{array}$ & $\begin{array}{c}14,444 \\
(25.4 \%)\end{array}$ & $\begin{array}{c}290 \\
(8.9 \%)\end{array}$ & $\begin{array}{c}3,085 \\
(18.0 \%)\end{array}$ & $\begin{array}{c}20 \\
(14.2 \%)\end{array}$ & $\begin{array}{c}11,490 \\
(21.3 \%)\end{array}$ \\
\hline 4 to 7 p.m. & $\begin{array}{c}38,510 \\
(23.0 \%)\end{array}$ & $\begin{array}{l}2,268 \\
(6.3 \%)\end{array}$ & $\begin{array}{c}12,345 \\
(21.7 \%)\end{array}$ & $\begin{array}{c}664 \\
(20.3 \%)\end{array}$ & $\begin{array}{c}4,562 \\
(26.6 \%)\end{array}$ & $\begin{array}{c}34 \\
(24.1 \%)\end{array}$ & $\begin{array}{c}18,637 \\
(34.6 \%)\end{array}$ \\
\hline 7 to 10 p.m. & $\begin{array}{l}14,486 \\
(8.7 \%)\end{array}$ & $\begin{array}{c}551 \\
(1.5 \%)\end{array}$ & $\begin{array}{l}3,643 \\
(6.4 \%)\end{array}$ & $\begin{array}{c}247 \\
(7.6 \%)\end{array}$ & $\begin{array}{c}2,076 \\
(12.1 \%)\end{array}$ & $\begin{array}{c}22 \\
(15.6 \%)\end{array}$ & $\begin{array}{c}7,946 \\
(14.7 \%)\end{array}$ \\
\hline $\begin{array}{l}10 \text { p.m. to } \\
1 \text { a.m. }\end{array}$ & $\begin{array}{l}4,343 \\
(2.6 \%)\end{array}$ & $\begin{array}{c}351 \\
(1.0 \%)\end{array}$ & $\begin{array}{c}665 \\
(1.2 \%)\end{array}$ & $\begin{array}{c}6 \\
(0.2 \%)\end{array}$ & $\begin{array}{c}359 \\
(2.1 \%)\end{array}$ & $\begin{array}{c}5 \\
(3.5 \%)\end{array}$ & $\begin{array}{l}2,956 \\
(5.5 \%)\end{array}$ \\
\hline
\end{tabular}

Note:

- All tables reporting totals could include some unreported characteristics.

- Weekday is defined as the time between 12.01 a.m. Monday and 6:00 p.m. Friday. 


\section{TABLE 5.21}

\section{Number of WeEkend Vehicle Trips by Time of Day and Trip Purpose 1995 NPTS \\ (MILLIONS)}

\begin{tabular}{|c|c|c|c|c|c|c|c|}
\hline & ALL & $\begin{array}{c}\text { Earning a } \\
\text { Living }\end{array}$ & $\begin{array}{l}\text { Family/ } \\
\text { Personal } \\
\text { Business }\end{array}$ & $\begin{array}{l}\text { School/ } \\
\text { Church }\end{array}$ & $\begin{array}{c}\text { Social/ } \\
\text { Recreational }\end{array}$ & Other & $\begin{array}{c}\text { Returning } \\
\text { Home }\end{array}$ \\
\hline ALL & $\begin{array}{c}62,520 \\
(100.0 \%)\end{array}$ & $\begin{array}{c}4,270 \\
(100.0 \%)\end{array}$ & $\begin{array}{c}21,163 \\
(100.0 \%)\end{array}$ & $\begin{array}{c}2,243 \\
(100.0 \%)\end{array}$ & $\begin{array}{c}11,631 \\
(100.0 \%)\end{array}$ & $\begin{array}{c}55 \\
(100.0 \%)\end{array}$ & $\begin{array}{c}23,153 \\
(100.0 \%)\end{array}$ \\
\hline 1 to 6 a.m. & $\begin{array}{c}989 \\
(1.6 \%)\end{array}$ & $\begin{array}{c}291 \\
(6.8 \%)\end{array}$ & $\begin{array}{c}149 \\
(0.7 \%)\end{array}$ & $\begin{array}{c}12 \\
(0.5 \%)\end{array}$ & $\begin{array}{c}123 \\
(1.1 \%)\end{array}$ & $\begin{array}{c}2 \\
(3.6 \%)\end{array}$ & $\begin{array}{c}412 \\
(1.8 \%)\end{array}$ \\
\hline 6 to 9 a.m. & $\begin{array}{l}4,588 \\
(7.3 \%)\end{array}$ & $\begin{array}{c}1,216 \\
(28.5 \%)\end{array}$ & $\begin{array}{l}1,398 \\
(6.6 \%)\end{array}$ & $\begin{array}{c}475 \\
(21.2 \%)\end{array}$ & $\begin{array}{c}730 \\
(6.3 \%)\end{array}$ & $\begin{array}{c}2 \\
(3.6 \%)\end{array}$ & $\begin{array}{c}767 \\
(3.3 \%)\end{array}$ \\
\hline $\begin{array}{c}9 \text { a.m. to } \\
1 \text { p.m. }\end{array}$ & $\begin{array}{c}16,862 \\
(27.0 \%)\end{array}$ & $\begin{array}{c}1,114 \\
(26.1 \%)\end{array}$ & $\begin{array}{c}7,096 \\
(33.5 \%)\end{array}$ & $\begin{array}{c}1,109 \\
(49.4 \%)\end{array}$ & $\begin{array}{c}2,895 \\
(24.9 \%)\end{array}$ & $\begin{array}{c}9 \\
(16.4 \%)\end{array}$ & $\begin{array}{c}4,638 \\
(20.0 \%)\end{array}$ \\
\hline 1 to 4 p.m. & $\begin{array}{c}12,710 \\
(20.3 \%)\end{array}$ & $\begin{array}{c}675 \\
(15.8 \%)\end{array}$ & $\begin{array}{c}5,062 \\
(23.9 \%)\end{array}$ & $\begin{array}{c}175 \\
(7.8 \%)\end{array}$ & $\begin{array}{c}2,358 \\
(20.3 \%)\end{array}$ & $\begin{array}{c}12 \\
(21.8 \%)\end{array}$ & $\begin{array}{c}4,423 \\
(19.1 \%)\end{array}$ \\
\hline 4 to 7 p.m. & $\begin{array}{c}13,775 \\
(22.0 \%)\end{array}$ & $\begin{array}{c}533 \\
(12.5 \%)\end{array}$ & $\begin{array}{c}4,316 \\
(20.4 \%)\end{array}$ & $\begin{array}{c}380 \\
(16.9 \%)\end{array}$ & $\begin{array}{c}2,868 \\
(24.7 \%)\end{array}$ & $\begin{array}{c}6 \\
(10.9 \%)\end{array}$ & $\begin{array}{c}5,672 \\
(24.5 \%)\end{array}$ \\
\hline 7 to 10 p.m. & $\begin{array}{c}10,026 \\
(16.0 \%)\end{array}$ & $\begin{array}{c}257 \\
(6.0 \%)\end{array}$ & $\begin{array}{c}2,558 \\
(12.1 \%)\end{array}$ & $\begin{array}{c}82 \\
(3.7 \%)\end{array}$ & $\begin{array}{c}2,238 \\
(19.2 \%)\end{array}$ & $\begin{array}{c}17 \\
(30.9 \%)\end{array}$ & $\begin{array}{c}4,873 \\
(21.0 \%)\end{array}$ \\
\hline $\begin{array}{l}10 \text { p.m. to } \\
1 \text { a.m. }\end{array}$ & $\begin{array}{c}3,569 \\
(5.7 \%)\end{array}$ & $\begin{array}{c}185 \\
(4.3 \%)\end{array}$ & $\begin{array}{c}585 \\
(2.8 \%)\end{array}$ & $\begin{array}{c}9 \\
(0.4 \%)\end{array}$ & $\begin{array}{c}418 \\
(3.6 \%)\end{array}$ & $\begin{array}{c}6 \\
(10.9 \%)\end{array}$ & $\begin{array}{c}2,367 \\
(10.2 \%)\end{array}$ \\
\hline
\end{tabular}

Note:

- All tables reporting totals could include some unreported characteristics.

- Weekend is defined as the time between 6:00 p.m. Friday and midnight Sunday. 
FIGURE 5.9

Distribution OF TRIPS OVER WEEKDAYS AND WEEKENDS BY TRIP PURPOSE 1995 NPTS

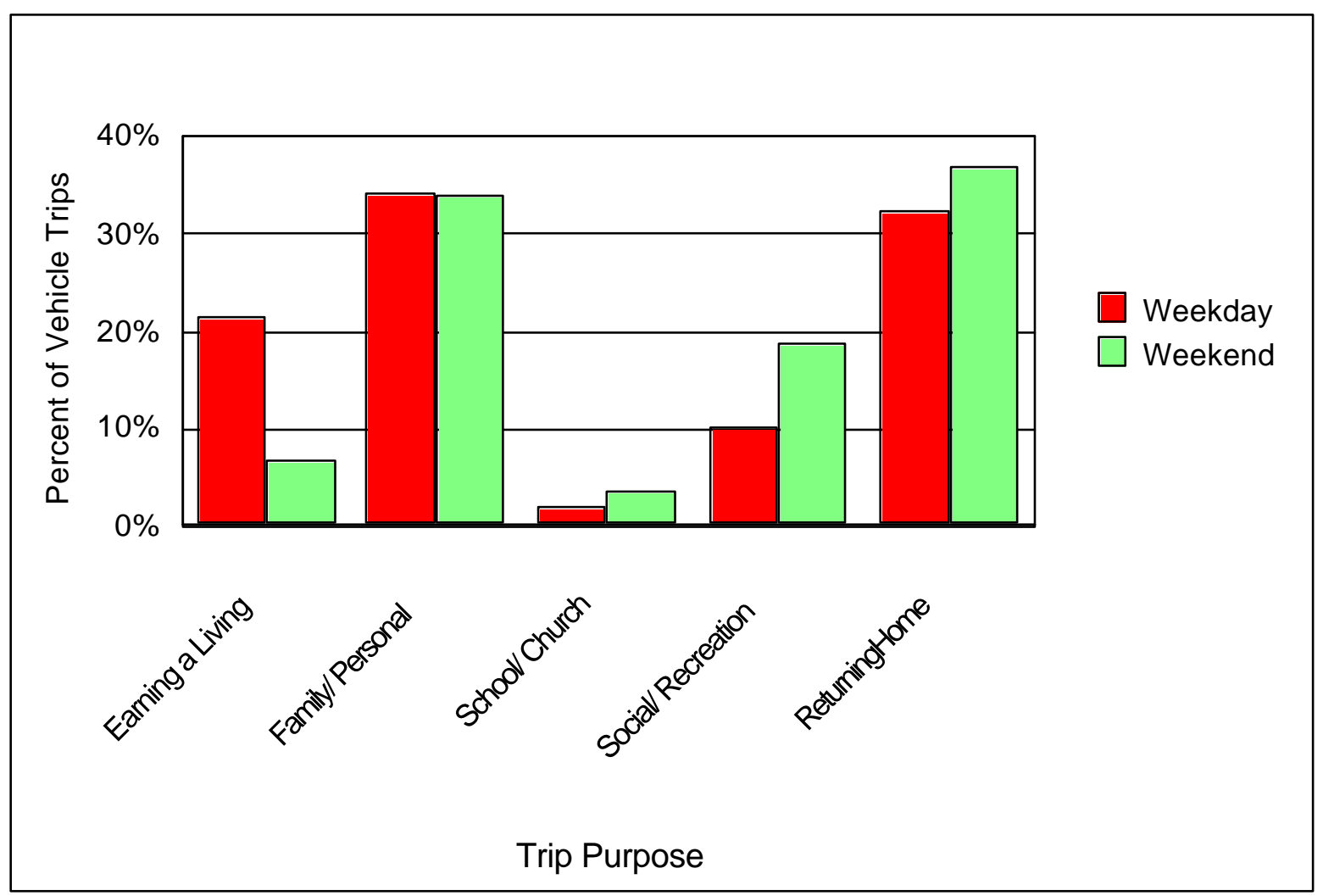


On any day of the week, individuals 65 or over took fewer daily vehicle trips than individuals under age 65 (Table 5.22). Older drivers drove more trips at midweek (Wednesday) than any other day. Individuals less than 65 took the fewest trips on Sunday.

Figures 5.10 and 5.11 illustrate the differences in daily vehicle trips for those over and under age 65 . Both male and female senior drivers took more vehicle trips between 9 a.m. and 1 p.m. than during any other time period; in addition, 9 a.m. to 1 p.m. was the only time period when senior drivers took more vehicle trips than drivers under 65 .

\section{TABLE 5.22}

Average Daily Vehicle Trips Per Driver Taken by INDIVIDUALS 65 OR OLDER VS. INDIVIDUALS UNDER 65 BY DAY OF WEEK 1995 NPTS

\begin{tabular}{||lccc||}
\hline & TOTAL & $\begin{array}{c}\text { Individuals } \\
\text { Under 65 }\end{array}$ & $\begin{array}{c}\text { Individuals } \\
\text { 65 or Older }\end{array}$ \\
\hline TOTAL & 3.57 & 3.67 & 2.94 \\
Sunday & 2.69 & 2.75 & 2.33 \\
Monday & 3.63 & 3.73 & 2.98 \\
Tuesday & 3.75 & 3.88 & 2.90 \\
Wednesday & 3.85 & 3.92 & 3.41 \\
Thursday & 3.78 & 3.89 & 3.06 \\
Friday & 4.02 & 4.16 & 3.18 \\
Saturday & 3.28 & 3.37 & 2.70 \\
\hline \hline
\end{tabular}

Note:

- All tables reporting totals could include some unreported characteristics.

- Average daily vehicle trips per driver was estimated by including only those drivers interviewed on a particular day of the week in the denominator. 
FigURE 5.10

Average Daily Vehicle Trips PER Driver TaKen by Individuals 65 OR Older VS. INDIVIDUALS UNDER 65 BY DAY OF WEEK 1995 NPTS

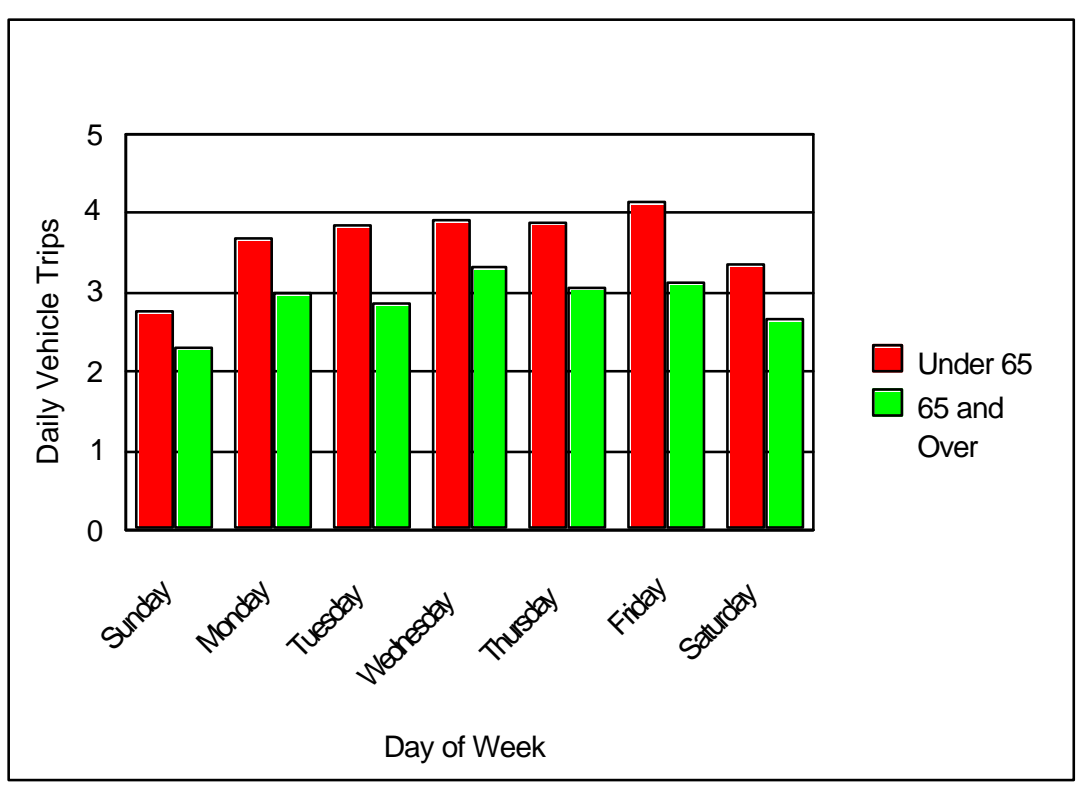

FIGURE 5.11

Average Vehicle Trips Per Driver TaKen by Individuals 65 Or Older vs. INDIVIDUALS UNDER 65 By Time OF DAY 1995 NPTS

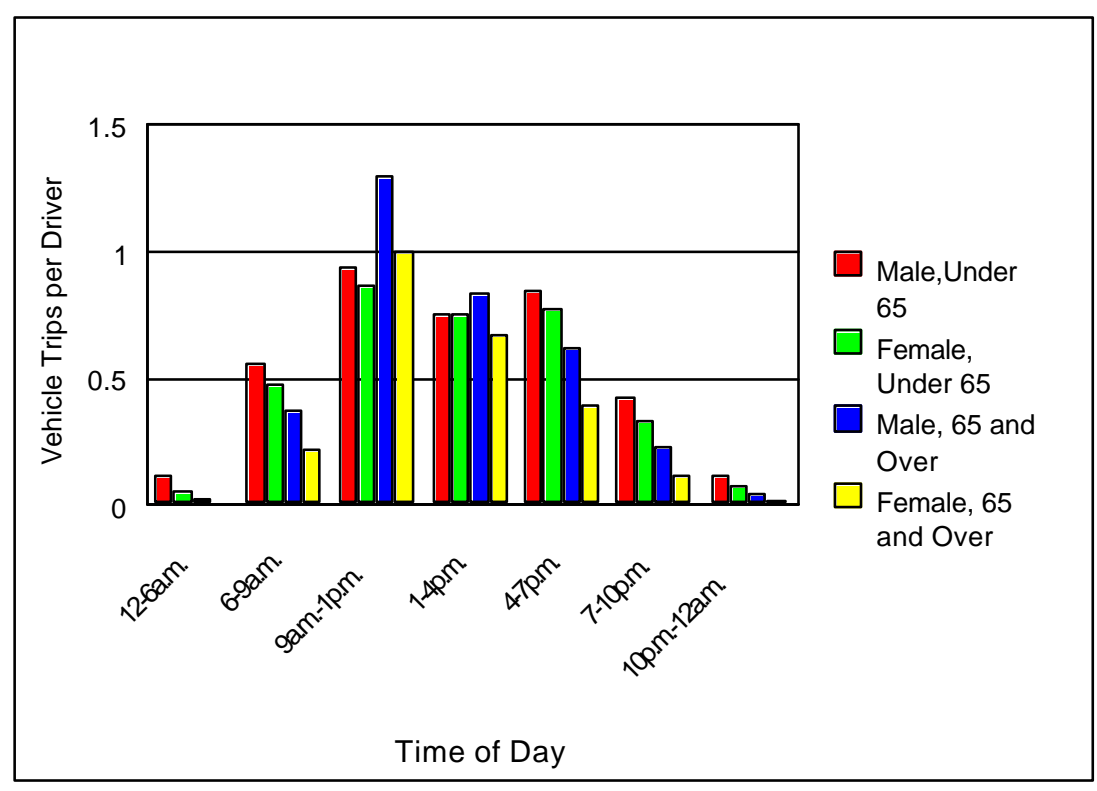


Most trips were taken between 9 a.m. and 7

p.m. (Table 5.23). The percentage distribution

of vehicle trips over time of day was consistent across all metropolitan and non-metropolitan areas.

\section{TABLE 5.23}

Number of Vehicle Trips by MSA Size AND Time OF DAy

1995 NPTS

(MILLIONS)

\begin{tabular}{|c|c|c|c|c|c|c|c|}
\hline Time of Day & TOTAL & $\begin{array}{c}\text { Less than } \\
250,000\end{array}$ & $\begin{array}{c}250,000 \text { to } \\
499,999\end{array}$ & $\begin{array}{c}500,000 \text { to } \\
999,999\end{array}$ & $\begin{array}{l}1 \text { to } 2.9 \\
\text { million }\end{array}$ & 3 million + & $\begin{array}{c}\text { Not in } \\
\text { MSA }\end{array}$ \\
\hline TOTAL & $\begin{array}{c}229,745 \\
(100.0 \%)\end{array}$ & $\begin{array}{c}19,280 \\
(100.0 \%)\end{array}$ & $\begin{array}{c}17,296 \\
(100.0 \%)\end{array}$ & $\begin{array}{c}19,951 \\
(100.0 \%)\end{array}$ & $\begin{array}{c}40,881 \\
(100.0 \%)\end{array}$ & $\begin{array}{c}82,688 \\
(100.0 \%)\end{array}$ & $\begin{array}{c}49,649 \\
(100.0 \%)\end{array}$ \\
\hline $\begin{array}{l}10 \text { p.m. to } \\
1 \text { a.m. }\end{array}$ & $\begin{array}{c}7,912 \\
(3.4 \%)\end{array}$ & $\begin{array}{c}667 \\
(3.5 \%)\end{array}$ & $\begin{array}{c}607 \\
(3.5 \%)\end{array}$ & $\begin{array}{c}771 \\
(3.9 \%)\end{array}$ & $\begin{array}{c}1,499 \\
(3.7 \%)\end{array}$ & $\begin{array}{c}2,971 \\
(3.6 \%)\end{array}$ & $\begin{array}{c}1,398 \\
(2.8 \%)\end{array}$ \\
\hline 1 to 6 a.m. & $\begin{array}{c}4,766 \\
(2.1 \%)\end{array}$ & $\begin{array}{c}448 \\
(2.3 \%)\end{array}$ & $\begin{array}{c}346 \\
(2.0 \%)\end{array}$ & $\begin{array}{c}373 \\
(1.9 \%)\end{array}$ & $\begin{array}{c}870 \\
(2.1 \%)\end{array}$ & $\begin{array}{c}1,687 \\
(2.0 \%)\end{array}$ & $\begin{array}{c}1,042 \\
(2.1 \%)\end{array}$ \\
\hline 6 to 9 a.m. & $\begin{array}{c}33,449 \\
(14.6 \%)\end{array}$ & $\begin{array}{c}2,827 \\
(14.7 \%)\end{array}$ & $\begin{array}{c}2,589 \\
(15.0 \%)\end{array}$ & $\begin{array}{c}2,889 \\
(14.5 \%)\end{array}$ & $\begin{array}{c}5,925 \\
(14.5 \%)\end{array}$ & $\begin{array}{c}11,834 \\
(14.3 \%)\end{array}$ & $\begin{array}{c}7,385 \\
(14.9 \%)\end{array}$ \\
\hline $\begin{array}{l}9 \text { a.m. to } \\
1 \text { p.m. }\end{array}$ & $\begin{array}{c}58,420 \\
(25.4 \%)\end{array}$ & $\begin{array}{c}4,904 \\
(25.4 \%)\end{array}$ & $\begin{array}{c}4,248 \\
(24.6 \%)\end{array}$ & $\begin{array}{c}5,112 \\
(25.6 \%)\end{array}$ & $\begin{array}{c}10,228 \\
(25.0 \%)\end{array}$ & $\begin{array}{c}20,519 \\
(24.8 \%)\end{array}$ & $\begin{array}{c}13,409 \\
(27.0 \%)\end{array}$ \\
\hline 1 to 4 p.m. & $\begin{array}{c}48,369 \\
(21.1 \%)\end{array}$ & $\begin{array}{c}4,030 \\
(20.9 \%)\end{array}$ & $\begin{array}{c}3,651 \\
(21.1 \%)\end{array}$ & $\begin{array}{c}4,129 \\
(20.7 \%)\end{array}$ & $\begin{array}{c}8,542 \\
(20.9 \%)\end{array}$ & $\begin{array}{c}17,639 \\
(21.3 \%)\end{array}$ & $\begin{array}{c}10,379 \\
(20.9 \%)\end{array}$ \\
\hline 4 to 7 p.m. & $\begin{array}{c}52,285 \\
(22.8 \%)\end{array}$ & $\begin{array}{c}4,433 \\
(23.0 \%)\end{array}$ & $\begin{array}{c}4,019 \\
(23.2 \%)\end{array}$ & $\begin{array}{c}4,489 \\
(22.5 \%)\end{array}$ & $\begin{array}{c}9,469 \\
(23.2 \%)\end{array}$ & $\begin{array}{c}18,743 \\
(22.7 \%)\end{array}$ & $\begin{array}{c}11,131 \\
(22.4 \%)\end{array}$ \\
\hline 7 to 10 p.m. & $\begin{array}{c}24,512 \\
(10.7 \%)\end{array}$ & $\begin{array}{c}1,972 \\
(10.2 \%)\end{array}$ & $\begin{array}{c}1,835 \\
(10.6 \%)\end{array}$ & $\begin{array}{c}2,187 \\
(11.0 \%)\end{array}$ & $\begin{array}{c}4,345 \\
(10.6 \%)\end{array}$ & $\begin{array}{c}9,284 \\
(11.2 \%)\end{array}$ & $\begin{array}{c}4,888 \\
(9.8 \%)\end{array}$ \\
\hline
\end{tabular}

Note:

- All tables reporting totals could include some unreported characteristics. 

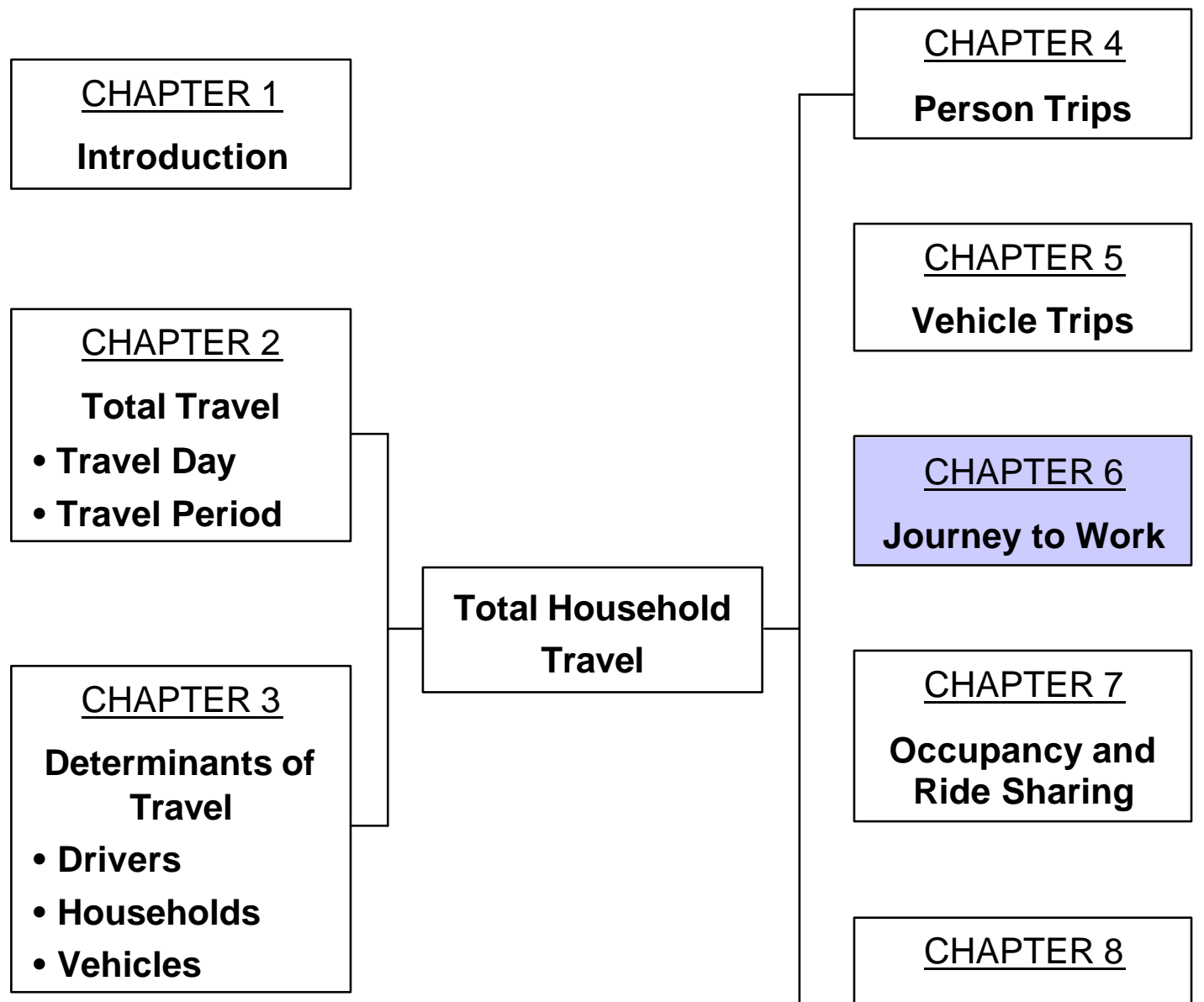
CHAPTER 7
Occupancy and
Ride Sharing

- Drivers

- Households

- Vehicles

CHAPTER 8

Population

Subgroups

- Elderly

- Women

- Low-Income

- Walkers

- Transit Riders 


\section{Chapter 6}

\section{JOURNEY TO WORK AND WORK-RELATED TRIPS}

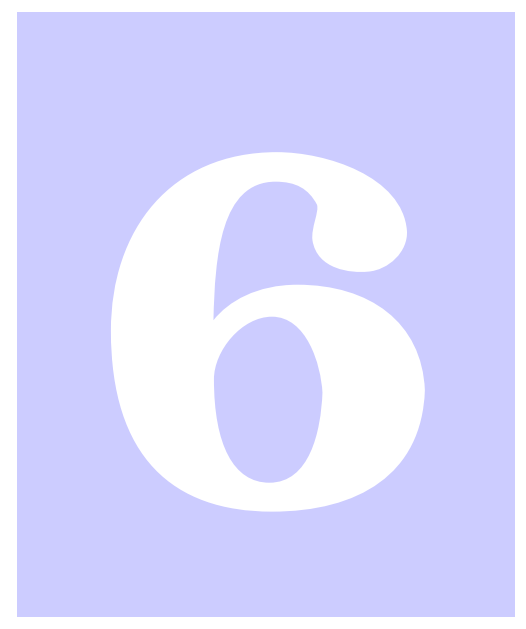

\section{IN 1995:}

- There were almost 67 billion journey to work person trips and an additional 10 billion work-related trips, amounting to over 780 billion vehicle miles traveled.

- About $54 \%$ of all workers were male, and there was an average of 1.33 workers per household.

- Most workers drove alone to work in a private vehicle. 
1995 Workers by AgE AND SeX

(THOUSANDS)

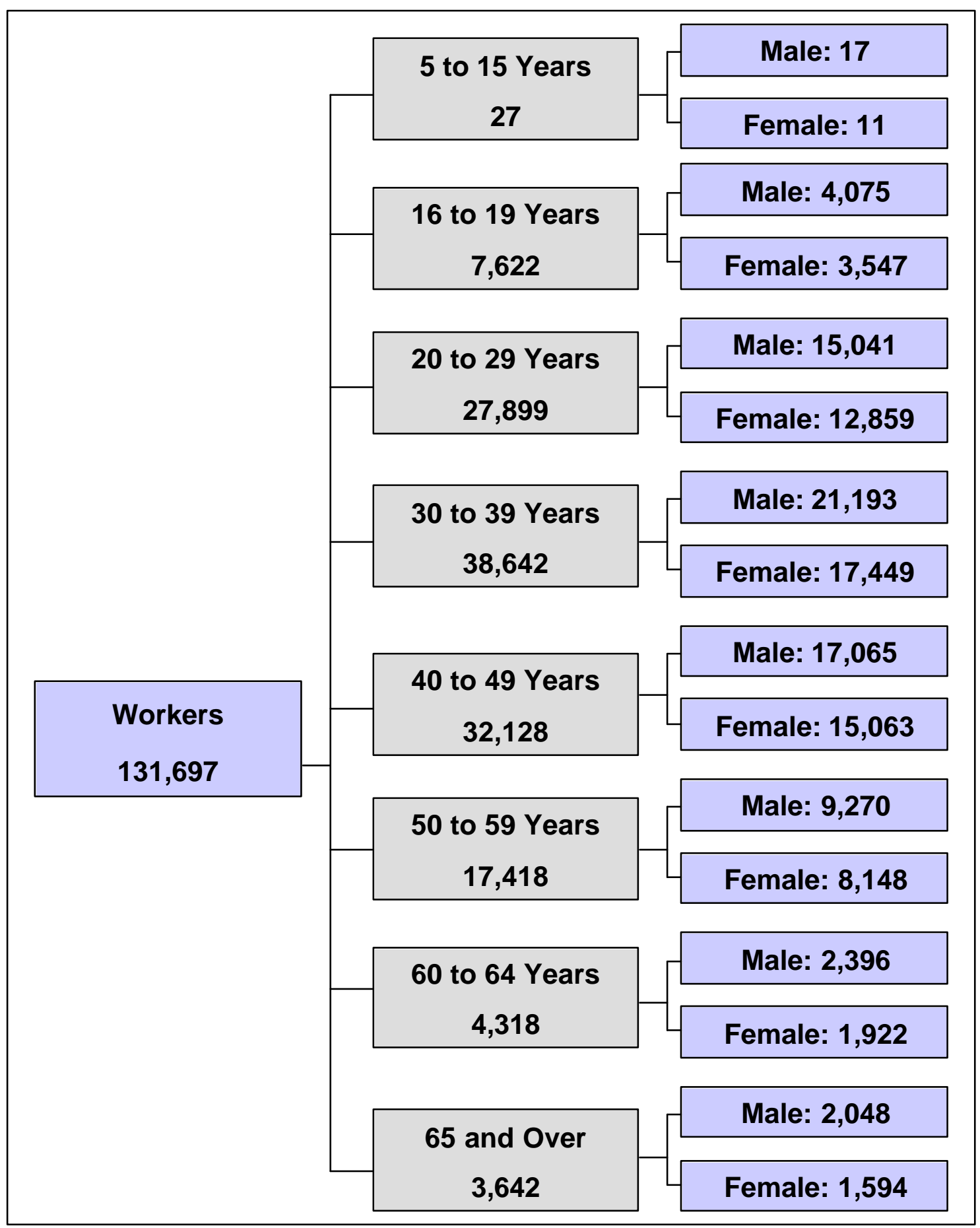


1995 Journey to Work Person Trips and Miles of Travel by Mode

(MILLIONS)

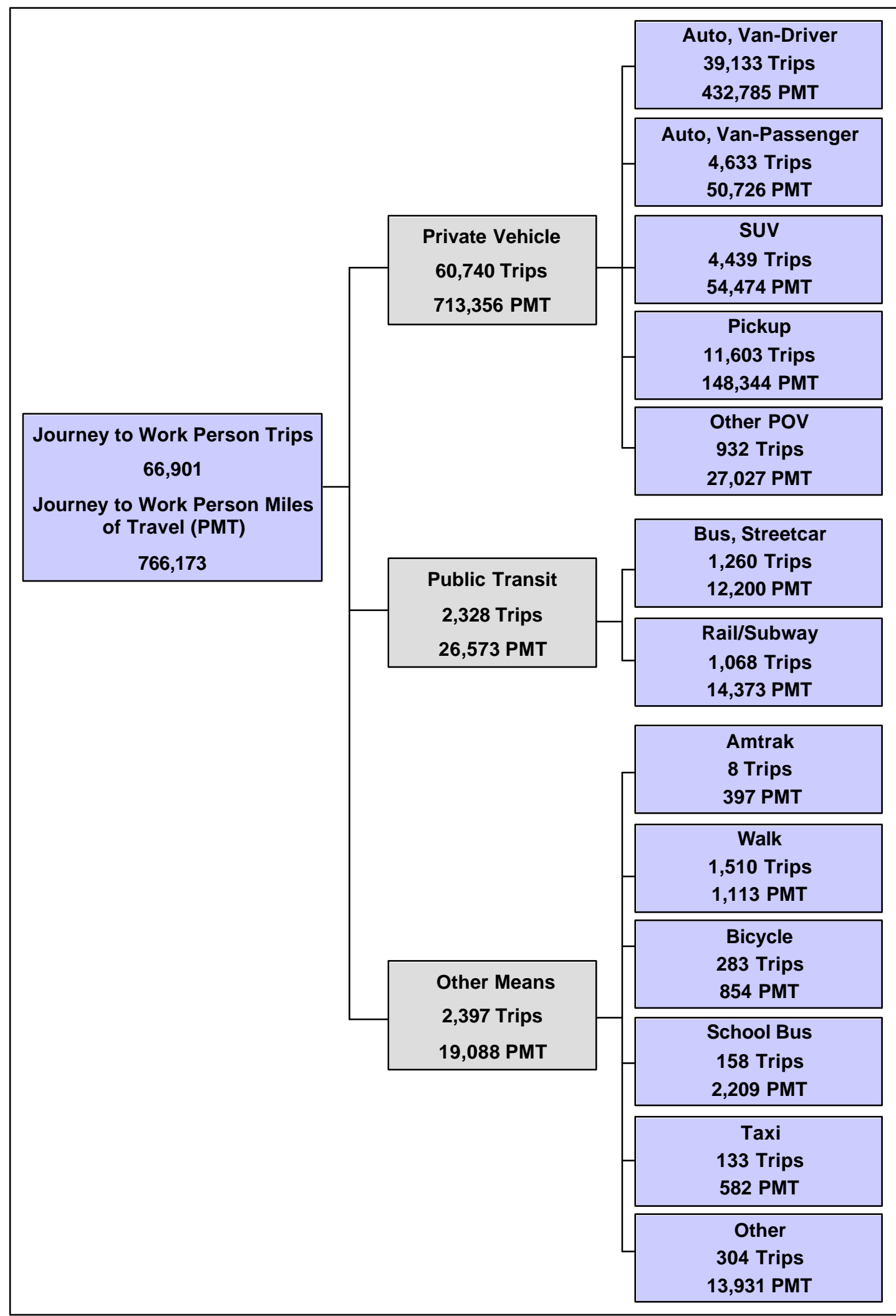


1995 Journey to Work Vehicle Trips and Miles of Travel by Vehicle Type

(MILLIONS)

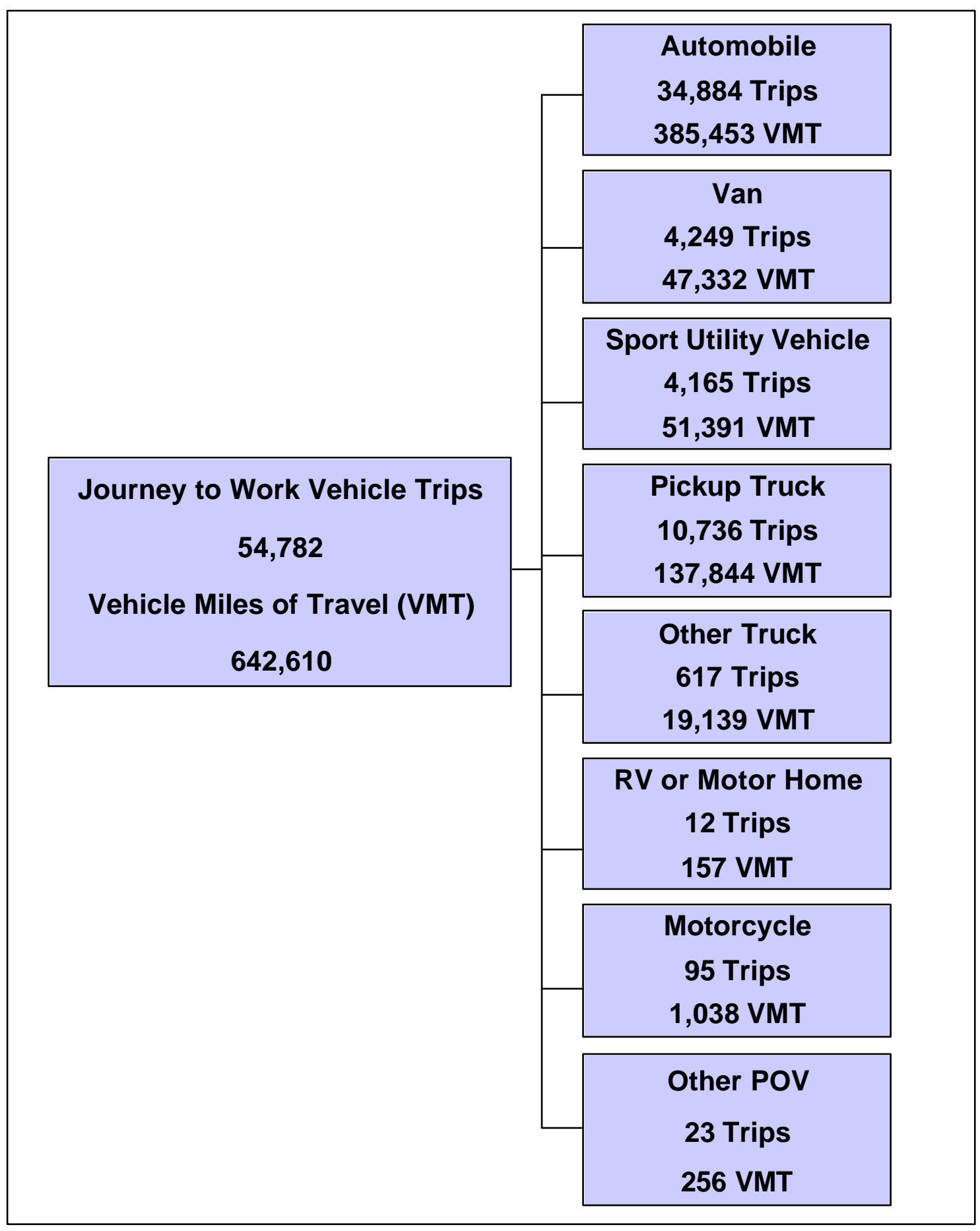




\section{LIST OF TABLES}

TABle 6.1 Summary Statistics on Journey to Work AND Work-Related TRAVEL 1969, 1977, 1983, 1990, AND 1995 NPTS ................ 6-4

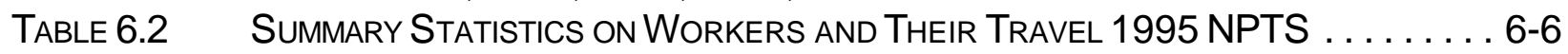

TABle 6.3 Average Daily Work-Related Person Trips Per Worker by WoRKER'S AGE AND GENDER 1995 NPTS ................... 6-8

Table 6.4 Number of Journey to Work Person Trips by SeX and Actual Mode OF COMMUTING 1990 AND 1995 NPTS (THOUSANDS) ........... 6-9

Table 6.5 Average Travel Time, Trip Length, and Speed of Commute Person Trips by Population Density 1995 NPTS ................ 6-11

TABle 6.6 Number of HOUSEHOLdS AND JouRney to Work PERSON TRIPS BY HOUSEHOLD INCOME (INCOME IN 1995 DolLARS) 1990 AND 1995 NPTS . . . 6-12

Table 6.7 Workers and Their Home to Work Person Travel by Mode of TRANSPORTATION 1990 AND 1995 NPTS $\ldots . \ldots \ldots \ldots \ldots \ldots \ldots .6 .6 .14$

Table 6.8 Average Journey to Work Person Trip Length by Mode of Transportation and Census Tract URban/Rural Code

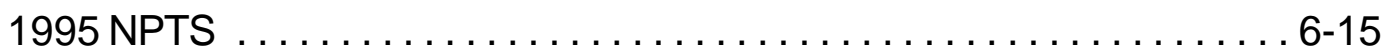

Table 6.9 Statistics on Journey to Work Person Trips by Actual Mode of TRANSPORTATION 1995 NPTS .......................... 6-17

Table 6.10 Statistics on Journey to Work Vehicle Trips by Vehicle Type 1995 NPTS (MILLIONS) …........................... 6-19

TABle 6.11 Number Of Journey to Work Person TriPs by Mode OF TRANSPORTATION AND TRIP LENGTH 1995 NPTS (MILLIONS) $\ldots \ldots \ldots \ldots 6-20$

Table 6.12 Statistics on Work-Related Person Trips by Mode of TRANSPORTATION 1995 NPTS . . . . . . . . . . . . . . . . . . . . 6-23

TABle 6.13 Journey to Work Person Trips by Segmented VS.

Nonsegmented Trips ANd MSA Size 1995 NPTS $\ldots . . \ldots \ldots \ldots \ldots 66-25$

TABlE 6.14 Distribution OF JOURNEY TO Work PERSON TRIPS BY TRIP Segmented Status and Primary Mode of Transportation 1995

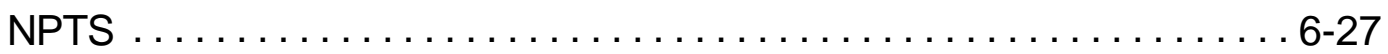

TABLE 6.15 Average TRIP Length OF JOURNEY TO Work PERSON TRIPS BY TRIP Segmented Status and Primary Mode of Transportation 1995

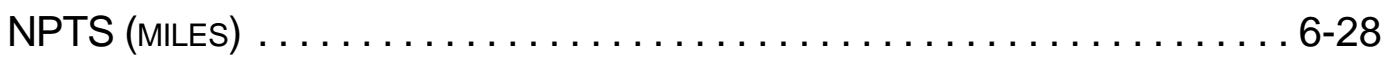

TABle 6.16 Number of SEgmented JoURneY to Work Person TRIPS by Number OF Segments TAKEn 1995 NPTS (THOUSANDS) . . . . . . . . . 6-29

TABle 6.17 Number of PeRson TRIPS (MilLIONS) BY WeEkDAY VS. WeEkEND, Trip PuRPose, AND Time of DaY 1995 NPTS . . . . . . . . . . . . . 6-30

Table 6.18 Number of Person Trips (MilLions) by WeekDay Vs. Weekend, 1990 Trip PuRPose, AND TIME OF DAY 1995 NPTS $6-31$ 


\section{LIST OF FIGURES}

Figure 6.1 Comparison of Work-Involved Travel to All Other Travel

PURPOSES 1995 NPTS (MILLIONS) $\ldots \ldots \ldots \ldots \ldots \ldots \ldots \ldots \ldots .6 .2$

Figure 6.2 SUMmary Statistics ON JOURNEY TO Work TRAVEL 1969, 1977, 1983, 1990, AND 1995 NPTS $\ldots \ldots \ldots \ldots \ldots \ldots \ldots \ldots \ldots \ldots \ldots . \ldots \ldots$

FIGURE 6.3 DISTRIBUTION OF WORKERS BY USUAL MODE OF TRANSPORTATION TO WORK 1995 NPTS $\ldots \ldots \ldots \ldots \ldots \ldots \ldots \ldots \ldots \ldots \ldots .6 .7$

Figure 6.4 Number of Journey to Work Person Trips by SeX and Actual Mode OF COMMUting 1990 AND 1995 NPTS ................... 6-10

Figure 6.5 Number of COMMUTE TRIPS PER HOUSEHOLd BY HOUSEHOld INCOME

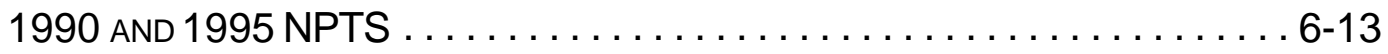

Figure 6.6 Distribution of Journey to Work Person Travel by Mode of

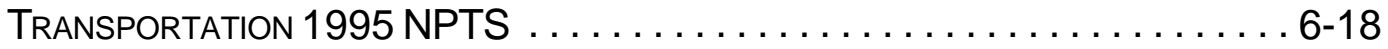

FIGURE 6.7 DistRIBUTION OF JOURNEY TO WORK PERSON TRIPS BY TRIP LENGTH for Selected Modes of Transportation 1995 NPTS . . . . . . . . . . 6-21

Figure 6.8 Distribution OF JOURNEY TO WORK PERSON TRIPS BY MSA SIZE FOR Segmented And Nonsegmented Trips 1995 NPTS $\ldots \ldots \ldots \ldots \ldots \ldots .6-26$

FIGURE 6.9 COMPARISON OF JOURNEY TO WORK AVERAGE TRIP LENGTHS BY MSA Size for Segmented and Nonsegmented Trips 1995 NPTS $\ldots \ldots \ldots .6-26$

Figure 6.10 Number of Person Trips (MilLions) by Weekday vs. Weekend, TriP PurPose, AND Time of DaY 1995 NPTS .................. 6-32 


\section{Chapter 6 Journey to Work and Work-Related Trips}

$\mathrm{D}$ ATA on journey to work and workrelated trips were collected in the travel day section of the NPTS questionnaire. It should be noted that a person was considered employed if he/she worked for pay, either full time or part time, during the week before the interview.

For the 1995 NPTS, trip purposes were collected in a From-To approach to add objectivity and aid in trip-chaining analysis. In the 1990 NPTS, the trip reason used to define journey to work travel was "To or From Work," which included travel between the respondent's home and the work place, in either direction. In the 1995 survey, this was broken into two trip reasons: "To Work" and "Home" (when the trip home originated at work). Work-related travel for both the 1990 and the 1995 surveys included trips for the respondent's job or business, other than "To or From Work." (For example, a plumber's trips to a wholesale dealer to purchase business supplies are included in this trip reason; out-oftown business trips and professional conventions are also included.) Another new code in the 1995 survey was "Return to Work," which enumerated the trips for returning to the workplace after leaving for some reason (e.g., returning to work from lunch, shopping, a meeting, etc. $)^{1}$

In this chapter, the 1990 NPTS definitions for trips involving work/workers were used to allow comparison with earlier NPTS data

\footnotetext{
${ }^{1}$ User's Guide to the Public Use Data Tapes, 1995 Nationwide Personal Transportation Survey, Appendix D, 1995 NPTS website publication, http://www-cta.ornl.gov/npts/1995/Doc/users_guide.html .
}

concerning work/worker travel.

As shown in earlier chapters of this Databook, personal travel, in terms of person trips and vehicle miles, has increased dramatically since 1969. Journey to work and work-related travel has also seen substantial increases. In 1995, a worker's commute to work was $12.7 \%$ longer than it was in 1969. In addition, there were 73.8\% more workers. Between 1983 and 1995 , the total journey to work and workrelated trips increased even more rapidly than between 1969 and 1983; the number of annual person trips increased $48 \%$ and the annual VMT increased $227 \%$.

\subsection{JOURNEY TO WORK AND WORK- Related Travel Characteristics}

The 1995 NPTS estimated that there were almost 67 billion journey to work person trips in 1995 and almost 10 billion additional workrelated trips, which together amounted to over 780 billion vehicle miles traveled. As shown in Figure 6.1, work-involved travel is a significant portion of personal transportation.

In $1995,54 \%$ of all workers were male, and there were 1.33 workers per household. The average commute time to work was 20.65 minutes, and most workers drove alone to work in a private vehicle. 
FIGURE 6.1
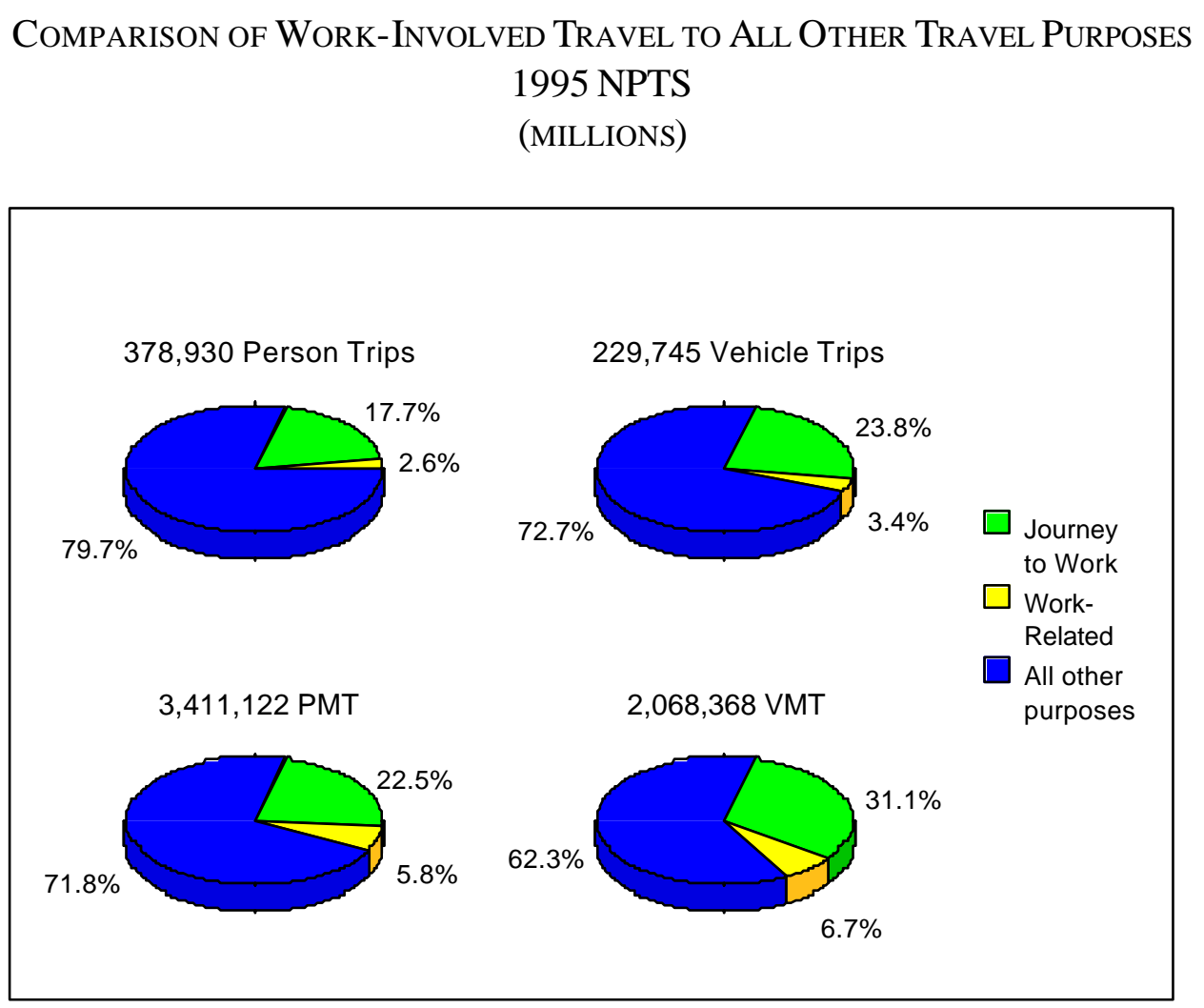

Overall, male workers took $14.4 \%$ more daily work-related person trips than females in 1995. In addition, female workers were more likely than males to be passengers in a private vehicle during the journey to work. Between 1990 and 1995, male and female workers increased their journey to work person trips by $40.2 \%$ and $24.3 \%$, respectively. The use of public transportation for work-involved trips decreased slightly for both males and females between 1990 and 1995 .

Commuter person trips from areas with a population density of less than 2,000 persons per square mile were, on the average, over 4 miles longer than the average commute trip for persons in areas with a population density of 10,000 persons or more. However, because of congestion in highly dense areas, the average commute times of persons in the less dense areas were almost 5 minutes less, even though their commute distance was greater.

For households with incomes of up to $\$ 70,000$, higher household incomes imply higher numbers of journey to work person trips. Households making \$60,000-69,999 made almost four times as many commute trips as households making under $\$ 10,000$.

\subsection{JOURNEY TO WORK AND WORK- RELATEd MOdes OF TRANSPORTATION}

The private vehicle was the preferred mode of transportation for getting to/from work. Over half of all journey to work person trips were 
made as the driver of an automobile or van.

Workers living in the urban/rural designation of Second City had the lowest average trip length (9.36 miles), and those with a designation of Rural had the longest (13.75). Work-related person trip statistics were very similar to journey to work person trips.

The automobile/van vehicle type was used for over $60 \%$ of all vehicle trips and vehicle miles involving work, when the mode chosen was private vehicle.

According to a report based on the 1995 survey, people did not use transit for commuting for three reasons: (1) a general dislike of public transit, (2) the unavailability of transit near their work, or (3) inconvenient schedules. $^{2}$

\subsection{Segmented JOURneY to Work TRIPS}

Only $2.2 \%$ of all journey to work trips were segmented in the 1995 NPTS. Most of these segmented journey to work trips were taken in MSAs of over 3 million persons. Most segmented work trips were longer than nonsegmented trips, and most segmented trips contained two or three segments. In $70 \%$ of the segmented trips, at least one segment was walked.

\subsection{Temporal Patterns of COMMUTING}

In 1995, most weekday journey to work trips occurred during the typical morning and afternoon "rush" hours (6-9 a.m. and 4-7 p.m.). Work-related travel occurred generally from 9 a.m. to 1 p.m. Persons who worked on the weekends started later in the day (almost a fourth of all weekend journey to work trips occurred between 4 p.m. and 7 p.m.).

${ }^{2}$ Polzin, Steven E., Joel R. Rey, and Xuehao

Chu, "Public Transit in America: Findings from the 1995 Nationwide Personal Transportation Survey," NUTI4-USF-4, p. 4-4, http://www.cutr.eng.usf.edu/research/transit.PDF. 
Between 1969 and 1995, the population increased by $31.8 \%$ while the number of workers increased by $73.8 \%$ (Table 6.1 ). This increase in workforce numbers is at least partially explained by a greater percentage of women obtaining jobs.

In 1969, the average worker drove 3,441 miles commuting to work each year; by 1995 , the commuting distance had increased to 3,879 miles, an increase of $12.7 \%$. The very large increases in the number of work-related trips between 1990 and 1995 (almost 300\% increase in person trips and vehicle trips and $325 \%$ increase in VMT) was due to the new NPTS trip purpose codes.

Figure 6.2 shows the increases in journey to work and work-related travel indexed to1969 values. Especially noteworthy is the growth in journey to work vehicle miles since 1983.

\section{TABLE 6.1}

SUMmary Statistics ON JOURNEY TO WORK AND WORK-RELATED TRAVEL 1969, 1977, 1983, 1990, AND 1995 NPTS

\begin{tabular}{||lrrrrr||}
\hline & 1969 & 1977 & 1983 & 1990 & 1995 \\
\hline Persons (000) & 197,213 & 213,141 & 229,453 & 239,416 & 259,994 \\
Workers (000) & 75,758 & 93,019 & 103,244 & 118,343 & 131,697 \\
Journey to Work Trips & & & & & \\
Annual Person Trips (000,000) & 37,638 & 43,767 & 46,493 & 50,314 & 66,901 \\
Annual Vehicle Trips (000,000) & 27,844 & 31,886 & 35,271 & 41,792 & 54,782 \\
Annual VMT (000,000) & 260,716 & 287,710 & 301,644 & 453,042 & 642,610 \\
Work-Related Trips & & & & & \\
Annual Person Trips (000,000) & $* *$ & 7,624 & 5,283 & 3,529 & 9,860 \\
Annual Vehicle Trips (000,000) & 3,840 & 5,768 & 3,679 & 2,845 & 7,921 \\
Annual VMT (000,000) & 61,299 & 68,978 & 42,090 & 42,336 & 137,867 \\
& & & & & \\
\hline \hline
\end{tabular}

Note:

- ** Indicates data not available. 
FIGURE 6.2

Summary Statistics ON JOURNEY TO WORK TRAVEL 1969, 1977, 1983, 1990, AND 1995 NPTS

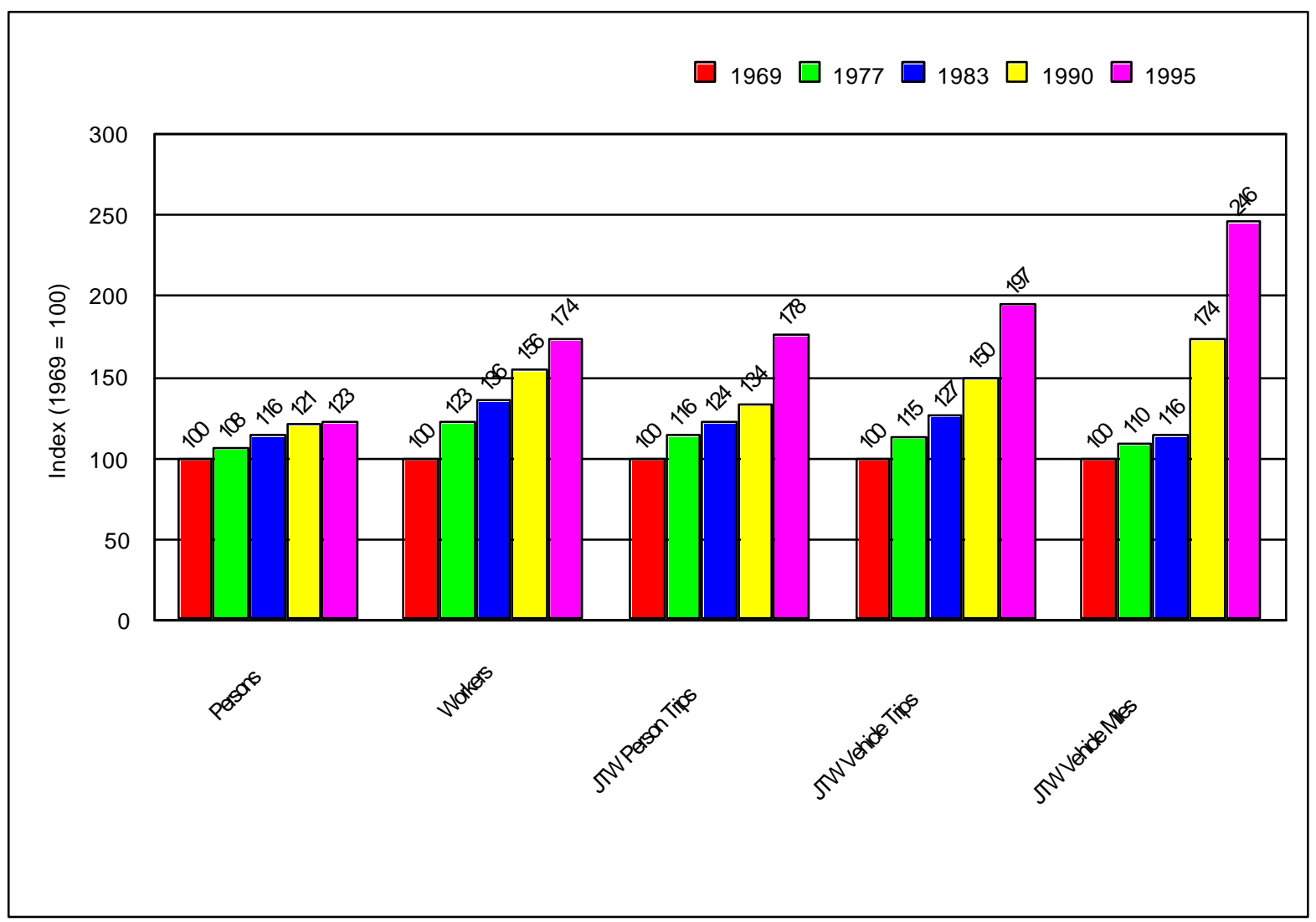

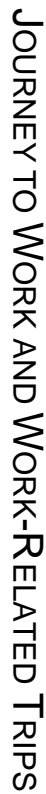


In 1995, the "typical" worker was a male who spent 20.65 minutes commuting to work as the driver of a privately owned vehicle with no passengers (Table 6.2). The distribution of workers by usual mode of transportation to work is provided in Figure 6.3.

\section{TABLE 6.2}

\section{SUMmary Statistics ON WORKERS AND THEIR TRAVEL}

1995 NPTS

\begin{tabular}{||lr|}
\hline Workers & \\
\hline Number of Workers (000) & 131,697 \\
$\%$ Male & 54.0 \\
$\%$ Female & 46.0 \\
Workers as a Percent of Population & 54.49 \\
Workers per Household & 1.33 \\
Workers per Vehicle & 0.75 \\
Workers' Average Commute Time to Work (minutes) & 20.65 \\
& \\
Distribution of Workers by Usual Mode of Transportation to Work (000) & $107,317(81.5 \%)$ \\
Private Vehicle & 71.5 \\
$\%$ Drive Alone & 10.0 \\
$\quad \%$ Car Pool & \\
Public Transit & $6012.84(4.6 \%)$ \\
Walked to Work & $3086.57(2.3 \%)$ \\
Other & $1208.79(0.9 \%)$ \\
Unknown & $14071.81(10.7 \%)$ \\
\hline
\end{tabular}

Note:

- Private vehicle includes car, truck, jeep, van, and sports utility vehicle.

- The percentages of those who carpool and those who drive alone are calculated based on data on the first journey to work trip taken on the respondent's sample day. This does not include those persons usually driving a private vehicle to work, whose carpooling status on the sample day is unknown.

- Public transit figures include bus, streetcar, subway, railroad, and ferry.

- The category Other includes bicycle, taxicab, and other means. 


\section{FIGURE 6.3}

\section{Distribution OF WORKERS BY USUAL MODE OF TRANSPORTATION TO WORK}

1995 NPTS

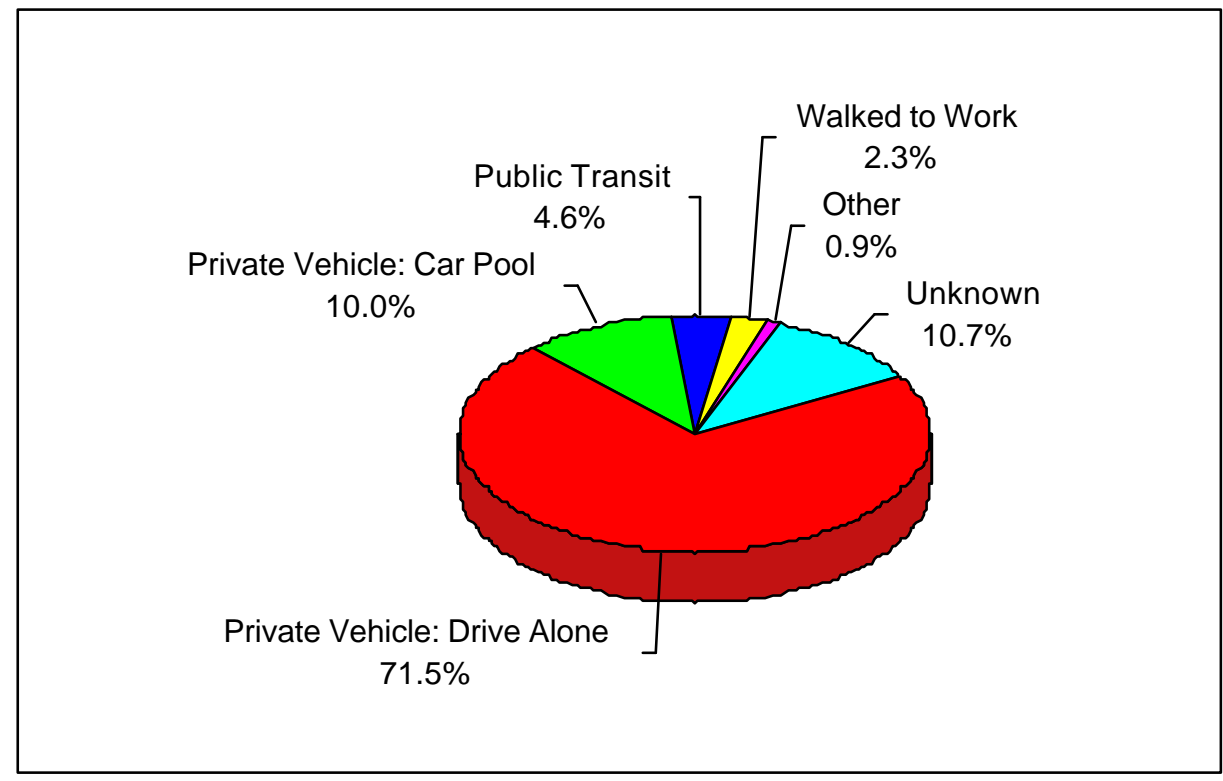


Except for age group 5-15, males of all ages took more average daily work-related person trips than females (Table 6.3). Males and females aged 65 and over averaged more than one work-related trip daily.

\section{TABLE 6.3}

Average Daily Work-Related Person Trips Per Worker by Worker's Age and Gender 1995 NPTS

\begin{tabular}{|lccc|}
\hline \hline Age & ALL & Male & Female \\
\hline ALL & 1.35 & 1.43 & 1.25 \\
$5-15$ & 0.77 & 0.41 & 1.27 \\
$16-19$ & 1.12 & 1.13 & 1.10 \\
$20-29$ & 1.40 & 1.46 & 1.33 \\
$30-39$ & 1.38 & 1.48 & 1.25 \\
$40-49$ & 1.36 & 1.45 & 1.26 \\
$50-59$ & 1.31 & 1.41 & 1.20 \\
$60-64$ & 1.29 & 1.40 & 1.14 \\
$65+$ & 1.26 & 1.36 & 1.13 \\
All Ages & $100.0 \%$ & $54.0 \%$ & $46.0 \%$ \\
Number of Workers & 131,697 & 71,105 & 60,593 \\
\hline \hline
\end{tabular}

Note:

- Includes trips where worker's age was unreported. 
Between 1990 and 1995, the number of journey to work person trips increased by $40.2 \%$ for males and $24.3 \%$ for females (Table 6.4). Both men and women used privately owned vehicles in their journey to work more than any other mode of transportation. Women were more likely than men to be passengers (rather than drivers) of private vehicles, and women were more likely than men to use public transportation or to walk to work. The use of public transportation for the journey to work was lower for both men and women in 1995 than in 1990. Changes in mode of transportation for males and females are shown in Figure 6.4.

\section{TABLE 6.4}

Number of Journey to Work Person Trips by Sex And Actual Mode of Commuting 1990 AND 1995 NPTS

(THOUSANDS)

\begin{tabular}{|c|c|c|c|c|c|c|}
\hline \multirow[b]{2}{*}{ Mode } & \multicolumn{2}{|c|}{ TOTAL } & \multicolumn{2}{|c|}{ Male } & \multicolumn{2}{|c|}{ Female } \\
\hline & 1990 & 1995 & 1990 & 1995 & 1990 & 1995 \\
\hline TOTAL & $\begin{array}{r}50,314,271 \\
(100.0 \%)\end{array}$ & $\begin{array}{r}66,901,023 \\
(100.0 \%)\end{array}$ & $\begin{array}{r}27,474,321 \\
(100.0 \%)\end{array}$ & $\begin{array}{r}38,519,415 \\
(100.0 \%)\end{array}$ & $\begin{array}{r}22,835,631 \\
(100.0 \%)\end{array}$ & $\begin{array}{r}28,381,609 \\
(100.0 \%)\end{array}$ \\
\hline Private Vehicle-Driver & $\begin{array}{r}41,782,983 \\
(83 . \%)\end{array}$ & $\begin{array}{r}54,782,050 \\
(81.9 \%)\end{array}$ & $\begin{array}{r}23,366,048 \\
(85.0 \%)\end{array}$ & $\begin{array}{r}32,122,899 \\
(83.4 \%)\end{array}$ & $\begin{array}{r}18,412,617 \\
(80.6 \%)\end{array}$ & $\begin{array}{r}22,659,150 \\
(79.8 \%)\end{array}$ \\
\hline Private Vehicle-Passengers & $\begin{array}{r}4,073,477 \\
(8.1 \%)\end{array}$ & $\begin{array}{r}5,957,637 \\
(8.9 \%)\end{array}$ & $\begin{array}{r}1,748,889 \\
(6.4 \%)\end{array}$ & $\begin{array}{r}2,886,457 \\
(7.5 \%)\end{array}$ & $\begin{array}{r}2,324,588 \\
(10.2 \%)\end{array}$ & $\begin{array}{r}3,071,181 \\
(10.8 \%)\end{array}$ \\
\hline Public Transportation & $\begin{array}{r}2,011,887 \\
(4.0 \%)\end{array}$ & $\begin{array}{r}2,328,074 \\
(3.5 \%)\end{array}$ & $\begin{array}{r}1,021,843 \\
(3.7 \%)\end{array}$ & $\begin{array}{r}1,209,285 \\
(3.1 \%)\end{array}$ & $\begin{array}{r}990,044 \\
(4.3 \%)\end{array}$ & $\begin{array}{r}1,118,789 \\
(3.9 \%)\end{array}$ \\
\hline Walk & $\begin{array}{r}1,999,294 \\
(4.0 \%)\end{array}$ & $\begin{array}{r}1,510,407 \\
(2.3 \%)\end{array}$ & $\begin{array}{r}1,034,708 \\
(3.8 \%)\end{array}$ & $\begin{array}{r}806,829 \\
(2.1 \%)\end{array}$ & $\begin{array}{r}964,587 \\
(4.2 \%)\end{array}$ & $\begin{array}{r}703,579 \\
(2.5 \%)\end{array}$ \\
\hline Other & $\begin{array}{r}407,665 \\
(0.8 \%) \\
\end{array}$ & $\begin{array}{r}886,713 \\
(1.3 \%) \\
\end{array}$ & $\begin{array}{r}284,748 \\
(1.0 \%) \\
\end{array}$ & $\begin{array}{r}647,927 \\
(1.7 \%) \\
\end{array}$ & $\begin{array}{r}122,918 \\
(0.5 \%) \\
\end{array}$ & $\begin{array}{r}238,785 \\
(0.8 \%) \\
\end{array}$ \\
\hline
\end{tabular}

Note:

- All tables reporting totals could include some unreported characteristics. 


\section{FIGURE 6.4}

Number of Journey to Work Person Trips by SeX And Actual Mode of Commuting 1990 AND 1995 NPTS

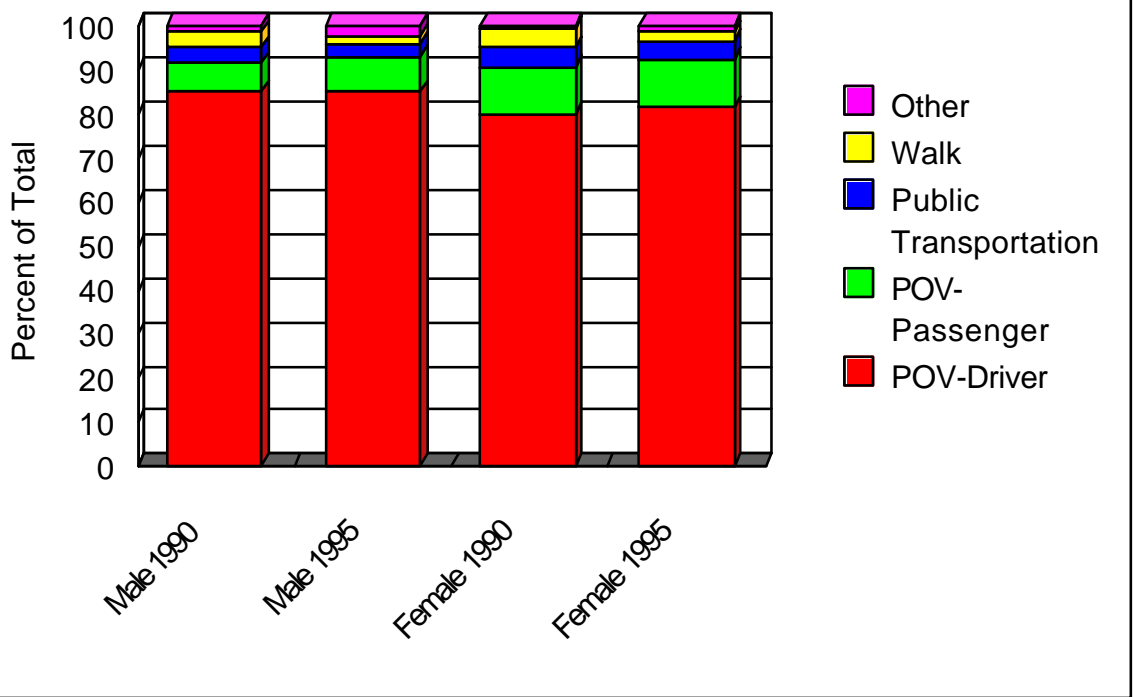


Traffic congestion is typically a more serious

problem in densely populated areas than in, for example, rural areas. Table 6.5 presents commute distances and speeds by different population density categories. People living in the densest areas $(10,000$ persons or more per square mile) have a commute distance a third shorter than those living in the least dense areas; however, their commute trips took almost $24 \%$ longer.

\section{TABLE 6.5}

\section{Average Travel Time, Trip Length, and Speed of Commute Person Trips By Population DENSITY 1995 NPTS}

\begin{tabular}{|c|c|c|c|c|c|}
\hline & Average & Average & & & \\
\hline Population Density & $\begin{array}{c}\text { Commute Trip } \\
\text { Distance } \\
\text { (miles) }\end{array}$ & $\begin{array}{c}\text { Commute } \\
\text { Travel Time } \\
\text { (minutes) }\end{array}$ & $\begin{array}{c}\text { Average } \\
\text { Commute Speed } \\
\text { (miles per hour) }\end{array}$ & $\begin{array}{c}\text { Percent of } \\
\text { Person Trips }\end{array}$ & $\begin{array}{l}\text { Percent of } \\
\text { Households }\end{array}$ \\
\hline TOTAL & 11.63 & 20.83 & 34.61 & 100.0 & 100.0 \\
\hline Less than 2,000 & 13.15 & 20.66 & 38.30 & 46.3 & 45.3 \\
\hline $2,000-4,000$ & 10.87 & 19.20 & 34.51 & 16.3 & 16.4 \\
\hline $4,000-10,000$ & 10.54 & 20.16 & 32.09 & 25.2 & 24.8 \\
\hline 10,000 or more & 8.81 & 25.53 & 23.82 & 11.3 & 12.6 \\
\hline
\end{tabular}

Note:

- Population density is calculated as persons per square mile for the zip code in which the household is located.

- Average commute travel time includes both travel time and time spent waiting for transportation.

- Average commute speed is calculated using nonsegmented trips only. 
In general, in 1995, households with higher incomes made more commute trips per household than households with less household income (Table 6.6). Households making $\$ 60,000-69,999$ made $385 \%$ more commute trips than households making less than
$\$ 10,000$. Overall, households made $25.4 \%$ more journey to work trips in 1995 than they made in 1990. Figure 6.5 compares 1990 and 1995 trips for household in the different income levels.

\section{TABLE 6.6}

Number of Households And Journey to Work Person Trips by Household Income (INCOME IN 1995 DOLLARS) 1990 AND 1995 NPTS

\begin{tabular}{|c|c|c|c|c|c|c|}
\hline \multirow[b]{2}{*}{ Income } & \multicolumn{3}{|c|}{1990} & \multicolumn{3}{|c|}{1995} \\
\hline & $\begin{array}{c}\text { Number of } \\
\text { Households } \\
(000)\end{array}$ & $\begin{array}{c}\text { Number of } \\
\text { Commute } \\
\text { Person Trips } \\
(000)\end{array}$ & $\begin{array}{l}\text { Number of } \\
\text { Commute } \\
\text { Trips per } \\
\text { Household } \\
\end{array}$ & $\begin{array}{c}\text { Number of } \\
\text { Households } \\
(000)\end{array}$ & $\begin{array}{c}\text { Number of } \\
\text { Commute } \\
\text { Person Trips } \\
(000)\end{array}$ & $\begin{array}{c}\text { Number of } \\
\text { Commute } \\
\text { Trips per } \\
\text { Household } \\
\end{array}$ \\
\hline TOTAL & $\begin{array}{c}93,347 \\
(100.0 \%)\end{array}$ & $\begin{array}{r}50,314,271 \\
(100.0 \%)\end{array}$ & 539 & $\begin{array}{r}98,990 \\
(100.0 \%)\end{array}$ & $\begin{array}{r}66,901,023 \\
(100.0 \%)\end{array}$ & 676 \\
\hline Under $\$ 10,000$ & $\begin{array}{c}7,247 \\
(7.8 \%)\end{array}$ & $\begin{array}{r}2,507,967 \\
(5.0 \%)\end{array}$ & 346 & $\begin{array}{c}8,410 \\
(8.5 \%)\end{array}$ & $\begin{array}{r}2,019,877 \\
(3.0 \%)\end{array}$ & 240 \\
\hline$\$ 10,000-\$ 19,999$ & $\begin{array}{c}11,121 \\
(11.9 \%)\end{array}$ & $\begin{array}{r}4,660,120 \\
(9.3 \%)\end{array}$ & 419 & $\begin{array}{c}13,983 \\
(14.1 \%)\end{array}$ & $\begin{array}{r}6,665,101 \\
(10.0 \%)\end{array}$ & 477 \\
\hline$\$ 20,000-\$ 29,999$ & $\begin{array}{c}11,050 \\
(11.8 \%)\end{array}$ & $\begin{array}{r}5,820,246 \\
(11.6 \%)\end{array}$ & 527 & $\begin{array}{c}15,152 \\
(15.3 \%)\end{array}$ & $\begin{array}{r}10,210,778 \\
(15.3 \%)\end{array}$ & 674 \\
\hline$\$ 30,000-\$ 39,999$ & $\begin{array}{c}10,017 \\
(10.7 \%)\end{array}$ & $\begin{array}{r}6,075,727 \\
(12.1 \%)\end{array}$ & 607 & $\begin{array}{c}12,775 \\
(12.9 \%)\end{array}$ & $\begin{array}{r}9,915,703 \\
(14.8 \%)\end{array}$ & 776 \\
\hline$\$ 40,000$ - \$49,999 & $\begin{array}{c}8,318 \\
(8.9 \%)\end{array}$ & $\begin{array}{r}5,565,431 \\
(11.1 \%)\end{array}$ & 669 & $\begin{array}{c}9,830 \\
(9.9 \%)\end{array}$ & $\begin{array}{r}8,512,145 \\
(12.7 \%)\end{array}$ & 866 \\
\hline$\$ 50,000-\$ 59,999$ & $\begin{array}{l}6,312 \\
(6.8 \%)\end{array}$ & $\begin{array}{r}4,835,945 \\
(9.6 \%)\end{array}$ & 766 & $\begin{array}{c}6,985 \\
(7.1 \%)\end{array}$ & $\begin{array}{r}6,300,704 \\
(9.4 \%)\end{array}$ & 902 \\
\hline$\$ 60,000-\$ 69,999$ & $\begin{array}{c}4,373 \\
(4.7 \%)\end{array}$ & $\begin{array}{r}3,306,443 \\
(6.6 \%)\end{array}$ & 756 & $\begin{array}{c}4,708 \\
(4.8 \%)\end{array}$ & $\begin{array}{r}4,351,215 \\
(6.5 \%)\end{array}$ & 924 \\
\hline$\$ 70,000-\$ 79,999$ & $\begin{array}{c}2,821 \\
(3.0 \%)\end{array}$ & $\begin{array}{r}2,187,233 \\
(4.3 \%)\end{array}$ & 775 & $\begin{array}{l}3,246 \\
(3.3 \%)\end{array}$ & $\begin{array}{r}2,931,152 \\
(4.4 \%)\end{array}$ & 903 \\
\hline$\$ 80,000$ or more & $\begin{array}{c}6,327 \\
(6.8 \%)\end{array}$ & $\begin{array}{r}4,795,937 \\
(9.5 \%)\end{array}$ & 758 & $\begin{array}{c}7,352 \\
(7.4 \%)\end{array}$ & $\begin{array}{r}6,327,759 \\
(9.5 \%)\end{array}$ & 861 \\
\hline
\end{tabular}

Note:

- All tables reporting totals could include some unreported characteristics.

- Note that the 1990 data have been adjusted to make them more comparable with the 1995 data. Thus, there are limits on the conclusions that can be drawn in comparing travel with earlier survey years. The adjustments to 1990 data affect only person trips, vehicle trips, person miles of travel (PMT) and vehicle miles of travel (VMT). 


\section{FIGURE 6.5}

Number of COMMUte TRIPS PeR HOUSEHOld By HouseHold INCOME 1990 AND 1995 NPTS

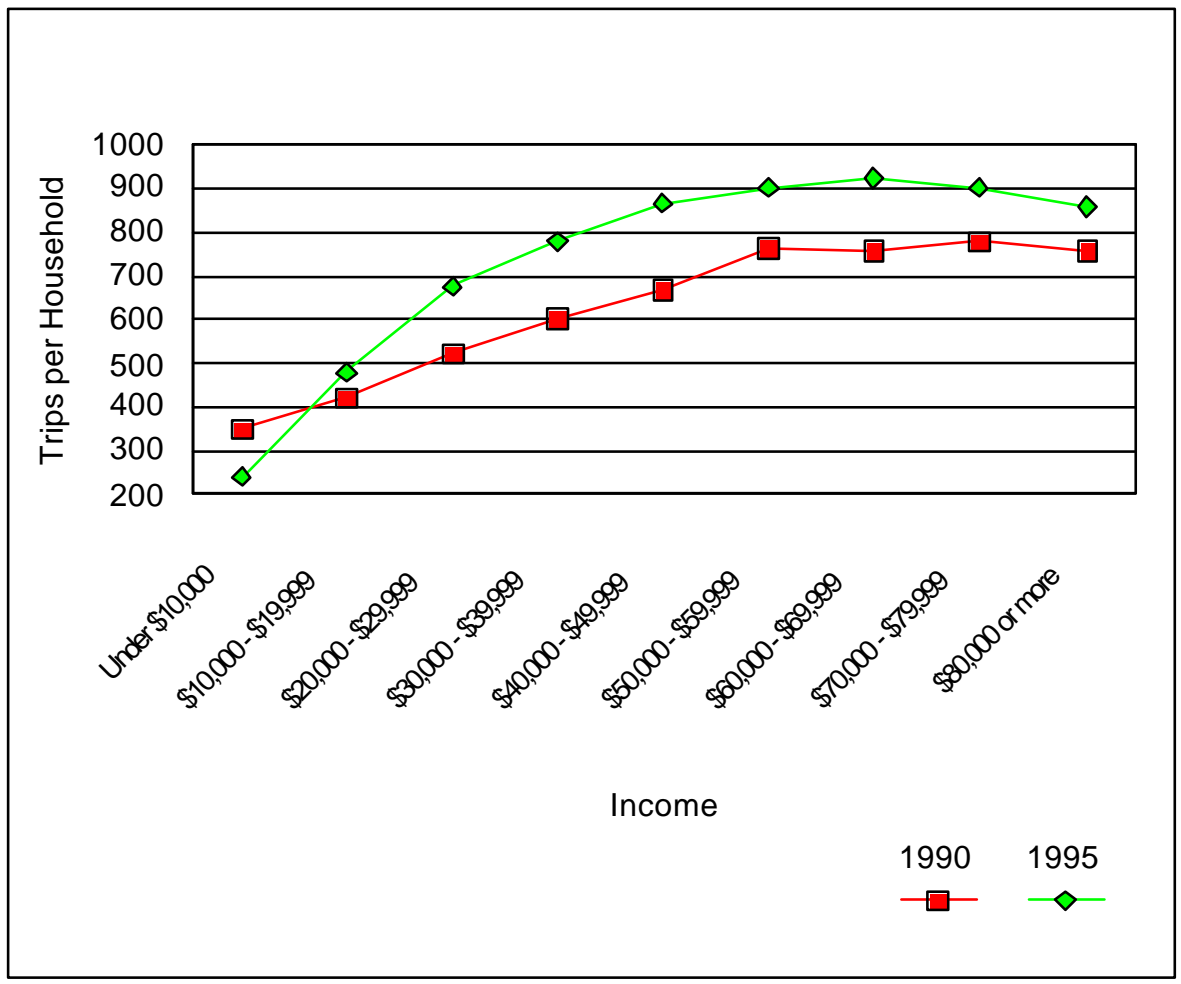


In 1995, the private vehicle continued to be the preferred mode of choice for getting to work.

The length of the average commute to work trip increased by almost a mile $(9.2 \%$ increase $)$ between 1990 and 1995. The average travel speed also increased slightly; therefore, the net result was an average increase in commute time of less than a minute overall.

\section{TABLE 6.7}

\section{Workers and Their Home to Work Person Travel by Mode of Transportation 1990 AND 1995 NPTS}

\begin{tabular}{||lrrrrc||}
\hline \multicolumn{1}{||l}{ TOTAL } & Private & Public & Walk & Other \\
\hline 1990 & & & & & \\
Percent of Workers & 100.0 & 82.9 & 5.0 & 3.7 & 2.5 \\
Average trip length (miles) & 10.65 & 11.02 & 12.75 & 0.83 & 8.38 \\
Average commute time (minutes) & 19.60 & 19.06 & 50.51 & 9.89 & 24.48 \\
Average travel speed (MPH) & 33.33 & 34.75 & 18.23 & 3.97 & 15.70 \\
& & & & & \\
1995 & & & & & \\
Percent of Workers & 100.0 & 81.5 & 4.6 & 0.9 & 2.3 \\
Average trip length (miles) & 11.63 & 11.84 & 12.88 & 0.74 & 21.61 \\
Average commute time (minutes) & 20.83 & 20.09 & 49.78 & 10.86 & 32.29 \\
Average travel speed (MPH) & 34.61 & 35.36 & 19.29 & 4.07 & 40.33 \\
& & & & & \\
\hline
\end{tabular}

Note:

- All tables reporting totals could include some unreported characteristics.

- The percentage of workers traveling by different modes of transportation is based on the worker's usual mode of transportation. The rest of the statistics in this table are based on the actual mode of transportation as reported in the sampled day (travel day).

- Average trip length includes workers whose usual mode of transportation was unreported.

- Average commute time includes both travel time and time waiting for transportation.

- Average travel speed is calculated using nonsegmented trips only. 
Workers designated as living in a Second City had the lowest average journey to work person trip length, followed closely by workers living in an urban environment. As expected, rural residents had the longest average journey to work person trip length. Rural persons who took public transportation to get to work had the longest commute -56.75 miles/day.

\section{TABLE 6.8}

Average Journey to Work Person Trip Length by Mode of Transportation AND CEnsus Tract URban/RuRal Code

1995 NPTS

\begin{tabular}{|c|c|c|c|c|c|}
\hline & TOTAL & Private & Public & Walk & Other \\
\hline TOTAL & 11.63 & 11.84 & 12.88 & 0.74 & 21.61 \\
\hline Second City & 9.36 & 9.63 & 11.50 & 0.75 & 8.96 \\
\hline Rural & 13.75 & 13.99 & 56.75 & 0.48 & 16.48 \\
\hline Suburban & 11.69 & 11.49 & 19.00 & 0.79 & 30.16 \\
\hline Town & 12.75 & 12.92 & 34.41 & 0.51 & 18.23 \\
\hline Urban & 9.55 & 9.99 & 9.52 & 0.88 & 28.84 \\
\hline
\end{tabular}

Note:

- All tables reporting totals could include some unreported characteristics. 
The average journey to work person trip length was 11.63 miles (Table 6.9), 2.4 miles longer than the average trip length for all trip purposes (see Chapter 4, Table 4.1). Over $90 \%$ of all journey to work person trips were made via private vehicle. Public transportation was used for $3.5 \%$ of all journey to work trips.

The distribution of journey to work person trips

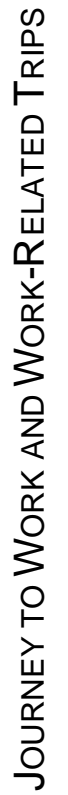

mode are shown in Figure 6.6. As shown in the figure, Amtrak and "Other" had significantly longer average trip lengths than any other mode.

The automobile/van was used for over $72 \%$ of all person trips and almost $68 \%$ of all person miles when the journey to work mode was privately-owned vehicle. 
TABLE 6.9

STATISTICS ON JOURNEY TO WORK PERSON TRIPS BY ACTUAL MODE OF TRANSPORTATION 1995 NPTS

\begin{tabular}{|c|c|c|c|}
\hline & $\begin{array}{c}\text { Number of } \\
\text { Person Trips }(000,000)\end{array}$ & $\begin{array}{c}\text { Number of } \\
\text { Person Miles }(000,000)\end{array}$ & $\begin{array}{l}\text { Average Trip Length } \\
\text { (miles) }\end{array}$ \\
\hline TOTAL & $\begin{array}{c}66,901 \\
(100.0 \%)\end{array}$ & $\begin{array}{r}766,173.32 \\
(100.0 \%)\end{array}$ & 11.63 \\
\hline \multicolumn{4}{|l|}{ Private Vehicles } \\
\hline Auto, Van - Driver & $\begin{array}{c}39,133 \\
(58.5 \%)\end{array}$ & $\begin{array}{r}432,784.52 \\
(56.5 \%)\end{array}$ & 11.13 \\
\hline Auto, Van - Passenger & $\begin{array}{c}4,633 \\
(6.9 \%)\end{array}$ & $\begin{array}{r}50,726.14 \\
(6.6 \%)\end{array}$ & 11.29 \\
\hline Sports Utility Vehicle & $\begin{array}{c}4,439 \\
(6.6 \%)\end{array}$ & $\begin{array}{r}54,474.48 \\
(7.1 \%)\end{array}$ & 12.31 \\
\hline Pickup & $\begin{array}{c}11,603 \\
(17.3 \%)\end{array}$ & $\begin{array}{r}148,343.85 \\
(19.4 \%)\end{array}$ & 12.86 \\
\hline Other Private Vehicles & $\begin{array}{c}932 \\
(1.4 \%)\end{array}$ & $\begin{array}{r}27,027.20 \\
(3.5 \%)\end{array}$ & 29.56 \\
\hline Subtotal & $\begin{array}{c}60,740 \\
(90.8 \%)\end{array}$ & $\begin{array}{r}713,356.19 \\
(93.1 \%)\end{array}$ & 11.84 \\
\hline \multicolumn{4}{|l|}{ Public Transportation } \\
\hline Bus, Streetcar & $\begin{array}{c}1,260 \\
(1.9 \%)\end{array}$ & $\begin{array}{r}12,199.73 \\
(1.6 \%)\end{array}$ & 10.61 \\
\hline Rail/Subway & $\begin{array}{c}1,068 \\
(1.6 \%)\end{array}$ & $\begin{array}{r}14,373.20 \\
(1.9 \%)\end{array}$ & 15.73 \\
\hline Subtotal & $\begin{array}{c}2,328 \\
(3.5 \%)\end{array}$ & $\begin{array}{r}26,572.93 \\
(3.5 \%)\end{array}$ & 12.88 \\
\hline \multicolumn{4}{|l|}{ Other Means } \\
\hline Amtrak & $\begin{array}{r}8 \\
(0.0 \%)\end{array}$ & $\begin{array}{c}397.32 \\
(0.1 \%)\end{array}$ & 53.15 \\
\hline Taxi & $\begin{array}{c}133 \\
(0.2 \%)\end{array}$ & $\begin{array}{l}582.15 \\
(0.1 \%)\end{array}$ & 4.43 \\
\hline Bike & $\begin{array}{c}283 \\
(0.4 \%)\end{array}$ & $\begin{array}{c}854.34 \\
(0.1 \%)\end{array}$ & 3.04 \\
\hline Walk & $\begin{array}{c}1,510 \\
(2.3 \%)\end{array}$ & $\begin{array}{r}1,113.25 \\
(0.1 \%)\end{array}$ & 0.74 \\
\hline School Bus & $\begin{array}{c}158 \\
(0.2 \%)\end{array}$ & $\begin{array}{r}2,209.14 \\
(0.3 \%)\end{array}$ & 15.45 \\
\hline Other & $\begin{array}{c}304 \\
(0.5 \%)\end{array}$ & $\begin{array}{r}13,931.37 \\
(1.8 \%)\end{array}$ & 51.78 \\
\hline Subtotal & $\begin{array}{r}2,397 \\
(3.6 \%) \\
\end{array}$ & $\begin{array}{r}19,087.57 \\
(2.5 \%) \\
\end{array}$ & 8.15 \\
\hline
\end{tabular}

Note:

- Journey to work person trips are based on journey to work data collected on the sampled day (travel day).

- $\quad$ Average trip length is calculated using only those records with trip mile information present.

- Rail/Subway includes trips by subway, elevated rail, and commuter train.

- Totals include trips where mode of transportation was unreported. 


\section{FIGURE 6.6}

\section{Distribution of Journey to Work Person Travel by Mode of Transportation 1995 NPTS}

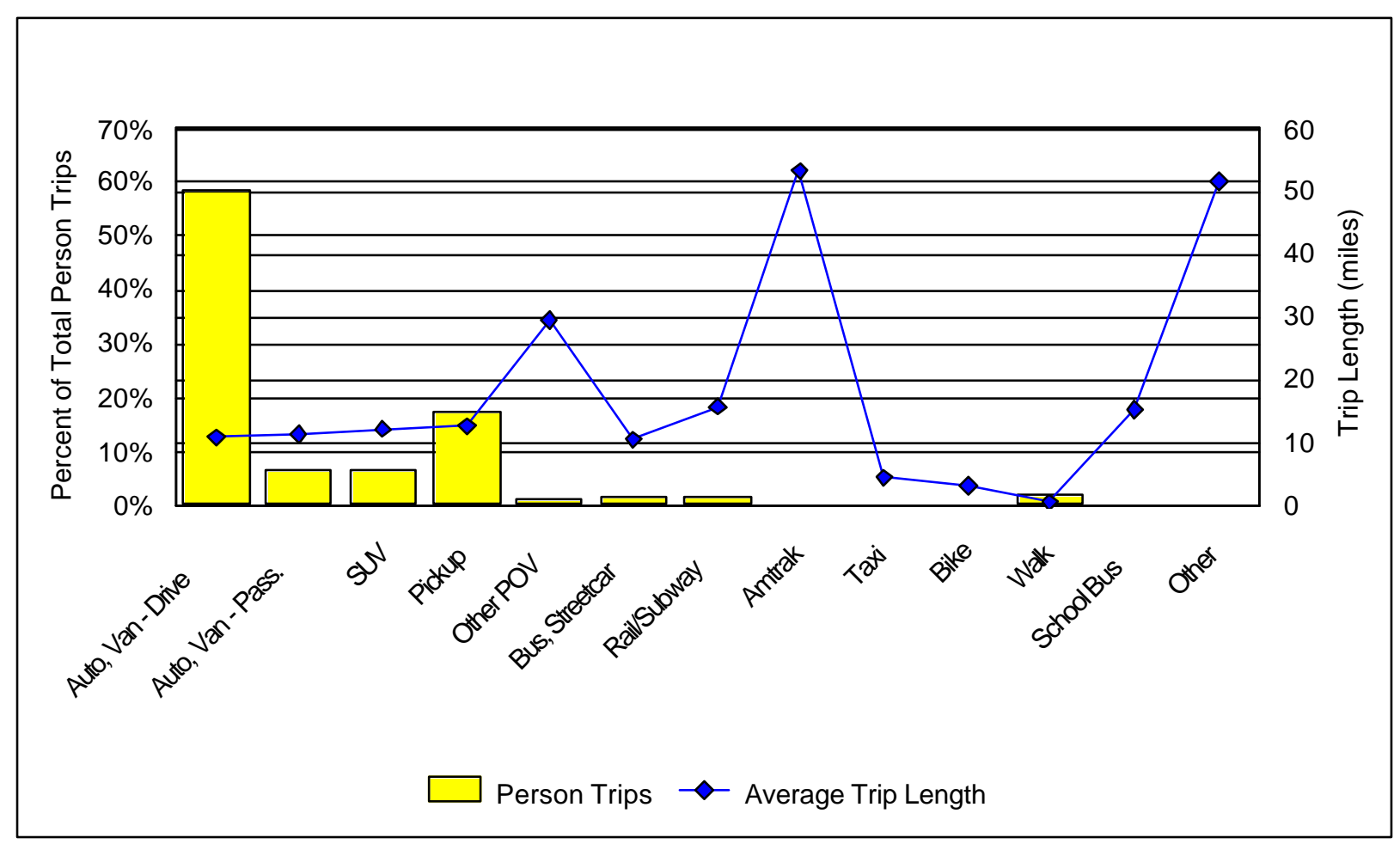


The automobile was used for over $60 \%$ of all vehicle trips and VMT when the journey to work mode was privately-owned vehicle (Table 6.10). When public transportation was used, it was used most often (37\% of all journey to work trips) for trips of 5 miles or less (Table 6.11). The most common mode for getting to work, after privately owned vehicles and public transportation, was walking $(2.3 \%$ of all journey to work trips and $5 \%$ of all journey to work trips of 5 miles or less). The distribution of journey to work person trips by selected mode and trip length is shown in Figure 6.7.

\section{TABLE 6.10}

Statistics on Journey to Work Vehicle Trips by Vehicle Type 1995 NPTS

(MILLIONS)

\begin{tabular}{|lrc|}
\hline \hline Vehicle Type & Vehicle Trips & Vehicle Miles of Travel \\
\hline TOTAL & 54,782 & 642,610 \\
Auto & $(100.0 \%)$ & $(100.0 \%)$ \\
& 34,884 & 385,453 \\
Van & $(63.7 \%)$ & $(60.0 \%)$ \\
& 4,249 & 47,332 \\
Sports Utility Vehicle & $(7.8 \%)$ & $(7.4 \%)$ \\
Pickup Truck & 4,165 & 51,391 \\
& $(7.6 \%)$ & $(8.0 \%)$ \\
Other Truck & 10,736 & 137,844 \\
& $(19.6 \%)$ & $(21.5 \%)$ \\
RV & 617 & 19,139 \\
& $(1.1 \%)$ & $(3.0 \%)$ \\
Motorcycle & 12 & 157 \\
Other POV & $(0.0 \%)$ & $(0.0 \%)$ \\
& $(0.2 \%)$ & 1,038 \\
& 23 & $(0.2 \%)$ \\
& & 256 \\
\hline
\end{tabular}

Note:

- All tables reporting totals could include some unreported characteristics. 
TABLE 6.11

NUMBER OF JOURNEY TO WORK PERSON TRIPS BY MODE OF TRANSPORTATION AND TRIP LENGTH 1995 NPTS

(MILLIONS)

\begin{tabular}{|c|c|c|c|c|c|c|c|}
\hline Primary Mode & TOTAL & $\begin{array}{l}5 \text { miles } \\
\text { or less }\end{array}$ & $\begin{array}{l}6-10 \\
\text { miles }\end{array}$ & $\begin{array}{l}11-15 \\
\text { miles }\end{array}$ & $\begin{array}{l}16-20 \\
\text { miles }\end{array}$ & $\begin{array}{c}21-30 \\
\text { miles }\end{array}$ & $\begin{array}{l}30 \text { miles } \\
\text { or more }\end{array}$ \\
\hline TOTAL & $\begin{array}{r}66,901 \\
(100.0 \%)\end{array}$ & $\begin{array}{c}30,259 \\
(100.0 \%)\end{array}$ & $\begin{array}{c}13,485 \\
(100.0 \%)\end{array}$ & $\begin{array}{c}7,705 \\
(100.0 \%)\end{array}$ & $\begin{array}{r}4,740 \\
(100.0 \%)\end{array}$ & $\begin{array}{c}5,024 \\
(100.0 \%)\end{array}$ & $\begin{array}{r}4,690 \\
(100.0 \%)\end{array}$ \\
\hline \multicolumn{8}{|l|}{ Private Vehicles } \\
\hline Auto, Van - Driver & $\begin{array}{r}39,133 \\
(58.5 \%)\end{array}$ & $\begin{array}{c}17,336 \\
(57.3 \%)\end{array}$ & $\begin{array}{r}8,256 \\
(61.2 \%)\end{array}$ & $\begin{array}{c}4,685 \\
(60.8 \%)\end{array}$ & $\begin{array}{c}2,828 \\
(59.7 \%)\end{array}$ & $\begin{array}{c}3,153 \\
(62.8 \%)\end{array}$ & $\begin{array}{r}2,619 \\
(55.8 \%)\end{array}$ \\
\hline Auto Van -Pascenger & 4,633 & 2,346 & 863 & 411 & 294 & 264 & 316 \\
\hline Auto, van - Passenger & $(6.9 \%)$ & $(7.8 \%)$ & $(6.4 \%)$ & $(5.3 \%)$ & $(6.2 \%)$ & $(5.3 \%)$ & $(6.7 \%)$ \\
\hline & 4,439 & 1,904 & 1,030 & 571 & 332 & 310 & 278 \\
\hline Sport Utility Venicle & $(6.6 \%)$ & $(6.3 \%)$ & $(7.6 \%)$ & $(7.4 \%)$ & $(7.0 \%)$ & $(6.2 \%)$ & $(5.9 \%)$ \\
\hline Dickun & 11,603 & 4,662 & 2,449 & 1,515 & 962 & 947 & 1,003 \\
\hline РІскир & $(17.3 \%)$ & $(15.4 \%)$ & $(18.2 \%)$ & $(19.7 \%)$ & $(20.3 \%)$ & $(18.8 \%)$ & $(21.4 \%)$ \\
\hline Other Private Vehicle & 932 & 282 & 209 & 105 & 67 & 79 & 173 \\
\hline Ueter ritsale verite & $(1.4 \%)$ & $(0.9 \%)$ & $(1.5 \%)$ & $(1.4 \%)$ & $(1.4 \%)$ & $(1.6 \%)$ & $(3.7 \%)$ \\
\hline & 60,740 & 26,530 & 12,807 & 7,287 & 4,483 & 4,753 & 4,389 \\
\hline Subtotal & $(90.8 \%)$ & $(87.7 \%)$ & $(95.0 \%)$ & $(94.6 \%)$ & $(94.6 \%)$ & $(94.6 \%)$ & $(93.6 \%)$ \\
\hline \multicolumn{8}{|l|}{ Public Transportation } \\
\hline Du Strotor & 1,260 & 600 & 229 & 91 & 87 & 87 & 55 \\
\hline Bus, streetcar & $(1.9 \%)$ & $(2.0 \%)$ & $(1.7 \%)$ & $(1.2 \%)$ & $(1.8 \%)$ & $(1.7 \%)$ & $(1.2 \%)$ \\
\hline D : i1/C & 1,068 & 265 & 190 & 118 & 109 & 108 & 124 \\
\hline Ra1l/subway & $(1.6 \%)$ & $(0.9 \%)$ & $(1.4 \%)$ & $(1.5 \%)$ & $(2.3 \%)$ & $(2.1 \%)$ & $(2.6 \%)$ \\
\hline & 2,328 & 865 & 419 & 209 & 196 & 195 & 179 \\
\hline Subtotal & $(3.5 \%)$ & $(2.9 \%)$ & $(3.1 \%)$ & $(2.7 \%)$ & $(4.1 \%)$ & $(3.9 \%)$ & $(3.8 \%)$ \\
\hline \multicolumn{8}{|l|}{ Other Means } \\
\hline & 8 & $* *$ & $* *$ & 3 & $* *$ & $* *$ & 4 \\
\hline Amtrak & $(0.0 \%)$ & $(0.0 \%)$ & $(0.0 \%)$ & $(0.0 \%)$ & $(0.0 \%)$ & $(0.0 \%)$ & $(0.1 \%)$ \\
\hline Tovi & 133 & 96 & 26 & 5 & 1 & 2 & * \\
\hline Iaxi & $(0.2 \%)$ & $(0.3 \%)$ & $(0.2 \%)$ & $(0.1 \%)$ & $(0.0 \%)$ & $(0.0 \%)$ & $(0.0 \%)$ \\
\hline Dit & 283 & 240 & 31 & 7 & 1 & 2 & ** \\
\hline B1ke & $(0.4 \%)$ & $(0.8 \%)$ & $(0.2 \%)$ & $(0.1 \%)$ & $(0.0 \%)$ & $(0.0 \%)$ & $(0.0 \%)$ \\
\hline Walk & 1,510 & 1,501 & 10 & $* *$ & $* *$ & $* *$ & $* *$ \\
\hline Walk & $(2.3 \%)$ & $(5.0 \%)$ & $(0.1 \%)$ & $(0.0 \%)$ & $(0.0 \%)$ & $(0.0 \%)$ & $(0.0 \%)$ \\
\hline School Rus & 158 & 36 & 34 & 35 & 7 & 9 & 22 \\
\hline Scnool Bus & $(0.2 \%)$ & $(0.1 \%)$ & $(0.3 \%)$ & $(0.5 \%)$ & $(0.1 \%)$ & $(0.2 \%)$ & $(0.5 \%)$ \\
\hline Other & 304 & 117 & 33 & 46 & 12 & 11 & 51 \\
\hline Uiner & $(0.5 \%)$ & $(0.4 \%)$ & $(0.2 \%)$ & $(0.6 \%)$ & $(0.3 \%)$ & $(0.2 \%)$ & $(1.1 \%)$ \\
\hline & 2,388 & 1,990 & 134 & 93 & 21 & 24 & 73 \\
\hline Subtotal & $(3.6 \%)$ & $(6.6 \%)$ & $(1.0 \%)$ & $(1.2 \%)$ & $(0.4 \%)$ & $(0.5 \%)$ & $(1.6 \%)$ \\
\hline
\end{tabular}

Note:

- All tables reporting totals could include some unreported characteristics.

- Rail/Subway includes trips by subway, elevated rail, and commuter train.

- $\quad *$ Indicates insufficient data reported.

- $\quad * *$ Indicates no data reported. 
FIGURE 6.7

DISTRIBUTION OF JOURNEY TO WORK PERSON TRIPS BY TRIP LENGTH FOR SELECTED MODES OF TRANSPORTATION

1995 NPTS

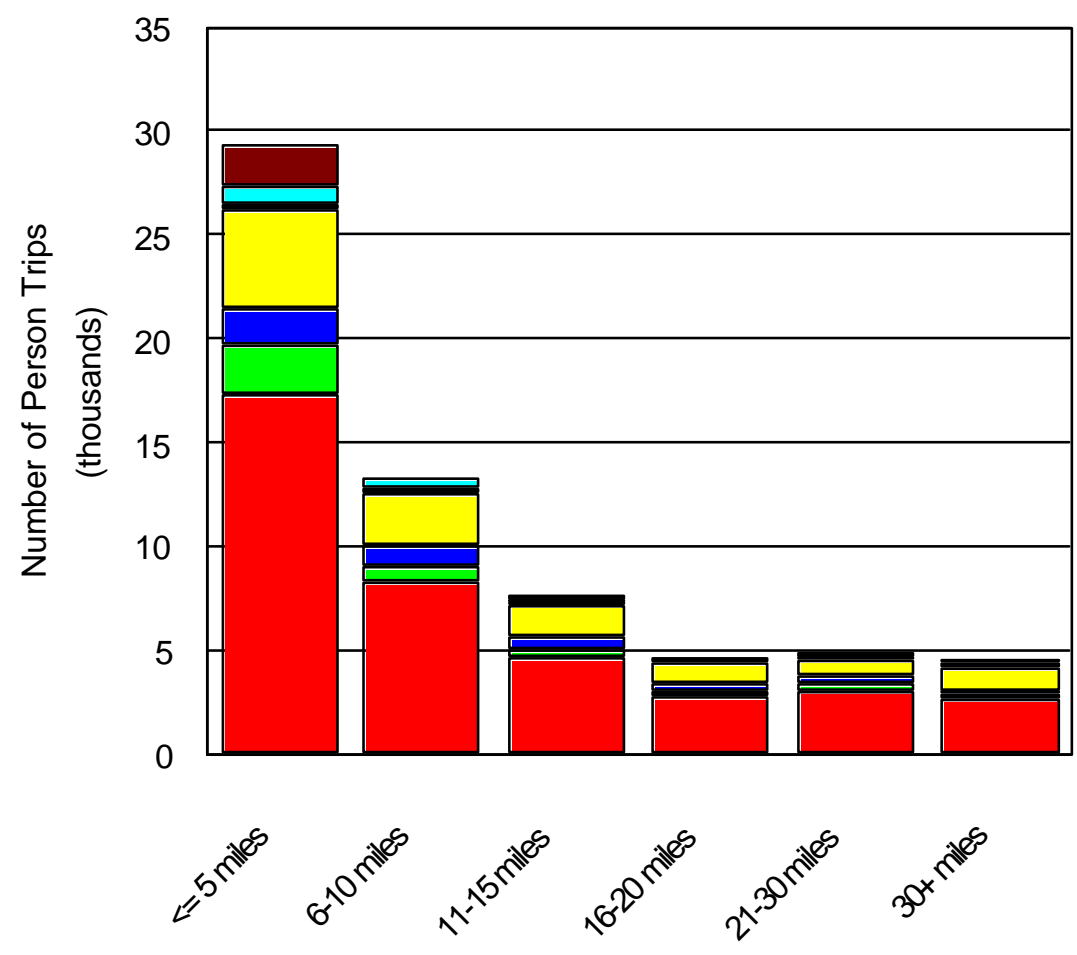

Other Means

$\square$ Public

Transportation

$\square$ Other POV

$\square$ Pickup

Sports Utility Vehicle

$\square$ Auto, Van Passenger

$\square$ Auto, Van Driver 
Statistics on work-related person trips by mode (Table 6.12) in 1995 were very similar to those for journey to work person trips by mode (see Table 6.9). Private vehicles were used for almost $90 \%$ of all work-related person trips, and the automobile/van was the most often used private vehicle type. The average trip length for work-related person trips taken via private vehicles (18.59 miles) was shorter than the average length via either public transportation (21.29 miles) or other means (47.36 miles). 


\section{TABLE 6.12}

STATISTICS ON WORK-RELATED PERSON TRIPS BY MODE OF TRANSPORTATION 1995 NPTS

\begin{tabular}{|c|c|c|c|}
\hline & $\begin{array}{c}\text { No. of Person Trips } \\
(000,000)\end{array}$ & $\begin{array}{c}\text { No. of Person Miles } \\
(000,000)\end{array}$ & $\begin{array}{l}\text { Average Trip Length } \\
\text { (miles) }\end{array}$ \\
\hline TOTAL & $\begin{array}{c}9,860 \\
(100.0 \%)\end{array}$ & $\begin{array}{c}196,699 \\
(100.0 \%)\end{array}$ & 20.3 \\
\hline \multicolumn{4}{|l|}{ Private Vehicles } \\
\hline Auto, Van - Driver & $\begin{array}{c}4,921 \\
(49.9 \%)\end{array}$ & $\begin{array}{c}66,964 \\
(34.0 \%)\end{array}$ & 13.7 \\
\hline Auto, Van - Passenger & $\begin{array}{c}516 \\
(5.2 \%)\end{array}$ & $\begin{array}{l}12,081 \\
(6.1 \%)\end{array}$ & 23.6 \\
\hline Sports Utility Vehicle & $\begin{array}{r}609 \\
(6.2 \%)\end{array}$ & $\begin{array}{c}6,202 \\
(3.2 \%)\end{array}$ & 10.2 \\
\hline Pickup & $\begin{array}{c}1,964 \\
(19.9 \%)\end{array}$ & $\begin{array}{c}33,276 \\
(16.9 \%)\end{array}$ & 17.0 \\
\hline Other Private Vehicle & $\begin{array}{c}825 \\
(8.4 \%)\end{array}$ & $\begin{array}{c}44,602 \\
(22.7 \%)\end{array}$ & 55.8 \\
\hline Subtotal & $\begin{array}{c}8,835 \\
(89.6 \%)\end{array}$ & $\begin{array}{l}163,125 \\
(82.9 \%)\end{array}$ & 18.59 \\
\hline \multicolumn{4}{|l|}{ Public Transportation } \\
\hline Bus, Streetcar & $\begin{array}{c}81 \\
(0.8 \%)\end{array}$ & $\begin{array}{c}1,118 \\
(0.6 \%)\end{array}$ & 16.4 \\
\hline Rail/Subway & $\begin{array}{c}41 \\
(0.4 \%)\end{array}$ & $\begin{array}{c}1,071 \\
(0.5 \%)\end{array}$ & 31.0 \\
\hline Subtotal & $\begin{array}{c}123 \\
(1.2 \%)\end{array}$ & $\begin{array}{c}2,189 \\
(1.1 \%)\end{array}$ & 21.29 \\
\hline \multicolumn{4}{|l|}{ Other Means } \\
\hline Amtrak & $\begin{array}{r}0 \\
(0.0 \%)\end{array}$ & $\begin{array}{r}4 \\
(0.0 \%)\end{array}$ & 69.2 \\
\hline Taxi & $\begin{array}{c}44 \\
(0.4 \%)\end{array}$ & $\begin{array}{c}404 \\
(0.2 \%)\end{array}$ & 9.3 \\
\hline Bike & $\begin{array}{c}14 \\
(0.1 \%)\end{array}$ & $\begin{array}{c}27 \\
(0.0 \%)\end{array}$ & 2.0 \\
\hline Walk & $\begin{array}{r}240 \\
(2.4 \%)\end{array}$ & $\begin{array}{c}120 \\
(0.1 \%)\end{array}$ & 0.5 \\
\hline School Bus & $\begin{array}{r}87 \\
(0.9 \%)\end{array}$ & $\begin{array}{c}908 \\
(0.5 \%)\end{array}$ & 11.1 \\
\hline Other & $\begin{array}{c}272 \\
(2.8 \%)\end{array}$ & $\begin{array}{c}28,100 \\
(14.3 \%)\end{array}$ & 114.8 \\
\hline Subtotal & $\begin{array}{r}658 \\
(6.7 \%) \\
\end{array}$ & $\begin{array}{c}29,563 \\
(15.0 \%) \\
\end{array}$ & 47.36 \\
\hline
\end{tabular}

Note:

- All tables reporting totals could include some unreported characteristics.

- Average trip length is calculated using only those records with trip mile information present.

- Rail/Subway includes trips by subway, elevated rail, and commuter train. 
Segmented travel is defined as a trip in which there is a change in vehicle AND one of the segments involves the use of public transportation. (A fuller description of segmented travel is given in Chapter 4.) Tables 6.13-6.16 provide additional information about journey to work trips that are segmented.

As shown in Table 6.13 , only $2.2 \%$ of all

The average trip length for segmented journey to work trips was $25 \%$ longer than a nonsegmented trip. The longest segmented journey to work trips (32.9 miles) were for workers not in an MSA, and the second longest (20.1 miles) were for residents of MSAs with a population of less than 250,000. Figure 6.9 shows the average trip lengths by MSA size for segmented and nonsegmented journey to work person trips.

For segmented journey to work person trips, 99.2\% involved public transportation (bus, streetcar, rail, subway) as the primary mode of transportation (Table 6.14).

The average trip length of a segmented journey to work person trip was 14.5 miles, almost 3 miles longer than the average length of a typical journey to work commute (Table 6.15).
For segmented journey to work trips, $43.8 \%$ involved two segments, $43.1 \%$ involved three segments, and at least one segment was walked in over $70 \%$ of the trips (Table 6.16). 
TABLE 6.13

Journey to Work Person Trips by Segmented vs. Nonsegmented Trips ANd MSA Size 1995 NPTS

\begin{tabular}{|c|c|c|c|c|c|c|c|c|c|}
\hline \multirow[b]{2}{*}{ MSA Size } & \multicolumn{3}{|c|}{ TOTAL COMMUTE TRIPS } & \multicolumn{3}{|c|}{ Segmented Commute Trips } & \multicolumn{3}{|c|}{ Nonsegmented Commute Trips } \\
\hline & $\begin{array}{l}\text { Number } \\
\text { of Trips } \\
(000)\end{array}$ & $\begin{array}{c}\text { Number } \\
\text { of Person } \\
\text { Miles } \\
(000)\end{array}$ & $\begin{array}{l}\text { Avg. } \\
\text { Trip } \\
\text { Length } \\
\text { (miles) }\end{array}$ & $\begin{array}{l}\text { Number } \\
\text { of Trips } \\
(000)\end{array}$ & $\begin{array}{l}\text { Number } \\
\text { of Person } \\
\text { Miles } \\
(000)\end{array}$ & $\begin{array}{l}\text { Avg. } \\
\text { Trip } \\
\text { Length } \\
\text { (miles) }\end{array}$ & $\begin{array}{l}\text { Number } \\
\text { of Trips } \\
(000)\end{array}$ & $\begin{array}{c}\text { Number } \\
\text { of Person } \\
\text { Miles } \\
(000)\end{array}$ & $\begin{array}{l}\text { Avg. } \\
\text { Trip } \\
\text { Length } \\
\text { (miles) }\end{array}$ \\
\hline TOTAL & $\begin{array}{r}66,901,023 \\
(100.0 \%)\end{array}$ & $\begin{array}{r}766,173,323 \\
(100.0 \%)\end{array}$ & 11.6 & $\begin{array}{r}1,462,476 \\
(2.2 \%)\end{array}$ & $\begin{array}{r}18,402,547 \\
(2.4 \%)\end{array}$ & 14.5 & $\begin{array}{r}65,438,547 \\
(97.8 \%)\end{array}$ & $\begin{array}{r}747,770,776 \\
(97.6 \%)\end{array}$ & 11.6 \\
\hline $\begin{array}{l}\text { Less than } \\
250,000\end{array}$ & $\begin{array}{r}5,573,297 \\
(100.0 \%)\end{array}$ & $\begin{array}{r}56,401,044 \\
(100.0 \%)\end{array}$ & 10.2 & $\begin{array}{l}31,903 \\
(0.6 \%)\end{array}$ & $\begin{array}{r}585,171 \\
(1.0 \%)\end{array}$ & 20.1 & $\begin{array}{r}5,541,394 \\
(99.4 \%)\end{array}$ & $\begin{array}{r}55,815,873 \\
(99.0 \%)\end{array}$ & 10.2 \\
\hline $\begin{array}{r}250,000- \\
499,999\end{array}$ & $\begin{array}{r}4,735,946 \\
(100.0 \%)\end{array}$ & $\begin{array}{r}49,118,580 \\
(100.0 \%)\end{array}$ & 10.5 & $\begin{array}{l}21,604 \\
(0.5 \%)\end{array}$ & $\begin{array}{r}106,122 \\
(0.2 \%)\end{array}$ & 10.7 & $\begin{array}{r}4,714,342 \\
(99.5 \%)\end{array}$ & $\begin{array}{r}49,012,458 \\
(99.8 \%)\end{array}$ & 10.5 \\
\hline $\begin{array}{r}500,000- \\
999,999\end{array}$ & $\begin{array}{r}5,399,827 \\
(100.0 \%)\end{array}$ & $\begin{array}{r}59,001,578 \\
(100.0 \%)\end{array}$ & 11.1 & $\begin{array}{l}46,831 \\
(0.9 \%)\end{array}$ & $\begin{array}{r}401,519 \\
(0.7 \%)\end{array}$ & 10.3 & $\begin{array}{r}5,352,996 \\
(99.1 \%)\end{array}$ & $\begin{array}{r}58,600,059 \\
(99.3 \%)\end{array}$ & 11.1 \\
\hline $\begin{array}{l}1 \text { million - } \\
2.9 \text { million }\end{array}$ & $\begin{array}{r}11,610,584 \\
(100.0 \%)\end{array}$ & $\begin{array}{r}129,672,235 \\
(100.0 \%)\end{array}$ & 11.3 & $\begin{array}{r}124,246 \\
(1.1 \%)\end{array}$ & $\begin{array}{r}1,399,451 \\
(1.1 \%)\end{array}$ & 11.5 & $\begin{array}{r}11,486,338 \\
(98.9 \%)\end{array}$ & $\begin{array}{r}128,272,784 \\
(98.9 \%)\end{array}$ & 11.3 \\
\hline 3 million + & $\begin{array}{r}25,806,275 \\
(100.0 \%)\end{array}$ & $\begin{array}{r}318,658,775 \\
(100.0 \%)\end{array}$ & 12.7 & $\begin{array}{r}1,232,267 \\
(4.8 \%)\end{array}$ & $\begin{array}{r}15,821,751 \\
(5.0 \%)\end{array}$ & 14.8 & $\begin{array}{r}24,574,008 \\
(95.2 \%)\end{array}$ & $\begin{array}{r}302,837,024 \\
(95.0 \%)\end{array}$ & 12.6 \\
\hline $\begin{array}{l}\text { Not in } \\
\text { MSA }\end{array}$ & $\begin{array}{r}13,775,095 \\
(100.0 \%)\end{array}$ & $\begin{array}{r}153,321,111 \\
(100.0 \%)\end{array}$ & 11.2 & $\begin{array}{c}5,625 \\
(0.0 \%)\end{array}$ & $\begin{array}{l}88,533 \\
(0.1 \%)\end{array}$ & 32.9 & $\begin{array}{r}13,769,470 \\
(100.0 \%)\end{array}$ & $\begin{array}{r}153,232,579 \\
(99.9 \%)\end{array}$ & 11.2 \\
\hline
\end{tabular}

Note:

- Average trip length is calculated using only those records with trip mileage information present. 
FIGURE 6.8

Distribution of Journey to Work Person Trips by MSA Size

FOR SEGMENTED AND NONSEGMENTED TRIPS

1995 NPTS

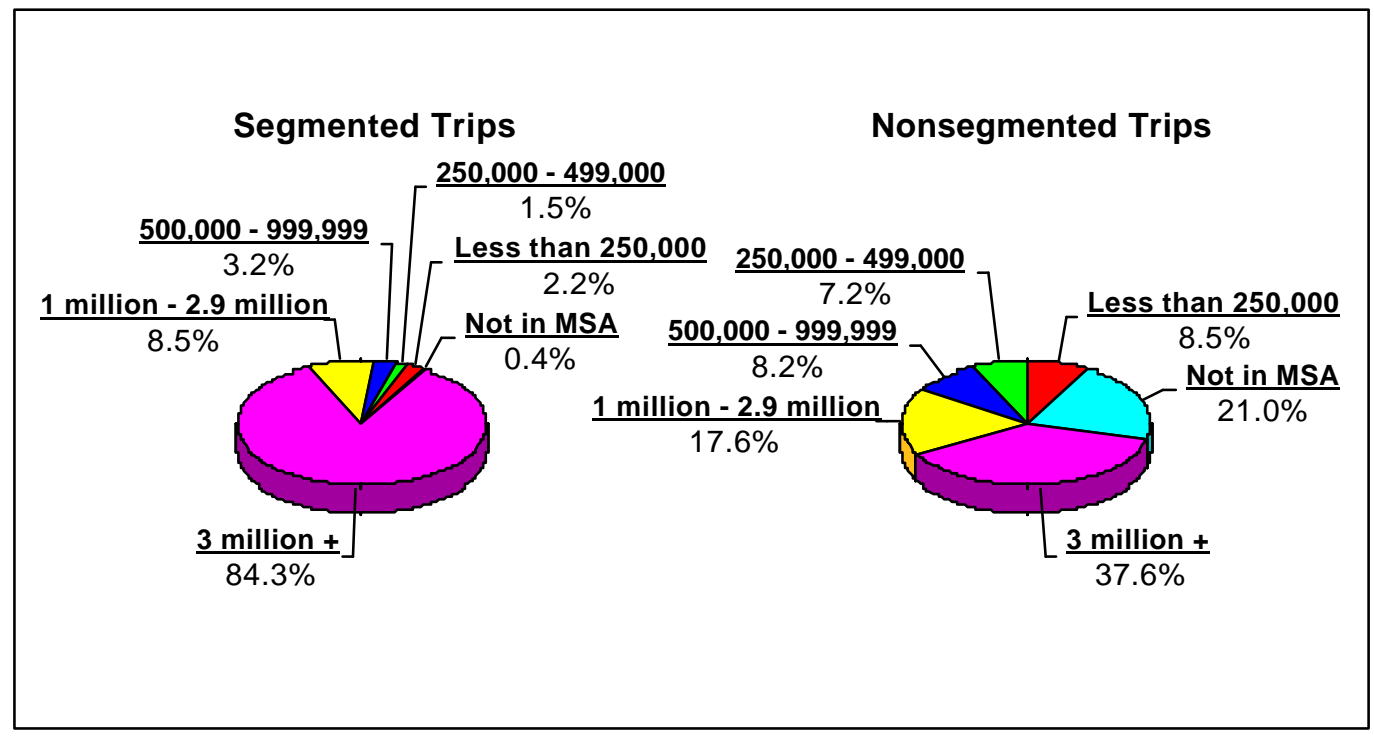

FIGURE 6.9

Comparison of Journey to Work Average Trip Lengths by MSA Size FOR SEGMENTED AND NONSEGMENTED TRIPS 1995 NPTS

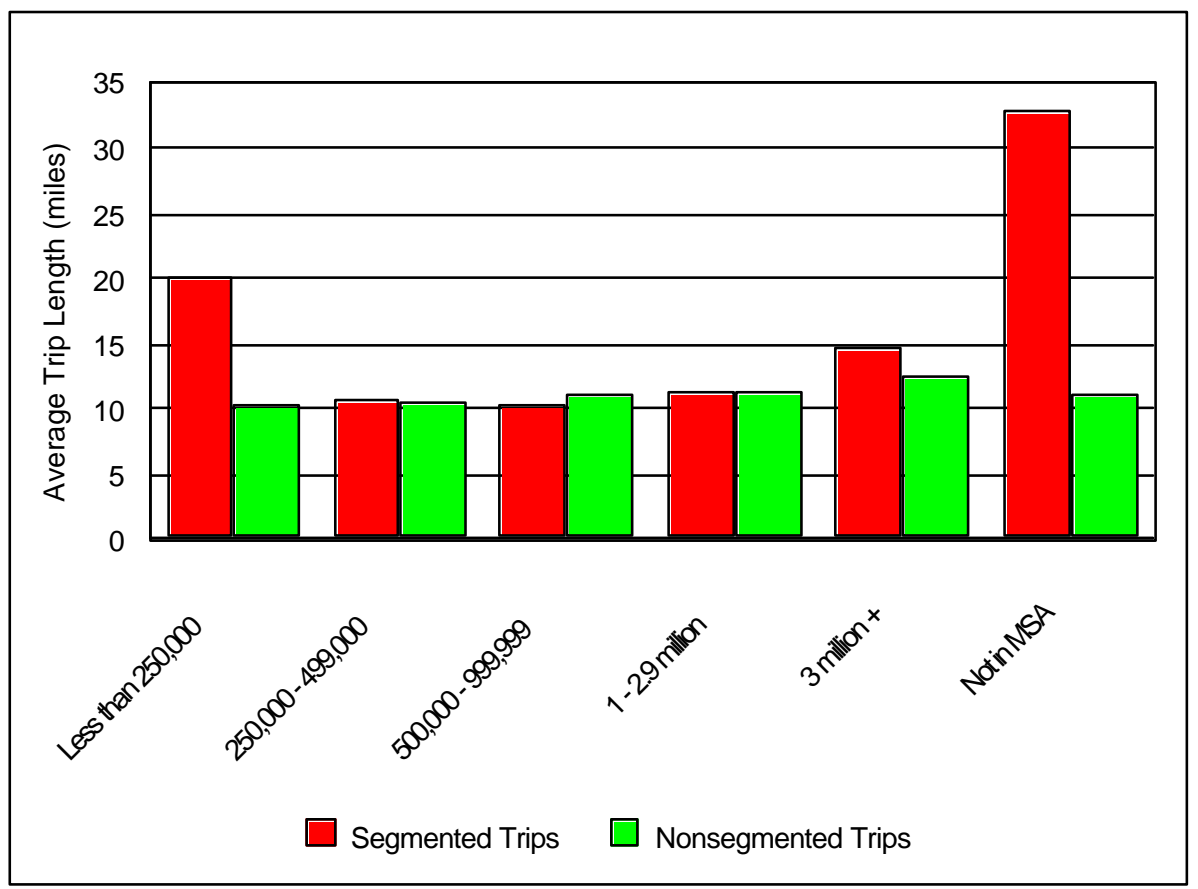


TABLE 6.14

\section{DISTRIBUTION OF JOURNEY TO WORK PERSON TRIPS BY TRIP SEGMENTED STATUS AND PRIMARY MODE OF TRANSPORTATION}

1995 NPTS

\begin{tabular}{|c|c|c|c|}
\hline Primary Mode & $\begin{array}{l}\text { TOTAL COMMUTE TRIPS } \\
(000)\end{array}$ & $\begin{array}{l}\text { Nonsegmented Commute Trips } \\
(000)\end{array}$ & $\begin{array}{l}\text { Segmented Commute } \\
\text { Trips }(000)\end{array}$ \\
\hline TOTAL & $\begin{array}{r}66,901,023 \\
(100.0 \%)\end{array}$ & $\begin{array}{r}65,438,547 \\
(100.0 \%)\end{array}$ & $\begin{array}{l}1,462,476 \\
(100.0 \%)\end{array}$ \\
\hline \multicolumn{4}{|l|}{ Private Vehicles } \\
\hline Auto, Van - Driver & $\begin{array}{r}39,132,814 \\
(58.5 \%)\end{array}$ & $\begin{array}{r}39,129,697 \\
(59.8 \%)\end{array}$ & $\begin{array}{r}3,118 \\
(0.2 \%)\end{array}$ \\
\hline Auto, Van - Passenger & $\begin{array}{r}4,632,938 \\
(6.9 \%)\end{array}$ & $\begin{array}{r}4,632,191 \\
(7.1 \%)\end{array}$ & $\begin{array}{r}748 \\
(0.1 \%)\end{array}$ \\
\hline Sports Utility Vehicle & $\begin{array}{r}4,438,715 \\
(6.6 \%)\end{array}$ & $\begin{array}{r}4,438,654 \\
(6.8 \%)\end{array}$ & $\begin{array}{r}61 \\
(0.0 \%)\end{array}$ \\
\hline Pickup & $\begin{array}{r}11,602,773 \\
(17.3 \%)\end{array}$ & $\begin{array}{r}11,602,506 \\
(17.7 \%)\end{array}$ & $\begin{array}{r}267 \\
(0.0 \%)\end{array}$ \\
\hline Other Private Vehicle & $\begin{array}{r}932,446 \\
(1.4 \%)\end{array}$ & $\begin{array}{r}929,631 \\
(1.4 \%)\end{array}$ & $\begin{array}{r}2,816 \\
(0.2 \%)\end{array}$ \\
\hline Subtotal & $\begin{array}{r}60,739,687 \\
(90.8 \%)\end{array}$ & $\begin{array}{r}60,732,678 \\
(92.8 \%)\end{array}$ & $\begin{array}{r}7,009 \\
(0.5 \%)\end{array}$ \\
\hline \multicolumn{4}{|l|}{ Public Transportation } \\
\hline Bus, Streetcar & $\begin{array}{r}1,260,002 \\
(1.9 \%)\end{array}$ & $\begin{array}{r}569,119 \\
(0.9 \%)\end{array}$ & $\begin{array}{l}690,883 \\
(47.2 \%)\end{array}$ \\
\hline Rail/Subway & $\begin{array}{r}1,068,072 \\
(1.6 \%)\end{array}$ & $\begin{array}{r}307,945 \\
(0.5 \%)\end{array}$ & $\begin{array}{l}760,127 \\
(52.0 \%)\end{array}$ \\
\hline Subtotal & $\begin{array}{r}2,328,074 \\
(3.5 \%)\end{array}$ & $\begin{array}{r}877,064 \\
(1.3 \%)\end{array}$ & $\begin{array}{r}1,451,010 \\
(99.2 \%)\end{array}$ \\
\hline \multicolumn{4}{|l|}{ Other Means } \\
\hline Amtrak & $\begin{array}{r}7,570 \\
(0.0 \%)\end{array}$ & $\begin{array}{c}3,406 \\
(0.0 \%)\end{array}$ & $\begin{array}{r}4,164 \\
(0.3 \%)\end{array}$ \\
\hline Taxi & $\begin{array}{r}133,409 \\
(0.2 \%)\end{array}$ & $\begin{array}{r}133,409 \\
(0.2 \%)\end{array}$ & $\begin{array}{r}0 \\
(0.0 \%)\end{array}$ \\
\hline Bike & $\begin{array}{r}283,454 \\
(0.4 \%)\end{array}$ & $\begin{array}{r}283,454 \\
(0.4 \%)\end{array}$ & $\begin{array}{r}0 \\
(0.0 \%)\end{array}$ \\
\hline Walk & $\begin{array}{r}1,510,407 \\
(2.3 \%)\end{array}$ & $\begin{array}{r}1,510,407 \\
(2.3 \%)\end{array}$ & $\begin{array}{r}0 \\
(0.0 \%)\end{array}$ \\
\hline School Bus & $\begin{array}{r}157,947 \\
(0.2 \%)\end{array}$ & $\begin{array}{r}157,947 \\
(0.2 \%)\end{array}$ & $\begin{array}{r}0 \\
(0.0 \%)\end{array}$ \\
\hline Other & $\begin{array}{r}304,332 \\
(0.5 \%)\end{array}$ & $\begin{array}{r}304,040 \\
(0.5 \%)\end{array}$ & $\begin{array}{r}293 \\
(0.0 \%)\end{array}$ \\
\hline Subtotal & $\begin{array}{r}2,397,120 \\
(3.6 \%) \\
\end{array}$ & $\begin{array}{r}2,392,663 \\
(3.7 \%) \\
\end{array}$ & $\begin{array}{r}4,457 \\
(0.3 \%) \\
\end{array}$ \\
\hline
\end{tabular}

Note:

- All tables reporting totals could include some unreported characteristics.

- For segmented trips, primary mode refers to the mode used during the trip segment with the longest travel time in minutes.

- Rail/Subway includes trips by subway, elevated rail, and commuter train. 
TABLE 6.15

\section{Average Trip Length of Journey to Work Person Trips By Trip Segmented Status and Primary Mode of Transportation 1995 NPTS}

(MILES)

\begin{tabular}{|c|c|c|c|}
\hline Primary Mode & $\begin{array}{c}\text { Total } \\
\text { Commute Trips } \\
\end{array}$ & $\begin{array}{l}\text { Nonsegmented } \\
\text { Commute Trips }\end{array}$ & $\begin{array}{c}\text { Segmented } \\
\text { Commute Trips }\end{array}$ \\
\hline TOTAL & 11.6 & 11.6 & 14.5 \\
\hline \multicolumn{4}{|l|}{ Private Vehicles } \\
\hline Auto, Van - Driver & 11.1 & 11.1 & 36.6 \\
\hline Auto, Van - Passenger & 11.3 & 11.3 & 2.0 \\
\hline Sports Utility Vehicle & 12.3 & 12.3 & 31.0 \\
\hline Pickup & 12.9 & 12.9 & 18.0 \\
\hline Other Private Vehicle & 29.6 & 29.6 & 28.0 \\
\hline Subtotal & 11.8 & 11.8 & 28.6 \\
\hline \multicolumn{4}{|l|}{ Public Transportation } \\
\hline Bus, Streetcar & 10.6 & 9.4 & 11.7 \\
\hline Rail/Subway & 15.7 & 13.8 & 16.5 \\
\hline Subtotal & 12.9 & 10.9 & 14.2 \\
\hline \multicolumn{4}{|l|}{ Other Means } \\
\hline Amtrak & 53.2 & 15.0 & 83.5 \\
\hline Taxi & 4.4 & 4.4 & 0 \\
\hline Bike & 3.0 & 3.0 & 0 \\
\hline Walk & 0.7 & 0.7 & 0 \\
\hline School Bus & 15.5 & 15.5 & 0 \\
\hline Other & 51.8 & 51.8 & 13.0 \\
\hline Subtotal & 8.2 & 8.0 & 82.6 \\
\hline
\end{tabular}

Note:

- All tables reporting totals could include some unreported characteristics.

- Average trip length is calculated using only those records with trip mile information present.

- For segmented trips, primary mode refers to the mode used during the trip segment with the longest travel time in minutes.

- Rail/Subway includes trips by subway, elevated rail, and commuter train. 
TABLE 6.16

Number of SEGmented Journey to Work Person Trips by Number of SEgMents Taken 1995 NPTS

(THOUSANDS)

\begin{tabular}{|c|c|}
\hline Number of Segments & Number of Trips \\
\hline TOTAL & $\begin{array}{r}1,462,476 \\
(100.0 \%)\end{array}$ \\
\hline Two & $\begin{array}{l}639,967 \\
(43.8 \%)\end{array}$ \\
\hline Three & $\begin{array}{l}630,893 \\
(43.1 \%)\end{array}$ \\
\hline Four + & $\begin{array}{l}191,616 \\
(13.1 \%)\end{array}$ \\
\hline At least one segment walked & $\begin{array}{r}1,029,098 \\
(70.4 \%)\end{array}$ \\
\hline
\end{tabular}

Journey to work and work-related person trips by weekend vs. weekday travel and by time of day is given in Table 6.17 and shown in Figure 6.10. As expected, weekday journey to work trips occur primarily between 6 to 9 a.m. and 4 to 7 p.m. On the weekends, $23.1 \%$ of all journey to work trips occur between 4 and 7 p.m. Work-related trips, both weekday and weekend, occur primarily between 9 a.m. and 1 p.m. Table 6.18 shows comparable information based on 1990 trip purpose codes. 


\section{TABLE 6.17}

Number of Person Trips (millions) by Weekday vs. Weekend, Trip Purpose, and Time of Day 1995 NPTS

\begin{tabular}{|c|c|c|c|c|c|c|c|c|}
\hline & & 1:00 a.m to & 6:00 a.m. to & 9:00 a.m. to & 1:00 p.m. to & $4: 00$ p.m. to & 7:00 p.m. to & 10:00 p.m. to \\
\hline & TOTAL & 6:00 a.m. & 9:00 a.m. & 1:00 p.m. & 4:00 p.m. & 7:00 p.m. & 10:00 p.m. & 1:00 a.m \\
\hline & 378,930 & 6,481 & 52,262 & 91,551 & 83,615 & 86,992 & 44,667 & 13,267 \\
\hline $101 \mathrm{AL}$ & $(100.0 \%)$ & $(1.7 \%)$ & $(13.8 \%)$ & $(24.2 \%)$ & $(22.1 \%)$ & $(23.0 \%)$ & $(11.8 \%)$ & $(3.5 \%)$ \\
\hline Weekday & & & & & & & & \\
\hline & 35,415 & 2,606 & 17,058 & 7,152 & 5,770 & 1,924 & 514 & 381 \\
\hline Joumey lo Work & $(100.0 \%)$ & $(7.4 \%)$ & $(48.2 \%)$ & $(20.2 \%)$ & $(16.3 \%)$ & $(5.4 \%)$ & $(1.5 \%)$ & $(1.1 \%) \|$ \\
\hline Work-Related & 9,283 & 158 & 1,727 & 3,594 & 2,401 & 1,097 & 231 & 73 \\
\hline Business & $(100.0 \%)$ & $(1.7 \%)$ & $(18.6 \%)$ & $(38.7 \%)$ & $(25.9 \%)$ & $(11.8 \%)$ & $(2.5 \%)$ & $(0.8 \%)$ \\
\hline$H_{0}$ & 86,442 & 1,134 & 3,509 & 13,469 & 22,056 & 28,111 & 13,704 & 4,457 \\
\hline Home & $(100.0 \%)$ & $(1.3 \%)$ & $(4.1 \%)$ & $(15.6 \%)$ & $(25.5 \%)$ & $(32.5 \%)$ & $(15.9 \%)$ & $(5.2 \%) \|$ \\
\hline Othor & 133,979 & 1,082 & 22,993 & 37,504 & 29,761 & 30,144 & 10,684 & 1,776 \\
\hline Uther & $(100.0 \%)$ & $(0.8 \%)$ & $(17.2 \%)$ & $(28.0 \%)$ & $(22.2 \%)$ & $(22.5 \%)$ & $(8.0 \%)$ & $(1.3 \%) \|$ \\
\hline Subtotol & 265,156 & 4,982 & 45,292 & 61,730 & 59,995 & 61,281 & 25,140 & 6,687 \\
\hline Subtotal & $(100.0 \%)$ & $(1.9 \%)$ & $(17.1 \%)$ & $(23.3 \%)$ & $(22.6 \%)$ & $(23.1 \%)$ & $(9.5 \%)$ & $(2.5 \%)$ \\
\hline Weekend & & & & & & & & \\
\hline $\mathbf{T}=\mathbf{H}$ & 4,129 & 314 & 1,280 & 974 & 622 & 505 & 253 & 177 \\
\hline Journey to Work & $(100.0 \%)$ & $(7.6 \%)$ & $(31.0 \%)$ & $(23.6 \%)$ & $(15.1 \%)$ & $(12.2 \%)$ & $(6.1 \%)$ & $(4.3 \%)$ \\
\hline Work-Related & 1,340 & 25 & 198 & 466 & 299 & 211 & 104 & 36 \\
\hline Business & $(100.0 \%)$ & $(1.9 \%)$ & $(14.7 \%)$ & $(34.8 \%)$ & $(22.3 \%)$ & $(15.8 \%)$ & $(7.8 \%)$ & $(2.7 \%) \|$ \\
\hline Home & 40,928 & 613 & 1,034 & 7,712 & 8,022 & 9,774 & 9,456 & 4,315 \\
\hline Home & $(100.0 \%)$ & $(1.5 \%)$ & $(2.5 \%)$ & $(18.8 \%)$ & $(19.6 \%)$ & $(23.9 \%)$ & $(23.1 \%)$ & $(10.5 \%) \|$ \\
\hline Q & 67,332 & 547 & 4,457 & 20,669 & 14,671 & 15,220 & 9,711 & 2,051 \\
\hline Otiles & $(100.0 \%)$ & $(0.8 \%)$ & $(6.6 \%)$ & $(30.7 \%)$ & $(21.8 \%)$ & $(22.6 \%)$ & $(14.4 \%)$ & $(3.0 \%)$ \\
\hline Sulbtotol & 113,742 & 1,499 & 6,970 & 29,820 & 23,620 & 25,711 & 19,527 & 6,580 \\
\hline Subtotal & $(100.0 \%)$ & $(1.3 \%)$ & $(6.1 \%)$ & $(26.2 \%)$ & $(20.8 \%)$ & $(22.6 \%)$ & $(17.2 \%)$ & $(5.8 \%) \|$ \\
\hline
\end{tabular}

Note:

- Weekday is defined as the time between 12:01 a.m. Monday and 6:00 p.m. Friday.

- Weekend is defined as the time between 6:01 p.m. Friday and midnight Saturday.

- All tables reporting totals could include some unreported characteristics. 
TABLE 6.18

Number of Person Trips (Millions) By WeEkday vs. WeEKend, 1990 Trip PuRpose, and TIME OF DAY 1995 NPTS

\begin{tabular}{|c|c|c|c|c|c|c|c|c|}
\hline & TOTAL & $\begin{array}{l}\text { 1:00 a.m. to } \\
\text { 6:00 a.m. }\end{array}$ & $\begin{array}{l}\text { 6:00 a.m. to } \\
\text { 9:00 a.m. }\end{array}$ & $\begin{array}{l}\text { 9:00 a.m. to } \\
\text { 1:00 p.m. }\end{array}$ & $\begin{array}{l}\text { 1:00 p.m. to } \\
\text { 4:00 p.m. }\end{array}$ & $\begin{array}{l}\text { 4:00 p.m. to } \\
\text { 7:00 p.m. }\end{array}$ & $\begin{array}{l}\text { 7:00 p.m. to } \\
\text { 10:00 p.m. }\end{array}$ & $\begin{array}{l}10: 00 \text { p.m. } \\
\text { to } 1: 00 \text { a.m. }\end{array}$ \\
\hline TOTAL & $\begin{array}{c}378,930 \\
(100.0 \%)\end{array}$ & $\begin{array}{c}6,481 \\
(1.7 \%)\end{array}$ & $\begin{array}{c}52,262 \\
(13.8 \%)\end{array}$ & $\begin{array}{c}91,551 \\
(24.2 \%)\end{array}$ & $\begin{array}{c}83,615 \\
(22.1 \%)\end{array}$ & $\begin{array}{c}86,992 \\
(23.0 \%)\end{array}$ & $\begin{array}{c}44,667 \\
(11.8 \%)\end{array}$ & $\begin{array}{l}13,267 \\
(3.5 \%)\end{array}$ \\
\hline \multicolumn{9}{|l|}{ Weekday } \\
\hline Journey to Work & $\begin{array}{c}57,694 \\
(100.0 \%)\end{array}$ & $\begin{array}{c}3,117 \\
(5.4 \%)\end{array}$ & $\begin{array}{c}17,594 \\
(30.5 \%)\end{array}$ & $\begin{array}{c}7,368 \\
(12.8 \%)\end{array}$ & $\begin{array}{c}8,825 \\
(15.3 \%)\end{array}$ & $\begin{array}{c}15,434 \\
(26.8 \%)\end{array}$ & $\begin{array}{c}3,394 \\
(5.9 \%)\end{array}$ & $\begin{array}{r}1,950 \\
(3.4 \%)\end{array}$ \\
\hline $\begin{array}{l}\text { Work-Related } \\
\text { Business }\end{array}$ & $\begin{array}{c}8,599 \\
(100.0 \%)\end{array}$ & $\begin{array}{c}157 \\
(1.8 \%)\end{array}$ & $\begin{array}{c}1,706 \\
(19.8 \%)\end{array}$ & $\begin{array}{c}3,359 \\
(39.1 \%)\end{array}$ & $\begin{array}{c}2,086 \\
(24.3 \%)\end{array}$ & $\begin{array}{c}1,028 \\
(12.0 \%)\end{array}$ & $\begin{array}{c}201 \\
(2.3 \%)\end{array}$ & $\begin{array}{r}62 \\
(0.7 \%)\end{array}$ \\
\hline Other & $\begin{array}{c}198,816 \\
(100.0 \%)\end{array}$ & $\begin{array}{c}1,706 \\
(0.9 \%)\end{array}$ & $\begin{array}{c}25,987 \\
(13.1 \%)\end{array}$ & $\begin{array}{c}50,991 \\
(25.6 \%)\end{array}$ & $\begin{array}{c}49,075 \\
(24.7 \%)\end{array}$ & $\begin{array}{c}44,812 \\
(22.5 \%)\end{array}$ & $\begin{array}{c}21,533 \\
(10.8 \%)\end{array}$ & $\begin{array}{r}4,675 \\
(2.4 \%)\end{array}$ \\
\hline Subtotal & $\begin{array}{c}265,156 \\
(100.0 \%)\end{array}$ & $\begin{array}{c}4,982 \\
(1.9 \%)\end{array}$ & $\begin{array}{c}45,292 \\
(17.1 \%)\end{array}$ & $\begin{array}{c}61,730 \\
(23.3 \%)\end{array}$ & $\begin{array}{l}59,995 \\
(22.6 \%)\end{array}$ & $\begin{array}{c}61,281 \\
(23.1 \%)\end{array}$ & $\begin{array}{l}25,140 \\
(9.5 \%)\end{array}$ & $\begin{array}{r}6,687 \\
(2.5 \%)\end{array}$ \\
\hline \multicolumn{9}{|l|}{ Weekend } \\
\hline Journey to Work & $\begin{array}{c}9,206 \\
(100.0 \%)\end{array}$ & $\begin{array}{c}454 \\
(4.9 \%)\end{array}$ & $\begin{array}{c}1,448 \\
(15.7 \%)\end{array}$ & $\begin{array}{c}1,389 \\
(15.1 \%)\end{array}$ & $\begin{array}{c}1,397 \\
(15.2 \%)\end{array}$ & $\begin{array}{c}2,126 \\
(23.1 \%)\end{array}$ & $\begin{array}{c}1,423 \\
(15.5 \%)\end{array}$ & $\begin{array}{r}966 \\
(10.5 \%)\end{array}$ \\
\hline Work-Related & 1,261 & 25 & 198 & 436 & 276 & 201 & 92 & 33 \\
\hline Business & $(100.0 \%)$ & $(2.0 \%)$ & $(15.7 \%)$ & $(34.6 \%)$ & $(21.9 \%)$ & $(15.9 \%)$ & $(7.3 \%)$ & $(2.6 \%)$ \\
\hline Other & $\begin{array}{c}103,255 \\
(100.0 \%)\end{array}$ & $\begin{array}{c}1,020 \\
(1.0 \%)\end{array}$ & $\begin{array}{c}5,324 \\
(5.2 \%)\end{array}$ & $\begin{array}{c}27,994 \\
(27.1 \%)\end{array}$ & $\begin{array}{c}21,941 \\
(21.2 \%)\end{array}$ & $\begin{array}{c}23,377 \\
(22.6 \%)\end{array}$ & $\begin{array}{c}18,008 \\
(17.4 \%)\end{array}$ & $\begin{array}{r}5,582 \\
(5.4 \%)\end{array}$ \\
\hline Subtotal & $\begin{array}{c}113,742 \\
(100.0 \%)\end{array}$ & $\begin{array}{c}1,499 \\
(1.3 \%)\end{array}$ & $\begin{array}{c}6,970 \\
(6.1 \%)\end{array}$ & $\begin{array}{c}29,820 \\
(26.2 \%)\end{array}$ & $\begin{array}{c}23,620 \\
(20.8 \%)\end{array}$ & $\begin{array}{c}25,711 \\
(22.6 \%)\end{array}$ & $\begin{array}{c}19,527 \\
(17.2 \%)\end{array}$ & $\begin{array}{r}6,580 \\
(5.8 \%)\end{array}$ \\
\hline
\end{tabular}

Note:

- Weekday is defined as the time between 12:01 a.m. Monday and 6:00 p.m. Friday.

- Weekend is defined as the time between 6:01 p.m. Friday and midnight Saturday.

- All tables reporting totals could include some unreported characteristics. 
FIGURE 6.10

NUMBER OF PERSON TRIPS (MILLIONS) BY WEEKDAY VS. WEEKEND, TRIP PURPOSE, AND

TIME OF DAY

1995 NPTS

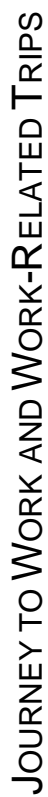

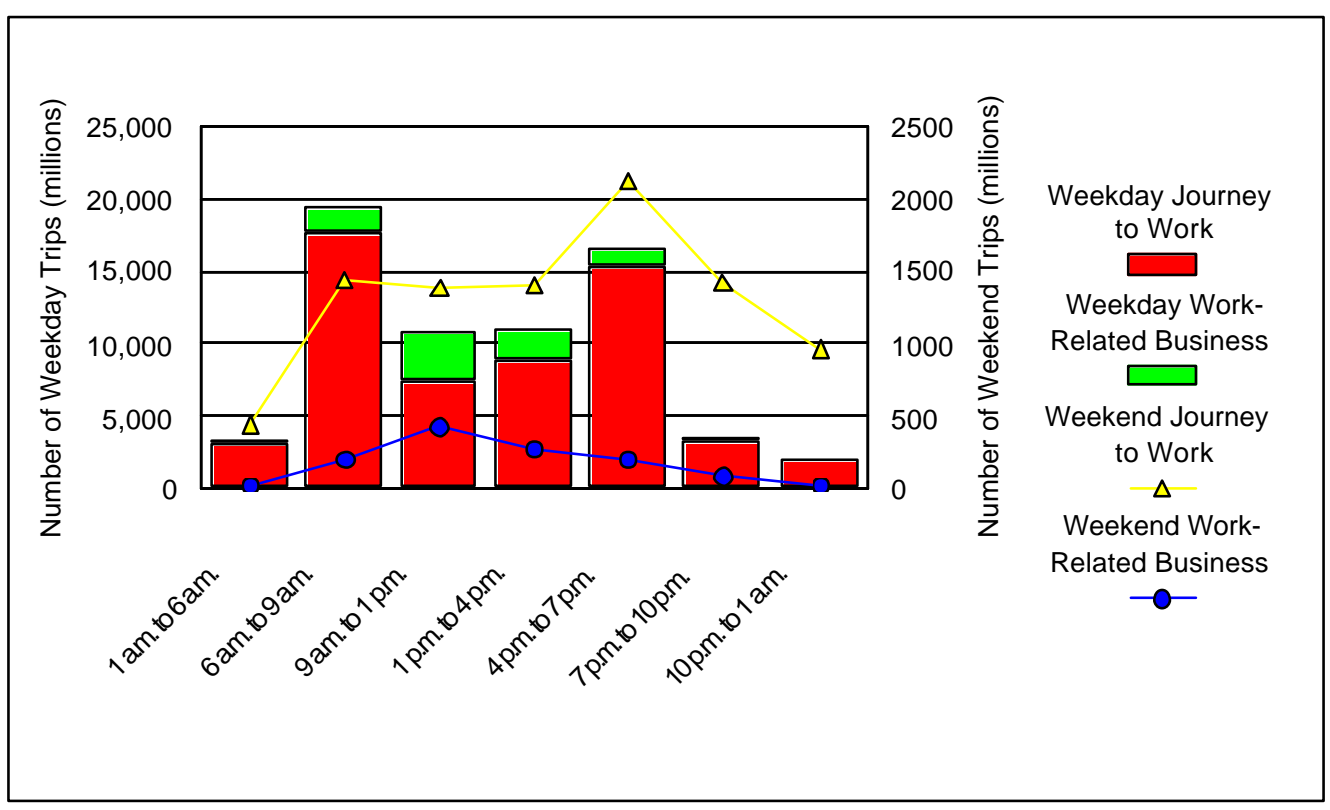



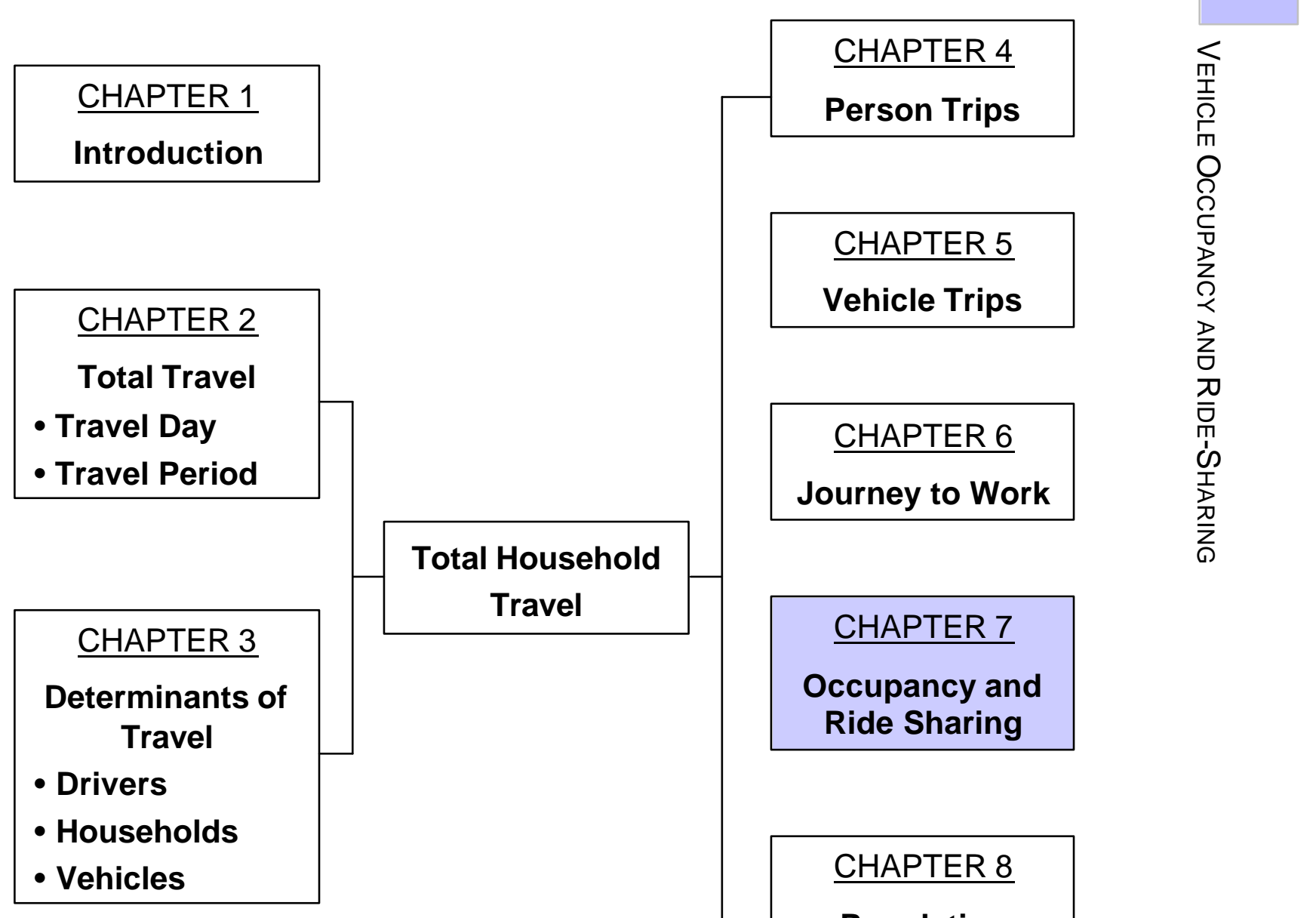


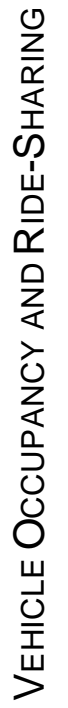

NATIONWIDE PERSONAL TRANSPORTATION SURVEY 


\section{Chapter 7}

\section{Vehicle Occupancy and Ride-ShaRing}

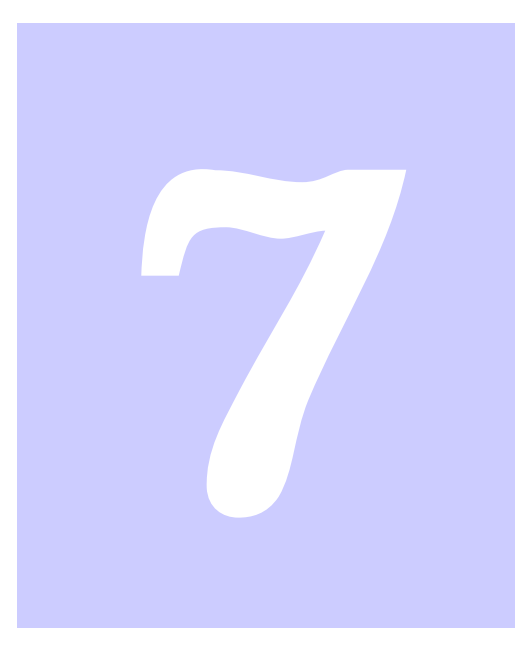

- Americans are taking more trips and driving further; however, they are also sharing rides less often. The number of trips spent driving alone increased by about $9 \%$ between 1977 and 1995 .

- The RV, van, and SUV were the vehicles with the highest occupancy rates.

- Commute trips had lower occupancy rates than any other trip purpose. 


\section{Vehicle Trips by Purpose and Ride-Sharing Status}

(MILLIONS)

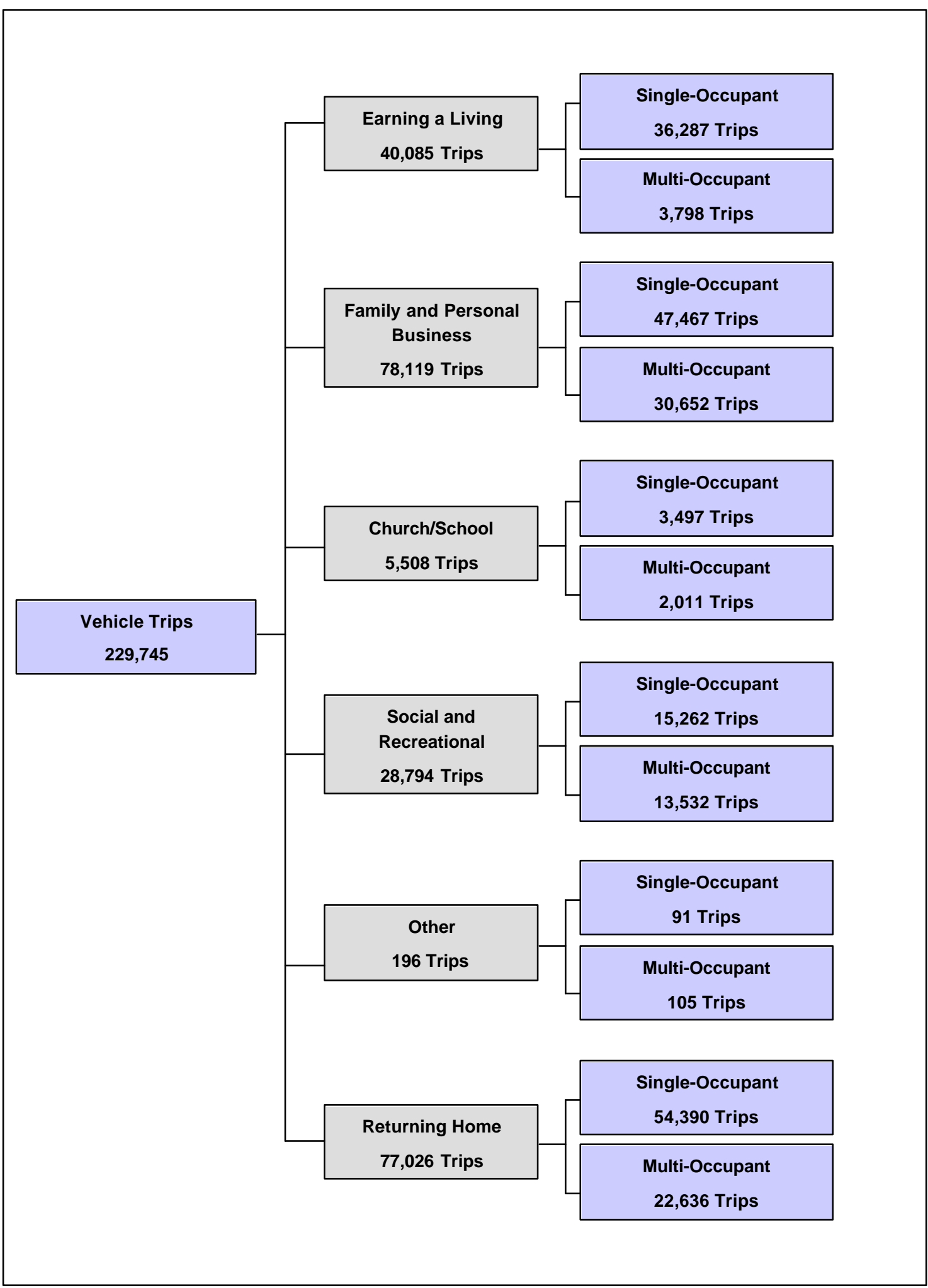




\section{Vehicle Trips by Vehicle Type and Ride-Sharing Status}

(MILLIONS)

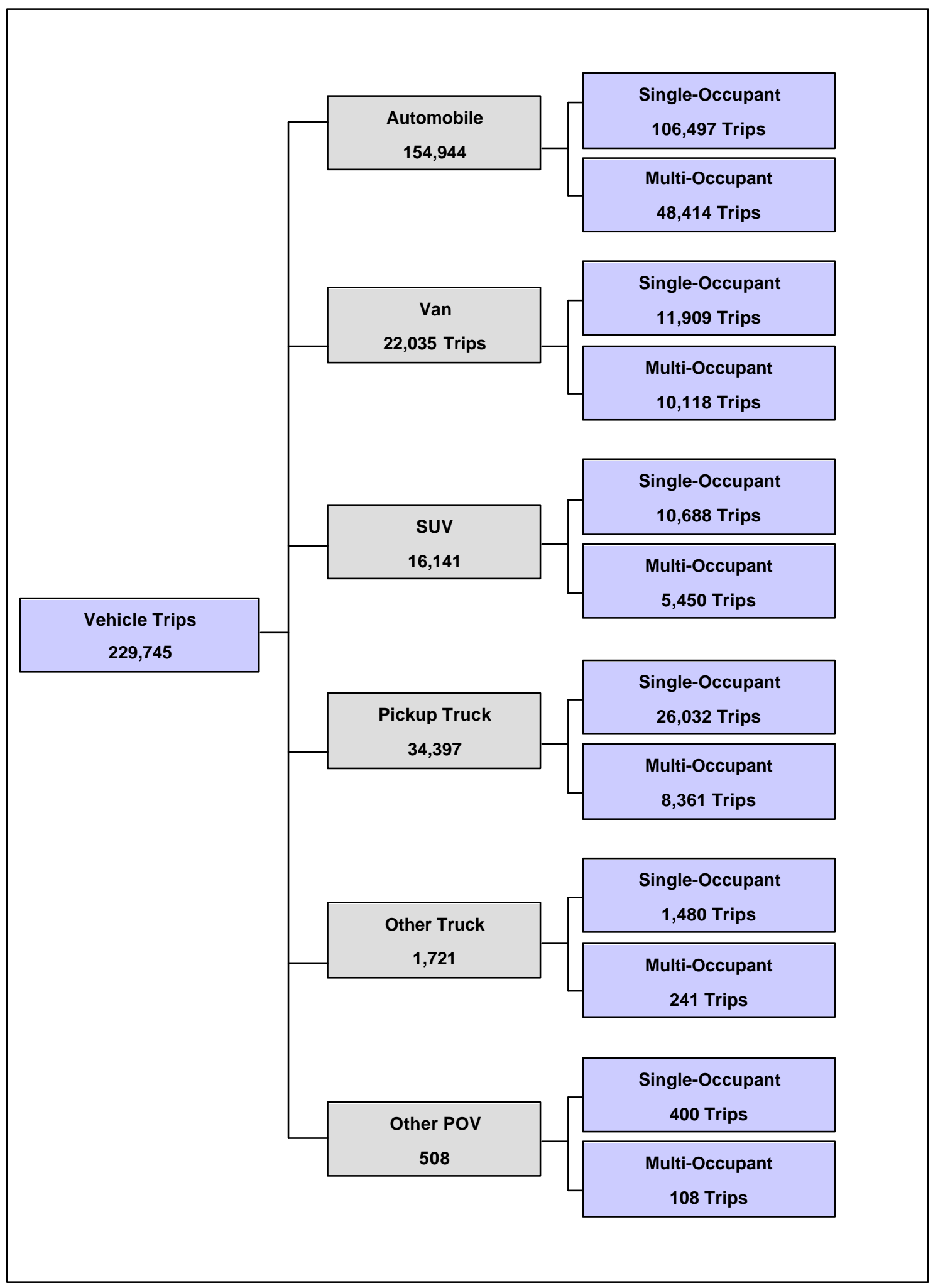




\section{Journey to Work Vehicle Trips by Vehicle Type and Ride-Sharing Status}

(MILLIONS)

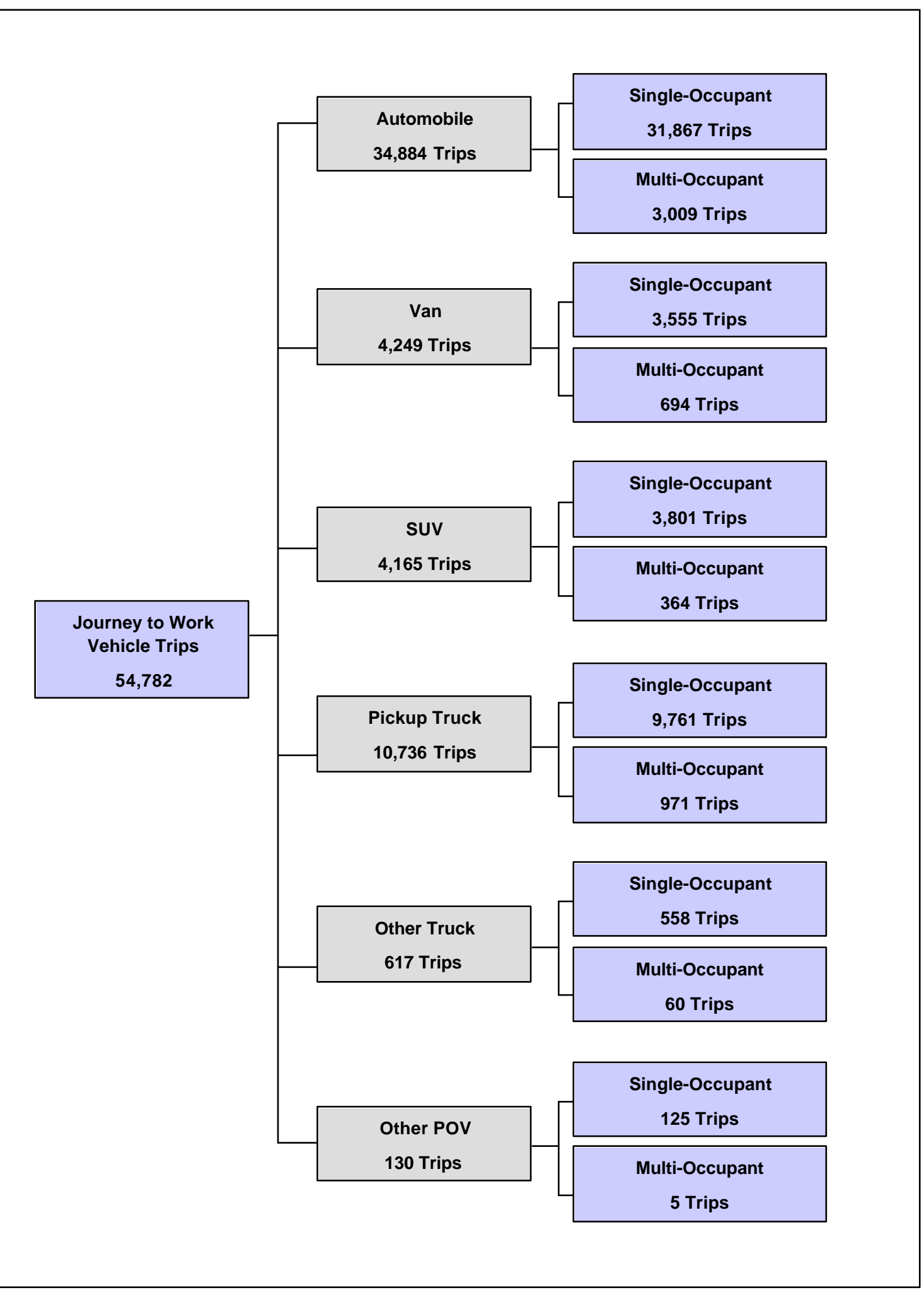




\section{LIST OF TABLES}

Table 7.1 Average Vehicle Occupancy by 1990 Trip Purposes 1977, 1983, 1990, 1990 ADJUSTED, AND 1995 NPTS (PERSON MILES PER VEHICLE

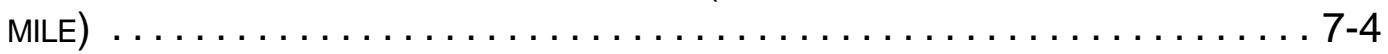

Table 7.2 AVERAge Vehicle OCCUPANCY by InSIDE/OUtSide MSA AND TRIP PURPOSE 1995 NPTS (PERSON MILES PER VEHICLE MILE) $\ldots \ldots \ldots \ldots \ldots \ldots 7-6$

Table 7.3 Number of Vehicle Trips by Trip Purpose and Number of Persons in Vehicle 1995 NPTS (millions) $\ldots \ldots \ldots \ldots \ldots \ldots \ldots \ldots \ldots .7$

Table 7.4 Number of Vehicle Trips by Number of OCCUPANTS AND Number OF Household Vehicles VS. Number OF HOUSEHOLd DRIVERS 1995

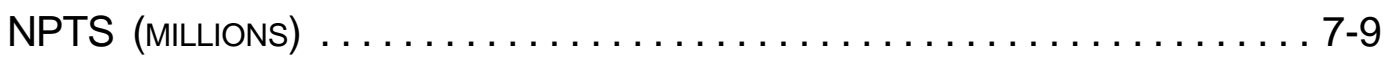

Table 7.5 Average Vehicle Occupancy by Household Composition and TriP PuRPOSE 1995 NPTS (PERSON MILES PER VEHICLE MILE) $\ldots \ldots \ldots \ldots \ldots .7-11$

Table 7.6 Average Vehicle Occupancy by Trip Purpose and Vehicle Type 1995 NPTS (PERSON MILES PER VEHICLE MILE) $\ldots \ldots \ldots \ldots \ldots \ldots \ldots .13$

Table 7.7 Average Commute Vehicle Occupancy by Household InCOME 1990 AND 1995 NPTS (PERSON MILES PER VEHICLE MILE) $\ldots \ldots \ldots \ldots \ldots .7-14$

Table 7.8 Average Commute Vehicle Occupancy by Trip Length 1977, 1983, 1990, AND 1995 NPTS (PERSON TRIPS PER VEHICLE TRIP) . . . . . . . 7-15

Table 7.9 Average Commute Vehicle Occupancy by Trip Length 1977, 1983, 1990, AND 1995 NPTS (PERSON MILES PER VEHICLE MILE) . . . . . . 7-17

\section{LIST OF FIGURES}

Figure 7.1 AVERAGe VeHICLE OCCUPANCy (PERSON MILES PER VEHICLE MILE) 1977, 1983, 1990, 1990 AdJusted, AND 1995 NPTS $\ldots \ldots \ldots \ldots \ldots .7-5$

Figure 7.2 Distribution of Trips by TRIP PuRPose AND Number OF Persons IN VEHICLE 1995 NPTS . . ........................... 7-8

Figure 7.3 Distribution of Vehicle OCCUPANCY by the Vehicles-to-DRiVERS

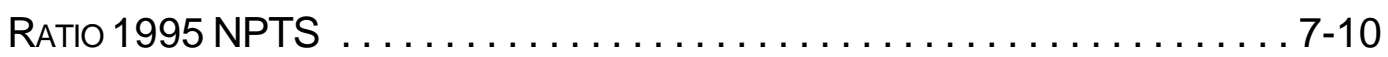

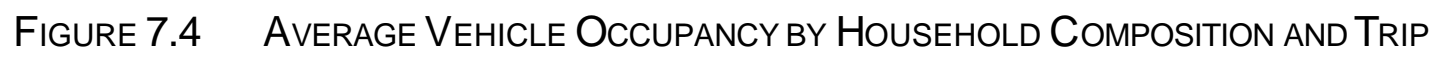
PURPOSE 1995 NPTS . ............................ 7-12

Figure 7.5 AVERAGE VEHICLE OCCUPANCY BY TRIP LENGTH FOR JOURNEY TO WORK TRIPS (PERSON TRIPS PER VEHICLE TRIP) 1977, 1983, 1990, AND 1995 NPTS 


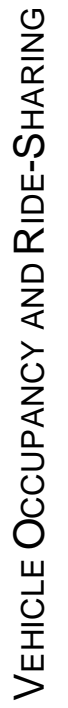




\section{Chapter 7 Vehicle Occupancy and Ride-Sharing}

$\mathrm{T}$ HIS chapter presents trends in vehicle occupancy and ride-sharing patterns. Vehicle occupancy is expressed in two different ways. One definition of vehicle occupancy is the average number of persons per vehicle trip. A second way of defining vehicle occupancy is the number of person miles of travel per vehicle mile of travel. The latter definition takes into account trip length and, therefore, may be a preferred measure for studying issues such as energy consumption. For each table throughout this chapter, the specific definition of vehicle occupancy being used is stated.

Since 1977, the number of vehicles/person in the United States has increased and ridesharing has decreased. The average vehicle occupancy rate (person miles/vehicle mile) in 1977 was 1.9; by 1995, this rate had decreased to 1.6. Not only has the occupancy rate decreased, the percentage of vehicle trips that are shared has also decreased over time. In 1977, 40.4\% of all vehicle trips involved multiple occupants; in 1995, this rate was only
$31.7 \%$. Even as the total number of vehicle trips increased by $111 \%$, the number of singleoccupancy vehicle trips increased by $142 \%$ while multiple-occupancy trips only increased by $65 \%$. Americans are driving more, and a much larger percentage of their driving is alone.

The likelihood of sharing rides is largely influenced by trip purpose, household characteristics, and vehicle type. A social/recreational trip by a single parent with a child under 6 years of age has the greatest likelihood of being shared.

\subsection{TrIP PURPOSE}

Throughout all NPTSs, trip purposes have been important indicators of occupancy rates. Trips for social/recreational purposes have had the highest occupancy rates (as measured in person miles/vehicle mile), and trips for earning a living have had the lowest.

\begin{tabular}{|c|c|c|c|}
\hline & $\begin{array}{c}\text { Single-Occupant } \\
\text { Vehicle Trips (000) }\end{array}$ & $\begin{array}{l}\text { Multiple-Occupant } \\
\text { Vehicle Trips (000) }\end{array}$ & TOTAL (000) \\
\hline \multirow[t]{2}{*}{1977} & $64,860,296$ & $43,965,704$ & $108,826,000$ \\
\hline & $(59.6 \%)$ & $(40.4 \%)$ & $(100 \%)$ \\
\hline \multirow[t]{2}{*}{1983} & $83,356,218$ & $43,517,782$ & $126,874,000$ \\
\hline & $(65.7 \%)$ & $(34.3 \%)$ & $(100 \%)$ \\
\hline \multirow[t]{2}{*}{1990} & $106,670,900$ & $52,256,713$ & $158,927,613$ \\
\hline & $(67.1 \%)$ & $(32.9 \%)$ & $(100 \%)$ \\
\hline \multirow[t]{2}{*}{1995} & $157,005,000$ & $72,740,000$ & $229,745,000$ \\
\hline & $(68.3 \%)$ & $(31.7 \%)$ & $(100 \%)$ \\
\hline
\end{tabular}


Of all trips taken for the purpose of earning a living, less than $10 \%$ were multiple-occupancy trips in 1995. In comparison, trips for family/personal business had multiple occupants in almost $40 \%$ of all trips, and trips for social/recreational purposes had multiple occupants in $47 \%$ of all trips.

\subsection{Household Characteristics}

Household composition has a very significant impact on ride sharing. In 1995, households especially those with a single adult - with a child under six years of age were the most likely to share rides, followed by households with a youngest child between the ages of 6 and 15. Households with no children were the least likely to share rides.

Another household characteristics that could impact vehicle occupancy rates is the relationship between number of household

\footnotetext{
${ }^{1}$ Ross, Catherine L., "Land Use

Transportation Interaction: An Examination of the 1995 NPTS Data," 1995 NPTS website publication, http://www-cta.ornl.gov/npts/1995/Doc/landuse3.pdf p. 5.

members and number of household vehicles. In 1995 , about $64 \%$ of all households had an equal number of vehicles and drivers, and $85 \%$ of all vehicle trips were taken by households with this composition. Over $69 \%$ of all trips of households with an equal number of household vehicles and drivers were single-occupancy. In addition, $15.6 \%$ of all households had more vehicles than drivers. In these households, $69.8 \%$ of all trips were taken alone. Even in households with no household vehicles or more drivers than vehicles, over $62 \%$ of all vehicle trips had a single occupant.

\subsection{Vehicle Characteristics}

The vehicle type with the highest occupancy rate (2.79 person miles per vehicle mile) was the recreational vehicle $(\mathrm{RV})$. The van, which averaged 2.07 person miles per vehicle mile, was next, and the sport utility vehicle (SUV) was third (1.70 person miles per vehicle mile). It is assumed that all of these vehicle types were purchased with multiple occupancy in mind.

\subsection{Commute TriPS}

Commute trips have very low occupancy rates. In 1995 as in past NPTSs, commute trips for all income levels had a low multiple-occupancy rate - only 1.14 person miles per vehicle mile. The lowest multiple-occupancy rates for commutes was for households with incomes less than $\$ 10,000$ or those with incomes between $\$ 70,000$ and $\$ 80,000$. Even for trips of 31 miles and over, commute occupancy rates were only slightly higher than for commutes of shorter distances. 
Between 1977 and 1995, the average vehicle occupancy rate, as measured in person miles per vehicle mile, decreased for every trip purpose (Table 7.1). Overall, the average occupancy decreased from 1.9 to 1.6 (almost $16 \%$ ). Note that pleasure driving was a trip purpose in 1990; however, in 1995, trips for this reason were included in the other social and recreational category.

A trip's purpose influences the vehicle occupancy rate. As in 1977, rides were most likely to be shared when the trip purpose was social/recreational, especially for vacation travel. However, vacation travel comprised a very small percentage of the total vehicle miles traveled. In every NPTS, travel involving work has had the lowest occupancy rate of any trip purpose.

Figure 7.1 shows changes in the average vehicle occupancy rate by trip purpose between 1977 and 1995. As seen in this figure, the occupancy rate was lower in 1995 than it was in 1977. 


\section{TABLE 7.1}

\section{Average Vehicle OCCuPANCy By 1990 Trip PuRPoses \\ 1977, 1983, 1990, 1990 ADJUSTED, AND 1995 NPTS \\ (PERSON MILES PER VEHICLE MILE)}

\begin{tabular}{|c|c|c|c|c|c|c|c|c|c|c|}
\hline \multirow[b]{2}{*}{ Trip Purpose } & \multicolumn{2}{|c|}{1977} & \multicolumn{2}{|c|}{1983} & \multicolumn{2}{|c|}{1990} & \multicolumn{2}{|c|}{1990 adj } & \multicolumn{2}{|c|}{1995} \\
\hline & $\begin{array}{l}\text { Avg. } \\
\text { Occ. }\end{array}$ & $\begin{array}{l}\% \text { of } \\
\text { VMT }\end{array}$ & $\begin{array}{l}\text { Avg. } \\
\text { Occ. }\end{array}$ & $\begin{array}{l}\% \text { of } \\
\text { VMT }\end{array}$ & $\begin{array}{l}\text { Avg. } \\
\text { Occ. }\end{array}$ & $\begin{array}{l}\% \text { of } \\
\text { VMT }\end{array}$ & $\begin{array}{l}\text { Avg. } \\
\text { Occ. }\end{array}$ & $\begin{array}{l}\% \text { of } \\
\text { VMT }\end{array}$ & $\begin{array}{l}\text { Avg. } \\
\text { Occ. }\end{array}$ & $\begin{array}{l}\% \text { of } \\
\text { VMT }\end{array}$ \\
\hline TOTAL & 1.9 & 100.0 & 1.8 & 100.0 & 1.6 & 100.0 & 1.7 & 100.0 & 1.6 & 100.0 \\
\hline \multicolumn{11}{|l|}{ Earning a Living } \\
\hline ALL & 1.3 & 39.3 & 1.3 & 34.3 & 1.2 & 35.1 & 1.2 & 29.2 & 1.2 & 37.7 \\
\hline To/From Work & 1.3 & 31.7 & 1.3 & 30.2 & 1.1 & 32.1 & 1.1 & 26.7 & 1.1 & 31.1 \\
\hline Work Related & 1.4 & 7.6 & 1.6 & 4.2 & 1.4 & 3.0 & 1.4 & 2.5 & 1.2 & 6.7 \\
\hline \multicolumn{11}{|c|}{ Family/Personal Business } \\
\hline ALL & 2.0 & 24.9 & 1.8 & 30.4 & 1.8 & 32.8 & 1.8 & 36.9 & 1.8 & 35.5 \\
\hline Shopping & 2.1 & 11.1 & 1.8 & 13.3 & 1.7 & 11.5 & 1.7 & 12.0 & 1.7 & 13.4 \\
\hline Medical/Dental & 2.1 & 1.8 & 1.7 & 1.5 & 1.5 & 1.3 & 1.5 & 1.5 & 1.5 & 1.5 \\
\hline Other & 2.0 & 12.0 & 1.8 & 15.5 & 1.8 & 20.0 & 1.8 & 23.4 & 1.8 & 20.6 \\
\hline \multicolumn{11}{|c|}{ Civic, Educational, and Religious } \\
\hline & 2.0 & 5.2 & 2.1 & 4.1 & 1.7 & 4.4 & 1.7 & 3.7 & 1.7 & 3.8 \\
\hline \multicolumn{11}{|c|}{ Social/Recreational } \\
\hline ALL & 2.4 & 27.3 & 2.1 & 30.0 & 2.1 & 26.9 & 2.1 & 29.5 & 2.0 & 22.8 \\
\hline Visiting Friends & 2.3 & 12.1 & 2.0 & 13.5 & 1.8 & 11.6 & 1.8 & 12.8 & 1.8 & 9.4 \\
\hline Pleasure Driving & 3.2 & 0.9 & 2.3 & 1.1 & 2.0 & 0.7 & 2.0 & 0.7 & $* *$ & $* *$ \\
\hline Vacation & 2.7 & 0.6 & 2.5 & 2.1 & 2.4 & 1.5 & 2.4 & 1.6 & 2.3 & 1.0 \\
\hline Other & 2.6 & 13.7 & 2.2 & 13.3 & 2.3 & 13.1 & 2.3 & 14.4 & 2.2 & 12.4 \\
\hline \multicolumn{11}{|c|}{ Other and Unknown } \\
\hline & 2.2 & 3.3 & 1.9 & 1.2 & 1.5 & 0.8 & 1.5 & 0.7 & 1.9 & 0.2 \\
\hline
\end{tabular}

Note:

- All tables reporting totals could include some unreported characteristics.

- Note that only the 1990 data have been adjusted to make them more comparable with the 1995 data. Thus, there are limits on the conclusions that can be drawn in comparing travel with earlier survey years. The adjustments to 1990 data affect only person trips, vehicle trips, person miles of travel (PMT), and vehicle miles of travel (VMT).

- The purpose codes used for 1995 NPTS reflect the 1990 purpose code scheme.

- ** Indicates no data available. Note that pleasure driving was a trip purpose in 1990, but in 1995 trips for this reason were simply included in other social and recreational travel. 
FIGURE 7.1

AVERAge Vehicle OCCUPANCy (PERSON MILES PER VEHICLE MILE) 1977, 1983, 1990, 1990 ADJUSTED, AND 1995 NPTS

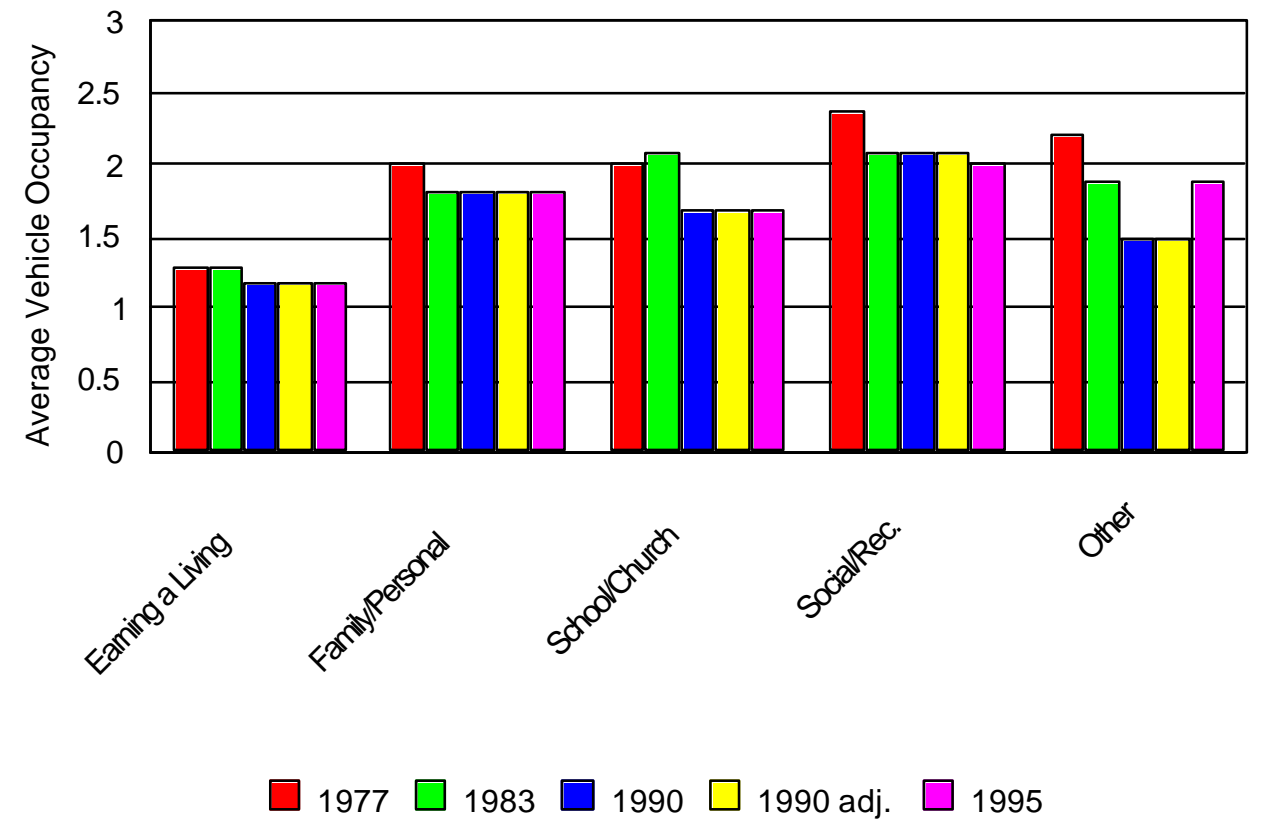


While trip purpose influences ride-sharing, there is very little difference between the vehicle occupancy rates of trips taken by persons living in an MSA and those not in an MSA, regardless of trip purpose (Table 7.2).

TABLE 7.2

Average Vehicle Occupancy by Inside/Outside MSA and Trip Purpose 1995 NPTS

(PERSON MILES PER VEHICLE MILE)

\begin{tabular}{|c|c|c|c|c|c|c|}
\hline & \multicolumn{2}{|c|}{ ALL } & \multicolumn{2}{|c|}{ In MSA } & \multicolumn{2}{|c|}{ Not in MSA } \\
\hline & $\begin{array}{c}\text { Average } \\
\text { Occupancy }\end{array}$ & $\begin{array}{l}\% \text { of } \\
\text { VMT }\end{array}$ & $\begin{array}{c}\text { Average } \\
\text { Occupancy }\end{array}$ & $\begin{array}{l}\% \text { of } \\
\text { VMT }\end{array}$ & $\begin{array}{c}\text { Average } \\
\text { Occupancy }\end{array}$ & $\begin{array}{l}\% \text { of } \\
\text { VMT }\end{array}$ \\
\hline TOTAL & 1.59 & 100.00 & 1.58 & 100.00 & 1.63 & 100.00 \\
\hline Earning a Living & 1.16 & 23.83 & 1.15 & 23.99 & 1.18 & 23.29 \\
\hline Family/Personal Business & 1.77 & 24.34 & 1.77 & 24.45 & 1.79 & 24.00 \\
\hline School/Church & 1.66 & 2.14 & 1.60 & 2.09 & 1.83 & 2.29 \\
\hline Social/Recreational & 2.07 & 15.16 & 2.08 & 15.19 & 2.07 & 15.07 \\
\hline Other & 1.82 & 0.17 & 1.81 & 0.18 & 1.90 & 0.12 \\
\hline Returning Home & 1.55 & 34.35 & 1.52 & 34.09 & 1.62 & 35.22 \\
\hline
\end{tabular}

Note:

- All tables reporting totals could include some unreported characteristics. 
As shown in Table 7.3, excluding the trip purpose for going home, most vehicle trips were for family/personal business in 1995. Of all family/personal business trips, $39.2 \%$ were in multiple-occupancy vehicles. This percentage is slightly higher than the $31.7 \%$ overall percentage of trips in vehicles with more than one person. Trips for social/recreational and other purposes had the highest-multipleoccupancy rates at $47 \%$ and $53.6 \%$, respectively. Only one in every ten commute trips were in a multiple-occupancy vehicle. Figure 7.2 displays the proportions of vehicle trips by trip purpose and number of occupants.

\section{TABLE 7.3}

Number of Vehicle Trips by Trip Purpose and Number of Persons in Vehicle 1995 NPTS

(MILLIONS)

\begin{tabular}{|c|c|c|c|c|c|c|c|}
\hline $\begin{array}{l}\text { Number of } \\
\text { Persons in } \\
\text { Vehicle }\end{array}$ & ALL & $\begin{array}{c}\text { Earning a } \\
\text { Living } \\
\end{array}$ & $\begin{array}{l}\text { Family/ } \\
\text { Personal } \\
\text { Business }\end{array}$ & $\begin{array}{l}\text { School/ } \\
\text { Church }\end{array}$ & $\begin{array}{c}\text { Social/ } \\
\text { Recreational }\end{array}$ & Other & $\begin{array}{c}\text { Returning } \\
\text { Home }\end{array}$ \\
\hline ALL & $\begin{array}{c}229,745 \\
(100.0 \%)\end{array}$ & $\begin{array}{c}40,085 \\
(100.0 \%)\end{array}$ & $\begin{array}{c}78,119 \\
(100.0 \%)\end{array}$ & $\begin{array}{c}5,508 \\
(100.0 \%)\end{array}$ & $\begin{array}{c}28,794 \\
(100.0 \%)\end{array}$ & $\begin{array}{c}196 \\
(100.0 \%)\end{array}$ & $\begin{array}{c}77,026 \\
(100.0 \%)\end{array}$ \\
\hline 1 & $\begin{array}{l}157,005 \\
(68.3 \%)\end{array}$ & $\begin{array}{c}36,287 \\
(90.5 \%)\end{array}$ & $\begin{array}{c}47,467 \\
(60.8 \%)\end{array}$ & $\begin{array}{c}3,497 \\
(63.5 \%)\end{array}$ & $\begin{array}{c}15,262 \\
(53.0 \%)\end{array}$ & $\begin{array}{c}91 \\
(46.4 \%)\end{array}$ & $\begin{array}{c}54,390 \\
(70.6 \%)\end{array}$ \\
\hline 2 & $\begin{array}{c}46,503 \\
(20.2 \%)\end{array}$ & $\begin{array}{c}2,874 \\
(7.2 \%)\end{array}$ & $\begin{array}{c}19,798 \\
(25.3 \%)\end{array}$ & $\begin{array}{c}1,161 \\
(21.1 \%)\end{array}$ & $\begin{array}{c}8,095 \\
(28.1 \%)\end{array}$ & $\begin{array}{c}58 \\
(29.6 \%)\end{array}$ & $\begin{array}{c}14,512 \\
(18.8 \%)\end{array}$ \\
\hline 3 & $\begin{array}{l}15,792 \\
(6.9 \%)\end{array}$ & $\begin{array}{c}617 \\
(1.5 \%)\end{array}$ & $\begin{array}{c}6,935 \\
(8.9 \%)\end{array}$ & $\begin{array}{c}410 \\
(7.4 \%)\end{array}$ & $\begin{array}{c}2,846 \\
(9.9 \%)\end{array}$ & $\begin{array}{c}25 \\
(12.8 \%)\end{array}$ & $\begin{array}{l}4,960 \\
(6.4 \%)\end{array}$ \\
\hline 4 & $\begin{array}{c}6,948 \\
(3.0 \%)\end{array}$ & $\begin{array}{c}204 \\
(0.5 \%)\end{array}$ & $\begin{array}{l}2,640 \\
(3.4 \%)\end{array}$ & $\begin{array}{c}271 \\
(4.9 \%)\end{array}$ & $\begin{array}{c}1,695 \\
(5.9 \%)\end{array}$ & $\begin{array}{c}14 \\
(7.1 \%)\end{array}$ & $\begin{array}{c}2,125 \\
(2.8 \%)\end{array}$ \\
\hline 5 to 10 & $\begin{array}{c}3,436 \\
(1.5 \%)\end{array}$ & $\begin{array}{c}94 \\
(0.2 \%)\end{array}$ & $\begin{array}{l}1,260 \\
(1.6 \%)\end{array}$ & $\begin{array}{c}165 \\
(3.0 \%)\end{array}$ & $\begin{array}{c}885 \\
(3.1 \%)\end{array}$ & $\begin{array}{c}8 \\
(4.1 \%)\end{array}$ & $\begin{array}{c}1,022 \\
(1.3 \%)\end{array}$ \\
\hline $11+$ & $\begin{array}{c}13 \\
(0.0 \%)\end{array}$ & $\begin{array}{c}2 \\
(0.0 \%)\end{array}$ & $\begin{array}{c}6 \\
(0.0 \%)\end{array}$ & $\begin{array}{c}4 \\
(0.1 \%)\end{array}$ & $* *$ & $* *$ & $\begin{array}{c}0 \\
(0.0 \%)\end{array}$ \\
\hline
\end{tabular}

Note:

- All tables reporting totals could include some unreported characteristics.

- ** Indicates no data available. 
FIGURE 7.2

Distribution of Trips by Trip Purpose and Number of Persons in Vehicle 1995 NPTS

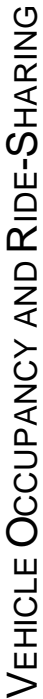

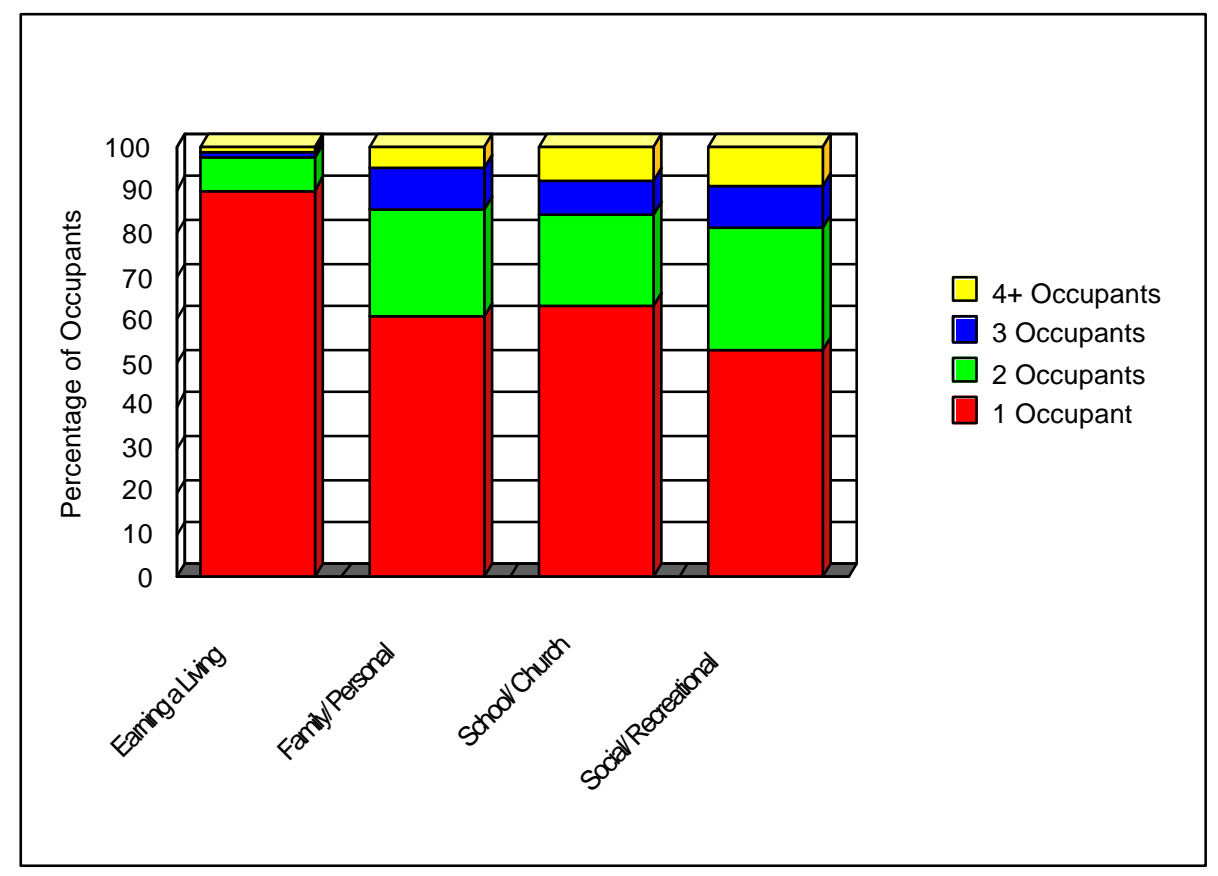

4+ Occupants

$\square 3$ Occupants

$\square 2$ Occupants

$\square 1$ Occupant 
Household characteristics affect vehicle occupancy rate. Tables 7.4-7.5 provide statistics on occupancy by vehicles-to-drivers ratio and household composition, respectively.

In 1995, 64\% of all households with at least one vehicle had the same number of drivers as vehicles in the household (see Table 3.10). Most trips (67.2\%) were made by households with an equal vehicle-to-driver ratio (Table 7.4). In addition, most vehicle trips (68.3\%) were made with only one person in the vehicle.
Even those households with no household vehicle took $62.8 \%$ of their trips with only one person in the vehicle. Figure 7.3 shows the distribution of vehicle trips based on vehicle occupancy for the four categories of household vehicles-to-drivers ratios. As shown in this figure, the distribution is very similar for each vehicles-to-drivers category, although a slightly greater percentage of trips are singleoccupancy $(69.8 \%)$ for households with more vehicles than drivers.

\section{TABLE 7.4}

Number of Vehicle Trips by Number of Occupants AND Number of Household Vehicles VS. NUMBER OF HOUSEHOLD DRIVERS

1995 NPTS

(MILLIONS)

\begin{tabular}{||cccccccc||}
\hline \multirow{2}{*}{$\begin{array}{l}\text { Household Vehicles } \\
\text { vs. Household } \\
\text { Drivers }\end{array}$} & & \multicolumn{7}{c||}{ Number of Persons on Trip } \\
\cline { 3 - 9 } & TOTAL & 1 & 2 & 3 & 4 & $5-10$ & $11+$ \\
\hline TOTAL & 229,745 & 157,005 & 46,503 & 15,792 & 6,948 & 3,436 & 13 \\
& $(100.0 \%)$ & $(68.3 \%)$ & $(20.2 \%)$ & $(6.9 \%)$ & $(3.0 \%)$ & $(1.5 \%)$ & $(0.0 \%)$ \\
No Household & 1,686 & 1,058 & 361 & 156 & 87 & 24 & $* *$ \\
$\quad$ Vehicles & $(100.0 \%)$ & $(62.8 \%)$ & $(21.4 \%)$ & $(9.2 \%)$ & $(5.2 \%)$ & $(1.4 \%)$ & \\
More Drivers than & 33,413 & 20,716 & 8,444 & 2,455 & 1,226 & 563 & 2 \\
Vehicles & $(100.0 \%)$ & $(62.0 \%)$ & $(25.3 \%)$ & $(7.4 \%)$ & $(3.7 \%)$ & $(1.7 \%)$ & $(0.0 \%)$ \\
Vehicles Equal to & 154,400 & 107,138 & 29,975 & 10,503 & 4,461 & 2,276 & 6 \\
Drivers & $(100.0 \%)$ & $(69.4 \%)$ & $(19.4 \%)$ & $(6.8 \%)$ & $(2.9 \%)$ & $(1.5 \%)$ & $(0.0 \%)$ \\
More Vehicles than & 40,247 & 28,093 & 7,724 & 2,679 & 1,174 & 573 & 5 \\
$\quad$ Drivers & $(100.0 \%)$ & $(69.8 \%)$ & $(19.2 \%)$ & $(6.7 \%)$ & $(2.9 \%)$ & $(1.4 \%)$ & $(0.0 \%)$ \\
\hline \hline
\end{tabular}

Note:

- All tables reporting totals could include some unreported characteristics.

- $\quad * *$ Indicates no data available. 


\section{FIGURE 7.3}

\section{Distribution of Vehicle OcCUPANCY By the Vehicles-To-Drivers Ratio 1995 NPTS}

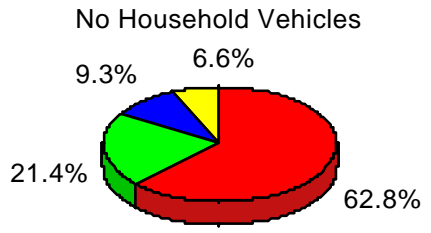

More Drivers than Vehicles

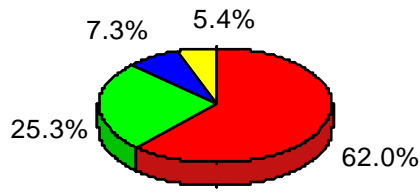

$\square 2$ persons

$\square$ persons

$\square$ 4+ persons

Vehicles Equal to Drivers

More Vehicles than Drivers $6.8 \% \quad 4.4 \%$ $6.7 \% \quad 4.4 \%$

$19.4 \%$

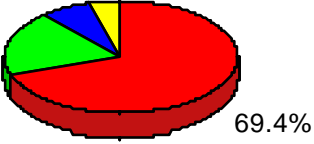

$19.2 \%$

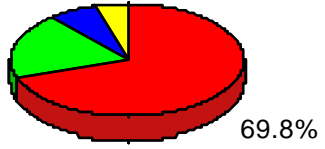


As shown in Table 7.5, households with a

youngest child less than six years old were the

most likely to share rides, followed by

households with a youngest child between 6

and 15. Vehicle occupancy rates for

households with a single adult and a youngest

child under 6 were $37 \%$ higher than the

average vehicle occupancy rates. The

combination of a household with a single adult

and a youngest child under 6 and a trip purpose

of social/recreational had the highest occupancy rate -3.44 person miles per vehicle mile. Households with no children were the least likely to share rides. These ride-sharing comparisons are shown in Figure 7.4. As shown in this figure, household composition had little impact on vehicle occupancy when the purpose of the trip was to earn a living; however, household composition had substantial impact on the other categories, especially when the youngest child was under 16.

\section{TABLE 7.5}

\section{Average Vehicle OCCupancy By Household Composition AND Trip Purpose 1995 NPTS}

(PERSON MILES PER VEHICLE MILE)

\begin{tabular}{|c|c|c|c|c|c|c|c|}
\hline $\begin{array}{l}\text { Household } \\
\text { Composition }\end{array}$ & ALL & $\begin{array}{l}\text { Earning a } \\
\text { Living }\end{array}$ & $\begin{array}{l}\text { Family/ } \\
\text { Personal } \\
\text { Business }\end{array}$ & $\begin{array}{l}\text { School/ } \\
\text { Church }\end{array}$ & $\begin{array}{l}\text { Social/ } \\
\text { Rec. }\end{array}$ & Other & $\begin{array}{c}\text { Returning } \\
\text { Home }\end{array}$ \\
\hline ALL & 1.59 & 1.16 & 1.77 & 1.66 & 2.07 & 1.82 & 1.55 \\
\hline $\begin{array}{l}\text { Single Adult, } \\
\text { No Children }\end{array}$ & 1.23 & 1.16 & 1.30 & 1.08 & 1.34 & 1.22 & 1.17 \\
\hline $\begin{array}{l}\text { Two or More Adults, } \\
\text { No Children }\end{array}$ & 1.37 & 1.13 & 1.53 & 1.46 & 1.74 & 2.43 & 1.29 \\
\hline $\begin{array}{l}\text { Single Adult, } \\
\text { Youngest Child Under } 6\end{array}$ & 2.18 & 1.10 & 1.92 & 1.16 & 3.44 & $* *$ & 2.52 \\
\hline $\begin{array}{l}\text { Two or More Adults, } \\
\text { Youngest Child Under } 6\end{array}$ & 1.89 & 1.19 & 2.18 & 2.29 & 2.75 & 2.40 & 1.90 \\
\hline $\begin{array}{l}\text { Single Adult, } \\
\text { Youngest Child 6-15 }\end{array}$ & 1.73 & 1.22 & 2.01 & 1.73 & 2.11 & 2.00 & 1.63 \\
\hline $\begin{array}{l}\text { Two or More Adults, } \\
\text { Youngest Child 6-15 }\end{array}$ & 1.79 & 1.15 & 2.09 & 1.90 & 2.50 & 1.84 & 1.72 \\
\hline $\begin{array}{l}\text { Single Adult, } \\
\quad \text { Youngest Child } 16+\end{array}$ & 1.58 & 1.03 & 1.65 & 1.53 & 2.21 & 2.17 & 1.35 \\
\hline $\begin{array}{l}\text { Two or More Adults, } \\
\text { Youngest Child } 16+\end{array}$ & 1.53 & 1.19 & 1.59 & 1.57 & 1.94 & 1.32 & 1.55 \\
\hline $\begin{array}{l}\text { Single Adult, } \\
\text { Retired }\end{array}$ & 1.44 & 1.05 & 1.35 & 1.48 & 1.88 & 1.00 & 1.28 \\
\hline $\begin{array}{l}\text { Two or More Adults, } \\
\text { Retired }\end{array}$ & 1.58 & 1.16 & 1.58 & 1.62 & 1.86 & 1.96 & 1.53 \\
\hline
\end{tabular}

Note:

- All tables reporting totals could include some unreported characteristics.

- $\quad * *$ Indicates no data available. 
FIGURE 7.4

\section{Average Vehicle Occupancy by Household Composition and Trip Purpose 1995 NPTS}

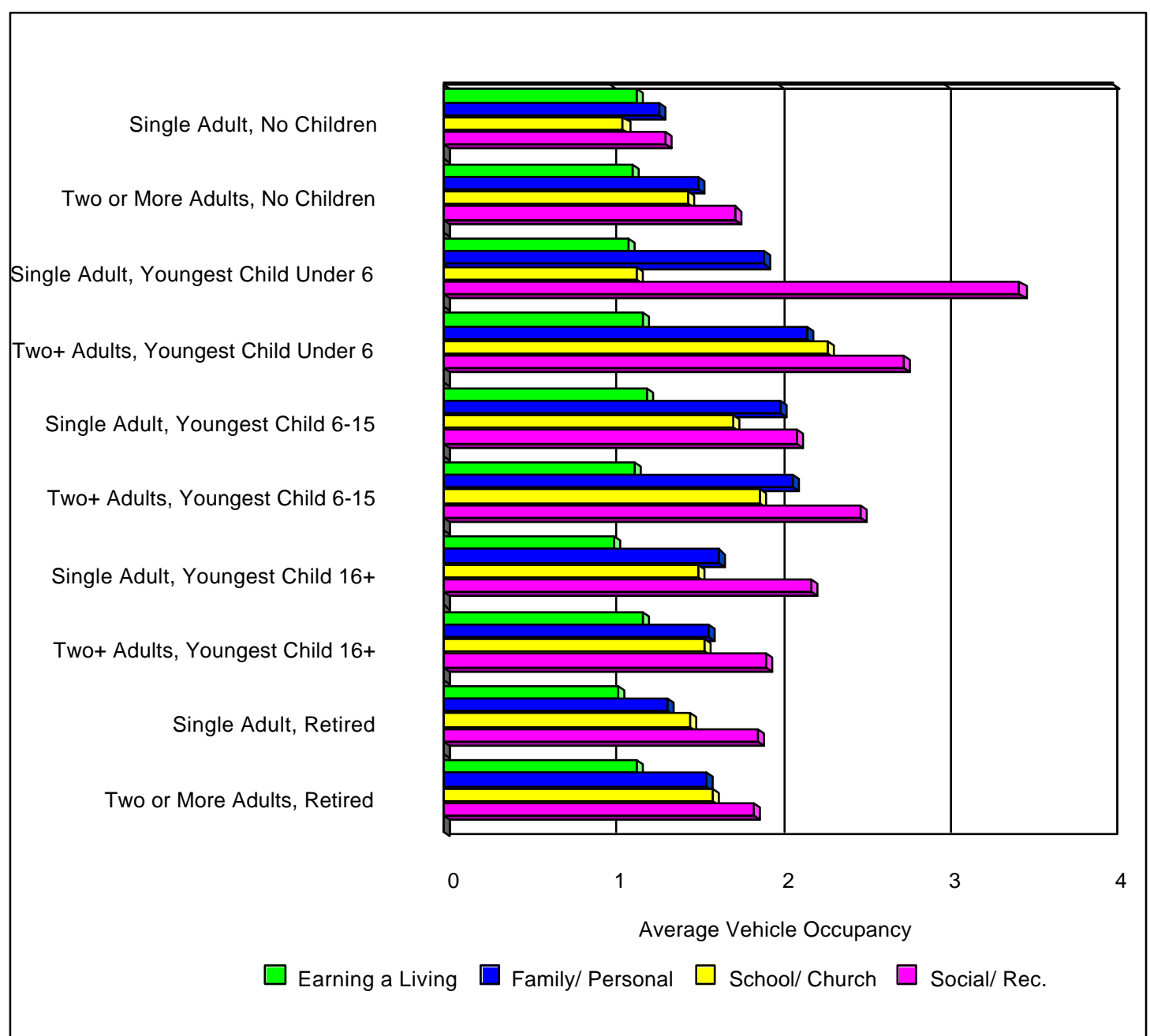


Table 7.6 shows that the highest average vehicle occupancy rate for any vehicle type (2.79 person miles per vehicle mile) was for RVs. Vans and sport utility vehicles also had higher-than-average vehicle occupancy rates. Social/recreational uses had higher occupancy rates than any other trip purpose for all vehicle types except the other truck category, for which the highest occupancy rate was for a school/church trip purpose. The very highest occupancy rate (3.2 person miles per vehicle mile) was for an RV with a social/recreational trip purpose. Although the van averaged more than two occupants for every trip purpose except earning a living, the automobile averaged less than two occupants for every trip purpose except social/recreational.

TABLE 7.6

Average Vehicle Occupancy by Trip Purpose and Vehicle Type

1995 NPTS

(PERSON MILES PER VEHICLE MILE)

\begin{tabular}{|c|c|c|c|c|c|c|c|}
\hline & ALL & $\begin{array}{l}\text { Earning a } \\
\text { Living }\end{array}$ & $\begin{array}{l}\text { Family/ } \\
\text { Personal } \\
\text { Business }\end{array}$ & $\begin{array}{l}\text { School/ } \\
\text { Church }\end{array}$ & $\begin{array}{c}\text { Social/ } \\
\text { Rec. }\end{array}$ & Other & $\begin{array}{c}\text { Returning } \\
\text { Home }\end{array}$ \\
\hline ALL & 1.59 & 1.16 & 1.77 & 1.66 & 2.07 & 1.82 & 1.55 \\
\hline Auto & 1.59 & 1.15 & 1.74 & 1.57 & 2.03 & 1.71 & 1.53 \\
\hline Van & 2.07 & 1.31 & 2.26 & 2.64 & 2.81 & 2.39 & 2.06 \\
\hline Sport Utility Vehicle & 1.70 & 1.14 & 1.87 & 1.73 & 2.25 & 2.47 & 1.63 \\
\hline Pickup & 1.38 & 1.14 & 1.51 & 1.60 & 1.74 & 1.53 & 1.35 \\
\hline Other Truck & 1.12 & 1.10 & 1.34 & 2.75 & 1.07 & 1.00 & 1.13 \\
\hline RV & 2.79 & 1.00 & 2.15 & 1.00 & 3.20 & 3.00 & 1.58 \\
\hline Motorcycle & 1.18 & 1.10 & 1.11 & 1.00 & 1.35 & 2.00 & 1.14 \\
\hline Other POV & 1.58 & 1.53 & 1.67 & 1.00 & 2.08 & $* *$ & 1.18 \\
\hline
\end{tabular}

Note:

- All tables reporting totals could include some unreported characteristics.

- ** Indicates no data available. 
As shown in Table 7.7, the overall average commute vehicle occupancy did not change between 1990 and 1995. For some income groups, however, there were dramatic changes. There were significant decreases in the average commute vehicle occupancy rate for households with incomes less than $\$ 10,000$ and between $\$ 70,000$ and $\$ 80,000$. Workers who made less than $\$ 10,000$ in household income in 1995 were the group least likely to share rides, only slightly behind commuters in the $\$ 70,000$ 80,000 income group. Households making $\$ 10,000-20,000$ were the income group most likely to share rides.

\section{TABLE 7.7}

Average Commute Vehicle Occupancy by Household Income 1990 AND 1995 NPTS

(PERSON MILES PER VEHICLE MILE)

\begin{tabular}{||lll||}
\hline $\begin{array}{l}\text { Household } \\
\text { Income }\end{array}$ & 1990 & 1995 \\
\hline ALL & 1.14 & 1.14 \\
$<\$ 10,000$ & 1.21 & 1.07 \\
$\$ 10$ to $\$ 20,000$ & 1.21 & 1.22 \\
$\$ 20$ to $\$ 30,000$ & 1.14 & 1.16 \\
$\$ 30$ to $\$ 40,000$ & 1.14 & 1.15 \\
$\$ 40$ to $\$ 50,000$ & 1.14 & 1.12 \\
$\$ 50$ to $\$ 60,000$ & 1.17 & 1.20 \\
$\$ 60$ to $\$ 70,000$ & 1.10 & 1.13 \\
$\$ 70$ to $\$ 80,000$ & 1.21 & 1.08 \\
$\$ 80,000+$ & 1.08 & 1.13 \\
Unreported & 1.11 & 1.12 \\
\hline \hline
\end{tabular}


As noted in Table 7.1, the lowest incidence of shared rides in NPTSs from 1977-1995 has been for the trip purpose of earning a living. In this category, rides are shared less frequently when going to and from work than for workrelated purposes.

Vehicle occupancy rates for commute trips did not change much between 1990 and 1995. The vehicle occupancy rates of commute trips in 1990 and 1995 decreased from the occupancy rates for 1977 and 1983 (see Figure 7.5), especially noticeable for trips of 31 miles and over. Longer trips generally have higher occupancy rates for all trip purposes; however, vehicle occupancy rates for commutes decreased by $30 \%$ between 1983 and 1990. In 1977 and 1983, commutes of 31 miles and greater averaged 1.5 and 1.7 person trips/vehicle trip; however, in the 1990 and 1995 NPTSs, the average vehicle occupancy rate was only 1.13 overall, and even trips of 31 miles or over averaged less than 1.2 person trips per vehicle trip (Table 7.8).

\section{TABLE 7.8}

Average Commute Vehicle Occupancy by Trip Length

1977, 1983, 1990, AND 1995 NPTS

(PERSON TRIPS PER VEHICLE TRIP)

\begin{tabular}{||llllllll||}
\hline \hline & \multicolumn{7}{c||}{ Trip Length (miles) } \\
\cline { 2 - 8 } & ALL & $\begin{array}{c}5 \text { or } \\
\text { Less }\end{array}$ & $6-10$ & $11-15$ & $16-20$ & $21-30$ & $\begin{array}{c}31 \& \\
\text { Over }\end{array}$ \\
\hline 1977 & 1.3 & 1.3 & 1.3 & 1.3 & 1.3 & 1.3 & 1.5 \\
1983 & 1.2 & 1.2 & 1.1 & 1.2 & 1.2 & 1.3 & 1.7 \\
1990 & 1.13 & 1.13 & 1.11 & 1.09 & 1.12 & 1.15 & 1.19 \\
1995 & 1.13 & 1.14 & 1.11 & 1.10 & 1.11 & 1.12 & 1.18 \\
\hline \hline
\end{tabular}

Note:

- All tables reporting totals could include some unreported characteristics. 
FIGURE 7.5

Average Vehicle OCCUPANCY By TRIP LENGTH

FOR JOURNEY TO WORK TRIPS (PERSON TRIPS PER VEHICLE TRIP)

1977, 1983, 1990, AND 1995 NPTS

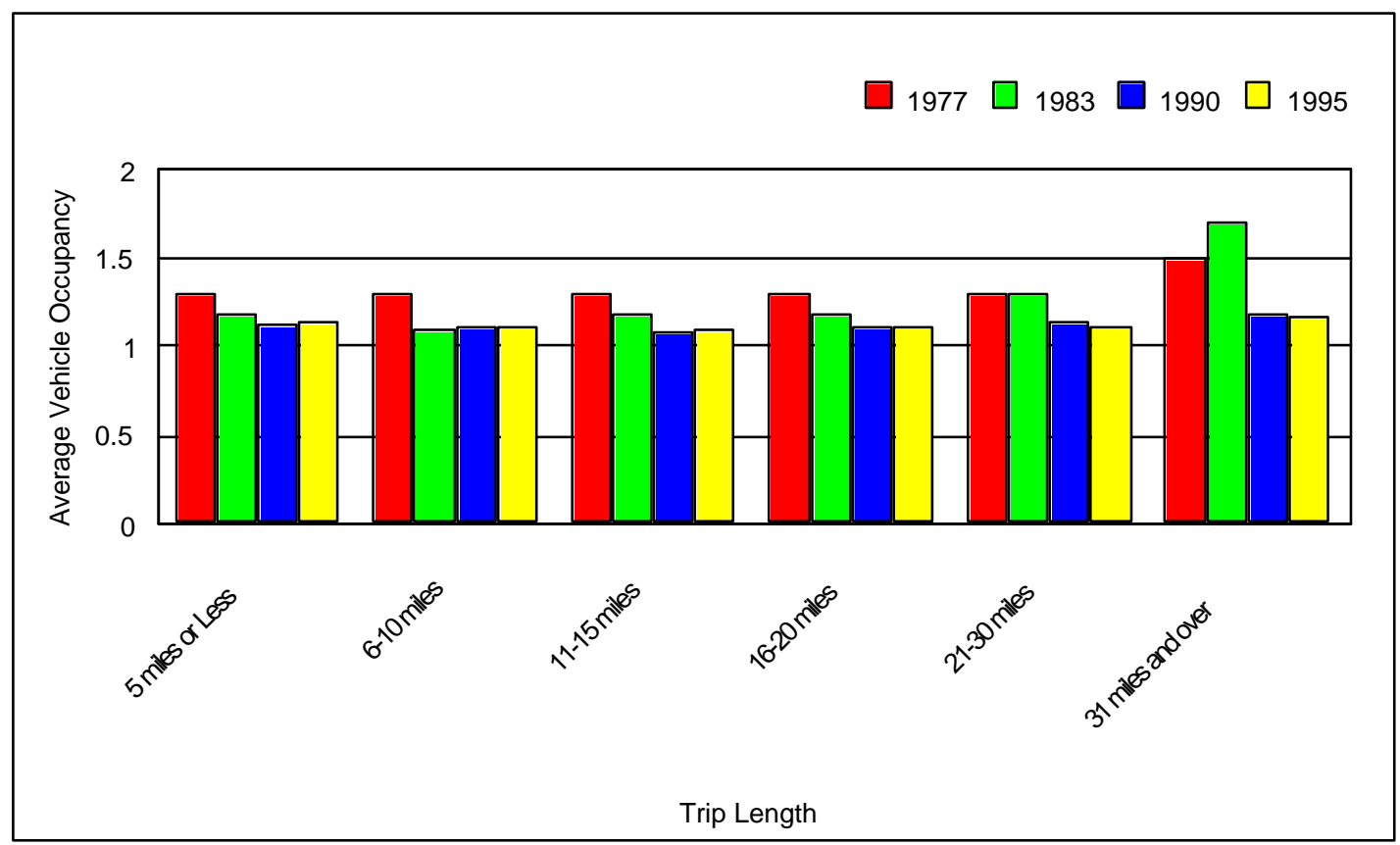


On the average, commute vehicle occupancy, as measured by person miles per vehicle mile (Table 7.9), were almost identical to the commute vehicle occupancy, measured by person trips per vehicle trip (Table 7.8).

TABLE 7.9

Average Commute Vehicle OcCupancy by Trip Length

1977, 1983, 1990, AND 1995 NPTS

(PERSON MILES PER VEHICLE MILE)

\begin{tabular}{||cccccccc||}
\hline \hline & \multicolumn{7}{c||}{ Trip Length (Miles) } \\
\cline { 2 - 8 } & ALL & $\begin{array}{c}5 \text { or } \\
\text { Less }\end{array}$ & $6-10$ & $11-15$ & $16-20$ & $21-30$ & $\begin{array}{c}31 \& \\
\text { Over }\end{array}$ \\
\hline 1977 & 1.3 & 1.2 & 1.3 & 1.3 & 1.3 & 1.3 & 1.6 \\
1983 & 1.3 & 1.2 & 1.1 & 1.1 & 1.2 & 1.3 & 1.8 \\
1990 & 1.14 & 1.12 & 1.11 & 1.09 & 1.12 & 1.14 & 1.21 \\
1995 & 1.14 & 1.13 & 1.11 & 1.10 & 1.11 & 1.12 & 1.21 \\
\hline \hline
\end{tabular}

Note:

- All tables reporting totals could include some unreported characteristics. 


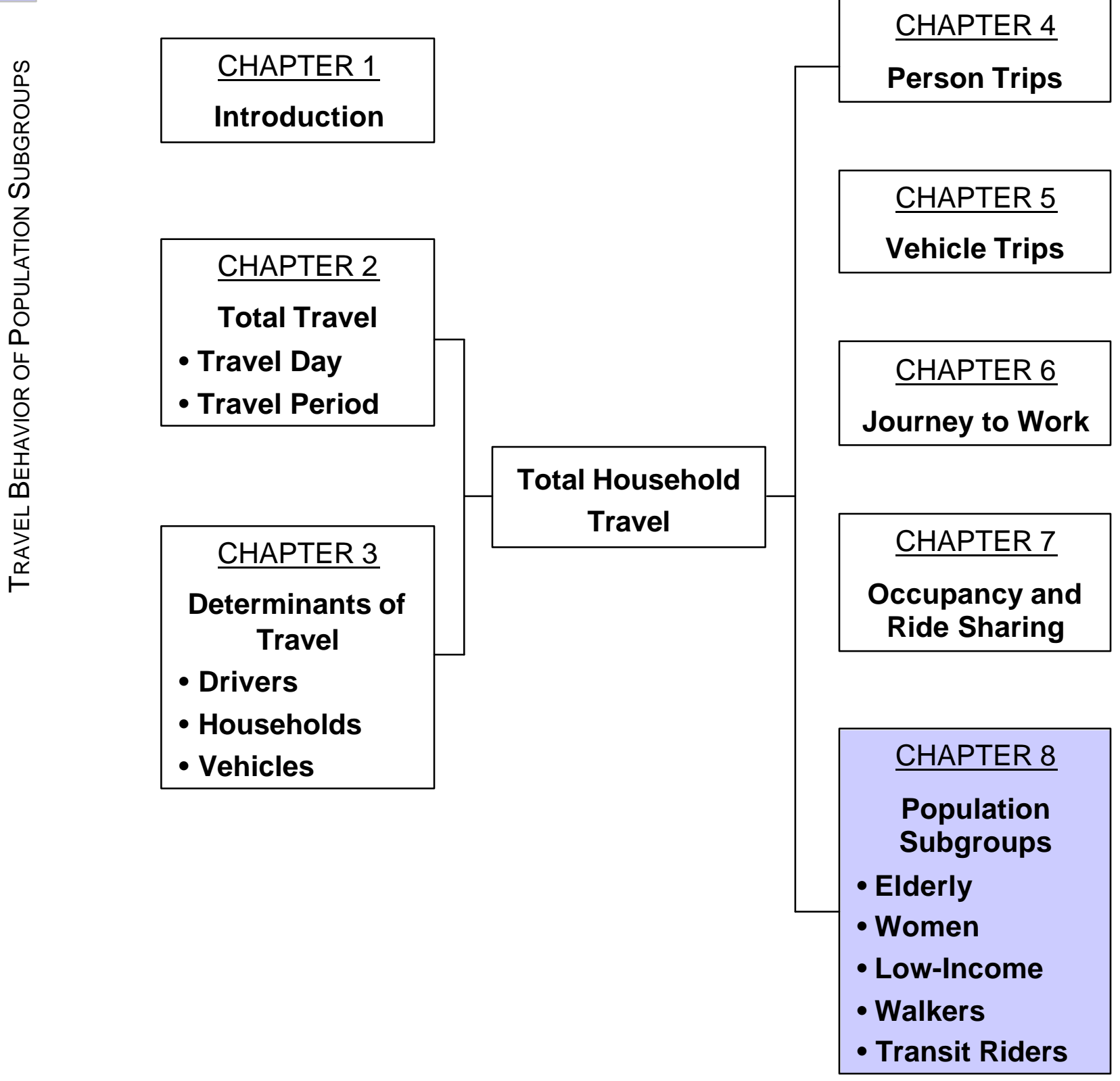




\section{Chapter 8}

\section{Travel Behavior of Population Subgroups}

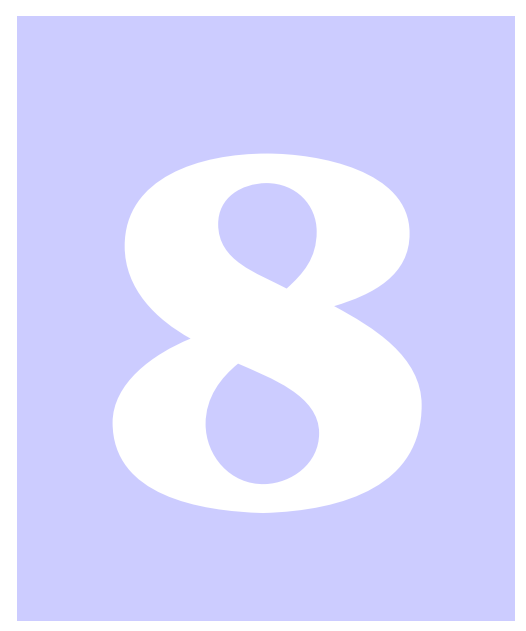

- The elderly made up $12 \%$ of the total population, took about $10 \%$ of all person trips, and traveled about 8\% of all person miles in 1995.

- Women took more person trips for family and personal business than for any other trip purpose; almost a third of these trips began between 9 a.m. and 1 p.m.

- Low-income persons traveled $4.2 \%$ of their person miles on public transit, as compared with $2.1 \%$ of all person miles traveled by the total population.

- Walkers took the greatest number of person trips and traveled the most person miles in areas with a population density of 10,000 or more.

- Almost a fourth of all public transit trips were taken for earning a living. 


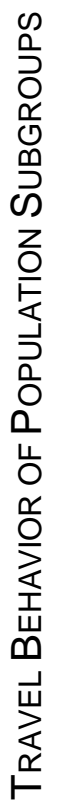




\section{LIST OF TABLES}

Table 8.1 Person Travel Statistics of Persons Under 65 vs. Persons 65 OR Older BY TRIP PuRPOSE 1995 NPTS .................... 8-4

Table 8.2 Person Miles Traveled of Persons 65 or Older vs. Persons Under 65 by MOdE OF TRANSPORTATION 1995 NPTS .............. 8-6

Table 8.3 Vehicle Miles Traveled for Persons 65 or Older by Time of Day and WeEKDAY Vs. WEeKEND 1995 NPTS ................... 8-8

TAble 8.4 Number OF PeRsons 65 OR OLdER (IN THOUSANDS) BY Number OF TRIPS Taken on Travel DaY 1995 NPTS ...................... 8-9

Table 8.5 Person Trips by Persons 65 or Older by Population Density 1995 NPTS

Table 8.6 Person Travel Statistics for Women by Start Time and TriP PuRPOSE 1995 NPTS $\ldots \ldots \ldots \ldots \ldots \ldots \ldots \ldots \ldots \ldots \ldots \ldots . \ldots \ldots .11$

TABle 8.7 Dally Person TRIPS PeR PeRSON FOR Women by EMPLOYMENT Status, Trip PurPose, and Start Time of Trip 1995 NPTS . . . . . . . . 8-13

TABle 8.8 Dally PMT PeR Person for Women by Employment Status, TriP Purpose, and StART Time of TRIP 1995 NPTS . . . . . . . . . . . . . . 8-14

Table 8.9 Person Travel Statistics for Low-Income Persons by Mode of TRANSPORTATION 1995 NPTS $\ldots \ldots \ldots \ldots \ldots \ldots \ldots \ldots \ldots \ldots \ldots . \ldots \ldots .17$

Table 8.10 Average Annual Person Trips Per Person for Low-Income Persons by Population Density and TRIP PuRPose 1995 NPTS . . . . . . 8 8-18

Table 8.11 Vehicle Travel Statistics for LoW-InCome Persons by HOUSEHOLD COMPOSITION 1995 NPTS . ................... 8-19

Table 8.12 Average Annual Person Trips Per Person of Walkers by MSA Size ANd TRIP PuRPose 1995 NPTS $\ldots \ldots \ldots \ldots \ldots \ldots \ldots \ldots . . \ldots .21$

Table 8.13 Person Trips and PMT of Walkers by Population Density 1995 NPTS ................................. 8-22

Table 8.14 Average Dally Person Trips Per Person of Walkers by Age AND Gender 1995 NPTS $\ldots \ldots \ldots \ldots \ldots \ldots \ldots \ldots \ldots \ldots \ldots . \ldots \ldots .23$

Table 8.15 Person Travel Statistics for Public Transit Trips by Age and GENDER 1995 NPTS . . . . . . . . . . . . . . . . . . . . . . 8 8-24

Table 8.16 PMT Per Person for Public Transit Trips by Household InCOME AND TRIP PuRPOSE 1995 NPTS $\ldots \ldots \ldots \ldots \ldots \ldots \ldots \ldots \ldots \ldots .6 .25$

Table 8.17 Public Transit Person Trips (IN thousands) by Population DENSITY AND MODE 1995 NPTS 


\section{LIST OF FIGURES}

Figure 8.1 A Comparison of Personal Travel Statistics of Persons Under 65 Years Old to Persons 65 or Older 1995 NPTS .............. 8-5

Figure 8.2 Comparison of Person Miles Traveled for Persons Under 65 AND Persons 65 or Older by Mode of Transportation 1995 NPTS . . . . . . . 8-7

Figure 8.3 Person Trips by Trip Purpose for Women by Start Time

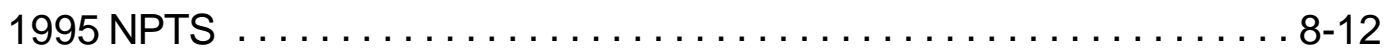

Figure 8.4 Average Trip Length by Trip Purpose for Women by Start Time 1995 NPTS . .................................. 8-12

Figure 8.5 Average DaILY PeRson Trips Per PeRson For Women by EMPLOYMENT STATUS AND TRIP PURPOSE 1995 NPTS

Figure 8.6 Dally Person Miles Traveled per Person for Women by EMPLOYMENT Status AND TRIP PuRPose 1995 NPTS .............. 8-15

Figure 8.7 Distribution of Average AnNual Person Trips PER Person for LOW-INCOME PERSONS BY TRIP PURPOSE1995 NPTS

Figure 8.8 Average Dally Person Trips Per Person of Walkers by Age AND GENDER 1995 NPTS ............................. 8-23

Figure 8.9 Public Transit Person Trips by Population Density and Mode 1995 NPTS 


\section{Chapter 8 Travel Behavior of Populations Subgroups}

$\mathrm{T}$ HIS chapter presents information on travel habits of subgroups within the United States. As noted in earlier chapters of this Databook, transportation behavior is influenced by many factors - for example, household composition, travel requirements related to a job, residence location, household income, age and gender, vehicle and/or transit availability, day of week and time of day, and trip purpose.

In this chapter, we examine the travel habits of five specific groups: the elderly (i.e., persons aged 65 and over), women, lowincome persons, pedestrians (that is, those persons whose mode of transportation is walking), and persons whose mode of transportation is transit.

\subsection{The ELDERLY}

The number of senior citizens - that is, persons who are 65 or over - is growing. This age group, which made up $12 \%$ of the total population in 1995, is projected to comprise $18.5 \%$ by 2025 . Their travel behavior, therefore, is of special importance to transportation professionals.

The average trip length for the elderly traveler was very similar to that of the under-65 age group for some trip purposes (school/church and social/recreational); however, their average trip length (for all trip purposes) was almost 2 miles (25\%) shorter. In addition, persons under age 65 took over 8.5 times as many total trips as those over age 65 .

The elderly used private vehicles for about $90 \%$ of their transportation needs. When other transportation was available, the elderly used it more often than those under age 65 . With respect to other modes of transportation, over half of all travel on Amtrak was taken by passengers 65 or over.

The elderly preferred to travel in the morning hours between 9 a.m. and 1 p.m. Less than $11 \%$ of their total VMT was traveled at night (between 7 p.m. and 6 a.m.).

\subsection{WOMEN}

Women initiated most of their trips and drove most of their person miles during the daytime (9 a.m. to 7 p.m.). Employed women took more trips than unemployed women for earning a living and family/personal business purposes; unemployed women took more trips for school/church and social/recreational trip purposes. Employed women traveled 54.3\% more person miles daily than unemployed women.

\subsection{LOW-INCOME PERSONS}

Murakami and Young ${ }^{1}$ defined a lowincome household as a household of 1-2 persons whose total annual income is under $\$ 10,000 ; 3-4$ persons with a household income less than $\$ 20,000$; or $5+$ persons with an income under $\$ 25,000$.

In the 1995 NPTS sample of 42,033

\footnotetext{
${ }^{1}$ Murakami, Elaine, and Jennifer Young, "Daily Travel by Persons with Low Income," 1995 NPTS website publication, http://wwwcta.ornl.gov/npts/1995/Doc/LowInc.pdf.
} 
households, there were 4,721 households classified as low-income by this definition.

Low-income households were more likely to live in urban centers or second cities and least likely to live in suburban areas. These households, which were less likely to have a car than non-low-income households, still made most trips using private vehicles. Lowincome households made a higher percentage of their trips walking or using public transit than the non-low-income households. $^{2}$

In the tables in this Databook, low-income is defined as any household with an income less than $\$ 25,000$ regardless of household size.

\subsection{WALKERS}

The average person took almost 2.4 walking trips daily in 1995, about one-half of which were taken for family/personal business or social/recreational purposes. Most walking trips were taken in densely populated areas.

\subsection{Transit RidERS}

Public transit includes buses, commuter trains, streetcars/trolleys, elevated rail, and subways. Amtrak, airlines, and other modes are not included. Although males traveled more person miles on transit, females took more person trips. Household income did not impact the use of transit; however, location did. Because transit was more common in cities than rural areas, most transit usage occurred in more densely populated areas.

${ }^{2}$ Murakami and Young, http://wwwcta.ornl.gov/npts/1995/Doc/LowInc.pdf, pp. 1-3. 
As the baby boom generation approaches retirement and the ranks of the elderly swell, it is critical to understand how travel behavior of the elderly differs from travel behavior of the under- 65 population.

In 1995, persons 65 and over made up 12\% of the total U.S. population (see Table 3.1). As shown in Table 8.1, based on total person travel, individuals 65 and over took about $11.5 \%$ as many person trips as persons under 65 , on the average. This percentage varied greatly, however, based on the trip purpose.

Figure 8.1 compares the travel habits of persons 65 or over with the under- 65 group according to trip purpose. As shown in the figure, the average trip lengths were about the same for both age groups for school/church and social/recreational trip purposes. Earning a living and family/personal business trips were longer for persons under age 65 . 
TABLE 8.1

\section{Person Travel Statistics of Persons Under 65 vs. Persons 65 or Older by TriP PURPOSE 1995 NPTS}

\begin{tabular}{|c|c|c|c|c|c|c|}
\hline \multirow[b]{2}{*}{ Trip Purpose } & \multicolumn{3}{|c|}{ Persons Under 65} & \multicolumn{3}{|c|}{ Persons 65 or Older } \\
\hline & $\begin{array}{l}\text { Number of } \\
\text { Person Trips } \\
\text { (thousands) }\end{array}$ & $\begin{array}{l}\text { Person Miles } \\
\text { Traveled } \\
\text { (millions) }\end{array}$ & $\begin{array}{l}\text { Avg Trip } \\
\text { Length } \\
\text { (miles) }\end{array}$ & $\begin{array}{l}\text { Number of } \\
\text { Person Trips } \\
\text { (thousands) }\end{array}$ & $\begin{array}{c}\text { Person Miles } \\
\text { Traveled } \\
\text { (millions) }\end{array}$ & $\begin{array}{c}\text { Avg Trip } \\
\text { Length } \\
\text { (miles) }\end{array}$ \\
\hline TOTAL & $339,830,401$ & $3,123,246$ & 9.33 & $39,099,962$ & 287,876 & 7.46 \\
\hline \multicolumn{7}{|l|}{ Earning a Living } \\
\hline To Work & $31,790,212$ & 362,555 & 11.58 & 976,651 & 7,623 & 7.93 \\
\hline Work-Related Business & $10,074,193$ & 202,811 & 20.43 & 548,561 & 7,182 & 13.46 \\
\hline Return to Work & $6,584,588$ & 39,020 & 5.96 & 192,814 & 666 & 3.45 \\
\hline Subtotal & $48,448,993$ & 604,386 & 12.65 & $1,718,026$ & 15,471 & 9.17 \\
\hline \multicolumn{7}{|l|}{ Family/Personal Business } \\
\hline Shopping & $44,646,126$ & 274,384 & 6.21 & $7,740,685$ & 34,885 & 4.56 \\
\hline Medical/Dental & $2,640,019$ & 25,518 & 9.95 & 846,416 & 8,193 & 9.84 \\
\hline Other Family/Personal Business & $31,560,446$ & 262,651 & 8.43 & $5,749,352$ & 32,419 & 5.70 \\
\hline Take Someone Somewhere & $12,842,212$ & 98,477 & 7.78 & 967,630 & 10,035 & 10.42 \\
\hline Pick Up Someone & $10,887,885$ & 76,737 & 7.15 & 662,184 & 4,468 & 6.76 \\
\hline Subtotal & $102,576,688$ & 737,768 & 7.28 & $15,966,267$ & 90,001 & 5.70 \\
\hline \multicolumn{7}{|l|}{ School/Church } \\
\hline School & $12,110,229$ & 66,084 & 5.57 & 51,655 & 577 & 15.94 \\
\hline Religious Activity & $4,967,790$ & 31,995 & 6.56 & $1,151,822$ & 5,923 & 5.22 \\
\hline Subtotal & $17,078,019$ & 98,079 & 5.86 & $1,203,477$ & 6,500 & 5.55 \\
\hline \multicolumn{7}{|l|}{ Social/Recreational } \\
\hline Vacation & 643,451 & 48,134 & 77.46 & 73,274 & 4,014 & 55.37 \\
\hline Visit Friends/Relatives & $18,053,333$ & 231,936 & 13.12 & $1,950,488$ & 24,648 & 12.89 \\
\hline Out to Eat & $15,900,083$ & 106,922 & 6.80 & $2,466,647$ & 16,044 & 6.62 \\
\hline Other Social/Recreational & $22,676,719$ & 246,481 & 11.04 & $2,143,972$ & 25,158 & 11.89 \\
\hline Subtotal & $57,273,586$ & 633,473 & 11.24 & $6,634,381$ & 69,864 & 10.71 \\
\hline \multicolumn{7}{|l|}{ Other and Returning Home } \\
\hline Other & 553,764 & 9,673 & 18.93 & 54,440 & 2,962 & 55.96 \\
\hline Returning Home & $113,856,057$ & $1,038,384$ & 9.26 & $13,517,486$ & 102,967 & 7.72 \\
\hline Subtotal & $114,409,821$ & $1,048,058$ & 9.30 & $13,571,926$ & 105,928 & 7.91 \\
\hline
\end{tabular}

Note:

- All tables reporting totals could include some unreported characteristics. 


\section{FIGURE 8.1}

\section{A Comparison of Personal Travel Statistics of Persons Under 65 Years Old}

TO PERSONS 65 OR OLDER

1995 NPTS

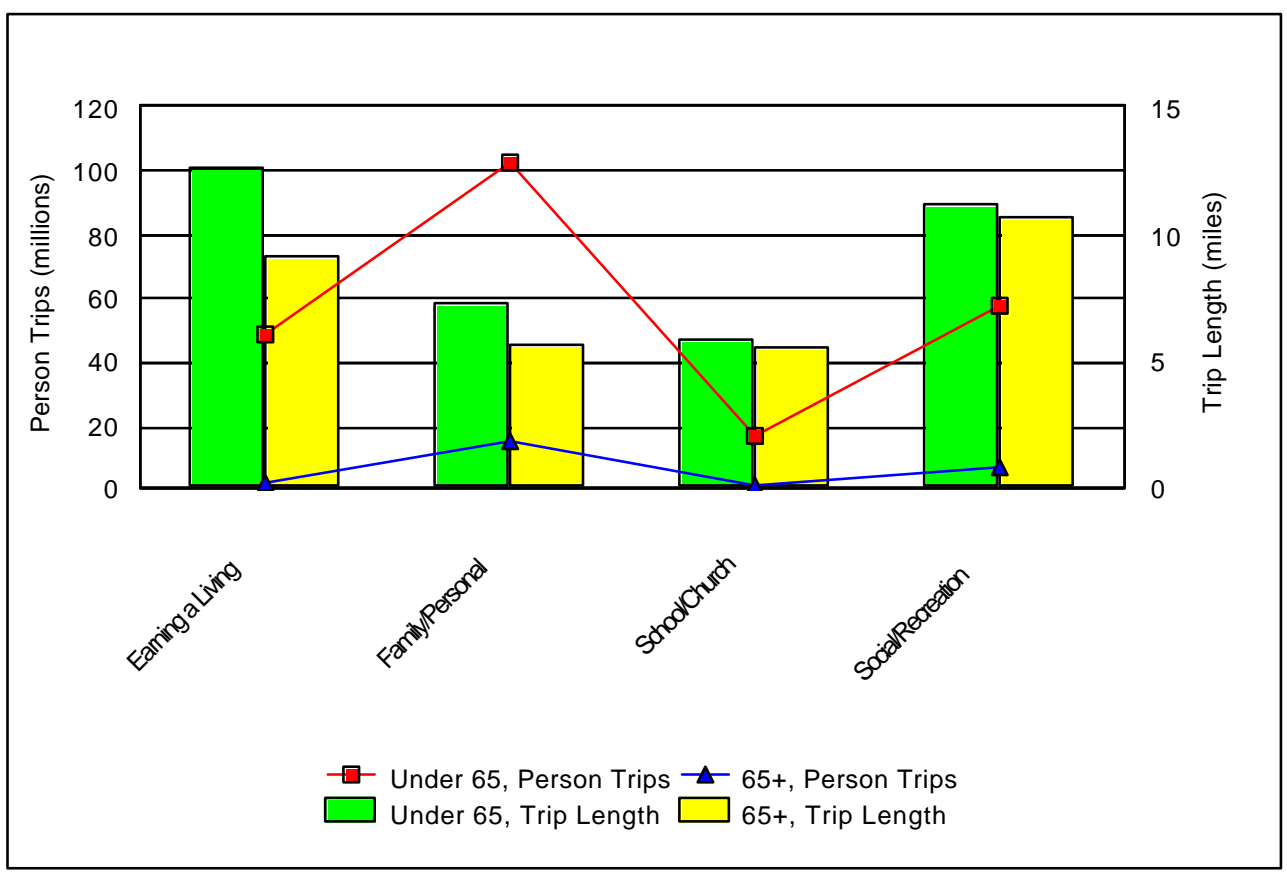

In 1995, persons under 65 and persons 65 years old or older exhibited similar patterns for selection of a mode of transportation; both age groups chose private vehicles about $90 \%$ of the time (Table 8.2 ). The privately owned vehicle of choice for the elderly was the automobile/van (74\% of all travel), while the automobile/van was used for $67 \%$ of all travel for persons under 65. Sport utility vehicles and pickups were the mode chosen for $21.4 \%$ of all travel for persons under 65 but were used only $14.5 \%$ of the time for persons 65 or older. The elderly used public transportation ( $4.2 \%$ of all person miles traveled by the elderly) more often than persons under 65 , who used public transportation for only $1.9 \%$ of all person miles.

As shown in Figure 8.2, more than half of all travel on Amtrak was taken by the elderly. This figure also shows that about one-fourth of the users of streetcars and buses were elderly. 


\section{TABLE 8.2}

Person Miles Traveled of Persons 65 Or Older vs. Persons Under 65 BY MODE OF TRANSPORTATION

1995 NPTS

\begin{tabular}{|c|c|c|c|}
\hline Transportation Mode & TOTAL & $\begin{array}{l}\text { Persons } \\
\text { Under } 65 \\
\end{array}$ & $\begin{array}{c}\text { Persons } 65 \text { or } \\
\text { Older }\end{array}$ \\
\hline TOTAL & $\begin{array}{r}3,411,122 \\
(100.0 \%)\end{array}$ & $\begin{array}{r}3,123,246 \\
(100.0 \%)\end{array}$ & $\begin{array}{r}287,876 \\
(100.0 \%)\end{array}$ \\
\hline \multicolumn{4}{|l|}{ Private Vehicles } \\
\hline Auto/Van - Driver & $\begin{array}{r}1,482,617 \\
(43.5 \%)\end{array}$ & $\begin{array}{r}1,341,532 \\
(43.0 \%)\end{array}$ & $\begin{array}{l}141,085 \\
(49.0 \%)\end{array}$ \\
\hline Auto/Van - Passenger & $\begin{array}{l}819,969 \\
(24.0 \%)\end{array}$ & $\begin{array}{c}748,139 \\
(24.0 \%)\end{array}$ & $\begin{array}{r}71,830 \\
(25.0 \%)\end{array}$ \\
\hline SUV & $\begin{array}{r}238,242 \\
(7.0 \%)\end{array}$ & $\begin{array}{r}227,851 \\
(7.3 \%)\end{array}$ & $\begin{array}{l}10,391 \\
(3.6 \%)\end{array}$ \\
\hline Pickup & $\begin{array}{l}471,416 \\
(13.8 \%)\end{array}$ & $\begin{array}{l}439,911 \\
(14.1 \%)\end{array}$ & $\begin{array}{r}31,505 \\
(10.9 \%)\end{array}$ \\
\hline Other POV & $\begin{array}{l}98,005 \\
(2.9 \%)\end{array}$ & $\begin{array}{c}95,161 \\
(3.0 \%)\end{array}$ & $\begin{array}{r}2,844 \\
(1.0 \%)\end{array}$ \\
\hline Subtotal & $\begin{array}{r}3,110,249 \\
(91.2 \%)\end{array}$ & $\begin{array}{r}2,852,595 \\
(91.3 \%)\end{array}$ & $\begin{array}{l}257,655 \\
(89.5 \%)\end{array}$ \\
\hline \multicolumn{4}{|l|}{ Public Transportation } \\
\hline Bus, Streetcar & $\begin{array}{l}48,154 \\
(1.4 \%)\end{array}$ & $\begin{array}{l}37,246 \\
(1.2 \%)\end{array}$ & $\begin{array}{l}10,909 \\
(3.8 \%)\end{array}$ \\
\hline Rail/Subway & $\begin{array}{l}24,423 \\
(0.7 \%)\end{array}$ & $\begin{array}{l}23,287 \\
(0.7 \%)\end{array}$ & $\begin{array}{r}1,137 \\
(0.4 \%)\end{array}$ \\
\hline Subtotal & $\begin{array}{l}72,577 \\
(2.1 \%)\end{array}$ & $\begin{array}{c}60,532 \\
(1.9 \%)\end{array}$ & $\begin{array}{l}12,045 \\
(4.2 \%)\end{array}$ \\
\hline \multicolumn{4}{|l|}{ Other Means } \\
\hline Amtrak & $\begin{array}{r}1,664 \\
(0.0 \%)\end{array}$ & $\begin{array}{c}797 \\
(0.0 \%)\end{array}$ & $\begin{array}{r}866 \\
(0.3 \%)\end{array}$ \\
\hline Taxi & $\begin{array}{r}3,204 \\
(0.1 \%)\end{array}$ & $\begin{array}{c}2,838 \\
(0.1 \%)\end{array}$ & $\begin{array}{r}366 \\
(0.1 \%)\end{array}$ \\
\hline Bike & $\begin{array}{r}4,586 \\
(0.1 \%)\end{array}$ & $\begin{array}{c}4,488 \\
(0.1 \%)\end{array}$ & $\begin{array}{r}98 \\
(0.0 \%)\end{array}$ \\
\hline Walk & $\begin{array}{l}10,821 \\
(0.3 \%)\end{array}$ & $\begin{array}{c}9,684 \\
(0.3 \%)\end{array}$ & $\begin{array}{r}1,137 \\
(0.4 \%)\end{array}$ \\
\hline School Bus & $\begin{array}{l}43,391 \\
(1.3 \%)\end{array}$ & $\begin{array}{c}43,048 \\
(1.4 \%)\end{array}$ & $\begin{array}{r}343 \\
(0.1 \%)\end{array}$ \\
\hline Other & $\begin{array}{r}130,554 \\
(3.8 \%)\end{array}$ & $\begin{array}{r}118,037 \\
(3.8 \%)\end{array}$ & $\begin{array}{l}12,517 \\
(4.3 \%)\end{array}$ \\
\hline Subtotal & $\begin{array}{r}194,220 \\
(5.7 \%)\end{array}$ & $\begin{array}{r}178,892 \\
(5.7 \%)\end{array}$ & $\begin{array}{l}15,328 \\
(5.3 \%)\end{array}$ \\
\hline
\end{tabular}

Note:

- All tables reporting totals could include some unreported characteristics. 


\section{FigURE 8.2}

Comparison of Person Miles Traveled for Persons Under 65 and Persons 65 or OldER By MODE OF TRANSPORTATION 1995 NPTS

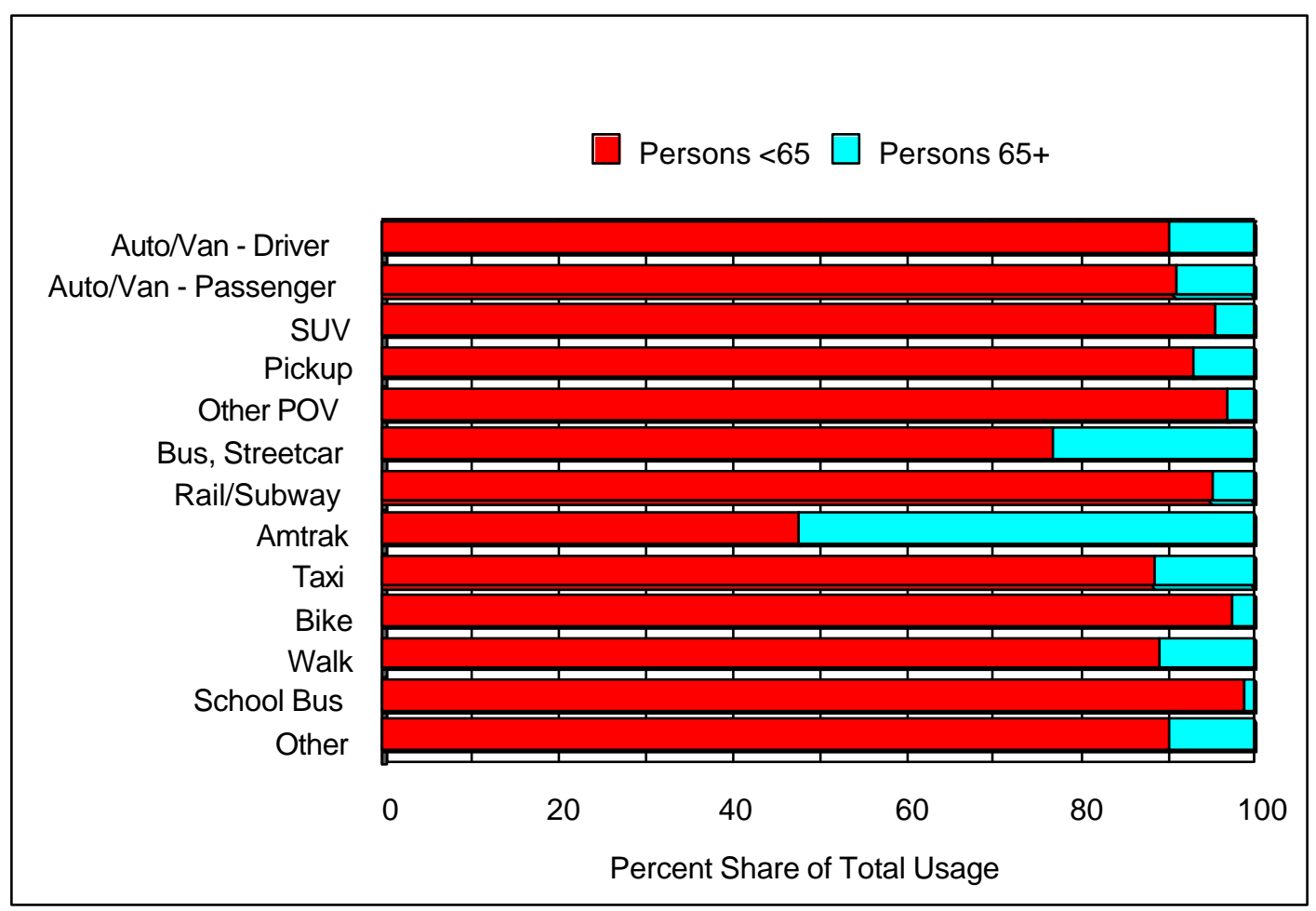

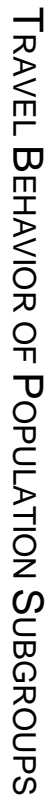


Over a third of all travel taken by the elderly occurred in the four hours between of 9 a.m. and 1 p.m. This time period was preferred both on the weekend and through the week (Table 8.3). Another one-fourth of all vehicle miles traveled occurred between 1 and 4 p.m. The elderly took only $10.9 \%$ of all their travel miles in the 11-hour period between 7 in the evening and 6 in the morning.

\section{TABLE 8.3}

VEHICLE MiLES TRAVELED FOR

Persons 65 Or Older by Time of DAy ANd WeEKDAY Vs. WeEKEnd 1995 NPTS

\begin{tabular}{|c|c|c|c|c|c|c|c|c|}
\hline & TOTAL & $\begin{array}{c}10 \text { p.m. to } \\
1 \text { a.m. }\end{array}$ & $\begin{array}{c}1 \text { a.m. to } \\
6 \text { a.m. }\end{array}$ & $\begin{array}{c}6 \text { a.m. to } \\
9 \text { a.m. }\end{array}$ & $\begin{array}{c}9 \text { a.m. to } \\
1 \text { p.m. }\end{array}$ & $\begin{array}{c}1 \text { p.m. to } \\
4 \text { p.m. }\end{array}$ & $\begin{array}{c}4 \text { p.m. to } \\
7 \text { p.m. }\end{array}$ & $\begin{array}{l}7 \text { p.m. to } \\
10 \text { p.m. }\end{array}$ \\
\hline TOTAL & $\begin{array}{l}172,781.5 \\
(100.0 \%)\end{array}$ & $\begin{array}{l}3,070.6 \\
(1.8 \%)\end{array}$ & $\begin{array}{l}5,366.9 \\
(3.1 \%)\end{array}$ & $\begin{array}{r}19,956.9 \\
(11.6 \%)\end{array}$ & $\begin{array}{c}60,488.1 \\
(35.0 \%)\end{array}$ & $\begin{array}{l}43,471.0 \\
(25.2 \%)\end{array}$ & $\begin{array}{r}29,852.7 \\
(17.3 \%)\end{array}$ & $\begin{array}{r}10,403.2 \\
(6.0 \%)\end{array}$ \\
\hline \multirow[t]{2}{*}{ Weekday } & $126,426.5$ & $1,494.8$ & $4,736.1$ & $15,814.3$ & $45,775.4$ & $32,235.5$ & $20,655.4$ & $5,543.8$ \\
\hline & $(100.0 \%)$ & $(1.2 \%)$ & $(3.7 \%)$ & $(12.5 \%)$ & $(36.2 \%)$ & $(25.5 \%)$ & $(16.3 \%)$ & $(4.4 \%)$ \\
\hline \multirow[t]{2}{*}{ Weekend } & $46,355.0$ & $1,575.8$ & 630.8 & $4,142.6$ & $14,712.7$ & $11,235.5$ & $9,197.3$ & $4,859.4$ \\
\hline & $(100.0 \%)$ & $(3.4 \%)$ & $(1.4 \%)$ & $(8.9 \%)$ & $(31.7 \%)$ & $(24.2 \%)$ & $(19.8 \%)$ & $(10.5 \%)$ \\
\hline
\end{tabular}

Note:

- Weekday is defined as the time between 12:01 a.m. Monday and 6:00 p.m. Friday.

- Weekend is defined as the time between 6:01 p.m. Friday and midnight Saturday.

- All tables reporting totals could include some unreported characteristics. 
The elderly generally either took several trips or no trips on their travel day; $45.2 \%$ of all persons 65 or older took four or more trips and $26.3 \%$ took no trips, as shown in Table 8.4. It should be noted that the 1995 NPTS questionnaire was designed to permit to-from trip analysis. Therefore, most travel would involve at least two individual trips to allow for a "to" trip and a return home trip.

Most person trips (44.4\%) taken by the elderly are taken by persons living in a rural area - that is, an area with a population density of less than 2,000 persons per square mile (Table 8.5).

TABLE 8.4

NUMBER OF PERSONS 65 OR OLDER (IN THOUSANDS) By NuMber of TRIPS TAKEN ON TRAVEL DAY 1995 NPTS

\begin{tabular}{||lc||}
\hline Number of Trips Taken & Number of Persons \\
\hline \multirow{2}{*}{ TOTAL } & $31,249.0$ \\
& $(100.0 \%)$ \\
& $8,204.8$ \\
One & $(26.3 \%)$ \\
& 310.0 \\
Two & $(1.0 \%)$ \\
& $5,906.8$ \\
Three & $(18.9 \%)$ \\
& $2,709.3$ \\
Four or more & $(8.7 \%)$ \\
& $14,118.1$ \\
\hline \hline
\end{tabular}

Note:

- All tables reporting totals could include some unreported characteristics. 


\section{TABLE 8.5}

Person Trips by Persons 65 OR Older by Population Density 1995 NPTS

\begin{tabular}{||lc||}
\hline \hline Population Density & Person Trips (thousands) \\
\hline TOTAL & $39,099,962$ \\
& $(100.0 \%)$ \\
Less than 2,000 & $17,370,497$ \\
& $(44.4 \%)$ \\
2,000 to 4,000 & $7,589,194$ \\
& $(19.4 \%)$ \\
4,000 to 10,000 & $10,140,295$ \\
& $(25.9 \%)$ \\
10,000 or more & $3,832,329$ \\
& $(9.8 \%)$ \\
\hline \hline
\end{tabular}

Note:

- All tables reporting totals could include some unreported characteristics.

- Population density is calculated as persons per square mile for the zip code in which the household is located. 
Tables 8.6-8.8 and Figures 8.3-8.6 provide travel information for the population subgroup of women. As shown in Table 8.6, women started most of their trips and drove the most overall person miles between 9 a.m. and 7 p.m. These hours, however, were also the hours with the shortest overall trip lengths. Women took more person trips for family/personal business than any other trip purpose, and almost $60 \%$ of these trips were made between 9 a.m. and 4 p.m. Trip lengths were greatest between 1 a.m. and 9 a.m. for social/recreational purposes (Figure 8.4).

\section{TABLE 8.6}

\section{Person Travel Statistics for Women by Start Time AND TRIP PuRPose \\ 1995 NPTS}

\begin{tabular}{|c|c|c|c|c|c|c|c|c|}
\hline Trip Purpose & TOTAL & $\begin{array}{l}10 \text { p.m. } \\
\text { to } \\
1 \text { a.m. }\end{array}$ & $\begin{array}{c}1 \text { a.m. to } \\
6 \text { a.m. }\end{array}$ & $\begin{array}{c}6 \text { a.m. to } \\
9 \text { a.m. }\end{array}$ & $\begin{array}{l}9 \text { a.m. to } \\
1 \text { p.m. }\end{array}$ & $\begin{array}{l}1 \text { p.m. to } \\
4 \text { p.m. }\end{array}$ & $\begin{array}{l}4 \text { p.m. to } \\
7 \text { p.m. }\end{array}$ & $\begin{array}{l}7 \text { p.m. to } \\
10 \text { p.m. }\end{array}$ \\
\hline \multicolumn{9}{|l|}{ Person Trips (millions) } \\
\hline TOTAL & 193,196 & 6,083 & 2,119 & 25,227 & 47,954 & 44,469 & 44,633 & 22,651 \\
\hline Earning a Living & 19,601 & 214 & 895 & 8,482 & 4,894 & 3,368 & 1,387 & 350 \\
\hline Family/Personal Business & 67,932 & 1,028 & 371 & 7,529 & 21,057 & 17,739 & 14,728 & 5,451 \\
\hline School/Church & 9,654 & 17 & 26 & 5,123 & 2,396 & 596 & 1,120 & 374 \\
\hline Social/Recreational & 31,417 & 770 & 180 & 1,828 & 8,639 & 6,726 & 8,672 & 4,592 \\
\hline Other & 331 & 29 & 2 & 21 & 68 & 57 & 77 & 71 \\
\hline Returning Home & 64,242 & 4,024 & 644 & 2,242 & 10,896 & 15,981 & 18,644 & 11,807 \\
\hline \multicolumn{9}{|l|}{ PMT (millions) } \\
\hline TOTAL & $\begin{array}{r}1,527,88 \\
4\end{array}$ & 59,405 & 35,671 & 241,912 & 340,066 & 324,206 & 343,827 & 182,353 \\
\hline Earning a Living & 180,467 & 2,796 & 12,816 & 90,878 & 35,460 & 23,617 & 11,745 & 3,144 \\
\hline Family/Personal Business & 439,321 & 8,413 & 4,442 & 68,424 & 125,559 & 105,856 & 92,327 & 33,927 \\
\hline School/Church & 56,934 & 118 & 340 & 25,631 & 13,070 & 5,590 & 9,957 & 2,229 \\
\hline Social/Recreational & 330,745 & 8,675 & 4,749 & 40,534 & 99,639 & 66,090 & 71,593 & 39,447 \\
\hline Other & 6,341 & 98 & 1 & 989 & 642 & 2,936 & 930 & 745 \\
\hline Returning Home & 514,030 & 39,305 & 13,322 & 15,439 & 65,695 & 120,116 & 157,265 & 102,845 \\
\hline $\begin{array}{l}\text { Average Trip Length } \\
\text { (miles) }\end{array}$ & & & & & & & & \\
\hline TOTAL & 8.05 & 10.06 & 17.55 & 9.76 & 7.20 & 7.41 & 7.82 & 8.22 \\
\hline Earning a Living & 9.36 & 13.17 & 14.71 & 10.88 & 7.36 & 7.11 & 8.61 & 9.23 \\
\hline Family/Personal Business & 6.56 & 8.53 & 12.37 & 9.26 & 6.05 & 6.05 & 6.34 & 6.34 \\
\hline School/Church & 6.02 & 7.04 & 12.99 & 5.09 & 5.58 & 9.53 & 9.13 & 6.30 \\
\hline Social/Recreational & 10.74 & 11.57 & 27.76 & 22.70 & 11.73 & 10.01 & 8.42 & 8.80 \\
\hline Other & 20.62 & 3.76 & 60.00 & 54.06 & 10.06 & 54.10 & 12.46 & 10.57 \\
\hline Returning Home & 8.15 & 10.04 & 22.02 & 7.03 & 6.12 & 7.67 & 8.56 & 8.88 \\
\hline
\end{tabular}

Note:

- All tables reporting totals could include some unreported characteristics. 


\section{FIGURE 8.3}

Person Trips by Trip Purpose for Women

By START TIME

1995 NPTS

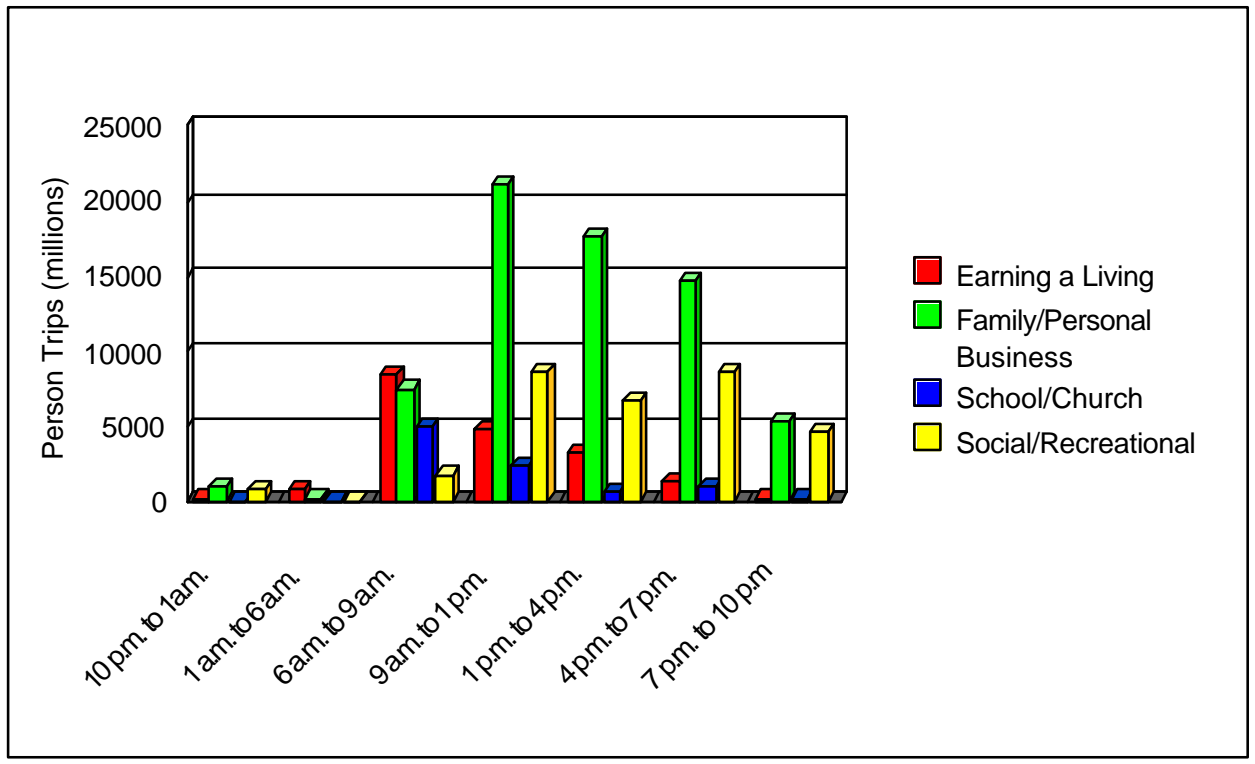

FIGURE 8.4

Average TriP LENGTH By TRIP PURPOSE FOR WOMEN

By START Time

1995 NPTS

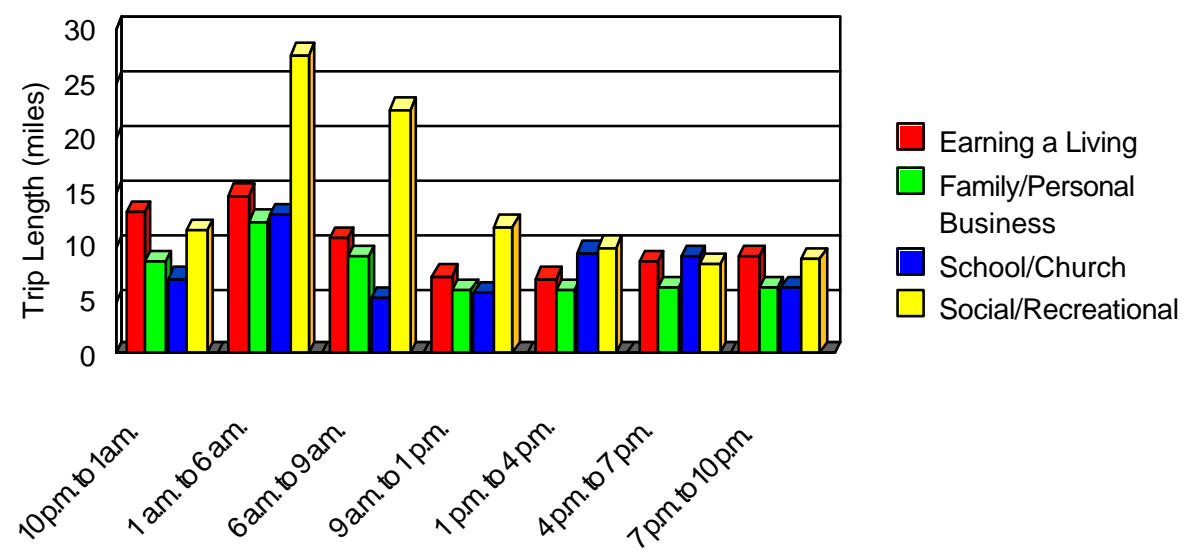


In 1995, employed women averaged taking 1.12 trips more each day than unemployed women (Table 8.7). Employed women took more trips for every trip purpose except school/church and social/recreational.

\section{TABLE 8.7}

DaILy Person Trips Per PERson for Women by Employment Status, Trip Purpose, and Start Time of Trip 1995 NPTS

\begin{tabular}{|c|c|c|c|c|c|c|c|c|}
\hline Trip Purpose & TOTAL & $\begin{array}{l}10 \text { p.m. to } \\
1 \text { a.m. }\end{array}$ & $\begin{array}{l}1 \text { a.m. to } \\
6 \text { a.m. }\end{array}$ & $\begin{array}{l}6 \text { a.m. to } \\
9 \text { a.m. }\end{array}$ & $\begin{array}{l}9 \text { a.m. to } \\
1 \text { p.m. }\end{array}$ & $\begin{array}{l}1 \text { p.m. to } \\
4 \text { p.m. }\end{array}$ & $\begin{array}{l}4 \text { p.m. to } \\
7 \text { p.m. }\end{array}$ & $\begin{array}{c}7 \text { p.m. to } \\
10 \text { p.m. }\end{array}$ \\
\hline \multicolumn{9}{|l|}{ Employed Women } \\
\hline TOTAL & 4.84 & 0.18 & 0.08 & 0.71 & 1.09 & 0.99 & 1.19 & 0.60 \\
\hline Earning a Living & 0.86 & 0.01 & 0.04 & 0.38 & 0.21 & 0.15 & 0.06 & 0.01 \\
\hline Family/Personal Business & 1.65 & 0.03 & 0.01 & 0.20 & 0.44 & 0.40 & 0.41 & 0.15 \\
\hline School/Church & 0.12 & 0.00 & 0.00 & 0.03 & 0.04 & 0.01 & 0.02 & 0.01 \\
\hline Social/Recreational & 0.66 & 0.02 & 0.01 & 0.03 & 0.18 & 0.12 & 0.18 & 0.12 \\
\hline Other & 0.01 & 0.00 & 0.00 & 0.00 & 0.00 & 0.00 & 0.00 & 0.00 \\
\hline Returning Home & 1.54 & 0.12 & 0.02 & 0.06 & 0.22 & 0.31 & 0.51 & 0.30 \\
\hline \multicolumn{9}{|l|}{ Unemployed Women } \\
\hline TOTAL & 3.72 & 0.09 & 0.01 & 0.41 & 1.03 & 0.98 & 0.79 & 0.41 \\
\hline Earning a Living & 0.02 & 0.00 & 0.00 & 0.01 & 0.01 & 0.01 & 0.00 & 0.00 \\
\hline Family/Personal Business & 1.35 & 0.02 & 0.00 & 0.13 & 0.49 & 0.38 & 0.24 & 0.09 \\
\hline School/Church & 0.30 & 0.00 & 0.00 & 0.19 & 0.06 & 0.02 & 0.02 & 0.01 \\
\hline Social/Recreational & 0.73 & 0.01 & 0.00 & 0.05 & 0.20 & 0.17 & 0.20 & 0.09 \\
\hline Other & 0.01 & 0.00 & 0.00 & 0.00 & 0.00 & 0.00 & 0.00 & 0.00 \\
\hline Returning Home & 1.31 & 0.06 & 0.01 & 0.04 & 0.26 & 0.40 & 0.32 & 0.22 \\
\hline
\end{tabular}

Note:

- All tables reporting totals could include some unreported characteristics. 
On the average, employed women in 1995 traveled 54.3\% more person miles daily than unemployed women. For the trip purpose of school/church, however, unemployed women traveled twice as many person miles as employed women. Overall, employed women reported more PMT daily for every time period in the 1995 NPTS (Table 8.8).

Figures 8.5 and 8.6 graphically compare the number of daily trips and PMT, respectively, by trip purpose for employed and unemployed women.

\section{TABLE 8.8}

\section{DAILY PMT PER PERSON FOR WOMEN \\ by Employment Status, Trip PuRpose, and Start Time of TriP \\ 1995 NPTS}

\begin{tabular}{|c|c|c|c|c|c|c|c|c|}
\hline Trip Purpose & TOTAL & $\begin{array}{l}10 \text { p.m. to } \\
1 \text { a.m. }\end{array}$ & $\begin{array}{l}1 \text { a.m. to } \\
6 \text { a.m. }\end{array}$ & $\begin{array}{l}6 \text { a.m. to } \\
9 \text { a.m. }\end{array}$ & $\begin{array}{l}9 \text { a.m. to } \\
1 \text { p.m. }\end{array}$ & $\begin{array}{l}1 \text { p.m. to } \\
4 \text { p.m. }\end{array}$ & $\begin{array}{l}4 \text { p.m. to } \\
7 \text { p.m. }\end{array}$ & $\begin{array}{l}7 \text { p.m. to } \\
10 \text { p.m. }\end{array}$ \\
\hline \multicolumn{9}{|l|}{ Employed Women } \\
\hline TOTAL & 41.15 & 1.76 & 1.15 & 7.44 & 8.11 & 7.95 & 9.73 & 5.01 \\
\hline Earning a Living & 7.95 & 0.13 & 0.58 & 4.06 & 1.55 & 1.02 & 0.48 & 0.14 \\
\hline Family/Personal Business & 11.41 & 0.27 & 0.14 & 1.95 & 2.67 & 2.56 & 2.80 & 1.01 \\
\hline School/Church & 0.83 & 0.00 & 0.00 & 0.27 & 0.27 & 0.07 & 0.17 & 0.03 \\
\hline Social/Recreational & 7.21 & 0.24 & 0.12 & 0.77 & 2.12 & 1.41 & 1.60 & 0.95 \\
\hline Other & 0.17 & 0.00 & 0.00 & 0.00 & 0.00 & 0.12 & 0.02 & 0.02 \\
\hline Returning Home & 13.59 & 1.12 & 0.31 & 0.39 & 1.48 & 2.76 & 4.67 & 2.86 \\
\hline \multicolumn{9}{|l|}{ Unemployed Women } \\
\hline TOTAL & 26.67 & 0.88 & 0.44 & 3.34 & 6.94 & 6.41 & 5.56 & 3.09 \\
\hline Earning a Living & 0.20 & 0.00 & 0.00 & 0.05 & 0.05 & 0.04 & 0.05 & 0.01 \\
\hline Family/Personal Business & 8.07 & 0.11 & 0.05 & 1.09 & 2.87 & 2.12 & 1.32 & 0.50 \\
\hline School/Church & 1.67 & 0.00 & 0.01 & 0.85 & 0.30 & 0.17 & 0.27 & 0.06 \\
\hline Social/Recreational & 7.40 & 0.15 & 0.09 & 1.01 & 2.28 & 1.50 & 1.57 & 0.80 \\
\hline Other & 0.12 & 0.00 & $* *$ & 0.04 & 0.02 & 0.01 & 0.02 & 0.01 \\
\hline Returning Home & 9.22 & 0.63 & 0.28 & 0.30 & 1.42 & 2.55 & 2.33 & 1.71 \\
\hline
\end{tabular}

Note:

- All tables reporting totals could include some unreported characteristics. 


\section{FIGURE 8.5}

Average Daily Person Trips Per Person for Women By EMPloyment Status and TRIP PURPose

1995 NPTS

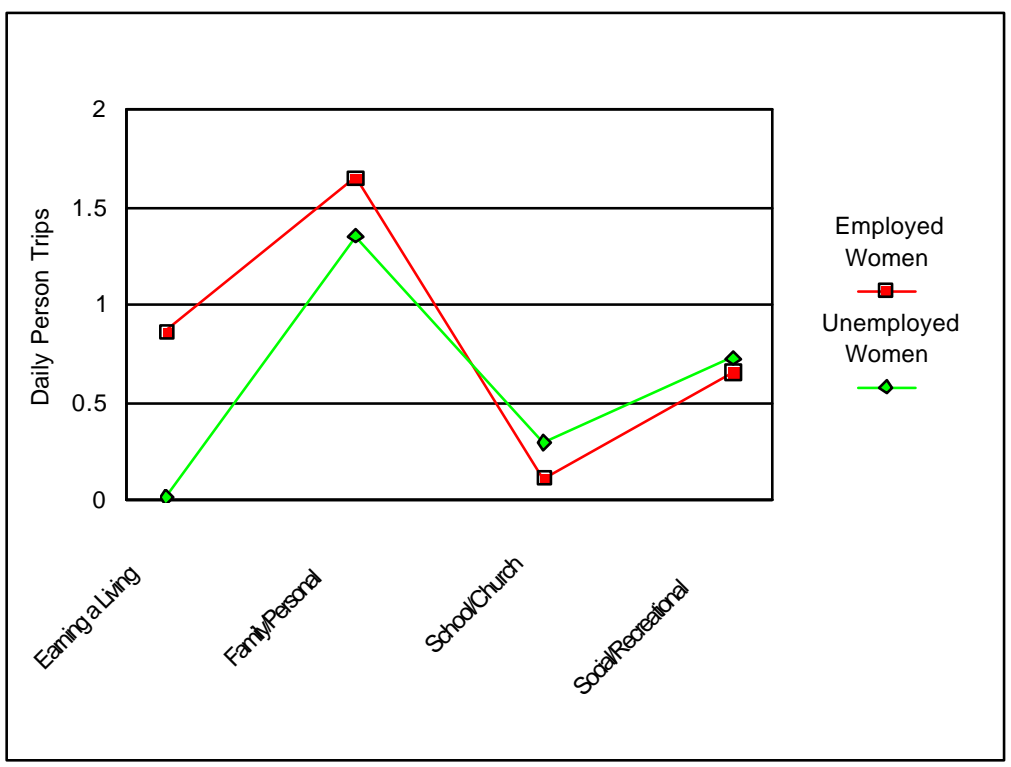

FigURE 8.6

Daily Person Miles Traveled Per Person for Women By EMPLOYMENT STATUS AND TRIP PURPOSE 1995 NPTS

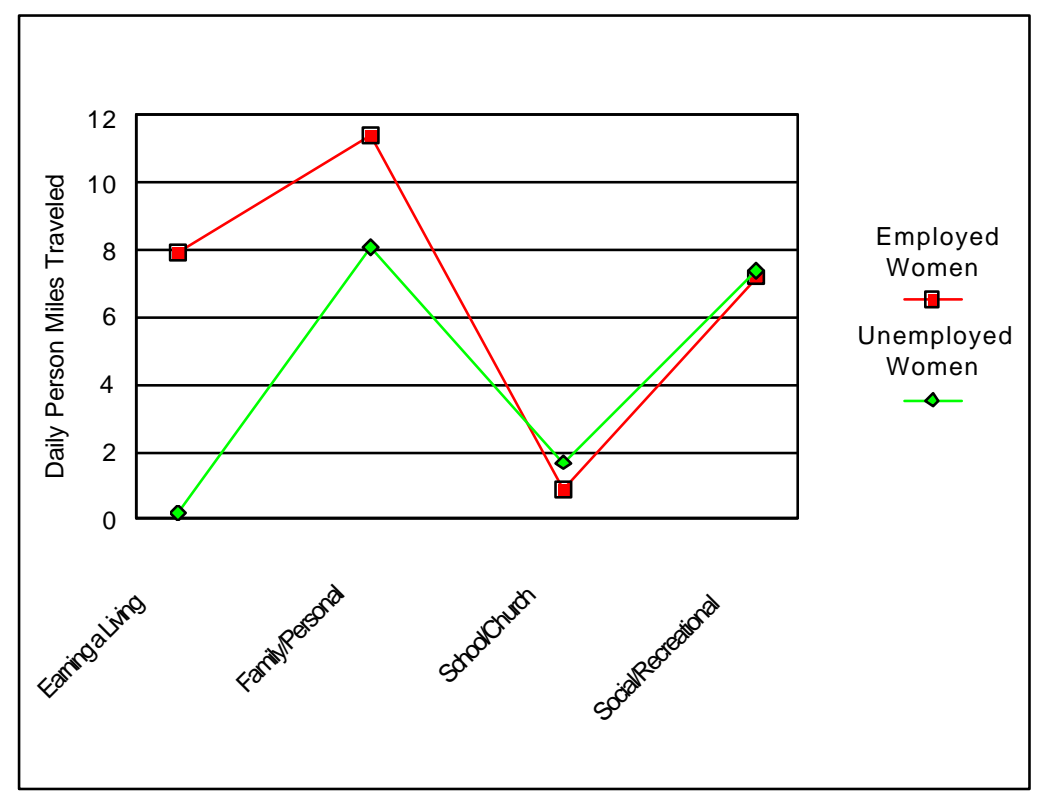


Travel statistics for low-income persons are provided in Tables 8.9-8.11. Although lowincome households are less likely to own a vehicle than non-low-income households, over $80 \%$ of the person trips and $90 \%$ of the person miles traveled are taken in private vehicles - mostly in an automobile or van as the driver. Slightly over $8 \%$ of all person trips were on foot; walking trips had an average trip length of just over $1 / 2$ mile.

As shown in Figure 8.7, most person miles traveled by low-income households are for family/personal business. 


\section{TABLE 8.9}

\section{Person Travel Statistics for Low-Income Persons By Mode of Transportation}

1995 NPTS

\begin{tabular}{|c|c|c|c|}
\hline Transportation Mode & $\begin{array}{l}\text { Person Trips } \\
\text { (thousands) }\end{array}$ & $\begin{array}{c}\text { PMT } \\
\text { (millions) }\end{array}$ & $\begin{array}{c}\text { Average Trip Length } \\
\text { (miles) }\end{array}$ \\
\hline TOTAL & $\begin{array}{r}81,526,904 \\
(100.0 \%)\end{array}$ & $\begin{array}{r}604,814 \\
(100.0 \%)\end{array}$ & 7.59 \\
\hline \multicolumn{4}{|l|}{ Private Vehicles } \\
\hline Auto/Van - Driver & $\begin{array}{r}35,941,810 \\
(44.1 \%)\end{array}$ & $\begin{array}{r}257,952 \\
(42.6 \%)\end{array}$ & 7.26 \\
\hline Auto/Van - Passenger & $\begin{array}{r}18,087,962 \\
(22.2 \%)\end{array}$ & $\begin{array}{r}166,362 \\
(27.5 \%)\end{array}$ & 9.49 \\
\hline SUV & $\begin{array}{r}1,910,417 \\
(2.3 \%)\end{array}$ & $\begin{array}{r}19,347 \\
(3.2 \%)\end{array}$ & 10.16 \\
\hline Pickup & $\begin{array}{r}9,112,734 \\
(11.2 \%)\end{array}$ & $\begin{array}{r}84,726 \\
(14.0 \%)\end{array}$ & 9.36 \\
\hline Other POV & $\begin{array}{l}580,493 \\
(0.7 \%)\end{array}$ & $\begin{array}{r}16,836 \\
(2.8 \%)\end{array}$ & 31.42 \\
\hline Subtotal & $\begin{array}{r}65,633,416 \\
(80.5 \%)\end{array}$ & $\begin{array}{r}545,223 \\
(90.1 \%)\end{array}$ & 8.45 \\
\hline \multicolumn{4}{|l|}{ Public Transportation } \\
\hline Bus, Streetcar & $\begin{array}{r}2,186,730 \\
(2.7 \%)\end{array}$ & $\begin{array}{r}20,077 \\
(3.3 \%)\end{array}$ & 10.2 \\
\hline Rail/Subway & $\begin{array}{l}593,507 \\
(0.7 \%)\end{array}$ & $\begin{array}{r}5,289 \\
(0.9 \%)\end{array}$ & 11.44 \\
\hline Subtotal & $\begin{array}{r}2,780,237 \\
(3.4 \%)\end{array}$ & $\begin{array}{r}25,366 \\
(4.2 \%)\end{array}$ & 10.43 \\
\hline \multicolumn{4}{|l|}{ Other Means } \\
\hline Amtrak & $\begin{array}{r}6,878 \\
(0.0 \%)\end{array}$ & $\begin{array}{r}423 \\
(0.1 \%)\end{array}$ & 199.93 \\
\hline Taxi & $\begin{array}{l}216,366 \\
(0.3 \%)\end{array}$ & $\begin{array}{r}828 \\
(0.1 \%)\end{array}$ & 3.92 \\
\hline Bike & $\begin{array}{r}1,027,563 \\
(1.3 \%)\end{array}$ & $\begin{array}{r}1,437 \\
(0.2 \%)\end{array}$ & 1.42 \\
\hline Walk & $\begin{array}{r}6,736,716 \\
(8.3 \%)\end{array}$ & $\begin{array}{r}3,667 \\
(0.6 \%)\end{array}$ & 0.54 \\
\hline School Bus & $\begin{array}{r}1,442,777 \\
(1.8 \%)\end{array}$ & $\begin{array}{r}9,970 \\
(1.6 \%)\end{array}$ & 7.27 \\
\hline Other & $\begin{array}{l}265,230 \\
(0.3 \%)\end{array}$ & $\begin{array}{r}11,765 \\
(1.9 \%)\end{array}$ & 49.19 \\
\hline Subtotal & $\begin{array}{r}9,695,530 \\
(11.9 \%)\end{array}$ & $\begin{array}{r}28,091 \\
(4.6 \%)\end{array}$ & 2.93 \\
\hline
\end{tabular}

Note:

- All tables reporting totals could include some unreported characteristics. 
TABLE 8.10

\section{Average Annual Person Trips Per Person for Low-Income Persons By PoPUlation DeNSITY AND TRIP PURPOSE 1995 NPTS}

\begin{tabular}{|c|c|c|c|c|c|}
\hline Trip Purpose & TOTAL & $\begin{array}{c}\text { Less than } \\
2,000\end{array}$ & $\begin{array}{c}2,000 \text { to } \\
4,000\end{array}$ & $\begin{array}{c}4,000 \text { to } \\
10,000\end{array}$ & $\begin{array}{c}10,000 \text { or } \\
\text { more }\end{array}$ \\
\hline TOTAL & $1,413.3$ & $1,383.9$ & $1,515.8$ & $1,452.1$ & $1,357.1$ \\
\hline \multicolumn{6}{|l|}{ Earning a Living } \\
\hline To Work & 104.6 & 105.0 & 107.0 & 110.2 & 93.6 \\
\hline Work-Related Business & 24.8 & 28.2 & 23.6 & 25.1 & 17.1 \\
\hline Return to Work & 17.8 & 20.8 & 18.3 & 17.5 & 10.5 \\
\hline Subtotal & 147.2 & 154.0 & 148.9 & 152.8 & 121.2 \\
\hline \multicolumn{6}{|l|}{ Family/Personal Business } \\
\hline Shopping & 209.3 & 208.3 & 225.3 & 208.8 & 201.5 \\
\hline Medical/Dental & 17.1 & 15.5 & 16.3 & 19.9 & 19.0 \\
\hline Other Family/Personal Business & 146.8 & 151.2 & 160.5 & 146.5 & 125.0 \\
\hline Take Someone Somewhere & 50.2 & 46.6 & 59.7 & 54.9 & 46.9 \\
\hline Pick Up Someone & 41.1 & 36.7 & 51.9 & 47.3 & 36.6 \\
\hline Subtotal & 464.5 & 458.3 & 513.8 & 477.4 & 429.0 \\
\hline \multicolumn{6}{|l|}{ School/Church } \\
\hline School & 49.3 & 41.6 & 52.1 & 55.5 & 58.4 \\
\hline Religious Activity & 23.3 & 20.9 & 26.7 & 22.7 & 27.2 \\
\hline Subtotal & 72.6 & 62.5 & 78.8 & 78.2 & 85.6 \\
\hline \multicolumn{6}{|l|}{ Social/Recreational } \\
\hline Vacation & 1.0 & 1.6 & 0.3 & 0.5 & 0.6 \\
\hline Visit Friends/Relatives & 94.0 & 93.3 & 94.6 & 92.2 & 95.5 \\
\hline Out to Eat & 60.2 & 60.1 & 60.4 & 62.0 & 57.1 \\
\hline Other Social/Recreational & 81.2 & 81.1 & 89.8 & 80.3 & 75.3 \\
\hline Subtotal & 236.4 & 236.1 & 245.2 & 235.1 & 228.6 \\
\hline \multicolumn{6}{|l|}{ Other and Returning Home } \\
\hline Other & 1.6 & 0.9 & 2.6 & 2.8 & 1.0 \\
\hline Returning Home & 490.8 & 472.0 & 526.6 & 505.1 & 491.5 \\
\hline Subtotal & 492.4 & 472.9 & 529.2 & 507.9 & 492.5 \\
\hline
\end{tabular}

Note:

- All tables reporting totals could include some unreported characteristics.

- Population density is calculated as persons per square mile for the zip code in which the household is located. 


\section{FIGURE 8.7}

\section{Distribution of Average Annual Person Trips Per Person FOR LOW-INCOME PERSONS BY TRIP PURPOSE \\ 1995 NPTS}

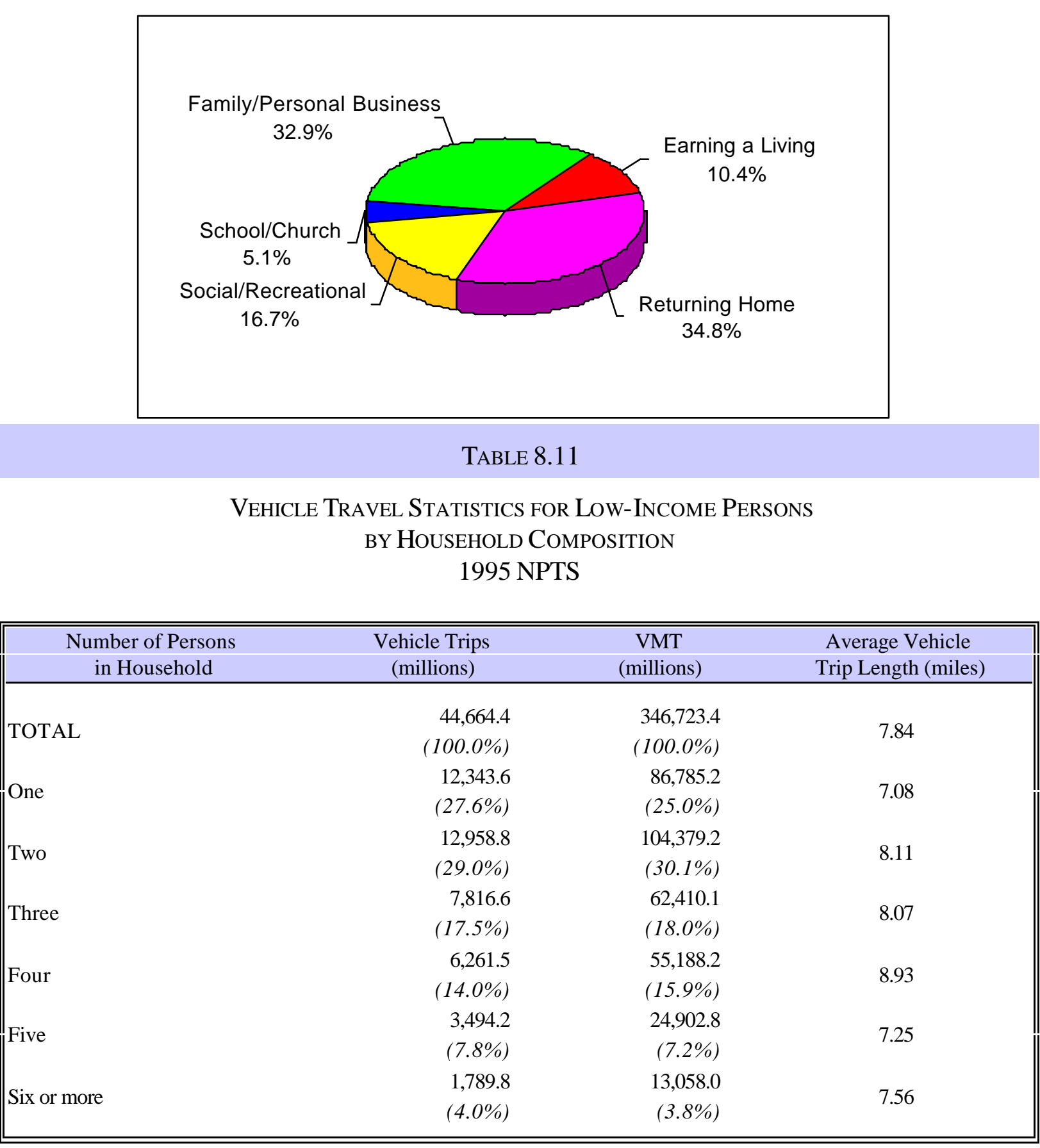

Note:

- All tables reporting totals could include some unreported characteristics. 
Tables 8.12-8.14 provide additional information about the population subgroup of persons who walk as a mode of transportation. Most people took an average of almost 2.4 walking trips each day. Generally speaking, females of all age groups took more walking trips than males. The age group that took the fewest walking trips was 5-15 year olds.

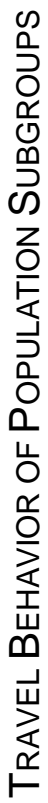

for family/personal business or social/recreational purposes. Less than $10 \%$ of all walking trips were for earning a living.

Persons in large MSAs (3 million persons or more) had a higher average number of walking trips than persons in any other MSA size. The fewest trips were taken by persons living in MSAs of 1 to 2.9 million persons. Most walking trips were taken in densely populated areas. 
TABLE 8.12

Average Annual Person Trips Per Person of Walkers by MSA Size And Trip Purpose 1995 NPTS

\begin{tabular}{|c|c|c|c|c|c|c|c|}
\hline \multirow[b]{2}{*}{ Trip Purpose } & \multirow[b]{2}{*}{ TOTAL } & \multicolumn{6}{|c|}{ MSA Size } \\
\hline & & $\begin{array}{c}\text { Less than } \\
250,000\end{array}$ & $\begin{array}{r}250,000- \\
499,999\end{array}$ & $\begin{array}{l}500,000- \\
999,999\end{array}$ & $\begin{array}{l}1 \text { to } 2.9 \\
\text { million }\end{array}$ & $\begin{array}{l}3 \text { million } \\
\text { or more }\end{array}$ & $\begin{array}{l}\text { Not in } \\
\text { MSA }\end{array}$ \\
\hline TOTAL & 863.5 & 819.9 & 888.6 & 807.8 & 766.5 & 907.7 & 831.9 \\
\hline \multicolumn{8}{|l|}{ Earning a Living } \\
\hline To Work & 34.3 & 38.3 & 35.0 & 18.3 & 29.2 & 37.7 & 31.6 \\
\hline Work-Related Business & 11.7 & 17.6 & 11.7 & 15.2 & 7.4 & 13.2 & 7.0 \\
\hline Return to Work & 29.3 & 29.1 & 18.7 & 35.1 & 23.9 & 31.7 & 27.8 \\
\hline Subtotal & 75.3 & 85.0 & 65.5 & 68.6 & 60.4 & 82.5 & 66.3 \\
\hline \multicolumn{8}{|l|}{ Family/Personal Business } \\
\hline Shopping & 115.1 & 56.6 & 84.3 & 95.0 & 96.3 & 141.7 & 76.2 \\
\hline Medical/Dental & 4.2 & 1.8 & 4.9 & 6.2 & 2.8 & 4.7 & 3.4 \\
\hline Other Family/Personal Business & 81.1 & 107.0 & 91.7 & 64.9 & 87.4 & 73.8 & 94.8 \\
\hline Take Someone Somewhere & 9.9 & 5.1 & 11.7 & 14.0 & 7.1 & 12.4 & 2.6 \\
\hline Pick Up Someone & 10.3 & 8.5 & 13.3 & 11.9 & 6.6 & 12.5 & 4.9 \\
\hline Subtotal & 220.5 & 179.0 & 205.9 & 192.1 & 200.3 & 245.1 & 181.9 \\
\hline \multicolumn{8}{|l|}{ School or Church } \\
\hline School & 54.0 & 82.0 & 64.8 & 57.7 & 53.9 & 48.8 & 57.4 \\
\hline Religious Activity & 11.5 & 11.4 & 12.2 & 11.1 & 5.0 & 13.5 & 11.0 \\
\hline Subtotal & 65.5 & 93.3 & 77.0 & 68.8 & 58.9 & 62.3 & 68.4 \\
\hline \multicolumn{8}{|l|}{ Social/Recreational } \\
\hline Vacation & 1.4 & 0.0 & $* *$ & 3.9 & 2.6 & 1.5 & 0.0 \\
\hline Visit Friends/Relatives & 65.0 & 57.5 & 78.2 & 66.5 & 58.7 & 60.4 & 87.6 \\
\hline Out to Eat & 56.4 & 47.2 & 42.8 & 46.4 & 55.3 & 65.2 & 36.2 \\
\hline Other Social/Recreational & 83.7 & 79.3 & 89.8 & 84.5 & 80.6 & 81.2 & 96.5 \\
\hline Subtotal & 206.6 & 184.0 & 210.7 & 201.3 & 197.3 & 208.3 & 220.4 \\
\hline \multicolumn{8}{|l|}{ Other and Returning Home } \\
\hline Other & 2.0 & 1.4 & 2.9 & 2.7 & 2.4 & 1.9 & 1.4 \\
\hline Returning Home & 293.6 & 277.2 & 326.6 & 274.3 & 247.3 & 307.6 & 293.5 \\
\hline Subtotal & 295.6 & 278.6 & 329.5 & 277.0 & 249.6 & 309.5 & 294.9 \\
\hline
\end{tabular}

Note:

- All tables reporting totals could include some unreported characteristics.

- ** Indicates no data available. 


\section{TABLE 8.13}

\section{Person Trips and PMT of Walkers by Population Density}

1995 NPTS

\begin{tabular}{||lrr|}
\hline Population Density & $\begin{array}{r}\text { Person Trips } \\
\text { (thousands) }\end{array}$ & \multicolumn{1}{c|}{ PMT } \\
\hline \multirow{3}{*}{ ALL } & $20,325,156$ & $10,821,065$ \\
& $(100.0 \%)$ & $(100.0 \%)$ \\
Less than 2,000 & $4,802,628$ & $2,603,961$ \\
& $(23.6 \%)$ & $(24.1 \%)$ \\
2,000 to 4,000 & $2,669,025$ & $1,396,056$ \\
4,000 to 10,000 & $(13.1 \%)$ & $(12.9 \%)$ \\
& $5,569,807$ & $2,912,801$ \\
10,000 or more & $(27.4 \%)$ & $(26.9 \%)$ \\
& $7,156,823$ & $(3,838,153$ \\
\hline
\end{tabular}

Note:

All tables reporting totals could include some unreported characteristics. 


\section{TABLE 8.14}

Average Daily Person Trips Per Person of Walkers

BY AGE AND GENDER

1995 NPTS

\begin{tabular}{||l|ccc||}
\hline \hline \multicolumn{1}{||l|}{ Age Group } & TOTAL & Male & Female \\
\hline TOTAL & 2.37 & 2.34 & 2.39 \\
$5-15$ & 2.22 & 2.22 & 2.22 \\
$16-19$ & 2.31 & 2.19 & 2.46 \\
$20-29$ & 2.51 & 2.48 & 2.54 \\
$30-39$ & 2.47 & 2.53 & 2.43 \\
$40-49$ & 2.35 & 2.29 & 2.40 \\
$50-59$ & 2.40 & 2.44 & 2.38 \\
$60-64$ & 2.38 & 2.27 & 2.46 \\
$65+$ & 2.45 & 2.36 & 2.51 \\
\hline
\end{tabular}

Note:

- All tables reporting totals could include some unreported characteristics.

\section{FIGURE 8.8}

Average Daily Person Trips Per Person of Walkers

BY AGE AND GENDER

1995 NPTS

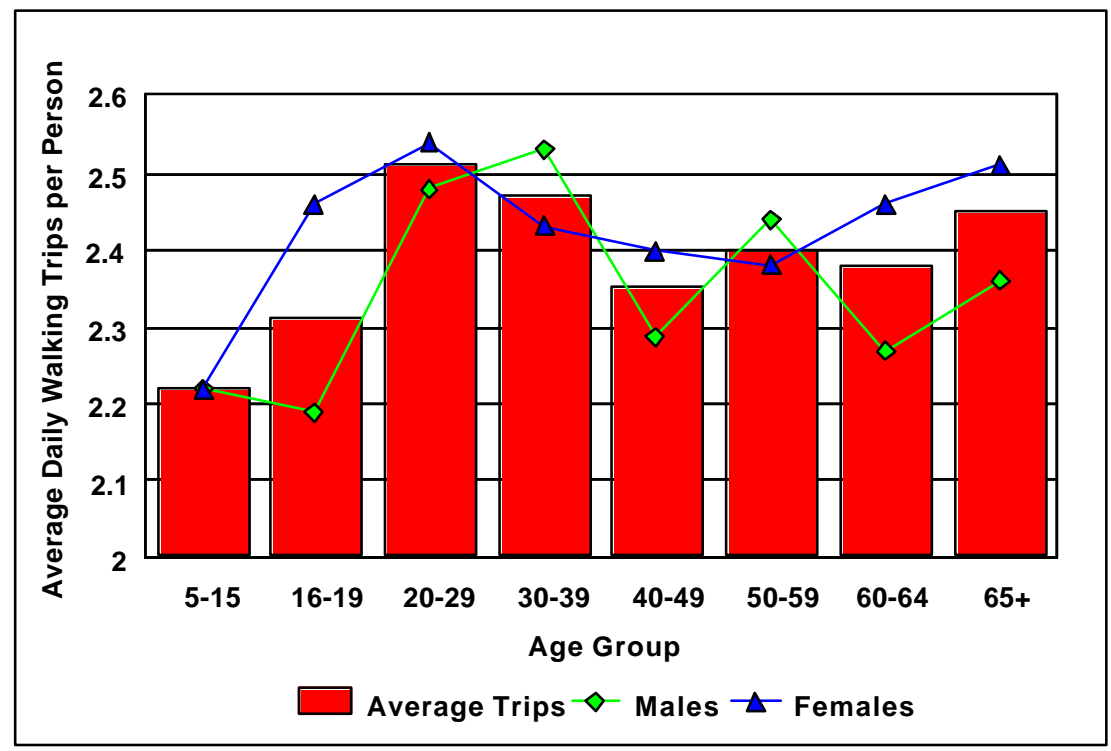


Public transit includes buses, commuter trains, streetcars/trolleys, elevated rail, and subways. Transit usage is shown in Tables 8.15-8.17. Females took public transit more often than males (30\% more person trips); however, males traveled slightly more (2\%) person miles on transit. The primary users of transit were persons between the ages of 20 and 40 . Household income did not seem to have any influence on transit usage. The most frequent reason for using public transit was for earning a living. As expected, transit usage was more prevalent in densely populated areas.

\section{TABLE 8.15}

\section{Person Travel Statistics for Public Transit Trips}

BY AGE AND GENDER

1995 NPTS

\begin{tabular}{|c|c|c|c|c|c|c|c|c|c|}
\hline \multirow[b]{2}{*}{$\begin{array}{l}\text { Age } \\
\text { Group }\end{array}$} & \multicolumn{3}{|c|}{ TOTAL } & \multicolumn{3}{|c|}{ Male } & \multicolumn{3}{|c|}{ Female } \\
\hline & $\begin{array}{l}\text { Number of } \\
\text { Person Trips } \\
\text { (thousands) }\end{array}$ & $\begin{array}{c}\text { PMT } \\
\text { (millions) }\end{array}$ & $\begin{array}{l}\text { Avg Trip } \\
\text { Length } \\
\text { (miles) }\end{array}$ & $\begin{array}{l}\text { Number of } \\
\text { Person Trips } \\
\text { (thousands) }\end{array}$ & $\begin{array}{c}\text { PMT } \\
\text { (millions) }\end{array}$ & $\begin{array}{l}\text { Avg Trip } \\
\text { Length } \\
\text { (miles) }\end{array}$ & $\begin{array}{l}\text { Number of } \\
\text { Person Trips } \\
\text { (thousands) }\end{array}$ & $\begin{array}{c}\text { PMT } \\
\text { (millions) }\end{array}$ & $\begin{array}{l}\text { Avg Trip } \\
\text { Length } \\
\text { (miles) }\end{array}$ \\
\hline TOTAL & $\begin{array}{r}6,638,338 \\
(100.0 \%)\end{array}$ & $\begin{array}{r}72,577 \\
(100.0 \%)\end{array}$ & 12.43 & $\begin{array}{r}2,885,239 \\
(100.0 \%)\end{array}$ & $\begin{array}{r}36,617 \\
(100.0 \%)\end{array}$ & 14.15 & $\begin{array}{r}3,753,099 \\
(100.0 \%)\end{array}$ & $\begin{array}{r}35,961 \\
(100.0 \%)\end{array}$ & 11.06 \\
\hline $5-15$ & $\begin{array}{l}815,873 \\
(12.3 \%)\end{array}$ & $\begin{array}{r}7,498 \\
(10.3 \%)\end{array}$ & 10.01 & $\begin{array}{r}343,499 \\
(11.9 \%)\end{array}$ & $\begin{array}{r}3,168 \\
(8.7 \%)\end{array}$ & 9.93 & $\begin{array}{r}472,374 \\
(12.6 \%)\end{array}$ & $\begin{array}{r}4,331 \\
(12.0 \%)\end{array}$ & 10.08 \\
\hline 16-19 & $\begin{array}{r}574,931 \\
(8.7 \%)\end{array}$ & $\begin{array}{r}5,039 \\
(6.9 \%)\end{array}$ & 10.53 & $\begin{array}{l}276,503 \\
(9.6 \%)\end{array}$ & $\begin{array}{r}2,422 \\
(6.6 \%)\end{array}$ & 10.22 & $\begin{array}{l}298,428 \\
(8.0 \%)\end{array}$ & $\begin{array}{r}2,617 \\
(7.3 \%)\end{array}$ & 10.84 \\
\hline 20-29 & $\begin{array}{r}1,328,814 \\
(20.0 \%)\end{array}$ & $\begin{array}{r}11,948 \\
(16.5 \%)\end{array}$ & 10.33 & $\begin{array}{r}510,040 \\
(17.7 \%)\end{array}$ & $\begin{array}{r}4,691 \\
(12.8 \%)\end{array}$ & 10.74 & $\begin{array}{r}818,774 \\
(21.8 \%)\end{array}$ & $\begin{array}{r}7,257 \\
(20.2 \%)\end{array}$ & 10.08 \\
\hline 30-39 & $\begin{array}{r}1,367,700 \\
(20.6 \%)\end{array}$ & $\begin{array}{r}15,813 \\
(21.8 \%)\end{array}$ & 13.22 & $\begin{array}{r}664,831 \\
(23.0 \%)\end{array}$ & $\begin{array}{r}7,889 \\
(21.5 \%)\end{array}$ & 13.15 & $\begin{array}{r}702,869 \\
(18.7 \%)\end{array}$ & $\begin{array}{r}7,923 \\
(22.0 \%)\end{array}$ & 13.28 \\
\hline $40-49$ & $\begin{array}{r}1,029,844 \\
(15.5 \%)\end{array}$ & $\begin{array}{r}11,521 \\
(15.9 \%)\end{array}$ & 12.70 & $\begin{array}{r}490,789 \\
(17.0 \%)\end{array}$ & $\begin{array}{r}6,278 \\
(17.1 \%)\end{array}$ & 14.60 & $\begin{array}{r}539,055 \\
(14.4 \%)\end{array}$ & $\begin{array}{r}5,243 \\
(14.6 \%)\end{array}$ & 10.98 \\
\hline $50-59$ & $\begin{array}{r}624,613 \\
(9.4 \%)\end{array}$ & $\begin{array}{r}6,144 \\
(8.5 \%)\end{array}$ & 11.21 & $\begin{array}{l}268,914 \\
(9.3 \%)\end{array}$ & $\begin{array}{r}3,306 \\
(9.0 \%)\end{array}$ & 13.17 & $\begin{array}{l}355,699 \\
(9.5 \%)\end{array}$ & $\begin{array}{r}2,838 \\
(7.9 \%)\end{array}$ & 9.56 \\
\hline $60-64$ & $\begin{array}{r}206,500 \\
(3.1 \%)\end{array}$ & $\begin{array}{r}2,569 \\
(3.5 \%)\end{array}$ & 15.04 & $\begin{array}{r}60,606 \\
(2.1 \%)\end{array}$ & $\begin{array}{r}1,164 \\
(3.2 \%)\end{array}$ & 21.93 & $\begin{array}{l}145,894 \\
(3.9 \%)\end{array}$ & $\begin{array}{r}1,405 \\
(3.9 \%)\end{array}$ & 11.94 \\
\hline $65+$ & $\begin{array}{l}690,063 \\
(10.4 \%)\end{array}$ & $\begin{array}{r}12,045 \\
(16.6 \%)\end{array}$ & 19.01 & $\begin{array}{l}270,057 \\
(9.4 \%)\end{array}$ & $\begin{array}{r}7,699 \\
(21.0 \%)\end{array}$ & 29.43 & $\begin{array}{r}420,006 \\
(11.2 \%)\end{array}$ & $\begin{array}{r}4,347 \\
(12.1 \%)\end{array}$ & 11.69 \\
\hline
\end{tabular}

Note:

- All tables reporting totals could include some unreported characteristics. 


\section{TABLE 8.16}

\section{PMT Per Person for Public Transit Trips BY Household INCOME AND TRIP PURPOSE 1995 NPTS}

\begin{tabular}{|c|c|c|c|c|c|c|c|c|c|c|}
\hline Trip Purpose & TOTAL & $\begin{array}{l}\text { Less than } \\
\$ 10,000\end{array}$ & $\begin{array}{l}\$ 10,000- \\
\$ 20,000\end{array}$ & $\begin{array}{l}\$ 20,000- \\
\$ 30,000\end{array}$ & $\begin{array}{l}\$ 30,000- \\
\$ 40,000\end{array}$ & $\begin{array}{l}\$ 40,000- \\
\$ 50,000\end{array}$ & $\begin{array}{l}\$ 50,000- \\
\$ 60,000\end{array}$ & $\begin{array}{l}\$ 60,000- \\
\$ 70,000\end{array}$ & $\begin{array}{l}\$ 70,000- \\
\$ 80,000\end{array}$ & $\begin{array}{l}\$ 80,000 \\
\text { or more }\end{array}$ \\
\hline TOTAL & $8,245.4$ & $6,137.1$ & $7,391.5$ & $9,244.6$ & $7,950.5$ & $7,030.5$ & $12,422.6$ & $11,883.0$ & $9,853.3$ & $10,880.4$ \\
\hline \multicolumn{11}{|l|}{ Earning a Living } \\
\hline To Work & $1,557.5$ & 533.9 & $1,056.4$ & $1,101.1$ & $1,970.8$ & $1,097.5$ & $2,631.7$ & $4,659.3$ & $2,530.8$ & $3,158.7$ \\
\hline $\begin{array}{l}\text { Work-Related } \\
\text { Business }\end{array}$ & 249.5 & 5.0 & 135.0 & 16.2 & 65.0 & 8.0 & $1,968.5$ & 268.1 & 308.7 & 853.1 \\
\hline Return to Work & 9.3 & 6.4 & 0.3 & 1.7 & 11.8 & 12.1 & 4.7 & 42.4 & 23.6 & 0.1 \\
\hline Subtotal & $1,816.4$ & 545.3 & $1,191.7$ & $1,119.0$ & $2,047.7$ & $1,117.6$ & $4,605.0$ & $4,969.9$ & $2,863.1$ & $4,011.9$ \\
\hline \multicolumn{11}{|c|}{ Family/Personal Business } \\
\hline Shopping & 287.4 & 348.9 & 286.2 & 266.4 & 351.2 & 321.6 & 159.4 & 202.0 & 295.8 & 115.4 \\
\hline Medical/Dental & 106.6 & 157.4 & 161.0 & 104.9 & 82.8 & 23.5 & 7.1 & 151.7 & 58.8 & 148.3 \\
\hline $\begin{array}{l}\text { Other Family/ } \\
\text { Personal Business }\end{array}$ & 552.3 & 917.6 & 601.0 & 340.8 & 373.5 & 493.1 & 264.5 & 620.8 & 235.1 & $1,169.3$ \\
\hline $\begin{array}{l}\text { Take Someone } \\
\text { Somewhere }\end{array}$ & 146.4 & 103.7 & 90.0 & 39.5 & 76.1 & 51.2 & 4.4 & 585.6 & $* *$ & 672.1 \\
\hline Pick Up Someone & 74.6 & 57.8 & 59.7 & 7.2 & 150.7 & 348.3 & 19.8 & $* *$ & 26.4 & 54.1 \\
\hline Subtotal & $1,167.3$ & $1,585.4$ & $1,198.0$ & 758.9 & $1,034.4$ & $1,237.7$ & 455.3 & $1,560.1$ & 616.1 & $2,159.1$ \\
\hline \multicolumn{11}{|l|}{ School or Church } \\
\hline School & 356.7 & 184.1 & 356.0 & 650.3 & 232.2 & 261.6 & 96.5 & 485.4 & $1,026.8$ & 49.1 \\
\hline Religious Activity & 107.6 & 30.1 & 289.2 & 97.8 & 3.8 & 175.7 & 27.7 & 7.8 & $* *$ & 219.8 \\
\hline Subtotal & 464.3 & 214.2 & 645.2 & 748.1 & 236.0 & 437.3 & 124.2 & 493.2 & $1,026.8$ & 268.9 \\
\hline \multicolumn{11}{|l|}{ Social/Recreational } \\
\hline Vacation & 219.1 & ** & 3.3 & 654.9 & ** & 160.6 & $2,480.9$ & $* *$ & 6.9 & $* *$ \\
\hline $\begin{array}{l}\text { Visit Friends/ } \\
\text { Relatives }\end{array}$ & 308.7 & 342.6 & 319.4 & 439.6 & 142.5 & 281.1 & 582.5 & 36.9 & $* *$ & 257.5 \\
\hline Out to Eat & 159.5 & 19.2 & 274.1 & 395.3 & 69.2 & 121.6 & 34.8 & 307.3 & 26.5 & 73.8 \\
\hline $\begin{array}{l}\text { Other Social/ } \\
\text { Recreational }\end{array}$ & 952.6 & $1,038.5$ & 709.4 & $1,084.1$ & 942.7 & $1,160.4$ & 533.8 & 54.7 & $1,844.8$ & 685.5 \\
\hline Subtotal & $1,640.0$ & $1,400.3$ & $1,306.2$ & $2,573.9$ & $1,154.4$ & $1,723.6$ & $3,631.9$ & 398.9 & $1,878.3$ & $1,016.8$ \\
\hline \multicolumn{11}{|c|}{ Other and Returning Home } \\
\hline Other & 13.6 & 1.1 & 8.4 & 5.9 & 55.9 & $* *$ & 2.1 & 79.1 & $* *$ & 17.1 \\
\hline Returning Home & $3,143.8$ & $2,390.8$ & $3,041.9$ & 4,038.9 & $3,422.0$ & $2,514.3$ & $3,604.2$ & $4,381.8$ & $3,469.1$ & $3,406.6$ \\
\hline Subtotal & $3,157.5$ & $2,391.9$ & $3,050.4$ & $4,044.8$ & $3,477.9$ & $2,514.3$ & $3,606.2$ & $4,460.9$ & $3,469.1$ & $3,423.7$ \\
\hline
\end{tabular}

Note:

- All tables reporting totals could include some unreported characteristics.

- ** Indicates no data available. 


\section{TABLE 8.17}

\section{Public Transit Person Trips (in thousands) by Population Density and Mode 1995 NPTS}

\begin{tabular}{|c|c|c|c|c|c|}
\hline \multirow{2}{*}{$\begin{array}{l}\text { Population } \\
\text { Density }\end{array}$} & \multirow[b]{2}{*}{ TOTAL } & \multicolumn{4}{|c|}{ Transportation Mode } \\
\hline & & Bus & Commuter Train & Streetcar/Trolley & Subway/Elev. Rail \\
\hline \multirow[t]{2}{*}{ TOTAL } & $6,638,338$ & $4,541,375$ & 624,880 & 41,661 & $1,430,422$ \\
\hline & $(100.0 \%)$ & $(68.4 \%)$ & $(9.4 \%)$ & $(0.6 \%)$ & $(21.5 \%)$ \\
\hline \multirow[t]{2}{*}{ Less than 2000} & 611,850 & 481,456 & 66,999 & 9,097 & 54,298 \\
\hline & $(100.0 \%)$ & $(78.7 \%)$ & $(11.0 \%)$ & $(1.5 \%)$ & $(8.9 \%)$ \\
\hline \multirow[t]{2}{*}{2,000 to 4,000} & 616,999 & 468,315 & 95,474 & $* *$ & 53,211 \\
\hline & $(100.0 \%)$ & $(75.9 \%)$ & $(15.5 \%)$ & $(0.0 \%)$ & $(8.6 \%)$ \\
\hline \multirow[t]{2}{*}{4,000 to 10,000} & $1,424,758$ & $1,123,362$ & 126,721 & 6,667 & 168,008 \\
\hline & $(100.0 \%)$ & $(78.8 \%)$ & $(8.9 \%)$ & $(0.5 \%)$ & $(11.8 \%)$ \\
\hline \multirow[t]{2}{*}{10,000 or more } & $3,934,343$ & $2,424,582$ & 332,093 & 25,897 & $1,151,771$ \\
\hline & $(100.0 \%)$ & $(61.6 \%)$ & $(8.4 \%)$ & $(0.7 \%)$ & $(29.3 \%)$ \\
\hline
\end{tabular}

Note:

- All tables reporting totals could include some unreported characteristics.

- Population density is calculated as persons per square miles for the zip code in which the household is located.

- ** Indicates no data available.

\section{FIGURE 8.9}

Public Transit Person Trips by Population Density and Mode 1995 NPTS

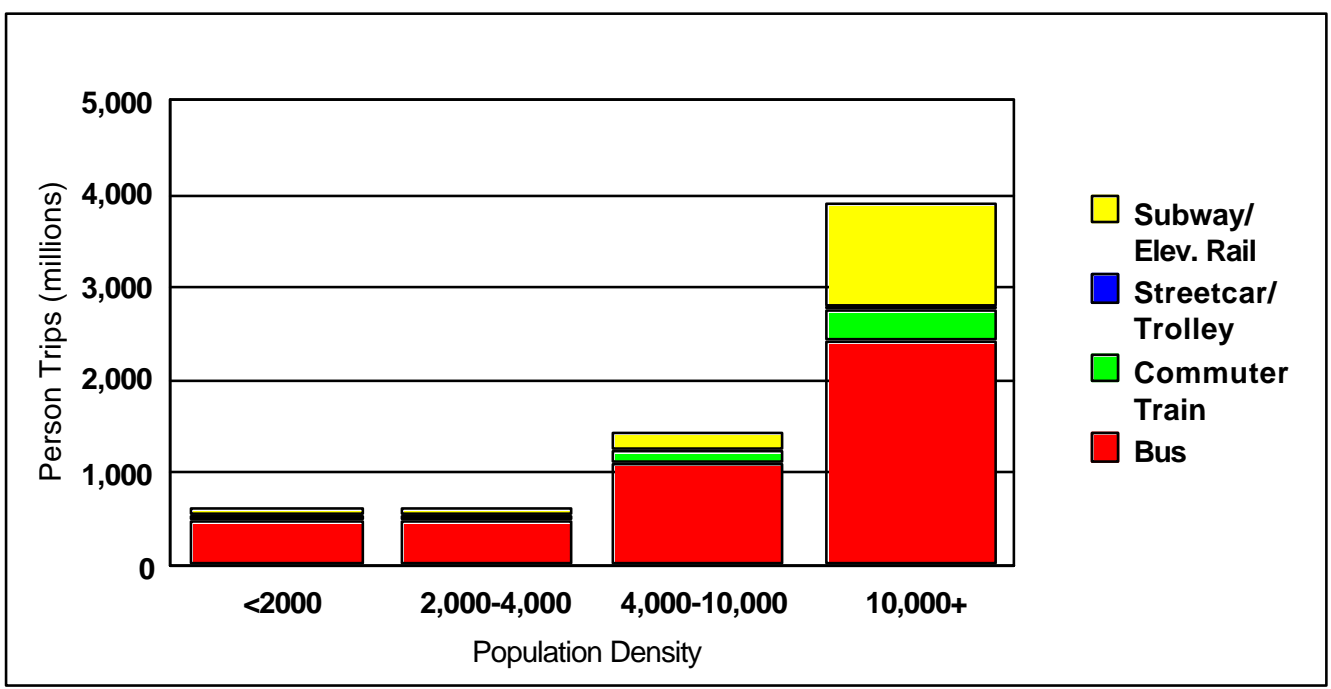




\section{APPENDIX A}

\section{Travel Concepts ANd Glossary OF TeRms}

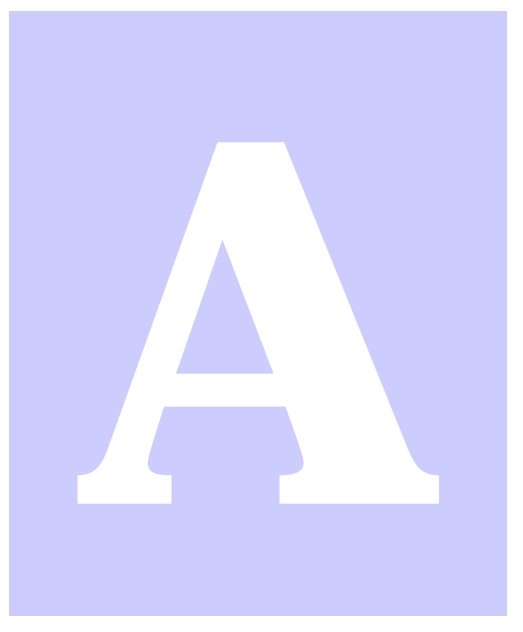

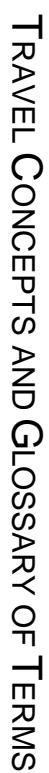




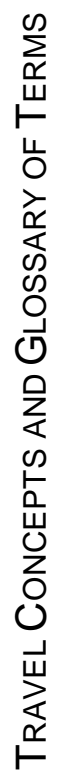




\title{
Appendix A. Travel Concepts and Glossary of Terms
}

\author{
Travel Concepts
}

PERSON TRIP

An understanding of the concepts defined in this section is intrinsic to an understanding of the tables in this Databook.

DEFINITION - A trip by one person in any mode of transportation. This is the most basic and universal measure of personal travel. Each record in the Travel Day and Travel Period files in the NPTS data set represents one person trip.

EXAMPLES - Two people traveling together in one car are counted as two person trips. Three people walking to the store together are counted as three person trips.

PERSON

MILES OF

TRAVEL (PMT)
DEFINITION - The number of miles traveled by each person on a trip.

EXAMPLES - If two people traveling together take a six-mile subway trip to the airport, that trip results in 12 person miles of travel. A four-mile van trip with a driver and three passengers counts as 16 person miles of travel.

DEFINITION - A trip by a single privately operated vehicle (POV) regardless of the number of persons in the vehicle.

EXAMPLES - Two people traveling together in a car would be counted as one vehicle trip. Four people going to a restaurant in a van is considered one vehicle trip.

NPTS MODE RESTRICTIONS - To be considered a vehicle trip in NPTS, the trip must have been made in a privately operated vehicle, namely a household-based car, van, sport utility vehicle, pickup truck, other truck, recreational vehicle, motorcycle or other POV. The vehicle does not need to belong to the household.

Trips made in other highway vehicles, such as buses, streetcars, taxis, and school buses are collected in the NPTS, but these are shown as person trips by those modes. The design of the NPTS is such that it does not serve as a source for vehicle trips in modes such as buses, because there is no way to trace the movement of the bus fleet throughout the day. Those interested in 
vehicle trips by buses, taxis, etc. need to use a data source that relies on reports from the fleet operators of those vehicles. The National Transit database (www.fta.dot.gov/ntl/index.html) provided by the Federal Transit Administration is one such source.

VEHICLE MILES OF TRAVEL (VMT)

VEHICLE OCCUPANCY
DEFINITION - One vehicle mile of travel is the movement of one privately operated vehicle (POV) for one mile, regardless of the number of people in the vehicle.

EXAMPLES - When one person drives her car 12 miles to work, 12 vehicle miles of travel have been made. If two people travel three miles by pickup, three vehicle miles of travel have been made.

NPTS MODE RESTRICTIONS - For NPTS data, vehicle miles are restricted to the same privately-operated vehicles as vehicle trips (see above) - that is, a household-based car, van, sport utility vehicle, pickup truck, other truck, recreational vehicle, or other POV.

DEFINITION - For NPTS data, vehicle occupancy is generally computed as person miles of travel per vehicle mile (referred to as the travel method). Note that the other commonly-used definition of vehicle occupancy is persons per vehicle trip (referred to as the trip method).

COMMENTS - Because longer trips often have higher occupancies, the travel method generally yields a higher rate (1.59 for the 1995 NPTS) than the trip method (1.50). The calculation of the travel method requires that trip miles be reported, thus it is calculated on a slightly smaller number of trips than the trip method. 


\section{Glossary OF TERMS}

This glossary provides the most common terms used in the NPTS and definitions of those terms. These definitions are provided to assist the user in the interpretation of the NPTS data.

Adult

Consolidated

Metropolitan

Statistical Area

(CMSA)

Destination

Driver

Employed

Education Level

Household

Household Income
For NPTS, this is defined as a person 18 years or older.

A large metropolitan complex of 1 million or more population, containing two or more identifiable component parts designated as primary metropolitan statistical areas (PMSAs). For example, the Boston CMSA is composed of six PMSAs.

- $\quad$ For travel day trips, the destination is the point at which there is a break in travel, except if the break is only to change vehicles or means of transport.

- $\quad$ For travel period trips, the destination is the farthest point of travel.

A driver is a person who operates a motorized vehicle. If more than one person drives on a single trip, the person who drives the most miles is classified as the principal driver.

A person is considered employed if he/she worked for pay, either full time or part time, during the week before the interview.

The number of years of regular schooling completed in graded public, private, or parochial schools, or in colleges, universities, or professional schools, whether day school or night school. Regular schooling advances a person toward an elementary or high school diploma, or a college, university, or professional school degree.

A group of persons whose usual place of residence is a specific housing unit; these persons may or may not be related to each other. The total of all U.S. households represents the total civilian non-institutionalized population. A household does not include group quarters (i.e., 10 or more persons living together, none of whom are related).

Household income is the money earned by all family members in a household, including those temporarily absent. Annual income consisted of the income earned 12 months preceding the interview. Household income includes monies from all sources, such as wages and salary, commissions, tips, cash 
bonuses, income from a business or farm, pensions, dividends, interest, unemployment or workmen's compensation, social security, veterans' payments, rent received from owned property (minus the operating costs), public assistance payments, regular gifts of money from friends or relatives not living in the household, alimony, child support, and other kinds of periodic money income other than earnings. Household income excludes in-kind income such as room and board, insurance payments, lump-sum inheritances, occasional gifts of money from persons not living in the same household, withdrawal of savings from banks, tax refunds, and the proceeds of the sale of one's house, car, or other personal property.

Household Members

Household Vehicle

Licensed Driver

Means of Transportation
Household members include all people, whether present or temporarily absent, whose usual place of residence is in the sample unit. Household members also include people staying in the sample unit who have no other usual place of residence elsewhere.

A household vehicle is a motorized vehicle that is owned, leased, rented or company-owned and available to be used regularly by household members during the two-week travel period. Household vehicles include vehicles used solely for business purposes or business-owned vehicles, so long as they are driven home and can be used for the home to work trip (e.g., taxicabs, police cars, etc.). Household vehicles include all vehicles that were owned or available for use by members of the household during the travel period, even though a vehicle may have been sold before the interview. Vehicles excluded from household vehicles are those which were not working and were not expected to be working within 60 days, and vehicles that were purchased or received after the designated travel day.

A licensed driver is any person who holds a valid driver's license from any state.

A mode of travel used for going from one place (origin) to another (destination). A means of transportation includes private and public modes, as well as walking. For all travel day trips, each change of mode constitutes a separate trip. The following transportation modes, grouped by major mode, are included in the NPTS data.

\section{Private Vehicle}

Automobile A privately owned and/or operated licensed motorized vehicle including cars and station wagons. Leased and rented cars are included if they are privately operated and not used for picking up passengers in return for fare. 
Van A privately owned and/or operated van or minivan designed to carry 5 to 13 passengers, or to haul cargo.

Sport Utility Vehicle A privately owned and/or operated vehicle that is a hybrid of design elements from a van, a pickup truck, and a station wagon. Examples include a Chevrolet Blazer, Ford Bronco, Jeep Cherokee, or Nissan Pathfinder.

Pickup Truck A pickup truck is a motorized vehicle, privately owned and/or operated, with an enclosed cab that usually accommodates 2-3 passengers, and an open cargo area in the rear. Pickup trucks usually have the same size of wheel-base as a full-size station wagon. This category also includes pickups with campers.

Other Truck This category consists of all trucks other than pickup trucks (i.e., dump trucks, trailer trucks, etc.).

RV or Motor Home An RV or motor home includes a self-powered recreational vehicle that is operated as a unit without being towed by another vehicle (e.g., a Winnebago motor home).

Motorcycle This category includes large, medium, and small motorcycles. Minibikes are excluded because they cannot be licensed for highway use.

Other POV A vehicle that cannot be classified into one of the categories above.

\section{Public Transportation}

Bus The bus category includes intercity buses, mass transit systems, and shuttle buses that are available to the general public. Also, Dial-ABus and Senior Citizen buses that are available to the public are included in this category. However, shuttle buses operated by a government agency or private industry for the convenience of employees, contracted or chartered buses, or school buses are excluded from this category.

Commuter Train This category includes commuter trains and passenger trains other than elevated rail trains and subways. Commuter train also includes local and commuter train service. Amtrak intercity service is excluded from this category. 
Streetcar/Trolley This category includes trolleys, street-cars, and cable cars.

Elevated Rail/Subway This category includes elevated railways and subway trains in a city.

\section{OTHER Modes}

Amtrak Amtrak is defined as the U.S. national passenger railroad service providing intercity train service. Amtrak intercity service is excluded from the commuter train data.

Airplane Airplanes include commercial airplanes and smaller planes that are available for use by the general public in exchange for a fare. Private planes and helicopters are included under "Other."

Taxi Taxis include the use of a taxicab by a driver for hire, or by a passenger for fare, and airport limousines. The taxi category does not include rental cars if they are privately operated and not picking up passengers in return for fare.

Bicycles This category includes bicycles of all speeds and sizes that do not have a motor.

Walk This category includes walking and jogging.

School Bus This category includes county school buses, private school buses, and buses chartered from private companies for the express purposes of carrying students to or from school and/or school-related activities.

Moped (Motorized Bicycle) This category includes motorized bicycles equipped with a small engine, typically characteristic of a two horsepower motor or less. Minibikes, dirt bikes, and trail bikes are excluded from this category. Note that a motorized bicycle may or may not be licensed for highway use.

Other Includes any type of transportation not previously listed, e.g., ferry boat.

Metropolitan Statistical Area (MSA)
Except in the New England States, a Metropolitan Statistical Area is a county or group of contiguous counties which contains at least one city of 50,000 inhabitants or more, or "twin cities" with a combined population of at least 
50,000. In addition, contiguous counties are included in an MSA if, according to certain criteria, they are socially and economically integrated with the central city. In the New England States, MSA's consist of towns and cities instead of counties.

\section{Motorized \\ Vehicle}

Occupancy

Passenger

Person Miles of Travel (PMT)

Person Trip

POV

Travel Day

Travel Day Trip
Motorized vehicles are all vehicles that are licensed for highway driving. Snowmobiles and minibikes are specifically excluded.

Occupancy is the number of persons, including driver and passenger(s) in a vehicle. NPTS occupancy rates are generally calculated as person miles divided by vehicle miles.

For a specific trip, a passenger is any occupant of a motorized vehicle, other than the driver.

PMT is a primary measure of person travel. When one person travels one mile, one person mile of travel results. Where two or more persons travel together in the same vehicle, each person makes the same number of person miles as the vehicle miles. Therefore, four persons traveling 5 miles in the same vehicle results in 20 person miles $(4 \times 5=20)$.

A person trip is a trip by one or more persons in any mode of transportation. Each person is considered as making one person trip. For example, four persons traveling together in one auto are counted as four person trips.

A privately-owned vehicle or privately-operated vehicle. Either way, the intent here is that this is not a vehicle available to the public for a fee, such as a bus, subway, taxi, etc.

A travel day is a 24-hour period from 4:00 a.m. to 3:59 a.m. designated as the reference period for studying trips and travel by members of a sampled household.

A travel day trip is defined as any trip when the respondent went from one address to another by private motor vehicle, public transportation, bicycle, walking, or other means. However, a separate trip is not counted in two instances:

1. When the sole purpose for the trip is to get to another vehicle or mode of transportation in order to continue to the destination.

2. When travel is within a shopping center, mall, or shopping areas of 4-5 blocks. 
A trip purpose is the main reason that motivates a trip. For purposes of this report, there are 11 trip reasons. For travel day trips, if there is more than one reason, and the reasons do not involve different destinations, then only the main reason is chosen. If there are two or more reasons, and they each involve different destinations, then each reason is classified as a separate trip. For travel period trips, if there is more than one reason, the primary reason is collected. The 11 trip reasons (grouped into the six major purposes) are defined as follows:

\section{EARNING A LIVING}

To Work Travel between home and a place where one reports for work.

Work-Related Trips for the respondent's job or business, other than to or from the workplace (e.g., a plumber drives to a wholesale dealer to purchase supplies for his business, or a company executive travels from his office to another firm to attend a business meeting). Out-of-town business trips and professional conventions are included in this category.

Return to Work Travel to the workplace after leaving for some purpose (e.g., returning to work from lunch, meetings, etc.).

\section{FAmily and Personal Business}

Shopping Shopping includes "window-shopping" and purchases of commodities such as groceries, furniture, clothing, etc. for use or consumption elsewhere.

Doctor/Dentist This category includes trips made for medical, dental, or psychiatric treatment, or other related professional services.

Other Family or Personal Business This category includes the purchase of services such as cleaning garments, servicing an automobile, haircuts, banking, legal services, etc.

Take Someone Somewhere This trip purpose is primarily to take a passenger somewhere.

Pick Up Someone This purpose is to pick up a passenger. 


\section{SCHOOL OR CHURCH}

School/Church This category includes trips to school, college or university (for classes), or to PTA meetings, seminars, etc., or to church services or to participate in other religious activities.

Social activities that take place at a church or school, but cannot be classified as religious or educational are not included in this category.

\section{SOCIAL AND RECREATIONAL}

Vacation This category is for trips reported by the respondent as "vacation."

Visit Friends or Relatives Trips which are specifically designated to visit friends or relatives.

Out to Eat Driving trips made with "going out to eat" as the primary purpose.

Other Social or Recreational Trips taken to enjoy some form of social activity involving friends or acquaintances. This category includes trips for general entertainment or recreation (both as observer or as participant).

\section{OTHER}

Other For trips that do not fit in any of the other categories.

\section{RETURNING HOME}

Home Returning home is a new trip category added in the 1995 survey to aid to analyzing to-from trips. The purpose of this trip is to return home from some other trip destination.

Urbanized Area

An urbanized area consists of the built up area surrounding a central core (or central city), with a population density of at least 1,000 persons per square mile. Urbanized areas do not follow jurisdictional boundaries; thus, it is common for the urbanized area boundary to divide a county.

For the 1995 NPTS, an approximate classification of sample households was based upon the population density of the Census block group containing the household. Households in block groups estimated to have at least 1,000 
persons per square mile were classed as urban; those in block groups with less than 1,000 persons per square mile were classed as not urban.

Vehicle

Vehicle Miles of Travel (VMT)

Vehicle Occupancy

Vehicle Trip

Vehicle Type
In the 1995 NPTS, the term vehicle includes autos, passenger vans, sport utility vehicles, pickups and other light trucks, RV's, motorcycles and mopeds owned or available to the household. Note that in the 1969 NPTS, the term vehicle was limited to cars or passenger vans. Estimates show that in 1969 there were an additional 7.5 million pickups and other light trucks that are not reflected in the 1969 NPTS data.

VMT is a unit to measure vehicle travel made by a private vehicle, such as an automobile, van, pickup truck, or motorcycle. Each mile traveled is counted as one vehicle mile regardless of the number of persons in the vehicle.

Vehicle occupancy is the number of persons, including driver and passenger(s) in a vehicle; also includes persons who did not complete a whole trip. NPTS occupancy rates are generally calculated as person miles divided by vehicle miles.

A trip by a single privately-operated vehicle (POV) regardless of the number of persons in the vehicle.

For purposes of the 1995 NPTS, one of the following:

1. Automobile (including station wagon)

2. Van

3. Sport Utility Vehicle

4. Pickup Truck (including pickup with camper)

5. Other Truck

6. RV or Motor Home

7. Motorcycle

8. Other

See "Means of Transportation" for definitions of these vehicle types. For NPTS, vehicle types are limited to privately operated vehicles (POV) because other vehicles that the respondent may have ridden in (e.g., bus) were not tracked throughout the day, as was the case with household vehicles.

Weekday is defined as the time between 12:01 a.m. Monday and midnight Friday. 
Weekend

Weekend is defined as the time between 12:01 a.m. Saturday and midnight Sunday.

Worker See "Employed."

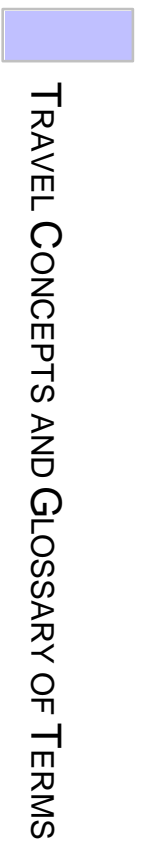




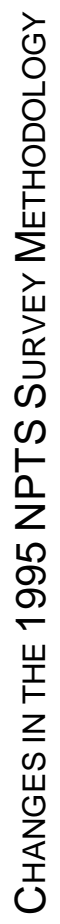




\section{Appendix B}

Changes in the 1995 NPTS Survey Methodology and Their Probable Impacts

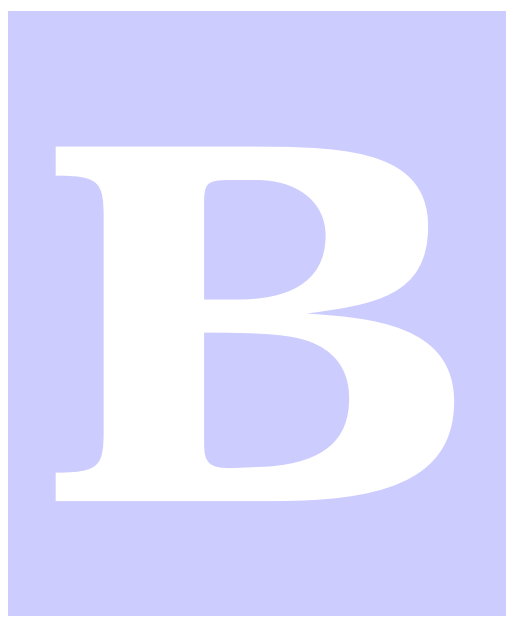

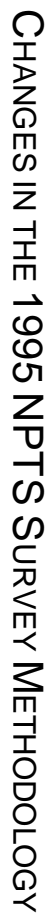




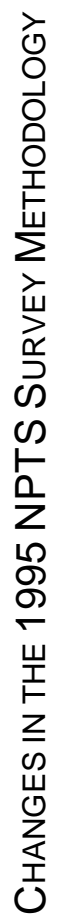


APPENDIX B. ChANGES IN THE 1995 NPTS SURVEY

Methodology and Their Probable ImpactS

\begin{tabular}{|c|c|c|c|}
\hline Change & From 1990 & To 1995 & Probable Impacts \\
\hline \multirow[t]{2}{*}{ Respondent Contact } & No advance letters & Advance letters & $\begin{array}{l}\text { Improved response. } \\
\text { Legitimizes the survey with } \\
\text { respondents. }\end{array}$ \\
\hline & No incentive & $\begin{array}{l}\text { Incentive } \\
\text { (\$2/person) }\end{array}$ & $\begin{array}{l}\text { Improved respondent } \\
\text { cooperation rates, may have } \\
\text { increased trip reporting. }\end{array}$ \\
\hline \multirow[t]{6}{*}{ Trip Reporting } & Recall & Travel Diary & $\begin{array}{l}\text { More trips reported, } \\
\text { especially incidental trips } \\
\text { and trips for family \& } \\
\text { personal business and social } \\
\& \text { recreational purposes. }\end{array}$ \\
\hline & $\begin{array}{l}\text { All trips for individual } \\
\text { person are collected } \\
\text { independently }\end{array}$ & $\begin{array}{l}\text { Household rostering } \\
\text { of trips }\end{array}$ & $\begin{array}{l}\text { Include trips that may have } \\
\text { been forgotten. More } \\
\text { consistent trip data. Lower } \\
\text { respondent burden. More } \\
\text { coherent picture of } \\
\text { household trip making. }\end{array}$ \\
\hline & $\begin{array}{l}\text { Did not specifically } \\
\text { confirm zero trips }\end{array}$ & $\begin{array}{l}\text { Specifically } \\
\text { confirmed zero trips }\end{array}$ & $\begin{array}{l}\text { More accurate count of } \\
\text { persons who made no trips } \\
\text { on their assigned travel day. }\end{array}$ \\
\hline & Proxy from memory & Proxy from diary & $\begin{array}{l}\text { More trips reported. More } \\
\text { accurate reporting of trip } \\
\text { characteristics. }\end{array}$ \\
\hline & Trip definition & $\begin{array}{l}\text { Clearer trip } \\
\text { definition }\end{array}$ & $\begin{array}{l}\text { Easier for respondent to } \\
\text { report trips. Interviewers } \\
\text { more attuned to pick up } \\
\text { incidental trips. }\end{array}$ \\
\hline & On-line edits & $\begin{array}{l}\text { Additional on-line } \\
\text { edits }\end{array}$ & $\begin{array}{l}\text { More coherent trip } \\
\text { reporting. Improved data } \\
\text { quality. }\end{array}$ \\
\hline $\begin{array}{l}\text { Completed } \\
\text { household definition }\end{array}$ & $\begin{array}{l}\text { At least one person } \\
\text { completed the travel- } \\
\text { day interview }\end{array}$ & $\begin{array}{l}\text { At least } 50 \% \text { of the } \\
\text { adults completed the } \\
\text { travel-day interview }\end{array}$ & $\begin{array}{l}\text { A more accurate } \\
\text { representation of travel by } \\
\text { the household unit. }\end{array}$ \\
\hline
\end{tabular}




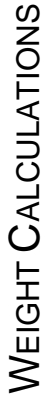




\section{Appendix C}

\section{Weight Calculations}

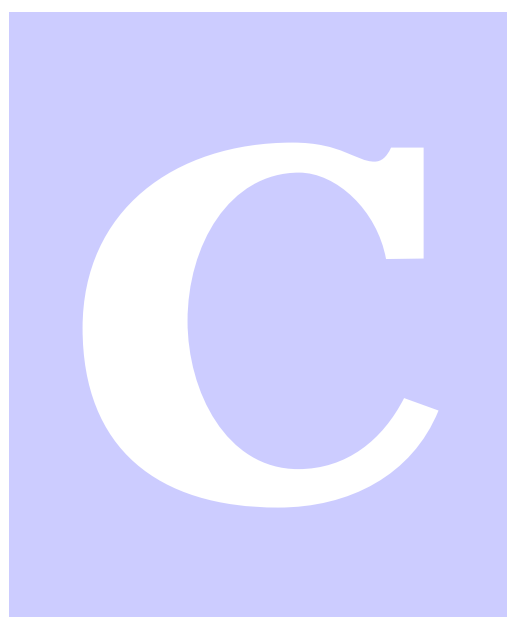

क 


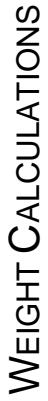




\section{Appendix C. Weight Calculations ${ }^{1}$}

\section{WEIGHTS}

The purpose of weighting in NPTS is to expand the sample data to estimates for the U.S. population. There are four different NPTS weights that are used to compute different kinds of population estimates. The methods used to calculate each of the four weights are discussed in the sections which follow.

\section{HOUSEHOLD WEIGHTS}

With the NPTS list-assisted sample design, all in-sample households have a known, nonzero probability of selection. The unadjusted household weight is simply the reciprocal of the household's selection probability.

Since household telephone numbers were selected with equal probabilities within each sample stratum, the initial household sampling weights are computed simply as the ratio of the number of sampling units (telephone numbers) in the sampling frame for a stratum to the number of sample telephone numbers released for calling.

The initial sampling weights were adjusted for multiplicities arising from households that had more than one residential telephone number in the sampling frame, i.e., more than one chance of being in the sample.

Then the household weights were adjusted to sum to $98,990,000$, an estimate of the number of U.S. households in 1995, to correct for non-responding households.
Note that the estimated number of households includes those with and without telephones.

The household weights were then adjusted to equal marginal totals for the important variables listed below, to correct for nonresponse and non-coverage, and to reduce non-response bias. The basic concept is to adjust the sampling weights of the survey respondents so that they sum to known external totals, e.g., Census totals. A method of iterative proportional fitting was used to adjust the household weights simultaneously so the sums agreed closely with the following marginal controls:

- $\quad$ Equal weight totals for each of the 12 months of the year.

- Geographic areas - estimated total households in the four Census regions plus sub-regions associated with the add-on areas (39 total areas).

- U.S.-level Current Population Estimates of the numbers of Black and non-Black households.

- U.S.-level Current Population Estimates of the numbers of Hispanic and nonHispanic households.

- $\quad$ Five categories of MSA population sizes.

- $\quad$ Four household size categories (1, 2, 3, and 4 or more persons).

The adjusted household weights are appropriate for use in weighting all NPTS household variable data and vehicle variable data, since information on vehicles was collected at the household level. This variable is WTHHFIN.

\footnotetext{
${ }^{1}$ Source:U.S. Department of Transportation, Federal Highway Administration, 1995Nationwide Personal Transportation Survey: User's Guide for the Public Use Tapes, pp. 3-22 to 3-25, Washington, DC, October 1997.
} 
NOTE: It is NOT appropriate to summarize travel day or travel period travel at the household level and then weight the estimate by the household weight. Travel data was collected at the person level, and a derivation of the person weight, such as the trip weight, must be used to obtain accurate estimates of travel day and travel period data. This is primarily because the person weight and the trip weights have been adjusted to account for non-interviewed persons within an interviewed household.

\section{Person Weights}

Since there was no sub-sampling of ageeligible persons within NPTS sample households, the household weights would also be appropriate for weighting the person data if data for 100 percent of the eligible persons within sample households had been obtained. Since that was not the case, the person weights were adjusted to compensate for person-level non-response in the 1995 NPTS. The sum of all person weights was adjusted to equal 241,675,000, an estimate of the number of U.S. residents in 1995 five years and older. Post-stratification weight adjustments were also made to adjust the person weights to the following external known totals:

- $\quad$ Equal weight totals for each of the 12 months of the year.

- Geographic areas - estimated total persons in the four Census regions plus sub-regions associated with the add-on areas (39 total areas).

- U.S.-level Current Population Estimates of the numbers of Black and non-Black persons.

- U.S.-level Current Population Estimates of the numbers of Hispanic and nonHispanic persons.

- $\quad$ Ten categories of U.S. level age by gender populations (males and females each by the following ages: 5 - 17 years; 18 - 34; 35 - 44; 45 - 64; and 65 years and older).

The adjusted person weight, variable WTPERFIN, should be used to weight all person-level data from the 1995 NPTS survey. Person weights form the basis of the travel day and travel period weights, since person weights are adjusted to account for non-interviewed persons within an interviewed household.

\section{Travel File Weights}

The two trip-level weights are simple functions of the adjusted person weights. There is no adjustment to be made for triplevel non-response, since the trip data had to be obtained in order for the person to be treated as a responding person. Each person's travel-day trip weight, variable WTTRDFIN, was calculated by multiplying the final person weight, WTPERFIN, times 365 to expand the person's travel day to an annual total. This weight is appropriate for weighting data from the travel day trip file and the segmented travel day trip file. The travel period weight, variable WTTRPFIN, for a person was calculated by dividing their travel day weight by 14 , to reflect the 14-day travel period. 


\section{APPENDIX D}

\section{StANDARD ERror TABLES}

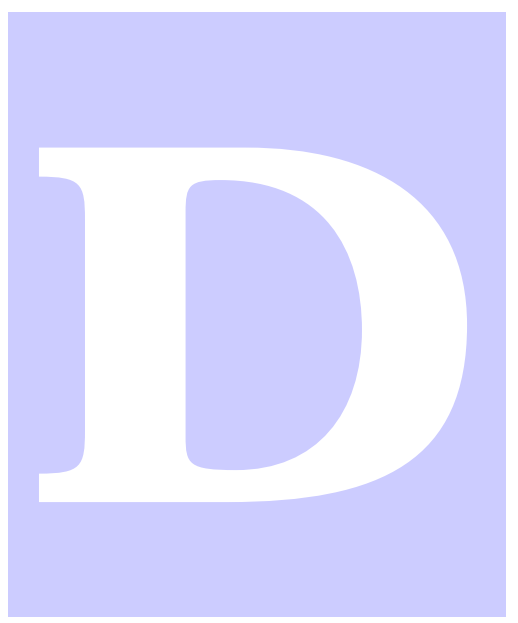

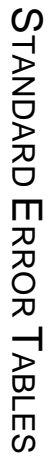




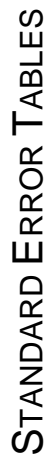




\section{Appendix D Standard Error Tables}

$\mathrm{T}$ HE final adjusted weights are used in calculating parameter estimates and their sample variance. The standard error estimates shown in the following tables were obtained using the ultimate cluster variance formula. Further information on calculating standard errors using this method can be found in Appendix $\mathrm{F}$ and Appendix $\mathrm{G}$ of the CENVAR, Variance Calculation System User's Guide (U.S. Department of Commerce, Bureau of the Census, International Systems Team, Washington, D.C., January, 1995).

The standard errors that are shown in the following tables reflect the sampling error and also the variation in estimates due to some nonsampling errors. Sampling error is due to variability between estimates from all other possible samples of the same size that could have been selected using the same sample design (e.g., variation that occurred by chance because a sample was surveyed rather than the entire household population). Estimates that were derived from any of these different samples would differ from one another. This variability and some nonsampling error are measured by the standard error. Nonsampling error can be attributed to several sources including the following:

- The inability to obtain information about all cases in the sample unit and item (nonresponse)

- $\quad$ The inability to obtain correct information from respondents

- $\quad$ Errors made in data collection such as recording and coding errors

- $\quad$ Errors made in data processing

- $\quad$ Failure to represent all units with the sample (noncoverage)

Sampling errors shown in this report are primarily measures of sampling variability although they may include some nonsampling error. Thus, the accuracy of the estimates given is dependent on the sampling error and nonsampling errors which are measured by the standard error, and also on the biases and nonsampling errors which are not measured by the standard error.

The standard error of these estimates can be used to construct an interval around specific estimates. This interval will include, with a given amount of confidence, the true population value. About 68 percent of the intervals, created by subtracting one standard error and adding one standard error, will include the true population value. About 95 percent of the intervals, created by subtracting two standard errors and adding two standard errors, will include the true population value, and about 99.75 percent of the intervals, created by subtracting and adding three standard errors, will include the true population value. Thus, one can state, with a given percent of confidence (as stated above) that the computed interval will contain the true population value.

An example of how these standard errors could be used is as follows. One may want to know the average person trips per person for females between the ages of 5 and 15 . The estimate of the average person trips per person for females between the ages of 5 and 15 in 1995 is 3.75. The standard error for this estimate, as found in Standard Errors for Table 4.4, is 0.05. To construct an interval that would include the true population value about 68 percent of the time, one would calculate: $3.75 \pm(1) 0.05$. Therefore, a 68 percent confidence interval for the true average of person trips per person, as shown by this data, would be included in the 
interval 3.70 to 3.80 person trips per person. An interval that would include the true person trips per person about 95 percent of the time would be constructed by solving: $3.75 \pm(2) 0.05$. Hence, a 95 percent confidence interval for the true average of person trips per person for females between the ages of 5 and 15 in 1995 is in the interval and their standard errors, through the Table Wizard in the Analysis section. These standard errors can be obtained by checking the box next to "Include standard error calculations" in the "Table Template" step of the wizard. Since standard errors for most tables can be obtained in such a manner, we present standard errors for only those tables that cannot be calculated through this interactive web site. The website can be found at http://www-cta.ornl.gov/npts .

\section{TABLE 4.4}

\section{Average Daily Person Trips Per Person by}

AGE AND GENDER

1995 NPTS STANDARD ERRORS

\begin{tabular}{||c|ccc||}
\hline \hline \multirow{2}{*}{ Standard Errors for: } & & \\
\hline & & 1995 & \\
\cline { 2 - 4 } Age & TOTAL & Male & Female \\
\hline TOTAL & 0.02 & 0.02 & 0.02 \\
$5-15$ & 0.04 & 0.05 & 0.05 \\
$16-19$ & 0.07 & 0.10 & 0.10 \\
$20-29$ & 0.05 & 0.07 & 0.06 \\
$30-39$ & 0.04 & 0.05 & 0.06 \\
$40-49$ & 0.04 & 0.06 & 0.06 \\
$50-59$ & 0.05 & 0.07 & 0.06 \\
$60-64$ & 0.09 & 0.14 & 0.09 \\
$65+$ & 0.05 & 0.07 & 0.05 \\
\hline
\end{tabular}

Note:

- $\quad$ Standard errors are not available for 1990 adjusted numbers. 


\section{TABLE 4.5}

Average PMT Per Person by Age And Gender 1995 NPTS STANDARD ERRORS

\begin{tabular}{|c|ccc||}
\hline \multirow{2}{*}{ Standard Errors for: } & & \\
\hline & & 1995 & \\
\cline { 2 - 4 } Age & TOTAL & Male & Female \\
\hline TOTAL & 0.52 & 0.67 & 0.55 \\
$5-15$ & 0.86 & 0.89 & 1.20 \\
$16-19$ & 1.79 & 2.37 & 2.70 \\
$20-29$ & 1.19 & 1.95 & 1.09 \\
$30-39$ & 1.07 & 1.54 & 1.20 \\
$40-49$ & 1.26 & 1.70 & 1.23 \\
$50-59$ & 1.48 & 2.07 & 1.49 \\
$60-64$ & 1.93 & 3.20 & 1.75 \\
$65+$ & 0.83 & 1.38 & 0.76 \\
\hline \hline
\end{tabular}

Note:

- Standard errors are not available for 1990 adjusted numbers. 


\section{TABLE 4.8}

Average Daily Person Travel

By GeNDER, Driver's LiCENSE (DL) StATUS, AND TRIP PURPOSE

1995 NPTS STANDARD ERRORS

\begin{tabular}{|c|c|c|c|c|c|c|}
\hline \multirow[b]{2}{*}{ Purpose } & \multicolumn{2}{|c|}{ ALL Persons } & \multicolumn{2}{|c|}{ Male } & \multicolumn{2}{|c|}{ Female } \\
\hline & $\begin{array}{c}\text { With } \\
\text { DL }\end{array}$ & $\begin{array}{c}\text { Without } \\
\text { DL }\end{array}$ & $\begin{array}{c}\text { With } \\
\text { DL }\end{array}$ & $\begin{array}{c}\text { Without } \\
\text { DL }\end{array}$ & $\begin{array}{c}\text { With } \\
\text { DL }\end{array}$ & $\begin{array}{c}\text { Without } \\
\text { DL }\end{array}$ \\
\hline \multicolumn{7}{|c|}{ Standard Errors for Average Daily Person Trips per Person } \\
\hline TOTAL & 0.02 & 0.03 & 0.03 & 0.04 & 0.03 & 0.04 \\
\hline Earning a Living & 0.01 & 0.00 & 0.01 & 0.01 & 0.01 & 0.00 \\
\hline Family/Personal Business & 0.01 & 0.01 & 0.01 & 0.02 & 0.01 & 0.01 \\
\hline School/Church & 0.00 & 0.01 & 0.00 & 0.01 & 0.00 & 0.01 \\
\hline Social/Recreational & 0.01 & 0.01 & 0.01 & 0.02 & 0.01 & 0.01 \\
\hline Other & 0.00 & 0.00 & 0.00 & 0.00 & 0.00 & 0.00 \\
\hline Returning Home & 0.00 & 0.00 & 0.00 & 0.00 & 0.00 & 0.00 \\
\hline \multicolumn{7}{|c|}{ Standard Errors for Average Daily Person Miles of Travel per Person } \\
\hline TOTAL & 0.59 & 0.66 & 0.79 & 0.80 & 0.62 & 0.82 \\
\hline Earning a Living & 0.21 & 0.05 & 0.37 & 0.08 & 0.17 & 0.05 \\
\hline Family/Personal Business & 0.29 & 0.35 & 0.34 & 0.36 & 0.32 & 0.40 \\
\hline School/Church & 0.05 & 0.06 & 0.06 & 0.08 & 0.08 & 0.07 \\
\hline Social/Recreational & 0.25 & 0.38 & 0.36 & 0.46 & 0.23 & 0.52 \\
\hline Other & 0.07 & 0.02 & 0.08 & 0.02 & 0.07 & 0.03 \\
\hline Returning Home & 0.23 & 0.21 & 0.30 & 0.26 & 0.24 & 0.28 \\
\hline
\end{tabular}

Note:

- Standard errors for the Average Person Trip Length (miles) portion of this table can be computed using the interactive web site. 


\section{TABLE 4.13}

Average Daily Person Trips Per Person by Mode of Transportation and Trip Purpose By INDIVIDUALs 65 YeARS ANd Older vs. Individuals Under 65 Years 1995 NPTS STANDARD ERRORS

\begin{tabular}{|c|c|c|c|c|c|}
\hline & TOTAL & POV Driver & POV Passenger & Public Transit & Other \\
\hline \multicolumn{6}{|c|}{ Standard Errors for Trips by Persons Under 65 Years of Age } \\
\hline TOTAL & 0.03 & 0.01 & 0.01 & 0.00 & 0.01 \\
\hline Earning a Living & 0.01 & 0.01 & 0.00 & 0.00 & 0.00 \\
\hline $\begin{array}{l}\text { Family/Personal } \\
\text { Business }\end{array}$ & 0.02 & 0.01 & 0.01 & 0.00 & 0.00 \\
\hline School/Church & 0.01 & 0.00 & 0.00 & 0.00 & 0.00 \\
\hline Social/Recreational & 0.01 & 0.01 & 0.01 & 0.00 & 0.01 \\
\hline Other & 0.00 & 0.00 & 0.00 & 0.00 & 0.00 \\
\hline Returning Home & 0.01 & 0.00 & 0.00 & 0.00 & 0.00 \\
\hline \multicolumn{6}{|c|}{ Standard Errors for Trips by Persons 65 Years or Older } \\
\hline TOTAL & 0.05 & 0.02 & 0.02 & 0.01 & 0.02 \\
\hline Earning a Living & 0.01 & 0.01 & 0.00 & 0.00 & 0.00 \\
\hline $\begin{array}{l}\text { Family/Personal } \\
\text { Business }\end{array}$ & 0.03 & 0.02 & 0.02 & 0.00 & 0.01 \\
\hline School/Church & 0.01 & 0.01 & 0.01 & $*$ & 0.00 \\
\hline Social/Recreational & 0.02 & 0.01 & 0.01 & 0.00 & 0.00 \\
\hline Other & 0.00 & 0.00 & 0.00 & $*$ & 0.00 \\
\hline Returning Home & 0.00 & 0.01 & 0.01 & 0.00 & 0.01 \\
\hline
\end{tabular}

Note:

- * Indicates that standard errors could not be computed for these cells. 


\section{TABLE 4.23}

Statistics on Daily Person Travel by Household Income and Trip Purpose 1995 NPTS STANDARD ERRORS

\begin{tabular}{|c|c|c|c|c|c|c|c|}
\hline $\begin{array}{l}\text { Household } \\
\text { Income }\end{array}$ & TOTAL & $\begin{array}{l}\text { Earning a } \\
\text { Living }\end{array}$ & $\begin{array}{c}\text { Family/ } \\
\text { Personal } \\
\end{array}$ & $\begin{array}{l}\text { School/ } \\
\text { Church }\end{array}$ & $\begin{array}{c}\text { Social/ } \\
\text { Recreational }\end{array}$ & Other & $\begin{array}{l}\text { Returning } \\
\text { Home }\end{array}$ \\
\hline \multicolumn{8}{|c|}{ Standard Errors for Average Daily Person Trips per Person } \\
\hline TOTAL & 0.02 & 0.01 & 0.01 & 0.00 & 0.01 & 0.00 & 0.00 \\
\hline$<\$ 10,000$ & 0.49 & 0.04 & 0.14 & 0.03 & 0.08 & 0.00 & 0.17 \\
\hline$\$ 10$ to $\$ 20,000$ & 0.41 & 0.05 & 0.11 & 0.02 & 0.06 & 0.00 & 0.14 \\
\hline$\$ 20$ to $\$ 30,000$ & 0.51 & 0.07 & 0.14 & 0.02 & 0.08 & 0.00 & 0.17 \\
\hline$\$ 30$ to $\$ 40,000$ & 0.55 & 0.08 & 0.14 & 0.02 & 0.09 & 0.00 & 0.18 \\
\hline$\$ 40$ to $\$ 50,000$ & 0.57 & 0.08 & 0.15 & 0.03 & 0.10 & 0.00 & 0.19 \\
\hline$\$ 50$ to $\$ 60,000$ & 0.61 & 0.09 & 0.15 & 0.03 & 0.10 & 0.00 & 0.19 \\
\hline$\$ 60$ to $\$ 70,000$ & 0.65 & 0.10 & 0.17 & 0.03 & 0.11 & 0.00 & 0.21 \\
\hline$\$ 70$ to $\$ 80,000$ & 0.68 & 0.09 & 0.17 & 0.03 & 0.14 & 0.00 & 0.21 \\
\hline$\$ 80,000+$ & 0.55 & 0.08 & 0.15 & 0.02 & 0.10 & 0.00 & 0.17 \\
\hline \multicolumn{8}{|c|}{ Standard Errors for Average Daily Person Miles of Travel per Person } \\
\hline TOTAL & 0.52 & 0.16 & 0.27 & 0.04 & 0.24 & 0.05 & 0.19 \\
\hline$<\$ 10,000$ & 3.19 & 0.35 & 0.93 & 0.40 & 0.83 & 0.03 & 1.03 \\
\hline$\$ 10$ to $\$ 20,000$ & 3.11 & 0.52 & 0.70 & 0.12 & 0.76 & 0.06 & 1.11 \\
\hline$\$ 20$ to $\$ 30,000$ & 4.80 & 1.02 & 0.98 & 0.20 & 1.23 & 0.15 & 1.50 \\
\hline$\$ 30$ to $\$ 40,000$ & 5.10 & 1.14 & 0.98 & 0.15 & 1.23 & 0.02 & 1.67 \\
\hline$\$ 40$ to $\$ 50,000$ & 4.84 & 1.02 & 1.01 & 0.19 & 0.90 & 0.02 & 1.76 \\
\hline$\$ 50$ to $\$ 60,000$ & 6.11 & 1.38 & 1.21 & 0.18 & 1.44 & 0.08 & 1.97 \\
\hline$\$ 60$ to $\$ 70,000$ & 6.29 & 1.38 & 1.21 & 0.18 & 1.52 & 0.04 & 2.11 \\
\hline$\$ 70$ to $\$ 80,000$ & 7.78 & 1.97 & 1.36 & 0.35 & 2.22 & 0.03 & 2.86 \\
\hline$\$ 80,000+$ & 6.25 & 1.29 & 1.77 & 0.16 & 1.63 & 0.54 & 2.11 \\
\hline
\end{tabular}

Note:

- Standard errors for the Average Person Trip Length (miles) portion of this table can be computed using the interactive web site. 


\section{TABLE 5.10}

Annual Vehicle Miles of Travel per Household by Trip Purpose and Household Composition 1995 NPTS Standard Errors

\begin{tabular}{|c|c|c|c|c|c|c|c|}
\hline \multicolumn{8}{|l|}{ Standard Errors for: } \\
\hline $\begin{array}{l}\text { Household } \\
\text { Composition } \\
\end{array}$ & TOTAL & $\begin{array}{l}\text { Earning a } \\
\text { Living } \\
\end{array}$ & $\begin{array}{l}\text { Family/ } \\
\text { Personal } \\
\text { Business } \\
\end{array}$ & $\begin{array}{l}\text { School/ } \\
\text { Church } \\
\end{array}$ & $\begin{array}{c}\text { Social/ } \\
\text { Recreational } \\
\end{array}$ & Other & $\begin{array}{c}\text { Returning } \\
\text { Home }\end{array}$ \\
\hline TOTAL & 234.25 & 107.18 & 90.17 & 22.21 & 84.65 & 11.58 & 93.11 \\
\hline $\begin{array}{l}\text { Single Adult, No } \\
\text { Children }\end{array}$ & 533.93 & 149.70 & 253.65 & 32.36 & 167.50 & 5.76 & 250.42 \\
\hline $\begin{array}{l}\text { Two or More Adults, } \\
\text { No Children }\end{array}$ & 465.08 & 236.04 & 156.19 & 62.33 & 157.19 & 5.22 & 137.01 \\
\hline $\begin{array}{l}\text { Single Adult, Youngest } \\
\text { Child Under } 6\end{array}$ & 1132.90 & 252.87 & 270.96 & 136.49 & 477.91 & $* *$ & 484.12 \\
\hline $\begin{array}{l}\text { Two or More Adults, } \\
\text { Youngest Child Under } 6\end{array}$ & 677.94 & 366.43 & 204.75 & 39.62 & 203.08 & 6.48 & 188.81 \\
\hline $\begin{array}{l}\text { Single Adult, Youngest } \\
\text { Child 6-15 }\end{array}$ & 1222.57 & 286.55 & 615.93 & 65.20 & 342.73 & 0.39 & 397.37 \\
\hline $\begin{array}{l}\text { Two or More Adults, } \\
\text { Youngest Child 6-15 }\end{array}$ & 688.61 & 296.51 & 234.37 & 37.91 & 287.55 & 12.90 & 193.46 \\
\hline $\begin{array}{l}\text { Single Adult, Youngest } \\
\text { Child 16-21 }\end{array}$ & 1813.11 & 244.77 & 498.42 & 100.43 & 1214.13 & 79.55 & 463.54 \\
\hline $\begin{array}{l}\text { Two or More Adults, } \\
\text { Youngest Child 16-21 }\end{array}$ & 1403.47 & 679.86 & 323.58 & 169.40 & 414.71 & 12.74 & 519.43 \\
\hline $\begin{array}{l}\text { Single Adult, Retired, } \\
\text { No Children }\end{array}$ & 475.33 & 9.00 & 221.27 & 35.19 & 300.78 & 77.14 & 147.47 \\
\hline $\begin{array}{l}\text { Two or More Adults, } \\
\text { Retired, No Children }\end{array}$ & 465.34 & 109.52 & 144.64 & 80.30 & 198.75 & 78.26 & 190.72 \\
\hline
\end{tabular}

Note:

- ** Indicates no data available. 


\section{TABLE 5.13}

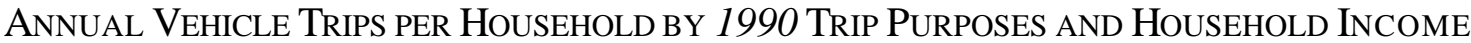 1995 NPTS STANDARD ERRORS}

\begin{tabular}{|c|c|c|c|c|c|c|c|c|c|c|}
\hline \multicolumn{11}{|c|}{ Standard Errors for: } \\
\hline Trip Purpose & TOTAL & $\begin{array}{c}\text { Less than } \\
\$ 10,000\end{array}$ & $\begin{array}{l}\$ 10 \text { to } \\
\$ 20,000\end{array}$ & $\begin{array}{l}\$ 20 \text { to } \\
\$ 30,000\end{array}$ & $\begin{array}{l}\$ 30 \text { to } \\
\$ 40,000\end{array}$ & $\begin{array}{l}\$ 40 \text { to } \\
\$ 50,000\end{array}$ & $\begin{array}{l}\$ 50 \text { to } \\
\$ 60,000\end{array}$ & $\begin{array}{l}\$ 60 \text { to } \\
\$ 70,000\end{array}$ & $\begin{array}{l}\$ 70 \text { to } \\
\$ 80,000\end{array}$ & $\begin{array}{l}\$ 80,000 \\
\text { or more }\end{array}$ \\
\hline \multicolumn{11}{|l|}{1995} \\
\hline TOTAL & 15.06 & 38.51 & 32.59 & 37.08 & 39.39 & 52.02 & 52.77 & 72.96 & 79.76 & 53.51 \\
\hline To/From Work & 5.17 & 18.28 & 11.10 & 9.28 & 8.21 & 9.56 & 6.91 & 16.43 & 16.29 & 7.66 \\
\hline $\begin{array}{l}\text { Work Related } \\
\text { Business }\end{array}$ & 2.51 & 2.26 & 4.11 & 7.89 & 7.79 & 10.97 & 10.06 & 15.17 & 13.82 & 9.29 \\
\hline $\begin{array}{l}\text { Family/Personal } \\
\text { Business }\end{array}$ & 10.04 & 27.95 & 14.21 & 12.67 & 7.39 & 13.81 & 0.00 & 37.28 & 30.49 & 14.71 \\
\hline School/Church & 2.46 & 8.68 & 5.88 & 6.24 & 6.55 & 8.49 & 11.92 & 11.71 & 15.32 & 7.85 \\
\hline $\begin{array}{l}\text { Social/ } \\
\text { Recreational }\end{array}$ & 5.16 & 13.90 & 9.38 & 9.78 & 12.16 & 12.88 & 14.80 & 23.95 & 31.70 & 14.78 \\
\hline Other & 0.25 & 0.08 & 0.40 & 0.96 & 0.61 & 0.40 & 0.80 & 1.55 & 0.88 & 1.52 \\
\hline
\end{tabular}

Note:

- Standard errors are not available for 1990 adjusted numbers.

- Standard errors for number. of households can be computed using the interactive web site. 


\section{TABLE 5.14}

\section{Annual Vehicle Miles of Travel Per Household by 1990 Trip Purposes \\ AND HOUSEHOLD INCOME 1995 NPTS STANDARD ERRORS}

\begin{tabular}{|c|c|c|c|c|c|c|c|c|c|c|}
\hline \multicolumn{11}{|c|}{ Standard Errors for: } \\
\hline Trip Purpose & TOTAL & $\begin{array}{c}\text { Less than } \\
\$ 10,000\end{array}$ & $\begin{array}{l}\$ 10 \text { to } \\
\$ 20,000\end{array}$ & $\begin{array}{l}\$ 20 \text { to } \\
\$ 30,000\end{array}$ & $\begin{array}{l}\$ 30 \text { to } \\
\$ 40,000\end{array}$ & $\begin{array}{l}\$ 40 \text { to } \\
\$ 50,000\end{array}$ & $\begin{array}{l}\$ 50 \text { to } \\
\$ 60,000\end{array}$ & $\begin{array}{l}\$ 60 \text { to } \\
\$ 70,000\end{array}$ & $\begin{array}{l}\$ 70 \text { to } \\
\$ 80,000\end{array}$ & $\begin{array}{l}\$ 80,000 \\
\text { or more }\end{array}$ \\
\hline \multicolumn{11}{|l|}{1995} \\
\hline TOTAL & 234.25 & 511.55 & 408.36 & 666.46 & 716.04 & 806.79 & 876.90 & 1041.84 & 1796.84 & 939.96 \\
\hline To/From Work & 102.21 & 159.28 & 185.72 & 214.45 & 328.05 & 338.47 & 267.35 & 418.60 & 601.33 & 458.22 \\
\hline $\begin{array}{l}\text { Work Related } \\
\text { Business }\end{array}$ & 77.80 & 36.76 & 126.99 & 273.39 & 231.55 & 270.58 & 414.12 & 409.35 & 660.97 & 194.77 \\
\hline $\begin{array}{l}\text { Family/Personal } \\
\text { Business }\end{array}$ & 121.12 & 312.68 & 202.82 & 316.61 & 320.97 & 402.38 & 315.60 & 450.26 & 442.62 & 482.26 \\
\hline School/Church & 37.39 & 162.65 & 83.71 & 102.98 & 80.27 & 112.87 & 113.88 & 172.34 & 545.90 & 92.61 \\
\hline $\begin{array}{l}\text { Social/ } \\
\text { Recreational }\end{array}$ & 115.63 & 280.64 & 200.67 & 317.11 & 323.20 & 291.82 & 462.49 & 497.43 & 1335.09 & 473.50 \\
\hline Other & 9.81 & 0.05 & 5.86 & 62.18 & 6.26 & 4.46 & 5.71 & 13.25 & 16.77 & 14.61 \\
\hline
\end{tabular}

Note:

- Standard errors are not available for 1990 adjusted numbers.

- Standard errors for Nbr. of households can be computed using the interactive web site. 


\section{TABLE 5.22}

Average Daily Vehicle Trips Per Driver Taken by INDIVIDUALS 65 AND OLDER VS. INDIVIDUALS UNDER 65 BY DAY OF WeEK 1995 NPTS STANDARD ERRORS

\begin{tabular}{|c|c|c|c|}
\hline \multicolumn{4}{|c|}{ Standard Errors for: } \\
\hline & TOTAL & $\begin{array}{c}\text { Individuals } \\
\text { Under } 65 \\
\end{array}$ & $\begin{array}{c}\text { Individuals } \\
65 \text { and Older }\end{array}$ \\
\hline TOTAL & 0.02 & 0.41 & 0.05 \\
\hline Sunday & 0.04 & 0.37 & 0.19 \\
\hline Monday & 0.05 & 0.40 & 0.21 \\
\hline Tuesday & 0.05 & 0.48 & 0.16 \\
\hline Wednesday & 0.05 & 0.34 & 0.17 \\
\hline Thursday & 0.05 & 0.39 & 0.18 \\
\hline Friday & 0.05 & 0.32 & 0.17 \\
\hline Saturday & 0.05 & 0.38 & 0.15 \\
\hline
\end{tabular}

\section{TABLE 6.3}

Average Daily Work-Related Person Trips Per

WORKER BY WORKER'S AGE AND GENDER

1995 NPTS STANDARD ERRORS

\begin{tabular}{|llll||}
\hline \hline Standard Errors for: & & & \\
\hline Age & ALL & Male & Female \\
\hline ALL & 0.01 & 0.01 & 0.01 \\
$5-15$ & 0.51 & 0.40 & 0.95 \\
$16-19$ & 0.04 & 0.06 & 0.05 \\
$20-29$ & 0.02 & 0.03 & 0.03 \\
$30-39$ & 0.02 & 0.03 & 0.02 \\
$40-49$ & 0.02 & 0.03 & 0.02 \\
$50-59$ & 0.03 & 0.04 & 0.03 \\
$60-64$ & 0.05 & 0.08 & 0.06 \\
$65+$ & 0.07 & 0.10 & 0.07 \\
\hline \hline
\end{tabular}

Note:

- Standard errors for Number of Workers can be computed using the interactive web site 


\section{TABLE 7.4}

Number of Vehicle TriPs by Number of OCCUPANTS AND NuMBER OF HOUSEHOLD

VEHICLES VS. NUMBER OF HOUSEHOLD DRIVERS

1995 NPTS STANDARD ERRORS

(MILLIONS)

\begin{tabular}{|c|c|c|c|c|c|c|c|}
\hline \multicolumn{8}{|l|}{ Standard Errors for: } \\
\hline \multirow{2}{*}{$\begin{array}{l}\text { Household Vehicles } \\
\text { vs. Household } \\
\text { Drivers }\end{array}$} & \multirow[b]{2}{*}{ TOTAL } & \multicolumn{5}{|c|}{ Number of Persons on Trip } & \multirow[b]{2}{*}{$11+$} \\
\hline & & 1 & 2 & 3 & 4 & $5-10$ & \\
\hline TOTAL & $1,600.35$ & $1,253.74$ & 575.09 & 349.43 & 228.42 & 164.44 & 4.90 \\
\hline $\begin{array}{l}\text { No Household } \\
\text { Vehicles }\end{array}$ & 154.59 & 111.52 & 48.01 & 30.68 & 26.62 & 11.17 & $* *$ \\
\hline $\begin{array}{l}\text { More Drivers than } \\
\text { Vehicles }\end{array}$ & 901.55 & 641.83 & 280.59 & 153.67 & 109.25 & 64.30 & 1.97 \\
\hline $\begin{array}{l}\text { Vehicles Equal to } \\
\text { Drivers }\end{array}$ & $1,495.32$ & $1,138.30$ & 487.31 & 281.97 & 185.54 & 136.46 & 3.46 \\
\hline $\begin{array}{l}\text { More Vehicles than } \\
\text { Drivers }\end{array}$ & 874.74 & 651.57 & 258.27 & 160.46 & 85.21 & 67.38 & 2.86 \\
\hline
\end{tabular}

Note:

- $\quad * *$ Indicates no data available.

TABLE 8.4

Number of Persons 65 OR Older by Number of TRIPS

Taken on TRavel Day

1995 NPTS STANDARD ERRORS

(THOUSANDS)

\begin{tabular}{|c|c|}
\hline \multicolumn{2}{|l|}{ Standard Errors for: } \\
\hline Number of Trips Taken & Number of Persons \\
\hline TOTAL & 337.80 \\
\hline None & 226.69 \\
\hline One & 44.84 \\
\hline Two & 188.52 \\
\hline Three & 129.60 \\
\hline Four or more & 264.72 \\
\hline
\end{tabular}




\section{TABLE 8.7}

Daily Person Trips Per Person for Women

by EMployment Status, Trip PuRpose, and Start Time of TriP 1995 NPTS STANDARD ERRORS

\begin{tabular}{|c|c|c|c|c|c|c|c|c|}
\hline \multicolumn{9}{|l|}{ Standard Errors for: } \\
\hline Trip Purpose & TOTAL & $\begin{array}{l}10 \text { p.m. to } \\
1 \text { a.m. }\end{array}$ & $\begin{array}{c}1 \text { a.m. to } \\
6 \text { a.m. }\end{array}$ & $\begin{array}{c}6 \text { a.m. to } \\
9 \text { a.m. }\end{array}$ & $\begin{array}{c}9 \text { a.m. to } \\
1 \text { p.m. }\end{array}$ & $\begin{array}{l}1 \text { p.m. to } \\
4 \text { p.m. }\end{array}$ & $\begin{array}{l}4 \text { p.m. to } \\
7 \text { p.m. }\end{array}$ & $\begin{array}{l}7 \text { p.m. to } \\
10 \text { p.m. }\end{array}$ \\
\hline \multicolumn{9}{|l|}{ Employed Women } \\
\hline TOTAL & 0.03 & 0.01 & 0.00 & 0.01 & 0.01 & 0.01 & 0.01 & 0.01 \\
\hline Earning a Living & 0.01 & 0.00 & 0.00 & 0.00 & 0.01 & 0.00 & 0.00 & 0.00 \\
\hline Family/Personal Business & 0.01 & 0.00 & 0.00 & 0.01 & 0.01 & 0.01 & 0.01 & 0.01 \\
\hline School/Church & 0.00 & 0.00 & 0.00 & 0.00 & 0.00 & 0.00 & 0.00 & 0.00 \\
\hline Social/Recreational & 0.01 & 0.00 & 0.00 & 0.00 & 0.00 & 0.00 & 0.00 & 0.00 \\
\hline Other & 0.00 & 0.00 & 0.00 & 0.00 & 0.00 & 0.00 & 0.00 & 0.00 \\
\hline Returning Home & 0.00 & 0.00 & 0.00 & 0.00 & 0.00 & 0.00 & 0.00 & 0.00 \\
\hline \multicolumn{9}{|l|}{ Unemployed Women } \\
\hline TOTAL & 0.03 & 0.00 & 0.00 & 0.01 & 0.01 & 0.01 & 0.01 & 0.01 \\
\hline Earning a Living & 0.00 & 0.00 & 0.00 & 0.00 & 0.00 & 0.00 & 0.00 & 0.00 \\
\hline Family/Personal Business & 0.01 & 0.00 & 0.00 & 0.00 & 0.01 & 0.01 & 0.01 & 0.00 \\
\hline School/Church & 0.01 & 0.00 & 0.00 & 0.00 & 0.00 & 0.00 & 0.00 & 0.00 \\
\hline Social/Recreational & 0.01 & 0.00 & 0.00 & 0.00 & 0.01 & 0.01 & 0.01 & 0.00 \\
\hline Other & 0.00 & 0.00 & 0.00 & 0.00 & 0.00 & 0.00 & 0.00 & 0.00 \\
\hline Returning Home & 0.00 & 0.00 & 0.00 & 0.00 & 0.00 & 0.01 & 0.01 & 0.00 \\
\hline
\end{tabular}




\section{TABLE 8.8}

\section{DAILY PMT PER PERSON FOR WOMEN \\ by Employment Status, Trip Purpose, and Start Time of Trip 1995 NPTS STANDARD ERRORS}

\begin{tabular}{|c|c|c|c|c|c|c|c|c|}
\hline \multicolumn{9}{|l|}{ Standard Errors for: } \\
\hline Trip Purpose & TOTAL & $\begin{array}{l}10 \text { p.m. to } \\
1 \text { a.m. }\end{array}$ & $\begin{array}{l}1 \text { a.m. to } \\
6 \text { a.m. }\end{array}$ & $\begin{array}{l}6 \text { a.m. to } \\
9 \text { a.m. }\end{array}$ & $\begin{array}{l}9 \text { a.m. to } \\
1 \text { p.m. }\end{array}$ & $\begin{array}{l}1 \text { p.m. to } \\
4 \text { p.m. }\end{array}$ & $\begin{array}{l}4 \text { p.m. to } \\
7 \text { p.m. }\end{array}$ & $\begin{array}{l}7 \text { p.m. to } \\
10 \text { p.m. }\end{array}$ \\
\hline \multicolumn{9}{|l|}{ Employed Women } \\
\hline TOTAL & 0.80 & 0.10 & 0.09 & 0.39 & 0.24 & 0.24 & 0.19 & 0.26 \\
\hline Earning a Living & 0.24 & 0.03 & 0.05 & 0.12 & 0.11 & 0.10 & 0.05 & 0.02 \\
\hline Family/Personal Business & 0.43 & 0.05 & 0.04 & 0.36 & 0.11 & 0.09 & 0.11 & 0.10 \\
\hline School/Church & 0.05 & 0.00 & 0.00 & 0.03 & 0.03 & 0.01 & 0.02 & 0.01 \\
\hline Social/Recreational & 0.26 & 0.04 & 0.03 & 0.10 & 0.14 & 0.13 & 0.07 & 0.07 \\
\hline Other & 0.09 & 0.00 & 0.00 & 0.00 & 0.00 & 0.09 & 0.01 & 0.01 \\
\hline Returning Home & 0.29 & 0.05 & 0.05 & 0.05 & 0.12 & 0.11 & 0.13 & 0.23 \\
\hline \multicolumn{9}{|l|}{ Unemployed Women } \\
\hline TOTAL & 0.65 & 0.07 & 0.13 & 0.27 & 0.24 & 0.19 & 0.22 & 0.22 \\
\hline Earning a Living & 0.04 & 0.00 & 0.00 & 0.01 & 0.01 & 0.02 & 0.02 & 0.00 \\
\hline Family/Personal Business & 0.28 & 0.02 & 0.02 & 0.21 & 0.12 & 0.10 & 0.08 & 0.06 \\
\hline School/Church & 0.11 & 0.00 & 0.01 & 0.04 & 0.02 & 0.03 & 0.09 & 0.02 \\
\hline Social/Recreational & 0.37 & 0.04 & 0.04 & 0.16 & 0.19 & 0.10 & 0.12 & 0.17 \\
\hline Other & 0.04 & 0.00 & $* *$ & 0.04 & 0.01 & 0.01 & 0.01 & 0.00 \\
\hline Returning Home & 0.25 & 0.06 & 0.13 & 0.05 & 0.08 & 0.12 & 0.13 & 0.11 \\
\hline
\end{tabular}

Note:

- ** Indicates no data available. 
TABLE 8.12

Average Annual Person Trips Per Person of Walkers by MSA Size and Trip Purpose 1995 NPTS STANDARD ERRORS

\begin{tabular}{|c|c|c|c|c|c|c|c|}
\hline \multicolumn{8}{|l|}{ Standard Errors for: } \\
\hline \multirow[b]{2}{*}{ Trip Purpose } & \multirow[b]{2}{*}{ TOTAL } & \multicolumn{6}{|c|}{ MSA Size } \\
\hline & & $\begin{array}{c}\text { Less than } \\
250,000\end{array}$ & $\begin{array}{r}250,000- \\
499,999\end{array}$ & $\begin{array}{l}500,000- \\
999,999\end{array}$ & $\begin{array}{l}1 \text { to } 2.9 \\
\text { million }\end{array}$ & $\begin{array}{l}3 \text { million } \\
\text { or more }\end{array}$ & $\begin{array}{l}\text { Not in } \\
\text { MSA }\end{array}$ \\
\hline TOTAL & 10.24 & 40.64 & 37.34 & 28.40 & 18.08 & 15.47 & 26.75 \\
\hline \multicolumn{8}{|l|}{ Earning a Living } \\
\hline To Work & 1.77 & 7.14 & 7.35 & 3.45 & 4.01 & 2.55 & 4.80 \\
\hline Work-Related Business & 1.29 & 7.03 & 4.46 & 5.46 & 2.45 & 1.94 & 2.18 \\
\hline Return to Work & 1.98 & 6.76 & 5.29 & 8.42 & 4.68 & 2.68 & 6.49 \\
\hline Subtotal & 3.18 & 11.93 & 10.62 & 13.39 & 6.34 & 4.31 & 10.06 \\
\hline \multicolumn{8}{|l|}{ Family/Personal Business } \\
\hline Shopping & 3.93 & 8.54 & 12.29 & 11.38 & 8.18 & 5.76 & 8.86 \\
\hline Medical/Dental & 0.62 & 1.71 & 3.83 & 3.02 & 1.17 & 0.84 & 1.83 \\
\hline Other Family/Personal Business & 2.76 & 16.58 & 12.56 & 7.86 & 7.26 & 3.22 & 8.43 \\
\hline Take Someone Somewhere & 0.93 & 2.37 & 4.10 & 3.99 & 1.88 & 1.46 & 1.00 \\
\hline Pick Up Someone & 1.03 & 5.45 & 4.25 & 3.96 & 2.28 & 1.52 & 1.71 \\
\hline Subtotal & 4.58 & 18.98 & 18.22 & 11.91 & 8.89 & 5.57 & 12.74 \\
\hline \multicolumn{8}{|l|}{ School or Church } \\
\hline School & 2.86 & 14.85 & 11.61 & 8.36 & 9.41 & 3.33 & 8.45 \\
\hline Religious Activity & 1.33 & 4.27 & 4.88 & 3.63 & 1.76 & 2.04 & 4.06 \\
\hline Subtotal & 3.06 & 14.90 & 11.87 & 8.41 & 9.45 & 3.72 & 9.08 \\
\hline \multicolumn{8}{|l|}{ Social/Recreational } \\
\hline Vacation & 0.73 & 0.03 & $* *$ & 2.38 & 1.71 & 1.24 & 0.02 \\
\hline Visit Friends/Relatives & 3.16 & 9.24 & 11.52 & 10.24 & 6.76 & 4.65 & 8.45 \\
\hline Out to Eat & 2.90 & 9.54 & 8.19 & 6.72 & 7.15 & 4.46 & 5.00 \\
\hline Other Social/Recreational & 3.85 & 10.69 & 11.16 & 13.01 & 9.08 & 5.73 & 9.30 \\
\hline Subtotal & 5.48 & 15.42 & 11.98 & 12.88 & 10.19 & 8.11 & 11.79 \\
\hline \multicolumn{8}{|l|}{ Other and Returning Home } \\
\hline Other & 0.57 & 1.39 & 2.09 & 1.70 & 1.44 & 0.90 & 0.92 \\
\hline Returning Home & * & * & $*$ & * & $*$ & * & $*$ \\
\hline Subtotal & $*$ & $*$ & $*$ & $*$ & $*$ & $*$ & $*$ \\
\hline
\end{tabular}

Note:

- * Indicates standard error could not be computed.

- ** Indicates no data available. 


\section{TABLE 8.14}

Average Daily Person Trips Per Person of Walkers

BY AGE AND GENDER

1995 NPTS STANDARD ERRORS

\begin{tabular}{|c|c|c|c|}
\hline \multicolumn{4}{|c|}{ Standard Errors for: } \\
\hline Age Group & TOTAL & Male & Female \\
\hline TOTAL & 0.03 & 0.04 & 0.03 \\
\hline $5-15$ & 0.05 & 0.06 & 0.06 \\
\hline $16-19$ & 0.08 & 0.11 & 0.12 \\
\hline $20-29$ & 0.08 & 0.12 & 0.10 \\
\hline $30-39$ & 0.06 & 0.09 & 0.07 \\
\hline $40-49$ & 0.06 & 0.10 & 0.08 \\
\hline $50-59$ & 0.11 & 0.17 & 0.12 \\
\hline $60-64$ & 0.14 & 0.21 & 0.17 \\
\hline $65+$ & 0.08 & 0.10 & 0.11 \\
\hline
\end{tabular}




\section{TABLE 8.16}

\section{PMT Per Person for Public Transit Trips \\ By HouseHOLd INCOME AND TRIP PURPoSE 1995 NPTS STANDARD ERRORS}

\begin{tabular}{|c|c|c|c|c|c|c|c|c|c|c|}
\hline Standard Errors for: & & & & & & & & & & \\
\hline Trip Purpose & TOTAL & $\begin{array}{l}\text { Less than } \\
\$ 10,000\end{array}$ & $\begin{array}{l}\$ 10,000- \\
\$ 20,000\end{array}$ & $\begin{array}{l}\$ 20,000- \\
\$ 30,000\end{array}$ & $\begin{array}{l}\$ 30,000- \\
\$ 40,000\end{array}$ & $\begin{array}{l}\$ 40,000- \\
\$ 50,000\end{array}$ & $\begin{array}{l}\$ 50,000- \\
\$ 60,000\end{array}$ & $\begin{array}{l}\$ 60,000- \\
\$ 70,000\end{array}$ & $\begin{array}{l}\$ 70,000- \\
\$ 80,000\end{array}$ & $\begin{array}{l}\$ 80,000 \\
\text { or more }\end{array}$ \\
\hline TOTAL & 500.75 & $1,150.70$ & $1,305.78$ & $1,728.29$ & $2,032.02$ & $1,225.75$ & $2,679.04$ & $1,926.83$ & $1,712.87$ & $1,571.04$ \\
\hline \multicolumn{11}{|l|}{ Earning a Living } \\
\hline To Work & 84.12 & 106.14 & 196.87 & 256.56 & 173.63 & 123.12 & 343.77 & 610.95 & 363.96 & 353.67 \\
\hline $\begin{array}{l}\text { Work-Related } \\
\text { Business }\end{array}$ & 95.18 & 3.05 & 91.81 & 6.91 & 43.45 & 3.87 & $1,590.77$ & 172.20 & 244.78 & 624.56 \\
\hline Return to Work & 3.04 & 4.60 & 0.25 & 0.88 & 10.51 & 10.11 & 4.72 & 27.24 & $*$ & 0.15 \\
\hline Subtotal & 125.52 & 105.88 & 209.87 & 256.18 & 172.08 & 122.13 & $1,536.55$ & 597.43 & 369.63 & 617.91 \\
\hline \multicolumn{11}{|c|}{ Family/Personal Business } \\
\hline Shopping & 28.96 & 99.82 & 63.30 & 70.68 & 90.86 & 123.81 & 63.68 & 155.55 & 203.44 & 57.63 \\
\hline Medical/Dental & 20.41 & 48.37 & 67.28 & 57.65 & 58.67 & 11.93 & $*$ & 144.54 & 50.59 & 120.27 \\
\hline $\begin{array}{l}\text { Other Family/ } \\
\text { Personal Business }\end{array}$ & 92.70 & 360.96 & 165.86 & 75.86 & 93.27 & 213.05 & 161.40 & 284.34 & 152.22 & 911.60 \\
\hline $\begin{array}{l}\text { Take Someone } \\
\text { Somewhere }\end{array}$ & 56.10 & 81.75 & 48.50 & $*$ & 51.77 & 47.47 & 3.12 & 402.43 & $* *$ & 624.62 \\
\hline Pick Up Someone & 29.84 & 31.43 & 44.74 & 3.67 & 135.27 & 339.39 & 14.03 & $* *$ & $*$ & 35.98 \\
\hline Subtotal & 120.91 & 406.70 & 204.14 & 127.51 & 190.26 & 399.56 & 172.40 & 561.71 & 259.35 & $1,082.81$ \\
\hline \multicolumn{11}{|l|}{ School or Church } \\
\hline School & 61.98 & 80.76 & 134.29 & 332.20 & 63.67 & 110.65 & 45.75 & 201.24 & 690.34 & 17.47 \\
\hline Religious Activity & 34.29 & 13.27 & 144.08 & 89.02 & 2.89 & 136.52 & 22.77 & 7.79 & ** & 206.33 \\
\hline Subtotal & 70.65 & 81.54 & 194.36 & 340.87 & 63.62 & 173.83 & 51.03 & 201.23 & 690.34 & 204.91 \\
\hline \multicolumn{11}{|l|}{ Social/Recreational } \\
\hline Vacation & 143.72 & $* *$ & 3.31 & $*$ & $* *$ & 128.54 & $2,376.40$ & $* *$ & $*$ & $* *$ \\
\hline $\begin{array}{l}\text { Visit Friends/ } \\
\text { Relatives }\end{array}$ & 44.09 & 90.32 & 120.83 & 140.85 & 66.02 & 103.02 & 424.93 & 29.38 & $* *$ & 146.78 \\
\hline Out to Eat & 62.54 & 12.31 & 233.52 & 319.70 & 33.85 & 107.81 & 16.42 & 293.65 & 19.28 & 30.33 \\
\hline $\begin{array}{l}\text { Other Social/ } \\
\text { Recreational }\end{array}$ & 173.41 & 542.70 & 213.18 & 505.03 & 668.38 & 832.81 & 257.32 & 28.28 & $1,137.82$ & 256.82 \\
\hline Subtotal & 242.93 & 551.39 & 327.79 & $1,016.15$ & 671.52 & 846.56 & $2,410.66$ & 294.87 & $1,137.00$ & 289.05 \\
\hline \multicolumn{11}{|c|}{ Other and Returning Home } \\
\hline Other & 6.46 & 1.11 & 4.97 & $*$ & 54.80 & $* *$ & 1.58 & 78.88 & $* *$ & 15.62 \\
\hline Returning Home & 287.41 & 511.11 & 824.85 & $1,244.06$ & $1,289.27$ & 506.83 & 395.61 & 731.12 & 218.37 & 345.97 \\
\hline Subtotal & 287.42 & 511.07 & 828.87 & $1,243.93$ & $1,288.39$ & 506.83 & 395.36 & 726.66 & 218.37 & 342.74 \\
\hline
\end{tabular}

Note:

- * Indicates standard error could not be computed.

- ** Indicates no data available. 


\section{Appendix E}

\section{Adjustment of 1990 Travel Data}

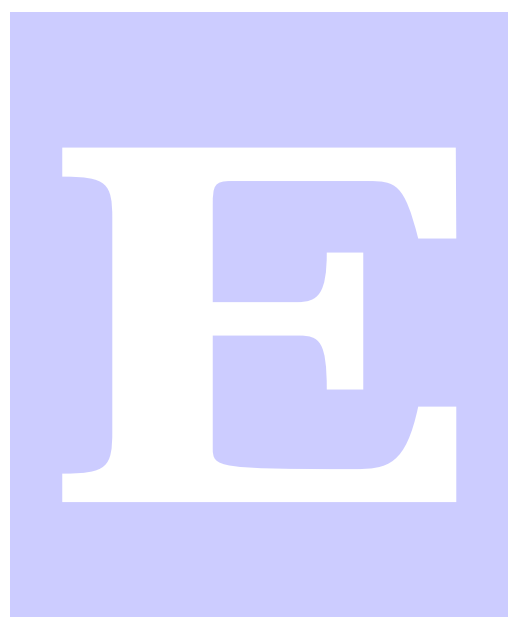

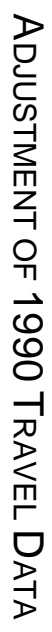




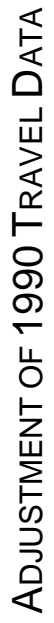




\section{Appendix E. Adjustment of 1990 Travel Data}

$\mathrm{T}$ HE 1995 Nationwide Personal Transportation Survey (NPTS) was a significant improvement over previous surveys in the NPTS series. Different methods were used to ensure that more complete trip reporting was obtained. Specifically,

- a travel diary was used by respondents in the 1995 survey, in lieu of memory recalling; and

- "household rostering" was used to capture some trips that may otherwise have been overlooked.

Although these improvements enhance the completeness and accuracy of trip reporting, they prevent any direct comparisons between the 1990 and 1995 travel data. Any travel changes observed between the 1990 and 1995 surveys now reflect not only actual changes in travel during the period but also artifacts of differences in survey methodology. That is, any changes observed between the 1990 and 1995 travel data are presumably attributable to: (1) actual changes in travel behavior, (2) use of travel diaries, (3) use of household rostering, and (4) other improvements in the 1995 survey method such as a better coding scheme to decipher trip purposes. The latter is expected to have a smaller effect than the first three factors. Since no data are available to quantify the impact of these "other" improvements, their impacts are not evaluated in this exercise.

However, the improved coding scheme in 1995 had an effect on trip recording. In 1990, 1.9 billion trips were coded as "other" trip purpose. In 1995, this number was 700 million, a decline of $64 \%$. These "other" trips are those that can not be classified into any of the existing trip purpose categories. Two reasons contribute to this substantial decrease in "other" trips. First, the information was collected in the 1995 survey on "from" where the trip was originated and "to" where the trip was destined. This type of "to" and "from" information enabled the trip purposes to be determined more accurately. As a result, the number of trips with unspecified trip purposes decreased. Second, better schemes to code trip purposes were used both during and after the data collection phase, significantly reducing the ambiguity in trip purposes.

The reduction in trips with unspecified trip purposes presumably increases the number of trips categorized into the proper trip purpose categories. Ideally, one should remove all artifacts that result from an improved method. However, data to address the effects of each of the individual improvements are extremely limited. Our approach was developed to remove as many artifacts as the data allow. Specifically, our approach quantified and removed the effect of the travel diary and household trip rostering on the amount and type of trips in the 1995 NPTS.

\section{AdJustment Approach}

To more accurately reflect travel trends, the 1990 travel data were adjusted to account for two major changes in survey methodology: (1) travel diary and (2) household rostering. In essence, the 1990 travel data were adjusted in such a way as if a travel diary and household rostering were used in the 1990 survey. The theory is that more trips would have been recorded in the 1990 
survey if travel diaries were used. This theory is supported by data collected in the 1995 NPTS pre-test. Data from the 1995 NPTS pre-test showed that travel diaries led to more complete reporting, particularly for incidental trips, such as stopping at a convenience store, which are often forgotten and, therefore, difficult to capture in a household travel survey. Household rostering is also expected to capture more complete trip reporting by helping remind respondents of forgotten trips. Since data from the 1995 NPTS pre-test suggest that the impact of travel diary varies for different trip purposes, separate adjustment factors were developed for different purposes.

Although more detailed trip purpose information was collected in the 1995 survey, for this analysis trip purposes were grouped into four broad categories: (1) work and school, (2) shopping, (3) family and personal business other than shopping, and (4) social and recreational. Separating shopping trips from trips taken for other family and personal businesses is based on the belief that travel diaries and household rostering influence reporting on these trips differently. This appendix describes the approach used to quantify impacts of travel diary and household rostering on the number of person trips recorded by these purposes.

Rather than adjust travel data in all previous surveys (e.g., 1969, 1983 NPTS), only 1990 travel data were adjusted. Both original and adjusted 1990 statistics are presented in this report. The user is warned not to compare
1995 results to those from any previous NPTS. For trend analysis, the 1995 results should only be compared to the adjusted 1990 statistics.

\section{ImPact OF TRavel Diary on TriP REPORTING}

A methodological experiment was designed as part of the 1995 NPTS pre-test to test three different survey methods: memory recall $(n=875)$, memory jogger $(n=729)$, and travel diary $(\mathrm{n}=708)$. Although the pre-test sample sizes are not particularly large, these pretest data provide the only platform to quantify the impact of travel diaries on trip reporting. On an individual basis, using a travel diary indeed captures more trips than recalling the day's trips from the memory (Table 1). It was found that the diary method averaged 0.5 trips more per person per day than the recall, or retrospective method. ${ }^{1}$ In addition, travel diary use has greater impact on reporting non-work or non-school related trips than on work or school trips. Its impact is the greatest for non-shopping types of family and personal travel, such as visiting a doctor's office, dropping off or picking up someone: $37 \%$ more such trips were reported by using travel diaries than by recalling from memory.

'PlanTrans, Draft report on NPTS Pretest Methods, Spring 1997. 


\section{TABLE E. 1}

Annual Person Trips Per Person by Survey Methods BASED ON 1995 NPTS PRE-TEST DATA

\begin{tabular}{|l|c|c|c|}
\hline & $\begin{array}{c}\text { Travel Diary } \\
(1)\end{array}$ & $\begin{array}{c}\text { Recall } \\
(2)\end{array}$ & $\%$ Different $=[(1)-(2)] /(2)$ \\
\hline Work and school & 312.50 & 341.64 & $-8.5 \%$ \\
\hline Shopping & 273.09 & 226.20 & $20.7 \%$ \\
\hline Other family and personal & 317.47 & 231.36 & $37.2 \%$ \\
\hline Social and recreational & 293.82 & 244.39 & $20.2 \%$ \\
\hline Other & 8.29 & 7.58 & $9.4 \%$ \\
\hline ALL & $1,205.17$ & $1,051.17$ & $14.7 \%$ \\
\hline
\end{tabular}

The ratio of travel rates between those collected by travel diaries and those by recall approximates the additional trips that would have been reported if travel diaries were used in the 1990 survey. Contrary to our assumption that travel diaries will not increase the number of work and school trips reported, there were fewer work and school trips reported in the 1995 NPTS pre-test when travel diaries were used rather than recall. For trip purposes other than work and school, travel diaries capture more trips than recall (Table 1). Since travel diaries are not believed to improve the reporting of nonincidental trips such as commute or school trips and since there is no other evidence supporting a decrease in commute or school trips from 1990 to 1995, the impact of travel diaries on reporting these trips is considered null, and no adjustment was made to the 1990 data.

\section{IMPACT OF HOUSEHOLD ROSTERING ON TRIP REPORTS}

In "household rostering," the interviewer has the benefit of trip data from all household members who had already been interviewed. For example, suppose person \#1 took a trip and reported that persons \#2 and \#3 were on the trip with him. When persons \#2 and \#3 were interviewed, they were asked to confirm that they were on the trip with person \#1. If they were, the trip characteristics were "copied" from person \#1's record to those of person \#2 and person $\# 3$. If person \#2 or person \#3 indicated that they were not on the trip with person \#1, this response was accepted. One benefit of household rostering is that it aids the memory of the respondent and improves trip reporting.

If household rostering had been used in the 1990 NPTS, how many more trips would have been reported? Unfortunately, this question can not be answered directly due to the lack of data. Instead, an indirect approach was developed. The basic idea behind this approach is simple: It is assumed that household rostering does not increase trip reporting from 1990 to 1995 for trips where only one household member is on the trip. Therefore, the travel trends observed between 1990 and 1995 in the "non- 
accompany" trips are basically due to (1) changes in travel behavior, (2) use of travel diaries, and (3) other improvements in the 1995 survey method (these effects being relatively inconsequential). It should be emphasized that the "non-accompany" trips are not necessarily all single-occupant trips. Rather, they are trips where only one household member is on the trip, with or without being accompanied by nonhousehold members. These trips are referred hereafter as "non-accompany trips."

After adjusting these "non-accompany" trips in 1990 for the impact of travel diaries, the remaining difference between the 1990 and 1995 "non-accompany" trip rates is presumably attributable to the change in travel during the period. Now, adjusting all of the 1990 trips to reflect the impact of trip diary and the change in travel during the five-year period, the remaining difference between the 1995 survey data and the adjusted 1990 data presumably reflects the impact of household rostering.

Table 2 illustrates the steps taken to estimate the real changes in trip rates observed in the "non-accompany" trips from 1990 to 1995. The total numbers of "non-accompany" trips reported in the 1990 NPTS are in Column 1. The impact of using travel diaries on reporting trips are listed in Column 2. Adjusting 1990 data for diary impact, Column 3 reports the estimated number of trips by purpose that would have been collected in 1990 had travel diaries been used. Comparing the adjusted 1990 figures (Column 3) to comparable 1995 data (Column 4), one can calculate the percentage change in travel from 1990 to 1995 by trip purpose. The overall increase is nearly $30 \%$, approximately $4.5 \%$ per year for the five-year period. 


\section{TABLE E.2}

Estimated Travel Changes From 1990 to 1995

BASED ON TRIPS WITHOUT OTHER HOUSEHOLD MEMBERS “ACCOMPANIED”

\begin{tabular}{||l|c|c|c|c|c||}
\hline \hline \multicolumn{1}{|c|}{ Purpose } & $(1)$ & $(2)$ & $(3)=(1) \times[(=1+(2)]$ & $(4)$ & $\begin{array}{c}(5)= \\
{[(4)-(3)] /(3)}\end{array}$ \\
\cline { 2 - 6 } & $\begin{array}{c}19901-\mathrm{hhm}^{1} \\
\text { Trips } \\
(000)\end{array}$ & $\begin{array}{c}\text { Diary } \\
\text { Impact }^{2} \\
(\%)\end{array}$ & $\begin{array}{c}19901 \text { 1-hhm Trips } \\
\text { Adjusted for } \\
\text { Diary Impact }\end{array}$ & $\begin{array}{c}\text { Change } \\
\text { in Travel } \\
(\%)\end{array}$ \\
\hline Work, School & $62,973,929$ & 0 & $62,973,929$ & $84,974,961$ & 34.9 \\
\hline Shopping & $27,983,544$ & 20.7 & $33,860,088$ & $45,996,625$ & 35.8 \\
\hline Other Fam/Per & $33,237,593$ & 37.2 & $45,535,502$ & $58,602,172$ & 28.7 \\
\hline Soc/Rec & $33,166,604$ & 20.2 & $39,799,925$ & $46,509,286$ & 16.9 \\
\hline Other & $1,233,007$ & 9.4 & $1,343,978$ & 356,444 & -73.5 \\
\hline TOTAL & $158,594,677$ & & $182,383,879$ & $236,439,488$ & \\
\hline
\end{tabular}

${ }^{1} 1$-household-member $(1-\mathrm{hhm})$ trips $=$ trips where no other household members "accompanied."

${ }^{2}$ From Table 1.

This approach suggests that Americans as a whole took approximately 35 percent more commute and school trips from 1990 to 1995. A number of factors could contribute to this increase in the total number of work and school trips. For example, the number of workers increased by $11 \%$ during this period. Note that the number of "other" trips decreased by $74 \%$ due to a better trip purpose coding scheme. The lack of appropriate and sufficient data prohibits an evaluation of the impact of this improved coding scheme. Thus, no adjustments are made to 1990 trips categorized as "other" trip purpose. These trips are a very small proportion of all trips.

With these calculations, the revised estimates of 1990 trips now reflect adjustments for (1) trip diary and (2) change in travel. Presumably, the remaining difference between the 1995 survey data and the adjusted 1990 data reflects the impact of household rostering. Table 3 demonstrates the steps to estimate this effect. First, the number of trips collected in the 1990 survey was adjusted for the diary impact (e.g., 21\% for shopping trips) and for the change in travel between 1990 and 1995 (e.g., 36\% for shopping trips). It can be reasonably assumed that after this adjustment the 1990 data are almost comparable to the 1995 data except for the impact of household rostering. The percentage difference between this adjusted 1990 data and the observed 1995 data is used to estimate the impact of household rostering (Table 3). Based on this somewhat convoluted approach, we estimated that approximately $4 \%$ more shopping trips would have been reported in the 1990 survey if household rostering had been used. Again, the number of "other" trips decreased by $74 \%$ due to a better trip purpose coding scheme. The lack of appropriate and sufficient data prohibits an evaluation of the impact of this improved coding scheme. Thus, no adjustment is done to 1990 trips categorized with the "other" trip purpose. 
TABLE E.3

Estimated Impacts of Household Rostering By TRIP PuRPose

\begin{tabular}{|l|c|c|c|c|c|c|}
\hline \hline \multirow{7}{*}{ Purpose } & $(1)$ & $(2)$ & $(3)$ & $\begin{array}{c}(4)= \\
(1) \times[(2)+(3)] / 100\end{array}$ & $\begin{array}{c}(6)= \\
{[(5)-(4)] /(4)}\end{array}$ \\
\cline { 2 - 7 } & $\begin{array}{c}1990 \\
\text { Total Trips } \\
(000)\end{array}$ & $\begin{array}{c}\text { Diary } \\
\text { Impact } \\
(\%)\end{array}$ & $\begin{array}{c}\text { Change } \\
\text { in Travel } \\
(\%)\end{array}$ & $\begin{array}{c}\text { 1990 Trips Adjusted } \\
\text { for Diary Impact } \\
\text { and \% Change in } \\
\text { Travel }\end{array}$ & $\begin{array}{c}1995 \\
\text { Total Trips } \\
(000)\end{array}$ & $\begin{array}{c}\text { Impact of } \\
\text { Trip Rostering } \\
(\%)\end{array}$ \\
\hline Work, School & $82,240,011$ & 0 & 34.9 & $110,941,885$ & $110,115,282$ & -0.7 \\
\hline Shopping & $47,056,740$ & 20.7 & 35.8 & $73,643,798$ & $76,688,225$ & 4.1 \\
\hline Other Fam/Per & $56,551,552$ & 37.2 & 28.7 & $93,819,025$ & $97,075,588$ & 3.5 \\
\hline Soc/Rec & $61,799,215$ & 20.2 & 16.9 & $84,726,724$ & $94,361,999$ & 11.4 \\
\hline Other & $1,914,779$ & 9.4 & -73.5 & 687,406 & 689,270 & 0.3 \\
\hline \hline
\end{tabular}

\section{AdJuStMent Factors fOR 1990 Travel DATA}

By combining the impact of travel diary (Column 2 of Table 3) and the impact of household rostering (Column 6 of Table 3), the factors used to adjust 1990 travel data range from no adjustment for work and school trips to a $41 \%$ increase for trips taken for other family and personal business (i.e., non-shopping trips) (Table 4). These adjustment factors suggest that between 1990 and 1995 the total number of person trips increased about $4.5 \%$ per year, compared to a rate of $2.6 \%$ between 1969 and 1990. However, after taking into account the population increases over the years, these adjustment factors suggest that a typical American increased his/her trips by $2.7 \%$ per year (Table 5). This rate is comparable to the $2 \%$ increase observed between the 1969 and 1990 surveys.

The fundamental assumption in this approach is that the changes observed in the "non-accompany" trips reflect the changes observed in all trips. The validity of this assumption is checked by first examining how representative the "non-accompany" trips are in both 1990 and 1995. "Nonaccompany" trips in both 1990 and 1995 account for no less than 50 percent of the total person trips (Table 6), suggesting that using "non-accompany" trips to estimate the magnitude of travel changes in all trips appears to be reasonable. The validity of this assumption is further verified by checking whether the "non-accompany" rate has changed from 1990 to 1995 . More than three quarters of work trips and school trips are not accompanied by other household members. This percentage remains relatively stable from 1990 to 1995 (Table 6). Note that dropping off and picking up children from schools are not considered "school trips" they are categorized under "Other family and personal business." Almost all trips remain somewhat stable for the non-accompany rate between 1990 and 1995 except social and recreational trips. There is a smaller percentage of social and recreational trips in 1995 that went "unaccompanied by other households" than in 1990: $49 \%$ vs. $54 \%$. That fact seems to support the idea that using only "nonaccompany" trips to estimate travel changes between 1990 and 1995 is reasonable. 


\section{TABLE E. 4}

\section{Table 4. 1990 Travel Data Adjustment}

(PERSON TRIPS IN THOUSANDS)

\begin{tabular}{||l|c|c|c|c|c||}
\hline Purpose & $\begin{array}{c}1990 \text { Trips } \\
(1)\end{array}$ & $\begin{array}{c}\text { Adjustment } \\
\text { Factor } \\
(2)\end{array}$ & $\begin{array}{c}\text { Adjusted } \\
1990 \text { Trips } \\
(1) \times(2)\end{array}$ & 1995 Trips & $\begin{array}{c}\text { Average } \\
\text { Annual \% } \\
\text { Change }\end{array}$ \\
\hline Work, School & $82,240,011$ & 1.00 & $82,240,011$ & $110,115,282$ & 6.01 \\
\hline Shopping & $47,056,740$ & 1.25 & $58,820,925$ & $76,688,225$ & 5.45 \\
\hline Other Fam/Per Bus & $56,551,552$ & 1.41 & $79,737,688$ & $97,075,588$ & 4.01 \\
\hline Social/Recreational & $61,799,215$ & 1.32 & $81,574,964$ & $94,361,999$ & 2.96 \\
\hline Other & $1,914,779$ & 1.00 & $1,914,779$ & 689,270 & - \\
\hline TOTAL & $249,562,297$ & - & $304,288,367$ & $378,930,363$ & 4.49 \\
\hline
\end{tabular}

\section{TABLE E.5}

DAILy PeRson TRIPS PER Person

ADJUSTED 1990 AND 1995 NPTS

\begin{tabular}{||l|c|c|c|c|c||}
\hline \hline & $\begin{array}{c}1990 \text { Trip } \\
\text { Rate }\end{array}$ & $\begin{array}{c}\text { Adjustment Factor } \\
\text { Diary+Rostering }\end{array}$ & $\begin{array}{c}\text { Adjusted } \\
1990 \\
\text { Trip Rate }\end{array}$ & $\begin{array}{c}\text { 1995 Trip } \\
\text { Rate }\end{array}$ & $\begin{array}{c}\text { Average Annual } \\
\text { Change Rate } \\
(\%)\end{array}$ \\
\hline Work, School & 1.015 & 1.00 & 1.015 & 1.248 & 4.22 \\
\hline Shopping & 0.580 & 1.25 & 0.725 & 0.869 & 3.70 \\
\hline Other Fam/Per Bus & 0.698 & 1.41 & 0.984 & 1.100 & 2.26 \\
\hline Social/Recreational & 0.762 & 1.32 & 1.006 & 1.070 & 1.24 \\
\hline Other & 0.024 & 1.00 & 0.024 & 0.008 & - \\
\hline TOTAL & $\mathbf{3 . 0 7 9}$ & - & $\mathbf{3 . 7 5 4}$ & $\mathbf{4 . 2 9 6}$ & $\mathbf{2 . 7 3}$ \\
\hline
\end{tabular}




\section{TABLE E.6}

One-Household-Member Person Trips, Total Person Trips, AND Non-ACCOMPANy RATE By TRIP PURPOSE 1990 AND 1995 NPTS

(PERSON TRIPS IN THOUSANDS)

\begin{tabular}{|l|c|c|c||c|c|c|}
\hline \multirow{1}{*}{ Purpose } & \multicolumn{3}{|c||}{1990 NPTS } & \multicolumn{3}{c|}{1995 NPTS } \\
\cline { 2 - 7 } & $\begin{array}{c}\text { HH Non- } \\
\text { Accompany } \\
\text { Person Trips }\end{array}$ & $\begin{array}{c}\text { Total Person } \\
\text { Trips }\end{array}$ & $\begin{array}{c}\text { Non- } \\
\text { Accompany } \\
\text { Rate }\end{array}$ & $\begin{array}{c}\text { HH Non- } \\
\text { Accompany } \\
\text { Person Trips }\end{array}$ & $\begin{array}{c}\text { Total } \\
\text { Person } \\
\text { Trips }\end{array}$ & $\begin{array}{c}\text { Non- } \\
\text { Accompany } \\
\text { Rate }\end{array}$ \\
\hline Work, School & $62,973,929$ & $82,240,011$ & $76.57 \%$ & $84,974,961$ & $110,115,282$ & $77.17 \%$ \\
Shopping & $27,983,544$ & $47,056,740$ & $59.47 \%$ & $45,996,625$ & $76,688,225$ & $59.98 \%$ \\
Other Fam/Per Bus & $33,237,593$ & $56,551,552$ & $58.77 \%$ & $58,602,172$ & $97,075,588$ & $60.37 \%$ \\
Social/Recreational & $33,166,604$ & $61,799,215$ & $53.67 \%$ & $46,509,286$ & $94,361,999$ & $49.29 \%$ \\
Other & $1,233,007$ & $1,914,779$ & $64.39 \%$ & 356,444 & 689,270 & $51.71 \%$ \\
TOTAL & $158,594,677$ & $249,562,297$ & $\mathbf{6 3 . 5 5 \%}$ & $236,439,488$ & $378,930,363$ & $\mathbf{6 2 . 4 0 \%}$ \\
\hline
\end{tabular}

This analysis was conducted using simple methods with the data available. These calculations might raise as many questions as they have answered. Notwithstanding, this is the first attempt to explain the differences on travel that can be attributed to the improvements in the survey methods. Hopefully more research on the effects of different survey methods will follow. 

APPEndix F
Differences in Workers ANd Commute Trips BETWEEN 1990 AND 1995 NPTS

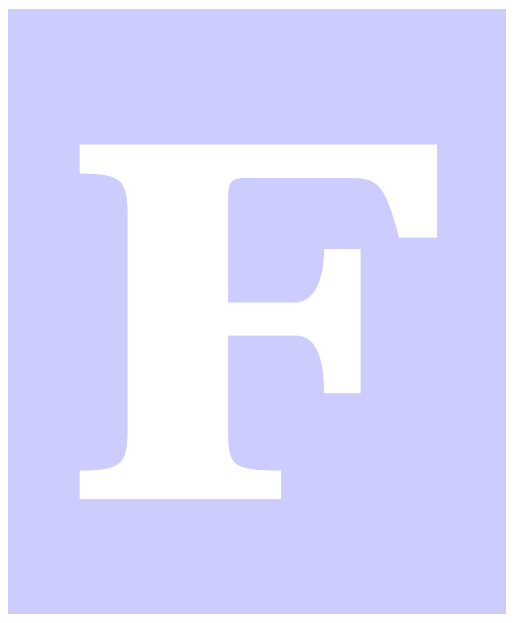

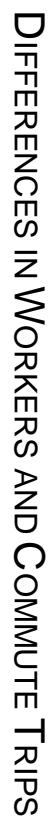




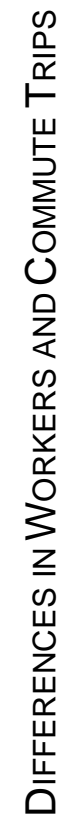




\section{Appendix F. Differences in Workers and Commute Trips Between 1990 and 1995 NPTS}

$\mathrm{D}$ ATA from the NPTS indicate that a significant jump occurred in overall travel from 1990 to 1995 . This unprecedented increase is attributable to two factors: the real increase in travel, and "statistical artifacts" stemming from the different survey methods used in 1990 and 1995. For example, the 1995 survey used trip rostering to improve the consistency between trips reported by different household members.
This unprecedented increase in total travel and driving is also observed in work trips. While the number of workers increased by an average of $2.2 \%$ each year between 1990 and 1995, travel related to earning a living increased at an annual rate of $5.6 \%$ for the total number of journey-to-work (JTW) vehicle trips, or $7.2 \%$ for the total JTW VMT (Table 1). The changes in workrelated trips are significantly more pronounced than those in JTW (Table 1).

\section{TABLE F.1}

Statistics On COMmUtes AND Work-Related TRIPS

1983, 1990, AND 1995 NPTS

\begin{tabular}{||l|c|c|c|c|c||}
\hline & 1983 & 1990 & 1995 & \multicolumn{2}{|c||}{ Compound Annual Change } \\
\cline { 5 - 6 } & & & & $83-90$ & $90-95$ \\
\hline Workers $\left(10^{3}\right)$ & 103,244 & 118,343 & 131,697 & $2.0 \%$ & $2.2 \%$ \\
\hline Journey-to-work Trips & \multicolumn{5}{|l||}{} \\
\hline Person Trips $\left(10^{6}\right)$ & 46,493 & 50,314 & 66,901 & $1.1 \%$ & $5.9 \%$ \\
\hline Vehicle Trips $\left(10^{6}\right)$ & 35,271 & 41,792 & 54,737 & $2.5 \%$ & $5.6 \%$ \\
\hline VMT $\left(10^{6}\right)$ & 301,644 & 453,042 & 642,610 & $6.0 \%$ & $7.2 \%$ \\
\hline Work-related Trips & & & & \\
\hline Person Trips $\left(10^{6}\right)$ & 5,283 & 3,529 & 9,860 & $-5.6 \%$ & $22.8 \%$ \\
\hline Vehicle Trips $\left(10^{6}\right)$ & 3,679 & 2,845 & 7,921 & $-3.6 \%$ & $22.7 \%$ \\
\hline VMT $\left(10^{6}\right)$ & 42,090 & 42,336 & 137,867 & $0.01 \%$ & $26.6 \%$ \\
\hline
\end{tabular}


Comparisons between 1990 and 1995 survey data are complicated by (1) differences in survey methodology and (2) definitional differences. To more accurately reflect travel trends, the 1990 travel data were adjusted to account for two major changes in survey methodology: use of travel diary and household rostering (See Appendix E). In essence, the 1990 travel data were adjusted in such a way as if a travel diary and household rostering were used in the 1990 survey. For trip purposes other than work and school, travel diaries capture more trips than do traveler recalls. Since travel diaries are not believed to improve the reporting of non-incidental trips such as commute or school trips and since there is no other evidence supporting a decrease in commute or school trips from 1990 to 1995, the impact of travel diaries on reporting these trips is considered null, and no adjustment was made to the 1990 data.

Two definitional differences potentially bias any comparisons between 1990 and 1995 on workers and commutes. They are the definition of workers and the definition of commute trips. Unfortunately, lack of benchmark data prohibits any adjustments to the 1990 data to account for the definitional differences.

\section{DEFINITION OF WORKERS}

In the 1990 NPTS, a respondent was defined as a worker if:
1. the respondent was working most of the previous week (a one-week period prior to the interview), or

2.

- the respondent was with a job but not at work most of the previous week, or

- $\quad$ the respondent was doing something else most of the previous week (e.g. looking for work, keeping house, going to school, etc.), but responded "Yes" to either of the following:

a) "Did you do any work last week, not counting work around the house?"

b) "Did you have a job or business from which you were temporarily absent last week?"

In the 1995 survey, a worker was defined based on the response to a single question, "Do you have a full or part-time job working for pay or profit?" Because of the difference in the definition of a worker between the two surveys, any comparisons of the difference in the number of workers between the 1990 and 1995 NPTS should be made with caution. Different estimates of the number of workers are presented in Table 2. Apparently, the more stringent criteria used in 1990 yield an estimate of the total number of workers that is considerably closer to that estimated by the Bureau of Labor Statistics. 


\section{TABLE F.2}

NUMBER OF WORKERS (IN 000)

1983, 1990, AND 1995 NPTS AND BLS DATA

\begin{tabular}{||c|c|c|c||}
\hline & NPTS & BLS $^{1}$ Data & \% Different \\
\hline 1983 & 103,244 & 100,834 & $2.4 \%$ \\
\hline 1990 & 118,343 & 118,793 & $-0.4 \%$ \\
\hline 1995 & 131,697 & 124,900 & $5.4 \%$ \\
\hline
\end{tabular}

${ }^{1}$ U.S. Bureau of Labor Statistics, Bulletin 2306; also, Employment and Earnings, January issues for appropriate years. BLS data beginning 1994, not directly comparable with earlier years. See text, section 13, and February 1994 issue of Employment and Earnings.

\section{Definition of Commute Trips}

Commute trips include trips from home to work and trips from work to home. In the 1990 NPTS, trip purposes were "activitybased" and were determined using a roundtrip scheme. Using this scheme, trips to and from work were both coded as "to and from work" and a commute trip was defined as a trip taken with a purpose categorized as "to or from work." This was mainly done to assign both parts of the round-trip to the reason the travel was made, thus avoiding the use of "return home" or "return to work." In 1995, the basis for determining trip purpose was significantly different from that used in the 1990 NPTS. The 1995 NPTS was "destination-based" and defined trip purposes as to why the one-way trip was made. Therefore, each trip purpose was defined based on the destination of that oneway trip. The reasons for this coding scheme are (1) to obtain better data on trip chaining, (2) to have a coding scheme that was more direct and precise, and (3) to have a coding scheme that was easier for the interviewer to apply.

Nationwide Personal Transportation Survey
To apply the 1990 trip-purpose coding scheme to the 1995 NPTS data, a considerable number of intermediate steps were required. For example, in the 1990 trip-purpose coding scheme, if there was more than one trip before the return-home trip, then the destination where the longest time was spent was the "purpose" of that trip. Thus, the steps in the recoding process are to (1) create trip chains, (2) measure time spent at each destination, and (3) determine the main purpose of the trip. These steps can be illustrated by an example (Figure 1). In this example, the traveler stops on the way to work to drop off a child at school. She runs some errands during lunch by shopping at a store and banking at a bank. On her way home, she stops at the grocery store to shop and then the school to pick up her child. All her trips during this day are enumerated in a tabular format, under both the 1990 and 1995 definitions. Under the 1990 trip-purpose coding scheme, Trip No. 5 will be for "shopping" if more time is spent at the store than at the bank. However, if more time is spent at the bank than at the store, then the trip purpose for Trip No. 5 
will be "other family and personal business" according to the 1990 trip-purpose definition. The same logic applies to Trip No. 8. Because it is most common to spend the longest time at work, rather than at the store (Trip No. 6) or at school (Trip No. 7), the purpose for Trip No. 8 is "to or from work." Appendix M of the 1995 NPTS User's Guide provides more detailed information on the coding of the 1995 and 1990 trip purposes.

Although significantly improving the way trips are characterized with respect to why travel takes place, this re-coding scheme inevitably introduces more discrepancies between the two surveys than would otherwise have occurred. Re-coding the 1995 trip purposes is a complicated process. Table 3 illustrates how 1995 data could be coded incorrectly. Incidentally, all trips in Table 3 qualify as commute trips because their purposes, based on the 1990 definition, are "to and from work." To investigate the likelihood of mis-coding trip purposes, information on the "to" and "from" purposes is used. In 1995, additional information was collected on individual trips with respect to the destination "to" which travel takes place and the destination "from" which travel returns. All of these commute person trips (with a 1990 trip purpose of "to and from work") have the "to" part of the trip as "return to work" (Column 2). The primary purpose for the trip can then be ascertained by the information on the "from" portion of the trip. For example, there are 102 trips that were "return to work" "from work" - which is highly illogical. One reasonable interpretation of these 102 trips would be "return to work" from "work-related business." If these trips' purposes are coded correctly, then they would not count as commute trips. Another example are the 58 trips which "return to work" from "shopping." If these trips are correctly coded, then they should be "shopping" trips rather than "to and from work" trips which qualify them as commute trips. The third column of Table 3 gives the trip purposes that are probably correct. Should all the trips reported in Table 3 be coded correctly, they would be disqualified as commute trips, partially explaining the unprecedented increase in commutes from 1990 to 1995. Unfortunately, the magnitude of the miscoding of 1995 trips can not be readily quantified.

Another possible explanation of the apparently great increase in work trips is the large percentage of non-workers who reportedly commuted to work on their designated travel day. This percentage is almost always higher in 1995 than in 1990 for every age group (Table 4). However, the difference between 1990 and 1995 increases substantially for age categories older than 55 years. The reasons for these differences are unclear. One plausible explanation is that more people 55 years old and over volunteered for work without pay in 1995 than in 1990. Persons who perform unpaid volunteer work might not consider themselves a "worker" but consider daily travel to their unpaid volunteer work as "going to work." Unfortunately, this possible explanation can not be substantiated. Although three surveys on voluntarism have been conducted through the Current Population Survey in 1965, 1974, and 1989, each of these surveys differs in terms of questions, concepts, and coverage. Consequently, their usefulness for identifying changes in volunteer behavior over time is very limited.

In summary, any comparisons on statistics related to workers and commutes between 1990 and 1995 should include a caveat

Nationwide Personal Transportation Survey 
indicating that part of the differences between the two surveys are due to different definitions of workers and trip purposes in the two surveys, and not due to actual changes in travel or in social economy.

\section{FIGURE F.1}

\section{An Example to Illustrate Trip-Purpose Coding Schemes}

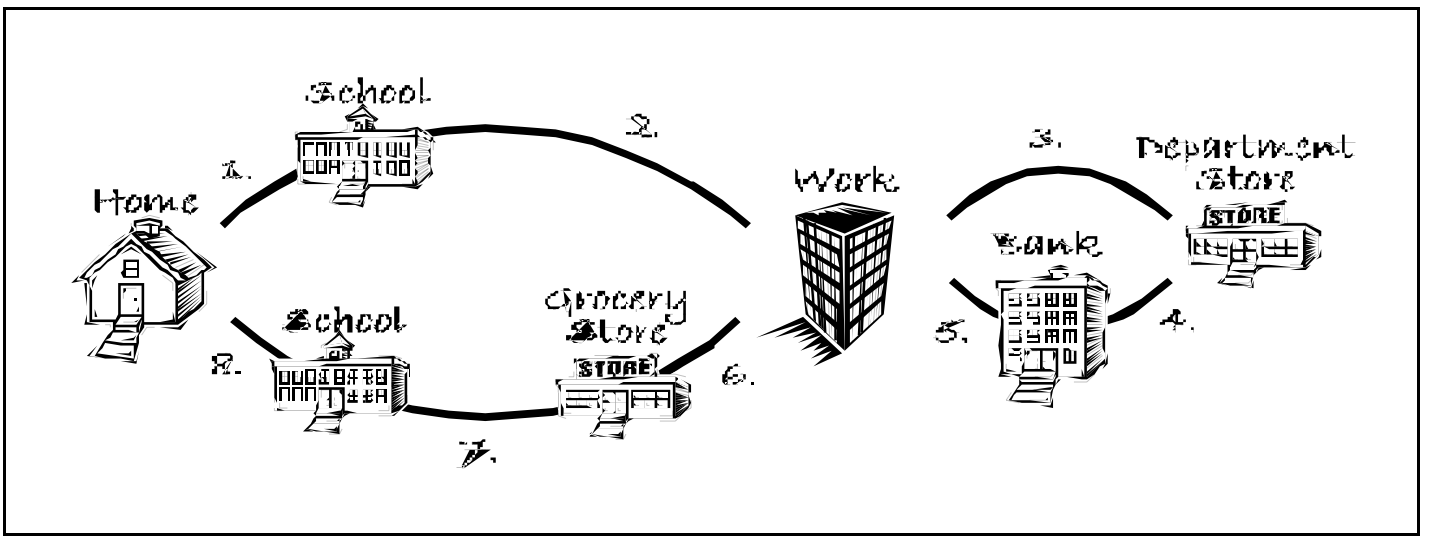

\begin{tabular}{|l|l|l|l|}
\hline \multirow{2}{*}{$\begin{array}{c}\text { Trip } \\
\text { Number }\end{array}$} & \multicolumn{1}{c|}{ Description } & \multicolumn{2}{c|}{ Trip Purpose } \\
\cline { 3 - 4 } & \multicolumn{1}{c|}{1990 Definition } & \multicolumn{1}{c|}{ 1995 Definition } \\
\hline 1. & From home to child's school & $\begin{array}{l}\text { Other family/personal } \\
\text { bus. }\end{array}$ & Take someone somewhere \\
\hline 2. & From child's school to work & To or from work & To work \\
\hline 3. & From work to store & Shopping & Shopping \\
\hline 4. & From store to bank & Other family/personal bus. & Other family/personal bus. \\
\hline 5. & From bank back to work & Shopping* & Return to work \\
\hline 6. & From work to store & Shopping & Shopping \\
\hline 7. & From store to child's school & Other family/personal bus. & Pick up someone \\
\hline 8. & From child's school to home & To or from work & Home \\
\hline
\end{tabular}

* If more time is spent at the store than at the bank. 


\section{TABLE F.3}

EXAMPle of Presumably InCORRECTLY-CODED 1995 COMMUTE TRIPS (WITH THE 1990 TRIP PURPOSE OF “TO AND FROM WORK”)

\begin{tabular}{|c|c|c|c|}
\hline \multicolumn{2}{|c|}{1995 Trip-Purpose Definition } & \multicolumn{2}{|c|}{1990 Trip-Purpose Definition } \\
\hline $\begin{array}{c}\text { 'From" Part of the } \\
\text { Trip }\end{array}$ & $\begin{array}{l}\text { "To" Part of the Trip } \\
=\text { "return to work" }\end{array}$ & $\begin{array}{l}\text { Currently Coded } \\
\text { Trip Purpose }\end{array}$ & $\begin{array}{c}\text { Presumably Correct } \\
1990 \text { Trip Purpose }\end{array}$ \\
\hline To work & 102 & To and from work & Work-related business \\
\hline Work-related business & 1,490 & , & Work-related business \\
\hline Return to work & 35 & , & Work-related business \\
\hline Shopping & 58 & , & Shopping \\
\hline School & 3 & , & School \\
\hline Religious activity & 2 & , & Religious activity \\
\hline Medical or dental & 6 & , & Medical or dental \\
\hline $\begin{array}{l}\text { Other family/personal } \\
\text { business }\end{array}$ & 64 & ” & $\begin{array}{l}\text { Other family/personal } \\
\text { business }\end{array}$ \\
\hline $\begin{array}{l}\text { Take someone } \\
\text { somewhere }\end{array}$ & 20 & ” & $\begin{array}{l}\text { Other family/personal } \\
\text { business }\end{array}$ \\
\hline Pick up someone & 0 & , & $\begin{array}{l}\text { Other family/personal } \\
\text { business }\end{array}$ \\
\hline Vacation & 0 & , & Vacation \\
\hline $\begin{array}{l}\text { Visit friends or } \\
\text { relatives }\end{array}$ & 13 & " & $\begin{array}{l}\text { Visit friends or } \\
\text { relatives }\end{array}$ \\
\hline Went out to eat & 24 & , & Other soc/rec \\
\hline $\begin{array}{l}\text { Other } \\
\text { social/recreational }\end{array}$ & 12 & " & Other soc/rec \\
\hline Home & 1,091 & " & $\begin{array}{l}\text { Other family/personal } \\
\text { business }\end{array}$ \\
\hline Not ascertained & 19 & , & Not ascertained \\
\hline ALL & 2,938 & , & ALL \\
\hline
\end{tabular}


TABLE F.4

Percent of Non-Workers COMmute to Work 1990 AND 1995 NPTS

\begin{tabular}{|l|c|c|}
\hline Age of Worker & 1990 NPTS & 1995 NPTS \\
\hline 16 to 19 & $4.78 \%$ & $4.74 \%$ \\
\hline 20 to 24 & $1.51 \%$ & $2.71 \%$ \\
\hline 25 to 29 & $0.93 \%$ & $0.94 \%$ \\
\hline 30 to 34 & $0.87 \%$ & $1.12 \%$ \\
\hline 35 to 39 & $0.91 \%$ & $1.12 \%$ \\
\hline 40 to 44 & $1.02 \%$ & $0.83 \%$ \\
\hline 45 to 49 & $0.70 \%$ & $1.03 \%$ \\
\hline 50 to 54 & $1.39 \%$ & $1.51 \%$ \\
\hline 55 to 59 & $1.41 \%$ & $4.05 \%$ \\
\hline 60 to 64 & $2.62 \%$ & $6.64 \%$ \\
\hline 65 to 69 & $7.24 \%$ & $15.12 \%$ \\
\hline 70 to 74 & $6.56 \%$ & $27.23 \%$ \\
\hline 75 to 79 & $15.23 \%$ & $33.66 \%$ \\
\hline 80 to 84 & $24.39 \%$ & $58.95 \%$ \\
\hline $85+$ & $53.99 \%$ & $64.02 \%$ \\
\hline
\end{tabular}

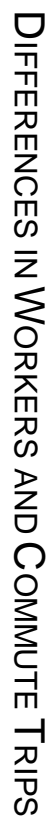




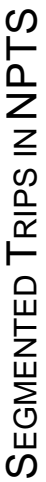




\section{APPENDIX G}

Differences in Metropolitan Area Definitions BETWEen 1983 AND 1995 NPTS

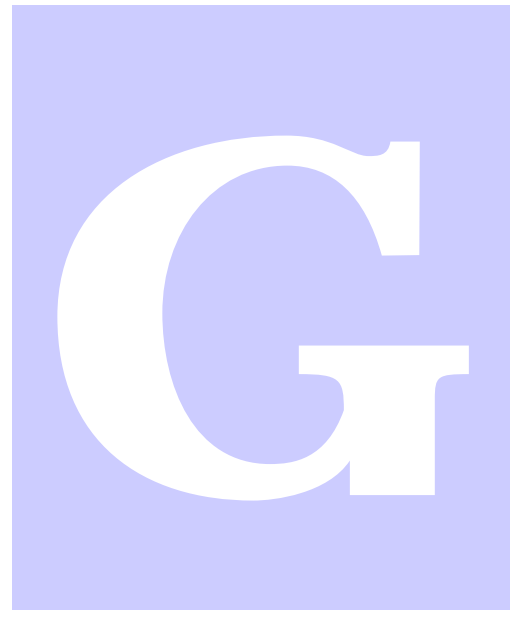

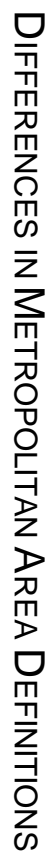




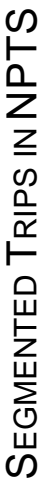




\section{Appendix G. Differences in Metropolitan Area Definitions BetweEn 1983 AND 1995 NPTS}

$\mathrm{B}$

ETWEEN 1983 and 1990, the

United States Office of Management and Budget changed the definition of a Metropolitan Statistical Area

(MSA). This change complicates any comparisons of metropolitan area data from the 1983 and 1990 NPTS. In 1983 all areas were divided into combinations of counties called Standard Metropolitan Statistical Areas (SMSAs), with the exception that SMSAs in New England consisted of cities and towns. Typically, metropolitan areas are redefined following each census, resulting in additions or subtractions of counties, New England towns, and central cities.

Substantial changes were made following the 1980 Census because of considerable revisions in the standards used by the Office of Management and Budget to define the areas.

By 1990 the term "metropolitan statistical area" (MSA) replaced "standard metropolitan statistical area" (SMSA). An optional twotiered metropolitan structure was introduced for MSAs of a million people or more. These MSAs could be subdivided into primary MSAs (PMSAs) if certain decentralization conditions were met and if the locality desired such subdivisions. If PMSA's were defined within an MSA, then the MSA became a consolidated MSA (CMSA).

Of the 318 preexisting SMSAs, 53 became
PMSAs within 15 CMSAs, and 8 new

PMSAs were established within these CMSAs. In addition, 5 preexisting SMSAs became CMSAs which were further subdivided into 10 PMSAs. These redefinitions resulted in 20 CMSAs with 71 component PMSAs when the 1990 NPTS was conducted. Among these 20 CMSAs, there were ten with a population of more than 3 million. These ten CMSAs were made up of 48 PMSAs, most of which did not by themselves have a population more than 3 million. Moreover, there was one MSA in 1990 with a population of more than 3 million.

In the 1990 and 1995 NPTS, the variable MSASIZE was given a population size value based on its MSA or CMSA size. Therefore, if a household was located in an area within a PMSA of less than 3 million but its CMSA had a population of more than 3 million, then the household was categorized as being located in an MSA of 3+ million. In 1983 and all previous NPTS surveys, however, only the SMSAs which by themselves had a population of more than 3 million were categorized as being " $3+$ million." The implication of this definitional change on the NPTS data is that many more households were estimated by the 1990 and 1995 data as being located within metropolitan areas with a population of more than 3 million than that estimated by the previous NPTS surveys. 


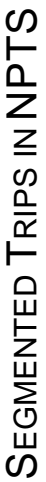




\section{APPENDiX H}

\section{SEGMENTED TRIPS IN NPTS}

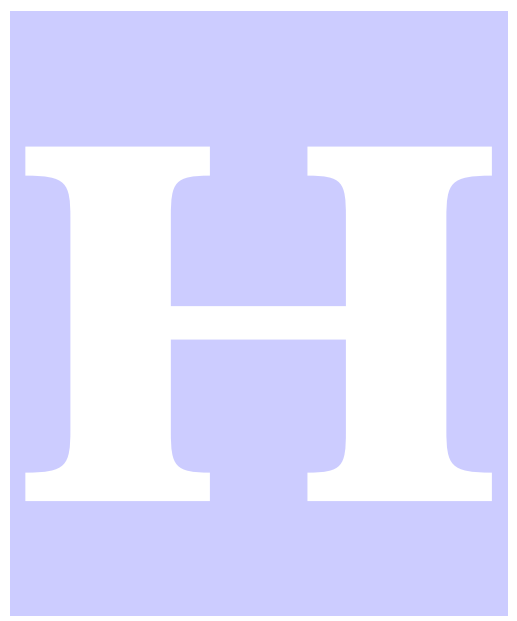

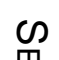

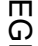

而

z

김

$\bar{z}$

Z

ज 


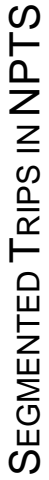




\section{Appendix H. Segmented Trips in NPTS}

\section{WHAT}

In the 1990 and 1995 surveys, certain trips were given "segmented" treatment; that is, they were broken into component parts. A trip was given segmented treatment if both of the following conditions occurred:

- $\quad$ there was a change of vehicle or a change of mode on the trip, AND

- $\quad$ one of the modes used was a public transportation mode (bus, subway, elevated rail, commuter train, streetcar or trolley).

\section{WHY}

Transportation planners and researchers have a high degree of interest in multi-modal trips, and the data from segmented trips can help in answering questions such as "What access modes are used to get to the bus, subway and commuter train?" or "How does travel time of segmented trips compare with non-segmented?" Certain trips were given segmented treatment in order to get more complete data on multi-modal trips and on the use of public transportation. In earlier NPTS surveys, if more than one mode was used on a trip, the entire trip was considered to be made on the mode that was used for the longest distance. However, this procedure had the effect of undercounting the use of transit. For example, if you walked to the bus stop, took the bus to a subway station, and took the subway to work, the entire trip would have been considered a subway trip (assuming this was the longest segment), and the walk and bus portions would have been ignored.

How

If a trip met the two conditions above, it would be given segmented treatment. First, characteristics of the trip as a whole would be collected, such as purpose, number of people on the trip, starting time of the trip, whether it was a home-based trip, etc.

Second, each time there was a change of mode (e.g. auto to commuter train) or a change of vehicle (e.g. one bus to another), it would be considered a segment.

Certain information was collected on each segment, namely, the mode used, the starting time of the segment, the length of the segment in minutes, and, if the segment was on transit, the waiting time and whether the respondent sat or stood on the segment. 


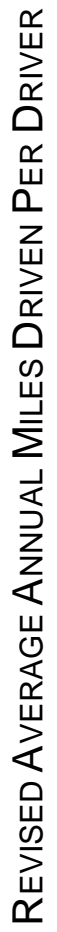




\section{APPENDIX I}

Revised Average Annual Miles Driven Per Driver

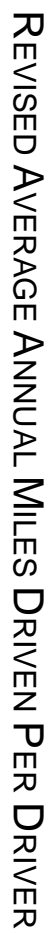




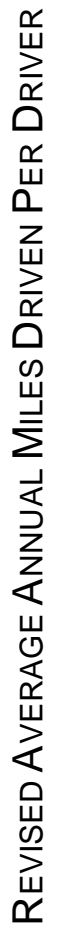




\section{Appendix I. Revised Average Annual Miles Driven Per DRIVER}

\section{WHY THE REVISION?}

Numerous data users had questioned the earlier annual average miles driven because there were per driver declines between 1990 and 1995 in virtually all age/gender categories other than men 65 or older. This seemed incongruous, given the overall strong increase in travel during this time. Upon checking the reasons for the declines in average annual miles per driver, it was discovered that in 1990 only 2 percent of the drivers reported driving no miles during the year, while this rose to 9 percent in 1995. Further, many of the 9 percent of 1995 drivers indicated that they actually did drive, either on their assigned Travel Day or as the primary driver of one of the household vehicles which reported mileage. Those drivers that reported not driving but also showed up as having driven, were moved from 'no miles' to 'miles not reported.' After this change was made, only about one and a half percent of all drivers remained in the "no miles category."

\section{WHAT THE REVISED DATA MEANS}

The revised data show modest increases of generally less than $10 \%$ for most age/gender groups. The big exception is the 16-19 yearold group, where miles declined between
1990 and 1995. This may be due to delayed licensing laws and/or higher auto insurance premiums. However, a number of reviewers questioned this decline in teenage driving. The driving reported by this group on their assigned travel day was reviewed and also showed a slight decline. But there was still concern that this decline was a survey effect, not a real decline. A number of other survey attributes were analyzed, including the degree of proxy reporting by teenagers in 1990 and 1995 and whether they were a primary driver of a household vehicle.

Nothing conclusive was found. Thus, use the data on 16-19 year-olds with caution.

For men, the most dramatic increases in travel were for those 65 and older. Younger men, namely those 20-54 may finally be reaching saturation in their travel. Women's travel shows a very different pattern, with declines in the youngest group (16-19), consistent increases of 7 to 8 percent for those 20 through 64, and no change in average travel for those 65 and older. Given what we know about older women, it is somewhat surprising that their average driving did not grow. However, perhaps the fact of their increased health and financial status is offset by the more women in this group staying alive longer, keeping their driver's licenses, but not necessarily still driving. 


\section{TABLE I. 1}

\section{Revised Annual Miles Driven Per Driver}

BY DRIVER's AGE AND GENDER

\begin{tabular}{|c|c|c|c|c|c|c|}
\hline \multirow[b]{2}{*}{ Age } & \multicolumn{3}{|c|}{ Male } & \multicolumn{3}{|c|}{ Female } \\
\hline & 1990 & 1995 & \%change & 1990 & 1995 & \%change \\
\hline 16-19 & 9,543 & 8,206 & $-14.0 \%$ & 7,387 & 6,873 & $-7.0 \%$ \\
\hline $20-34$ & 18,310 & 17,976 & $-1.8 \%$ & 11,174 & 12,004 & $+7.4 \%$ \\
\hline $35-54$ & 18,871 & 18,858 & $0.0 \%$ & 10,539 & 11,464 & $+8.8 \%$ \\
\hline $55-64$ & 15,224 & 15,859 & $+4.2 \%$ & 7,211 & 7,780 & $+7.9 \%$ \\
\hline $65+$ & 9,162 & 10,304 & $+12.5 \%$ & 4,750 & 4,785 & $+0.8 \%$ \\
\hline ALL & 16,536 & 16,550 & $0.0 \%$ & 9,528 & 10,142 & $+6.5 \%$ \\
\hline
\end{tabular}




\section{APPENDIX J}

Procedure to Adjust 1983 AND 1990 Income Categories into 1995 Dollars

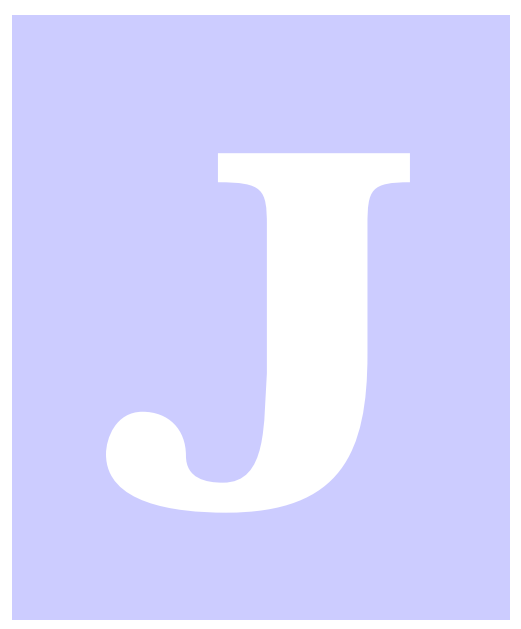

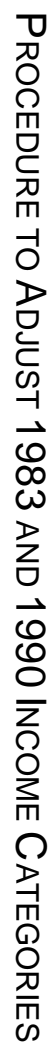




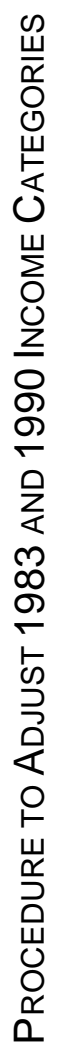




\section{ApPENDIX J Estimates OF Total Travel}

To protect the confidentiality of NPTS' respondents, their household income data were categorized and available only in income categories. To assure compatibility in comparing 1983, 1990, and 1995 survey results, the 1983 and 1990 income categories needed to be adjusted to reflect monetary inflation between 1983 and 1995 and between 1990 and 1995. The adjustment is not straightforward due to the categorical nature of the data. A cumulative polynomial fitting technique is used, consisting of three steps:

1. The basic idea of this technique is to first fit a polynomial curve to the cumulative frequency distribution (of any data element).

2. The 1983 and 1990 income are adjusted by the Consumer Price Index (CPI) to 1995 dollars.

3. Without altering the cumulative frequency distribution, one can then "recategorize" the cumulative frequency distribution into any desired categories.

An example of how the data were adjusted is given. This example redistributes 1990 households into adjusted 1990 income categories reflecting 1995 dollars.

Table J.1 gives the 1990 income categories, and the corresponding number of households in each category. Since the cumulative polynomial fitting technique fits a polynomial curve to the cumulative distribution based on the endpoints of the income categories and since the last income category $-\$ 80,000$ and up - has an indefinite range, it is impossible to determine the endpoint of this income category. To overcome this difficulty, this income category is divided into several categories with income intervals of equal size. In order to determine the number of "equally-spaced" categories that should represent the last income category, the following equation is used:

$$
I=\frac{\text { Total number of households earning } \$ 80,000 \& \mathrm{Lp}}{\text { Total number of houscholds earning } \$ 75,000-80,000}=\frac{3,935,167}{862,902}=4.56
$$


TABLE J.1

Number OF HouSEHOLDS BY 1990 HouSEHOLD INCOME

\begin{tabular}{||c|c||c|c||}
\hline $\begin{array}{c}\text { 1983 Income } \\
\text { (thousands) }\end{array}$ & $\begin{array}{c}\text { Total Number of } \\
\text { Households }\end{array}$ & $\begin{array}{c}\text { 1983 Income } \\
\text { (thousands) }\end{array}$ & $\begin{array}{c}\text { Total Number of } \\
\text { Households }\end{array}$ \\
\hline Less than $\$ 5$ & $2,757,031$ & $\$ 45-50$ & $3,394,577$ \\
\hline$\$ 5-10$ & $6,494,757$ & $\$ 50-55$ & $3,071,826$ \\
\hline$\$ 10-15$ & $6,330,740$ & $\$ 55-60$ & $2,721,392$ \\
\hline$\$ 15-20$ & $6,680,265$ & $\$ 60-65$ & $1,484,647$ \\
\hline$\$ 20-25$ & $5,717,564$ & $\$ 65-70$ & $1,618,207$ \\
\hline$\$ 25-30$ & $6,576,868$ & $\$ 70-75$ & $1,059,712$ \\
\hline$\$ 30-35$ & $5,784,371$ & $\$ 75-80$ & 862,902 \\
\hline$\$ 35-40$ & $5,538,990$ & $\$ 80$ and up & $3,935,167$ \\
\hline
\end{tabular}

${ }^{1}$ Does not include households where household income was unreported.

The solution to this equation implies that the last income category should be divided into five categories (\$80,000-85,000, \$85,000-90,000, \$90,000-95,000,\$95,000-100,000, and \$100,000-105,000). Each of the first four categories is assumed to have the same number of households as the " $\$ 75,000$ 80,000 "category. That is, the categories “ $\$ 75,000-80,000, "$ " $\$ 80,000-85,000, "$ " $\$ 85,000-90,000, "$ “\$90,000-95,000," and "\$95,000-100,000" will each have an estimated total of 862,902 households. To estimate the total number of households in the last income category, " $\$ 100,000-105,000$," the following equation is used:

Total number of households in the " $\$ 100,000-105,000 "$ category

$=$ Total households in the original " $\$ 80,000$ and up" category -

[ (Number of new categories created - 1) $\times$

Total households in the " $\$ 75,000-80,000$ " category]

$=3,935,167-(4 \times 862,902)$

$=483,559$.

The revised 1990 income categories and the corresponding number of households in each category are shown in Table J.2. 


\section{TABLE J.2}

\section{Number of HouseHOLdS AND THE ENDPOINTS OF REVISED 1990 InCOME CATEGORIES, (INCLUding FIVE NEW INCOME CATEGORIES)}

\begin{tabular}{|c|c|c|c|}
\hline $\begin{array}{l}\text { Revised } 1990 \\
\text { Income } \\
\text { Category } \\
\text { (Thousands) } \\
\end{array}$ & $\begin{array}{l}\text { Endpoint of } \\
\text { Income } \\
\text { Categories } \\
\quad\left(\mathrm{X}_{90, \mathrm{j}}\right) \\
\end{array}$ & $\begin{array}{l}\text { Total Number of } \\
\text { Households } \\
\text { in } 1990 \\
\left(\mathrm{Y}_{90 . \mathrm{j}}\right) \\
\end{array}$ & $\begin{array}{c}\text { Cumulative Total Number } \\
\text { of Households }{ }^{1} \text { in } 1990 \\
\left(\mathrm{~W}_{90, \mathrm{j}}\right)\end{array}$ \\
\hline Less than $\$ 5$ & $\$ 5$ & $2,757,031$ & $2,757,031$ \\
\hline$\$ 5-10$ & $\$ 10$ & $6,494,757$ & $9,251,788$ \\
\hline$\$ 10-15$ & $\$ 15$ & $6,330,740$ & $15,582,528$ \\
\hline$\$ 15-20$ & $\$ 20$ & $6,680,265$ & $22,262,793$ \\
\hline$\$ 20-25$ & $\$ 25$ & $5,717,564$ & $27,980,357$ \\
\hline$\$ 25-30$ & $\$ 30$ & $6,576,868$ & $34,557,225$ \\
\hline$\$ 30-35$ & $\$ 35$ & $5,784,371$ & $40,341,596$ \\
\hline$\$ 35-40$ & $\$ 40$ & $5,538,990$ & $45,880,586$ \\
\hline$\$ 40-45$ & $\$ 45$ & $3,555,783$ & $49,436,369$ \\
\hline$\$ 45-50$ & $\$ 50$ & $3,394,577$ & $52,830,946$ \\
\hline$\$ 50-55$ & $\$ 55$ & $3,071,826$ & $55,902,772$ \\
\hline$\$ 55-60$ & $\$ 60$ & $2,721,392$ & $58,624,164$ \\
\hline$\$ 60-65$ & $\$ 65$ & $1,484,647$ & $60,108,811$ \\
\hline$\$ 65-70$ & $\$ 70$ & $1,618,207$ & $61,727,018$ \\
\hline$\$ 70-75$ & $\$ 75$ & $1,059,712$ & $62,786,730$ \\
\hline$\$ 75-80$ & $\$ 80$ & 862,902 & $63,649,632$ \\
\hline$\$ 80-85$ & $\$ 85$ & 862,902 & $64,512,534$ \\
\hline$\$ 85-90$ & $\$ 90$ & 862,902 & $65,375,436$ \\
\hline$\$ 90-95$ & $\$ 95$ & 862,902 & $66,238,338$ \\
\hline$\$ 95-100$ & $\$ 100$ & 862,902 & $67,101,240$ \\
\hline$\$ 100-105$ & $\$ 105$ & 483,559 & $67,584,799$ \\
\hline
\end{tabular}

1 Does not include households where household income was unreported. 


\section{Step 1. Fita Polynomial Model}

The first step in the cumulative polynomial fitting technique is to fit a polynomial model based on the endpoints of the revised 1990 income categories. Based on the end points $\mathrm{X}_{90, \mathrm{i}}$ and their corresponding cumulative totals, $\mathrm{W}_{90, \mathrm{i}}$ (Table J.2), a $k=8$ order polynomial fit was developed. To estimate the parameters $a_{k}, k=1,2, \ldots, 8$, the sum of the squares of the residuals, $e_{\mathrm{i}}^{2}$, is minimized.

$$
\begin{aligned}
\mathrm{W}_{90, \mathrm{i}}= & a_{0}+\left(a_{1} \times\left(\mathrm{X}_{90, \mathrm{i}}\right)\right)+\left(a_{2} \times\left(\mathrm{X}^{2}{ }_{90, \mathrm{i}}\right)\right)+\ldots .+\left(a_{k} \times\left(\mathrm{X}_{90, \mathrm{i}}^{\mathrm{k}}\right)\right)+e_{\mathrm{i}} \\
\text { where } & i \text { is the } i^{\text {th }} \text { income category, } i=1,2, \ldots,(16+5) ; \text { and } \\
& \mathrm{X}_{90, \mathrm{i}} \text { is the endpoint of } i \text {, expressed in thousands in this equation. }
\end{aligned}
$$

In fitting this curve, the following parameters for $a_{k}$ were estimated:

\begin{tabular}{||lll||}
\hline Parameter: & & \\
\hline$a_{0}=-2,802,202.3$ & $a_{1}=1,064,029.7$ & $a_{2}=15,326.168$ \\
$a_{3}=-299.72494$ & $a_{4}=-1.3030999$ & $a_{5}=0.38818779 \mathrm{E}-01$ \\
$a_{6}=-0.11870581 \mathrm{E}-03$ & $a_{7}=-0.2651394 \mathrm{E}-06$ & $a_{8}=-0.27107913 \mathrm{E}-09$ \\
\hline
\end{tabular}

Figure J.1 illustrates the cumulative number of households categorized by the revised 1990 income category and the fitted polynomial curve. 
FIGURE J.1

FITTED POLYNOMIAL CURVE AND THE CUMULATIVE NUMBER OF HOUSEHOLDS BY

REVISED 1990 INCOME CATEGORY

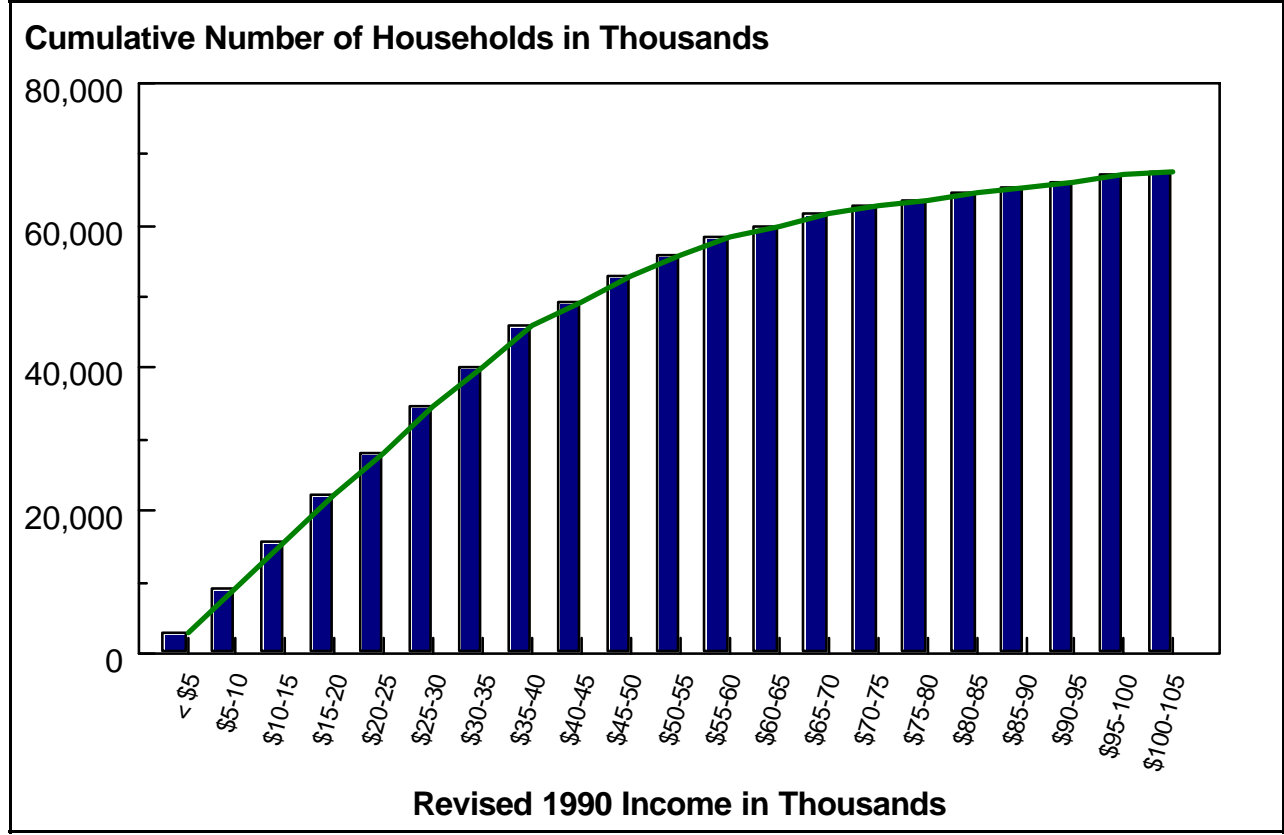

Step 2. Convert 1990 Income Categories Into 1995 Dollars

Since the 1995 NPTS household income distribution is grouped into 18 income categories, but 1983 and 1990 income categories were grouped into only 17 categories, the adjusted 1983 and 1990 income categories will be presented in only 17 categories. When comparing the 1995 NPTS income data with either the 1983 or 1990 NPTS income data, the last two categories ("\$80,000 to $\$ 100,000$ " and " $\$ 100,000$ or more") will have to be combined. To take into account the inflation factor the following is done. First, the endpoint of each 1995 income category is converted to 1990 dollars by using an inflation factor, $r$, which is calculated by dividing the 1995 consumer's price index (CPI) by the 1990 CPI.

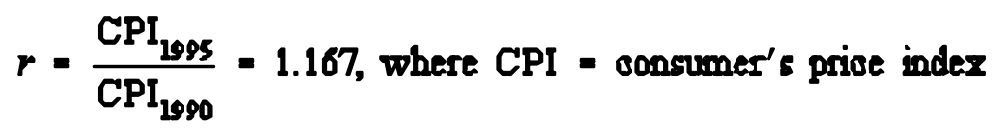


The inflation factor for converting the 1983 income categories into 1995 dollars is as follows:

\section{$r=\frac{\mathrm{CPI}_{1095}}{\mathrm{CPI}_{1093}}=1.530$, where $\mathrm{CPI}=$ oonsumer's prise inder}

The rationale for this conversion is to determine the equivalent endpoints in 1990, given 1995 buying power. In other words, for households earning less than $\$ 5,000$ per year in 1995 , what would have been the equivalent cutoff point for this income category in 1990? With the inflation rate of 1.167, the equivalent cutoff point for the "less then $\$ 5,000$ " category in 1995 is "less than $\$ 4,284$ $(=\$ 5,000 / 1.167)$ " in 1990. Similarly, earnings between $\$ 5,000$ and $\$ 10,000$ in 1995 are equivalent to earnings between $\$ 4,284$ and $\$ 8,569(=\$ 10,000 / 1.167)$ in 1990. Table J.3 shows the revised 1990 income categories that are in 1995 dollars.

\section{Step 3. Estimate 1983 Household Distribution Using the Revised InCOME CATEgORIES}

To categorize the number of 1990 households in the revised 1990 income categories (Table J.3), the following equation is used:

$$
\begin{aligned}
\mathrm{W}_{95, \mathrm{i}}= & a_{0}+\left(a_{1} \times\left(\mathrm{Z}_{95, \mathrm{i}}\right)\right)+\left(a_{2} \times\left(\mathrm{Z}_{95, \mathrm{i}}^{2}\right)\right)+\ldots+\left(a_{10} \times\left(\mathrm{Z}_{95, \mathrm{i}}^{8}\right)\right) \\
= & -2,802,202+1,064,030 \times\left(\mathrm{Z}_{95, \mathrm{i}}\right)+15,326 \times 4\left(\mathrm{Z}_{95, \mathrm{i}}^{2}\right)-299.72 \times \\
& \left(\mathrm{Z}_{95, \mathrm{i}}^{3}\right)-1.303 \times\left(\mathrm{Z}_{95, \mathrm{i}}^{4}\right)+0.039 \times\left(\mathrm{Z}_{95, \mathrm{i}}^{5}\right) .
\end{aligned}
$$

where - $\quad \mathrm{W}_{95, \mathrm{i}}$ is the cumulative number of households in the revised 1990 income categories;

- $\quad i$ is the $i^{\text {th }}$ income category, $i=1,2,3,4,5,6,7,8$ and

- $\quad Z_{95, \mathrm{i}}=$ the endpoint of the revised 1990 income category $i$, in thousands of dollars (from Table J.3).

To calculate the number of households earning less then $\$ 4,284$ per year in $1990, Z_{95,1}$ in the above equation was replaced by 4.284 :

$$
\begin{aligned}
\mathrm{W}_{95,1}= & -2,802,202+1,064,030 \times 4.284+15,326 \times 4.284^{2} \\
& -299.72 \times 4.284^{3}-1.303 \times 4.284^{4}+0.039 \times 4.284^{5} \\
& 2,014,010 .
\end{aligned}
$$




\section{TABLE J.3}

\section{REVISED 1990 INCOME CATEGORIES}

\begin{tabular}{|c|c|}
\hline $\begin{array}{l}\text { Income Category } \\
\text { Used in the } 1995 \text { NPTS }\end{array}$ & $\begin{array}{c}\text { Revised } 1990 \text { Income Category in } 1995 \\
\text { Dollars }\end{array}$ \\
\hline Less than $\$ 5,000$ & Less than $\$ 4,284$ \\
\hline$\$ 5,000-10,000$ & $\$ 4,284-8,569$ \\
\hline$\$ 10,000-15,000$ & $\$ 8,569-12,853$ \\
\hline$\$ 15,000-20,000$ & $\$ 12,853-17,138$ \\
\hline$\$ 20,000-25,000$ & $\$ 17,138-21,422$ \\
\hline$\$ 25,000-30,000$ & $\$ 21,422-25,707$ \\
\hline$\$ 30,000-35,000$ & $\$ 25,707-29,991$ \\
\hline$\$ 35,000-40,000$ & $\$ 29,991-34,276$ \\
\hline$\$ 40,000-45,000$ & $\$ 34,276-38,560$ \\
\hline$\$ 45,000-50,000$ & $\$ 38,560-42,845$ \\
\hline$\$ 50,000-55,000$ & $\$ 42,845-47,129$ \\
\hline$\$ 55,000-60,000$ & $\$ 47,129-51,414$ \\
\hline$\$ 60,000-65,000$ & $\$ 51,414-55,698$ \\
\hline$\$ 65,000-70,000$ & $\$ 55,698-59,983$ \\
\hline$\$ 70,000-75,000$ & $\$ 59,983-64,267$ \\
\hline$\$ 75,000-80,000$ & $\$ 64,267-68,552$ \\
\hline More than $\$ 80,000$ & More than $\$ 68,552$ \\
\hline
\end{tabular}


The 1990 household distribution categorized by the income categories that are in 1995 dollars is given in Table J.4.

\section{TABLE J.4}

HouseHold Distribution By INCOME CATEGORIES IN 1995 DOLLARS

\begin{tabular}{|c|c|c|}
\hline 1990 Income Category & $\begin{array}{l}\text { Revised } 1990 \text { Income } \\
\text { Category in } 1995 \text { Dollars }\end{array}$ & $\begin{array}{c}\text { Number of } \\
1990 \text { Households }{ }^{1} \\
\text { (thousands) }\end{array}$ \\
\hline Less than $\$ 5,000$ & Less than $\$ 4,284$ & $\mathrm{~W}_{95,1}=2,014$ \\
\hline$\$ 5,000-10,000$ & $\$ 4,284-8,569$ & $\mathrm{~W}_{95,2^{2}}-\mathrm{W}_{95,1}=5,233$ \\
\hline$\$ 10,000-15,000$ & $\$ 8,569-12,853$ & $\mathrm{~W}_{95,3}-\mathrm{W}_{95,2}=5,500$ \\
\hline$\$ 15,000-20,000$ & $\$ 12,853-17,138$ & $\mathrm{~W}_{95,4}-\mathrm{W}_{95,3}=5,620$ \\
\hline$\$ 20,000-25,000$ & $\$ 17,138-21,422$ & $\mathrm{~W}_{95,5}-\mathrm{W}_{95,4}=5,600$ \\
\hline$\$ 25,000-30,000$ & $\$ 21,422-25,707$ & $\mathrm{~W}_{95,6}-\mathrm{W}_{95,5}=5,450$ \\
\hline$\$ 30,000-35,000$ & $\$ 25,707-29,991$ & $\mathrm{~W}_{95,7}-\mathrm{W}_{95,6}=5,187$ \\
\hline$\$ 35,000-40,000$ & $\$ 29,991-34,276$ & $\mathrm{~W}_{95,8}-\mathrm{W}_{95,7}=4,830$ \\
\hline$\$ 40,000-45,000$ & $\$ 34,276-38,560$ & $\mathrm{~W}_{95,9}-\mathrm{W}_{95,8}=4,399$ \\
\hline$\$ 45,000-50,000$ & $\$ 38,560-42,845$ & $\mathrm{~W}_{95,10}-\mathrm{W}_{95,9}=3,918$ \\
\hline$\$ 50,000-55,000$ & $\$ 42,845-47,129$ & $\mathrm{~W}_{95,11}-\mathrm{W}_{95,10}=3,411$ \\
\hline$\$ 55,000-60,000$ & $\$ 47,129-51,414$ & $\mathrm{~W}_{95,12}-\mathrm{W}_{95,11}=2,901$ \\
\hline$\$ 60,000-65,000$ & $\$ 51,414-55,698$ & $\mathrm{~W}_{95,13}-\mathrm{W}_{95,12}=2,411$ \\
\hline$\$ 65,000-70,000$ & $\$ 55,698-59,983$ & $\mathrm{~W}_{95,14}-\mathrm{W}_{95,13}=1,962$ \\
\hline$\$ 70,000-75,000$ & $\$ 59,983-64,267$ & $\mathrm{~W}_{95,15}-\mathrm{W}_{95,14}=1,570$ \\
\hline$\$ 75,000-80,000$ & $\$ 64,267-68,552$ & $\mathrm{~W}_{95,16}-\mathrm{W}_{95,15}=1,250$ \\
\hline More than $\$ 80,000$ & More than $\$ 68,552$ & $\mathrm{~W}_{95.17}-\mathrm{W}_{95.16}=6,327$ \\
\hline
\end{tabular}

${ }^{1}$ Does not include households where household income was unreported. 